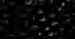

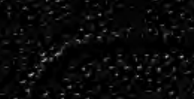

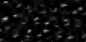

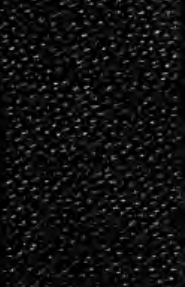

a

$\therefore \therefore-1$

$-2,8 ; 0 ;$

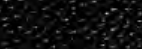

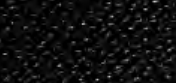
$\therefore$ 


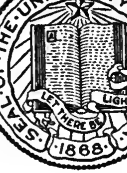

THE LIBRARY OF THE UNIVERSITY OF CALIFORNIA LOS ANGELES

The RALPH D. REED LIBRARY DEPARTMENT OF GEOLOGY UNIVERAITY OF CALIFORNIA LOS ANGLILS, CNIF. Gift of Robert W. Webb. 
ROBERT W. WEBB
GEOLOGY DEPT., U.C.L.A:

Curia Cubebs 
$\zeta$ 


\section{ECONOMIC GEOLOGY \\ OF THE \\ UNITED STATES}


The $>$ X 



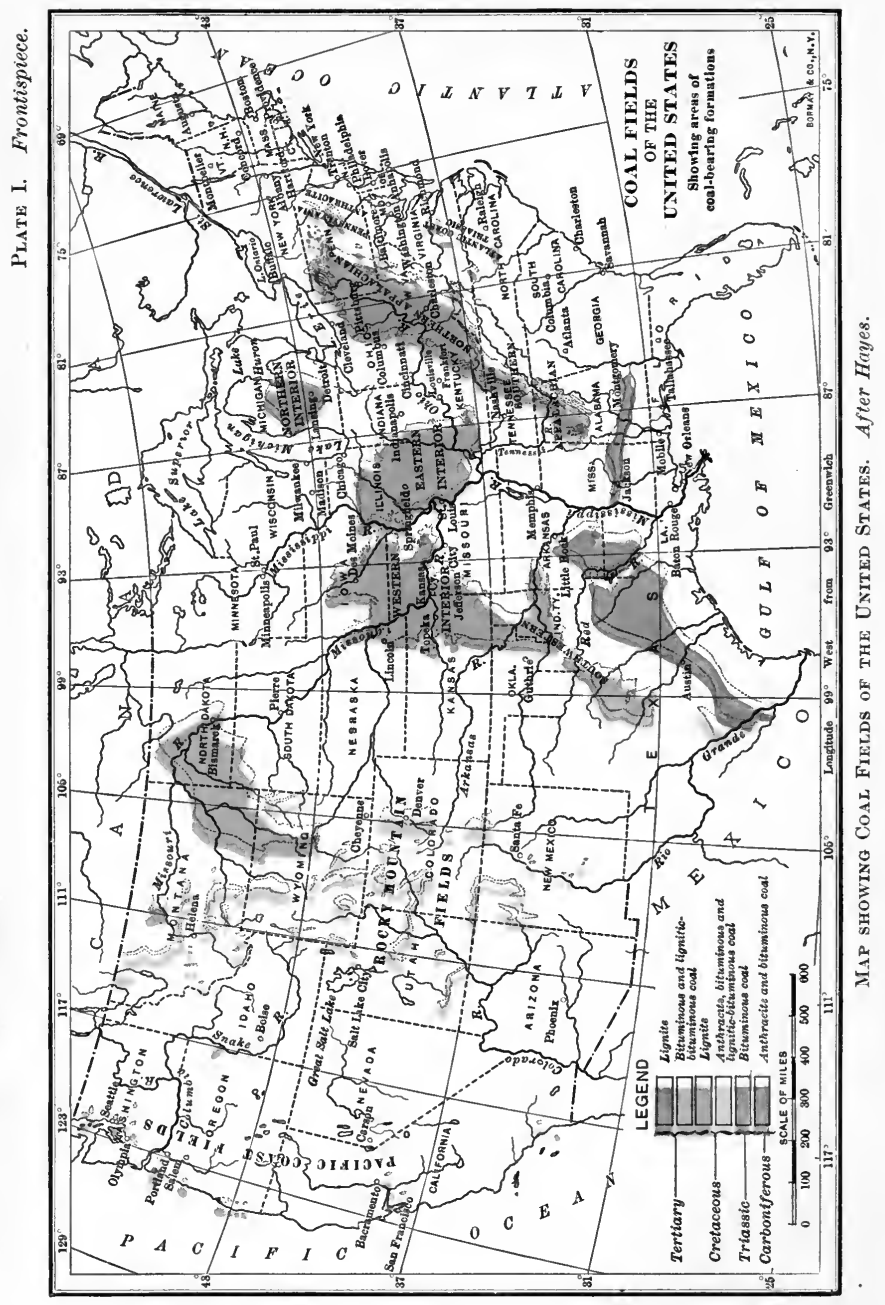




\section{ECONOMIC GEOLOGY}

OF THE

\section{UNITED STATES}

BY

HEINRICH RIES, A.M., Ph.D.

PROFESSOR OF ECONOMIC GEOLOGY AT CORNELL CNIVERSITY

Now Matk

THE MACMILLAN COMPANY

LONDON: MACMILLAN \& CO., LTD.

1908

All rights reserved 
Copreight, 1905, 1907,

By THE MACMILLAN COMPANY.

Set up and electrotyped. Published November, 1905. New edition January, 1907 ; February, rgo8. 


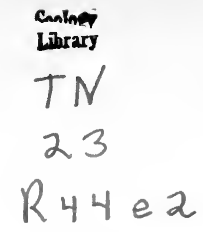

\section{PREFACE}

The following work on the Economic Geology of the United States covers essentially the ground which is gone over in the elementary course in this subject in Cornell University, but it is hoped that it will prove useful as a text-book in other colleges.

The mode of arrangement is markedly different from that found in other books on the same subject, in that the nonmetallic minerals are discussed first and the metallic minerals last. This, to the author, seems the most desirable method of treatment, for the reason that the non-metallics are not only the most important, the value of their production having exceeded the metallics by over one hundred and fifty million dollars in 1903, but also because it leads from a discussion of the simpler to the more complex forms of mineral deposits.

It has not been thought desirable to include a chapter on geologic and physiographic principles, since the space which could be allotted to it is altogether too small, and, moreover, the study of economic geology presupposes a knowledge of geology and mineralogy on the part of the student. While the references given at the end of each chapter do not include every paper that has been written on the subject to which they refer, still it is believed that they are suffciently numerous to permit one to follow out the subject in considerable detail if he so desire.

In the preparation of the manuscript all available sources of information have been freely drawn upon, and the numbers in parentheses in the text refer to the numbered references at the end of each chapter. 
All statistical figures, unless otherwise stated, are taken from the reports of the United States Geological Survey.

Descriptions of mineral occurrences in foreign countries are not included, except in a few cases where the deposits serve as an important if not the only source of supply for the United States.

The writer wishes to express his thanks to Professor R. S. Tarr for examination and criticism of much of the manuscript, and to W. E. McCourt, Instructor in Geology, and H. Leighton, Assistant in Geology, for aid in the preparation of drawings and statistical tables. For the loan of photographs or cuts acknowledgments are due to Messrs. H. F. Bain, J. E. Spurr, J. M. Boutwell, G. H. Eldridge, W. Lindgren, F. H. Oliphant, and J. H. Pratt of the United States Geological Survey; Professor A. C. Lane, Michigan Geological Survey; Dr. D. H. Newland, New York State Museum; Professor C. C. O'Harra, South Dakota School of Mines; Professor E. A. Smith, Alabama Geological Survey; Professor G. H. Perkins, Vermont Geological Survey ; Dr. H. B. Kümmel, New Jersey Geological Survey; Dr. W. B. Phillips, Texas Geological Survey; Dr. G. P. Merrill, United States National Museum; also to Messrs. H. W. Turner, F. S. Witherbee, A. W. Sheafer, L. Martin, Wiley \& Sons, Vermont Marble Co., and Bedford Quarries Co.

Cornell UnIVERsity,

IтнACA, N.Y., June, 1905. 


\section{PREFACE TO THE SECOND EDITION}

THE publication of a second edition has become necessary in such a comparatively short time, that it has not been deemed advisable to materially alter the text. An attempt has, however, been made to correct all errors of which the author has knowledge. Recognizing the value of fresh statistics, those for 1905 (the most recent available) have been given in an appendix, and for the benefit of those who make use of the bibliography, a second appendix has been included, containing a list of the more important papers published since the appearance of the first edition.

Cormell University,

IтHACA, N.Y., Nov. 10, 1906. 



\section{CONTENTS}

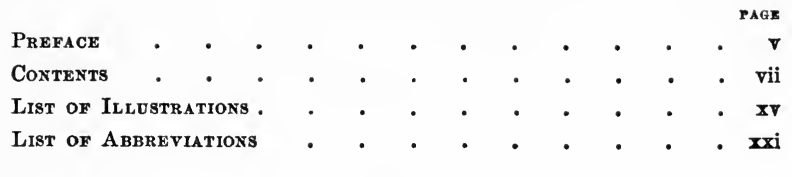

\section{PART I}

\section{NON-METALLIC MINERALS}

\section{CHAPTER I}

COAL

Kinds of coal, 3 ; Peat, 3 ; Lignite, 4 ; Bituminous coal, 4 ; Cannel coal, 5; Semi-bituminous coal, 5 ; Anthracite coal, 5 ; Proximate analysis of coal, 6 ; Origin of coal, 9 ; Conditions of vegetable accumulation, 10 ; Chemical changes occurring during coal formation, 12 ; Effect of heat and pressure, 14; Structural features of coal beds, 15 ; Outcrops, 15 ; Associated rocks, 16 ; Variations in thickness, 16; Other irregularities, 17 ; Coal fields of the United States, 18; Geologic distribution of coals in the United States, 19 ; Appalachian field, 20 ; Bituminous area, 21; Character of Appalachian bituminous coals, 22 ; Pennsylvania anthracite field, 22 ; Rhode Island field, 25; The Triassic field, 25; Eastern Interior field, 26 ; Northern Interior field, 27 ; Western Interior field and southwestern fields, 28 ; Western Interior field, 29 ; Southwestern field, 29; Gulf states lignite area, 30 ; Rocky Mountain fields, 30 ; The Pacific Coast fields, 31 ; Alaska, 32 ; Production of coal, 33; Production of coke, 35 ; References on coal, 35 ; References on peat, 38.

\section{CHAPTER II}

Petroleum, Natural Gas, and Other Hydrocarbons .

History of petroleum development, 39 ; History of natural gas development, 40; Properties of petroleum, 40; Properties of natural gas, 42 ; Mode of occurrence, 43; Pressure of oil and gas wells, 44; Origin, 46; Inorganic theory, 46; Organic theory, 47; Geological 
distribution of petroleum and natural gas, 48; Distribution of petroleum in the United States, 48 ; Appalachian field, 48; OhioIndiana field, 50 ; Texas-Louisiana oil fields, 51 ; Kansas, 52 ; California, 52; Wyoming, 53; Colorado, 53 ; Alaska, 54; Distribution of natural gas in the United States, 54 ; New York, 54 ; Pennsylvania, 54 ; West Virginia, 55 ; Ohio, 55 ; Indiana, 55 ; Kansas, 55 ; Uses of petroleum, 56 ; Uses of natural gas, 56 ; Oil shales, 56 ; Solid bitumens, 57 ; Occurrence, 57; Asphaltites, 58; Albertite, 59 ; Anthraxolite, 59 ; Ozokerite, 59 ; Grahamite, 59 ; Lake asphalt, 59 ; Uintaite or gilsonite, 59 ; Manjak, 59 ; Bituminous rocks, 60 ; Analyses, 60 ; Uses, 61 ; Production of petroleum, natural gas, and asphaltum, 61 ; References on petroleum, 66 ; References on natural gas, 67 ; References on oil shale, 67 ; References on asphaltum, 67 .

\section{CHAPTER III}

Building Stones

Properties of building stones, 69 ; Color, 70 ; Texture, 70 ; Density, 70; Hardness, 71; Strength, 71; Crushing strength, 72; Transverse strength, 72; Porosity and ratio of absorption, 73; Resistance to frost, 73 ; Resistance to heat, 73 ; Structural features affecting quarrying, 74 ; Bedding planes, 74 ; Granites, 75 ; Characteristics of granites, 75 ; Distribution of granites in the United States, 76 ; Eastern crystalline belt, 77 ; Central states, 77 ; Western 'states, 77 ; Uses of granite, 77 ; Miscellaneous igneous rocks, 78; Limestones and marbles, 78; General characteristics, 78; Varieties of limestones, 79 ; Distribution of limestones in the United States, 80 ; Distribution of marbles in the United States, 81 ; Onyx marbles, 83 ; Serpentine, 83 ; Sandstones, 84 ; General properties, 84 ; Varieties of sandstone, 85 ; Distribution of sandstones in the United States, 86; Uses of sandstones, 87 ; Slates, 87; General characteristics, 87; Distribution of slates in the United States, 88 ; Uses of slate, 89 ; Production of building stones, 89 ; References on building stones, 90 ; References on onyx marble, 91.

\section{CHAPTER IV}

\section{Clat}

Definition, 92 ; Residual clays, 92 ; Sedimentary clays, 93 ; Marine clays, 94 ; Flood-plain clays, 94 ; Lake clays, 94 ; Glacial clays, 94 ; Æolian clays, 94 ; Properties of clay, 95 ; Chemical properties, 95; Physical properties, 96 ; Plasticity, 96; Tensile strength, 96; Shrinkage, 96 ; Fusibility, 97 ; Specific gravity, 97; 
Chemical composition, 97 ; Classification of clay, 98 ; Kinds of clay, 99 ; Geological distribution, 100 ; Distribution of clays in the United States by kinds, 100 ; Kaolins, 100 ; Fire clays, 102 ; Pottery clays, 103 ; Brick and tile clays, 104 ; Miscellaneous clays of importance, 104; Uses of clay, 105; Production of clay, 105; References on clay, 106.

\section{CHAPTER V}

Lime and Calcareous Cements .

Composition of limestone, 109 ; Changes in burning, 110 ; Lime, 110; Hydraulic cements, 111 ; Pozzuolano cements, 111; Hydraulic limes, 112 ; Natural rock cements, 112 ; Portland cement, 113 ; Distribution of lime and cement materials in the United States, 116 ; Limestone for lime, 116 ; Hydraulic limes, 117 ; Natural rock cement, 117 ; Portland cements, 118; Uses of lime, 119 ; Uses of cement, 119; Production of cement, 120 ; References on lime and cement materials, 121 .

\section{CHAPTER VI}

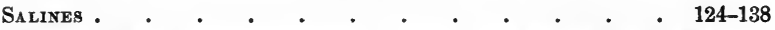

Salt, 124; Occurrence of salt in sea and lake waters, 124 ; Rock salt, 125; Origin of rock salt, 125 ; Natural brines, 127; Salt marshes and soils, 127 ; Distribution of salt in the United States, 127 ; New York, 127; Michigan, 129; Other eastern states, 129 ; Louisiana, 129 ; Kansas, 130 ; Other western states, 130 ; Extraction, 131 ; Uses, 132 ; Production of salt, 132 ; References on salt, 134 ; Borax, 134; Borax minerals, 134; Distribution in United States, 134 ; Uses, 134 ; Production of borax, 136 ; References on borax, 136; Sodium sulphate, 136; References, 137 ; Sodium carbonate, 137; References, 137; Soda niter, 137; References, 138.

\section{CHAPTER VII}

GYPSUM • • • • • • • • • • • • • 139-146

Gypsum, 139 ; Anhydrite, 139 ; Origin of gypsum, 139 ; Gypsite, 140; Distribution in the United States, 140 ; Iowa, 140; Kansas, 141 ; Michigan, 142 ; New York, 142; Other occurrences, 142; Analyses, 143; Uses, 143 ; Production of gypsum, 145 ; References on gypsum, 146.

\section{CHAPTER VIII}

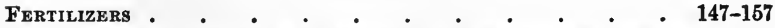

Phosphate of lime, 147; Apatite, 147 ; Amorphous phosphates, 147; Florida phosphates, 148; Land pebble or matrix rock, 149 ; 
River pebble, 149 ; South Carolina phosphates, 150 ; Tennessee phosphates, 150 ; Other phosphate occurrences, 153; Composition, 153 ; Uses, 154 ; Guano, 155 ; Greensand, 155 ; Production, 156 ; References on fertilizers, 157 .

\section{CHAPTER IX}

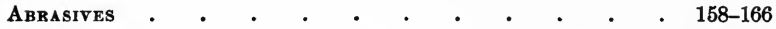

Introductory, 158; Grindstones, 158; Whetstones and oilstones, 159 ; Buhrstones and millstones, 161; Pumice and volcanic ash, 161 ; Infusorial earth and tripoli, 162; Crystalline quartz, 163; Garnet, 163 ; Corundum and emery, 163 ; Artificial abrasives, 165 ; Production of abrasives, 165 ; References on abrasives, 166.

\section{CHAPTER $\mathrm{X}$}

Minor Minerals . • . . . . . . . . 167-203

Asbestos, 167 ; Asbestos minerals, 167 ; Distribution, 167 ; Uses, 169 ; Production of asbestos, 169 ; References on asbestos, 169 ; Barite, 170; Uses, 170 ; Production, 170; References on barite, 171 ; Fluorspar, 171 ; Distribution in United States, 172 ; Uses, 173 ; References on fluorspar, 174; Fuller's earth, 174 ; Production of fuller's earth, 176 ; References on fuller's earth, 176 ; Glass sand, 176 ; References on glass sand, 178 ; Graphite, 178 ; Distribution of graphite in the United States, 178 ; Uses, 179 ; Production of graphite, 180 ; References on graphite, 181; Lithographic stone, 181 ; References on lithographic stone, 183; Lithium, 183; Magnesite, 183; References on magnesite, 184 ; Mica, 184 ; References on mica, 186 ; Mineral pigments, 186 ; Hematite, 186 ; Ochers, 186 ; Slate, 187 ; Gypsum, 187 ; Barite, 187 ; Asbestos, 188 ; Graphite, 188 ; Calcium carbonate, 188; Other paints, 188; Production of mineral pigments, 189 ; References on mineral paints, 189 ; Molding sand, 189 ; References on molding sand, 190 ; Monazite, 190 ; Uses, 191 ; Production of monazite, 191 ; References on monazite, 191 ; Precious stones, 192 ; Diamond, 192 ; Ruby, 193 ; Sapphire, 193 ; Emerald, 193 ; Topaz, 194 ; Turquoise, 194 ; Garnet, 194 ; Opal, 195; Other precious stones, 195; Production of precious stones, 195; References on precious stones, 196; Sulphur and pyrite, 196 ; Sulphur, 196 ; Solfataric type, 196 ; Gypsum type, 197 ; Uses, 198; Production of sulphur, 198; References on sulphur, 199 ; Pyrite, 199 ; Distribution, 199; Uses, 200 ; References on pyrite, 200 ; Strontium, 200 ; Uses, 201 ; References on strontium, 201 ; Talc and soapstone, 201; Uses, 202; Pyrophyllite, 203 ; Production, 203 ; References on talc and soapstone, 203. 


\section{CHAPTER XI}

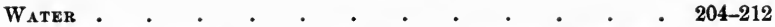

Mineral waters, 204; Distribution of mineral waters in the United States, 205 ; Production of mineral waters, 206 ; References on mineral waters, 207 ; Underground waters, 207 ; Ground water, 207 ; Artesian waters, 209 ; References on underground water, 211.

\section{CHAPTER XII}

\section{Solls and Road Materials}

Soils, 213 ; Origin, 213 ; Residual soils, 213 ; Transported soils, 213 ; Properties of soils, 213 ; Chemical properties, 214 ; Physical properties, 215; Distribution of soils in the United States, 216 ; References on soils, 216 ; Road materials, 217 ; References on road materials, 219.

\section{PART II}

\section{METALLIC MINERALS OR ORES}

\section{CHAPTER XIII}

\section{Ore Deposits}

Definition, 223 ; Gangue minerals, 223 ; Origin of ore bodies, 224 ; Ores of contemporaneous origin, 224 ; Concentration of ores in rocks, 225 ; Formation of cavities, 231 ; Precipitation of metals from solution, 232 ; Replacement or metasomatism, 233 ; Concentration by eruptive after-action or pneumatolysis, 234; Other causes of precipitation, 235; Forms of ore bodies, 236; Fissure veins, 236; Other forms of ore deposits, 241; Secondary changes in ore deposits, 242 ; Weathering or superficial alteration, 242 ; Secondary deposition below water level, 244 ; Value of ores, 245 ; Classification of ore deposits, 246 ; References on ore deposits, 249.

\section{CHAPTER XIV}

IroN

Ores of iron, 251 ; Magnetite, 254 ; Distribution of magnetites in the United States, 254 ; Non-titaniferous magnetites, 254 ; Other occurrences, 254 ; Titaniferous magnetites, 257 ; Magnetite sands, 258 ; Hematite, 259 ; Distribution of hematite ores in the United States, 259 ; Lake Superior region, 259 ; Clinton ore, 266 ; Other 
hematite occurrences, 268; Limonite, 269 ; Bog ores, 269 ; Residual limonites, 270 ; Other occurrences, 271 ; Siderite, 272 ; Production of iron ores, 273; References on iron ores, 276.

\section{CHAPTER XV}

Copper

Ores, 278 ; Impurities in copper ores, 280 ; Superficial alteration of copper ores, 280; Distribution of copper ores in the United States, 281 ; Montana, 282 ; Michigan, 287 ; Arizona, 290 ; Bisbee or Warren district, 290; Jerome district, 292 ; Clifton district, 293 ; Globe district, 294; Appalachian region, 294; Utah, 296 ; California, 297 ; Other occurrences, 298 ; Uses of copper, 298 ; Production of copper, 299 ; References on copper, 301.

\section{CHAPTER XVI}

LEAD AND ZINC

Ores of lead, 303; Ores of zinc, 303; Superficial alteration of lead and zinc ores, 305; Distribution of lead and zinc ores in the United States, 305 ; Lead alone, 306 ; Appalachian belt, 306 ; Southeastern Missouri, 306 ; Desilverized lead, 307 ; Zinc ores alone, 307 ; Eastern and southern states, 308; Sussex County, N.J., 308; Virginia and Tennessee, 310 ; Pennsylvania, 311 ; Lead and zinc ores of the Mississippi Valley region, 311 ; Upper Mississippi Valley area, 311; Ozark region, 314; Origin of the ores, 316; Rocky Mountain states, 318 ; Uses of lead and zinc, 319 ; Uses of lead, 319 ; Uses of zinc, 320 ; Production of lead and zinc, 321 ; References on lead and zinc, 323 .

\section{CHAPTER XVII}

Gold AND Silver .

Ores of gold, 325 ; Ores of silver, 325 ; Mode of occurrence, 326 ; Weathering and secondary enrichment, 327; Classification, 327 ; Geological distribution, 329; Extraction, 329; Distribution of gold and silver ores, 331 ; Cordilleran region, 332 ; Pacific coast Cretaceous gold-quartz ores, 332; Mother Lode belt, 333; Nevada County, 334 ; Central belt of gold-silver ores, 335 ; Mercur, Utah, 336 ; Other occurrences, 337 ; Eastern belt of Tertiary gold-silver veins, 337; Cripple Creek, 338 ; San Juan region, 341 ; Tonopah, Nev., 343 ; Comstock Lode, Nev., 344 ; Other occurrences, 345 ; Auriferous gravels, 346 ; Black Hills region, 350 ; Homestake belt, 
351 ; Siliceous Cambrian ores, 352 ; Michigan region, 352 ; Eastern crystalline belt, 352 ; Alaska, 353; Uses of gold, 357 ; Uses of silver, 358; Production of gold and silver, 358; References on gold and silver, 360 .

\section{CHAPTER XVIII}

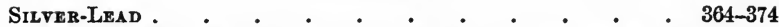

Silver-lead ores, 364 ; Leadville District, Colo., 364 ; Aspen, Colo., 367 ; Other occurrences, 369 ; Park City, Utah, 370 ; Tintic District, Utah, 372 ; Cœur d'Alene, Ido., 372 ; Montana, Nevada, etc., 373 ; References on silver-lead ores, 374 .

\section{CHAPTER XIX}

Alumindm, Manganese, and Mercurt • • • • . 375-395

Ores of aluminum, 375; Distribution of bauxite in the United States, 376 ; Georgia-Alabama, 377 ; Arkansas, 378; New Mexico, 379 ; Uses of aluminum, 379 ; Uses of bauxite, 380 ; Production of bauxite and aluminum, 380 ; References on bauxite and aluminum, 383 ; Manganese, 383; Manganese ores, 383; Origin, 384 ; Distribution of manganese ores in the United States, 384 ; Eastern area, 385; Arkansas, 387 ; Other United States occurrences, 387 ; Uses of manganese, 388; Production of manganese, 388 ; References on manganese, 390 ; Ores of mercury, 390 ; Mode of occurrence, 390 ; Distribution in the United States, 390; California, 391 ; Texas, 392 ; Origin, 393 ; Uses of mercury, 393 ; Production of mercury, 394 ; References on mercury, 395.

\section{CHAPTER XX}

Mnor Metals . . . . . . . . . . 396-417

Ores of antimony, 396 ; Distribution of antimony in the United States, 396 ; Uses, 397 ; Production of antimony, 397 ; References on antimony, 397 ; Arsenic, 398 ; References on arsenic, 398 ; Bismuth, 399; Ores, 399; Distribution, 399; Uses and production, 399 ; Ores of chromic iron, 399 ; Origin of chromite, 400 ; Analyses, 400 ; Distribution of chromic iron in United States, 400 ; Uses, 401 ; Production of chromite, 402 ; References on chromic iron ore, 402 ; Molybdenum, ores and occurrences, 403 ; Uses of molybdenum, 403; Production of molybdenum, 403 ; References on molybdenum, 403; Nickel and cobalt, 403 ; Ores, 403 ; Distribution, 404; Eastern occurrences of nickel, 404 ; Other occurrences, 405 ; Uses of nickel, 405; Uses of cobalt, 406; Production, 406; References on nickel 
and cobalt, 407; Platinum group of metals, 407 ; Platinum, 407 ; Distribution in the United States, 407 ; Uses of platinum, 408; Production of platinum, 408 ; References on platinum, 409 ; Palladium, 409 ; Osmium, 409 ; Iridium, 410 ; Tin, 410 ; Ores, 410 ; Mode of occurrence, 410 ; Distribution in the United States, 411 ; Uses of tin, 412 ; Production of tin, 412 ; References on tin, 413 ; Titanium, 413 ; Ores, 413 ; Occurrence, 413 ; Uses, 414 ; References on titanium, 414 ; Tungsten, 414 ; Ores, 414; Occurrence, 415 ; Uses, 415 ; Production, 415 ; References on tungsten, 416 ; Uranium and vanadium, 416; Ores, 416; Lses, 416; Production, 416; References on uranium and vanadium, 417 .

\section{APPENDIX I}

Statistics of Prondction for 1905 . $\quad$. . . . . . 419-428

\section{APPENDIX II}

Bibliography of Important Papers published since Appearance of First Edition. 


\section{LIST OF ILLUSTRATIONS}

Fie.

1. Diagram showing changes occurring in passage of vegetable tissue to graphite . . . . . . . . . . 13

2. Section in coal measures of western Pennsylvania, showing fire clay under coal beds .

3. Section showing irregularities in coal seam. $a$, split; $b$, parting of shale ; $c$, pinch ; $d$, swell; $e$, cut out . . . . . 17

4. Section of faulted coal seam . $\quad . \quad$. $\quad . \quad . \quad . \quad$. 17

5. Section across Coosa, Ala., coal field, showing folding and faulting characteristic of southern end of Appalachian coal field . $\quad 20$

6. Map of Pennsylvania anthracite field . . . . . . 23

7. Sections in Pennsylvania anthracite field . . . . 24

8. Coal breaker in Pennsylvania anthracite region . . . . 25

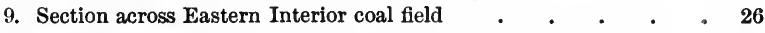

10. Shaft house and tipple, bituminous coal mine, Spring Valley, Ill. . 27

11. Generalized section of Northern Interior coal field . . . $\quad$ - 28

12. Composite section showing structure of lower coal measures in Iowa 29

13. Section of anticlinal fold showing accumulation of gas, oil, and water

14. Map showing oil and gas fields of United States _ $\quad$. $\quad$ - $\quad$ - 49

15. Geological section in Ohio-Indiana oil and gas field . . $\quad 50$

16. Section of Spindle Top oil field near Beaumont, Tex. . . $\quad$ - 51

17. Section in Los Angeles oil field $\quad . \quad$. $\quad . \quad$. $\quad$. 53

18. Map of asphalt and bituminous rock deposits of United States . 58

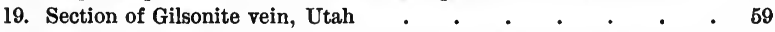

20. Map showing distribution of crystalline rocks (mainly granite) in United States . . . . . . . . . . 76

21. Map showing marble areas of eastern United States _ . 81

22. Section showing cleavage and bedding in slate $\quad . \quad$. $\quad$. $\quad$. 87

23. Section in slate quarry with cleavage parallel to bedding. $a$, purple slate ; $b$, unworked; $c$ and $d$, variegated; $e$ and $f$, green; $g$ and $h$, gray green; $i$, quartzite; $j$, gray with black patches .

24. Section showing formation of residual clay . . . . $\quad$. 93

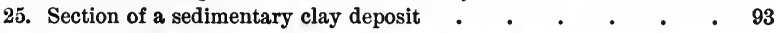

26. Map showing distribution of salt-producing areas in United States, compiled from various geological survey reports . . . 128

27. Map showing gypsum-producing localities of United States . $\quad 141$

28. Map of Florida phosphate deposits . $\quad$ - . . . . $\quad$. 148

29. Map of Tennessee phosphate areas . . . . . . 151 
FIG.

30. Vertical section showing geologic position of Tennessee phosphates

31. Map showing distribution of abrasives in United States 159

32. Section showing occurrence of corundum around border of dunite mass

33. Asbestos vein in serpentine

34. Ideal section across a river valley, showing the position of ground 168 water and the undulations of the water table with reference to the surface of the ground and bed rock

35. Geologic section of Atlantic Coastal Plain, showing water-bearing horizons . . . . . . . . . . .

36. Section from Black Hills across South Dakota, showing artesian well conditions . . . . . . . . . .

37. Replacement vein in syenite rock, War Eagle mine, Rossland, B.C. $a$, granular orthoclase with a little sericite ; $b$, secondary biotite ; $q$, secondary quartz; $c$, chlorite; $b l a c k$, secondary pyrrhotite

38. Section of vein in Enterprise mine, Rico, Colo. The right side shows later banding due to reopening of the fissure.

39. Section showing change in character of vein passing from gneiss $(g)$ to quartz porphyry $(p)$. $\quad . \quad . \quad . \quad . \quad . \quad$.

40. Tabulation of strikes of principal veins in Monte Cristo, Wash., district

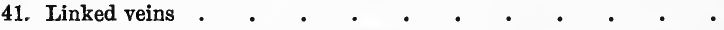

42. Gash vein with associated "flats" and "pitches" - Wisconsin zinc region

43. Section at Bonne Terre, Mo., showing ore disseminated through limestone .

44. Section through Copper Queen mine, Bisbee, Ariz., showing variable depth of weathering . . . . . . . . 243

45. Map showing distribution of iron ores in United States . $\quad$. 253

46. Map of Lake Superior iron regions, shipping ports, and transporta-

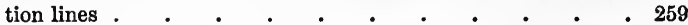

47. Sections of iron ore deposits in Marquette range . . . 260

48. Generalized vertical section through Penokee-Gogebic ore deposit and adjacent rocks, Colby mine, Bessemer, Mich. . . .

49. Generalized vertical section through Mesabi ore deposit and adja-

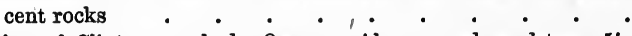

50. Section of Clinton ore beds, Oxmoor, Ala. $a$, red sandstone, $5^{\prime}$; $b$, yellow sandstone, $6^{\prime} ; c$, red sandstone, $15^{\prime} ; d$, ore, $22^{\prime}$, upper $2^{\prime}$ soft; $e$, shale, $6^{\prime} ; f$, rich ore, $2^{\prime} 6^{\prime \prime}$. . . .

51. Section illustrating formation of residual limonite in limestone

52. Map showing distribution of copper ores in United States . . 266 270 282

53. Map of Butte, Mont., district, showing distribution of veins and geology . . • • • • • • • • . 283

54. Section at Butte, Mont., showing mode of occurrence of the ore $\quad 284$ 
rIG.

55. Section across Keweenaw Point

56. Section showing occurrence of amygdaloidal copper, Quincy mine, Michigan . . . . . . . . . . .

57. Geological section at Bisbee, Ariz. . . . . . .

58. Generalized section of ore bodies at Bisbee, Ariz. . . .

59. Section of Morenci district. P, porphyry ; S, unaltered sediments ;

F, fissure veins; M, metamorphosed limestone and shale;

$\mathrm{O}$, contact metamorphic ores; $\mathrm{R}$, disseminated chalcocite .

60. Section of ore body at Bully Hill, Calif. . $\quad$ • . . . $\quad$. 298

61. Map showing distribution of lead and zinc ores in United States $\quad 305$

62. Generalized section of southeastern Missouri lead region _ . 306

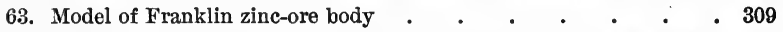

64. Section of Bertha zinc mines, Wythe County, Va., showing irregu-

lar surface of limestone covered by residual clay bearing ore .

65. Section showing occurrence of lead and zinc ores in Wisconsin, with fissure ore in flats and pitches, and disseminated ore in oil rock . . . . . . . . . . .

66. Map of Ozark region . • . • $\quad \cdot \quad \cdot \quad \cdot$

67. Generalized section showing occurrence of lead and zinc ore in southwestern Missouri . . . . . . . . 315

68. A typical hoisting outfit in the southwestern Missouri zinc region . 316

69. Map showing distribution of gold and silver ores in United States .

70. Map and section of portion of Mother Lode district, Calif. Pgv, river gravels, usually auriferous ; $\mathrm{Ng}$, auriferous river gravels. Sedimentary rocks : $J m$, mariposa formation (clay, slate, sandstone, and conglomerate); $C c$, calaveras formation (slaty mica schists). Igneous rocks : $N l$, latite ; Nat, andesite tuffs, breccia, and conglomerate ; $m d i$, meta-diorite; $S p$, serpentine ; $m a$, meta-andesite; ams, amphibole schist

71. Section illustrating relations of auriferous quartz veins at Nevada City, Calif.

72. Section at Mercur, Utah .

73. Map of Colorado showing location of mining regions $\quad . \quad$.

74. Section of vein at Cripple Creek, Colo. . . . . .

75. Geologic map of Telluride district, Colorado, showing outcrop of more important veins

76. Ideal cross section of rocks at Tonopah, Nev. . $\quad . \quad$. $\quad . \quad$.

77. Section of Comstock Lode. D, diorite; Q, quartz; V, vein matter in earlier diabase $(\mathrm{Db}) ; \mathrm{H}$, earlier hornblende andesite;

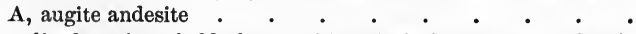

78. Generalized section of old placer, with technical terms. $a$, volcanic cap ; $b$, upper lead; $c$, bench gravel ; $d$, channel gravel . .

79. Section of Homestake Belt at Lead, S.D., showing relation of ancient and modern placers to Homestake Lode . . . 
FIG. PAGR

80. Typical section of siliceous gold ores, Black Hills, S.D. . $\quad$. $\quad 351$

81. Map showing mineral deposits of Alaska as far as known _ . $\quad 354$

82. Sketch map of Douglas Island, Alaska . . . . . . $\quad 355$

83. Cross section through Alaska Treadwell mine on norchern side of

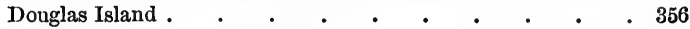

84. Ideal section across Leadville district $\quad$ - . . . . . $\quad$ • 366

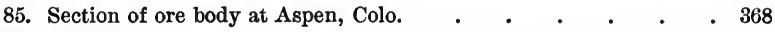

86. Diagrammatic section across a northeasterly lode at Rico, Colo., showing "blanket" of ore . . . . . . . . 369

87. Vein filling a fault fissure, Enterprise mine, Rico, Colo. $\quad . \quad$. 370

88. Section of lead-silver vein, Cœur d'Alene, Ido. ․ . . . $\quad$. 373

89. Geologic map of Alabama-Georgia bauxite region . _ . . $\quad$. 377

90. Section of bauxite deposit. $a$, Residual mantle; $b$, Red sandy clay soil; $c$, Pisolitic ore ; $d$, Bauxite with clay; $e$, Clay with bauxite ; $f$, Talus; $g$, Mottled clay; $h$, Drainage ditch . . 378

91. Map showing Georgia manganese areas . . . . . . 385

92. Section in Georgia manganese area showing geologic relations of

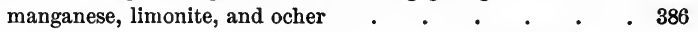

93. Section of Batesville, Ark., manganese region, illustrating geological structure and relation of different formations to marketable and non-marketable ore . $\quad . \quad$. . . . . 387

94. Map of California mercury localities _ . . . . . . 391

95. Map showing Texas mercury region _ . . . . . $\quad$. 392

96. Section of cinnabar vein in limestone, Terlingua, Tex. . . . 393

97. Sketch map showing location of Carolina tin belt . . . . 411 


\section{PLATES}

PLATE

I. Map showing distribution of coal in United States. Frontispiece

II. Fig. 1. Pit working (stripping) near Milnesville, $\mathrm{Pa}$. The mammoth seam is uncovered in bottom of pit . $\quad$ - 31

Fig. 2. Lignite seam, Williston, N.D. . $\quad$. $\quad$ • $\quad . \quad 31$

III. Fig. 1. General view of Tuna Valley, in Pennsylvania oil field 48

Fig. 2. View in Los Angeles, Calif., oil field. Such close spacing of oil derricks tends to hasten the exhaustion of the

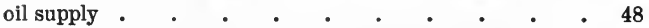

IV. General view of Spindle Top oil field, Beaumont, Tex. . $\quad$ - 51

V. Fig. 1. Quarry of bituminous sandstone, Santa Cruz, Calif. . 60

Fig. 2. Granite quarry, Hardwick, Vt. • • • • $\quad$ 60

VI. Quarry in limestone, Bedford, Ind. $\quad . \quad$. $\quad .80$

VII. Marble quarry, Proctor, Vt. . . . . . . $\quad . \quad 82$

VIII. View of green slate quarry, Pawlet, Vt. - . $\quad . \quad$ - 88

IX. Bank of sedimentary clay, Woodbridge, N.J. This section affords at least five kinds of clay . . . . 103

X. Fig. 1. Quarry of natural cement rock, Cumberland, Md. $\quad 117$

Fig. 2. Marl pit at Warners, N.Y. The dark streaks are peat and the marl is underlain by clay . $\quad$. $\quad 117$

XI. Fig. 1. Interior view of salt mine, Livonia, N.Y. . . 129

Fig. 2. Borax mine near Daggett, Calif. $\quad$ $\quad$ • $\quad$ • $\quad$ - 129

XII. Fig. 1. Gypsum quarry, Alabaster, Mich. Shows gypsum overlain by glacial drift. The dump in foreground is overburden removed from gypsum . • • • • • 139

Fig. 2. Rock phosphate mine near Ocala, Fla. $\quad$ - $\quad$ - $\quad 139$

XIII. Fig. 1. Grindstone quarry, Tippecanoe, Ohio . 159

Fig. 2. Corundum vein between peridotite and gneiss, Corundum Hill, Ga. $\quad$ • $\quad$ • $\quad$ • $\quad$ • $\quad$ • 159

XIV. Fig. 1. View of open cut in magnetite deposit, Mineville, N.Y. The pillars are ore left standing to support the gneiss hanging wall . $\quad . \quad$. . . . . .

Fig. 2. General view of magnetic separating plants and shaft houses, Mineville, N.Y. • • . • • • • 254

XV. Fig. 1. Iron mine, Soudan, Minn. Shows old open pit with

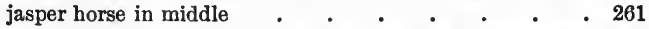

Fig. 2. Outcrop of Clinton iron ore, Red Mountain, near Birmingham, Ala. . • • . • • • . 261 
XVI. General view of Mountain Iron mine, Mesabi Range, Minn. Shows mining of ore with steam shovels and covering of (a) glacial drift . . . . . . . . . 264

XVII. Fig. 1. Pit of residual limonite, Shelby, Ala. . . . . 270

Fig. 2. Old limonite mine, Ivanhoe, Va., showing pinnacled surface of limestone which underlies the ore-bearing clay. The level of surface before mining began is seen on either

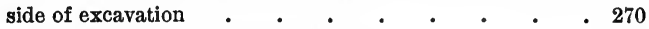

XVIII. Anaconda group of mines, Butte, Mont. . $\quad$ • . . $\quad 285$

XIX. Fig. 1. Smelter of Clifton Copper Co., Clifton, Ariz. $\quad$ - 293

Fig. 2. View of Bingham Cañon, Utah . . . . . 293

XX. Fig. 1. Kennedy mine on the Mother Lode near Jackson, Calif. . . . . . . . 333

Fig. 2. Auriferous quartz veins in Maryland mine, Nevada City, Calif. . . . . . . . . . 333

XXI. Fig. 1. View of Independence mine and Battle Mountain, Cripple Creek, Colo. . $\quad$ • . . . . $\quad$ • $\quad 340$

Fig. 2. General view of region around Tonopah, Nev. . $\quad$. 340

XXII. Fig. 1. Hydraulic mining of auriferous gravel. The sluice box in foreground is for catching the gold . . - . 348

Fig. 2. An Alaskan placer deposit . $\quad$ - . $\quad$ • $\quad .348$

XXIII. Homestake mills, hoists and open cuts at Lead, S.D. - . 351

XXIV. Fig. 1. General view of Rico, Colo., and Enterprise group of mines. . . . . . . . . . 369

Fig. 2. Ontario mine, Park City, Utah . $\quad$. $\quad$ - $\quad$ - $\quad 369$

XXV. Fig. 1. Bauxite bank, Rock Run, Ala. . . . . . 376

Fig. 2. Furnace for roasting mercury ore, Terlingua, Tex. . 376 


\section{ABBREVIATIONS USED}

In the references at the end of each chapter, the volume numbers are given in Roman numerals. Numbers following a : indicate page numbers. The date of publication follows these, and is separated from them by a comma.

Ala. Ind. and Sci. Soc., Proc. - Alabama Industrial and Scientific Society, Proceedings.

Amer. Geol. - American Geologist.

Amer. Inst. Min. Eng., Trans. - American Institute Mining Engineers, Transactions.

Amer. Jour. Sci - American Journal of Science.

Col. Sci. Soc., Proc. - Colorado Scientific Society, Proceedings.

Eng. and Min. Jour. - Engineering and Mining Journal.

Geol. Soc. Amer., Bull. — Geological Society of America, Bulletin.

Jour. Geol. - Journal of Geology.

Min. and Met. - Mining and Metallurgy.

Min. and Sci. P. - Mining and Scientific Press.

Min. Indus. - Mineral Industry.

Min. Mag. - Mining Magazine.

Mo. Geol. Surv. - Missouri Geological Survey.

N. Y. Acad. Sci., Trans. - New York Academy of Science, Transactions.

N. Ca. Geol. Surv. - North Carolina Geological Survey.

Sch. M. Quart. - School of Mines Quarterly.

U. S. Geol. Surv., Mon. - United States Geological Survey, Monograph.

U. S. Geol. Surv., Ann. Rept. - United States Geological Survey, Annual Report.

Zeitsch. f. Prak. Geol. - Zeitschrift für Praktische Geologie. 



\section{PART I}

NON-METALLIC MINERALS 



\section{CHAPTER I}

\section{COAL}

Kinds of Coal. - There is such an intimate gradation between vegetable accumulation now in process of formation and mineral coal that it is generally admitted that coal is of vegetable origin. By a series of slow changes (p. 12), the vegetable remains lose water and gases, the carbon becomes concentrated, and the materials assume the mineralized appearance of coal. To the stages of this process names are given, four of which - peat, lignite, bituminous coal, and anthracite coal - are commonly known.

Peat (79-83). - This, which may represent the first stage in coal formation, is formed chiefly by the growth of the bog moss, sphagnum, in moist places. A section in a peat bog, from the top downward, shows: (1) a layer of living moss, and other plants; (2) a layer of dead moss fibers, whose structure is clearly recognizable, and which grades into (3) a layer of fully formed peat, a dense brownish black mass, in which the vegetable structure is often indistinct.

The following analyses show the difference in composition of the different layers. They also show that while during this change the hydrogen and oxygen diminish, the carbon increases in proportion. 


\begin{tabular}{|c|c|c|c|c|}
\hline MAterial & Carbon & HYDROGEN & OXYGEN & NITROGEN \\
\hline Sphagnum . . . . . & 49.88 & 6.54 & 42.42 & 1.16 \\
\hline $\begin{array}{l}\text { Porous, light brown sphag- } \\
\text { num peat . . . . . }\end{array}$ & 50.86 & 5.8 & 42.57 & .77 \\
\hline Porous, red brown peat . . & 53.51 & 5.9 & \multicolumn{2}{|c|}{40.59} \\
\hline Heavy brown peat. . . . & 56.43 & 5.32 & \multicolumn{2}{|c|}{38.25} \\
\hline Heavy black peat... & 59.7 & 5.7 & 33.04 & 1.56 \\
\hline
\end{tabular}

Lignite. - This substance, also called brown coal, representing the second stage in coal formation, is brownish black or black in color, and often shows a brilliant luster, conchoidal fracture, and brown streak. Where the lumps have formed from trunks or other large, woody masses, the vegetable structure is often clearly visible. It burns readily, but with a long, smoky flame, and hence with lower heating power than the true coal. Because of the large amount of moisture, it often dries out on exposure to the air, and rapidly disintegrates to a powdery mass.

The lignites have been found in the more recent geological periods. Because of the greater age and the greater compression of the vegetable matter, due to the pressure of overlying strata, lignite resembles true coal more closely than peat. In fact, in favorable situations, the alteration of Tertiary and Cretaceous coals has proceeded as far as to transform them beyond the stage of lignite.

$J e t$ is a coal-black variety of lignite, with resinous luster and sufficient density to permit its being carved into small ornaments. It is obtained on the Yorkshire coast of England, where a single seam produced 5180 pounds, valued at $\$ 1250$. According to Phillips, jet is simply a coniferous wood, still showing the characteristic structure under the microscope. ("Geology of England and Wales," p. 278.)

Bituminous Coal. - This represents the third stage in coal formation. It is denser than lignite, deep black, compara- 
tively brittle, and breaks with cubical, or sometimes conchoidal, fracture. On superficial inspection it usually shows no trace of vegetable remains; but in thin sections examined under the microscope, traces of woody fiber, lycopod spores, etc., are commonly seen. Bituminous coal burns readily, with a smoky flame of yellow color, but with much greater heating power than lignite. It does not disintegrate on exposure to air as readily as lignite does. Most bituminous coal is of earlier age than lignite; but where the two occur in the same formation, as in parts of the West, the lignite is commonly in horizontal strata, while the bituminous coal occurs in areas of at least slight disturbance.

When freed of their volatile hydrocarbons and other gaseous constituents by heating to redness in an oven, many bituminous coals cake to a hard mass called coke. Since some bituminous coals do not possess this characteristic, it is customary to divide these coals into coking and noncoking coals.

Cannel coal is a compact variety of non-coking bituminous coal with a dull luster and conchoidal fracture. Owing to its unusually high percentage of volatile hydrocarbons, upon which its chief value depends, cannel coal ignites easily, burning with a yellow flame. (See analysis No. 14.)

Semi-bituminous is a name applied to certain varieties intermediate between bituminous and anthracite coal.

Anthracite Coal. - This coal is black, hard, and brittle, with high luster and conchoidal fracture. It represents the last stage in the formation of coal, and shows no traces of vegetable structure within its mass, although plant impressions are often abundant in the rocks immediately above and belowit. Anthracite has a lower percentage of volatile hydrocarbons and higher percentage of fixed 
carbons than any of the other varieties (p. 8). On this account, it ignites much less easily and burns with a short flame, but gives great heat.

The geological distribution of anthracite is more restricted tinan that of bituminous coal and, in fact, its occurrence is often more or less intimately connected with dynamic disturbances.

Proximate Analysis of Coal. - An elementary analysis of coal (see p. 14) is of comparatively little practical value. Therefore proximate analyses are commonly employed, in which the probable method of combination of the elements is given. By the proximate method the elements in the coal are grouped as moisture, volatile hydrocarbons, fixed carbon, ash, and sulphur.

The following table gives the proximate analysis of a number of coals from all parts of the United States. The analyses are arranged in the following order: Peat, Lignite, Bituminous Coal, Anthracite.

Proximate Analyses of Coal

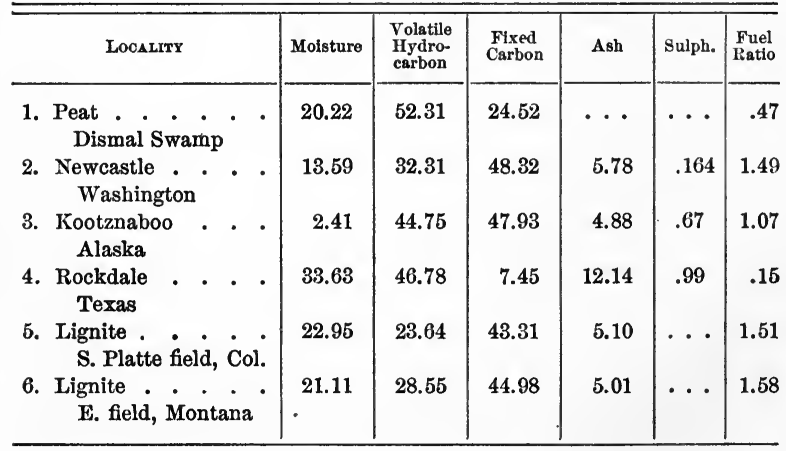


COAL

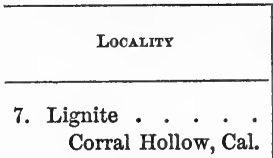

8. Brookville Coal . . Conemaugh, Cambric Co.

9. Pittsburg Coal. . Connelsville, Fayette Co.

10. Hocking Valley Coal Ohio

11. Warrior . . . . Jeff. Co., Ala.

12. Jellico . . . . Campbell Co., Tenn.

13. Brazil Block Coal . Brazil, Ind.

14. Cannel Coal . . . Cannelburg, Ind.

15. Bituminous Coal . . Belleville, Ill.

16. Butler Kentucky

17. Owasso Coal Comp'ny Owasso, Mich.

18. Saginaw Company . Verne, Mich.

19. Fort Dodge . . . Iowa

20. Lexington . . . Missouri

21. Hartshorne Coal . . Hartshorne, I.T.

22. Gwyn's shaft . . Sebastian Co., Ark.

23. Semi-bituminous . . Johnson Co., Ark.

24. Coal No. 1 . . . Thurber, Texas

25. Coking Coal . . Raton field, Col.

\begin{tabular}{|c|c|c|c|c|c|}
\hline Moisture & $\begin{array}{l}\text { Volatile } \\
\text { Hydro- } \\
\text { carbon }\end{array}$ & $\begin{array}{c}\text { Fixed } \\
\text { Carbon }\end{array}$ & Ash & Sulph. & $\begin{array}{l}\text { Fuel } \\
\text { Ratio }\end{array}$ \\
\hline 10.80 & 43.10 & 38.57 & 7.53 & ... & .87 \\
\hline 1.47 & 17.93 & 75.508 & 4.525 & .567 & 4.21 \\
\hline 1.26 & 31.79 & 57.79 & 7.16 & .79 & 1.81 \\
\hline 5.93 & 36.48 & 52.41 & 5.13 & 1.09 & 1.44 \\
\hline 4.83 & 18.95 & 72.76 & 3.28 & .17 & 3.83 \\
\hline 4.40 & 31.56 & 61.87 & 1.86 & .31 & 1.96 \\
\hline 13.82 & 35.16 & 49.96 & 1.06 & 1.47 & 1.42 \\
\hline 1.47 & 49.08 & 26.35 & 23.10 & 1.48 & .53 \\
\hline 5.50 & 39.50 & 54.60 & 5.40 & . . & 1.38 \\
\hline . • & 30.66 & 54.94 & 11.00 & 2.544 & 1.71 \\
\hline 7.58 & 35.70 & 52.96 & 3.76 & 1.50 & 1.48 \\
\hline 5.82 & 39.79 & 45.15 & 9.24 & 3.83 & 1.13 \\
\hline 7.48 & 39.52 & 45.54 & 8.44 & 5.28 & 1.15 \\
\hline 9.24 & 29.01 & 42.19 & 15.18 & 4.38 & 1.45 \\
\hline 1.68 & 41.00 & 51.91 & 5.41 & 2.72 & 1.26 \\
\hline .892 & 14.57 & 77.09 & 6.24 & 1.19 & 5.28 \\
\hline 1.10 & i1.27 & 72.83 & 12.04 & 2.74 & 6.46 \\
\hline .88 & 31.57 & 56.81 & 8.93 & 1.47 & 1.79 \\
\hline .75 & 31.13 & 57.07 & 11.05 & .. & 1.80 \\
\hline
\end{tabular}




\begin{tabular}{|c|c|c|c|c|c|c|}
\hline Localiti & Moisture & $\begin{array}{l}\text { Volatlle } \\
\text { Hydro- } \\
\text { carbon }\end{array}$ & $\begin{array}{c}\text { Fixed } \\
\text { Carbon }\end{array}$ & Ash & Sulph. & $\begin{array}{l}\text { Fuei } \\
\text { Ratio }\end{array}$ \\
\hline $\begin{array}{l}\text { 26. Newcastle . . . } \\
\text { Washington }\end{array}$ & 7.992 & 29.031 & 53.806 & 8.023 & 1.148 & 1.85 \\
\hline $\begin{array}{l}\text { 27. Bituminous Coal . } \\
\text { Canyon City, Col. }\end{array}$ & 6.21 & 31.32 & 52.47 & 11.10 & $\cdots$ & 1.65 \\
\hline $\begin{array}{l}\text { 28. Anthracite } \cdot \text { Crested Butte, Col. } \\
\text { Cre }\end{array}$ & 1.58 & 6.70 & 87.46 & 4.26 & .58 & 13.05 \\
\hline $\begin{array}{l}\text { 29. Anthracite } \\
\text { Cerillos field, New } \\
\text { Mexico }\end{array}$ & 2.90 & 3.18 & 88.91 & 5.21 & $\cdots$ & 27.96 \\
\hline $\begin{array}{l}\text { 30. Mammoth } \cdot \dot{\text { W. Middle field, Pa. }} \\
\text { W. }\end{array}$ & 3.163 & 3.717 & 81.143 & 11.078 & .899 & 21.83 \\
\hline $\begin{array}{l}\text { 31. Mammoth } \\
\text { N. Middle field, Pa. }\end{array}$ & 3.421 & 4.381 & 83.268 & 8.203 & .727 & 19.00 \\
\hline
\end{tabular}

The moisture can be driven off at $100^{\circ} \mathrm{C}$. and is usually highest in peat and lignite; the volatile hydrocarbons are the easily combustible elements, and decrease toward the anthracitic end of the series; the fixed carbon burns with difficulty and is highest in the anthracite coals. The ash represents noncombustible mineral matter and bears no direct relation to the kind of coal; and the same is true of sulphur, which is present as an ingredient of pyrite or gypsum.

The value of coal for fuel or other purposes is determined mainly by the relative amounts of its fuel constituents, viz. the volatile hydrocarbons and the nonvolatile or fixed carbons. The fuel value, or fuel ratio, is determined by dividing the fixed carbon percentage by that of the volatile hydrocarbons.

The fixed carbon represents the heating element of the coal, while the volatile hydrocarbons burn easily, but have little heating power. The heating power and fuel ratio will, therefore, increase together. This increase in the heating power of the coal is only true, however, up to a certain point, after which the difficulty in making the coal burn offsets the extra amount of heat developed. Coals with a high percentage of fixed carbon develop great heating power, while those lower in fixed carbon and high in volatile hydrocarbons lack in heating power, but are free burning. 
Moisture is a nonessential constituent of coal. It not only displaces so much combustible matter, but requires heat for its evaporation. When present in large amounts it often causes the coal to disintegrate while drying out. It ranges from 1 per cent in anthracite to 20 or 30 per cent in lignites.

Ash also displaces combustible matter, but otherwise it is in most cases an inert impurity. The clinkering of coal is commonly due to a high percentage of fusible impurities in the ash, and for metallurgical work the composition of the ash often has to be considered.

The following analyses will also serve to illustrate the composition of the ash:-

Ash Analyses

\begin{tabular}{|c|c|c|c|c|c|c|c|c|c|c|}
\hline & $\mathrm{SiO}_{2}$ & $\mathrm{Al}_{2} \mathrm{O}_{3}$ & $\mathrm{Fe}_{2} \mathrm{O}_{3}$ & $\mathrm{CaO}$ & $\mathrm{MgO}$ & $\mathrm{MnO}_{2}$ & $\mathrm{SO}_{3}$ & $\begin{array}{l}\text { Alka- } \\
\text { lies }\end{array}$ & $\begin{array}{l}\text { Chlo- } \\
\text { rine }\end{array}$ & $\mathrm{P}_{3} \mathrm{O}_{5}$ \\
\hline $\begin{array}{l}\text { Peat, average of } \\
\text { several . . . }\end{array}$ & 25.50 & 5.78 & 18.70 & 24.00 & 3.20 & & 7.50 & 1.72 & .60 & 2.56 \\
\hline Lignite . . . & 30.14 & 13.48 & 11.70 & 23.59 & .88 & 3.32 & 14.22 & & & \\
\hline Bituminous Coal & 34.32 & 14.62 & 22.94 & 14.85 & 1.42 & 1.16 & 10.97 & & & \\
\hline
\end{tabular}

Sulphur is an objectionable impurity in steaming coals on account of its corrosive action on the boiler tubes. It is also undesirable in coals to be used for metallurgical purposes and gas manufacture.

Origin of Coal (4). - It has been shown that there are gradations between unquestioned plant beds and mineral coal, and that coal, besides containing the same materials as plant tissue, often shows the presence of plant fibers, leaves, stems, seeds, etc. Moreover, stumps or trunks of trees are sometimes found standing upright in the coal, with their roots penetrating the underlying bed of clay (5), just as trunks of trees at present stand in bogs. While these facts point unmistakably to a vegetable origin of coal, it is less easy to understand the exact manner in which the great accumulations of vegetable matter have been made, and the changes from plant tissue to mineral 
coal. Each of these points, therefore, demands further consideration.

Conditions of Vegetable Accumulation (4). - At present there are several conditions under which plant remains accumulate to considerable depth over areas in some cases of large size. All of these are closely associated with water, either fresh or salt, because plant remains falling in water have their decay so retarded by the exclusion of air that accumulation is possible. Of these the following are the most important: (1) accumulation due to algæ on the sea bottom beneath a sargasso sea; (2) marine swamps, including salt marshes and mangrove swamps; (3) delta deposits ; (4) peat bogs ; (5) coastal plain marshes.

While accumulations made in any one of these ways may form coal beds, and while individual beds may be formed which are due to any of these causes, to many of them there are such objections as to render them extremely improbable as general explanations for the great number of widely extended deposits of coal. The theory of accumulation from deposits of algæ, for example, demands deep water of an open ocean for the circulation of ocean currents. But most coal beds are evidently formed either on the land or else in shallow water of lakes, lagoons, or seacoast swamps.

To the theory of various swamps there are two serious objections: (1) that in such deposits as are now forming, the currents are bringing more fragmental sediments than are commonly present in coal beds; (2) that at present only one kind of tree, the mangrove, is adapted to growth in salt water. It is, of course, possible that in earlier ages the number of trees adapted to this mode of life was far greater. 
Streams are bringing plant remains to lakes or oceans and incorporating them in their deltas; but nowhere are such extensive accumulations now forming as to make large coal fields in this manner. Moreover, the amount of sediment brought in such places would seem to exclude the possibility of the deposit of large areas of vegetable matter free from a great admixture of sediment. The combination of this source of vegetable supply with that caused by the growth of marine or fresh-water swamp plants in the delta lagoons would increase the chances of the formation of coal beds by this means; but even with this addition, it seems impossible to accept this as a general theory for the formation of extensive beds of coal.

It is a well-known fact that thick deposits of vegetable matter, often covering areas of several square miles, are formed in the peat bogs that in so many places represent the last stage of lake or pond filling in cool, temperate climates. Each of these bogs would, under favorable circumstances, change to a bed of coal, and some of them are extensive enough to form coal beds of large size. But such bogs are, compared to our larger coal fields, far too limited in area to admit of the acceptance of this explanation to account for great coal fields without assuming far more widespread bog-forming conditions than any at present known.

Perhaps the most perfect resemblance to coal-forming condition is that now found on such coastal plain areas as that of southern Florida and the Dismal Swamp of Virginia, North Carolina. Both of these areas are very level, though with slight depressions in which there is either standing water or swamp conditions. In both regions there is such 
general interference with free drainage that there are extensive areas of swamp, and in both there are beds of vegetable accumulations. In each of these areas there is a general absence of sediment and therefore a marked variety of vegetable deposit. If either of these areas were submerged beneath the sea, the vegetable remains would be buried and a further step made toward the formation of a coal bed. Reelevation, making a coastal plain, would permit the accumulation of another coal bed above the first, and this process might be continued again and again.

In support of the theory that coal was accumulated in some such situation as this, are a number of facts: (1) the coal beds occur over wide areas in sediments which were deposited near land borders and which may therefore have been again and again raised above sea level to form extensive coastal plains ; (2) there are evidences of land conditions revealed in the workings of some mines; (3) the enormous area of some coal fields call for some such widespread conditions as coastal plains might provide; (4) the slight admixture of sediment indicates the absence of conditions of sediment supply, e.g. rivers, waves, tidal currents, and windformed currents ; (5) vegetable accumulations made in such situations would require but slight changes in land level to be buried beneath sedimentary strata as the coal beds have been.

Chemical Changes occurring during Coal Formation.Dead plant tissue when exposed to the air oxidizes rapidly and decays, all of the gaseous elements passing off, leaving only the mineral matter which the plant tissue contained. The exclusion of air caused by the presence of water, as in a pond or a swamp, greatly retards oxidation; but, as it slowly 
proceeds the oxygen, nitrogen, and hydrogen of the plant tissue, together with some of the carbon pass off in the form of carbon dioxide $\left(\mathrm{CO}_{2}\right)$, carbon monoxide ( $\left.\mathrm{CO}\right)$, marsh gas $\left(\mathrm{CH}_{4}\right)$, and water. As a result, as the process continues an increasing percentage of carbon is left behind. The change is also accompanied by a change in color to deep brown, and finally to black.

The changes that take place in the passage of vegetable matter into coal are graphically shown in the following diagram prepared by the late Professor Newberry:-

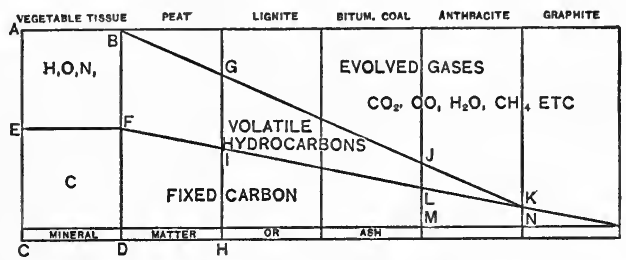

FIG. 1. - Diagram showing changes occurring in passage of vegetable tissue to graphite. After Newberry.

In this diagram the rectangle $A B C D$ represents a given volume of fresh vegetable matter, which contains a small percentage of mineral matter, the rest being organic substances consisting roughly of 50 per cent carbon (EFCD) and 50 per cent hydrogen, oxygen, and nitrogen (ABEF). In the change from fresh vegetable tissue to peat, part of these four elements pass off as gaseous compounds, so that the remaining volume of peat is less (BGDH) than the original volume of vegetable matter (ABCD). Since, however, $\mathrm{H}, \mathrm{O}$, and $\mathrm{N}$ have passed off in larger amounts than the carbon, the percentage of the latter in the peat will be higher than it was in the fresh plant tissue. (Compare BFGI and 
FIDH with ABEF and EFCD.) The actual weight of mineral matter will be the same, but its percentage will be larger. This change continued will result finally in anthracite, the last of the coal series, in which the per cent of carbon (LKMN) is high and that of the other organic elements low (JKL). The amount of compression that occurs in such changes as those illustrated in the diagram may be understood when it is stated that it is estimated that from 16 to 30 feet of peat are required to make one foot of true coal.

The following analyses of various grades of coal from peat to anthracite clearly illustrate this gradual concentration of carbon by loss of volatile elements.

Elementary Analyses of Coals

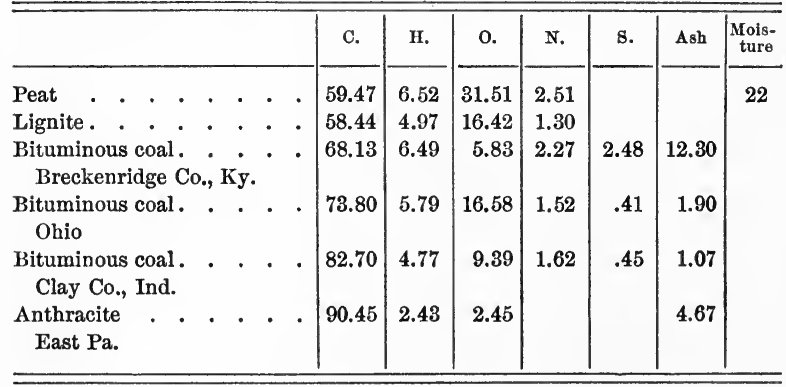

Effect of Heat and Pressure. - While the first stage in coal formation is brought about simply by the exclusion of air, for further development pressure seems necessary. Even in peat beds the lower layers are under the gentle pressure of the upper layers; but peat is not changed even to lignite until buried under many feet of sediments. Great pressure, possibly aided by heat, seems necessary for the 
change from lignite to bituminous coal; and long periods of time are apparently required for the slow changes to take place. That heat may sometimes have been present is indicated by the evidence of rock folding that is sometimes, though by no means invariably, present in bituminous coal areas.

Most of the anthracite coal in the United States orcurs in the highly folded Appalachians of Pennsylvania. Such folding must have been productive of much heat and pressure, and that the folding has produced the anthracite is by many believed to be proved by the fact that these coal beds pass into bituminous coal when traced southward or westward into areas of less disturbances. This view is questioned by some geologists, especially J. J. Stevenson, who has argued that the anthracite has not been developed from bituminous coal by metamorphism, but that the volatile constituents were partly removed by longer exposure of the vegetable matter to oxidation before burial (7).

There are some cases, as in the Cerillos coal field of New Mexico (50), where anthracite probably has been produced by heat. Here a bituminous coal has been deprived of its volatile matter and converted into anthracite in those portions of the bed near an intrusion of andesite. A similar change has taken place in the Crested Butte district of Colorado (29).

Structural Features of Coal Beds. - Outcrops (1,3).-The outcrop of a coal bed is usually easily recognizable on account of its color and coaly character; but unless the exposure is a rather fresh one, the material is disintegrated and mellowed, the wash from it mingling with the soil, and 
if the outcropping bed is on a hillside, often extending some feet down the slope. This weathered outcrop has been termed the "smut" or "blossom" by coal miners. In areas where the beds have been tilted and the slopes are

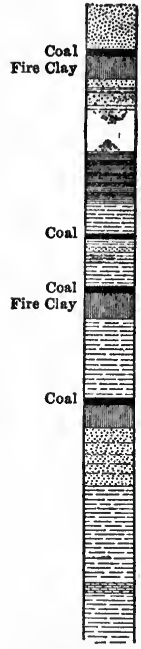

Fra. 2. - Section in coal measures of western Pennsylvania, showing fire clay under coal beds. After Hopkins. steep, the outcrops of coal can usually be easily traced; but in regions where the dip is low and the surface level, the search for coal is often attended with difficulty, which is increased if the country is covered with glacial drift. In such eases boring or pitting is commonly resorted to.

Associated Rocks. - Most coal beds are interbedded with shales, clays, or sandstones, though conglomerates or limestones are at times also found in close proximity. Coal beds are often underlain by a bed of clay, which in some regions is of refractory character (Fig. 2); but the widespread belief that all these under clays are fire clays is unwarranted.

Variations in Thickness.-Coal beds or "seams" are rarely of uniform thickness over large areas; indeed, a bed which is of sufficient thickness to work in one mine may be so thin in a neighboring mine as to be scarcely noticeable. This irregularity is in some cases due to variations in thickness of vegetable accumulations, in other cases to local squeezing of the coal bed subsequent to its formation. These thinnings and thickenings are commonly called "pinchings" and "swellings" (Fig. 3). In regions of pronounced folding, the coal beds are usually 
found in separate synclinal basins, the intervening anticlinal folds having been worn away.

Other Irregularities. - Splitting (Fig. 3) is a common feature of many coal seams. The Mammoth bed, so prominent in most of the anthracite basins of Pennsylvania, splits

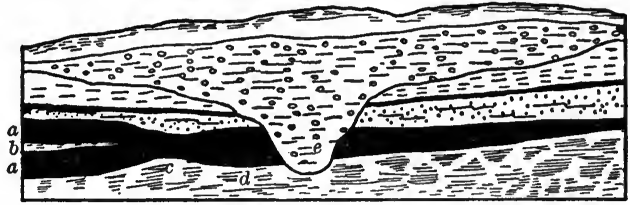

Frg. 3. - Section showing irregularities in coal seam. $a$, split; $b$, parting of shale; $c$, pinch; $d$, swell; $e$, cut out.

into three separate beds in the Wilkesbarre basin. This splitting is caused by the appearance of beds of shale (called "slate" by coal miners), which often become so thick as to split up the coal seam into two or more beds. When narrow, such a bed of slate is called a parting. The Pittsburg seam of western Pennsylvania shows a fire-clay parting or "horseback" (Fig. 3) from six to ten inches thick over many square miles.

In addition to these "slate" partings, which run parallel with the bedding, others are often encountered which cut across the beds from top

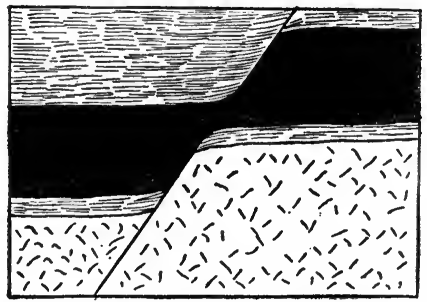

Fia. 4. - Section of faulted coal seam. After Keyes, Ia. Geol. Surv., II: 86, 1894.

to bottom. These in some cases represent erosion channels, formed in the coal during or subsequent to its formation, and later filled by the deposition of sand or clay. In other 
cases they are due to the filling of fissures formed during the folding of the sitrata.

Faulting (Fig. 4) is not an uncommon feature of coal beds, and the coal is sometimes badly crushed on either side of the line of fracture. The amount of throw and the number and kind of faults may vary, so that one might expect normal, reverse, overthrust, and even step faults.

Coal Fields of the United States (Pl. I). - Coal in commercial quantities occurs in twenty-seven of the forty-seven states and territories as well as in Alaska. 'These occurrences can be grouped into the following ten fields:-

(1) Appalachian, including parts of Pennsylvania, Ohio, Maryland, Virginia, West Virginia, Eastern Kentucky, Tennessee, Georgia, and Alabama . . 71,291 sq. mi.

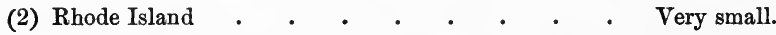

(3) Atlantic Coast Triassic, including parts of Virginia and North Carolina. . . . . . . 1070 sq. mi.

(4) Eastern Interior, including parts of Indiana, Illinois, and western Kentucky . • • • • . 58,000 sq. mi.

(5) Northern Interior, including parts of Michigan - 11,300 sq. mi.

(6) Western Interior, including parts of Iowa, Missouri,

Nebraska, and Kansas . . . . . . 66,200 sq. mi.

(7) Southwestern field, including parts of Indian Territory, Arkansas, and Texas . . . . . 27,876 sq. mi.

(8) Rocky Mountain field, including parts of South Dakota, Montana, Idaho, Wyoming, Utah, Colorado, and New Mexico . . . . . . . 43,610 sq. mi.

(9) Pacific Coast, including parts of Washington, Oregon,

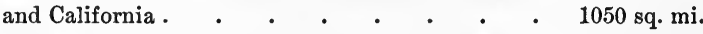
(10) Alaska

The above grouping does not include the areas of lignitebearing formations, although these are shown on the map 
(Pl. I). According to Hayes there are in Montana, the Dakotas, and Wyoming, approximately 56,500 square miles of lignite-bearing formations, chiefly of Cretaceous age. A series of fields in the Tertiary of Alabama, Mississippi, Louisiana, Arkansas, and Texas cover approximately as large an area.

The estimates given above are of course only approximate, and some of these fields may be extended in the future by the development of areas now classed as unproductive. This applies especially to those in which the coal lies too deep to be profitably mined at present. It is a noteworthy fact that the production of the fields is by no means proportional to their areas. (Compare above list with table, p. 34.) Proximity to markets, value of the coal for fuel, and relative quantity of coal per square mile of productive area, are factors of importance in determining the output of a field.

Geologic Distribution of Coals in the United States. - The coal-bearing formations of the United States range in age from Carboniferous to Tertiary. Carboniferous coals occur east of the 100th meridian, Cretaceous coals between the 100 th and 115th meridian, and the Tertiary coals chiefly between the 120th meridian and the Pacific coast. Exceptions to this distribution are the occurrence of a small area of Triassic coals in Virginia and North Carolina, and a large Tertiary area of lignite in the Gulf States. This indicates that during the coal-forming periods there was in North America a slow westward shifting of the zone in which conditions favorable to coal formation occurred, the only exceptions being those mentioned above.

The Carboniferous coals are commonly grouped into several well-marked and clearly separated areas; but this isolation is probably the result of folding and erosion, all 
excepting the Michigan field having apparently been originally continuous. To a certain extent the same is true

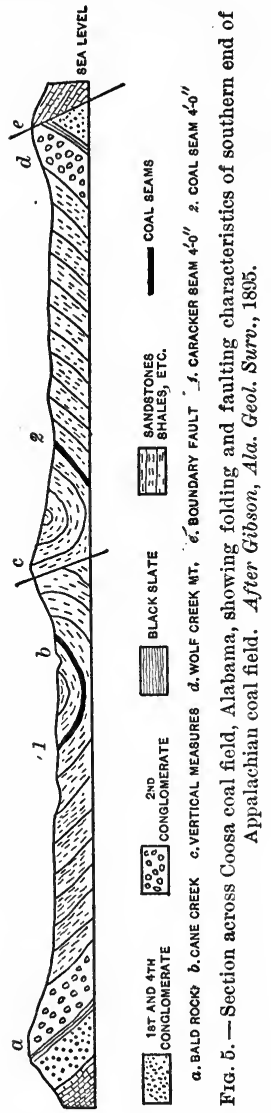
of the Rocky Mountain coal fields. These have often been seriously disturbed by post-Cretaceous uplifts, which in many instances have improved the qualities of the coal. As a whole, the Tertiary coals are medium to low grade, though in some sections, notably in Washington, they are of excellent quality.

Appalachian Field $(12,15,18,55,58$, 60 , etc.). - This, the most important coal field in the United States, extends 850 miles, from northeastern Pennsylvania to Alabama, and about 75 per cent of its area contains workable coal. At the southern end the coal measures pass beneath the coastal plain deposits, and they may connect with the Arkansas coal measures beneath the Mississippi embayment.

Being closely associated with the Appalachian Mountain uplift, the coal measures of this region partake of the structural features of the Appalachian belt. Thus, while the strata of the western portion are either horizontal or only slightly bent, those farther east are often highly folded (Fig. 7), and in the southern 
Appalachians the strata are both folded and faulted (Fig. 5). Extensive erosion following the folding of the coal measures has resulted in the development of a number of basins.

The coal measures of the Appalachian field consist of a great thickness of overlapping lenses of conglomerate, sandstone, shale, coal, and some limestones, and owing to this lenticular character of the deposits, and to local thickenings, it is difficult to trace individual beds of coal over wide areas, or to correlate sections at widely separated points.

The middle Carboniferous, or Pennsylvanian, includes most of the coal beds of the Appalachian area, and is divided into the following five major subdivisions which are recognizable throughout the field: (1) Dunkard or Upper Barren Measures; (2) Monongahela or Upper Productive Measures; (3) Conemaugh or Lower Barren Measures; (4) Alleghany or Lower Productive Measures; (5) Pottsville or Seral Conglomerate.

This classic section was first worked out in Pennsylvania, and has since been identified in other parts of the Appalachian field. At the time it was made, the second and fourth members were thought to be the only ones carrying coal, and hence the name "Productive"; but since then the Pottsville has been found to be locally productive, and a few seams have been found even in the Barren Measures.

The Appalachian field is divisible into two parts of very unequal size: (1) the anthracite field of northeastern Pennsylvania; and (2) the bituminous area, which occupies the balance of the field.

Bituminous Area $(15,20)$. - In western Pennsylvania, where we have the type section of the Carboniferous of eastern 
America, about 95 per cent of the coal mined comes from the Alleghany and Monongahela groups, though beds of coal are found as high as the Dunkard and as low as the Pottsville. While most of the coal beds are of limited extent, the celebrated Pittsburg bed, at the base of the Monongahela, with an average thickness of 6 feet over 2500 sq. mi. of its area, has an estimated original capacity of $10,000,000,000$ tons of available coal, thus making it one of the most important bituminous coal beds in the world. This same bed is recognizable and important in Ohio and Maryland.

In the southern portion of the Appalachian field, the coal beds lie in the Pottsville, which here is much thicker than farther north, reaching a maximum thickness of 5000 to 6000 feet, as against 300 feet in western Pennsylvania, and most of the workable coal occurs in its upper portion.

Character of Appalachian Bituminous Coals. - The coals of this field differ greatly from place to place. In general there is a decrease in volatile hydrocarbons from the west toward the east and southeast. Good coking coals are found throughout the field. Those of Maryland are semi-bituminous, and have a high reputation for steaming purposes; but those of Pennsylvania include many coking coals, and are hence of further value in smithing, and coke and gas manufacture. While much of the coke is used locally by the great metallurgical establishments, a large amount is also shipped to other states, even in the far Northwest.

The markets for these coals are chiefly in the South where, excepting along the seacoast, they come into successful competition with the Pennsylvania anthracite for domestic purposes. In the north and northwest they compete less successfully with coals from the interior fields.

Pennsylvania Anthracite Field (18). - This field (Fig. 6) lies in the eastern central part of the state, covering an area 
of about 3300 square miles, about one-seventh of which is underlain by workable coal measures. Intense folding (Fig. 7) has placed some of the coal in the synclinal troughs where it has been preserved from erosion which has removed the coal from the intervening anticlines. Therefore the anthracite is found in a number of more or less separated narrow basins. It has been estimated that from 94 to 98 per cent of the coal originally deposited has been removed from this field by denudation.

The coal measures of the anthracite district consist of beds of sandstone, shale, and clay, with coal beds at intervals varying from a few feet to several hundred feet, though rarely exceeding 200 feet. The coal. beds, which vary in thick-

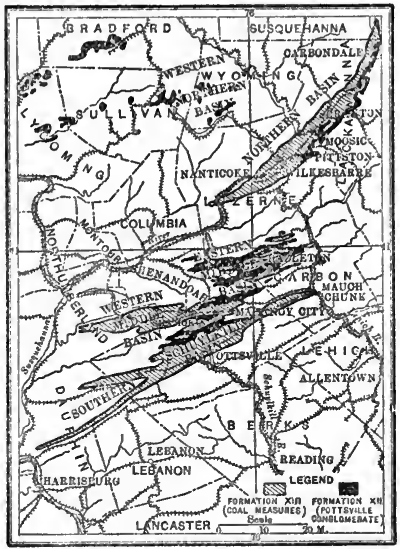

Fig. 6. - Map of Pennsylvania anthracite field. After Stoek, U.S. Geol. Surv., 22d Ann. Rept., III.

ness from a few inches to 50 or 60 feet, occur throughout the entire section of the coal measures, but are most important in the lower 300 to 500 feet. Beneath the Productive Measures is the hard Pottsville conglomerate, which forms an important stratigraphic horizon, recognizable by its lithological character and bold outcrops. Local variations in the coal beds, and lack of uniformity in naming them, have rendered their correlation in the different fields more or less difficult. 
The position of the coal beds and physical characteristics of the coal have necessitated the use of special methods of mining and of treatment after mining. Sharpness of folding and steep dips prevail, these introducing many mining problems not found in bituminous regions. When brought to the surface, it consists of lumps varying in size and mixed with more or less shaly coal, called "bone," so that, before shipment to market, it is necessary to break, size, and sort it. This is done

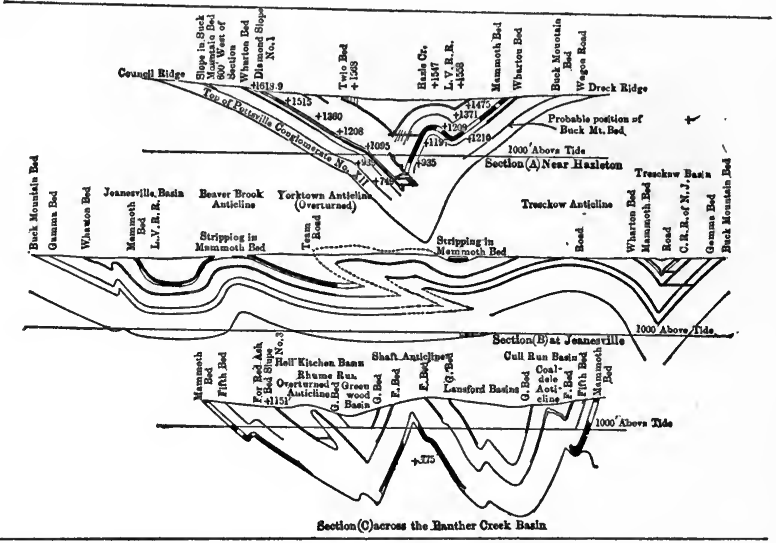

FIG. 7.-Sections in Pennsylvania anthracite field. After Stoek, U. S. Geol. Surv., $22 d$ Ann. Rept., III: 72.

in a coal breaker (Fig. 8), in which the coal is crushed in rolls, and sized by screens, while the slate is separated either by hand, automatic pickers, or jigs. These breakers are a prominent feature of the anthracite region, and much money has been spent in increasing their efficiency. As the result of years of mining, the refuse from the breakers, consisting of a fine coal-dust and bone, termed "culm," has accumulated in enormous piles. Much of it is now being washed to save the finer particles of clean coal; and much is also washed into the mines to support the roof, so that the pillars of coal, originally left for that purpose, can be extracteci. 
On account of its cleanliness and high fuel ratio, anthracite coal is much prized for domestic purposes. Most of that mined is marketed in the eastern and middle states, although small quantities are shipped to the western states,' especially those that can be reached by way of the Great Lakes.

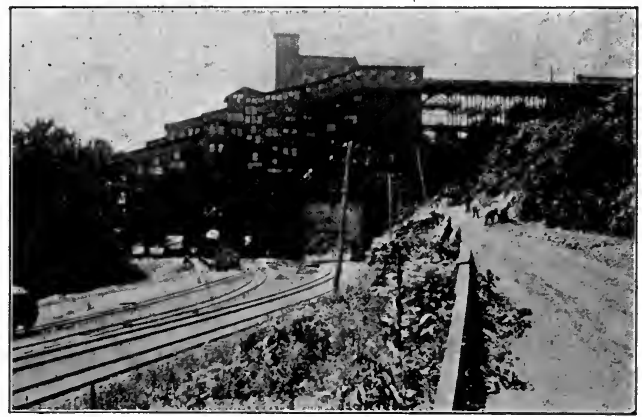

FIG. 8. - Coal breaker in Pennsylvania anthracite region.

Rhode Island Field $(63,64)$. - A small area of metamorphosed, folded, and faulted Carboniferous occurs in the Narragansett Bay region of Rhode Island, extending up into Massachusetts. The inclosing strata of conglomerate and clay are often changed to schist, and the coal to a form of anthracite so nearly pure earbon as to be exceedingly difficult to burn. In fact, in places the coal has been metamorphosed to graphite. Attempts to utilize this have not met with much success on account of the high percentage of impurities which the material contains.

The Triassic Field (52). - This coal field which is more important historically than economically, having been worked as early as 1700 , includes several small steep-sided basins lying in the Piedmont region of Virginia and North Carolina. It is probable that the coal-bearing beds of the several areas, originally horizontal, were formerly continuous, having been separated by folding, faulting, and denudation. In addition to this, the coal is cut by dikes and sheets of igneous rock, which have locally altered it to natural coke or carbonite. 


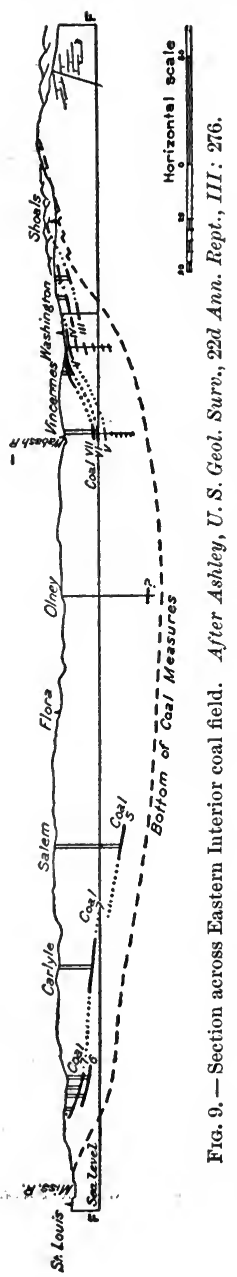

Eastern Interior Field $(13,32)$. - This field is an oval, elongated basin (Fig. 9) extending northeast and southwest, with the marginal beds dipping gently toward the lowest portion, which lies in Illinois, where the beds are nearly horizontal.

The coal-bearing rocks rest uncomformably on lower Carboniferous, Devonian, and Silurian strata, the basal member being a sandstone probably the equivalent of the Pottsville. The entire section of coal-bearing rocks, attaining a thickness of 1200 feet, belongs to the Coal Measures, although the upper part may be of Permian age, and the highest workable coal beds are classed as Freeport or Conemaugh. The coal seams occur in the lower portion of the section, and hence outcrop around the margin, and the mining operations are confined to a narrow belt, because near the center of the basin the coal beds underlie too great a thickness of unproductive strata to permit of profitable working under present conditions.

Great difficulty has been encountered in attempts at correlation of the coal beds of different parts of the field, because of the varying section shown 
from place to place, and lack of continuity of the beds. In consequence, the custom has arisen of giving the coal beds numbers instead of names.

In Indiana coal is found in at least twenty horizons with workable beds in not less than eight; but at any given point the number of workable beds never exceeds three, and in places there is only one. One of the Indiana coals is known as "block coal," the name arising from the fact that the presence of joint planes at right angles causes the coal to break into blocks.

There are many coal beds in Illinois worked at depths of from 50 to 200 feet or more; but there is a marked

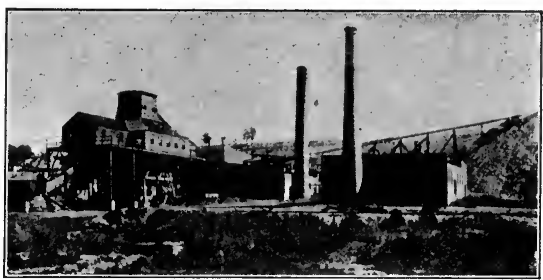

Fic. 10. - Shaft house and tipple, bituminous coal mine, Spring Valley, Ill.

absence of stratigraphic knowledge regarding this part of the field. In Kentucky, on the other hand, there are only two workable coal beds of decided importance, and fully 75 per cent of the coal produced in the strata comes from the upper of these. This bed is so persistent that it underlies a part of the whole of 8 counties, with an average thickness of 5 feet and at a depth commonly less than 200 feet.

The coals of the eastern interior field, although varying widely in quality, are all bituminous. On account of their higher percentage of ash and sulphur, they are little used for coking. Most of the coal used in and near this field is supplied from it; but even within the field the Appalachian coals enter into competition. The Cannel coal found near Cannelsburg, Kentucky, which is the only good gas producer found in this field, finds a ready market.

Northern Interior Field (43). - This field forms a large basin in which the coal dips irregularly from the margin toward the center (Fig. 11), but on account of the heavy 
mantle of glacial drift it has been difficult to determine its exact boundaries, and prospecting is necessarily done by means of drilling. The coal measures attain a total thickness of 600 to 700 feet in the center of the basin, and include 7 horizons of workable coal with an average thickness of 2 feet and rarely exceeding 4 feet. Coal is found near the center of the basin at depths of 400 feet or more, though the beds that are mined are mostly
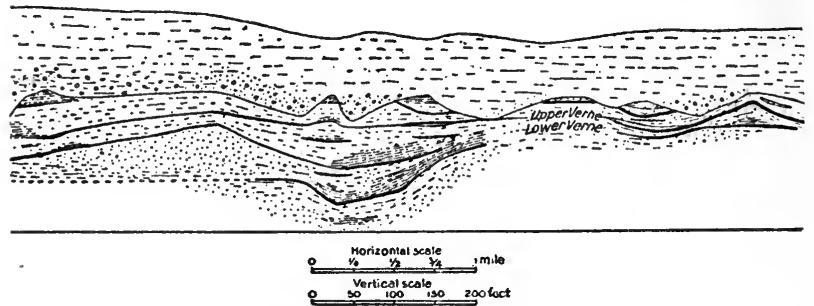

Fia. 11. - Generalized section of Northern Interior coal field. After "Lane, U. S. Geol. Surv., 22d Ann. Rept., III: 316.

at depths of 100 to 250 feet. All the coals are bituminous and used chiefly for fuel, but some are coking, and others will probably prove of value for gas manufacture.

Western Interior Field and Southwestern Fields (14). These two fields form a practically continuous belt of coalbearing formations, extending from northern Iowa southwestward for a distance of 880 miles into central Texas. Throughout most of this area the beds lie horizontal, or have a gentle westward dip averaging 10 to 20 feet per mile. A notable exception is found in the beds of eastern Indian Territory and Arkansas which are rather strongly folded, reminding one of the Pennsylvania anthracite area. 
Western Interior Field. - The coal measures, composed of limestones, sandstones, shales, fireclays, and coal beds, rest unconformably on the Mississippian and dip westwardly under beds of Permian, Cretaceous, and Pleistocene (Fig. 12). Toward the south and west the beds increase in thickness, the maximum being 1000 feet in Iowa (36) and 3000 in Kansas (37).

Most of the coal mined in this field comes from the lower part of the coal measures where the beds are irregular in

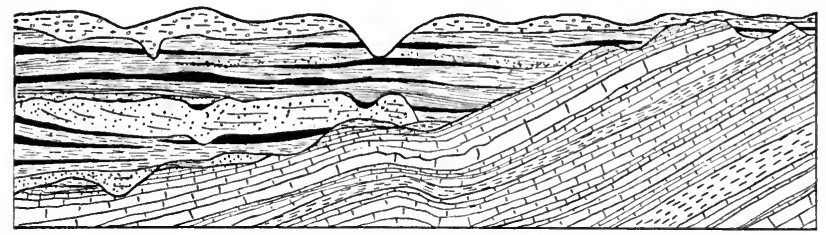

F1G. 12. - Composite section showing structure of lower coal measures of Jowa. After Keyes, Ia. Geol. Surv., I: 105.

thickness and distribution, in consequence of deposition on a very uneven surface.

All the coals of this field are essentially bituminous and used chiefly for steaming and heating purposes, being of no value for either coking or gas making. Some of the seams will coke, but there is no demand for the product, and the sulphur and ash are too high for gas making.

Southwestern Field. - While it is known that there is much good coal in this field, full development has not been undertaken in most parts of it. The Indian Territory coals $(34,35)$, of which there are 7 important beds in a section of 4500 feet of shales and sandstone, are both folded and faulted. These coals, as well as those of Texas (69), where there are three workable beds, are all bituminous; 
but in the eastern end of the Arkansas (25) field there is anthracitic coal of probable Permian age.

The coal from this field finds its most important market in the South, though some is sent North. The Texas coals are of especial importance on the railways, being used as far west as the Pacific coast. It has, however, found a serious competitor in the Texas crude petroleum; but it remains to be seen whether this competition will be lasting. On account of the value for domestic purposes the anthracite finds an important market to the northward.

Gulf States Lignite Area (9). - There is a narrow lignitebearing belt extending across the lower part of Alabama and Mississippi; and another much larger belt extending from near Little Rock, Arkansas, southwestward across the northwestern corner of Louisiana (42), and in a narrowing belt across Texas. Both of these are of Eocene age. The lignites are usually high in moisture and ash, the best grade being that mined in the lower end of the area, near Laredo on the Rio Grande.

A small field of Cretaceous lignitic coal has been developed around Eagle Pass on the Rio Grande (70). This is an extension of the Mexican field, but is of poorer quality.

Rocky Mountain Fields (17). - These cover a broad area, extending from the Canadian boundary southward into New Mexico, a distance of about 1000 miles, and including over 50 fields of various size and irregular shape. Most of the beds lie within the mountainous region, but at the northern end of the area, in Wyoming and the Dakotas, the coal fields extend eastward under the plains for some 



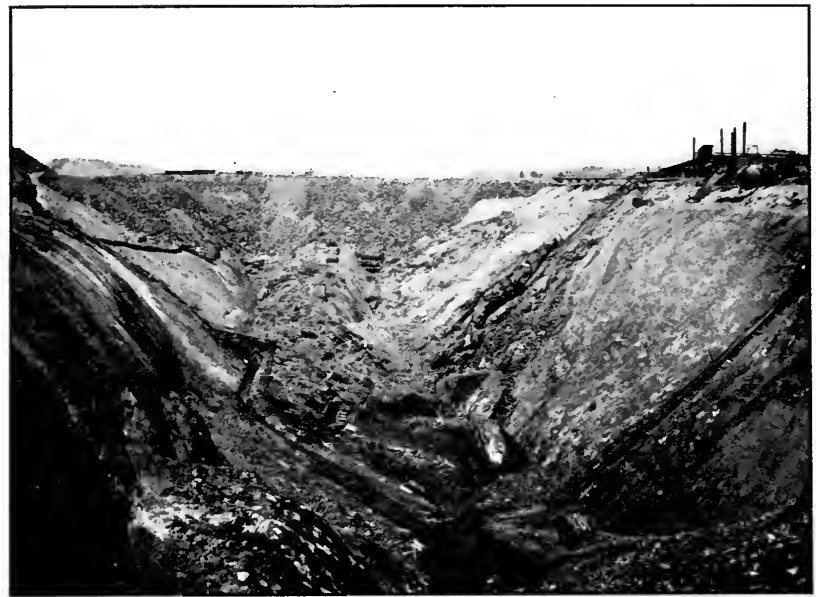

FIG. 1. - Pit working (Strippings) near Milnesville, Pa. The Mammoth seam is uncovered in bottom of pit.

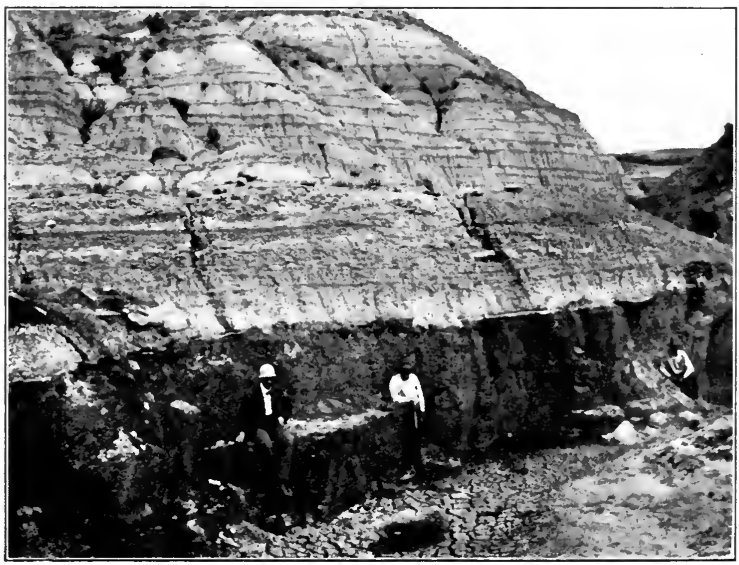

FIG. 2. - Lignite seam, Williston, N.D. After Wilder photo. 
distance. The age of the coal ranges from Cretaceous to Tertiary, though most of it belongs to the former.

While portions of this enormous area of coal-bearing strata are only slightly disturbed, mountain-building forces and igneous intrusions have affected a large proportion of the region, often materially changing the character of the coal. Thus, while in undisturbed portions of the field the beds are lignitic (Pl. II, Fig. 2), in the disturbed parts they have been altered to bituminous and even to anthracite coal. Some of the bituminous coals produce an excellent quality of coke.

Colorado $(29,30)$ is the most important coal-producing state of the Rocky Mountain region. This is due, not only to the quality of its coals, but also to the presence within the state of extensive metallurgical industries. The Raton field, in the southeastern part of the state and extending into New Mexico $(50,51)$, is at present the most important producer. Like many of the fields of this region the age of these is Laramie, and the beds are both folded and faulted. They are, moreover, crossed by igneous intrusions which have in some places produced natural coke, but in other's destroyed the value of the coal. In a section of from 3000 to 4500 feet of Laramie strata there are 40 coal beds, only a few of which are, however, workable. There are both coking and semi-coking coals, and some anthracite.

In Montana $(45,46,47)$ the coals range in age from Triassic to Tertiary, and in quality from lignite to bituminous. The coals of Wyoming, which occupy a very large area, show the same range in quality, but are more commonly lignite because found to so large an extent in regions of slight disturbance. The Utah coals are prevailingly semibituminous, and those of the two Dakotas lignitic.

The Pacific Coast Fields (16). - Tertiary coals, partly bituminous, though mainly lignitic, occur scattered over a wide area in the states of California (28), Washington (75), 
and Oregon $(56,57)$. The separate fields are limited in extent, widely separated, and with a small total output. Of the four fields recognized in Washington, the most important lie directly east of Seattle and Tacoma. The total thickness of coal-bearing sandstones and strata is about 10,000 feet, but important coal beds are found only in the lower 2000 feet. It is stated that there are 100 coal seams of sufficient thickness to attract the prospector; and in a single district there may be from 5 to 10 workable beds. Since the quality of the coal varies with the extent of dynamic disturbance, there is considerable variation even in a single field, and, in fact, in a single mine.

Both California and Oregon produce small quantities of lignitic coal of Tertiary age, but show no promise of becoming important producers. Indeed, the coal-trade conditions of the Pacific coast are unique. The local supply is not equal to the demand, and the Rocky Mountain fields are too far off to supply the Pacific coast with cheap fuel. Therefore much coal is imported, bringing about a competition in San Francisco from many countries, including England, Wales, Scotland, Australia, Japan, and British Columbia. These foreign coals are all of better quality than the Pacific coast coals, and they can be imported with low freight rate as ballast in wheat-carrying vessels that come to San Francisco for cargoes. These coal imports form three-quarters of the total import coal tonnage of the United States; but since 1895 there has been a steady decrease in the importation of coal and an increase in the Pacific coast production.

Alaska (23, 24). - Although Alaskan coal was first mined in $\mathbf{1 8 5 2}$ at Port Graham, the resources of the region are still but little known and slightly developed. The explorations for gold during the last few years, together with the field work done by the United States Geological 
Survey, have proved that coal is widely distributed in the Alaskan Territory (Fig. 81). So far as known the coal beds are all in Mesozoic and Tertiary formations. While most of the coal is lignitic, there is considerable bituminous coal and some semi-anthracite.

Coal mining has been carried on at a number of localities, especially along the rivers and coast. The higher grade coals along the coast, particularly in the southern part where shipinents can be made throughout the year, will doubtless be developed with profit in the near future. Coals in the Yukon Valley, though of low grade and variable character, bring $\$ 15$ a ton at the mines because of the local demand in the mining camps. The effect of such a local demand on the coal is even more strikingly shown by the fact that the semi-bituminous coal near the Cape Nome gold field sold, at times, for as much as $\$ 100$ per ton.

Production of Coal. - While coal mining in the United States began at an early date, the figures of production for the first few years are more or less incomplete. The phenomenal growth of the coal-mining industry is well shown, however, by the following figures : -

\begin{tabular}{|c|c|c|c|c|c|c|c|c|c|c|}
\hline \multicolumn{4}{|c|}{ YEAR } & $\begin{array}{c}\text { QUaNTITY } \\
\text { SHORT TONS }\end{array}$ & \multicolumn{5}{|c|}{ YeAR } & $\begin{array}{c}\text { QUaNTITY } \\
\text { SHORT TONS }\end{array}$ \\
\hline 1868 . & • & - & & $31,648,960$ & 1890 . & . & • & • & • & $157,770,963$ \\
\hline 1870 . & . . & . & - & $36,806,560$ & 1895 . & & - & - & - & $193,117,530$ \\
\hline 1875 . & • & - & - & $52,288,320$ & 1900 . & - & - & - & - & $269,684,027$ \\
\hline 1880 . & - & - & • & $76,157,944$ & 1903 . & & • & & - & $357,356,416$ \\
\hline 1885 . & . . & - & $\theta^{\circ}$ & $111,159,795$ & & & & & & \\
\hline
\end{tabular}

The production and value of the coal produced by the 12 largest producers in point of output since 1901 has been as follows:- 


\begin{tabular}{|c|c|c|c|c|c|c|}
\hline \multirow[b]{2}{*}{ State } & \multicolumn{2}{|c|}{1901} & \multicolumn{2}{|c|}{1902} & \multicolumn{2}{|c|}{1903} \\
\hline & $\begin{array}{c}\text { QUANTITY } \\
\text { SHoRT } \\
\text { ToNs }\end{array}$ & VALUE & $\begin{array}{l}\text { QUANTITY } \\
\text { SHoRT } \\
\text { ToNs }\end{array}$ & VALUR & $\begin{array}{c}\text { QUANTITY } \\
\text { SHoRT } \\
\text { ToNs }\end{array}$ & VALTE \\
\hline Pennsylvania: & & & & & & \\
\hline Anthracite & $67,471,667$ & $112,504,020$ & $41,373,595$ & $76,173,586$ & $74,607,068$ & $152,036,448$ \\
\hline Bituminous & $82,305,946$ & $81,397,586$ & $98,574,367$ & $106,032,460$ & $103,117,178$ & $121,752,759$ \\
\hline Illinois & $27,331,552$ & $28,163,937$ & $32,939,373$ & $33,945,910$ & $36,957,104$ & $43,196,809$ \\
\hline West Virginia & $24,068,402$ & $20,848,184$ & $24,570,826$ & $24,748,658$ & $29,337,241$ & $34,297,01 !$ \\
\hline Ohio & $20,943,807$ & $20,928,158$ & $23,519,894$ & $26,953,789$ & $24,838,103$ & $31,932,327$ \\
\hline Alabama & $9,099,052$ & $10,000,892$ & $10,354,570$ & $12,419,666$ & $11,654,324$ & $14,246,798$ \\
\hline Indiana & $6,918,225$ & $7,017,143$ & $9,446,424$ & $10,399,660$ & $10,794,692$ & $13,244,817$ \\
\hline Colorado & $5,700,015$ & $6,441,891$ & $7,401,343$ & $8,397,812$ & $7,423,602$ & . $9,150,943$ \\
\hline Kentucky & $5,469,986$ & $5,213,076$ & $6,766,984$ & $6,666,967$ & $7,538,032$ & 2. $7,979,342$ \\
\hline lowa & $5,617,499$ & $7,822,805$ & $5,904,766$ & $8,660,287$ & $6,419,811$ & $10,563,910$ \\
\hline Maryland & $5,113,127$ & $5,046,491$ & $5,271,609$ & $5,579,869$ & $4,846,165$ & $\begin{array}{l}7,189,784 \\
\end{array}$ \\
\hline Kansas & $4,900,528$ & $5,991,599$ & $5,266,065$ & $6,862,787$ & $5,839,976$ & $8,871,953$ \\
\hline Tennessee & $3,633,290$ & $4,067,389$ & $4,382,968$ & $5,399,721$ & $4,798,004$ & $5,979,830$ \\
\hline
\end{tabular}

Grouping the output by fields, the overwhelming importance of the Appalachian field is well seen.

$$
\begin{gathered}
\text { Production of Coal in United States by Fields from } \\
1901-1903
\end{gathered}
$$

\begin{tabular}{|c|c|c|c|c|c|c|c|c|}
\hline \multicolumn{6}{|c|}{ Field } & $\begin{array}{c}1901 \\
\text { Short Tons }\end{array}$ & $\begin{array}{c}1902 \\
\text { ShORT ToNs }\end{array}$ & $\begin{array}{c}1903 \\
\text { SHORT TONS }\end{array}$ \\
\hline Anthracite ( $\mathrm{Pa}$ & a., & $\mathrm{Co}$ & lo., & N. & Mex.) & $67,538,536$ & $41,467,5332$ & $74,679,799$ \\
\hline Triassic . & & & 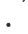 & 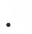 & , & 12,000 & 39,206 & 35,393 \\
\hline Appalachian & . & & . & . & . & $150,501,214$ & $173,274,861$ & $185,600,161$ \\
\hline Northern . & . & • & . & . & . & $1,241,241$ & 964,718 & $1,367,619$ \\
\hline Eastern Interio & or & • & . & - & . & $37,450,871$ & $46,133,024$ & $52,130,856$ \\
\hline Western. . & . & ${ }^{\circ}$ & - & . & . & $19,665 \tilde{,}, 985$ & $20,727,495$ & $23,171,692$ \\
\hline Rocky Mt. . & . & . & . & . & . & $14,090,362$ & $16,149,545$ & $16,981,059$ \\
\hline Pacific Coast & . & - & . & . & . & $2,799,607$ & $2,834,058$ & $3,389,837$ \\
\hline
\end{tabular}

The average price of anthracite coal, per short ton, in 1903 was $\$ 2.04$, while that of bituminous was $\$ 1.24$. 
The exports in 1903 amounted to 2,008,857 long tons of anthracite, valued at $\$ 9,680,044$, and $6,303,241$ long tons of bituminous, valued at $\$ 17,410,385$.

\section{Production of Leading Coal-producing Countrieg}

Country

United States (1903)

Great Britain (1903)

Germany (1903)

Austria-Hungary (1902)

France (1903) .

Belgium (1903)

Russia (1902) .

Japan (1901) .
SHORT ToNs

- $357,356,416$

$257,974,605$

$178,916,600$

$43,518,319$

$38,583,798$

$26,312,805$

$17,090,835$

$9,861,107$

Production of Coke. - The quantity of coke now produced annually in the United States is very large, and there is an extensive demand for it in smelting operations. In 1903 there were produced 25,262,360 short tons of coke from $39,410,729$ short tons of coal, which gave an average yield of 64.1 per cent coke per ton of coal, with the average value of $\$ 2.63$ per ton coke. This quantity was supplied by 77,188 coke ovens, and over 50 per cent of the supply came from Pennsylvania. In addition 1,882,394 short tons, or 7.4 per cent of the total production, was made in byproduct coke ovens, the approximate percentage of byproducts obtained from a ton of coal being: coal tar, 12.55 gallons; ammonia liquor, 14.4 gallons; ammonium sulphate, 17.6 pounds.

\section{REFERENCES ON COAL}

General. 1. Catlett, Amer. Inst. Min. Engrs., Trans. XXX : 559, 1901. (Coal outcrops.) 2. Bain, Jour. Geol. III : 646, 1895. (Structure of coal basins.) 3. Lesley, Manual of Coal and its Topography; Philadelphia, 1856. 4. Lesquereux, 2d Geol. Surv. Pa., Ann. Rept., p. 95, 1885. (Origin.) 5. Lyell, Amer. Jour. Sci. CLV : 353, 1843. 
(Upright trees in coal.) 6. Moffat, Amer. Inst. Min. Engrs., Trans. XV : 819, 1887. (Change of mine prop to coal.) 7. Stevenson, Geol. Soc. Amer. Bull., V : 39, 1893. (Origin Pa. anthracite.) 8. Wormley, Geol. Surv., Ohio, VI : 403, 1870. (Proximate and ultimate analysis.) See also Nos. $32,32 a, 37,55$.

General Areal Reports. 9. Hayes, U. S. Geol. Surv., 22d Ann. Rept., III : 7, 1902. (U. S. coal fields.) 10. MacFarlane, Coal Regions of Anerica, 700 pp., 3d ed., 1877, New York. 11. Nicholls, The Story of American Coals, 1897 (Phila.). 12. White, U. S. Geol. Surv., Bull.' 65. ' (Bituminous field, Pa., Ohio, and W. Va.) 13. Series of papers on the several coal fields of the United States, in U. S. Geol. 'Surv., 22d Ann. Rept., III : 11-571, 1902, as follows: Ashley, p. 271. (Eastern Interior.) 14. Bain, p. 339. (Western Interior.) 15. Hayes, p. 233. (Southern Appalachians.) 16. Smith, p. 479. (Pacific coast.)" 17. Storrs, p. 421. (Rocky Mountain field.) 18. Stoek, p. 61. (Pa. anthracite.) 19. Taff, p. 373. (Southwestern.) 20. White, Campbell, and Hazeltine, p. 125. "Northern Appalachians.)-Alabama: 21. Gibson, Ala. Geol. Surv., 1895. (Coosa field.) 22. McCalley, Ala. Geol. Surv., 1900. (Warrior field.) - Alaska: 23. Ball, U. S. Geol. Surv., 17th Ann. Rept., I: 771, 1896. (Coal and lignite.) 24. Brooks, lbid., 22d Ann. Rept., III : 521. - Arkansas : 25. Taff, U. S. Geol. Surv., 21st Ann. Rept., II : 313. (Camden field.) - Arizona : 26. Blake, Amer. Geol., XXI : 345, 1898. 27. Campbell, U. S. Geol. Surv., Bull. 225: 240, 1904. (Deer Creek field.) - California: See Pacific Coast Report referred to above and also various county reports in (28) 11th Ann. Rept. Calif. State Mining Bureau.-Colorado: 29. Eldridge, U. S. Geol. Surv., Geol. Atlas of the U. S., folio 9. (Anthracite.) 30. Hills, U. S. Geol. Surv., Min. Res., 1892, 319. Georgia : 31. McCallie, Ga. Geol. Surv., Bull. 12, 1904. (General.) -Iowa : 32a. Keyes, Ia. Geol. Surv., II : 1894. (General.) - Indiana: 32. Ashley, Ind. Dept. of Geol. and Nat. Hist., 23d Ann. Rept., 1899: 1.- Illinois: 33. Also Worthen and others, Ill. Geol. Surv., I : 1866 ; III : 1868 ; IV : 1870 ; V : 1873 and VI : 1875 . Indian Territory : 34. Adams, U. S. G. S., 21st Ann. Rept., II : 257, 1900. (Eastern Choctaw field.) 35. Taff, White, and Girty, U. S. Geol. Surv., 19th Ann. Rept., III : 423, 1898. (McAlester-Lehigh field.) Iowa: 36. Keyes, Iowa Geol. Surv., II: 536. - Kansas: 37. Haworth and Crane, Kas. Univ. Geol. Surv., III : 13, 1898. - Kentucky: 38. Moore, Ky. Geol. Surv., Ser. 2, IV, pt. XI: 423. (Eastern border and Western field.) 39. Lesley, Ky. Geol. Surv., IV : 443, 1858. (Eastern.) 40. Norwood, Ann. Rept., Inspector of Mines, 1901-1902. (Much general information.) ...41. For analyses, see 
Ky. Geol. Surv., New Series, Chem. Rept., etc., pt. I, II, and III. Louisiana: 42. Harris, Prelim. Rept. on Geol. of Louisiana for 1899 : 134. (Lignite.) - Maryland : 42a. Clark, Md. Geol. Surv., Vol. V, 1905. - Michigan : 43. Lane, Mich. Geol. Surv., VIII : pt. 2. Missouri : 44. Winslow, Mo. Geol. Surv., 1891 : 19-226. - Montana : 45. Weed, Eng. and Min. Jour., LIII: 520, 542, and LV: 197, also Geol. Soc. Amer., Bull. III : 301, 1892. (Great Falls and Rocky Fork fields.) 46. Rowe, Amer. Geol., XXXII: 369, 1903. 47. Burchard, U. S. Geol. Surv., Bull. 225:276, 1904. (Lignites, Upper Missouri Valley.) - Nebraska: 48. Barbour, Neb. Geol. Surv., I: 198, 1903. - Nevada: 49. Spurr, U. S. Geol. Surv., Bull. 225 : 289, 1904. - New Mexico: 50. Johnson, Sch. of M. Quart., XXIV : 456. (Cerillos.) 51. Stevenson, N. Y. Acad. Sci., Trans. XV: 105, 1896. (Cerillos field.) - North Carolina: 52. Woodworth, U. S. Geol. Surv., 22d Ann. Rept., III: 31, 1902. - North Dakota: 53. Babcock, N. Dak. Geol. Surv., 1st Biennial Rept., $1901: 56$. 54. Wilder, Eng. and Min. Jour., 74: 674, 1902. (Lignite.) Ohio: 55. Orton, Ohio Geol. Surv., VII : 255. - Oregon : 56. Diller, U. S. Geol. Surv., 17th Ann. Rept., I. (N. W. Ore.) 57. Diller, Ibid., 19th Ann. Rept., III : 309. (Coos Bay.) - Pennsylvania: 58. d'Invilliers, 2d Pa. Geol. Surv. Rept., 1885 and 1886. (Pittsburg region.) 59. McFarlane, Coal Regions of America, 3d ed.; New York, 1877. 60. Rept. MM. contains many analyses. 61. See also various county reports of same survey. 62. Final Summary Rept., III: pt. 1, and 2.-Rhode Island : 63. Emmons, Amer. Inst. Min. Eng., Trans. XIII : 510, 1885. 64. Stevenson, Manchester Geol. Soc., Trans. XXIII: 127. (New Eng. fields.) - South Dakota: 65. Todd, S. Dakota Geol. Surv., Bull. I : 159. - Tennessee: 66. Duffield, Eng. and Min. Jour., LXXIV: 442, 1902. (Cumberland Plateau.) 67. Safford, U. S. Geol. Surv., Min. Res., 497, 1892. - Texas: 68. Dumble, Bull. on Lignites of Texas, Tex. Geol. Surv. (Lignites.) 69. Phillips, Univ. Tex. Mineral Surv., Bull. 3: 1902. (Coal and lignite.) 70. Vaughan, U. S. Geol. Surv., Bull. 164, 1900. (Rio Grande fields.) - Utah : 71. Forrester, U. S. Geol. Surv., Min. Res., 511, 1892. - Vermont: 72. Hitchcock, Amer. Jour. Sci., ii, XV: 95, 1853. (Lignite at Brandon.) - Virginia: 73. Campbell, U. S. Geol. Surv., Bull. 111, 1893. (Big Stone Gap field.) 74. Woodworth, U. S. Geol. Surv., 22d Ann. Rept., III : 31, 1902. (Triassic coal.) - Washington: 75. Landes and Ruddy, Wash. Geol. Surv., II; Willis, U. S. Geol. Surv., 18th Ann. Rept., III : 393, 1898. (Puget Sound.) - West Virginia : 76. White, West Va. Geól. Surv., II: '1903. - Wyoming : 77. Fisher, U. S. Geol. Surv., Bull. 225 : 345, 1904. 78. Knight, Min. Ind., III : 145, 1894. 


\section{REFERENCES ON PEAT}

79. Ries, N. Y. State Museum, 54th Ann. Rept., 1903. (N. Y., Origin and uses in general, Bibliography.) 80. Carter, Ont. Bur. Mines, Rept. for 1903. (General.) 81. Shaler, U. S. Geol. Surv., 12th Ann. Rept., p. 311. (Peat and swamp soils.) 82. Koller, Die Torfindustrie, Vienna, 1889. 83. Ries, Min. Res., U. S. Geol. Surv., 1901. (U. S.) 


\section{CHAPTER II}

\section{PETROLEUM, NATURAL GAS, AND OTHER HYDROCARBONS}

UNDER this head are included a number of hydrocarbon compounds, of complex and variable composition, ranging from the solid to the gaseous state, the series including four well-marked and well-known members; viz., natural gas, petroleum, mineral tar or maltha, and asphalt. The development of these products, and especially the first two, has been so remarkable and attended by such important economic results that it seems well to preface the following description by a brief outline of this history of their development.

History of Petroleum Development. - Petroleum has long been known in many parts of the world because of its presence in bituminous springs or as a floating scum on the surface of pools. It was used at an early date on the walls of Babylon and Nineveh, and was obtained by the Romans from Sicily for use in their lamps.

In the United States petroleum was mentioned by French missionaries even in 1635, and the early Pennsylvania settlers obtained small quantities by scooping out the oil from dug wells. Its discovery at greater depth on the western slope of the Alleghanies was made during the drilling of brine wells; but its early use was chiefly a medicinal one until 1863, when attempts were made to purify it for use as a 
lubricant and illuminant. The beginning of the oil industry is usually considered to date from the sinking of a successful well by Colonel Drake on Oil Creek, Pennsylvania, in 1860. From this center prospectors spread out in all directions making valuable discoveries, until now petroleum production and refining rank among the leading industries of the country, the supply coming from many states.

History of Natural Gas Development. - Natural gas was discovered and first employed for economic purposes at Fredonia, New York, in 1821. In 1841 it was used in the Great Kanawah Valley as a fuel in salt furnaces, but its first extensive use began in 1872 at Fairview, Pennsylvania. It was used in 1885 for iron smelting at Etna Borough near Pittsburg, and in 1886 was piped nineteen miles from Murrayville to Pittsburg. Now natural gas is piped long distances to cities, being used as a fuel in many industries, as well as for domestic heating and lighting.

Properties of Petroleum $(1,2,7)$. - Crude petroleum is a liquid of complex composition and variable color and density. It consists of a mixture of hydrocarbons, the American petroleum belonging usually to the paraffin series although some has an asphaltic base. The Mississippi River forms a rough dividing line between fields containing oil with a paraffin base and those, with an asphaltic base. In addition to these compounds, petroleum may contain substances with a small percentage of nitrogen and sulphur.

The following are analyses of several petroleums from American and foreign localities :- 
Elementary Analyses of Petroleums

\begin{tabular}{|c|c|c|c|c|c|c|}
\hline \multirow{2}{*}{ LOCALITY } & & & \multicolumn{3}{|c|}{ Per Cent } & \multirow{2}{*}{$\begin{array}{c}\text { SPECIFIC } \\
\text { GRAVITY } \\
\mathrm{H}_{2} \mathrm{O}=1\end{array}$} \\
\hline & & & C. & H. & O. & \\
\hline Heavy oil, W. Va. . & . & - & 83.5 & 13.3 & 3.2 & .873 \\
\hline Light oil, W. Va. . & . & . . & 84.3 & 14.1 & 1.6 & .8412 \\
\hline Heavy oil, Pa. . & . & - & 84.9 & 13.7 & 1.04 & .886 \\
\hline Light oil, Pa. . & - & - & 82.0 & 14.8 & 3.2 & .816 \\
\hline Parma, Italy . . & • & - & 84.0 & 13.4 & 1.8 & .786 \\
\hline Hanover, Germany & . & - & 80.4 & 12.7 & 6.9 & .892 \\
\hline Galicia, Austria . . & - & & 82.2 & 12.1 & 5.7 & .870 \\
\hline Light oil, Baku, Rus. & - & - & 86.3 & 13.6 & 0.1 & .884 \\
\hline Heavy oil, Baku, Rus. & & & 86.6 & 12.3 & 1.1 & .938 \\
\hline Java . • • • • • & - & . & 87.1 & 12.0 & 0.9 & .923 \\
\hline Beaumont, Texas . & - & - & 86.8 & 13.2 & & .920 \\
\hline
\end{tabular}

Petroleums commonly vary in specific gravity between .801 and .965 , the following being some of the limits shown by American oils : -

Specific Gravity of Some American Petroleums

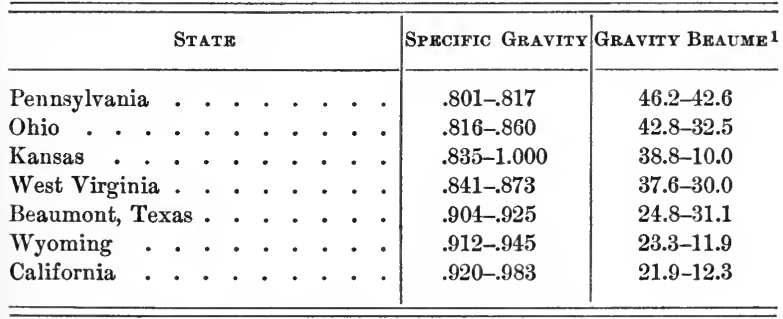

The temperature at which crude petroleum solidifies ranges from $82^{\circ} \mathrm{F}$., in some Burma oils, to several degrees below zero in certain Italian oils. The flashing point, or the lowest

1 A specific gravity of 1 , compared with water, is $10^{\circ}$ on the Beaume scale. 
temperature at which inflammable vapors are given off, may be as low as zero degrees in the Italian oils to as high as $370^{\circ} \mathrm{F}$. in an oil found on the Gold Coast of Africa, but these are extreme limits. There is also a great range in the boiling point, which is $180^{\circ} \mathrm{F}$. in some Pennsylvania oils and $338^{\circ} \mathrm{F}$. in oils found at Hanover, Germany.

The various liquid hydrocarbons making up crude petroleum vary in their specific gravity and boiling point. The more important oils which can be separated from crude petroleum by distillation are gasoline, benzine, heavy naphthas, and residuum. Those with a paraffin base are generally lighter and more valuable on account of the higher quantity and quality of the naphthas, illuminating oils, and lubricating oils which they produce. Those with an asphalt base are of inferior quality and chiefly valuable for fuel. Their transportation by pipe lines is also more difficult.

The percentage of the different distillates varies.

The following average percentages of distillates were yielded by the oils of several fields in 1902 (Oliphant) :-

\begin{tabular}{|c|c|c|c|}
\hline & $\begin{array}{c}\text { APPALACHIAN } \\
\text { FIRLD }\end{array}$ & $\begin{array}{c}\text { LIMA, IND. } \\
\text { FIELD }\end{array}$ & $\begin{array}{c}\text { Kansas } \\
\text { Field }\end{array}$ \\
\hline 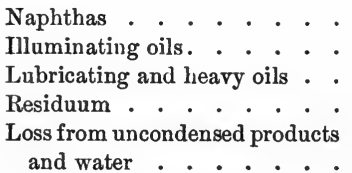 & $\begin{array}{r}20.1 \\
61.4 \\
7.1 \\
6.3\end{array}$ & $\begin{array}{l}10.9 \\
48.8 \\
17.2\end{array}$ & $\begin{array}{l}18 \\
30 \\
25\end{array}$ \\
\hline
\end{tabular}

Properties of Natural Gas. - This consists chiefly of Marsh gas - fire damp- $\mathrm{CH}_{4}$. It is colorless, odorless, burns readily with a luminous flame, and when mixed with air, 
it is highly explosive. As is shown by the following analyses, several other gases are commonly present in small quantities : -

\section{Analyses of Natural Gas}

\begin{tabular}{l|c|c|c|c|c|c|c|c}
\hline \hline & $\begin{array}{c}\text { HYDRo- } \\
\text { GEN }\end{array}$ & $\begin{array}{c}\text { MARSH } \\
\text { GAS }\end{array}$ & $\begin{array}{c}\text { OLRFI- } \\
\text { ANT GAS }\end{array}$ & $\begin{array}{c}\text { CAR- } \\
\text { BONIO } \\
\text { OXIDI }\end{array}$ & $\begin{array}{c}\text { CAR- }_{\text {BON DI- }} \\
\text { OXIDE }\end{array}$ & OXYGR & $\begin{array}{c}\text { NITBO- } \\
\text { GRN }\end{array}$ & $\begin{array}{c}\text { SUL- } \\
\text { PHURIO } \\
\text { HYDRo- } \\
\text { GEN }\end{array}$ \\
\hline Fostoria, O. & 1.89 & 92.84 & .20 & .55 & .20 & .35 & 3.82 & .15 \\
Findlay, O. & 1.64 & 93.35 & .35 & .41 & .25 & .39 & 3.41 & .20 \\
Muncie, Ind. & 2.35 & 92.67 & .25 & .45 & .25 & .35 & 3.53 & .15 \\
\hline
\end{tabular}

Mode of Occurrence $(4,5,6,8)$, - Oil is rarely found without gas, and saline water is likewise often present. If the containing strata are horizontal, the oil and gas are usually irregularly scattered, but if tilted or folded, they collect at the highest point possible. It was the result of observa-

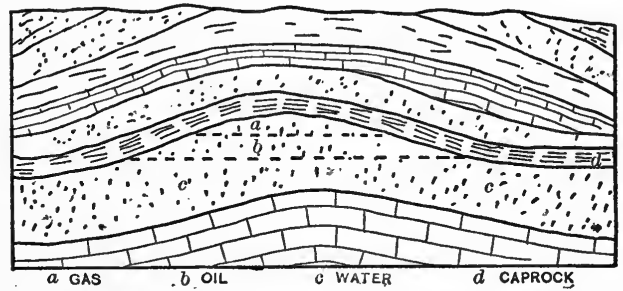

Fig. 13. - Section of anticlinal fold showing accumulation of gas, oil, and water. After Hayes, U. S. Geol. Surv., Bull. 212.

tions along this line that led I. C. White to develop what is known as the "Anticlinal Theory" (8). According to this theory, in folded areas the gas collects at the summit of the fold, with the oil immediately below, on either side, followed by water (Fig. 13). Unless there are secondary 
anticlines, the intervening synclines are liable to be barren of oil and gas. For this theory, as for others, it is necessary that the oil-bearing stratum shall be capped by a practically impervious one.

Such anticlinal waves are found in the oil fields of the Appalachians, Indiana, western Ohio, and many other localities. While this theory has been disputed, it may be considered established for many localities. The rival theory advanced by Lesley and Ashburner, that the oil has accumulated in porous areas of rock, perhaps ancient shore-line deposits, may likewise apply in some cases. It supplies all the necessary conditions of a subterranean reservoir for the accumulation of oil in "pools."

In the first discovered fields, the oil and gas were found in porous, sandy strata, varying from fine-grained, cemented sandstone to loose gravels. These strata were termed sands, and the area of porous oil sand was called the pool. Later discoveries in Ohio and Indiana showed that the gas and oil might occur in limestone also.

The quantity of oil which a cubic foot of apparently dense rock can hold is often surprising. White (36) estimated that fairly productive sands may hold from six to twelve pints of oil per cubic foot, but that probably not more than three-fourths of the quantity stored in the rock is obtainable. The ease with which the containing rock yields its supply of oil depends largely on the openness of the pores.

Pressure of Oil and Gas Wells. - Since both oil and gas usually occur in the earth under pressure, any break in the porous rock or reservoir which contains them allows them to escape, frequently giving rise to surface indications, and the force with which oil and gas oftentimes issue from a 
well indicates the pressure under which they are confined. It is sometimes sufficient to blow out the drilling tools and casing, as well as to cause the oil to spout many feet into the air.

There are several remarkable cases of the amount sponted by these gushing wells. One of these is the famous Lucas well at Beaumont, Texas, which in 1901 for nine days gushed a six-inch stream to a height of 160 feet, at the rate of 75,000 barrels per day. This, however, is small compared with the records of some Russian oil wells. Although many wells flow when first drilled, this does not usually continue long, and the oil then has to be brought to the surface by pumping. The depth of the wells drilled in the United States ranges from 250 to 3700 feet, and over 70 per cent of the total number drilled are located in Ohio and Pennsylvania.

The maximum pressure which a well develops when closed has been called rock pressure. As a result of his studies in the Ohio-Indiana field, Orton (29) found that the rock pressure was the same as that of a column of water whose height was equal to the difference in elevation between the level of Lake Erie and that of the oil or gas bearing stratum. He therefore considered it to be hydrostatic pressure. This theory, while apparently applicable in many localities, was found to be inadequate to explain the great pressure shown in many shallow wells. In such cases, no doubt, as in many others, the pressure is due to the expansive force of the imprisoned gas.

Either the drilling of additional wells or a drain by excessive use from wells already bored commonly causes a slow decrease in pressure in an oil or gas field. Thus in the natural-gas region of Findlay, Ohio, the rock pressure in 1885 was 450 pounds per square inch; 400 in 1886; 360380 in $1887 ; 250$ in $1889 ; 170-200$ in 1890 . Some West 
Virginia wells have shown a measured rock pressure of 1110 pounds per square inch and an estimated pressure of 2000 pounds.

Origin. - That the solid, liquid, and gaseous hydrocarbons are more or less closely related is evident from the fact that the gases given off by petroleum are similar to those predominating in natural gas, while the exposure of many petroleums to the air results in a change to a viscous mass and finally to a solid, asphalt-like substance. It is a wellknown fact that petroleum is rarely free from natural gas, although this gas may sometimes form alone, as in coal mines, or from decaying vegetation in stagnant pools. The origin of the hydrocarbon compounds has been the subject of much speculation among both chemists and geologists, the former for a time arguing for an inorganic or mineral origin, the latter for an organic derivation.

Inorganic Theory. - Several theories have been advanced to account for an inorganic origin of oil, the most important of which, though not the earliest, was that of Mendeljeff, the Russian chemist. According to his theory, the interior of the earth contains metallic iron, as well as carbid of iron like that found in meteorites. Waters percolating downward through the earth's crust, on reaching the heated interior, become converted into steam, which, attacking the carbid of iron, forms hydrocarbons. These are forced to the surface by the expansive force of the steam.

From a purely chemical standpoint, this theory is reasonable, but it does not accord with geologic facts. If petroleum were found in this manner, we should expect to find it widely distributed through the oldest rocks of the earth's 
crust. On the contrary, it is known in these rocks at only one locality, in Ontario, where a hard, compressed asphalt is found in crystalline rocks. It is significant that this material, which was probably originally petroleum, occurs in rocks which show evidence of having been originally stratified.

Organic Theory. - This considers that petroleum has been derived from either animal or vegetable matter by a process of slow distillation, although the exact changes involved are uncertain. There are several strong arguments in favor of it. (1) Petroleum is a combustible substance, and all other similar combustibles have originated organically. (2) It is possible to artificially produce, from either animal or vegetable substances, both gaseous and liquid compounds which are closely analogous to those found in petroleum and natural gas. Fish oil, for example, will on distillation yield petroleum compounds, including illuminating oil, lubricating oil, benzine, and paraffin. (3) These substances occur in fossil-bearing rocks. (4) They are practically absent from the crystalline rocks. (5) In some places these substances occur in close proximity to fossils. (6) Natural gas is actually generated in coal seams.

Some geologists, including Orton (4) and Newberry (Ohio State Agric. Rep. 1859), have believed that the formation of petroleum has taken place at low temperatures; but others, including Peckam (6), have considered heat necessary. In the case of Appalachian oils, the folding of the strata is supposed to have supplied this heat.

It seems doubtful whether either petroleum or natural gas have migrated any great distance through the strata subsequent to their formation. :. When any movement has taken 
place through pores of the rock, it has probably been due to gravity separation, the gas rising to the highest point of the stratum while the oil settles.

Geological Distribution of Petroleum and Natural Gas. Petroleum is widely distributed geologically, being found in rocks whose age ranges from the Ordovician to the most recent, the occurrences in Paleozoic strata being chiefly in eastern United States, those in post-Carboniferous strata in the western and southern states.

Natural gas may show an equally wide geological distribution, although in the United States the larger amount is now obtained from the Paleozoic formations.

Distribution of Petroleum in the United States. - The important petroleum occurrences of the United States, so far as at present known, may be considered to belong to the seven following fields (Fig. 14): (1) the Appalachian field, including New York, western Pennsylvania, eastern Ohio, West Virginia, Kentucky, and Tennessee; (2) the Ohio-Indiana field; (3) the Texas-Louisiana field; (4) the Kansas-Indian Territory field; (5) the Colorado fields; (6) the Wyoming fields; (7) the California fields. In addition to these there are scattered occurrences in Michigan, etc. (See map, Fig. 14.)

Appalachian Field. - This field, which supplied over 85 per cent of the oil produced in the United States in 1902, extends from southwestern New York (25) into West Virginia $(37,38)$ and is subdivided into several districts, each containing several "pools." The region is of interest historically and geologically, some of the earliest discoveries of oil having been made in it. The oil is obtained from sandstones and conglomerates, ranging in age from the Upper Carboniferous 
Plate III

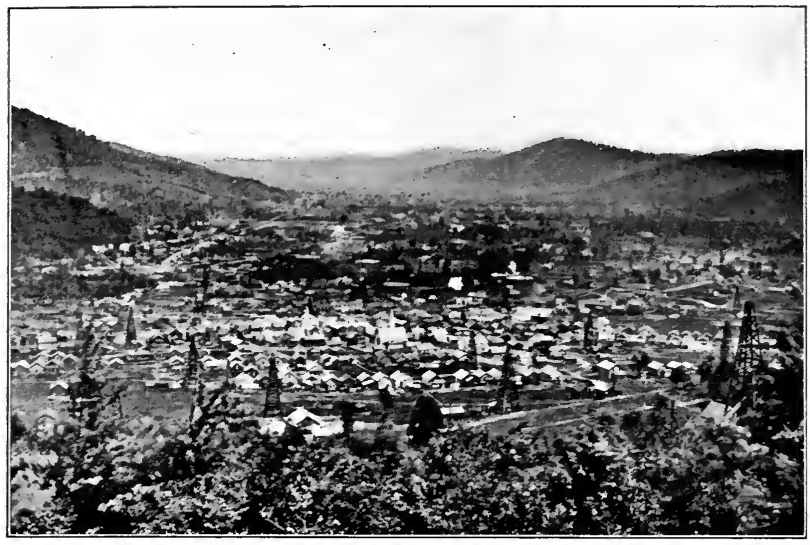

Fig, 1. - General view of Tuna Valley, in Pennsylvania oil field. Photo. by $F$. $H$. Oliphant.

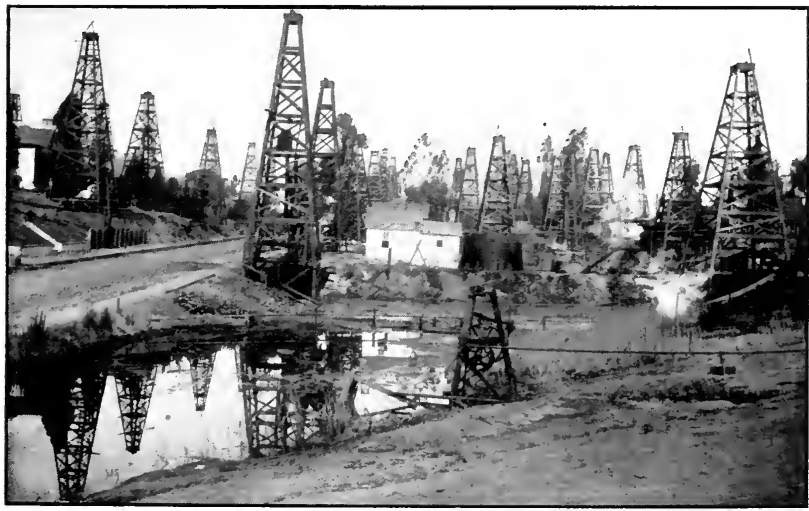

FIG. 2. - View in Los Angeles, Calif., oil field. Such close spacing of oil derricks tends to hasten the exhaustion of the oil supply. 

in the upper part of the field, to Middle Devonian in the lower portion, which underlie an area of probably 55,000

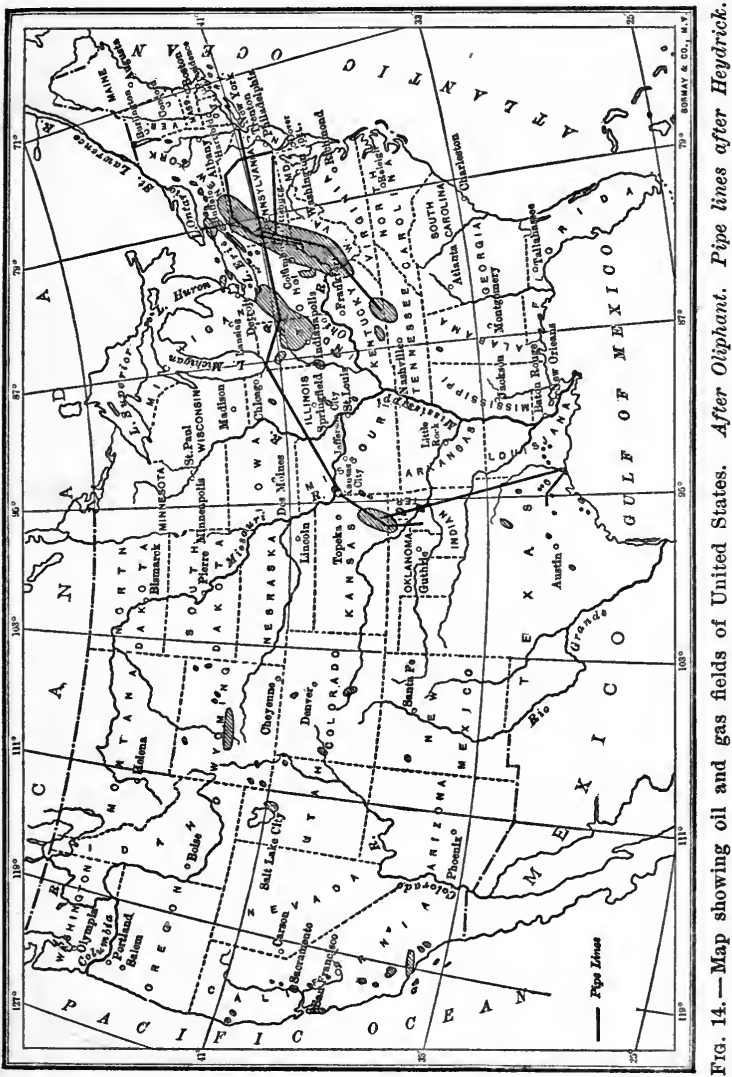

square miles. There are often several productive beds in a single formation, and 40 oil sands have been recognized in 
the entire section. This field, which is the most important in the United States, supplies a large amount of high-grade petroleum, and has a large output; but apparently the production has practically reached its maximum. The petroleumproducing areas of Pennsylvania $(31,32)$ are divided into a number of districts, this division being based partly on quality and partly on county lines. Each district may be subdivided into pools. In the Clarendon and Warren County district is found some of the finest petroleum produced in the United

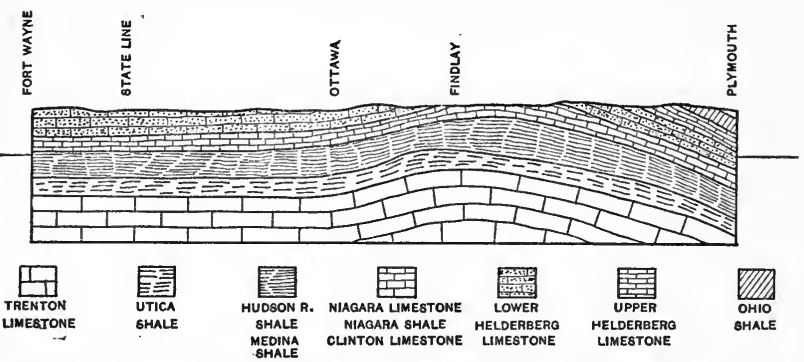

Fig. 15. - Geological section of Ohio-Indiana oil and gas fields. After Orton. U.S. Geol. Surv., 8th Ann. Rept., II.

States, while the Franklin district is noted for the fine, natural lubricating oil which it yields. In Kentucky (22) and Tennessee a limited amount of petroleum is obtained from Silurian rocks. The total number of wells drilled in the Appalachian field from 1877 to the end of 1903 was 137,679.

Ohio-Indiana Field (16-18, 26-30). - The discovery of oil and gas in the Trenton rocks of western Ohio in 1884 caused considerable excitement, since it showed the existence of petroleum in limestone, an exception to previously known conditions, and at a much lower geological horizon than any in which oil or gas had hitherto been found. This field 

Plate IV

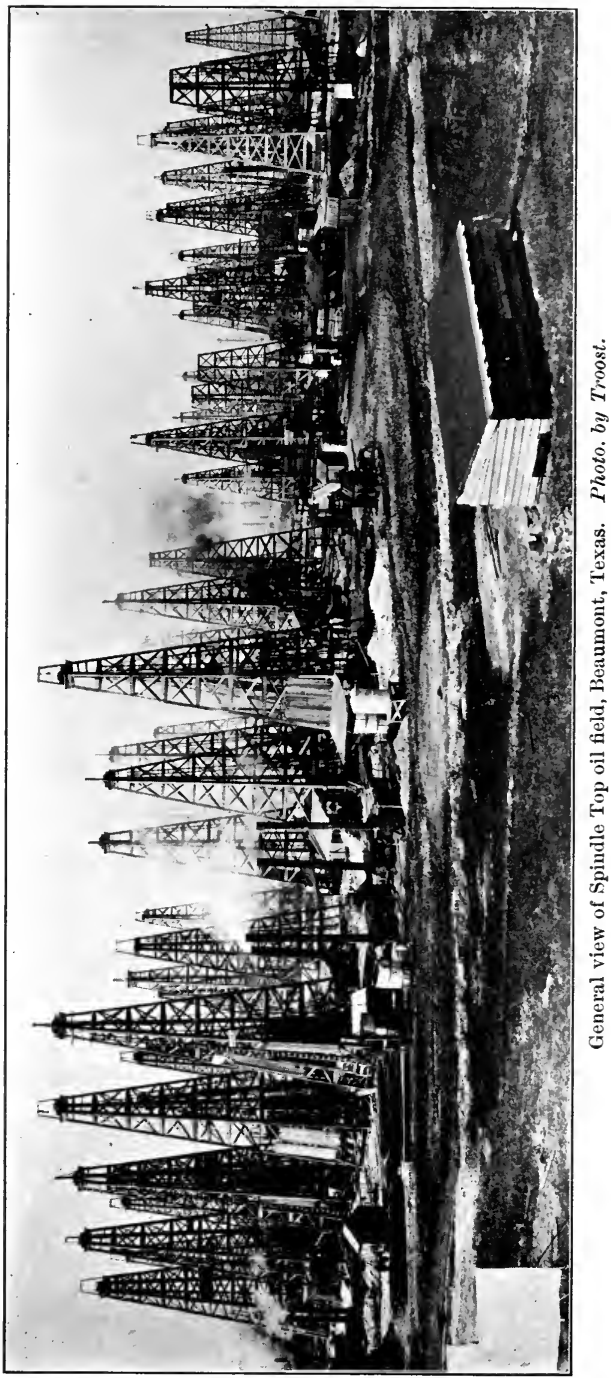


extends from Findlay in northwestern Ohio southwestward into Indiana. The oil, which is dark and heavy, and contains a higher percentage of sulphur than the Pennsylvania oil, is found near the top of the porous, dolomitized portions of the Trenton limestones, at depths of about 1100 feet. The limestone, which shows several low folds (Fig. 15), is covered by the impervious Hudson River shales.

Texas-Louisiana Oil Fields (33-35). - These occur in a belt from 50 to 75 miles wide along the Gulf Coast from near the Mississippi River in Louisiana to a point about two thirds the way across Texas (Fig. 14). The nearly flat surface of this coastal plain is occasionally interrupted by low mounds or swells which seem to indicate favorable conditions for the accumulation of oil below the surface. Underlying this area is a series of mont, Texas. After Fenneman, Min. Mag., XI:317. Quaternary and Tertiary clays, sands, and gravels, with occasional limestones, having in general a gentle southeastern dip interrupted by low domes.

The oil pools are all of small size, that at Beaumont, which is the best known, covering an area of about 200 acres (Pl. IV). It was discovered in 1901, and within a year and a half 280 successful wells had been drilled. The oil rock, which lies from 900 to 1000 feet below the surface, is a very porous, crystalline dolomitic limestone, and the cap- 
rock is clay. The occurrence of gypsum and salt underlying the oil rock in some of the wells is unique (Fig. 16). Many of the wells in this pool were gushers, but so great was the drain on this field that by the end of the first year after its discovery the pressure was considerably reduced, and in 1903 many of the wells had practically ceased producing, while others were yielding a mixture of salt water and oil. The production, however, is still considerable, although the supply is no doubt exhaustible. The coastal-plain oils have an asphaltic base, or are "heavy," and at times contain considerable sulphur.

In 1903 many wells were being developed in the Sour Lake district about 20 miles northwest of Beaumont. The oil is heavy like that of Beaumont, but runs lower in sulphur. In Louisiana active drilling operations have been carried on in the region around Jennings, and one well yielded 20,000 barrels per day while it was gushing. The oil resembles that of Beaumont.

The belt of Cretaceous rocks of central Texas has yielded both oil and gas at several localities, but the only important one is at Corsicana, where both a light and heavy oil have been found in sands interbedded with dense clay shales. The two kinds of oil occur at different horizons.

Kansas (19-21). - In southeastern Kansas a dark green oil is obtained from the sugar sands near the bottom of the Cherokee shales, about 800 feet below the surface. A second horizon is found about 300 feet lower.

California. - There are a number of productive fields in California (10-12), all lying south of the latitude of San Francisco. Altogether there are $\mathbf{1 0}$ or $\mathbf{1 2}$ horizons in the folded Tertiary strata, which have a total thickness of 20,000 feet. The oil which is found in conglomerates, sandstones, and arenaceous shales, is, in the most productive areas, found closely associated with anticlines, but the strata are in many 
places extensively faulted (Fig. 17), and it is doubtless to these faults that many of the California oil springs are due. By adding to the porosity of the rocks, the faulting has probably also increased the capacity of some of the oil reservoirs.

In 1903 the Kern River field was the most productive in California. It has an area of 12 square miles, the oil being found at depths ranging from 200 to 300 feet in a series of lower Miocene sands interbedded with clay. The wells yield from a few barrels up to 600 per

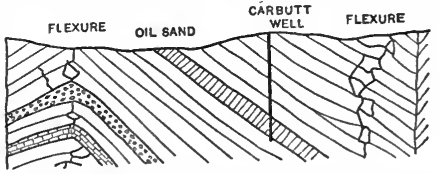

Fig. 17. - Section in Los Angeles oil field. After Watts, Calif. State Min. Bureau, Bull. 11 : 7, 1897. day, but are flowing usually for only a short period.

The California oils, like those of Texas, have an asphaltic base, those found in the shale being generally lighter.

Wyoming (39-41). - This state contains 18 oil districts, most of which are but slightly developed and the geology imperfectly known. Most of them are in the Mesozoic strata, the balance in Upper Carboniferous, the oil being commonly found along the axes of anticlinal folds. The wells vary from 300 to 1500 feet in depth, and the oils are mostly lubricating, although a few contain considerable kerosene (39).

Colorado. - The oil at Florence $(13,15)$, in this state, is found in porous, sandy layers of Cretaceous age, at depths of from 1000 to 2000 feet, and, unlike most other occurrences, in a synclinal trough. It is a heavy oil. Near Boulder (14) there is another oil field, recently developed, in which the oil is found at depths as great as 3400 feet. 
Alaska. - Petroleum has been found at several localities in Alaska (Fig. 81), and the developmental work already done gives promise of a supply in the future $(9,10)$.

Distribution of Natural Gas in the United States. - The distribution of natural gas is almost coextensive with that of petroleum, but the commercially important fields are fewer in number. The most important producing states are New York (51), Pennsylvania (54), Ohio (53), Indiana (45), and Kansas (47).

New York. - Gas is found in several formations, including the Medina and Oswego sandstones, Utica shale, and Potsdam sandstone, but the main supply is distributed through the Devonic sandstones of southwestern New York. A large field in Erie County obtains its supply from the Medina sandstone, some of the wells having yielded as high as 1,000,000 cubic feet daily. In Onondaga County gas is found in the Trenton limestone.

Pennsylvania. - Gas is obtained from the same formations that carry the oil. The Bradford district was the first developed, and formerly yielded gas of high pressure. Much is still obtained from McKean, Elk, and Warren counties. Extensive deposits were also found about Pittsburg, and later to the south of it. Green and Washington counties now produce important supplies from a pool whose length is about 25 miles and width 3 to 4 miles, with pressure ranging from 800 to 1000 pounds. Although in recent years several new gas-bearing sands have been discovered in southwestern Pennsylvania, the enormous demand for the gas threatens exhaustion of the available supply at no very distant date. 
West Virginia (see Petroleum references). - This state is now the leading producer of natural gas in the United States, and is looked to as an important source of future supply for both Ohio and Pennsylvania, whose gas supply is slowly falling off. The main supply is obtained from the Gordon and Fifth sands of the Catskill formation, this being a higher horizon than that yielding the gas in the Bradford district of Pennsylvania. Immense quantities are obtained from the fields of Wetzel and Tyler counties, the wells being from 2700 to 3200 feet deep. Pipe lines are now run from this district to Pittsburg, and a line has been laid from Tyler County to Cleveland, Ohio. Unfortunately, by allowing it to escape with the petroleum, many thousand cubic feet of gas have been wasted in this state.

Ohio (52-53). — The Trenton limestone, which formerly supplied large quantities of natural gas, is now so nearly exhausted that little gas is obtained except by pumping. Some gas is obtained from the Clinton sandstone of central and eastern Ohio, and small amounts from the Corniferous limestone; but many towns in this state are now supplied by the West Virginia fields.

Indiana $(45,46)$. - The gas fields of this state, covering about 2500 square miles, were formerly among the most important in the country, the gas being obtained from the Trenton limestone. The supply is, however, rapidly giving out, and its complete exhaustion is probable at no very distant date.

Kansas (47-50). - Southeastern Kansas and northern Indian Territory are underlain by what is probably an extensive sandstone gas field. The supply comes from the Cherokee 
shale, and is now much used as a source of fuel in the local metallurgical and manufacturing industries.

Some gas is obtained from eastern Kentucky. Scattered pockets of high-pressure gas have also been found at several localities in Texas and also in California.

Uses of Petroleum. - The three most important uses are for light, heat, and lubrication; but the various distillates have special uses. Rhigolene is used as a local anæsthetic, gasoline is used as a fuel, and naphtha as a solvent for resins in making varnish and in oilcloth manufacture, while benzine is of value for cleaning and as a substitute for and an adulterant of turpentine. Astral oil and mineral sperm oil are special grades of illuminating oil with high flashing points. Crude petroleum is now much used for fuel purposes in engines, as along the Pacific coast and in the southwest, where good coal is so scarce that many of the locomotives are run by the use of crude oil.

The paraffin residue is placed on the market for medicinal purposes under the name of vaseline, petroleum ointment, and cosmoline. It is also used as an adulterant of candy and for electrical insulation.

Uses of Natural Gas. - Natural gas is widely employed as a fuel in factories, metallurgical establishments, glass works, cement plants, etc. For domestic purposes, such as heiating, cooking, and lighting, it is also widely used. Its cheapness, cleanliness, and high calorific power, and the ease with which it can be used have been important factors in insuring its widespread selection for the above purposes.

Oil Shales (55 $a$ and $b$ ). - Shale containing sufficient petroleum to permit its extraction by a process of distillation is 
known as torbanite or kerosene shale. Such shales are found in the Carboniferous of New South Wales, Australia, New Zealand, and Scotland, and in the Cretaceous of Brazil. They are almost unknown in the United States. The following analysis indicates the composition and richness of shale in hydrocarbons :-

\begin{tabular}{c|c|c|c|c|c}
\hline \hline & MoIst & $\begin{array}{c}\text { Volatile } \\
\text { Hydro- } \\
\text { CARBoN }\end{array}$ & $\begin{array}{c}\text { Fixmo } \\
\text { CARBoN }\end{array}$ & Ash & SulPHUR \\
\hline Rich shale, Joadja, N.S.W. . & .16 & 89.59 & 5.27 & 4.96 & .384 \\
\hline
\end{tabular}

The oil can be obtained by distillation in retorts; but in view of the large available supplies of petroleum, obtainable in many parts of the world, the material at present has but little commercial value. It is distilled in New South Wales and also in Scotland.

\section{SOLID BITUMENS}

Occurrence $(56-60,66)$. - Solid bitumens may be grouped according to their mode of occurrence, as (1) asphaltites, which represent the varieties free from sandy and clayey impurities, found filling either fissures or basins ; (2) bituminous rocks, in which the bitumen fills the pores of sandstones, limestones, or other rocks. They are found over a wide range (Fig. 18), both geographically and geologically.

A study of the deposits leads to the conclusion that these solid bituminous compounds have been derived from petroleum $(58,59,60)$, for the following reasons: In the asphaltite deposits the solid bitumens are often associated with petroleum springs, or with fissures leading down to or toward petroleum-bearing strata. In some cases the asphaltite not only fills such a fissure, but impregnates the wall 
rock to a distance of a foot or two on' either side of the vein, indicating that the material came up through the fissure in a liquid condition, filling it, and even penetrating the wall rock.

The bitumen in bituminous rocks may either have originated from organic remains within the rock itself or have seeped into it from some neighboring pool. In either case the material seems originally to have been liquid petroleum which later solidified.

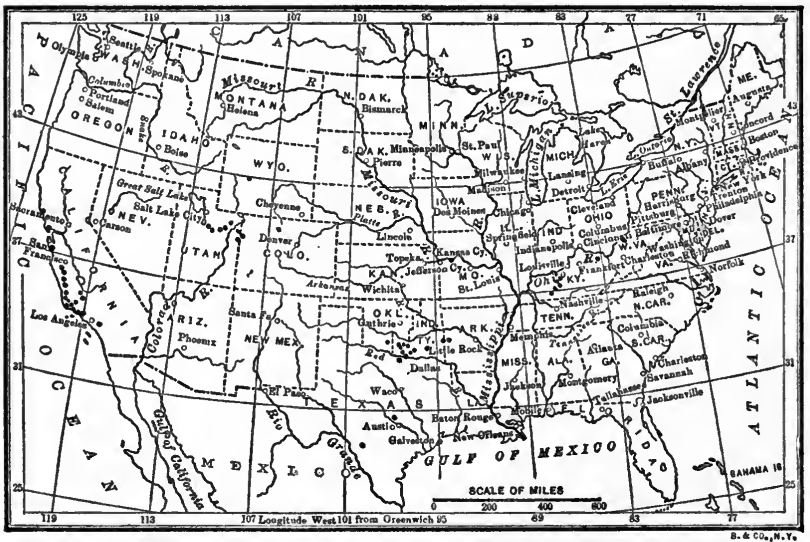

FIG. 18. - Map of asphalt and bituminous rock deposits of United States. After Eldridge, U. S. Geol. Surv., $22 d$ Ann. Rept., IX.

Asphaltites. - There are several varieties of asphaltites, all black or dark brown in color, commonly with a pitchy odor, burning readily with a smoky flame, and insoluble in water, but soluble in ether, oil of turpentine, and naphtha. Their specific gravity ranges from 1 to 1.1 . They are 
closely related chemically and in their mode of occurrence, but differ somewhat in their behavior toward solvents, as well as in their fusibility. The most important varieties are described below.

Albertite (61), a black bitumen with a brilliant luster and conchoidal fracture, a hardness of 1 to 2 and specific gravity 1.097, is found flling fissures in bituminous shales in New Brunswick.

Anthraxolite (63) is a coaly, lustrous, black mineral, with a hardness of 3 to 4, and specific gravity of 1.965. It is found at Sudbury, Ontario, forming veins in a black fissile slate, but has also been described from other localities.

Ozokerite (67), also termed mineral wax or native paraffin, is a waxlike hydrocarbon, yellow brown to green, translucent when pure, and of greasy feel. Its specific gravity is $\mathbf{9 5 5}$. While known to occur in Utah, the most important deposit is in Galicia. At the latter locality the Ozokerite is found forming veins from a few millimeters up to several feet in thickness in much-disturbed Miocene shales and sandstones.

Grahamite (66) is a vein asphalt found in the Carboniferous of West Virginia.

Lake Asphalt (71) is not found in the United States, but occurs in the famous pit or lake on the island of Trinidad, off the coast of Venezuela.

Uintaite, or Gilsonite (66), is a black, brilliant bitumen, with conchoidal fracture, hardness 2 to 2.5 , and specific gravity of 1.065 to 1.07 . It is found filling a series of fissures, termed veins, in the Bridger beds of the Tertiary in eastern Utah, and, to a less extent, in western Colorado. One of these veins, the Duchesne, has been worked to a depth of 105 feet, and is traceable for about a mile, its width for half this distance being 3 to 4 feet. It is usually vertical and in places faulted.

Manjak is the name applied to a bitumen resembling Uintaite, found on the island of Barbados. It is a hydrocarbon of high purity, black color, brilliant luster, and conchoidal frac-

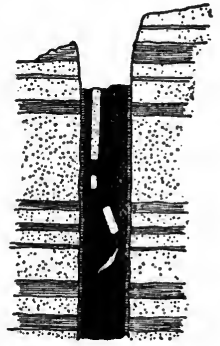

Fra. 19.-Section of Gilsonite vein, Utah. After Eldridge, U.S. Geol. Surv., 17th Ann. Rept., I: 932. 
ture, and forms seams from a quarter of an inch to 30 feet thick in a blue shale. The material brings $\$ 60$ a short ton in New York.

Bituminous Rocks (66). - These are commonly classified according to the character of the containing rock, as bituminous sandstones, bituminous limestones, and bituminous schists. They are much more widely distributed than the asphaltites, being found in several geological horizons, and are worked in Kentucky (66), Indian Territory (66), and California (64).

As ill"strative of its mode of occurrence, we may mention the oituminous sandstone, which is extensively quarried near Santa Cruz, California (Pl. V, Fig. 1). The rock, which is of blackish or brownish-black color, weathering to gray, occurs beneath the Monterey shales, sometimes resting directly on granites. The bitumen impregnates the heavy bedded sandstone immediately under the shale, and also the sand that fills cracks which extend up into the shale. These cracks, which vary in width from very minute size up to 25 or 30 feet, are sometimes traceable for several hundred feet, being at times of value as guides in finding the main bed.

Analyse8. - The variable composition of asphaltites and bituminous rocks can be seen from the following table:-

Analyses of Asphaltites axd Maltha

\begin{tabular}{|c|c|c|c|}
\hline Locality & $\begin{array}{c}\text { SoLUBLE IN } \\
\mathrm{CS}_{2}\end{array}$ & $\begin{array}{l}\text { Mineral } \\
\text { Matters }\end{array}$ & $\begin{array}{l}\text { Non-bituminous } \\
\text { ORGanic MatTkR }\end{array}$ \\
\hline $\begin{array}{l}\text { Trinidad Lake Asphalt. } \\
\text { Grahamite, W. Va. • } \\
\text { Gilsonite, Utah . . } \\
\text { Maltha, Kern. Co., Calif. }\end{array}$ & $\begin{array}{r}54.25 \\
100.00 \\
100.00 \\
93.20\end{array}$ & $\frac{36.51}{.10}$ & $\frac{9.24}{-.54}$ \\
\hline
\end{tabular}




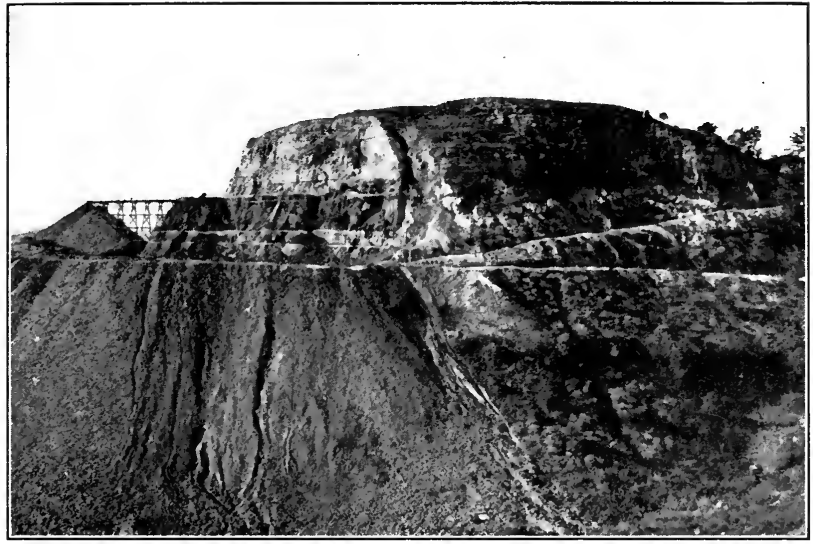

Fic. 1. - Quarry of bituminous sandstone, Santa Cruz, Calif. After Eldridge, U.S. Geol. Surv., 22l Ann. Rept., I.

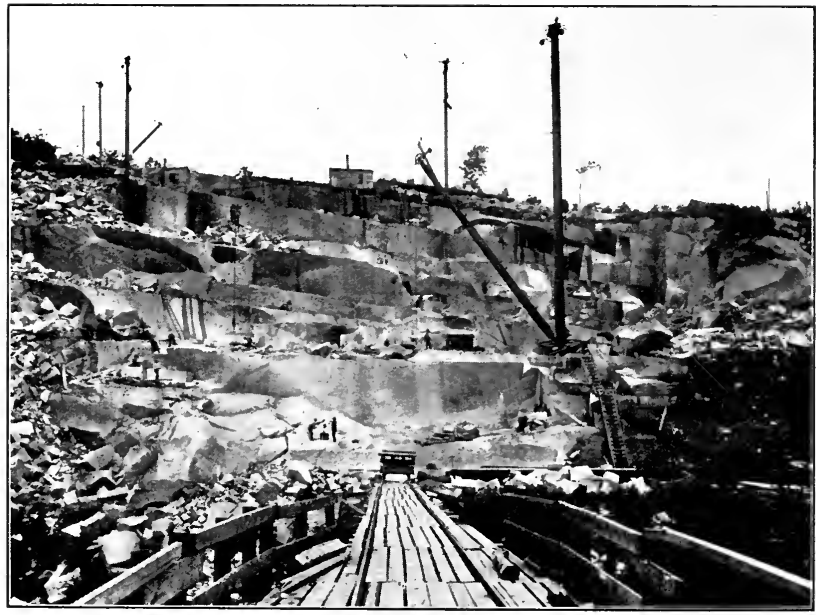

Fig. 2. - Granite quarry, Hardwick, Vt. Photo. by G. H. Perkins. 

Analyses of Bituminous Rocks

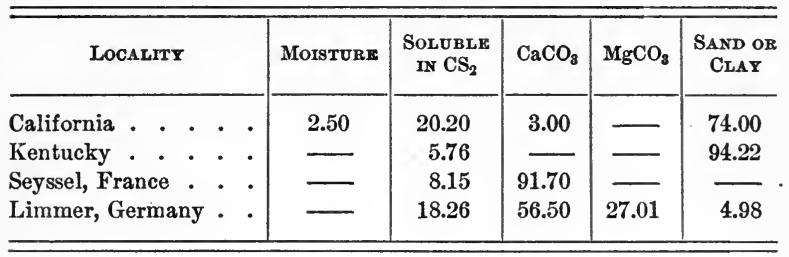

Uses. - Trinidad asphalt mixed with powdered rock and tar is much in use for pavements, and the bituminous rocks are employed for similar purposes. Ozokerite, known as Ceresin in its purified form, is used in the manufacture of candles, ointments, powders, as an adulterant of beeswax, and for bottles to hold hydrofluoric acid.

The most important use of Uintaite and Manjak is for making low-grade and dipping varnishes, such as are used for iron work and baking Japans. Other uses to which the Uintaite at least has been put are for preventing electrolytic action on iron plates of ship bottoms, coating masonry, acid-proof lining for chemical tanks, roofing pitch, insulating electric wires, as a substitute for rubber in common garden hose, and as a binder pitch in making coal briquettes.

Production of Petroleum, Natural Gas, and Asphaltum. The production of crude petroleum and natural gas for several years is given below:- 


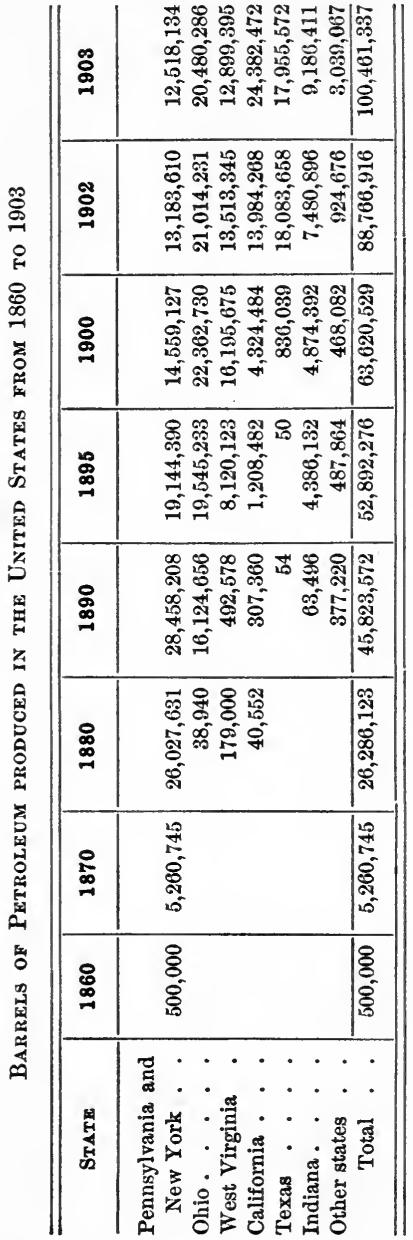

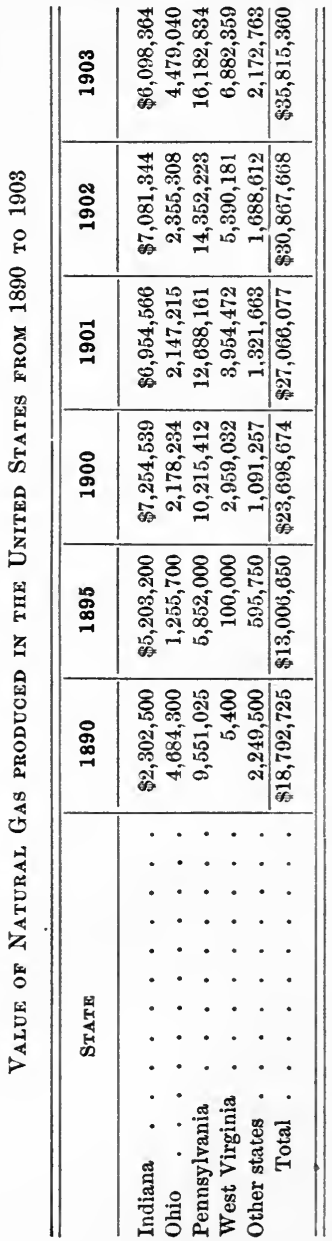


Value of Petroleum axd Natural Gas produced in 1903

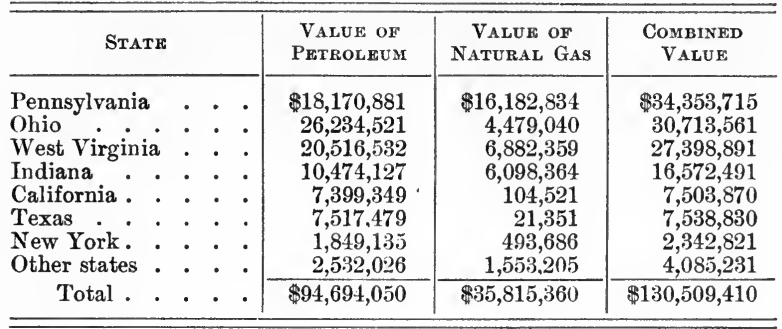

The average price per barrel of petroleum naturally varies somewhat from year to year. In 1885 it was $87 \frac{7}{8} \phi$; in $1890,86 \frac{3}{4} \phi$; in $1895, \$ 1.36 \frac{7}{8}$; in $1900, \$ 1.194$; in $1903,94 \frac{1}{4} \phi$.

The total number of barrels of petroleum produced in the United States from 1859 to the end of 1903 was $1,265,751,585$, while the total value of the natural gas produced in the United States from 1885 to the end of 1903 was $\$ 322,872,792$.

The world's production of petroleum in 1902 and 1903 was as follows:-

World's Production of Petroleum in 1902 and 1903

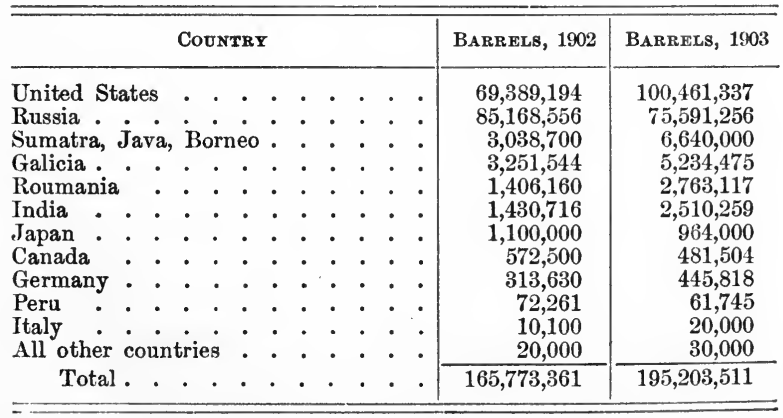


Exports of Mineral Oils

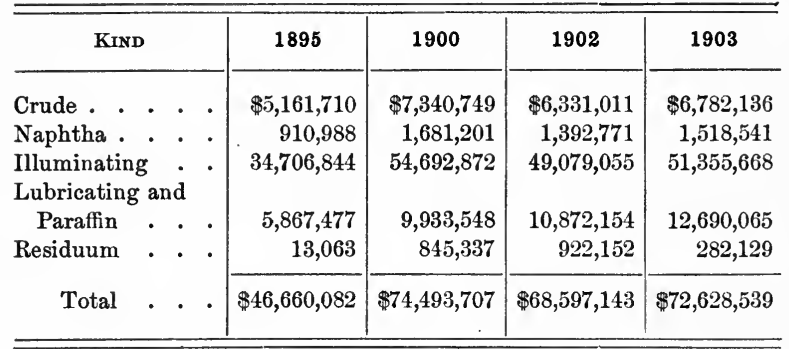

The petroleums reach a wider market than any of our other exports, and over 38 per cent of the total quantity of crude oil produced is now exported in either crude or refined form. This was formerly sent away in cans, but it is now transported largely in bulk in tank steamers, some of which have a capacity of 60,000 barrels. (8a)

The following table gives the production of the different kinds of asphaltum for the last three years:-

Production of Asphaltum in the United States from 1901-1903

\begin{tabular}{|c|c|c|c|c|c|c|}
\hline \multirow{2}{*}{ VARIETY } & \multicolumn{2}{|c|}{1901} & \multicolumn{2}{|c|}{1902} & \multicolumn{2}{|c|}{1903} \\
\hline & $\begin{array}{l}\text { SHORT } \\
\text { ToNs }\end{array}$ & Value & $\begin{array}{c}\text { SHORT } \\
\text { ToNS }\end{array}$ & Value & $\begin{array}{l}\text { SHORT } \\
\text { ToNs }\end{array}$ & Value \\
\hline Bituminous sandstone & 34,248 & $\$ 138,601$ & 57,837 & $\$ 156,993$ & 38,633 & $\$ 118,001$ \\
\hline Bituminous limestone & 6,970 & 33,375 & 2,869 & 19,817 & 2,520 & 8,800 \\
\hline Mastic . . . . . & & & & & 961 & 11,532 \\
\hline $\begin{array}{l}\text { Hard and refined or } \\
\text { gum . . . . }\end{array}$ & 19,316 & 333,509 & 22,321 & 264,817 & 12,896 & 343,799 \\
\hline Liquid or maltha . & 2,600 & 49,850 & 1,605 & 20,172 & 58 & 1,150 \\
\hline
\end{tabular}


The production by states in 1903 was as follows:-

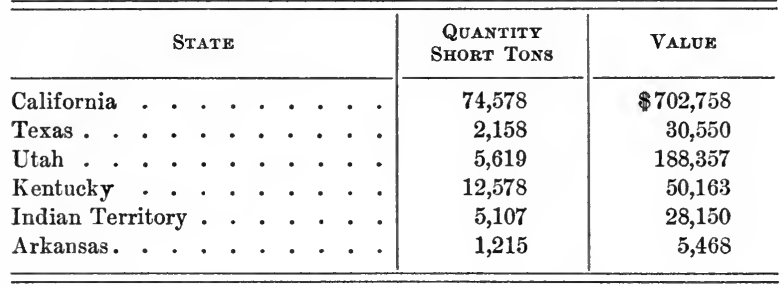

Since deposits of the purer type, such as lake asphalt, are very scarce in the United States, the supply for domestic consumption is obtained from foreign countries. The imports for the last two years are given below:-

Imports of Asphaltum

\begin{tabular}{|c|c|c|c|c|c|c|c|c|c|}
\hline \multirow{2}{*}{\multicolumn{5}{|c|}{ Country }} & & \multicolumn{2}{|c|}{1902} & \multicolumn{2}{|c|}{1903} \\
\hline & & & & & & Long Tons & Value & Long Tons & VALUE \\
\hline West Indies & • & & • & - & & 106,844 & $\$ 358,316$ & $139,0: 31$ & $\$ 415,221$ \\
\hline Venezuela. & & & & & & 12,406 & 62,028 & 16,445 & 74,874 \\
\hline All others. & - & & & & • & 375 & 8,533 & 17,416 & 95,770 \\
\hline Total . & - & & - & • & & 119,625 & $\$ 428,877$ & 172,892 & $\$ 585,865$ \\
\hline
\end{tabular}

The world's production for 1902 was as follows :World's Production of Asphaltum in 1902

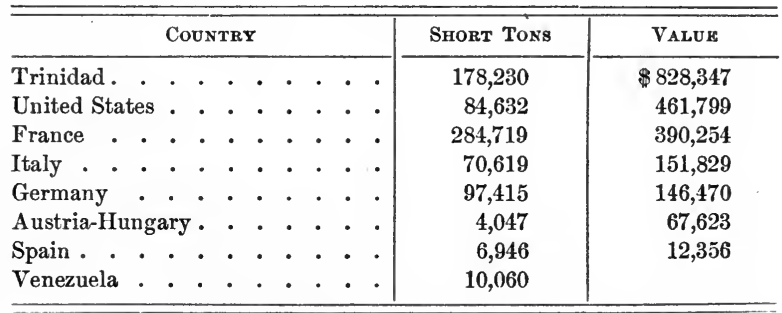




\section{REFERENCES ON PETROLEUM}

Origin, Occurrence, and Technology. 1. Folger, Ann. Rept. Secy. of Internal Affairs, 1892, Pt. III, p. B. (Petroleum production and products.) 2. Mineral Industry, II : 497, 1894. (Mining and Technology.) 3. Newberry, Ohio State Agric. Rept., 1859. 4. Orton, Geol. Soc. Amer., Bull. IX: 85, 1892. (Origin and accumulation.) 5. Orton, Kentucky Geol. Surv., 1894. (Origin.) 6. Peckham, Day, Maybery, etc., Proc. Amer. Phil. Soc., XXXVI: 93. (Origin and composition.) 7. Redwood, B., Treatise on Petroleum. (Excellent.) London. 8. White, Geol. Soc. Amer., Bull. III : 187, 1892. (Anticlinal theory.) 8a. Oliphant, Mineral Census, 1902, Rept. on Mines and Quarries. (General and statistical.)

Areal Reports. Alaska : 9. Martin, U. S. Geol. Surv., Bull. 225 : 365, 1904. Also U. S. Geol. Surv., Bull. 259 : 129, 1905. - California : 10. Eldridge, U. S. Geol. Surv., Bull. 213: 306, 1903. (General, good.) 11. Mabery and Hudson, Amer. Acad. Arts and Sci., Proc. XXVI : 255. (Composition.) 12. Watts, Bulls. Calif. State Min. Bureau, No. 3 (Central Valley), No. 11 (Los Angeles, Ventura, and Santa Barbara Cos.), No. 19 (General.) - Colorado: 13. Eldridge, Trans. Amer. Inst. Min. Engrs., XX: 442, 1892. (Florence field.) 14. Fenneman, U. S. Geol. Surv., Bull. 225: 383, 1904. (Boulder field.) 15. Fenneman, U. S. Geol. Surv., Bull. 260: 436, 1905. (Florence.) - Indiana: 16. Blatchley, Ind. Dept. Geol., 22d Ann. Rept.: 155, 1898. (Trenton limestone field.) 17. Chapters on petroleum in other annual reports of this series. 18. Orton, U. S. Geol. Surv., 8th Ann. Rept., II : 475, 1889. (Trenton limestone.) - Kansas: 19. Adams, U. S. Geol. Surv., Bull. 184, 1901. 20. Haworth, Kansas Geol. Surv., I : 232, 1896. (General.) 21. See also Volumes on Mineral Resources, issued by Kansas Geol. Surv. from 1897 to 1901. - Kentucky : 22. Orton, Ky. Geol. Surv., 1894. (General.) - Louisiana: 23. Hayes and Kennedy, U. S. Geol. Surv., Bull. 212, 1903. (General.) - Michigan : 24. Gordon, Mich. Geol. Surv., Ann. Rept., 1901; 269, 1902. (Port Huron field.) - New York: 25. Orton, N. Y. State Mus., Bull. 30, 1899. (General.) - Ohio: 26. Bownocker, Ohio Geol. Surv., 4th Series, Bull. 1, 1903. 27. Griswold, U. S. Geol. Surv., Bull. 198. (Berea grit oil.) 28. Mabery, Amer. Chem. Jour.; Dec., 1895. (Composition.) 29. Orton, Ohio Geol. Surv., VI : 60. 30. Orton, U. S. Geol. Surv., Sth Ann. Rept., II : 475, 1889. (Trenton limestone field.) - Pennsylvania : 31. Carll, Ann. Rept. Pa. Geol. Surv., 1885; II. 1886. 32. Reports I to I 5 of the same survey. - Texas: 33. Adams, U. S. Geol. Surv., Bull. 184, 1901. (General.) 34. Hayes and Kennedy, U. S. Geol. Surv., Bull. 
212, 1903. 35. Phillips, Tex. Univ. Min. Surv., Bull. No. 1, 1900. (General.) - Washington: 36. Landes, Wash. Geol. Surv., I: 207. (General.) - West Virginia : 37. White, W. Va. Geol. Surv., I $a: 1$, 1904. (General.) 38. White, Geol. Soc. Amer., Bull. III: 187, 1892. (Mannington field.) - Wyoming: 39. Knight and Slosson, Bull. 4, Wyo. School of Mines. (General.) 40. Bull. 3. (Crook and Uinta Cos.) 41. Bull. 5. (Newcastle field.) 42. Bull. 1. (Salt Creek field.)

\section{-REFERENCES ON NATURAL GAS}

Ashburner. 43. Amer. Inst. Min. Engrs., Trans. XIV : 428. (Geology and Distribution in the United States.) $43 a$. Orton, Geol. Soc. Amer., Bull. I : 87. (Rock pressure.)-California: 44. Watts, Calif. Min. Bureau, Bull. 3. (Central Valley.) - Indiana: 45. Phinney, U. S. Geol. Surv., 11th Ann. Rept., I: 589, 1891. 46. See also Ann. Repts. Ind. Geol. and Nat. Hist. Survey.-Kansas: 47. Adams, U. S. Geol. Surv., Bull. 184, 1901. 48. Haworth, Kan. Geol. Surv., I: 232, 1896. (General.) 49. Orton, Geol. Soc. Amer., Bull. X: 99, 1899. (Iola field.) 50. Volumes on Mineral Resources, issued by Kan. Geol. Surv., 1897-1901. - New York: 51. Orton, N. Y. State Mus., Bull. 30, 1899. (General.)-Ohio: 52. Orton, Ohio Geol. Surv., I. 3d ser. : 55. 53. Orton, U. S. Geol. Surv., 8th Ann. Rept., II : 475, 1889. - Pennsylvania : 54. Carll and Phillips, Ann. Rept. Pa. Geol. Surv., 1886, Pt. II, 1887. (General.) - Texas : 55. Adams, U. S. Geol. Surv., Bull. 184, 1901.

\section{REFERENCES ON OIL SHALES}

55 a. Branner, Amer. Inst. Min. Eng., XXX: 537. Brazil.) 55 b. Carne, Memoirs, Dept. Mines and Agric., New South Wales, Geology No. 3. (General treatise.)

\section{REFERENCES ON ASPHALTUM}

General. 56. Dow, Min. Indus., X: 51, 1902. (History of Asphalt Industry.) 57. Greene, Amer. Inst. Min. Engrs., Trans. XVII : 355. (Uses.)-Origiv: 58. Adams, Amer. Inst. Min. Engrs., Trans. XXXIII: 340, 1903. (Origin.) 59. Day, Eng. Record, XL: 346. 60. Peckham, Amer. Phil. Soc., XXXVII: 108. (Genesis of bitumens.)-Spectal Papers: 61. Bailey and Ells, Geol. Surv.; Canada, 1876-77, 384. (Albertite.) 62. Blake, Amer. Inst. Min. Engrs., Trans. XVIII: 563. (Uintaite, Albertite, and Grahamite.) 63. Coleman, Ontario Bur. Mines, 6th Ann. Rept., 159, 1897. (Anthraxolite.) - Areal: 64. Cooper, Calif. State Min. Bureau, Bull. 16. (California.) 65. Crosby, Amer. Naturalist, XIII : 229. 
(Trinidad.) 66. Eldridge, U. S. Geol. Surv., 22d Ann. Rept, I: 1901. (General occurrence in Uuited States, excellent.) 67. Gosling, Sch. M. Quart., XVI : 41. (Ozokerite.) 68. Lane, Eng. and Min. Jour., LXXIII : 50. (Mich.) 69. Merivale, Eng. and Min. Jour., LXVI : 790, 1898. (Barbados.) 70. Parker, U. S. Geol. Surv., 19th Ann. Rept., VI (ctd.) : 187, 1898. (Ozokerite.) Also Min. Ind., X: 50, 1902. 71. Peckham, Pop. Sci. Mo., LVIII : 225, 1901. (Trinidad and Venezuela.) 72. Phillips, Univ. of Tex. Min. Surv., Bull. 3, 1902. (Texas.) 73. Vaughn, Eng. and Min. Jour., LXXIII: 344. (Cuba.) 


\section{CHAPTER III}

\section{BUILDING STONES}

UNDER this term are included all stones for ordinary masonry construction, as well as for ornamentation, roofing, and flagging. The number of different kinds used is very great, and includes practically all varieties of igneous, sedimentary, and metamorphic rocks, but a few stand out prominently on account of their widespread occurrence and durability.

The cost of a building stone naturally exerts decided influence on its use. Since the ease of splitting and dressing a stone influences its cost, the texture is also of importance. Color is another factor in determining the value of a building stone, and this, together with other considerations, sometimes gets a fashion leading to the widespread use of certain stones. This has been well illustrated in the eastern cities of the United States where, for many, years, Connecticut browstone was in such great demand for use in building private dwellings that much inferior stone was put on the market. More recently Indiana limestone and Ohio sandstone have met the popular fancy, and these two are now used in vast quantities.

Properties of Building Stones (1-6).-The following properties have an important bearing on the value of a building stone:- 
Color. - The color of rocks varies greatly, and those shown by common building stones include white, black, brown, red, yellow, and buff, while some are green, blue, or mottled. The color may vary in the same quarry.

In igneous rocks the color may be that of the prevailing mineral, as in pink granite, where there is an excess of pink feldspar; or it may be a composite due to the blending of the colors of several minerals, as in the case of ordinary gray granite, where the color results from the mixture of black mica and whitish quartz and feldspar. Sedimentary rocks commonly owe their color either to ferruginous cements, or to carbonaceous matter. The former give brown, yellow, red, or green colors depending on the condition of oxidation of the iron, while the latter produces gray, black, and bluish tints depending on the amount present. Sandstone and limestone free from either of these coloring agents are nearly if not quite white.

Some stones change color on exposure to the air. For example, limestones or sandstones containing carbonaceous matter may bleach; some black marbles fade to a white or gray; and many red and green roofing slates, as well as many red granites, change color. Oxidation of evenly distributed pyrite may change gray or bluish-gray sandstones to buff color. If the minerals responsible for such change in color are not uniformly distributed, the stone assumes a blotchy appearance, but such changes are not necessarily an indication of deterioration.

Texture. - Building stones vary in their texture from coarse-grained granites and conglomerates to fine-grained sandstones, limestones, and porphyries.

Texture is an important property, for it influences both the durability and the cost of stone. Other things being equal, a fine-grained rock is not only more durable, but splits better and dresses more evenly than a coarse-grained rock. Uneven texture, whether due to mineral grains or cement, is undesirable since it often causes uneven weathering.

Density. - On the whole, dense stones resist weather better than porous ones, but there is great difference in the density of building stones. 
In general, though with some exceptions, igneous and metamorphic rocks have high density because of the close interlocking of the crystalline grains. Sedimentary rocks of clastic origin, on the other hand, have less closely fitting grains, and unless the latter are very small, or the pores well filled with cement, they are apt to be porous.

The specific gravity of a stone indicates its density; and from the specific gravity the weight per cubic foot may often be approximately estimated by multiplying it by 62.5 , the weight of an equal volume of water. While sufficiently accurate for very dense stones this method is liable to lead to incorrect results when applied to very porous rocks. Following are some average specific gravities of common building stones, as given by Hermann (1) : granite, 2.65 ; syenite, 2.80 ; serpentine, 2.60; gneiss, 2.65; limestone, 2.60; dolomite, 2.80; sandstone, 2.10 ; slate, $2.700^{\circ}$

Hardness. - The hardness of a building stone is not necessarily dependent on the hardness of its component minerals, but is largely influenced by their state of aggregation.

For example, a sandstone composed of quartz grains, but with little cementing material, may be so soft as to crumble easily in the fingers, while a limestone, whose grains of soft carbonate of lime fit closely and are firmly cemented, may be difficult to break with a hammer. The nature of the cement in sedimentary rocks, that is whether it is lime, silica, or iron, will also affect the hardness of the stone. Crystalline rocks owe their great hardness to the firm interlocking of the mineral grains.

Strength. - Two kinds of strength, compressive and transverse, are to be considered in building stones.

The compressive or crushing strength, which is expressed in pounds per square inch, is the resistance which the rock offers to a crushing force, and is dependent chiefly on the size of the grains, state of aggregation, and mineral composition. Because of the close interlocking of the grains of igneous rocks they are stronger than those of sedimentary origin, in which the strength is due chiefly to the cement which binds the grains together. Sedimentary rocks show greatest strength when dry, or when pressure is applied at right angles to the bedding. 
Few building stones are subjected to pressures even approximately equal to their crushing strength. No domestic building stone at present used in the eastern market has a crushing strength of less than 6000 pounds, yet the pressure even in the tallest buildings does not require a stone with a crushing strength exceeding 314.6 pounds, and this includes the factor of safety of twenty usually allowed by architects. Computations show that a stone at the base of the Washington monument sustains a maximum pressure of 6292 pounds per square inch, which includes the usual factor of safety of twenty; the crushing strength of the stone used in the base of the monument is however not less than 10,000 to 12,000 pounds per square inch.

The crushing strength of some soft limestones or sandstones may be but little above 3000 pounds per square inch, while that of diabase often exceeds 30,000 pounds per square inch. The accompanying table gives the crushing strength of a number of native stones.

\section{Crushing Strength of Building Stones}

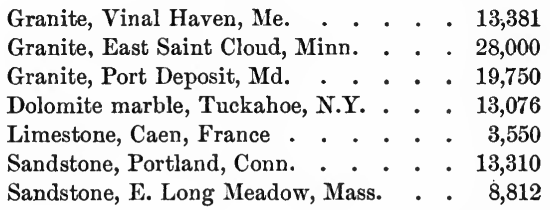

The published crushing tests of different stones cannot really be fairly compared because all have not been tested under exactly the same conditions.

Transverse Strength. - The transverse strength is the load which a bar of stone, supported at both ends, is able to withstand without breaking. It is measured in terms of the modulus of rupture, which represents the force necessary to break a bar of one square inch cross section, resting on supports one inch apart, the load being applied in the middle. Although stones in buildings are rarely, if ever, crushed, they are frequently broken transversely, and therefore a knowledge of the transverse strength is of more importance than the crushing strength. A high crushing strength does not necessarily mean a high transverse strength. Unfortunately few stones have been tested in this manner. 
Porosity and Ratio of Absorption. - The porosity of building stones varies widely. Most igneous rocks have little pore space and hence absorb little water; but sedimentary rocks, especially sandstones, are often very porous.

Many rocks, especially those of the sedimentary class, contain water in their pores when first quarried. This is known to quarrymen as quarry water, and it is present in some porous sandstones in sufficient quantities to interfere with quarrying during freezing weather. Mineral matter in solution in the quarry waters is deposited between the grains when the water evaporates, often in sufficient quantities to perceptibly harden the stone.

Water is also present in the joint planes, and by its passage along these planes causes oxidation and rusting of the iron of the rock-forming minerals. This discolors the stone along and on either side of the joint planes, giving rise to a yellow color known as sap.

Resistance to Frost. - Building stones show a varying degree of resistance to frost.

Dense rocks, like granites, quartzites, and many limestones, and even some very porous rocks, are little affected; but many porous and laminated rocks, like open sandstones and schists, disintegrate under frost action. This is due to the fact that moisture absorbed in the warmer weather, on freezing in the pores, expands, and either forces off small pieces or disrupts the stones. Since clay readily absorbs water, clayey rocks are sometimes similarly affected.

Resistance to Heat. - All rocks expand when heated, and contract when cooled, but do not shrink down to their original dimensions. This permanent increase in size is termed permanent swelling, and though small when figured for one linear foot, is appreciable in long pieces.

The following figures give the average of a number of tests of permanent swelling in stone bars 20 inches long, heated from $32^{\circ} \mathrm{F}$. to $212^{\circ} \mathrm{F}$., and then cooled to the original temperature: granite, .009 
inches; marble, .009 inches; limestone and dolomites, .007 inches; sandstone, .0047 inches.

The most severe test of a stone's resistance to rapid changes of temperature is to heat it to about $800^{\circ} \mathrm{C}$. and then immerse it in cold water. Quartzites and hard sandstones withstand such treatment best; some granites crack and crumble, and the carbonate rocks change to lime.

Structural Features affecting Quarrying. - All rocks are traversed by planes of separation of one sort or another. In sedimentary rocks these consist of bedding and joint planes; in igneous rocks, the latter alone are present; and in metamorphic rocks, joint planes, a banding of minerals, and, very often, cleavage planes.

Bedding Planes. - These may be either an advantage or a disadvantage to the quarryman. They are desirable because they facilitate the extraction of the stone; but if numerous and closely spaced, the layers may be too thin for any purpose except flagging. They often serve as a means of entrance for the agents of weathering, and the stone may be disintegrated along the bedding planes while elsewhere fresh.

Incipient planes of weakness, due either to the arrangement of minerals or to microscopic fractures in them, often give rise to planes of easy splitting which are of great value in quarrying, notably of granite. Such planes which permit splitting in approximately horizontal directions are called lift; the most prominent vertical plane is called rift; and a less prominent vertical plane, approximately at right angles to the rift, is called the cut off.

The position of the beds exerts an important influence on the cost of quarrying. When horizontal and of different quality, it may often be necessary to strip off worthless rock in order to reach the beds of good quality. In such cases, there is often less stripping to do in quarries opened on gently sloping ground. In regions of steep dip, it is sometimes possible to work the quarry as a cut, extracting the desired beds and leaving useless ones standing. 


\section{GRANITES}

Characteristics of Granites (3). - As commonly used by quarrymen, the term granite includes all igneous rocks and gneiss; but in this book it is used in the geological sense, which is more restricted. From the geological standpoint a granite is a holocrystalline, plutonic igneous rock consisting of quartz, orthoclase feldspar, and either mica or hornblende, or both. There are also varying but usually small quantities of other feldspars, and there may be subordinate accessory minerals, such as pyrite, garnet, tourmaline, and epidote.

Granites vary in texture from fine to coarse grained, and in some cases are porphyritic. They pass into gneisses by such insensible gradations that no sharp line can be drawn between the two. In color they vary, being, most commonly, gray, mottled gray, red, pink, white, or green, according to the color or abundance of the component minerals. Most granites are permanent in their color, but some of bright red color bleach on exposure to weather.

The average specific gravity of granites is 2.66 , which corresponds to a weight of 166.5 pounds per cubic foot. They commonly contain less than 1 per cent of water, and often absorb two or three tenths more. Their crushing strength varies, but is apt to lie between 15,000 and 30,000 pounds per square inch.

Granites are among the most durable of building stones, but there is some variation in the durability of the different kinds. Other things being equal, fine-grained granites are more durable than coarse-grained, being less easily affected by changes of temperature. One of the most beautiful granites known, the Rapikivi granite of Finland, lacks in durability on this account. Pyrite and marcasite are injurious minerals, since they rust rapidly and may discolor the stone in an 
unsightly manner. Very few granites now in use show signs of decay; but in those that do, the darker silicates are rusted, the luster of the feldspar is dulled, and, in some cases, the stone has begun to disintegrate. Some red granites bleach on continued exposure to sunlight.

Distribution of Granites in the United States (3). - Granite usually occurs in great bosses frequently forming the cores of mountain chains. Removal of the overlying strata by

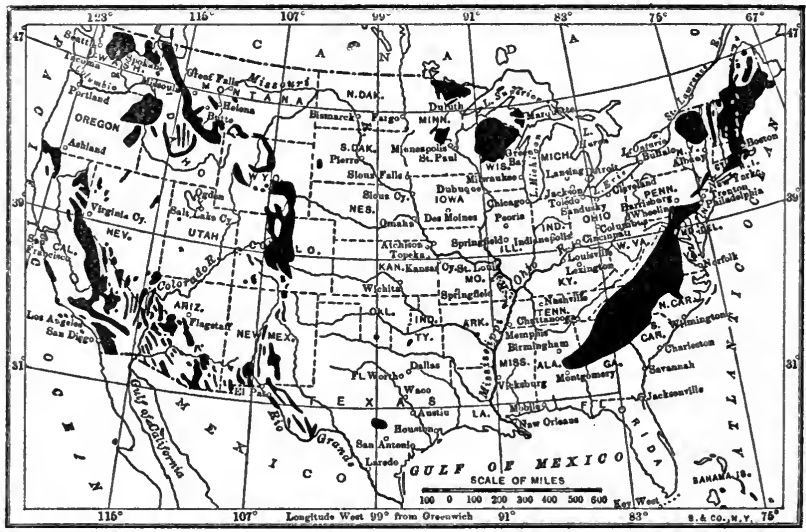

F1G. 20. - Map showing distribution of crystalline rocks (mainly granites) in United States. After Merrill. Stone for Building and Decoration.

denudation has revealed the granite, which, owing to its greater durability, is often left standing as peaks or domes by the farther removal of the surrounding, weaker strata. Granites show a wide, geologic range, but most known occurrences are associated with the older formations.

Granite forms an important source of durable building stone widely distributed in the United States (Fig. 20); but nearly 70 per cent of that quarried comes from the 
Atlantic states. There are several areas which will be briefly considered.

Eastern Crystalline Belt (3, 8, 15, 21, 25, 32, 33). - From northeastern Maine southwestward to eastern Alabama there is an important belt of granites and gneisses, mostly of pre-cambrian age. Those at the northeastern end of the belt, as far south as New York, are most extensively quarried, largely because of their peculiarly favorable location. In this belt those of Quincy, Massachusetts, Barre, Vermont, and Westerly, Rhode Island, are of value for monumental work.

Central States. - In these states there are several widely separated areas: (1) the Minnesota-Wisconsin area (35), affording many fine stones; (2) the southeastern Missouri area; (3) east central Arkansas; and (4) Llano County, Texas, all supplying stones of excellent quality.

Western States. - There are many granite areas in the Cordilleras, including stone of various colors and texture; but quarrying is almost entirely confined to California (12), Colorado (13), Montana, Washington (34), and Oregon for local use. The supply is inexhaustible. There is some quarrying, also, in the enormous mass of coarse-grained granite which forms the central portion of the Black Hills of South Dakota.

Uses of Granite. - On account of its massive character and durability, granite is much employed for massive masonry construction, while some of the granites that take and preserve a high polish, and are susceptible of being carved, are in great demand for ornamental and monumental work. Because of its greater durability, granite has 
in recent years largely replaced marble for monumental purposes.

The refuse of the quarries is often dressed for paving blocks or crushed for roads and railroad ballast. The size of the blocks which can be extracted from a granite quarry depends in part on the spacing of the joint planes, in part on the perfection of development of the rift, some of the monoliths that have been quarried being of immense size; for example, one from Stony Creek, Connecticut, measured $41 \mathrm{ft} . \times 6 \mathrm{ft} . \times 6 \mathrm{ft}$; one from Vinal Haven, Maine, $60 \mathrm{ft}$. $\times 5 \frac{1}{2} \mathrm{ft}$; one from Barre, Vermont, $60 \mathrm{ft} . \times 7 \mathrm{ft} . \times 6 \mathrm{ft}$.

Miscellaneous Igneous Rocks. - Other igneous rocks than granites are little used for structural work, though they are quarried in some localities. For example, the diabase, or trap, so abundant in the Triassic of the eastern states, is occasionally used for dimension blocks, but its chief value is for paving blocks and road metal. The basaltic rocks of the western states are often employed for similar purposes. Norites of great beauty occur in New York, and syenites of excellent quality have been quarried in Arkansas. Diorites are also quarried at scattered localities. Some of the porphyries and rhyolites of the Atlantic States possess considerable beauty when polished. A handsome porphyry is quarried in Wisconsin (35), and in the Cordilleran region both rhyolite and porphyry occur in numerous localities. A pink rhyolite and consolidated volcanic tuffs are used, to some extent, for building in Arizona.

\section{LIMESTONES AND MARBLES}

General Characteristics $(1,3)$. - A great series of sedimentary and metamorphic rocks, composed chiefly of carbonate of lime, or, in the case of dolomite, of carbonate of lime and magnesia, is included under the term limestone and marble. These rocks also contain varying, but usually small amounts of iron oxide, iron carbonate, silica, clay, 
and carbonaceous matter. When of metamorphic character, various silicates, such as mica, hornblende, and pyroxene, may be present.

These calcareous rocks vary in texture from fine-grained, earthy, to coarse-textured, fossiliferous rocks, and from finely crystalline to coarsely crystalline varieties. There is, also, great range in color, the most common being blue, gray, white, and black, but beautiful shades of yellow, red, pink, and green, usually due to iron oxides, are also found. Their crushing strength commonly ranges from 10,000 to 15,000 pounds per square inch, while their absorption is generally low.

The mineral composition of limestone exerts a strong influence on its durability. Those limestones which are composed chiefly or wholly of carbonate of lime are liable to solution in waters containing carbon dioxide; but dolomite limestones, especially coarse-grained ones, disintegrate rather than decompose. Streaks of mineral impurities cause the stone to weather unevenly. Pyrite is an especially injurious constituent, not only on account of its rusting, but also because the sulphuric acid set free by its decomposition attacks the stone. Black or gray limestones will sometimes bleach on exposure.

Varieties of Limestones. - In the geological sense limestones are of sedimentary origin, while marbles are of metamorphic character, but in the trade the term marble is applied to any calcareous rock capable of taking a polish. In addition to the different varieties of marble and the ordinary limestones there are certain kinds of calcareous rock to which special names are given, as follows :-

Dolomite, or dolomitic limestone, composed of carbonate of lime and magnesia, and to the eye alone often is indistinguishable from limestone. 
Oölitic limestone, composed of small, rounded grains of concretionary character.

Travertine, or calcareous tufa, a limestone deposited from springs. It is often sufficiently hard and durable for building, but rarely occurs in deposits of large size.

Stalactitic and stalagmitic deposits, formed on the roofs and floors of caves, respectively, are often of crystalline texture and beautifully colored, and, when of sufficient solidity, are known as onyx marble.

Fossiliferous limesiones is a general term applied to those limestones which contain many fossil remains. Under this heading are included crinoidal limestone and coral-shell marble. Coquina is a loosely cemented shell aggregate, like that found near St. Augustine, Florida. Chalk is a fine, white, earthy limestone, composed chiefly of foraminiferal remains.

Distribution of Limestones in the United States. - Limestones are found in many states, and in all geological formations from Cambrian to Tertiary, but those of the Paleozoic, which are much used in the Eastern and Central states, are more extensive and more massive than those of later formations. Although many large quarries have been opened to supply a local demand, the product is shipped to a distance from only a few localities. At present the sub-Carboniferous Bedford (18) oölitic limestone of Indiana (Pl. VI) is, perhaps, the most widely used limestone in the United States. It occurs in massive beds from 20 to 70 feet thick, and is said to underlie an area of more than 70 square miles. Although soft and easily dressed, it has good strength, and has been used in many important cities of the United States.

Cretaceous limestones are worked in Kansas, Nebraska, and Iowa, although the most important sources are in the Paleozoic formations. 
Plate VI

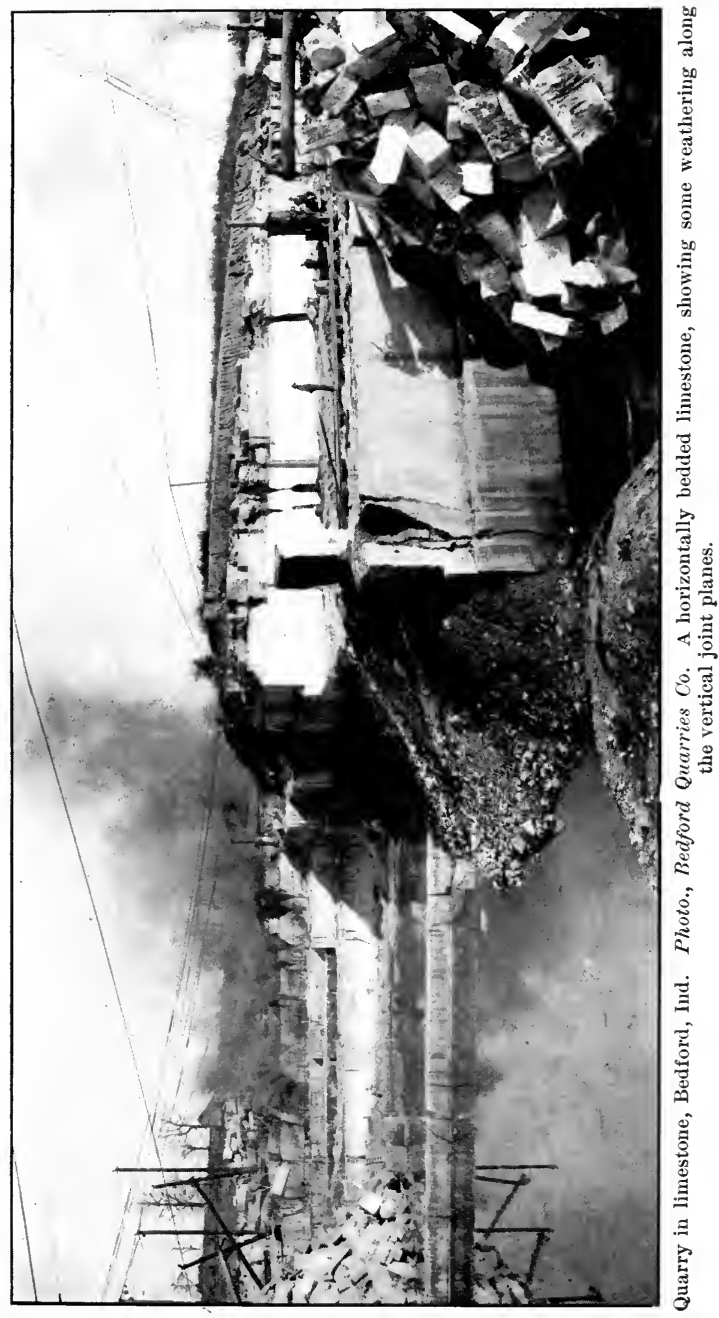



Distribution of Marbles in the United States (3). - While some variegated marble is produced in the United States,

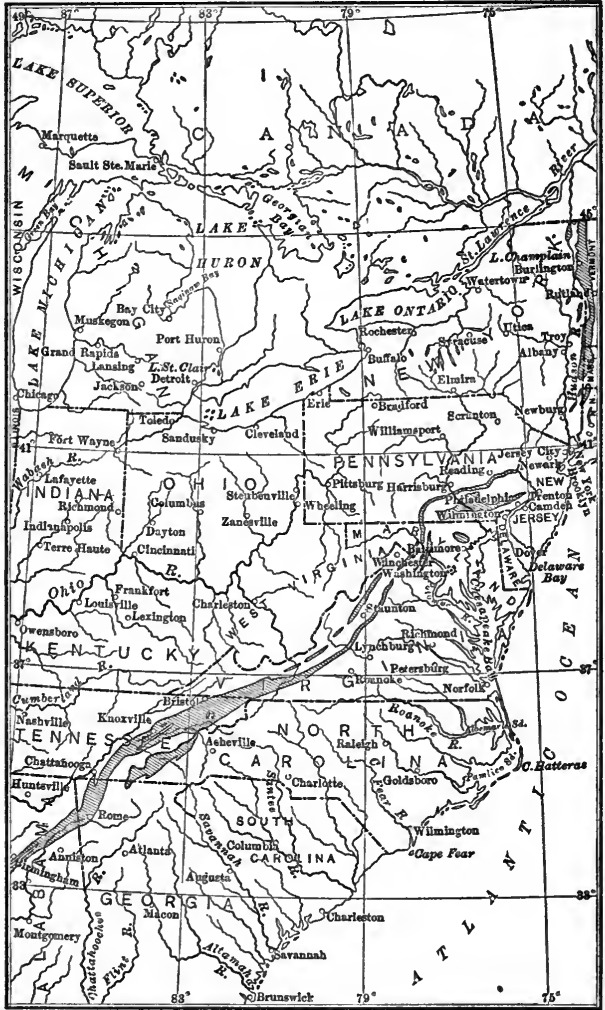

Fra. 21. - Map showing marble areas of eastern United States. After Merrill. Stones for Building and Decoration.

still most of those quarried are white, the greater part of the variegated stones being imported. The main supply 
comes chiefly from regions of metamorphic rock, the eastern crystalline belt being the principal producer (Fig. 21). Vermont $(32,33)$ leads all other states in marble production, supplying 80 per cent of all the marble used for ornamental work in the country. The most important and largest quarries are those at Proctor (Pl. VII) and West Rutland, where a thick and steeply dipping bed of marble occurs between other limestones. The marble bed, which has a thickness of 150 feet at the top of the quarry, narrowing to 75 feet at the bottom, is divisible into a series of well-marked layers of varying thickness, quality, and color, - white, blue, gray, and striped (33). Similar marbles are quarried in Massachusetts $(3,22)$, New York (3, 28), Maryland (21), and Georgia (15).

A variegated red and white marble of some hardness is quarried at Swanton, Vermont (33), the brilliant red being caused by iron oxide, the white by calcite deposited in breccia cavities.

The Trenton limestone in eastern Tennessee (3) supplies marbles of pinkish chocolate color with white variegation; and certain layers are rendered peculiarly beautiful by the replacement of the fossils by calcite. It is used chiefly for interior decoration.

Marble has been reported from various states west of the Mississippi, but as yet little quarrying has been done. That quarried in Inyo County, California, has attracted considerable attention in recent years.

Most of the variegated marble used for interior decoration in this country is obtained from abroad, although ornamental stones of this class occur in the United States; however, up to the present time few attempts have been made to place them on the market. This may be 


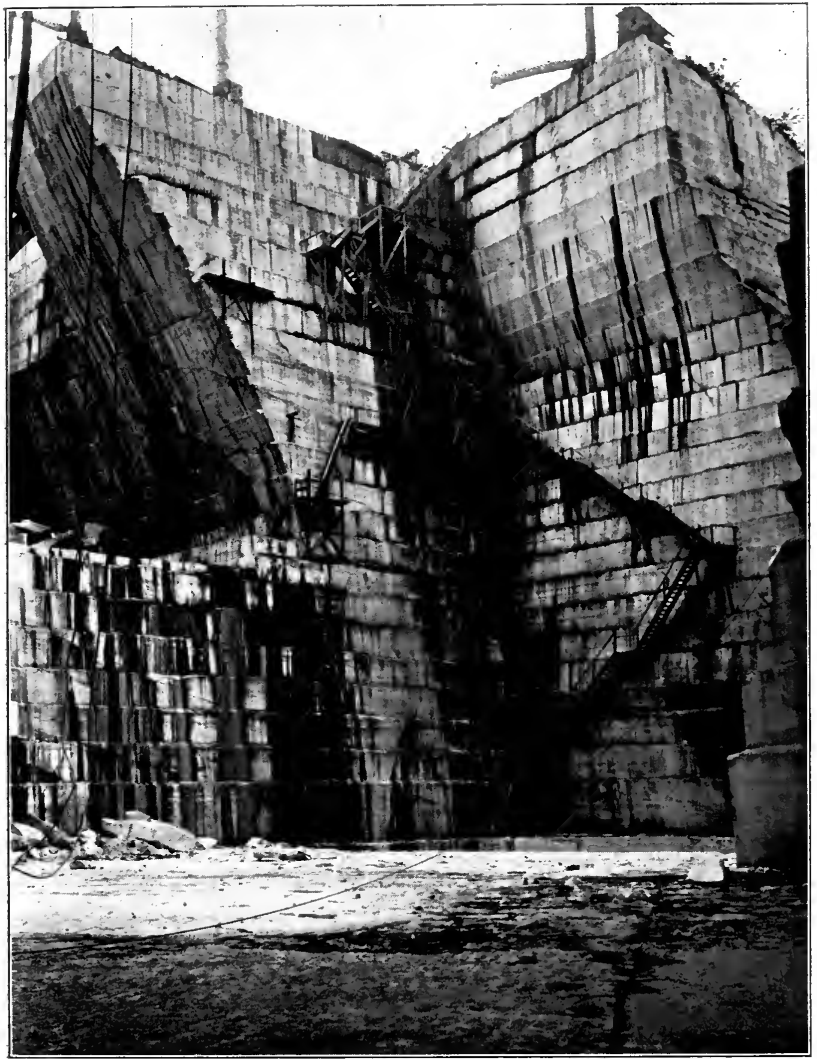

Marble quarry, Proctor, Vt. Photo., Vermont Marble Co. The banding of the rock is vertical. The horizontal lines are caused by the stone being quarried in benches. 

due to the fact that few quarrymen care to assume the temporary expense which their introduction might involve.

Onyx Marbles (37-40). - Under this term are included two types of calcareous rock, one a hot-spring deposit, or travertine, formed at the surface, the other a cold-water deposit formed in limestone caves in the same manner as stalagmites and stalactites. Cave onyx is more coarsely crystalline and less transluscent than travertine onyx. The beautiful banding of onyx is due to the deposition of successive layers of carbonate of lime, while the colored cloudings and veinings are caused by the presence of metallic oxides, especially iron.

Neither variety of onyx occurs in extensive beds, though both are widely distributed. Onyx is found in Arizona, California, and Colorado, but it has not been developed in any of these states except on a small scale. Most of the onyx used in the United States is obtained from Mexico, though small quantities are obtained from Egypt and north Algeria.

The value of onyx varies considerably, the poorer grades selling for as little as 50 cents per cubic foot, while the higher grades bring $\$ 50$ or more. The earliest-worked deposits were probably those of Egypt, which were used by the ancients for the manufacture of ornamental articles and religious vessels; and the Romans obtained onyx from the quarries of northern Algeria. Many of the travertine onyx deposits occur in regions of recent volcanic activity, and all of the known occurrences are of recent geological age.

\section{SERPENTINE}

Pure serpentine is a hydrous silicate of magnesia; but beds of serpentine are rarely pure, usually containing varying quantities of such impurities, as iron oxides, pyrite, hornblende, and carbonates of lime and magnesia. The purer varieties are green or greenish yellow, while the impure types are various shades of black, red, or brown. Spotted green and white varieties are called ophiolite or ophicalite.

Serpentine is sometimes found in sufficiently massive form for use in structural or decorative work; but, owing to the frequent and irregular joints found in nearly all serpentine quarries, it is difficult to obtain other than small-sized slabs. Its softness and beautiful color have led 
to its extensive use for interior decoration; but since it weathers irregularly and loses luster, it is not adapted to exterior work.

Though found in a number of states, most of the numerous attempts to quarry American serpentine have been unsuccessful. Considerable serpentine for ordinary structural work has been quarried in Chester County, Pennsylvania, and a variety known as Verdolite is worked near Easton, Pennsylvania. Quarrying operations are also under way in the state of Washington.

\section{SANDSTONES}

General Properties $(1,3)$. - While most sandstones are composed chiefly of quartz grains, some varieties contain an abundance of other minerals, such as mica, or, more rarely, feldspar, which in rare cases may even form the predominating mineral. Pyrite is occasionally present, and varying amounts of clay frequently occur between the grains, at times in sufficient quantity to materially influence the hardness and dressing qualities of the stone. The hardness of sandstones, however, usually depends on the amount and character of the cement, varying from those having so small an amount of silica or iron oxide cement that the stone crumbles in the fingers to those quartzites whose grains are so firmly bound by silica that the rock resembles solid quartz. With these differences the chemical composition varies from nearly pure silica to sandstone with a large percentage of other compounds. (For analyses, see Kemp's "Handbook of Rocks.")

There are many colors among sandstones, but light gray, white, brown, buff, bluish gray, red, and yellow are most common. In density sandstones range from the nearly impervious quartzites to the porous sandrocks of recent geologic formations, and consequently they show a variable absorption. 
Most sandstones contain some quarry water, and those with appreciable amounts are softer and more easy to dress when first quarried; but they cannot be quarried in freezing weather. The average specific gravity of sandstone is 2.3, and accordingly a cubic foot weighs about 140 to 150 pounds.

On the whole, sandstones resist heat well and are usually of excellent durability, since they contain few minerals that easily decompose. When they disintegrate it is commonly by frost action. The injurious minerals are pyrite, mica, and clay. Pyrite is likely to cause discoloration on weathering; the presence of mica tends to cause the stone to scale off if set on edge; and clay may cause injury to the stone in freezing weather on account of its capacity for absorbing moisture. The value of a sandstone is often lessened by careless quarrying, or by placing it on edge in the building, thus exposing the bedding planes to the entrance of water.

Varieties of Sandstone. - With an increase in the size of their grains, sandstones pass into conglomerates on the one hand and with an increase in clay into shales. By an increase in the percentage of carbonate of lime they may also grade into limestones.

On account of these variations, as well as the difference in color and the character of the cement, a number of varieties of sandstone are recognized, of which the following are of economic value: arkose, a sandstone composed chiefly of feldspar grains; flagstone, a thinly bedded, argillaceous sandstone used chiefly for paving purposes; bluestone, a flagstone much quarried in New York; freestone, a sandstone which splits freely and dresses easily; brownstone, a term formerly applied to sandstones of brown color, obtained from the eastern Triassic belt, and since stones of other colors are now found in the same formation, the term has come to have a geographic meaning and no longer refers to any specific physical character. 
Distribution of Sandstones in the United States. - Sand. stones occur in all formations from pre-Cambrian to $\mathrm{T} \in \mathrm{r}$ tiary. They are so widely distributed that for local supply there are numerous small quarries in many states, but there are several areas which have been operated on an extensive scale, some of them for many years. Of these, one of the best known is the Triassic Brownstone belt, which extends from the Connecticut Valley in Massachusetts southwestward into North Carolina.

Among the Paleozoic strata there are many sandstones, often massive, and usually dense and hard. Of these the Medina and Potsdam are specially important and much quarried in New York State $(27,28)$. The same formations extend southward along the Appalachians and are available at several points. Devonian flagstones are extensively quarried at several localities in New York and Pennsylvania. At the present time the Lower Carboniferous Berea sandstone of Ohio (29) is in great demand because of its light color, even texture, and the ease with which it is worked. Moreover, it has the peculiar property of changing to a uniform buff on exposure to the air. There are numerous other Paleozoic sandstones in the central states, among them the Potsdam which covers a wide area in Michigan and Wisconsin (35). Some of this stone is bright red in color.

The Mesozoic and Tertiary strata of the West contain an abundance of sandstone strata, and quarries opened in many of them yield a good quality of stone. Though usually less dense and hard than the Paleozoic sandstones, they serve admirably for buildings in the mild or dry climates of the West. 
Uses of Sandstones. - The wide distribution of sandstones makes them an important source of local structural material. They are chiefly used for ordinary building work, and but little for massive masonry or monuments. The thin-bedded flagstones are much used for flagging, and some of the harder sandstones are split up for paving blocks. For other uses, see Abrasives.

\section{SLATES}

General Characteristics $(3,26)$. - Slates are metamorphic rocks derived from clay or shale or more rarely from igneous rocks (11). Their value depends upon the presence of a well-defined plane of splitting, called cleavage (Fig. 22), developed by metamorphism through the rearrangement and flattening of the original mineral grains and the development of micaceous minerals. The cleavage usually develops at a variable angle to the bedding planes which are often

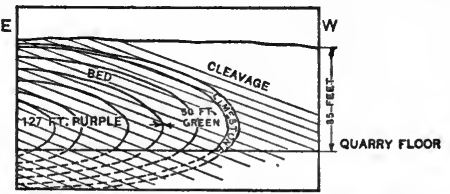

FIG. 22. - Section showing cleavage and bedding in slate. After Dale, U.S. Geol. Surv., 19th Ann. Rept., III. completely obliterated by the metamorphism. When not completely destroyed the bedding planes are marked by parallel bands, called ribbons, cutting across the planes of cleavage, but so perfect is the cleavage in the best slates that the rock readily splits into thin sheets with a smooth surface.

Slates are commonly so fine grained that the mineral composition is not evident to the eye, but the microscope reveals the presence of many of the varied mineral grains found in shale, and in addition much chlorite, developed by 
metamorphism. Owing to the presence of carbonaceous particles, most slates are black or bluish black, but green,

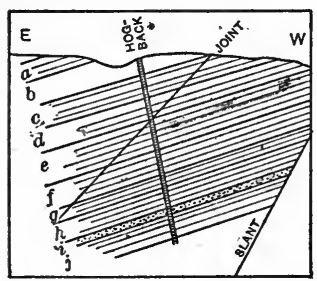

Fra. 23. - Section in slate quarry with cleavage parallel to bedding. $a$, purple slate; $b$, unworked; $c$ and $d$, variegated; $e$ and $f$, green; $g$ and $h$, gray green; $i$, quartzite; $j$, gray with black patches. After Dale. purple, and red slates are also known. The specific gravity of slate is about 2.7, and a cubic foot weighs between 170 and 175 pounds.

Most slates are fairly durable, though the presence of pyrite along the ribbons may lead to their decay. Some colored slates fade on exposure to the weather, but this change, which is due to the bleaching of certain mineral grains, does not necessarily result in loss of strength or disintegration.

Distribution of Slates in the United States. - Since slates are of metamorphic origin, they are limited to those regions in which the rocks are metamorphosed, and at present the greater part of our supply comes from the Cambrian and Silurian strata of the eastern crystalline belt of the Atlantic states.

A series of quarries producing red, green, purple, and variegated slates are located in a belt of Cambrian and Hudson River strata along the border of New York (Pl. VIII) and Vermont $(26,33)$.

Black slates are quarried in Maine (3), New Jersey (3), Pennsylvania (3), Maryland (21), Georgia (3), and Virginia (3). Other producing states are Minnesota, California (11), and Arkansas (9). 


\section{ROBERT W. WEBB GEOLOGY DEPT., U.C.L.A.}

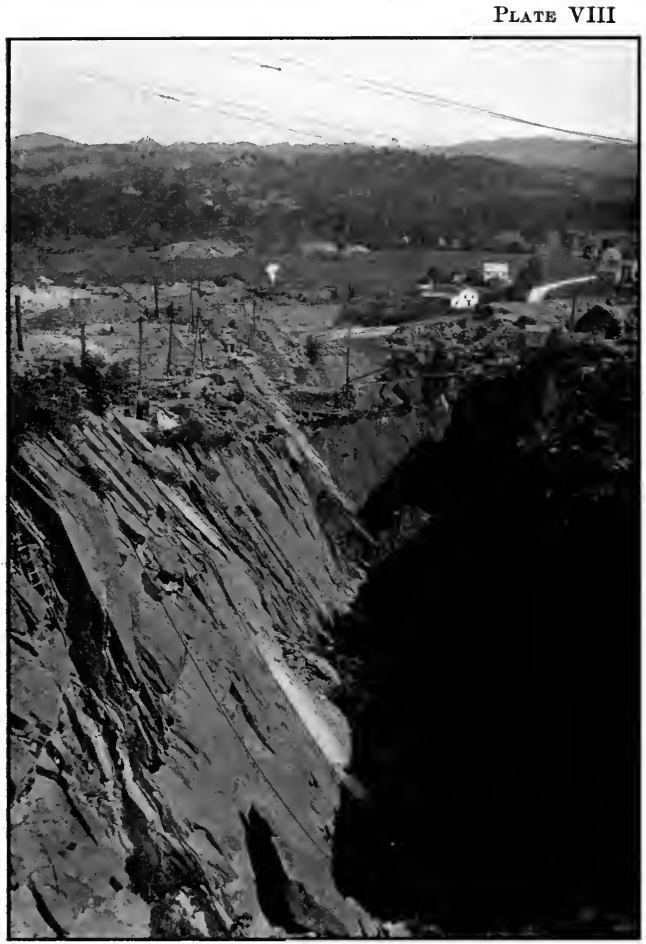

View of green-slate quarry, Pawlet, Vt. Photo. by H. Ries. 

Uses of Slate. - Slate is best known as a roofing material, but it is also used for mantels, billiard-table tops, floor tiles, steps, flagging, slate pencils, acid towers, wash tubs, etc. The process of marbleizing slates for mantels and fireplaces is carried on at several localities.

In quarrying slate there is from 40 to 60 per cent waste, which is greater than in any other building stone; but the introduction of channeling machines in quarrying has done much to reduce this. The discovery of a use for this waste has been an important problem, which has thus far been only partially solved. It is sometimes ground for paint, and attempts have been made to utilize it in the manafacture of bricks and Portland cement.

Production of Building Stones. - The production of building stones by kinds for several years was as follows:-

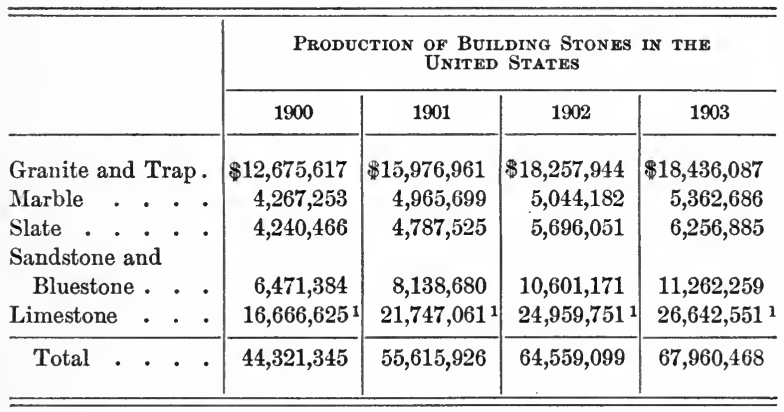

The value of the building stones produced by the several more important states, together with the kind of stone produced chiefly in 1903, is given below.

1 Does not include limestone nsed as flux. 


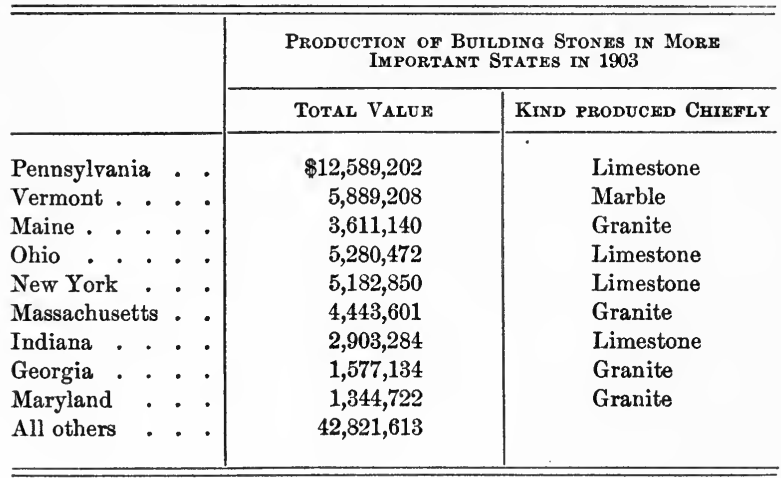

In 1903 the slate exported was valued at $\$ 628,612$.

\section{REFERENCES ON BUILDING STONES}

General on Properties. 1. Hermann, Steinbruchindustrie und Steinbruchgeologie, Berlin, 1899. Bornträger Bros. 2. Merrill, Mineral Census, 1902. (Mines and Quarries.) 3. Merrill, Stones for Building and Decoration, 3d ed., New York, 1904. Wiley \& Sons. For general information on properties and testing see also, 4. Buckley, Jour. Geol., VIII: 160 and 333, 1900. 5. Julien, Jour. Frankl. Inst., CXLVII, 1899. 6. Merrill, Maryland Geol. Surv., II : 47, 1898. 7. Watson, Ga. Geol. Surv., Bull. 9-A, 1903.

Areal Reports. Alabama: 8. Smith, Eng. and Min. Jour., LXVI : 398. (General.) - Arkansas : 9. Dale, U. S. Geol. Surv., Bull. 225 : 414, 1904. (Slate.) 10. Hopkins, Ark. Geol. Surv., Ann. Rept., 1890; IV, 1893. (Marbles.) - California : 11. Eckel, U. S. Geol. Surv., Bull. 225 : 417, 1904. (Slate.) 12. Jackson, Calif. State Min. Bureau ; 8th Ann. Rept.: 885, 1888. (General.) - Colorado: 13. Lakes, Mines and Minerals, XXII : 29 and 62, 1901. (General.) - 14 . Merrill, Stones for Building and Decoration, New York, 1904. - Georgia: 15. McCallie, Ga. Geol. Surv., Bull. 1, 1894. (Marbles.) 16. Watson, Ibid., Bull. 9-A, 1903. (Granites and Gneisses.)Indiana: 17. Hopkins, Ind. Geol. and Nat. Hist. Surv., 20th Ann. Rept. : 188, 1896. 18. Siebenthal, U. S. Geol. Surv., 19th Ann. Rept., VI : 292, 1898. (Bedford limestone.) 19. Thompson, Ind. Geol. and Nat. Hist. Surv., 17th Rept.: 19, 1891. (General.)-Maine: 20. 
Merrill, Stones for Building and Decoration. Wiley and Sons, New York, 1904.-Maryland: 21. Matthews, Md. Geol. Surv., II : 125, 1898. (General.) - Massachusetts : 22. Whittle, Eng. and Min. Jour., LXVI : 336, 1898. (General.) - Michigan: 23. Benedict, Stone, XVII : 153, 1898. (Bayport district.) - Missouri : 24. Buckley and Buehler, Mo. Bur. Geol. and Mines, Vol. 2, 1904. - New Hampshire : 25. Hitchcock, 10th Census U. S., X : 124, 1884.-New York: 26. Dale, U.S. Geol. Surv., 19th Ann. Rept., III : 153, 1899. (Slate belt.) 27. Dickinson, N.Y. State Museum, Bull. 61, 1903. (Bluestone and other Devonian sandstones.) 28. Smock, N. Y. State Museum, Bull. 3, 1888. - Ohio : 29. Orton, Ohio Geol. Surv., V : 578, 1884. (General.) - Pennsylvania : 30. Hopkins, Penn. State College, Ann. Rept., 1895; Appendix, 1897. (Brownstones.) 31. Lesley, Tenth Census, U. S., X : 146, 1884. (General.) 31 a. South Dakota : Todd, S. Dak. Geol. Surv., Bull. 3 : 81, 1902. (General.) - Vermont: 32. Perkins, Rept. of State Geologist on Mineral Industries of Vt., 1899-1900, 1900, 1903-1904; and 33. Report on Marble, Slate, and Granite Industries, 1898.-Washington: 34. Shedd, Wash. Geol. Surv., II : 3, 1902. (General.) - Wisconsin: 35. Buckley, Wis. Geol. and Nat. Hist. Surv., Bull. IV, 1898. (General.) - Wyoming : 36. Knight, Eng. and Min. Jour., LXVI: $546,1898$.

\section{REFERENCES ON ONYX MARBLE}

37. DeKalb, “Onyx Marbles," Trans., Am. Inst. Min. Engrs., XXV : 557, 1896. 38. Merrill, Stones for Building and Decoration (New York), 3d ed., 1904. 39. Merrill, Ann. Rept. U. S. Nat. Mus. (Washington), 1895. 40. Merrill, Min. Indus., Vol. II, "Onyx," 1894. 


\section{CHAPTER IV}

\section{CLAY}

Definition. - Clay, which is one of the most widely distributed materials and one of the most valuable commercially, may be defined as a fine-grained mixture of the mineral $k a o-$ linite (the hydrated aluminum silicate) with fragments of other minerals, such as silicates, oxides, and hydrates, and also often organic compounds (sometimes classed as colloids), the mass possessing plasticity when wet and becoming rock hard when burned to at least a temperature of redness.

Residual Clays (42). - Clays are derived primarily and principally from the decomposition of crystalline rocks, more especially feldspathic varieties, and deposits thus formed will be found overlying the parent rock and grading down into it. From its method of origin and position it is termed a residual clay (Fig. 24).

All residual clays show a variable amount of kaolinite or clay-substance. This mineral, which is white in color, results from the decomposition of feldspar, either by weathering, or, less often, by the action of volcanic vapors. The decay of a large mass of pure feldspar would therefore yield a mass of white clay, but in most instances, the feldspar is associated with other minerals, such as quartz, mica, and hornblende, all of which, except the quartz, decay with the greater or less rapidity, and some of these, such as the hornblende, may likewise yield a hydrous aluminum silicate. Any ferruginous minerals in the rock will, in decomposing, form limonite, which stains the mass. 
Large masses of pure feldspar are rare, but feldspathic rocks, such as granite or syenite, are more common, and these will also decompose to clay; but, since the parent rock contains other minerals, such as quartz or mica, these will either remain as sand grains in the clay, or, by decomposition, will form soluble compounds, or iron stains. The decay of many rocks, for example, limestone and shale, in addition to the crys-

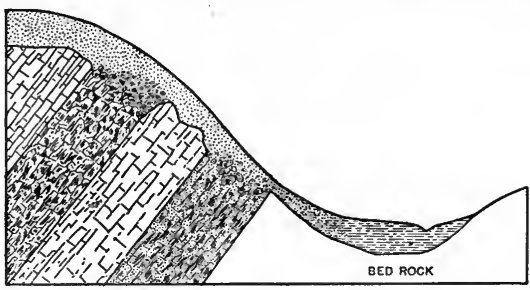

Fig. 24. - Section showing formation of residual clay. After Ries, U.S. Geol. Surv., Prof. Paper, 11:16. talline rocks, produces a residuum of clay. Kaolin is a white-burning residual clay, but it is rare.

The extent of a deposit of residual clay will depend on the extent of the parent rock and the topography of the land, which also influences its thickness. On steep slopes much of the clay may be washed away and residual clays are also rare in glaciated regions, for the reason that they have been swept away by the ice erosion. They are consequently wanting in most of the Northern states, but abundant in many parts of the Southern states, where the older formations appear at the surface.

Sedimentary Clays (42). - With the erosion of the land surface the particles of residual clay become swept away

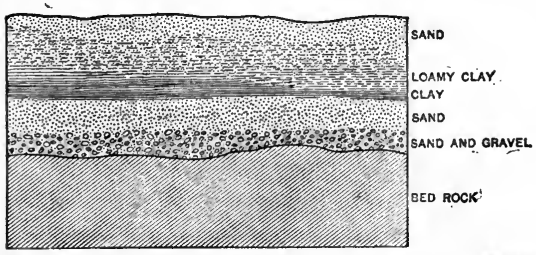

Fra. 25. - Section of a sedimentary clay deposit. After Ries, U. S. Geol. Surv., Prof. Paper, 11:18. to lakes, seas, or the ocean, where they settle down in the quiet water as a fine aluminous sediment, forming a deposit of sedimentary

clay (Fig. 25). Such beds are often of great thickness and 
vast extent. With the accumulation of many feet of other sediments on top of them, they often become solidated either by pressure or by the deposit of a cement around the grains. Consolidated clay is termed shale, and this upon being ground and mixed with water often becomes as plastic as an unconsolidated clay.

Sedimentary clays may be divided into the following groups according to their mode of origin and form of deposit.

Marine Clays. - Formed by the deposition on the ocean floor of the finer particles derived from the waste of the land. Such ancient sea-bottom clays have been elevated to form dry land in all the continents, in many cases forming consolidated clay strata, but elsewhere, especially in coastal plains, in unconsolidated condition. Extensive clay deposits are also formed in protected estuaries and lagoons along the sea coast.

Flood-plain Clays. - Formed by the deposition of clayey sediment on the lowlands bordering a river during periods of flood. Layer upon layer, this deposit builds a flood plain often of great extent and depth. Such areas of flood-plain clays are most extensive along the greater rivers and in the deltas which they have built in the sea.

Lake Clays. - Clay is deposited on the bottom of many lakes and ponds in the same manner as on the ocean bottom. Where the streams bring only fine particles the filling of a lake may be entirely of clay. Many lakes have been either drained or completely filled and their clays therefore made available. This is especially true of small, shallow lakes formed during the Glacial Period.

Glacial Clays, commonly known as till or bowlder clay, a rock flour ground in the glacial mill in which rock fragments were worn down to clay by being rubbed together or against the bed rock over which the ice moved. When the ice melted, this deposit was left in a sheet of varying thickness and characteristics over a large part of the area which the ice covered. 
Eolian Clays. - Wind drifts drive clay about, and in favorable positions causes its accumulation in beds. This is true of the Chinese loess, a wind-blown deposit derived from residual soils and drifted about in the arid climate of interior China. Some at least of the loess clays of the Mississippi Valley seem to have a similar origin, the source of the clay being glacial deposits; in other cases loess seems to be a water deposit either in shallow lakes or else in broad, slowly moving streams.

Properties of Clay. - These are of two kinds, physical and chemical, and since they exercise an important influence on the behavior of the clay, the most important ones may be described.

Chemical Properties (42). - The number of common elements which have been found in clays is great, and even some of the rarer ones have been noted; but in a given clay the number of elements present is usually small, being commonly confined to those determined in the ordinary chemical analysis, which shows their existence in the clay, but not always the state of the chemical combination. The common constituents of a clay are silica, alumina, ferric or ferrous oxide, lime, magnesia, alkalies, titanic acid, and combined water. Organic matter, though often present, is usually in small amounts, and carbon dioxide is always found in calcareous clays. The effect of these may be noted briefly.

Silica is most often present in the form of quartz grains; but it may also be contained in grains of undecomposed minerals. It aids in lowering the plasticity and shrinkage, and helps to increase the refractoriness at low temperatures. A clay high in silica (70 to 80 per cent) is usually sandy. Alumina, which is most abundant in white clays, is a refractory ingredient. Iron oxide acts as a coloring agent in both the raw and burned elay, small quantities coloring a burned clay 
buff, and larger amounts ( 4 to 7 per cent), if evenly distributed, turning it red. It also acts as a flux in burning. Whatever the iron compound present in the raw clay it changes to the oxide in burning. Lime, magnesia, and alkalies are also fluxing ingredients of the clay. The combined percentage of fluxing impurities is small in a refractory clay, and often high in a low grade one. Lime, if present in considerable excess over the iron, will, in burning, exert a bleaching effect on the iron. For this reason, highly calcareous clays, such as those in the Great Lake region, burn cream or buff. When lime is present in large amounts it also causes clay to soften more rapidly in firing than it otherwise would.

Chemically combined water and organic matter both pass off at a temperature of very dull redness $\left(450^{\circ}\right.$ to $650^{\circ} \mathrm{C}$.). Their loss leaves the clay temporarily porous until fire shrinkage sets in. Titanic acid, though rarely exceeding 1 per cent, acts as a flux at high temperatures at least. Sulphur trioxide is rarely present in sufficiently high amounts to interfere with the successful burning of the clay.

Physical Properties (42). - These include plasticity, tensile strength, air and fire shrinkage, fusibility, and specific gravity.

Plasticity may be defined as the property which clay possesses of forming a plastic mass when mixed with water, thus permitting it to be molded into any desired shape, which it retains when dry. This is an exceedingly important character of clay. Clays vary from exceedingly plastic, or "fat" ones, to those of low plasticity which are "lean" and sandy. Plasticity is probably due in part to fineness of grain, and in part to the presence of colloids.

Tensile strength is the resistance which a mass of air-dried clay offers to rupture, and is probably due to interlocking of the particles. Tests show that the tensile strength of clays varies from 15 to 20 pounds per square inch up to 400 pounds or more per square inch. Many common brick clays range from 100 to 200 pounds.

Shrinkage is of two kinds - air shrinkage and fire shrinkage. The former takes place while the clay is drying after being molded, and is 
due to the evaporation of the water, and the drawing together of the clay particles. The latter occurs during firing, and is due to a compacting of the mass as the particles soften under heat. Both are variable. In the manufacture of most clay products an average total shrinkage of about 8 or 9 per cent is commonly desired. Excessive air or fire shrinkage causes cracking or warping of the clay. To prevent this a mixture of clays is often used.

Fusibility is one of the most important properties of clays. When subjected to a rising temperature, clays, unlike metals, soften slowly, and hence fusion takes place gradually. In fusing, the clay passes through three stages, termed, respectively, incipient fusion, vitrification, and viscosity.

In the lower grades of clay, that is, those having a high percentage of fluxing impurities, incipient fusion may occur at about $1000^{\circ} \mathrm{C}$., while in refractory clays, which are low in fluxing impurities, it may not occur until $1300^{\circ}$ or $1400^{\circ} \mathrm{C}$. is reached. The temperature interval between incipient fusion and vitrification may be as low as $30^{\circ} \mathrm{C}$. in calcareous clays, or as much as $200^{\circ} \mathrm{C}$. in some others. The recognition of this variation is of considerable practical importance, and vitrified products, such as paving bricks and stoneware, have to be made from a clay in which the three stages of fusion are separated by a distinct temperature interval. The importance of this rests on the fact that it is impossible to control the temperature of a large kiln within a few degrees, and there must be no danger of running into a condition of viscosity in case the clay is heated beyond its point of vitrification.

Specific gravity varies commonly from about 1.70 to 2.30 .

Chemical Composition. - As might be expected from their diverse modes of origin, clays vary widely in their chemical composition. There is every gradation from those which, in composition, closely resemble the mineral kaolinite to those, like ordinary brick clays, in which there is a high percentage of impurities. This variation is shown in the following table : - 


\begin{tabular}{|c|c|c|c|c|c|c|c|c|c|c|c|}
\hline & 增 & 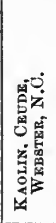 & 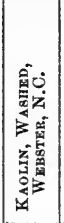 & 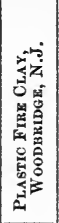 & 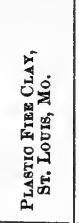 & 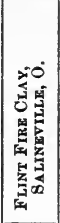 & 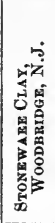 & | & 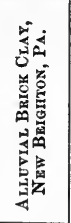 & 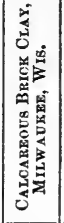 & 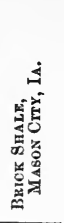 \\
\hline $\mathrm{SiO}_{2}$ & 46.3 & 62.4 & 45.7 & 61.6 & 52.52 & 59.92 & 67.84 & 68.62 & 67.78 & 38.07 & 54.64 \\
\hline $\mathrm{Al}_{2} \mathrm{O}_{3}$ & 39.8 & 26.51 & 40.61 & 28.38 & 31.40 & 27.56 & 21.83 & 14.98 & 16.29 & 9.46 & 14.62 \\
\hline $\mathrm{Fe}_{2} \mathrm{O}_{3}$ & - & 1.14 & 1.39 & .52 & 2.34 & 1.03 & 1.57 & 4.16 & 4.57 & 2.70 & 5.69 \\
\hline $\mathrm{CaO}$ & - & .57 & .45 & .46 & .4 & tr. & .28 & 1.48 & .6 & 15.84 & 5.16 \\
\hline $\mathrm{MgO}$ & - & .01 & .09 & .36 & .42 & tr. & .24 & 1.09 & .727 & 8.5 & 2.90 \\
\hline $\mathrm{K}_{2} \mathrm{O}$ & - & .98 & 2.82 & - & .61 & .64 & 2.24 & 3.36 & 2.001 & 2.76 & 5.89 \\
\hline $\mathrm{Na}_{2} \mathrm{O}$ & - & & & - & .01 & .07 & 2.24 & 0.00 & 2.001 & 2.00 & 0.00 \\
\hline $\mathrm{H}_{2} \mathrm{O}$ & 13.9 & 8.8 & 8.98 & 5.08 & 12.42 & $\{9.70$ & 5.90 & 3.55 & & & 3.74 \\
\hline \multirow[t]{4}{*}{ Moist } & - & .25 & .35 & - & & 1.12 & .80 & 2.78 & & 2.48 & .85 \\
\hline & & & & $\mathrm{TiO}_{2}$ & $\mathrm{TiO}_{2}$ & & & $\mathrm{MnO}$ & $\mathrm{TiO}_{2}$ & $\mathrm{CO}_{2}$ & $\mathrm{CO}_{2}$ \\
\hline & & & & 3.6 & .96 & & & .64 & & 20.46 & 4.80 \\
\hline & & & & & & & & & & & .76 \\
\hline
\end{tabular}

Classification of Clay. - It is possible to base a classification of clays either on origin, chemical and physical properties, or uses. But since the subdivisions which can be made are not sufficiently distinct, each of these gives rise to a more or less unsatisfactory grouping. The following classification is based partly on mode of origin and partly on physical characters : -

1. Residual clays.

A. White-burning (kaolins, formed from feldspathic rocks).

$B$. Colored-burning (formed from igneous, metamorphic, and many sedimentary rocks).

2. Clastic, or mechanically formed clays.

$A$. Water formed (of variable extent, depending on locality and mode of deposit).

a. White-burning (ball and paper clays).

b. Colored-burning (brick and pottery clays). 
B. Glacial clays (often stony; all colored-burning).

C. Wind-formed clays (some loess).

3. Chemical precipitates (some flint clays).

Kinds of Clays. - Many kinds of clays are known by special names, the more important of which are the following:-

Adobe. A sandy, often calcareous, clay used in the west and southwest for making sun-dried brick. Ball clay. A white-burning, plastic, sedimentary clay, employed by potters to give plasticity to their mixture. Brick clay. Any common clay suitable for making ordinary brick. China clay. A term applied to kaolin (q.v.). Earthenware clay. Clay suitable for the manufacture of common earthenware, such as flower pots. Fire clay. A clay capable of resisting a high degree of heat. Flint clay. A peculiar flintlike, fire clay, which when ground up and wet develops no plasticity. Chemically it differs but little, if at all, from the plastic fire clays. Moreover, the two often occur in the same bed, either in separate layers or irregularly mixed. Gumbo. A very sticky, highly plastic clay, occurring in the central states, and used for making burned-clay ballast (1). Kaolin. A white-burning residual clay, employed chiefly in manufacture of white earthenware and porcelain. Loess. A sandy, calcareous, fine-grained clay, covering thousands of square miles in the Central states, and of wide use in brick making. Paper clay. Any fine-grained clay, of proper color, that can be employed in the manufacture of paper. Pipe clay. A loosely used term applied to any smooth plastic clay. Strictly speaking, it refers to a clay suited to the manufacture of sewer pipe. Pottery clay. Any clay suitable for the manufacture of pottery. Retort clay. A plastic fire clay, used in making gas retorts. The term is a local one used chiefly in New Jersey. Sagger clay. A loose term applied to clays employed in making saggers; they are of value for other purposes as well. Stoneware clay. A very plastic clay, which burns to a vitrified or stoneware body. Terra-cotta clay. Clay suitable for the manufacture of terra cotta. The term has no special significance, as a wide variety of clays are adapted to this purpose. 
Geological Distribution. - Clays have a wider distribution than most other economic minerals or rocks, being found in all formations from the oldest to the youngest. The preCambrian crystallines yield both white and colored residual clays, usually the result of weathering, though more rarely of solfataric action. In the Paleozoic rocks, deposits of shale, and sometimes of clay, are found in many localities; and, since they are usually marine sediments, the beds are often of great extent and thickness. With the exception of certain Carboniferous deposits, the Paleozoic clays are mostly impure. The Mesozoic formations contain large supplies of clays and shale suitable for the manufacture of bricks, terra cotta, stoneware, fire brick, etc.

The Pleistocene clays are all surface deposits, usually impure, and individually of limited extent, although they are thickly scattered all over the United States. Their chief value is for brick and tile making. They have been accumulated by glacial action, on flood plains, in deltas, or in estuaries and lakes.

Distribution of Clays by Kinds. - Kaolins (59). - Since kaolins are derived only from crystalline or igneous rocks, their distribution is limited; indeed, at present the only deposits worked are in the eastern states. Being commonly formed by the weathering of pegmatite veins, kaolin deposits have great length as compared with their width, which may be anywhere from 5 to 300 feet. Their depth ranges from 20 to 120 feet, depending on the depth to which the feldspar has been weathered.

Quartz and white mica are often present in kaolin, and it is . then frequently necessary to put the clay through a washing process 
to remove these minerals. The difference between a washed and unwashed kaolin is well shown by the two following analyses, from which it is seen that the quartz contents have been considerably lowered, and that the washed product approaches more closely to the composition of kaolinite:-

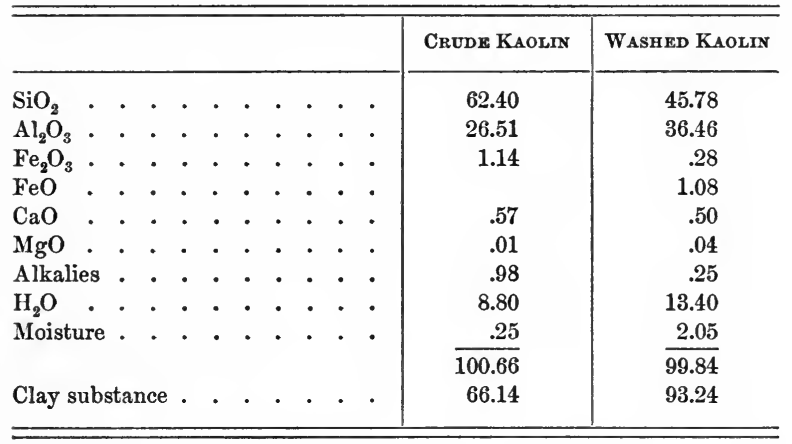

North Carolina (44) and Pennsylvania (50, 52) are the most important kaolin-producing states, but deposits are also worked in Connecticut, Maryland (30), and Virginia (59). It is known to occur in Alabama (9). All of these deposits except that in Connecticut are found south of the limit of the glacial drift.

The output from the American deposits is insufficient to supply the domestic pottery industry, and consequently many thousand tons are annually imported from England. Since this can be brought over as ballast, it is possible to put it on the American market at a low price. The best grades of kaolin sell for $\$ 10$ to $\$ 12$ per ton at Trenton, New Jersey, and East Liverpool, Ohio, these being the two most important pottery centers of this country. 
Fire Clays. - Fire clays are found in the rocks of all systems, from the Carboniferous to the Tertiary, inclusive, with the exception of the Triassic. In the Lower Cretaceous of New Jersey (42) there are many beds of refractory clay, variable in thickness and closely associated with beds of less refractory character. They not only support a thriving local fire-brick industry, but serve also as a source of supply for factories in other states. Similar, but less extensive and less refractory, beds occur in.strata of Cretaceous Age in the coastal plain of Maryland (30), Georgia (17), South Carolina (53), and Alabama (9).

The most extensive, and among the most important, beds of fire clay are those found in the Carboniferous strata of Pennsylvania (48, 52), Ohio $(46,47)$, Kentucky $(26,27)$, Indiana (20), and Illinois (19). Those of the first two named states are on the average the most refractory. Here the fire clays are usually found underlying coal seams and often at well-marked horizons, especially in the Upper Productive Measures.

The section given in Fig. 2 is fairly representative of their mode of occurrence.

Those of Indiana and Illinois are so placed that one mine shaft is often used for extracting coal, fire clay, stoneware clay, and shale.

The beds of refractory clay, found in the Carboniferous strata near St. Louis (38), are not only used in the manufacture of fire brick, but are, in some cases, found suitable, after washing, for mixture with imported German clays for the manufacture of glass pots. The Tertiary strata of Missouri also supply some refractory clays. 

Plate IX

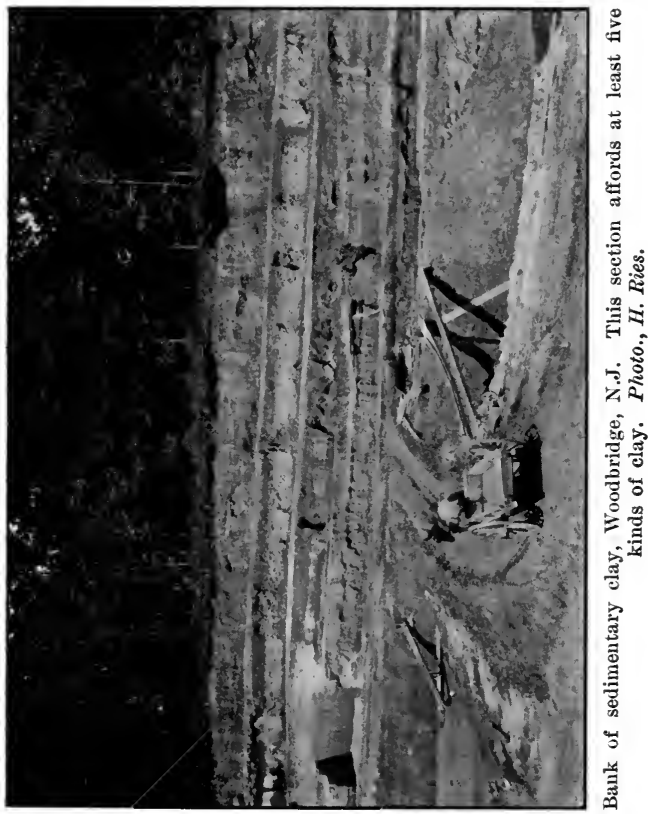


Fire clays are found in the Black Hills of South Dakota (54), in the Laramie beds of Colorado (13-15), and in California (12) ; but, excepting near Denver, where used for making fire brick and assayer's apparatus, these deposits are as yet slightly developed.

Pottery Clays. - Under this heading are included several grades of clay, the kaolins, already described, being the purest and best suited to the manufacture of high grades of pottery.

A second grade of pottery clay, the ball clay, is of limited distribution in the United States. A small quantity is found in the Cretaceous (Pl. IX) of New Jersey (42), and a much larger amount in the Tertiary of western Kentucky (26, 27) and Tennessee (55), and southeastern Missouri (38) and Florida (59). As in the case of kaolin. the domestic supply is not sufficient to meet the demand, and large quantities of ball clay are imported from England.

Stoneware clays form a third grade of pottery clays. Being usually of at least semi-refractory character, their distribution is essentially coextensive with that of fire clays; indeed, the two are often dug from the same pit or mine. Large quantities are obtained in New Jersey (42), western Pennsylvania (48), and eastern Ohio (47).

Stoneware clays usually in the same area as the fire clays are also obtained in Illinois (19), Indiana (20), Kentucky (26), Tennessee (55), Georgia (17), Alabama (9), and Texas (56); and they occur also in Missouri (38), Iowa (22), Colorado (14), and California (12), although little is known about these deposits.

Many of the Pleistocene surface clays in various states are sufficiently dense-burning to be used locally by small stoneware factories. 
Brick and Tile Clays (59). - None of our states lack an abundant supply of good brick and tile clays, and in many areas there are extensive deposits near the large markets, and often near tide water. In such cases the clay beds are exploited to an enormous extent.

In the northeastern states the Pleistocene surface clays are found almost everywhere in great abundance, and are made use of in many places, especially near the large cities.

In the Middle Atlantic states Columbian loams and clay marls are an important source of brick material.

In Ohio, Illinois, and Indiana Pleistocene clays, in part of glacial, and in part of flood-plain origin, are much used for brick and tile. Impure Paleozoic shales are also used in places, especially in the manufacture of vitrified paving brick, thousands of which are made annually in Ohio. Northern Illinois, Michigan, and Wisconsin draw their main supply of brick clays from the calcareous lake deposits.

Although glacial clays and flood-plain deposits are much used in the states west of the Mississippi, the loess which occurs over a wide area is probably even more important as a source of brick, while in the southwestern states loess and adobe are important. Residual clays, river silts, glacial clays, and other forms of clay are employed in brick making along the Pacific coast.

Miscellaneous Clays of Importance. - Paper clays of good quality are much sought for by paper manufacturers. At present the best ones are obtained from the Potomac formation of North Carolina. A small amount of glasspot clay (48), comes from western Pennsylvania and eastern Missouri; but our chief supply is imported. Terra-cotta clays are obtained from the same areas that supply fire clays, New Jersey being the principal producer. 
Uses of Clay. - So few people have even an approximate idea of the uses to which clays are put that it seems desirable to call attention to them briefly. In the following table an attempt has been made to do this: ${ }^{1}$ -

Domestic. - Pottery of various grades; Polishing brick, often known as bath bricks; Fire kindlers; Majolica stoves.

Structural. - Brick; Tiles and T'erra cotta; Chimney pots; Chimney flues ;

Door knols; Fireproofing; Copings; Fence posts.

Hygienic. - Closet bowls; Sinks, etc.; Sewer pipe; Ventilating flues;

Foundation Blocks; Vitrified bricks.

Decorative._Ornamental pottery; Terra cotta; Majolica; Garden furniture. Minor Uses. - Food adulterants; Paint fller; Paper filling; Electrical insulations; Pumps; Filling cloth; Scouring soap; Packing horses' hoofs; Chemical apparatus; Condensing worms ; Ink bottles; Ultramarine manufacture; Emery wheels.

Refractory Wares. - Crucibles and other assaying apparatus; Refractory bricks of various patterns; Glass pots.

Engineering Work. - Puddle; Portland cement; Railroad ballast; Water conduits; Turbine wheels.

Production of Clay. - Owing to the fact that clays are usually manufactured by the producer, it is necessary to give the value of the product, no record being kept of value of the raw material.

Value of Clay Products in United States, 1901-1903

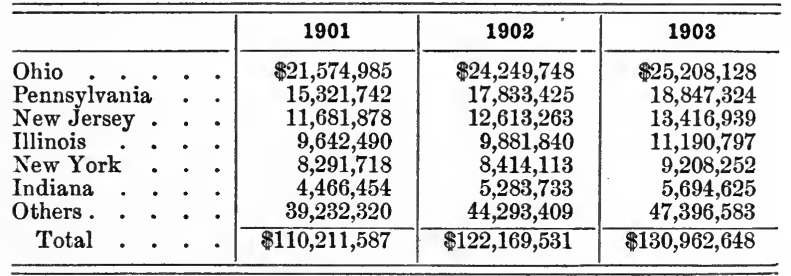

1 Table compiled by R. T. Hill and modified by H. Ries. 
Leading States in Production in 1903

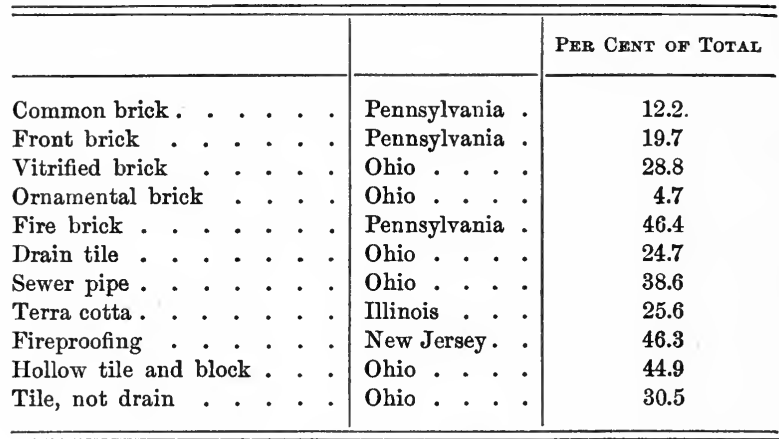

\section{REFERENCES ON CLAY}

Technology and Properties. 1. Bain, Min. Indus., VI : 157, 1898. (Clay ballast.) 2. Barber, The Pottery and Porcelain of the United States, 2d ed., N. Y., 1901 (G. P. Putnam's Sons), \$5.00. 3. Bourry, Treatise on Ceramic Arts, N. Y. (Van Nostrand \& Co.), London (Scott Greenwood \& Co.), 1901. 4. Bischof, Die Feuerfesten Thone, 2d ed., Leipzig, 1895 (Quandt \& Handel), 12 Mks. 5. Branner, Bibliography of Clays and the Ceramic Arts, U. S. Geol. Surv., Bull. 143, Washington, 1896. 7. Davis, A Practical Treatise on the Manufacture of Bricks, Tiles, and Terra Cotta, 2d ed., Philadelphia, \$5.00. 8. Wheeler, Vitrified Paving Brick, Indianapolis, 1895, (Clayworker Pub. Co.), \$1.00. Many excellent papers in Transactions American Ceramic Society, Vols. 1-6 of which have appeared. See also Nos. 22, 30, 42, 43 for general properties and technology.

Areal Reports. - Alabama: 9. Smith and Ries, Ala. Geol. Surv., Bull. 6, 1900. (General.)-Arkansas: 10. Branner, Ark. Geol. Surv., Rept. for 1888. (Many analyses.) 11. Also Amer. Inst. Min. Engrs., Trans. XXVII : 42, 1898. (S. W. Ark.) - California : 12. Johnston, Calif. State Mineralogist, 9th Ann. Rept.: 287, 1890. (General.) See also scattered notices in other annual reports. Colorado: 13. Eldridge, U. S. Geol. Surv., Mon. XXVII, 1896. (Denver Basin.) 14. Geijsbeek, Clay Worker, XXXVI : 424, 1901. (General.) 15. Ries, Amer. Inst. Min. Engrs., XXVII : 336, 1898. (Clays and Clay Industry.) - Delaware: 16. Booth, Geol. of Dela- 
ware: 94 and 106, 1841. - Georgia : 17. Ladd, Ga. Geol. Surv., Bull. 6 A., 1898. (Cretaceous clays.) 18. Spencer, Ga. Geol. Surv., Paleozoic Group : 276, 1893. (N. W. Ga.) - Illinois : 19. Many scattered references in volumes on Economic Geology of Illinois Geol. Survey, Résumé of these in U. S. Geol. Surv., Prof. Pap. 11, 1903. - Indiana: 20. Blatchley, Ind. Dept. Geol. and Nat. Hist., 20th Ann. Rept.: 23, 1896. (Carboniferous clays.) 21. Same author, $22 \mathrm{~d}$ Ann. Rept.: 105, 1898. (N. W. Ind.) Scattered references in other annual reports. - Iowa : 22. Beyer, Williams, and Weems, Ia. Geol. Survey, XIV : 29, 1904. — Kansas: 23. Prosser, U. S. Geol. Surv., Mineral Resources, 1892: 731, 1893. 24. See also Reports on Mineral Resources of Kansas, Kas. Geol. Survey, 1897-1901. — Kentucky: 25. Crump, Eng. and Min. Jour., LXVI: 190, 1898. 26. Ries, U. S. Geol. Surv., Prof. Pap. 11, 1903. 27. Many analyses in Ky. Geol. Surv., Chem. Rept. A, pts. 1, 2, and 3, 1885, 1886, 1888. - Louisiana : 28. Clendenin, Eng. and Min. Jour., LXVI : 456, 1898. 29. Ries, Preliminary Report on Geology of La., I: 264, 1899. - Maryland : 30. Ries, Md. Geol. Surv., IV, Pt. III : 205, 1902. - Massachusetts : 31. Crosby, Technol. Quart., III : 228, 1890. (Kaolin at Blandford.) 32. Shaler, Woodworth, and Marbut, U. S. Geol. Surv., 17th Ann. Rept., I : 957, 1896. (R. I. and S. E. Mass.) 33. Whittle, Eng. and Min. Jour., LXVI: 245, 1898. - Michigan: 34. Ries, Mich. Geol. Surv., VIII: Pt. I, 1903. (Clays and shales.) - Minnesota : 35. Berkey, Amer. Geol., XXIX: 171, 1902. (Origin and distribution.) 36. Winchell, Minn. Geol. Surv., Misc. publications, No. 8, 1881. (Brick clays.) - Mississippi : 37. Eckel, U. S. Geol. Surv., Bull. 213 : 382, 1903. (N. W. Miss.) - Missouri: 38. Wheeler, Mo. Geol. Surv., XI, 1896. (General.) - Nebraska : 39. Neb. Geol. Surv., I: 202, 1903. New Hampshire: 40. Hitchcock and Upham, Report on Geology of New Hampshire, V: 85, 1878. - New Jersey: 41. Cook, N. J. Geol. Surv., 1878. (Special Report on Clays.) 42. Kummel, Ries, Knapp, N. J. Geol. Surv., Final Reports, VI, 1904.-New York: 43. Ries, N. Y. State Museum, Bull. 35, 1900. (General.) - North Carolina : 44. Ries, N. Ca. Geol. Surv., Bull. 13, 1897. (General.) - North Dakota : 45. Babcock, N. D. Geol. Surv., 1st Rept. : 27. (General.) -Ohio: 46. Orton, Ohio Geol. Surv., VII : 45, 1893. (Geology.) 47. Orton, Jr., Ibid., p. 69. (Clay industries.) - Pennsylvania : 48. Hopkins, Pa. State College, Ann. Repts. as follows, 1897, Appendix. (W. Pa.) 49. Ibid., Append. to Rept. for 1899-1900. (Philadelphia and vicinity). 50. Ibid., 1898-1899. (S. E. Pa.) 51. Many analyses in 2d Pa. Geol. Surv., Rept. MM. : 257, 1879, and scattered references in Repts. $\mathrm{H} \mathrm{5,} \mathrm{H} \mathrm{4,} \mathrm{C} \mathrm{4,} \mathrm{C} \mathrm{5,} \mathrm{etc.} \mathrm{52.} \mathrm{Ré-}$ sumé in U. S. Geol. Surv., Prof. Pap. 11 : 208, 1903. — South Carolina : 
53. Sloane, Bull. I, S. Car. Geol. Surv. (S. Car.) - South Dakota : 54. Todd, S. D. Geol. Surv., Bull. 3: 101.-Tennessee : 55. Eckel, U.S. Geol. Surv. Bull., $213: 382,1903$. (W. Tenn.) - Texas : 56. See county reports issued by First Geol. Survey. - United States: 57. Hill, U. S. Geol. Surv. Min. Res. 1891 : 474, 1893. 58. Ries, U.S. Geol. Surv. 17th Ann. Rept., III : 845, 1896. (Pottery Clays.) 59. Ries, U. S. Geol. Surv., Prof. Pap. 11, 1903. (Clays east of Mississippi River.) - Vermont: 60. Nevius, Eng. and Min. Jour. LXIV : 189, 1897. (Kaolin.) 61. Ries, U. S. Geol. Surv., Prof. Pap. 11: 133, 1903.-Washington: 62. Landes, Wash. Geol. Surv., I: 173, 1902. (General.)-Wisconsin: 63. Buckley, Wis. Geol. and Nat. Hist. Surv., Bull. 7, Pt. I, Eco. Series 4, 1901. (General.) 64. Forthcoming bulletin by Ries. - Wyoming : 65 . Knight, Wyo. Experiment Station, Bull. 14, 1893. (General.) 


\section{CHAPTER V}

\section{LIME AND CALCAREOUS CEMENTS}

Composition of Limestones (35). - Limes and calcareous cements form an important class of economic products, obtained from limestones by heating them to a temperature ranging from that of decarbonation to clinkering. The term limestone is applied to one of the main divisions of the stratified rocks so widely distributed, both geologically and geographically, and formed under such different conditions, that its composition varies greatly, this range of variation becoming appreciable from an inspection of the following table, which contains a few selected types: ${ }^{1}$

Table of Limestone Analyses, including the Minerals Calcite and Dolomite

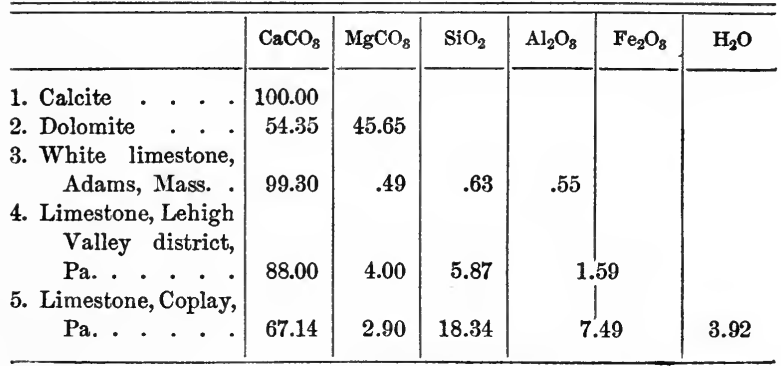

${ }^{1}$ Kemp, "Handbook of Rocks." 


\begin{tabular}{r|r|r|r|r|r|r}
\hline \hline & $\mathrm{CaCO}_{8}$ & $\mathrm{MgCO}_{8}$ & $\mathrm{SiO}_{2}$ & $\mathrm{Al}_{2} \mathrm{O}_{8}$ & $\mathrm{Fe}_{2} \mathrm{O}_{8}$ & $\mathrm{H}_{2} \mathrm{O}$ \\
\hline $\begin{array}{c}\text { 6. Limestone, Cum- } \\
\text { berland, Md. }\end{array}$ & 41.80 & 8.60 & 24.74 & 16.74 & 6.30 & \\
$\begin{array}{c}\text { 7. Dolomite, Pleasant- } \\
\text { ville, N.Y. . . }\end{array}$ & 59.84 & 36.80 & 2.31 & .40 & .25 & \\
$\begin{array}{c}\text { 8. Magnesian lime- } \\
\text { stone, Rosendale; } \\
\text { N.Y. . . . . }\end{array}$ & 45.91 & 26.14 & 15.37 & 11.38 & 1.20 \\
\hline \hline
\end{tabular}

From this table it will be seen that limestones vary from rocks composed almost entirely of carbonate of lime, or of carbonate of lime and carbonate of magnesia, to others which are high in clayey or siliceous impurities. The presence of such impurities in large quantity usually imparts an earthy appearance to the limestone, and sometimes even gives it a shaly structure.

Marked variations in composition may at times be found even in a single quarry, while in other cases a limestone formation may show remarkable uniformity of composition over a wide area.

Changes in Burning $(8,35)$. - When limestones are calcined or "burned" to a temperature sufficiently high to drive- off volatile constituents, such as carbon dioxide, water, and sulphur (in part), or, in other words, to the point of decarbonation, the rock is left in a more or less porous condition. If heated to a still higher temperature, the rock clinkers or fuses incipiently, but the temperature of clinkering depends on the amount of siliceous and clayey impurities in the rock.

Lime $(5,8)$. - Limestone free from or containing but a small percentage of argillaceous impurities is, by decarbona- 
tion, changed to quicklime, a substance which has a high affinity for water, and which, when mixed with water, "slakes," forming a hydrate of lime. This change is accompanied by the evolution of heat and by swelling, and this action becomes the more marked the higher the percentage of lime carbonate in the rock, for the slaking activity is retarded by the presence of magnesium carbonate, and especially by argillaceous impurities. Limes have, therefore, been divided into "fat" limes and "meager" limes, depending on the rapidity with which they slake and the amount of heat they develop in doing so (5).

Hydraulic Cements. - With an increase in clayey and siliceous impurities, the burned rock shows a decrease in slaking qualities, and develops hydraulic properties, or sets when mixed with water, and even under the same. Products of this type are termed cements, and owe their hydraulic properties to the formation during burning of silicates and aluminates of lime. On mixing the burned ground rock with water, these take up the latter and crystallize, thereby producing the set of the cement.

Hydraulic cements can be divided into the following classes: Pozzuolano cements, hydraulic limes, natural cements, and Portland cements.

Pozzuolano Cements (2, 9, 41). - These are produced from an uncalcined mixture of slaked lime and a silico-aluminous material, such as volcanic ash or blast-furnace slag.

This process was known to the ancients, and is named from its early use around Pozzuolano, Italy. The composition of an Italian Pozzuolano earth may vary between the following limits (9): $\mathrm{SiO}_{2}, 52-60 ; \mathrm{Al}_{2} \mathrm{O}_{3}, 9-21 ; \mathrm{Fe}_{2} \mathrm{O}_{3}$, 
5-22; $\mathrm{CaO}, 2-10 ; \mathrm{MgO}$, up to 2; alkalies, 3-16; $\mathrm{H}_{2} \mathrm{O}$, up to 12 .

The manufacture of slag cement is now carried on at several localities in the United States, and is a growing industry (2).

Hydraulic Limes (9) are formed by burning a siliceous limestone to a temperature not much above that of decarbonation. Owing to the high percentage of lime carbonate, considerable free lime appears in the finished product. Hydraulic limes generally have a yellow color, and a gravity of about 2.9. They slake and set slowly, and have little strength unless mixed with sand. 'This class is of little importance in the United States, but much more so in Europe.

Natural Cements (1, 8, 9, 41). - These, known also as Roman cement, quick-setting cement, and Rosendale cement, are made by burning a silico-aluminous limestone (containing from 15 to 40 per cent clayey impurities) at a temperature between decarbonation and clinkering. The product shows little or no free lime. The following analyses will give some idea of the range in composition of natural cement rocks quarried in the United States:-

\section{Avalyses of Certain American Cement Rocks}

\begin{tabular}{l|r|r|r|r|r|r|r|r}
\hline & $\mathrm{CaCO}_{8}$ & $\mathrm{MgCO}_{8}$ & $\begin{array}{l}\mathrm{SiO}_{2}+ \\
\mathrm{INSOL}^{\prime}\end{array}$ & $\mathrm{Fe}_{2} \mathrm{O}_{8}$ & $\mathrm{Al}_{2} \mathrm{O}_{8}$ & $\begin{array}{r}\text { AlkA- } \\
\text { LIEs }\end{array}$ & $\mathrm{H}_{2} \mathrm{O}$ & $\begin{array}{r}\text { UN- } \\
\text { DET. }\end{array}$ \\
\hline Rosendale, N.Y. & 45.91 & 26.14 & 15.37 & 11.38 & & 1.20 & \\
Utica, Ill. . . . & 42.25 & 31.98 & 21.12 & 1.12 & & 1.07 & 2.46 \\
Milwaukee, Wis. & 45.54 & 32.46 & 17.56 & 3.03 & 1.41 & & & \\
Fort Scott, Kas. & 65.21 & 10.65 & 15.21 & & 4.56 & & & 4.37 \\
Cement, Ga. . . & 43.50 & 22.00 & 22.10 & 1.80 & 5.45 & .22 & 4.95 & \\
Coplay, Pa. . . & 67.14 & 2.90 & 18.34 & 7.49 & .19 & & 3.94 \\
\hline
\end{tabular}


Natural cements differ from lime in possessing hydraulic properties, and refusal to slake unless ground very fine. They differ from Portland cements in lighter weight, lower temperature of burning, quicker set, lower ultimate strength, and greater latitude of composition. Magnesia is not regarded as a detrimental impurity in natural cements as it is in Portland cement.

The following are some analyses of the burned material :-

Analyses of Some Natural Rock Cements

\begin{tabular}{l|c|c|c|c|c|c|c}
\hline \hline & $\mathrm{CaO}$ & $\mathrm{MgO}$ & $\mathrm{SiO}_{2}$ & $\mathrm{Al}_{2} \mathrm{O}_{8}$ & $\mathrm{Fe}_{2} \mathrm{O}_{8}$ & $\mathrm{Na}_{2} \mathrm{O}, \mathrm{K}_{2} \mathrm{O}$ & IGNition \\
\hline $\begin{array}{c}\text { Natural rock cement, } \\
\text { Rosendale, N.Y. }\end{array}$ & 34.38 & 18 & 30.5 & 6.84 & 2.42 & 3.98 & 3.78 \\
$\begin{array}{c}\text { Natural rock cement, } \\
\text { Akron, N.Y. . }\end{array}$ & 40.68 & 22 & 22.62 & 7.44 & 1.40 & 2.23 & 3.63 \\
$\begin{array}{c}\text { Natural rock cement, } \\
\text { Cumberland, Md. }\end{array}$ & 43.97 & 2.21 & 22.38 & 11.71 & 2.29 & 9. & 2.44 \\
$\begin{array}{c}\text { Roman cement, Rü- } \\
\text { dersdorf, Germany . }\end{array}$ & $56.4 \tilde{y}$ & 4.84 & 27.88 & 6.19 & 4.64 & & \\
\hline \hline
\end{tabular}

Portland Cement $(4,6,7,10,41)$. - This term is applied to artificial mixtures of clay and lime rock, which are burned to a temperature of clinkering. Portland cement was first made by Joseph Apsdin, of Leeds, England, who desired to make an artificial cement that would replace natural hydraulic cements. It received its name because it hardened under water to a mass resembling the Portland stone of England.

The three essentials for Portland cement are lime, silica, and alumina, and it is consequently necessary to use raw materials supplying these three substances in the proper quantities. This is in all cases done by artificial mixture, 
and many of the so-called "natural" Portland cements used in the United States are not strictly such. The following six combinations of materials are at present used in the manufacture of true Portland cement in the United States : marl and clay; limestone and clay, or shale $;^{1}$ chalk and clay; pure limestone and argillaceous limestone; alkali waste and clay; limestone and slag.

In the first four of these combinations it is evident that the substances first named supply the lime and the second the silica and alumina. In the fourth the argillaceous limestone supplies some lime, as well as the silica and alumina. The nature of the raw materials chosen depends to a large degree on the location of the plant, whether in a limestone or a marl producing region. Where both of these raw materials are available, as in parts of New York, questions of manipulation in the process of manufacture govern the selection of one or the other.

Marls, for example, though easier to excavate and reduce than limestones, contain so much more organic matter and water than limestones that they are more expensive to handle and prepare. Marl beds are likewise apt to be of limited extent and irregular, while limestone beds are, so far as the needs of a manufacturing plant are concerned, practically limitless.

Comparing clay and shale, the former is often easier to excavate, but, on account of the water it contains, has to be dried before it can be ground and mixed. The fossils in shales are sometimes an important source of calcium carbonate, and then careful grinding and mixing is necessary to bring about a uniform distribution of the line through the mass. Shale is, however, used by only a few works.

Argillaceous limestone, mixed with a much smaller quantity of purer limestone, as in Pennsylvania and New Jersey, is superior to a limestone and clay mixture, because less thorough mixing and fine grinding are required. In such cements, even when grinding and mixing are

${ }^{1}$ It is probable that the refuse of many slate quarries could also be used in place of shale. 
incompletely done, the particles of argillaceous limestone so closely resemble the proper mixture in chemical composition as to affect the result but little.

The following table gives the analyses of some of the raw materials used in manufacture of Portland cement:-

Ayalyses of Raw Materials used for Portland Cement

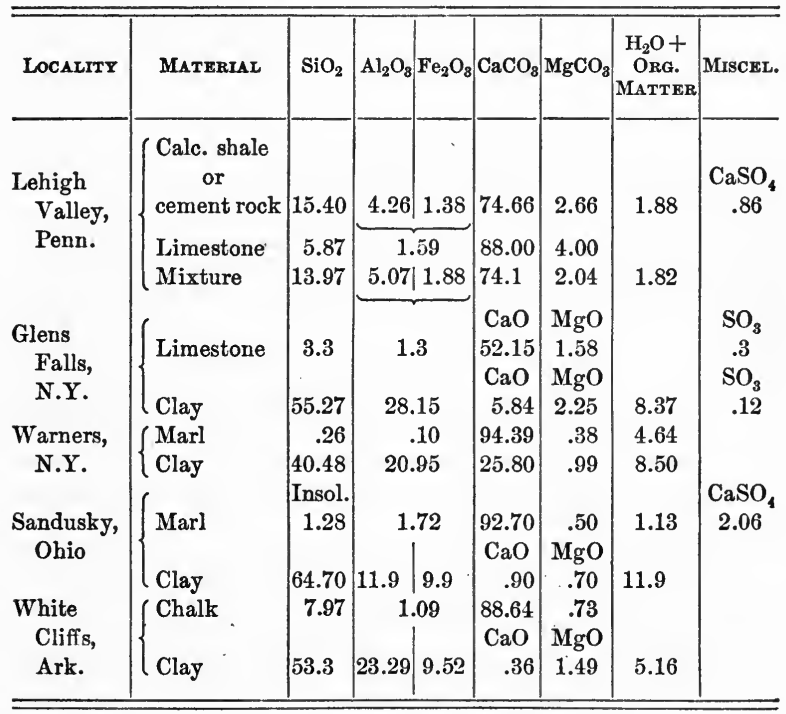

In the selection of raw materials the aim of the manufacturers is to produce a raw mixture which runs approximately 70 to 75 per cent lime carbonate and the balance clay (U. S. Geol. Surv., 21st Ann. Rept., VI : 404, 1900). The proportions of clay and lime rock used at each factory are not always disclosed, and the mixture of the two in- 
gredients is kept under careful control by frequent chemical analysis, since slight variations from the proper composition may injure the cement. The following analyses will serve to illustrate the composition of some American Portland cements : -

Analyses of Cements

\begin{tabular}{l|c|c|c|c|c|c}
\hline & $\mathrm{SiO}_{2}$ & $\mathrm{Al}_{2} \mathrm{O}_{8}$ & $\mathrm{Fe}_{2} \mathrm{O}_{3}$ & $\mathrm{CaO}$ & $\mathrm{MgO}$ & $\mathrm{SO}_{8}$ \\
\cline { 1 - 7 } Empire brand . . & 22.04 & 6.45 & 3.41 & 60.92 & 3.53 & 2.73 \\
Sandusky . . . . & 23.08 & 6.16 & 2.90 & 62.38 & 1.21 & 1.66 \\
Alpha . . . . & 22.62 & 8.76 & 2.66 & 61.46 & 2.92 & 1.53 \\
\hline \hline
\end{tabular}

Distribution of Lime and Cement Materials in the United States. Limestone for Lime. - Limestones of suitable composition for burning lime are so widely distributed that no particular regions or states require special mention. ${ }^{1}$ In the New England states, crystalline limestones are the chief source of supply. In the Appalachian states, from New York to Alabama, there are many Paleozoic limestones of high purity, notably the Trenton, Lower Helderberg, and Carboniferous limestones (see state references). The same series of rocks are also of importance in the Mississippi Valley states from Tennessee to Michigan (27). Lime of excellent quality is obtained from the Subcarboniferous in Iowa (41), Kansas (21), and Missouri (41), and from the Cretaceous in Texas (41). Limestones suitable for lime manufacture are also found in numerous localities in the Pacific coast states (41).

${ }^{1}$ Analyses and detailed descriptions will be found in the areal reports, mentioned in the list of References. 

Plate X

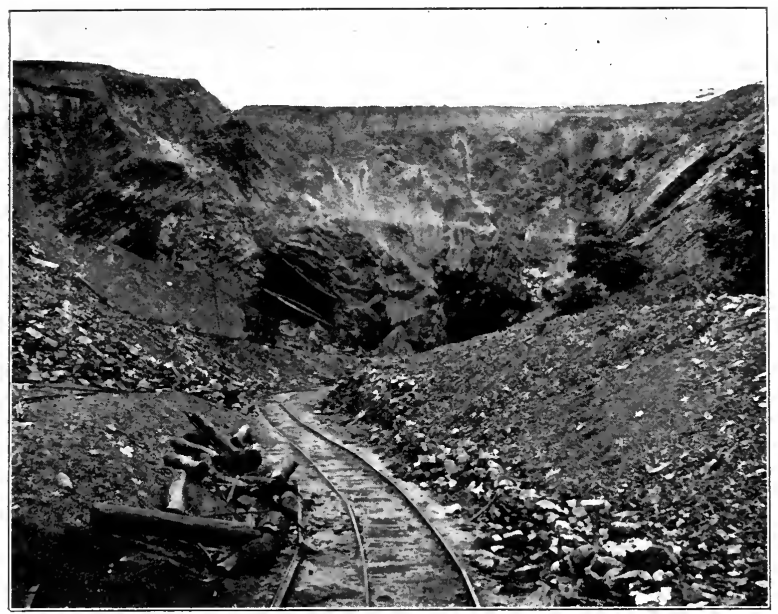

Fig. 1. - Quarry of natural cement rock, Cumberland, Md. Photo. by H. Ries.

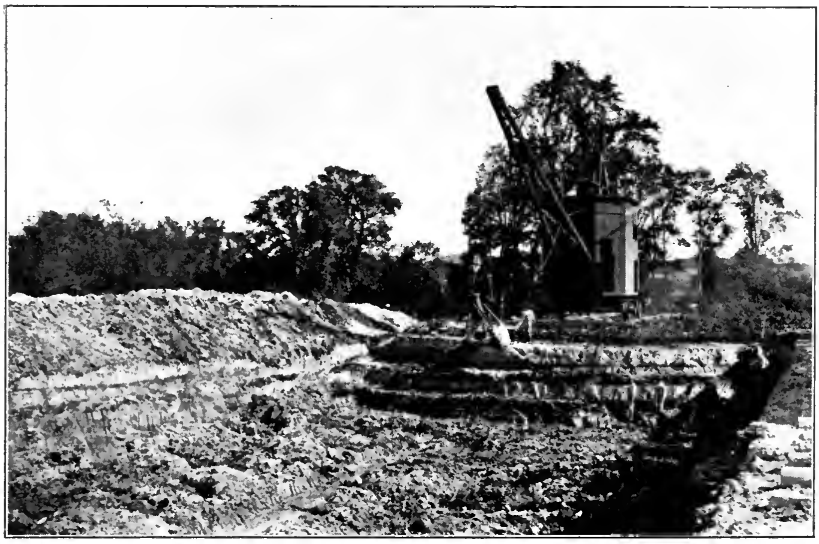

Fig. 2.-Marl pit at Warners, N.Y. The dark streaks are peat, and the marl is underlain by clay. Photo. by H. Ries. 
Hydraulic Limes. - Largely because of the great abundance of natural rock cements, which are of superior value, these materials, though much used abroad, are of no importance in the United States.

Natural Rock Cements $(1,41)$. - Calcareous rocks of this class are found at a number of points, mainly in the Paleozoic formations. In 1903 they were worked in sixteen different states, eleven of which are east of the Mississippi. These are found at a number of points in the Appalachian region, but, owing to the folded character of the beds (Pl. X, Fig. 1 ), their extraction is often difficult. The most important natural rock cement region of the United States is that of Rosendale, New York $(32,35)$, where the cement rocks are found in the Water Lime beds at the top of the Upper Silurian, being obtained from underground workings. The three beds are interstratified with other limestones, and often dipping at a high angle. Their thickness ranges from 7 to 25 feet. The great development of this region is due partly to the large supply of raw material, and partly to the proximity to New York City and the possibility of shipment by tide-water.

Farther west, around Akron, New York, and Buffalo (31), the cement rock occurs at a somewhat lower horizon. In eastern Pennsylvania, especially in the vicinity of Coplay and Catasauqua (39), cement rock of Trenton age occurs in a region of marked folding. This region, though an important producer of cement rock, is even more important as a producer of Portland cement (41).

The Water Lime beds again form an important source of cement rock in the vicinity of Cumberland, Maryland (24) (Pl. X, Fig. 1), where there are four beds of economic 
value, ranging from 6 to 17 feet in thickness, and separated by calcareous shales. The entire series is highly folded, the dip sometimes being as much as $90^{\circ}$.

Cement rock is also obtained in southeastern Ohio (36); at Louisville, Kentucky (23), probably the second most important center in the United States; in the Hamilton rocks at Milwaukee, Wisconsin (44); and at Utica and La Salle, Illinois (17), where it is found in the Calciferous formation in a bed from 6 to 8 feet thick.

Portland Cements. - Clay and limestone, in one form or another, are so widely distributed throughout the United States, that it is possible to manufacture Portland cement at many localities, and the geologic age of the materials used ranges from Ordovician to Pleistocene (41). Nineteen states were making this cement in 1903, the factories being spread over the country from the Atlantic to the Pacific (41).

By far the most important district is the Lehigh Valley in Penusylvania, which supplies about 70 per cent of the domestic product. Here the raw materials consist of beds of argillaceous limestone and nearly pure limestone, this being one of the few localities where such a mixture is obtainable. The same beds are found in the adjacent territory of New Jersey (30).

In the eastern half of New York (35) the Ordovician and Silurian limestones form an inexhaustible supply of material to mix with Pleistocene surface clays. In the south central part of New York the Tully limestone and Hamilton shales are employed, while in the central and southwestern portion, beds of marl (Pl. X, Fig. 2), associated with surface clays, are utilized. 
Ohio (36, 41), Indiana (18), and Michigan $(26,28)$ are important Portland cement producing states. The abundance of marl and Pleistocene clays makes them the favorite materials, notwithstanding the fact that beds of Paleozoic limestones occur in each of the states. Marl, although especially abundant in Michigan, is found in many states lying east of the Mississippi and north of the terminal moraine. It is precipitated from the waters of ponds through the agency of minute plants, especially Chara (26).

In Kansas Carboniferous shales and limestones are used for making Portland cement (21,22), and in Texas and Arkansas the Cretaceous shales and chalky limestones are employed $(13,14)$; Alabama has a Cretaceous limestone of such composition that very little clay or shale has to be added to it (12). Portland cement is also manufactured in North Dakota (41), South Dakota (41), Utah (41), Colorado (41), and California (15).

Uses of Lime. - The most important single use of lime is for mixing with sand to form mortar, and many thousands of tons are used annually for this purpose. In addition to this use, lime is employed for a great variety of purposes, of which the following are the most important: as a purifier in basic steel manufacture; in the manufacture of refractory bricks, ammonium sulphate, soap, bone ash, gas, potassium-dichromate, paper, pottery glazes, and calcium carbide; as a disinfectant; as a fertilizer; as a polishing material; for dehydrating alcohol, preserving eggs, and in tanning.

Uses of Cement. - The use of hydraulic cement is constantly increasing in the United States, this being specially 
true of Portland cement, which is superseding natural cement to a great extent, and is finding an increasing use in building and engineering operations. For pavements, Portland cement is probably more extensively used in America than in any other country; and as an ingredient of concrete it is widely employed. Blocks weighing as much as 65 to 70 tons have been made for harbor improvements at New York City (37a).

Production of Cement. - The following tables give the production of natural-rock and Portland cement. Those given for the latter cover a greater period than those of the former, and are grouped with figures of import and consumption in order to show more clearly the tremendous growth of the American Portland cement industry.

\section{Production of Natural Cement in United States}

\begin{tabular}{|c|c|c|c|c|c|c|}
\hline & \multicolumn{2}{|c|}{1901} & \multicolumn{2}{|c|}{1902} & \multicolumn{2}{|c|}{1903} \\
\hline & QUANTITY & VALUE & QUANTITY & VALTE & QUANTITY & VALUE \\
\hline & barrels & & barrels & & barrels & \\
\hline New York . & $2,234,131$ & $\$ 1,117,066$ & $3,577,340$ & $\$ 2,135,036$ & $2,417,137$ & $\$ 1,510,529$ \\
\hline Pennsylvania . & 942,364 & 376,954 & 796,876 & 340,669 & $1,339,090$ & 576,269 \\
\hline $\left.\begin{array}{l}\text { Indiana } \\
\text { Kentucky }\end{array}\right\}$. . & $2,150,000$ & 752,500 & $1,727,146$ & 869,163 & 533,573 & 766,786 \\
\hline Wisconsin . . & 481,020 & 182,788 & 437,913 & 162,628 & 330,522 & 139,373 \\
\hline Illinois . . & 469,842 & 187,936 & 607,820 & 156,855 & 543,132 & 178,900 \\
\hline Maryland . & 351,329 & 175,665 & 409,200 & 150,680 & 269,957 & 138,619 \\
\hline Others . . & 456,137 & 263,369 & 488,010 & 261,599 & 569,860 & 365,044 \\
\hline Total & $7,084,823$ & $\$ 3,056,278$ & $8,044,305$ & $\$ 4,076,630$ & $7,030,271$ & $\$ 3,675,520$ \\
\hline
\end{tabular}




\section{Production of Portland Cement in United States}

\begin{tabular}{|c|c|c|c|c|c|}
\hline & 1891 & 1900 & 1901 & 1902 & 1903 \\
\hline & barrels & barrels & barrels & barrels & bsrrels \\
\hline Production of United States & 454,813 & $8,482,020$ & $12,711,225$ & $17,230,644$ & $22,342,973$ \\
\hline Imports . . . . . . & $2,988,313$ & $2,386,683$ & 922,426 & $1,961,013$ & $2,251,969$ \\
\hline Total . . . . & $3,443,126$ & $10,868,703$ & $13,633,651$ & $19,191,657$ & $24,594,942$ \\
\hline $\begin{array}{l}\text { Exports (domestic and for- } \\
\text { eign) } \\
\end{array}$ & 一 & 139,939 & 417,625 & 373,414 & 285,463 \\
\hline $\begin{array}{l}\text { Total consumption . } \\
\text { Percentage of domestic } \\
\text { production to total con- } \\
\text { sumption in United States }\end{array}$ & $3,443,126$ & $10,728,764$ & $13,216,026$ & $18,818,248$ & $24,309,479$ \\
\hline
\end{tabular}

Production of Portland Cement by States in 1903

\begin{tabular}{|c|c|c|c|c|c|c|c|c|c|c|c|}
\hline & & & & & & & & & & BARRELS & VALUE \\
\hline Pennsylvani & & - & & - & • & - & - & - & - & $9,754,313$ & $\$ 11,205,892$ \\
\hline New Jersey & . & - & - & • & - & - & . & . & . & $2,693,381$ & $2,944,604$ \\
\hline Michigan. & . & . & . & . & - & - & . & . & . & $1,955,183$ & $2,674,780$ \\
\hline Illinois . & . & - & . & 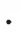 & - & . & . & . & . & $1,257,500$ & $1,914,500$ \\
\hline Indiana . & & • & • & • & • & - & . & . & - & $1,077,137$ & $1,347,797$ \\
\hline Kansas . & . & • & - & • & • & - & . & . & . & $1,019,682$ & $1,285,310$ \\
\hline Ohio . . & . & • & - & • & - & & - & . & - & 729,519 & 998,300 \\
\hline All others & • & & & $\theta^{\circ}$ & $\bullet^{\circ}$ & 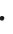 & - & - & - & $3,856,258$ & $5,342,136$ \\
\hline Total & - & - & - & - & • & - & - & - & - & $22,342,973$ & $\$ 27,713,319$ \\
\hline
\end{tabular}

\section{REFERENCES ON LIME AND CEMENT MATERIALS}

Technology. 1. Cummings, American Cements, Boston, 1898. (Many analyses.) 2. Eckel, Min. Indus. X: 84, 1902. (Slag cement manufacture.) 3. Eckel, Amer. Geol. XXIX: 146, 1902. (Classification.) 4. Green, Portland Cement Industry of the World, Journal of Association of Civil Engineering, XX: 391, 1898. 5. Gilmore, Practical Treatise on Limes, Hydraulic Cements and Mortars, N. Y., D. Van Nostrand, 1872. 6. Jameson, Portland Cement; its Manufacture and Use, New York, 1898. 7. Lewis, Manufacture of 
Hydraulic Cement in United States, Mineral Industry, VI: 91, 1898. 8. Richardson, Series of Articles on Lime and Cement Mortars in the Brickbuilder, 1897 and 1898. 9. Schoch, Die Moderne Aufbereitung u. Wertủng der Mörtel-Materialien, Berlin, 1896. 10. Spalding, Hydraulic Cement; its Properties, Testing, and Use, New York, 1897, John Wiley \& Sons.

Locality Reports. Alabama: 11. Meissner, Ala. Ind. and Sci., Proc., IV: 12. (Birmingham district limestone.) 12. Smith, Ala. Geol. Surv., Bull. 8, 1904. (Many analyses.) - Arkansas : 13. Branner, Amer. Inst. Min. Engrs., Trans. XXVII : 42, 1898. (S. W. Ark.) 14. Taff, U. S. Geol. Surv., 22d Ann. Rept., III : 687, 1902. (S. W. Ark.) - California : 15. Grimsley, Eng. and Min. Jour., LXXII : 71, 1901. (Cement industry.) 16. Irelan, 8th Ann. Rept. State Mineralogist: 865 to 883,1888 ; also 9th Ann. Rept.: 309-311, 1889 ; 13th Ann. Rept. Calif. State Mineralogist: 627, 1896 ; 12th Ann. Rept. : 391, 1894. (Cements.) - Illinois : 17. Freeman, Amer. Inst. Min. Eng., Trans. XIII : 172, 1885. (La Salle, natural rock cement.)-Indiana: 18. Blatchley, 25th Ann. Rept. Ind. Dept. Geol. and Nat. Res., 1900: 323, 1901. (Bedford limestone.) 19. Siebenthal, 25th Ann. Rept. Ind. Dept. Geol. and Nat. Hist. 1900 : 331, 1901. (Silver Creek hydraulic limestone.) Iowa : 20. Houser, Ia. Geol. Surv., I: 199, 1893. (Niagara limestone.)-Kansas: 21. Haworth, Kas. Geol. Surv., III : 31, 1898. 22. Haworth and Schrader, U. S. Geol. Surv., Bull. 260 : 506, 1905. (Independence Quadrangle.) - Kentucky : 23. Kentucky Geol. Surv., New Series, IV : 404. - Maryland : 24. Clark and others, Md. Geol. Surv. Rept. on Allegheny Co.: 185, 1900. (Lime and cements.) 25. Martin, Md. Geol. Surv. Rept. on Garrett Co.: 220, 1902. Michigan: 26. Hale and others, Mich. Geol. Surv., VIII, Pt. 3, 1903. (Marl for Portland cement.) 27. Lane, Eng. and Min. Jour., LXXI : 662, 693, and 725, 1901. (Mich. limestones.) 28. Russell, U. S. Geol. Surv., 22d Ann. Rept., III : 629, $1902 . \quad$ (Mich. Portland cement industry.) - Mississippi : 29. Crider, U. S. Geol. Surv., Bull. 260 : 510, 1905. (N. E. Miss.)-New Jersey: 30. Kümmel, Ann. Rept. N. J. State Geologist, 1900: 9. (N. J. Portland cement industry.) New York: 31. Bishop, 15th Ann. Rept. N. Y. State Geologist: 33s, 1897. (Erie Co.) 32. Nason, Rept. of N. Y. State Geologist, 1893 : 375. (Ulster Co.) 33. Pohlman, Amer. Inst. Min. Eng., Trans. XVIII : 250, 1889. (Cement rock at Buffalo.) 34. Ries, U. S. Geol. Surv., 17th Ann. Rept., III (cont.) : 795, 1896. (Limestone quarries, New Fngland and New York.) 35. Ries and Eckel, Bull. N. Y. State Museum, 44, 1901. (N. Y. lime and cement industry.) - Ohio : 36. Lord, Ohio Geol. Surv., VI : 671, 1888. (Natural and artificial 
cements.) 37. Orton, Ohio Geol. Surv., VI: 703, 1888. (Lime.) 37 a. Eno, Ohio Geol. Surv., 4th Series, Bull. 2, 1904. (Uses of cement.) $37 b$. Bleininger, Ibid., Bull. 3. (Manufacture of cement.) - Pennsylvania : 38. Prime, Second Geól. Surv. of Pa., Rep. DD : 59, 1878. 39. Eckel, U. S. Geol. Surv., Bull. 225 : 448, 1904. (Lehigh district.) 40. Clapp, U. S. Geol. Surv., Bull. 249, 1905. (Limestones, S. W. Pa.) - United States : 41. Eckel, U. S. Geol. Surv., Bull. 260 : 497, 1905. Also Bull. 243. (Cement resources and industry.)-Virginia: 42. Catlett, U. S. Geol. Surv., Bull. 225 : 457, 1904. (Cement resources, Valley of Va.) 43. Also Bassler, Ibid., Bull. 260: 531, 1905. - Wisconsin : 44. Chamberlin, Geol. of Wis., II, Pt. 2 : 395, 1873. (Natural rock cement.) 


\section{CHAPTER VI}

\section{SALINES}

Salt. - Common salt, the chloride of sodium $(\mathrm{NaCl})$, is a widely distributed mineral, being found, (1) in solution in sea water or salt lakes; (2) as solid masses termed rock salt; (3) as natural brine in cavities or pores of the rocks, from which it may exude as salt springs or be tapped by wells; and (4) in marshes and soils.

Although all four of these methods of occurrence may serve as commercial sources of salt, it is only the second that is of great economic importance.

Occurrences of Salt in Sea and Lake Waters. - Salt is present in all ocean water, and also in that of most inland lakes or seas having no outlet. As can be seen from the following analyses, the percentage of salt is greater in some salt lakes than in the ocean :-

\begin{tabular}{|c|c|c|c|c|c|c|c|c|c|}
\hline \multirow[b]{2}{*}{ Locality } & \multirow{2}{*}{ 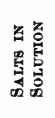 } & \multirow[b]{2}{*}{ 舅 } & \multicolumn{7}{|c|}{ Percentage of Salts in Solid Matter } \\
\hline & & & 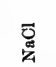 & D్ & ర్లే & 点商 & $\begin{array}{l}\delta^{*} \\
\text { Z } \\
\tilde{J}\end{array}$ & 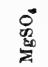 & 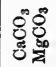 \\
\hline Black Sea . . . & 1.77 & 98.23 & 79.39 & 1.07 & 7.38 & .03 & .60 & 8.32 & 3.21 \\
\hline Mediterranean Sea . & 3.37 & 96.63 & 77.03 & 2.48 & 8.76 & .49 & 2.76 & 8.34 & .10 \\
\hline Atlantic Ocean . & 3.63 & 96.37 & 77.07 & 3.89 & 7.86 & 1.30 & 4.63 & 5.29 & - \\
\hline Dead Sea . . . & 22.30 & 77.70 & 36.55 & 4.57 & 45.20 & .85 & .45 & - & $\begin{array}{l}\mathrm{CaCl}_{2} \\
11.38\end{array}$ \\
\hline Great Salt Lake . . & 14.99 & 85.01 & 79.12 & .57 & 9.93 & - & .56 & 6.21 & $\begin{array}{r}\mathrm{K}_{2} \mathrm{SO}_{4} \\
3.47\end{array}$ \\
\hline
\end{tabular}


Salt is sometimes obtained by artificial evaporation from both the ocean and salt lakes; but in the United States this plan is profitable only under exceptional conditions, as around San Francisco Bay, California (6), or Great Salt Lake, Utah.

Rock Salt. - Rock salt, which is the most important source of commercial salt, is present in layers of variable thickness and purity embedded with sedimentary rocks, such as shales or sandstones. It is frequently associated with gypsum, and less commonly with limestone, or easily soluble compounds of magnesia, potash, and lime. The salt beds vary in thickness from a few inches up to as much as 3600 feet (Sperenberg, Germany), and while found in all geological formations from the Cambrian to the Pleistocene, except the Cretaceous, the rock salt of the United States is not found in formations older than the Upper Silurian.

Origin of Rock Salt (5). - One of the interesting problems of geology has been to find a correct theory to account for salt deposits of enormous thickness and often high purity. It is well known that salt is deposited in the course of evaporation of inland seas, such as the Dead Sea, and this is perhaps the origin of some of the salt beds found in the strata. But in many cases the material was evidently deposited in close connection with the open ocean, being both overlain and underlain by massive sediments with which it is directly continuous. It is inconceivable that such beds were precipitated in the open ocean, though they may well have been formed in seas or bays more or less completely cut off from the ocean.

This explanation, elaborated by Ochsenius (4), assumes a barrier partly shutting out the ocean water. Evaporation 
on the inclosed area of the sea exceeds the supply of water from inflowing rivers and from the open ocean. Therefore the water on the surface of the sea becomes more dense and settles to the bottom of the basin, being prevented from escape into the open ocean by the barriers at the entrance. As the surface of the bay is lowered by evaporation, ocean water enters, furnishing a constant supply of salt. If the barrier is complete, forming a bar, sea water may enter only at times of high tide or storm. Eventually evaporation will so concentrate the solution in the bay as to cause the precipitation of sodium chloride and other salts. So long as these conditions lasted, salt would be precipitated, but beds of clayey material would be deposited wherever fine-grained sediment was supplied from the land.

As will be seen by reference to the sea-water analyses given above, there are other salts present besides sodium chloride, and these will separate out in order of their solubilities, the least soluble ones being precipitated first. The order of precipitation would therefore be: (1) small amounts of lime carbonate and some hydrous iron oxide; (2) most of the sulphate of lime present; (3) a mixture of sodium chloride and lime sulphate; (4) sodium chloride of high purity; (5) a mixture of sodium chloride and soluble salts of magnesia, potash, bromine, and iodine.

This accounts for the frequent association of gypsum with salt; but the potash and magnesia salts, precipitated last, are rare, because even after being precipitated they may, owing to their easy solubility, be removed by an influx of fresh water or by leaching of the deposit. The only locality where the complete series is found is at Stassfurt, Prussia. 
This deposit, which is of Permian age, is one of the most interesting in the world. It shows the following section: at the bottom is the main bed of rock salt which is broken up into layers 2 to 5 inches thick by layers of anhydrite. Above this comes 200 feet of rock salt, with which are mixed layers of magnesium chloride and polyhalite $\left(\mathrm{K}_{2} \mathrm{SO}_{4}\right.$, $\mathrm{MgSO}_{4}, 2 \mathrm{CaSO}_{4}, 2 \mathrm{H}_{2} \mathrm{O}$ ). Resting on this is 180 feet of rock salt, with alternating layers of sulphates, chiefly kieserite, the sulphate of magnesia. These layers are about 1 foot thick. Lastly, and uppermost, is a 135foot bed consisting of a series of reddish layers of rock salt and salts of magnesia and potassium, kainite $\left(\mathrm{K}_{2} \mathrm{SO}_{4}, \mathrm{MgSO}_{4}, \mathrm{MgCl}_{2}, 6 \mathrm{H}_{2} \mathrm{O}\right)$, kieserite $\left(\mathrm{MgSO}_{4}\right)$, carnallite $\left(\mathrm{KCl}, \mathrm{MgCl}_{2}, 6 \mathrm{H}_{2} \mathrm{O}\right)$, tachhydrite $\left(\mathrm{CaCl}_{2}, 2 \mathrm{MgCl}_{2}\right.$, $\left.12 \mathrm{H}_{2} \mathrm{O}\right)$, as well as masses of snow-white boracite $\left(\mathrm{Mg}_{7} \mathrm{Cl}_{2} \mathrm{~B}_{16} \mathrm{O}_{30}\right)$.

Natural Brines. - These, sometimes found in porous layers of the rocks, may result either from sea water imprisoned in the layers of sediment or from the solution of rock salt by percolating waters.

Salt Marshes and Soils. - When away from the ocean, these owe their salinity to the infiltration of brine from neighboring saliferous formations. They sometimes represent the site of former salt lakes.

Distribution of Salt in the United States (Fig. 26). - In 1903 most of the domestic production came from nine states, either in the form of artificial brine obtained by forcing water through wells to the salt, which is then brought up in solution, or else as rock salt, raised through shafts from underground workings.

New York (13). - Salt was manufactured from brine springs at Onondaga Lake as early as in 1788; but the presence of rock-salt beds was not suspected until 1878, when a bed seventy feet thick was struck in drilling for petroleum in 
Wyoming County. Since then the development of the salt industry has been so rapid that for some years New York has been one of the two leading salt-producing states.

The salt occurs in lenticular masses interbedded with soft shales of the Salina series, which also carry gypsum deposits. The outcrop of the formation coincides approxi-

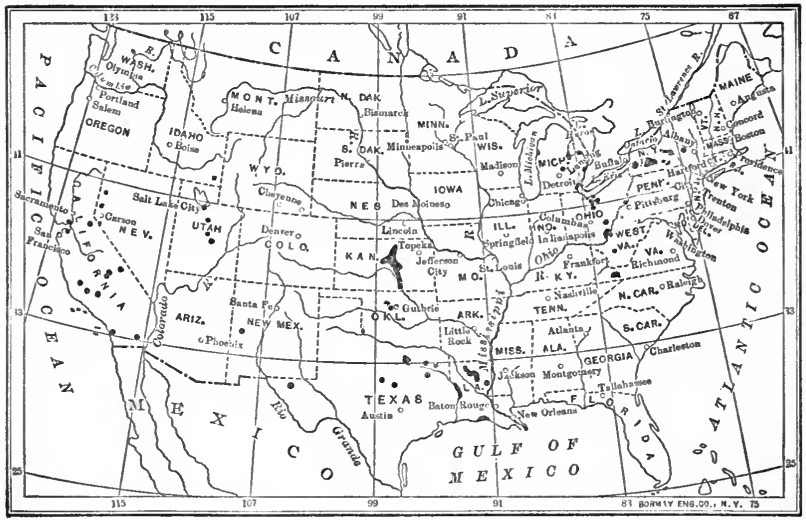

FIG. 26. - Map showing known occurrences of salt in United States, compiled from various geological survey reports.

mately with the line of the New York Central Railroad, but owing to its soluble character, no salt is found along the outcrops. The beds dip southward from 25 to 40 feet per mile, so that the depth of the salt beneath the surface increases in this direction.

At Ithaca, salt is struck at 2244 feet, and there are seven beds. The thickness of the individual beds varies, but the greatest known thickness is in a well near Tully, where 325 feet of solid salt was bored through. Though most of the New York product is obtained from artificial brines, a small quantity is mined by shafts. 

Plate XI

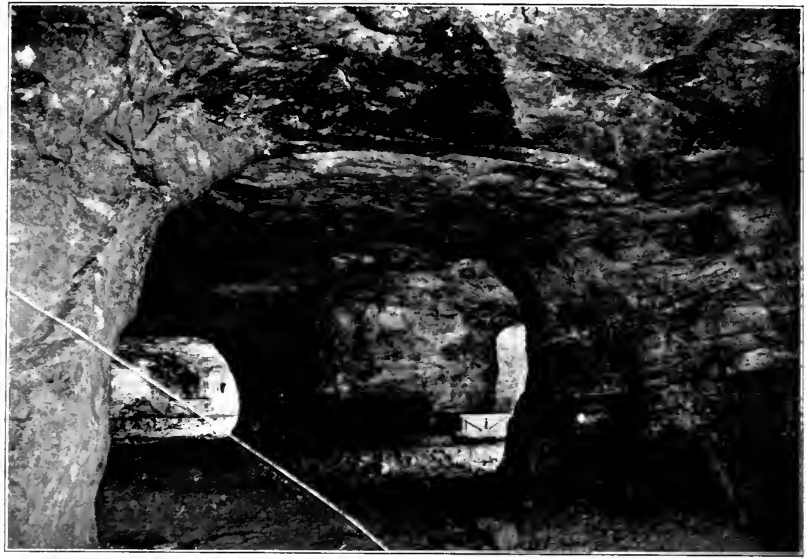

Fiti. 1. - Interior view of salt mine, Livonia, X.Y. Both roof and pillars are rock salt.

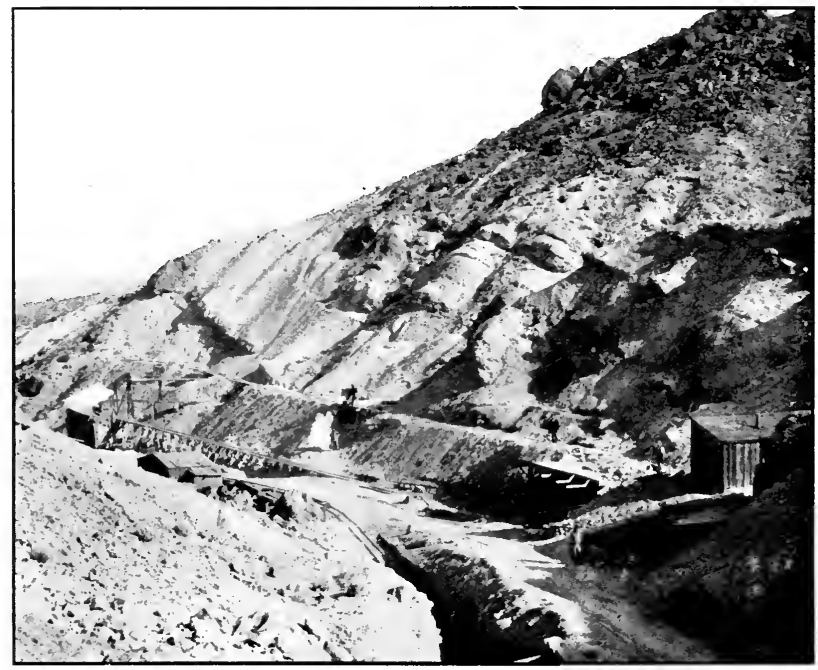

FIt. 2. - Borax mine near I)aggett, Calif. Photo. loaned by G. P. Merrill. 
Michigan (11). - Salt in Michigan is obtained both from natural brines and from brines obtained by dissolving rock salt, as in New York. The natural brines occur in the sandstones of the Subcarboniferous, the most important locality being in the Saginaw Valley, where the brines are found in the Napoleon or Upper Marshall sandstone. They are remarkable for the large amount of bromine contained, more than half the bromine produced in the United States being obtained here. The vast beds of rock salt which occur in the Salina (Monroe) are exploited along the Detroit and St. Clair rivers and at Manistee and Ludington. The salt is dissolved by lake water pumped down and then reevaporated, and soda ash (sodium carbonate) is made from the salt to a very great extent, by forced reaction with calcium carbonate. ${ }^{1}$

Other Eastern States. - In the Holston Valley of southwestern Virginia salt is obtained by wells from the Lower Carboniferous shaly limestones. Part of the product is marketed as salt, and the balance is used in the manufacture of alkali (19).

Brine is obtained from the Salina and Salt sand of Ohio (14), and from those portions of Pennsylvania and West Virginia adjacent to the Ohio salt district. In the Kanawha Valley of West Virginia a natural brine is obtained by wells from the oil horizons. Brines are also present in the Carboniferous of Illinois.

Louisiana (8-10). - Brine occurs in springs and wells in the Cretaceous area of northern Louisiana, but the most important source of salt is in the extensive beds of rock salt

${ }^{1}$ Private communications from Dr. A. C. Lane, State Geologist of Michigan. 
found in the southern portion of the state. These occur in a series of low knolls, called the Five Islands, beneath a series of clay, sand, and gravel beds. Though structural dețils are lacking, there seems in one case to be a dome fold and in Petite Anse a block fault. The age of the salt beds is Prepleistocene. Although the amount of rock salt present is evidently great, borings in one case having revealed a thickness of $\mathbf{1 7 5 6}$ feet of solid salt, these deposits yield but a small percentage of the country's output.

Kansas (7). - Salt is found in this state under the following conditions: (1) in the northern and central parts of Kansas as brine in salt marshes derived by leaching from the saliferous Dakota shales; (2) a limited amount in eastern Kansas from wells sunk in the Carboniferous; (3) in the Permian of south central Kansas as beds of rock salt. At the present time the rock salt is the most important commercial source, being obtained in part as artificial brines and in part as rock salt. The thickness of the salt varies, the greatest aggregate thickness recorded in any well being 324 feet. The deposits thin out to the eastward, and the north and south limits are fairly well known, but the western boundary remains undefined. The absence of gypsum in close association with the salt is a significant fact, but farther south it is found at a lower horizon, and the separation of the two is explained by a shifting sea bottom during deposition.

Other Western States $(16,17)$. - Rock salt has been found at several localities in Texas, notably in Mitchell County and under the oil beds at Beaumont; but none is yet produced. In Utah, some salt is obtained by evaporating the waters of Great Salt Lake (18). In California the main supply of salt is obtained by evaporating sea water (6), an 
elaborate system of ponds, covering thousands of acres, having been built on San Francisco Bay. These are filled at high tide, and the salt obtained by natural evaporation. A remarkable deposit of salt is worked at Salton Lake. 'This is a depression 27 miles long, $3 \frac{1}{2}$ to 9 miles wide, and at its lowest point 280 feet below sea level. The deposit is formed by evaporation of the lake waters, which are fed by saline springs from the surrounding foothills. The salt, which has accumulated to a depth of 6 inches, is gathered by scrapers. Salt is also found in marshes, springs, or wells in a number of other localities in California (6).

Analyses of Rock Salt from Various Localities

\begin{tabular}{|c|c|c|c|c|c|c|c|c|}
\hline Locality & 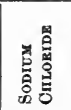 & 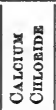 & 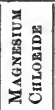 & 产量 & 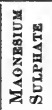 & 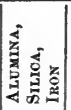 & 萦 & AUTHORITY \\
\hline Retsof, N.Y. . . . & 98.701 & Tr. & - & .446 & - & .743 & $\mathbf{T r}$ & F. E. Englehardt \\
\hline Pearl Creek, N.Y. & 96.885 & .157 & .103 & .437 & - & 1.21 & 1.21 & F. E. Englehardt \\
\hline Petite Anse, La. . & 98.90 & .146 & .022 & .838 & - & .014 & .08 & P. Collier \\
\hline Saltville, Va. & 99.084 & Tr. & - & .446 & - & .47 & - & C. B. Hayden \\
\hline
\end{tabular}

Analyses of Solid Matter of Brines from Various Localities

\begin{tabular}{|c|c|c|c|c|c|c|c|c|c|}
\hline Locality & 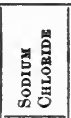 & 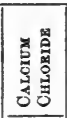 & 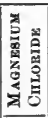 & 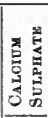 & 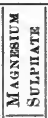 & 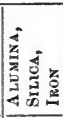 & 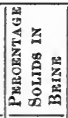 & 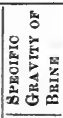 & A UTHORITY \\
\hline Warsaw, N.Y. & 97.60 & .51 & .20 & 1.68 & - & - & 26.34 & 1.204 & Englehardt \\
\hline Syracuse, N.Y. & 95.966 & .90 & .69 & 2.54 & - & .004 & 18.50 & 1.142 & G. H. Cook \\
\hline Saginaw, Mich. & 82.14 & 12.39 & 5.01 & .46 & - & - & 21.32 & - & C. A. Goessman \\
\hline Bay City, Mich. & 91.95 & 3.19 & 2.48 & 2.39 & - & - & 16.61 & - & C. A. Goessman \\
\hline Kanawha, W. Va. & 79.45 & 16.48 & 4.07 & - & - & - & 9.20 & 1.073 & G. H. Cook \\
\hline Pittsburg, Pa. & 81.27 & 13.93 & 4.80 & - & - & - & 2.80 & 1.019 & G. H. Cook \\
\hline Saltville, Va. & 97.792 & .033 & - & 2.17 & - & Tr. & 24.60 & - & C. B. Hayden \\
\hline
\end{tabular}

Extraction. - When salt forms underground deposits, it has to be extracted either by a process of solution or 
mining. In the former case water is forced down to the salt bed through a well, for the purpose of dissolving the salt, the brine being brought to the surface and evaporated, sometimes by solar heat, but more commonly by artificial means. In the latter case a shaft is sunk to the salt bed, and the material mined like coal and brought to the surface in lumps, known as rock salt. Natural brines are pumped to the surface for evaporation. In the evaporation of brine care has to be taken to separate the gypsum and other soluble impurities present, which precipitate before the salt does.

Uses. - Salt is largely used in the meat-packing business and the manufacture of dairy products, as well as for domestic purposes. Therefore a number of different grades are called for, known under various names, such as table, dairy, common, fine, packers, solar, rock, milling, etc. Large quantities of salt are also consumed in the manufacture of soda ash, sodium carbonate, caustic soda, and other sodium salts. The chlorination of gold ores calls for an additional large amount.

Production of Salt. - The increase in the amount of salt produced has been very marked, but it has been accompanied by a decrease in price, as shown in the statistics given below :-

Production of Salt in United States from 1880 to 1900

\begin{tabular}{|c|c|c|c|c|c|c|c|}
\hline YEAR & & BARRELS & Value & \multicolumn{2}{|c|}{ YeAR } & BARRELS & Value \\
\hline 1880 . . & & $5,961,060$ & $\$ 4,828,566$ & 1895 & - & $13,699,649$ & $\$ 4,423,084$ \\
\hline 1885 . . & . & $7,038,653$ & $4,825,345$ & 1900 & - & $20,869,342$ & $6,944,603$ \\
\hline 1890 . & - & $8,876,991$ & $4,752,286$ & & & & \\
\hline
\end{tabular}


Production of Salt by States from 1901 to 1903

\begin{tabular}{|c|c|c|c|c|c|c|}
\hline & \multicolumn{2}{|c|}{1901} & \multicolumn{2}{|c|}{1902} & \multicolumn{2}{|c|}{1903} \\
\hline & BARRELS & VALUE & BARBELS & VALUE & BARRELS & VALUE \\
\hline New York. & $7,286,320$ & $\$ 2,089,834$ & $8,523,389$ & $\$ 1,938,539$ & $8,170,648$ & $\$ 2,007,807$ \\
\hline Michigan . . & $7,729,641$ & $2,437,677$ & $8,131,781$ & $1,535,823$ & $4,297,542$ & $1,119,984$ \\
\hline Kansas. & $2,087,791$ & 614,365 & $2,158,486$ & 514,401 & $1,555,934$ & 564,232 \\
\hline Ohio. . & $1,153,535$ & 455,924 & $2,109,987$ & 593,504 & $2,798,899$ & 795,897 \\
\hline California . & 601,659 & 133,656 & 682,660 & 253,085 & 629,701 & 198,630 \\
\hline Texas . . & $(a)$ & $(a)$ & 347,906 & 143,683 & 314,000 & 117,647 \\
\hline West Virginia & 231,722 & 94,732 & 208,592 & 97,721 & 244,236 & 35,797 \\
\hline Utah . . & 324,484 & 326,016 & 417,501 & 270,626 & 212,955 & 181,710 \\
\hline Louisiana . . & $(a)$ & $(a)$ & $(a)$ & (a) & 568,936 & 178,342 \\
\hline Other States . & $1,141,509$ & 465,245 & $1,268,929$ & 321,254 & 175,238 & 86,942 \\
\hline Total. . & $20,566,661$ & $\$ 6,617,449$ & $23,849,231$ & $\$ 5,668,636$ & $18,968,089$ & $\$ 5,286,988$ \\
\hline
\end{tabular}

(a) Included in "Other States."

The exports in 1903 were 25,449,630 lbs., valued at $\$ 95,570$; while the imports for the same year amounted to $331,961,807$ lbs., valued at $\$ 495,948$.

World's Production of SALt in 1902

\begin{tabular}{|c|c|c|c|c|c|c|c|c|c|c|c|}
\hline \multicolumn{10}{|c|}{ Country } & \multirow{2}{*}{$\begin{array}{c}\text { SHort Tons } \\
3,339,891\end{array}$} & \multirow{2}{*}{$\frac{\text { VALUE }}{\$ 5,668,636}$} \\
\hline United S & tate & & • & . & & - & & & & & \\
\hline United K & King & gdon & & & & . & • & • & & $2,121,126$ & $2,886,665$ \\
\hline France & . & . . & • & - & & . & - & & & $982,479(a)$ & $2,605,800(a)$ \\
\hline Germany & 7 . & - & • & . & & . & - & & & $1,745,226$ & $4,992,600$ \\
\hline Japan. & . & . & & . & & - & • & & & $761,575(d)$ & $4,459,245(d)$ \\
\hline Italy . & & - . & & - & & & • & & & 505,401 & 711,400 \\
\hline Austria-I & Hun & agar & & & & . & - & & & 575,936 & $16,071,930$ \\
\hline Russia. & - &. & 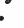 & - & & . & - & & & $1,913,696(e)$ & $2,767,168(e)$ \\
\hline Spain . & - & - & & & & & - & & & 470,057 & 707,424 \\
\hline India. & - & - & & $\theta^{\circ}$ & & & & & & $1,165,291$ & $1,554,914$ \\
\hline Canada & - & - & & ${ }^{\circ}$ & & & - & - & & 63,056 & 288,581 \\
\hline Others & - & - & & - & & & • & - & - & 125,467 & 970,522 \\
\hline Tota & & - & - & - & - & - & - & - & - & $13,769,201$ & $\$ 43,684,935$ \\
\hline
\end{tabular}

(a) Includes Algeria.

(d) Production and value, 1901.

(e) Production and value, 1901. 


\section{REFERENCES ON SALT}

Technology and Origin. 1. Chatard, U. S. Geol. Surv., 7th Ann. Rept. : 491, 1888. 2. Englehardt, N. Y. State Museum, Bull. No. XI : 38, 1893. 3. Hubbard, Mich. Geol. Surv., V, Pt. II : 1, 1895. 4. Ochsenius, Chem. Zeit., XI: 1887. (Bar theory.) 5. Wilder, Jour. Geol., XI : 725, 1903.

Areal. California : 6. Bailey, Calif. State Min. Bureau, Bull. XXIV : 105, 1902.-Kansas : 7. Kirk and Haworth, Min. Resources of Kas., 1898: 67. - Louisiana : 8. Lucas, Amer. Inst. Min. Engrs., Trans. XXIX : 462, 1900. (Rock salt.) 9. Veatch, La. Exp. Sta., Pt. V : 209, 1899. (Rock salt.) 10. Veatch, ibid., Pt. VI : 47, 1902. (N. La. salines.) - Michigan : 11. Lane, Mich. Geol. Surv., Ann. Rept., 1901 : 241, 1902. - New Mexico : 12. Darton, U. S. Geol. Surv., Bull. 260 : 565, 1905. (Zuni.) - New York: 13. Merrill, N. Y. State Museum, Bull. XI, 1893. - Ohio: 14. Root, Ohio Geol., VI: 653, 1888. - Oklahoma : 15. Gould, Kas. Acad. Soc., Trans. XVII : 181, 1901. (Salt plains.) - Texas : 16. Cummins, Tex. Geol. Surv., 2d Ann. Rept.: 444, 1890. (Northwestern Texas.) 17. Richardson, U. S. Geol. Surv., Bull. 260 : 572, 1905. (Trans-Pecos regions.) Utah : 18. U. S. Geol. Surv., Min. Res., 1888: 605, 1890. - Virginia: 19. Eckel, U. S. Geol. Surv., Bull. 213: 407, 1903. (S. W: Va.)

\section{BORAX}

Borax Minerals $(3,4)$. - The chief minerals containing boron are borax, tincal, or sodium biborate, $\mathrm{Na}_{2} \mathrm{~B}_{4} \mathrm{O}_{7}$, $10 \mathrm{H}_{2} \mathrm{O}$; colemanite, $\mathrm{Ca}_{2} \mathrm{~B}_{6} \mathrm{O}_{11}, 5 \mathrm{H}_{2} \mathrm{O}$; ulexite, $\mathrm{CaNaB}_{5} \mathrm{O}_{9}$, $8 \mathrm{H}_{2} \mathrm{O}$; boracite, $2 \mathrm{Mg}_{3} \mathrm{~B}_{8} \mathrm{O}_{15}, \mathrm{MgCl}_{2}$. These minerals are found usually as incrustations in alkaline marshes, or in lake waters of arid regions, or as bedded deposits. In some localities boric acid is found in fumarolic vapors.

Distribution in United States (5). - Deposits of borax have up to the present time been discovered only in California $(1,2)$, Nevada, and Oregon. Borax was originally obtained by evaporation from the waters of Clear Lake, north of San Francisco, being produced in commercial quantities in 1864, and the solution was enriched by crys- 
talline borax obtained from the marshes surrounding the lake. This and other lakes of California were worked until the discovery of large deposits of nearly pure borax in alkaline marshes of eastern California and western Nevada in the early seventies. Several refining plants were located at these marshes, and the product was sometimes hauled a hundred miles to the railroad. Increased production and importation from Italy, however, reduced the price and caused these plants to be abandoned.

The discovery, in 1890, that the marsh borax was a secondary deposit, derived from easily accessible and extensive bedded deposits in the Tertiary lake beds of that region, revolutionized the industry.

The most important of these beds is located near Daggett (Pl. XI, Fig. 2), San Bernadino County, California, but much larger deposits are known in Death Valley. The borax, which forms a regular stratum, interbedded with sands and clays, is supposed by Campbell (2) to have been deposited in a series of Tertiary lakes, but the beds are in many instances tilted, due to violent crustal movements, which interrupted sedimentation at intervals.

Uses. - The borax-bearing minerals are utilized chiefly for the manufacture of borax and boracic acid. Borax is used in industrial chemistry, in medicine, and as a laboratory reagent. It is also employed in the assaying of gold and silver ores.

Boric acid is used in the manufacture of borax, in colored glazes for decorating iron, steel, and metallic objects, in enamels and glazes for pottery, in making flint glass, as an antiseptic, and as a preservative for food. 
While several borax refineries are located on the Pacific coast, the main one is at Bayonne, New Jersey.

Production of Borax. - The California colemanite deposits form the main source of domestic supply, while small amounts are obtained from Nevada and Oregon.

The United States production in 1903 was 34,430 short tons of crude borax, valued at $\$ 661,400$. The value of the refined product is naturally much higher, and its total value for 1903 would be $\$ 2,735,000$.

World's Production of Borax in 1902

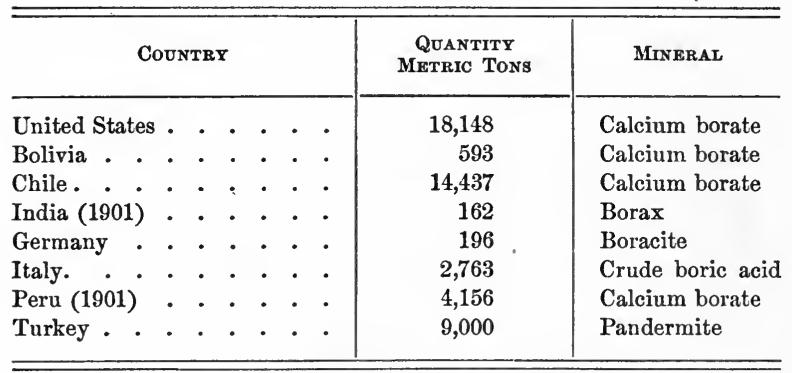

REFERENCES ON BORAX

(1) Bailey, Calif. State Mining Bureau, Bull. 24:33, 1902. (Calif. and general.) (2. Campbell, U. S. Geol. Surv., Bull. 200, 1902. (Calif.) 3. Kemp, Min. Indus. I : 43, 1893. (General.) (4.) Merrill, NonMetallic Minerals : 313, N. Y., 1904. 5. Struthers, Mineral Census of 1902, Mines and Quarries: 885, 1905. (General.)

\section{SODIUM SULPHATE}

The hydrous sulphate, mirabilite or glaubersalt $\left(\mathrm{Na}_{2} \mathrm{SO}_{4}\right.$ $+10 \mathrm{H}_{2} \mathrm{O}$ ), is a white saline material, which is collected on or near the surface of some alkaline marshes in desert regions. It is known to occur at several localities in Wyoming. 
REFERENCES ON SODIUM SULPHATE

1. Attfield, Jour. Soc. Chem. Ind., Jan. 31, 1895. 2. Knight, Min. Indus., III: 651, 1895. 3. Knight, Wyo. Agric. Exper. Sta., Bull. 14, 1893.

\section{SODIUM CARBONATE}

Sodium carbonate, or natural soda, is obtained by the evaporation of the waters of alkali lakes, or is found as a deposit on or near the surface of alkaline marshes in arid regions. It is usually a mixture of sodium carbonate and bicarbonate in varying proportions, as well as impurities such as sodium chloride, sodium sulphate, borax, and sodium nitrate.

Sodium carbonate is obtained from Owens Lake in California. An analysis of the waters by Chatard yielded: $\mathrm{SiO}_{2}, .220 ; \mathrm{Fe}_{2} \mathrm{O}_{3}, \mathrm{Al}_{2} \mathrm{O}_{3}, .038 ; \mathrm{CaCO}_{3}, .055 ; \mathrm{MgCO}_{3}, .479$; $\mathrm{KCl}, 3.137$; NaCl, 29.415; $\mathrm{Na}_{2} \mathrm{SO}_{4}, 11.080 ; \mathrm{Na}_{2} \mathrm{CO}_{3}, 26.963$; $\mathrm{NaHCO}_{3}, 5.725$. The soda is purified by fractional distillation. Soda is also known to occur in Oregon and Nevada.

\section{REFERENCES ON SODIUM CARBONATE}

1. Bailey, Calif. State Min. Bur., Bull. $24: 95,1902$. 2. Chatard, U. S. Geol. Surv., Bull. 60 : 27, 1888. (Analyses.) 3. Russell, U. S. Geol. Surv., Mon. XI : 73.

\section{SODA NITER. ${ }^{1}$}

Soda niter, or Chile saltpeter $\left(\mathrm{NaNO}_{3}\right.$, with 63.5 per cent $\mathrm{Na}_{2} \mathrm{O}_{5}$ when pure), is found in San Bernadino and Inyo counties, California, along the shore lines marking the boundary of Death Valley in Eocene times (1). It occurs in peculiar rounded hills of Eocene clay, the niter being found as a layer near the surface or distributed through the

1 The term niter, when used alone, refers to potash niter. 
clay. Very little soda niter is obtained from this source, and the main supply of this country continues to come from Chile, where extensive deposits are found in the desert region west of Iquique. There the niter (caliche) forms a bed 6 to 12 feet thick, under a cap of conglomerate (costra) 1 to 18 feet thick. The origin of this deposit is interesting, and has caused considerable discussion. One theory quite generally accepted is that the niter was formed primarily by the slow oxidation in air of guano or other nitrogenous organic matter in contact with alkali; a second theory refers its origin to the oxidation of organic materials and ammonia, by microscopic organisms known as nitrifying germs.

REFERENCES ON SODA NITER

1. Bailey, Calif. State Min. Bur., Bull. $24: 139,1902$. 



\section{(1)}

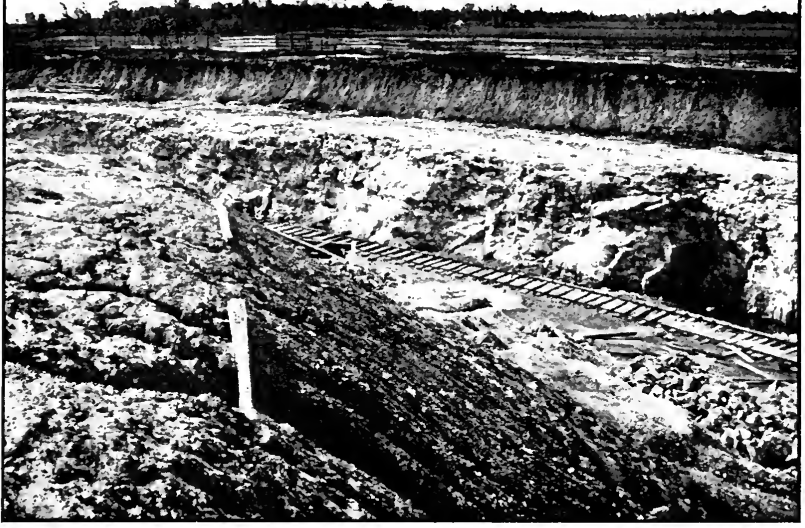

Fig. 1. - Gypsum quarry, Alabaster, Mich. Shows gypsum overlain by glacial drift. The dump in foreground is overburden removed from gypsum. Ploto., A. C. Lare.

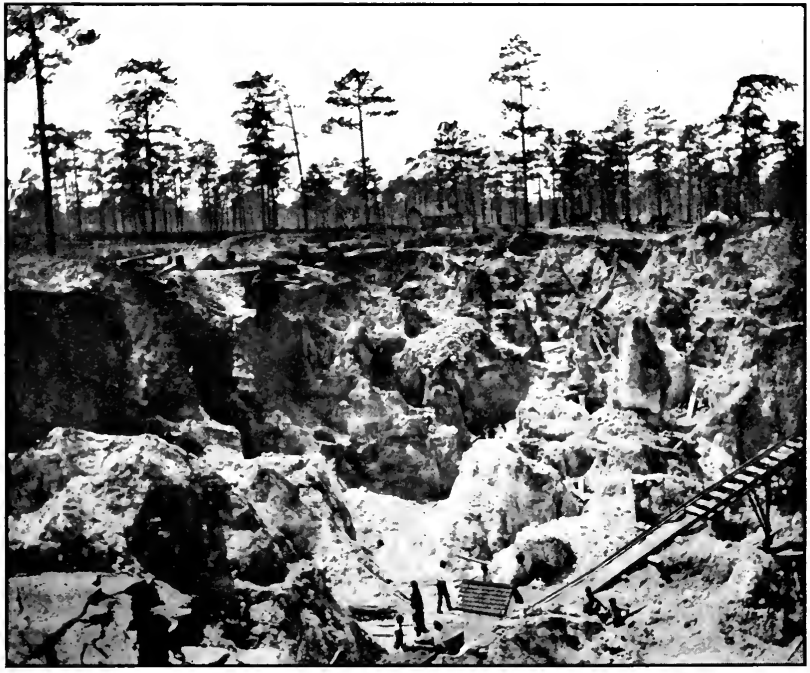

FIG. 2.- Rock phosphate mine near Ocala, Fla. Photo., A. W. Sheafer. 


\section{CHAPTER VII}

\section{GYPSUM}

Gypsum (1), the hydrous sulphate of lime $\left(\mathrm{CaSO}_{4}, 2 \mathrm{H}_{2} \mathrm{O}\right)$, occurs most frequently in sedimentary rocks, interbedded with shales, sandstones, and limestones, and often more or less closely associated with rock salt. It is also found as surface deposits of sand or mixed with clay (gypsite), as well as in limited quantities in volcanic regions, especially in lavas. When occurring in bedded deposits (Pl. XII, Fig. 1) it is massive, of finely crystalline or earthy appearance, and of variable color, although most commonly white and gray. Transparent, colorless forms, known as selenite, are found as veins or crystals in the massive gypsum, or as plates and crystals in many clays, shales, and limestones. This variety by itself never forms deposits of commercial importance.

Anhydrite differs from gypsum chemically in the absence of water, but changes to it on exposure to the air.

Origin of Gypsum (3). - Gypsum is widely distributed both geographically and geologically, being found in various horizons from the Silurian to the Recent. Most beds of this substance have no doubt been formed by the evaporation of salt water either in inland seas or else in arms of the ocean, the process of precipitation having been discussed in the chapter on Salt. As gypsum separates from sea water after 37 per cent of the water has evaporated, 
while salt precipitates only after 93 per cent has been removed, it is evident that gypsum beds may be deposited without salt. This also explains why gypsum is more widely distributed than salt; and the fact that the percentage of gypsum in salt water is much less than that of salt probably accounts for its usual occurrence in the thinner deposits.

Gypsum may also be formed by the decomposition of sulphides, such as pyrite, and the action of the sulphuric acid thus liberated on lime carbonate. Small quantities are formed in volcanic regions through the action of sulphuric vapors on the lime of volcanic tuffs or other rocks.

Gypsite, or gypsum dirt, is an earthy or sandy variety of gypsum forming a surface deposit in Kansas (9) and other western states $(16,19)$, which, in spite of its impure appearance, may run high in calcium sulphate. It is believed to be a deposit either in the soil or in shallow lakes supplied by springs whose water has dissolved the calcium sulphate from gypsum beds or other rocks. During its precipitation by the second method, its impure character is caused by its becoming mixed with clay or sand washed in from the land.

Distribution in the United States (Fig. 27). - Eighteen states are producers of gypsum, although four of theseIowa, Kansas, Michigan, and New York-supply most of the output of the country.

Iowa (8). - Important deposits are found in this state in an area of about 25 square miles in Webster County, especially near Fort Dodge. The gypsum, which is presumably of Permian age, rests on the Coal Measures and 
is covered by glacial drift. It varies from 3 to 30 feet in thickness, with an average of 16 feet, and much of it is sufficiently white for stucco.

Kansas. - Gypsum (9) is found occurring either as rock gypsum, or as gypsite, the deposits forming a belt extending across the central part of the state in a northeastsouthwest direction, and includes three important areas.

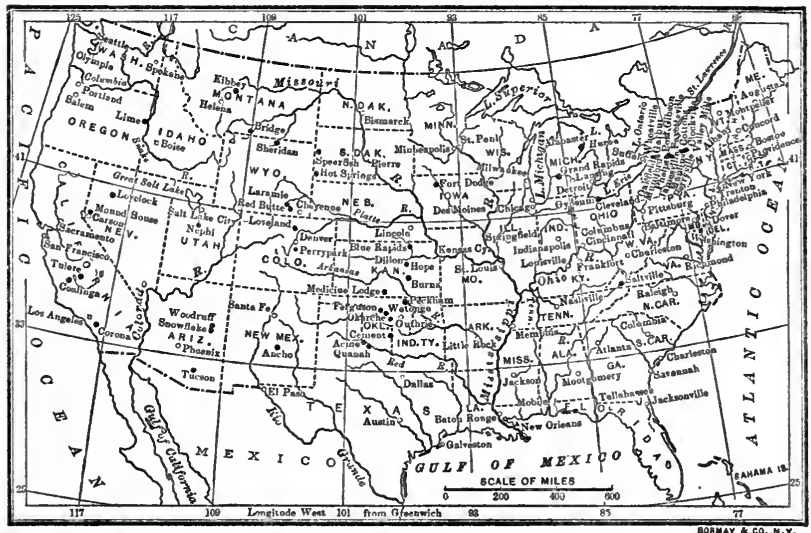

Fig. 27. - Map showing gypsum-producing localities of United States. After Adams, U.S. Geol. Surv., Bull. 223.

The beds of rock gypsum are of Permian age, interbedded with red shales, those at the southern end of the belt being stratigraphically 1000 feet higher than those at the northern end.

The gypsite or gypsum dirt, which is of more recent age, is found in the central area, as well as at a number of other localities. The spring waters which have supplied it have leached the calcium sulphate either from the gypsum 
beds or the red shales. The product is used for fertilizer and cement plaster.

Deposits of gypsum earth are found to the south of Kansas in Oklahoma (16) and northern Texas (16), as well as to the northwest in Wyoming $(19,20)$.

Michigan (10) contains two important occurrences of gypsum, one in the vicinity of Grand Rapids, and the other at Alabaster on Saginaw Bay (Pl. XII, Fig. 1), both in beds of Lower Carboniferous age. That at Grand Rapids runs from 6 to 12 feet in thickness, forming several beds interstratified with shale and limestone. A third possibly productive area is near St. Ignace on the upper peninsula, where it occurs in the Salina.

New York $(11,12)$. - Gypsum occurs in the Salina shales of central and west central New York. Most of the product is gray and used for land plaster; but in recent years some whiter deposits, suitable for stucco, have been worked near Batavia.

Other Occurrences. - Gypsum is also found in beds of Lower Carboniferous age in the Holston Valley of southwestern Virginia (18). The rock is mined partly by underground workings, and some of the beds are fully 30 feet thick. The product is used for land and wall plaster. In Ohio gypsum has been obtained from the lower Helderberg beds of Ottawa County, 10 miles west of Sandusky. The material occurs at different horizons, the beds being bent into rolls, the main ones having a thickness of about 12 feet $(13,16)$. Additional occurrences are known in Wyoming (19, 20), Utah (17), Arizona (5), Nevada (16), California (6), Iontana (16), Idaho (16), Colorado $(7,16)$, and South Dasota (14-16). 
Analyses. - The following analyses indicate the composition of gypsum from different localities in the United States :-

\section{Analyses of Gypsum from United States}

\begin{tabular}{|c|c|c|c|c|c|c|c|c|c|}
\hline & $\mathrm{CsO}$ & $\mathrm{SO}_{3}$ & $\mathrm{H}_{2} \mathrm{O}$ & $\begin{array}{c}\text { Insolu- } \\
\text { ble }\end{array}$ & $\mathrm{CaCO}_{3}$ & $\mathrm{Al}_{2} \mathrm{O}_{3}$ & $\mathrm{Fe}_{2} \mathrm{O}_{3}$ & $\mathrm{MgO}$ & $\mathrm{CO}_{2}$ \\
\hline Pure Gypsum . & 32.60 & 46.50 & 20.90 & - & 一 & - & 一 & 一 & \\
\hline Onondaga, N.Y. & & 73.92 & & 4.64 & 21.44 & - & - & - & \\
\hline Sandusky, 0. & 32.35 & 46.38 & 19.70 & .91 & - & .60 & - & .54 & \\
\hline Fort Dodge, Ia. & 78 & 44 & 20.76 & .65 & - & - & - & - & \\
\hline $\begin{array}{l}\text { Michigan . } \\
\text { Medicine Lodge }\end{array}$ & 32.88 & 45.79 & 20.98 & & - & 一 & 一 & 一 & \\
\hline Kas. . . & 32.53 & 45.73 & 20.46 & .19 & - & \multicolumn{2}{|c|}{.10} & .16 & \\
\hline $\begin{array}{c}\text { Gypsite, Salina, } \\
\text { Kas. - . }\end{array}$ & 29.14 & 37.49 & 16.75 & 12.13 & 一 & \multicolumn{2}{|c|}{.99} & .42 & 2.03 \\
\hline $\begin{array}{l}\text { Gypsite, Quanah, } \\
\text { Tex. . . . }\end{array}$ & \multicolumn{2}{|c|}{78.66} & 8.49 & 7.43 & 5.07 & \multirow{2}{*}{\multicolumn{2}{|c|}{$\begin{array}{l}.12 \\
.70\end{array}$}} & 一 & \\
\hline Plasterco, Va. & 33.20 & 46.04 & 19.40 & .10 & - & & & - & \\
\hline
\end{tabular}

Uses (1). - Gypsum is sold either in the ground, uncalcined condition, or after calcining and screening. In the former state its chief value is as a fertilizer, it being marketed under the name of land plaster, which is also used as a disinfectant. Though the softness of gypsum prevents its general employment as a building material, the pure white, massive varieties, known as alabaster, have been used for statuary, basins, vases, and other objects for interior decoration. Gypsum is also used to weight fertilizers, and as an absorbent of organic materials in them; as a flux in the manufacture of glass and porcelain; and, under the name of "terra alba," as an adulterant of foods and medicinal preparations. 


\section{ECONOMIC GEOLOGY OF THE UNITED STATES}

In its calcined form, gypsum is known as plaster of paris and has the following uses, dependent on its property of hardening or setting when mixed with water: stucco, plastering for walls, whitewash, pottery molds, statuary, and dental purposes, as a deodorizer, for crayons, and as a retarder of fermentation and absorbent of water in wines.

Calcining Gypsum. - When heated to $250^{\circ} \mathrm{F}$., gypsum loses a portion of its water of hydration, but if finely ground has the property of recombining with it. If heated to $300^{\circ} \mathrm{F}$. to $400^{\circ} \mathrm{F}$., it loses this power and is said to be dead-burned. In addition to dehydration, burning also breaks up the crystals into minute particles. The set is due to the formation of a crystalline network of the rehydrated grains.

Since calcined gypsum sets in from 6 to 10 minutes, some retarding material, such as organic matter from slaughter-house refuse, is often added to it, and thus the setting process may be delayed from 2 to 6 hours. Those plasters which set slowly are termed cement plasters.

The following analyses show the composition of (1) uncalcined gypsum; (2) the calcined rock; and (3) the plaster after it has taken np water and set. From these it will be seen that the plaster takes up the amount of water lost in calcination.

Series of Analyses showing Changes in Gypsum during Burning and after Setting

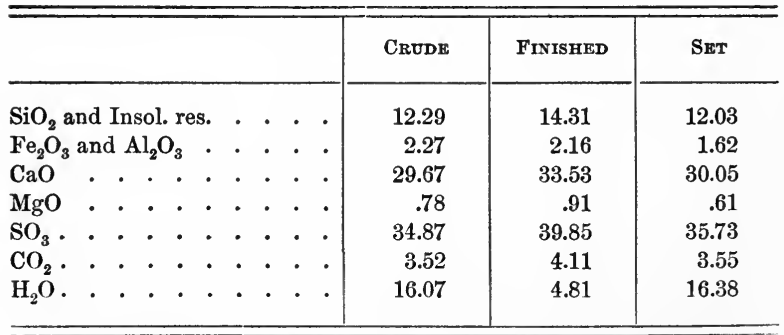


Production of Gypsum. - Michigan, New York, Iowa, and Kansas are the four leading producers, but many other states contribute small amounts as seen below.

Production of Gypsum in United States from 1901-1903

\begin{tabular}{|c|c|c|c|c|c|c|}
\hline & \multicolumn{2}{|c|}{1901} & \multicolumn{2}{|c|}{1902} & \multicolumn{2}{|c|}{1903} \\
\hline & $\begin{array}{l}\text { SHORT } \\
\text { TONS }\end{array}$ & VALUE & $\begin{array}{l}\text { SHORT } \\
\text { TONS }\end{array}$ & VALUE & $\begin{array}{l}\text { SHORT } \\
\text { TONS }\end{array}$ & VAlú \\
\hline $\begin{array}{c}\text { California, Ohio, } \\
\text { and Virginia }\end{array}$ & $18,786^{1}$ & $\$ 49,344^{1}$ & 101,545 & $\$ 290,393$ & 103,392 & $\$ 467,113$ \\
\hline Colorado and & & & & & & \\
\hline Wyoming . & 17,394 & 76,435 & 16,051 & 73,372 & 33,549 & 133,347 \\
\hline $\begin{array}{c}\text { Iowa, Kansas, } \\
\text { and Texas . }\end{array}$ & 213,419 & 629,336 & 295,769 & 807,355 & 307,102 & $1,087,045$ \\
\hline Michigan . . & 185,150 & 267,243 & 240,227 & 459,621 & 269,093 & 700,912 \\
\hline New York . & 119,565 & 241,669 & 110,364 & 259,170 & 137,886 & 462,383 \\
\hline Oklahoma . & 15,930 & 66,031 & 34,156 & 111,215 & 69,158 & 234,621 \\
\hline Other states & 63,547 & 176,583 & 18,366 & 88,215 & 121,524 & 707,522 \\
\hline Total . & 633,791 & $\$ 1,506,641$ & 816,478 & $\$ 2,089,341$ & $1,041,{ }^{\top} 04$ & $\$ 3,792,943$ \\
\hline
\end{tabular}

The imports for 1903 amounted to 269,484 short tons, valued at $\$ 378,597$.

World's Production of GyPSUM, 1902

\begin{tabular}{|c|c|c|c|c|c|c|c|c|c|}
\hline & & & & & & & & Short ToNs & ValUE \\
\hline France - . & • & - & • & • & • & - & & $1,975,513$ & $\$ 3,318,070$ \\
\hline United States & . & . & . & & . & . & - & 816,478 & $2,089,341$ \\
\hline Canada . . & - & . & . & - & . & . & - & 332,045 & 356,317 \\
\hline Great Britain & . & - & . & & & 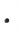 & & 251,629 & 384,263 \\
\hline Germany . & - & - & - & - & . & - & - & 34,944 & 12,732 \\
\hline Algeria . . & • & - & . & & . & - & - & 6,889 & 52,253 \\
\hline Cyprus . • & - & - & - & & & - & - & 7,874 & 17,443 \\
\hline Total $^{2}$ & - & - & - & • & ${ }^{*}$ & - & - & $3,425,372$ & $\$ 6,230,419$ \\
\hline
\end{tabular}

1 Ohio, none reported.

2 India not available. 


\section{REFERENCES ON GYPSUM}

Properties and Technology. 1. Grimsley, Mich. Geol. Surv., IX, Pt. 2, 1904. 2. Grimsley and Bailey, Kas. Geol. Surv., V, 1899. 3. Wilder, Eng. and Min. Jour., LXXIV: 276, 1902.

Areal. 4. Adams and others, U. S. Geol. Surv., Bull. 223, 1904. (United States.) - Arizona: 5. Blake, Amer. Geol., XVIII : 394, 1896.-California: 6. Crawford, Calif. State Mining Bureau, XII: 323, 1894. - Colorado : 7. Lee, Stone, XXI: 35, 1900. (Larimer Co.)Iowa : 8. Wilder, Ia. Geol. Surv., XII : 99, 1902, and Jour. Geol., XI : 723, 1903. - Kansas : 9. Grimsley and Bailey, Kas. Univ. Geol. Surv., V, 1899. - Michigan: 10. Grimsley, Mich. Geol. Surv., IX, Pt. 2, 1904. - New York: 11. Merrill, N. Y. State Museum, Bull. $11: 70,1893.12$. Parsons, N. Y. State Geologist, 20th Ann. Rept.: r 177, 1902. - Ohio: 13. Orton, Ohio Geol. Surv., VI : 696, 1888. South Dakota: 14, U. S. Geol. Surv., Geol. Atlas Folios 85: 6. 15. Todd, S. D. Geol. Surv., Bull. 3 : 99, 1902. - United States : 16. Adams and others, U. S. Geol. Surv., Bull. 223, 1904. - Utah : 17. Boutwell, U. S. Geol. Surv., Bull. 225: 483, 1904.-Virginia : 18. Eckel, U. S. Geol. Surv., Bull. 213 : 406, 1903. - Wyoming: 19. Knight, Wyo. Exper. Station, Bull. 14 : 189, 1893. 20. Slosson and Moody, Wyo. Coll. Agric. and Mech., 1uth Ann. Rept., 1902. 


\section{CHAPTER VIII}

\section{FERTILIZERS}

UNDER this term are included a number of mineral substances, limestone, marl, gypsum, phosphate of lime, greensand, and guano, which are of value for adding to the soil to increase its supply of plant food. Since the first three of these have other uses as well, they have already been discussed in Chapters III, V, and VII.

Phosphate of Lime. - This occurs both as crystalline phosphate of lime, or apatite, and amorphous phosphate of lime, or rock phosphate.

Apatite $(5,6) .-$ This mineral, which theoretically contains 42.3 per cent $\mathrm{P}_{2} \mathrm{O}_{5}$, is widely distributed in some igneous and metamorphic rocks, but rarely occurs in sufficient quantity, or in sufficiently concentrated masses, to render its extraction profitable, at least while the supply of amorphous phosphate lasts. No commercially valuable deposits have thus far been discovered in the United States; but in the provinces of Quebec and Ontario, Canada, apatite occurs in veins or pockets in metamorphic rocks, though little is now mined.

Amorphous Phosphates. - These, though composed chiefly of phosphate of lime, also carry variable quantities of other substances. (See table, p. 154.) They occur (1) as concretionary bodies in consolidated rocks; (2) as beds; (3) as 
irregular rocklike masses; and (4) as nodular masses of varying size, often scattered through unconsolidated beds. As is shown in the following descriptions, amorphous phosphates occur in various geological horizons, from the Silurian to Tertiary, and in several states in the Union, though most of the domestic supply comes from Florida, Tennessee, and South Carolina.

Florida Phosphates (10). - This state is at present the most important phosphate producer, although the full extent and value of the deposits were unsuspected until the dis-

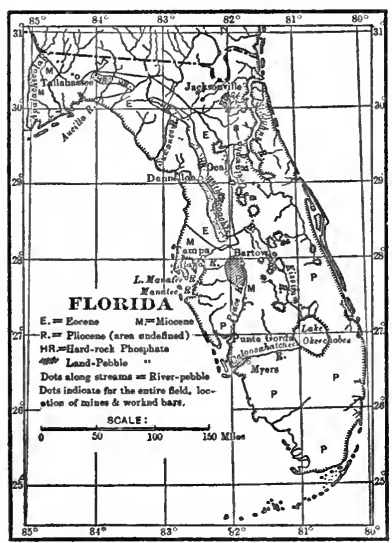

FIg. 28. - Map of Florida phosphate deposits. After Eldridge, Amer. Inst. Min. Eng., Trans. $X X I: 197$. covery of large beds along the Peace River in 1887. The phosphate deposits which are associated with Tertiary limestones of various horizons from the Eocene to the Pliocene form a curved belt, beginning west of the Appalachicola River and extending east and then south through Dunnellon, and approximately as far as Punta Gorda (Fig. 28). The topography varies from gently rolling to flat pine lands and swampy areas, the general elevation being under 75 feet.

Eldridge recognizes four types of phosphates in this area, viz. hard rock, soft rock, land pebble, and river pebble. Of these the hard rock phosphate (Pl. XII, Fig. 2) is the richest, and has had most influence in the rapid development of the 
district. It is a hard, massive, close-textured rock, of variable color, and often containing irregular cavities which show a secondary deposition of phosphate. Accompanying this in some places is a second type, the soft phosphate, which is evidently a disintegration product. Bowlders of hard phosphate are frequently embedded in a matrix of soft phosphate, and also in sands and clays overlying the Eocene limestone. While the hard rock has an average of a little over 36.65 per cent of phosphoric acid, the soft phosphate rarely averages over 22.90 .

The land pebble or matrix rock is made up of pebbles of varying size, shape, and color, and composed either (1) of earthy material with fossils, quartz grains, and pisolitic grains of phosphate, or (2) of pebbles closely resembling the hard-rock phosphate. To render it marketable, the pebbles, which average 32.06 per cent phosphoric acid, have to be freed from the matrix by washing and screening. The unit composition of sale for land pebble is 68 per cent of the bone phosphate and 3 per cent of the combined oxides of iron and alumina, with moisture at 2 per cent.

The river pebble consists of phosphate pebbles, having a blue, black, or dark gray surface, and mixed with sand, bones, and teeth. It is found in the present as well as in ancient river channels, in the latter case being covered by coastal sands. That found in the Peace River district averages 28.40 per cent phosphoric acid.

All of the above-mentioned types, with the exception of the soft phosphates, are found underlying more or less separate regions (Fig. 28).

The origin of the Florida phosphates has been a puzzling problem to geologists. Eldridge (10) has proposed two 
theories: (1) that they have been derived by the leaching of guano and bone beds, and the deposition of the phosphate in the underlying limestone, either by precipitation in its pores or replacement of the lime carbonate; (2) that they are due to the solution of the limestone and consequent concentrations of the less soluble phosphate of lime which was originally disseminated through the rock. Later solutions removed the limestones from around the phosphate deposits, leaving them as bowlders, which, at a still later date, were rounded by water currents which also deposited sand around them.

The land pebble and river pebble probably represent nodules of a highly phosphatized marl, formed in limestone pebbles, shell casts, or by segregation of the contained lime phosphate, and subsequently set free by the solution of the lime carbonate.

South Carolina Phosphates. - Phosphate is found both on the land and in the river bottoms in a belt about 60 miles long lying inland from Charleston and Beaufort $(6,17,18)$. The phosphate, which rarely averages much over one foot in thickness, is commonly of nodular character, and often contains many bones and teeth. The presence of these animal remains, including both land and marine forms, has given rise to the belief that the deposits were caused by the accumulation of bones and excrements along a shore line, probably of Upper Miocene age. Leaching of these remains may have permitted a later replacement of limestone or the formation of phosphatic concretions in swamp bottoms.

Tennessee Phosphates $(11,12,13,16,19)$. — Since the recognition, in 1893, of considerable quantities of high-grade phosphates in western middle Tennessee (Fig. 29), there have 
been important developments of the deposits. Three types are recognized. The first is brown phosphate occurring in terraces along Duck River, Maury County. It is evidently

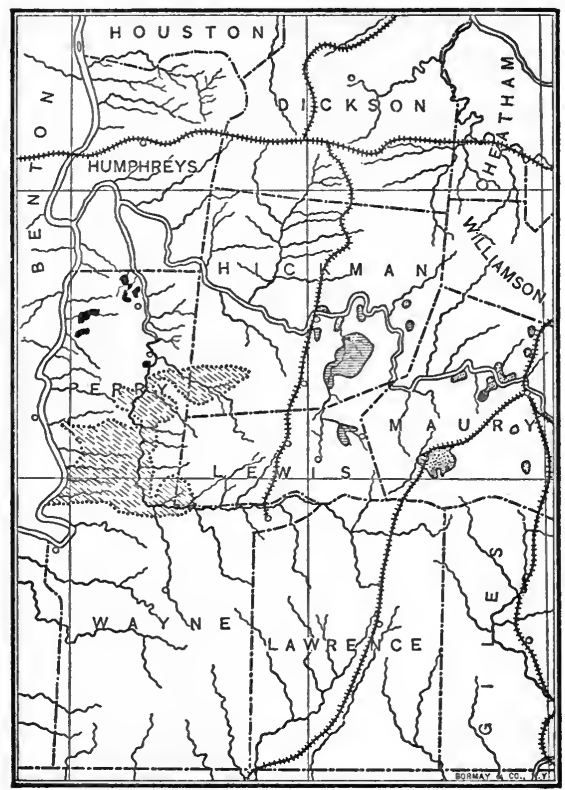

Black Phosphate

White Phosphate

Area in which Black 2 Phosphate may be found

Fig. 29. - Map of Tennessee phosphate areas. Compiled from data in U.S. Geol. Surv., Columbia Atlas folio, and papers by Hayes.

derived from the weathering of near-by phosphatic limestone of Ordovician age.

A second type, of black or blue color, occurs either in nodules or in beds. The bedded phosphate is underlain 
either by gray Devonian sandstone or by blue Silurian limestone, and capped by black carbonaceous shale; the nodular

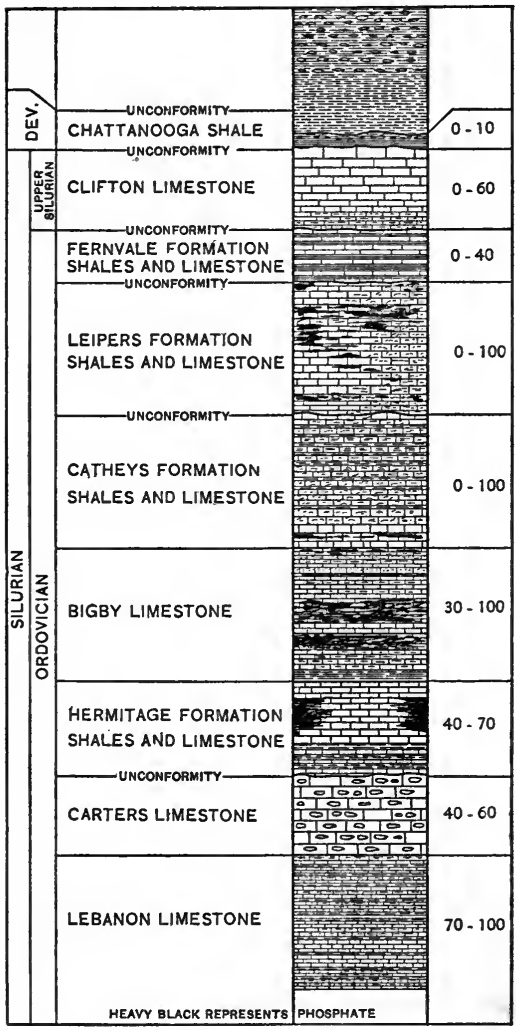

FIG. 30.-Vertical section showing geologic position of Tennessee phosphates. After Hayes. form occurs higher up in the section. Both are believed to be chemical precipitates on the floor of the Devonian sea.

The third group includes white phosphates occurring in three conditions: stony, brecciated, and lamellar, intimately associated with Carboniferous strata, but some occur in Silurian limestones. In the stony phase, the phosphate has been deposited in a siliceous limestone, replacing the lime. It alternates with beds of stony chert and contains under 50 per cent of bone phosphate. The brecciated form, which 
is the most abundant, consists of angular chert fragments in a phosphate matrix deposited between chert fragments of a limestone. The lamellar variety was deposited in caverns in the Silurian limestones, which, since the deposition of the phosphate, has weathered to a residual elay in which the phosphate masses occur.

Hayes has advanced the theory that the lime phosphate of the white phosphates was originally extracted from sea water by organisms, and accumulated on the bottom either as nodules or disseminated through the sediments. Later, when these strata were lifted above sea level and subjected to erosion and the action of percolating waters charged with acids from the soil, the phosphate was leached out and carried to lower levels where it was redeposited either in cavities or by replacing limestone.

Other Phosphate Occurrences. - Phosphate, in the form of nodules, white vesicular rock, and in limestone fragments, occurs along the contact of Oriskany sandstone and Lower Helderberg limestone, in Juniata County, Pennsylvania (14). It contains 30 to 54 per cent bone phosphate. Nodular phosphate, although not worked, is known to occur in Devonian strata in Arkansas (7), and in Cretaceous and Tertiary strata in Alabama (20), Georgia (15), and North Carolina (8).

Composition. - The following analyses will serve to show the composition of some native phosphates. Of the impurities present, lime carbonate is undesirable, since it neutralizes the acid used in phosphate manufacture. Iron oxide, alumina, and silica are inert impurities displacing just so much phosphate of lime.

The richness of a phosphate is usually expressed in terms of the tribasic-calcic phosphate, commonly termed bone 
phosphate. Of this about 45.80 per cent is phosphoric acid.

\section{Analyses of Phosphate Rock}

\begin{tabular}{|c|c|c|c|c|c|c|c|c|c|c|c|c|}
\hline & 䓪 & $\stackrel{\infty}{\infty}$ & $\overbrace{\substack{\infty \\
\infty}}^{\infty}$ & $\frac{0}{4}$ & $\delta^{n}$ & ర్ల్మ & $\begin{array}{l}\stackrel{0}{0} \\
\text { 要 } \\
\end{array}$ & $\begin{array}{l}\dot{\sharp} \\
0 \\
0 \\
=\end{array}$ & ڤ & 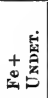 & 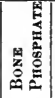 & $\begin{array}{l}\stackrel{\dot{*}}{0} \\
\text { 兽 }\end{array}$ \\
\hline Tennessee & & & & & & & & & & & & \\
\hline Mt. Pleasant . . & 1.05 & 34.69 & 2.39 & 3.36 & 1.40 & 3.18 & 4.05 & 2.64 & 46.76 & 1.39 & 76.42 & $\mathbf{s}$ \\
\hline $\begin{array}{l}\text { Swan Creek, } \\
\text { Hickman Co. . }\end{array}$ & & & 3.14 & & 1.15 & & 13.24 & & & & & 2.8 \\
\hline $\begin{array}{l}\text { White phosphate, } \\
\text { Stone Quarry } \\
\text { Hollow, Perry }\end{array}$ & & & & & & & & & & & & \\
\hline$\underset{\text { FLORIDA }}{\text { Co.. • }}$ & & 15.30 & & & & 8.23 & 54.88 & & 22.76 & & & $\mathrm{MgO}$ \\
\hline $\begin{array}{l}\text { Hard rock . } \\
\text { Washed land peb- }\end{array}$ & .07 & 38.84 & .96 & 3.07 & .65 & & .49 & 2.96 & 50.08 & 2.46 & & .21 \\
\hline ble. . . & .63 & 34.72 & 1.35 & 2.53 & 2.19 & & 4.34 & 2.72 & 47.95 & 3.15 & & .44 \\
\hline $\begin{array}{l}\text { River pebble } \\
\text { South Cakouna }\end{array}$ & .56 & 28.33 & 1.05 & 2.01 & 3.99 & & 12.23 & 4.90 & 42.75 & 2.44 & & \\
\hline $\begin{array}{c}\text { Average, S. C. } \\
\text { Analysis . . }\end{array}$ & 3.68 & 25.61 & & & 4.68 & & 11.55 & 4.78 & & & 55.91 & \\
\hline
\end{tabular}

Uses. - Fertilizers are used either in their raw condition or after undergoing proper preparation. Lime carbonate is commonly calcined before being spread on the soil, while gypsum is first pulverized before being sold as land plaster.

Phosphate rock is treated with sulphuric acid to produce superphosphate or acid phosphate, and in this treatment ammoniates, or potash, or both, are sometimes added to the material. Concentrated phosphate is made by treating the phosphate rock with enough sulphuric acid to entirely decompose it, converting all the lime into sulphate, the phosphoric acid solution being drawn off and further treated with additional quantities of high-grade phosphate. Since this form of phosphate therefore requires raw materials of a high grade, and is much more extensively manufactured in Europe than in the United States, most of the high-grade Florida rock is exported. 
Guano. - Under this name are included surface deposits of excrement, chiefly of birds. Penrose (25) recognizes two classes : (1) soluble guano, of recent origin, which still contains most of its soluble ingredients; (2) leached guano, which has lost its soluble constituents by the action of rain or sea water. Most of the soluble guano of commerce was formerly obtained from Peru, where, it is said, the Incas, as well as the early Spaniards, valued it so highly that a death penalty was imposed for killing the birds which produced it. These deposits, from which many thousand tons have been obtained, are now exhausted. No large deposits of bird guano are known in the United States. Leached guanos occur on islands in the southern Pacific and in the West Indies.

Bat guano has been found in the caves of Kentucky, Texas (26), and many other states, but few of the deposits have proved large enough to work, and none are of great extent, although one cave in Texas was known to yield 1000 tons. The following analysis is representative: ammonia, 9.44 per cent; available phosphoric acid, 3.17 per cent; potash, 1.32 per cent.

Greensand. - This term is applied to beds of marine origin, made up in large part of the green sandy grains of glauconite, the hydrated silicate of iron and potash. It also contains small amounts of phosphoric acid. Greensands (23) are found at many localities in the Cretaceous and Tertiary formations of the Atlantic Coastal Plain, but New Jersey (22) and Virginia are the two important producers. The New Jersey greensand is spread on the soil in its raw condition, but that from Virginia is dried and ground for use in commercial fertilizers. 
The following analyses show its variable composition, and the comparatively small amount of $\mathrm{P}_{2} \mathrm{O}_{5}$ and $\mathrm{K}_{2} \mathrm{O}$ necessary to make it of value as a fertilizer.

\section{Analyses of Greensand}

\begin{tabular}{l|l|l|l|l|l|l|l|l|l|l|l|l}
\hline \hline & $\mathrm{P}_{2} \mathrm{O}_{5}$ & $\mathrm{SO}_{3}$ & $\mathrm{SiO}_{2}$ & $\mathrm{CO}_{2}$ & $\mathrm{~K}_{2} \mathrm{O}$ & $\mathrm{Na}_{2} \mathrm{O}$ & $\mathrm{CaO}$ & $\mathrm{MgO}$ & $\mathrm{Al}_{2} \mathrm{O}_{3}$ & $\mathrm{Fe}_{2} \mathrm{O}_{3}$ & $\mathrm{H}_{2} \mathrm{O}$ \\
\hline $\begin{array}{r}\text { Pemberton, } \\
\text { N.J. . . . }\end{array}$ & 1.02 & .27 & 50.23 & - & 6.32 & 1.59 & 1.40 & 3.45 & 7.94 & 20.14 & 9.00 \\
$\begin{array}{r}\text { Aquia Creek, } \\
\text { Va. . . . }\end{array}$ & .09 & - & 21.58 & 29.79 & .37 & .59 & 36.78 & 1.05 & 7.70 & & .76 \\
\hline
\end{tabular}

Production of Fertilizers. - The production of phosphate in the United States for several years was as follows :-

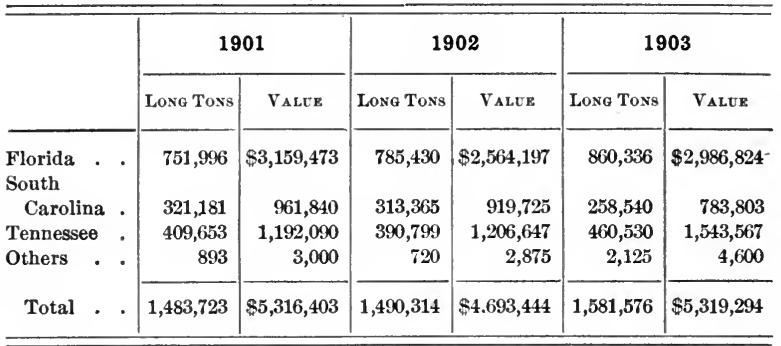

The imports of crude phosphates, guano, and fertilizers in 1903 were valued at $\$ 985,324$. The world's production in 1902, exclusive of Norway and Russia, was 2,766,253 metric tons, valued at $\$ 9,778,950$. The production of gypsum is given under that head. Greensand statistics are not available. 


\section{REFERENCES ON FERTILIZERS}

General. 1. Adams, Amer. Inst. Min. Engrs., Trans. XVIII : 649, 1890. (List of Commercial Phosphates.) 2. Davidson, Eng. and Min. Jour., LIII : 499, 1892. (Deep Sea Formations.) 3. Davidson, Amer. Inst. Min. Engrs., Trans. XXI : 139, 1893. (United States and Canada.) 4. Matthew, N. Y. Acad. Sci., Trans. XII : 108, 1893. (Nodules of Cambrian.)-Apatite: 5. Ells, Can. Rec. Sci., VI : 213, 1895. (Canada.) 6. Penrose, U.S. Geol. Surv., Bull.46, 1888. (General.)Phosphates : 7. Branner, Amer. Inst. Min. Engrs., Trans. XXVI: 580, 1897. (Arkansas.) 8. Carpenter, N. Ca. Agric. Exper. Station, Bull. 110, 1894. (North Carolina marls and phosphates.) 9. Eckel, U. S. Geol. Surv., Bull. 213: 424, 1903. (Decatur County, Tenn.) 10. Eldridge, Amer. Inst. Min. Engrs., Trans. XXI: 196, 1893. (Florida.) 11. Hayes, U. S. Geol. Surv., 21st Ann. Rept., III : 473, 1901. 12. Also 17th Ann. Rept., II: 513, 1896. 13. Hayes, 16 th Ann. Rept., IV : 610, 1895. (Tennessee white phosphates.) 14. Ihlseng, U. S. Geol. Surv., 17th Ann. Rept., III. (ctd.): 955, 1896. (Pennsylvania.) 15. McCallie, Ga. Geol. Surv., Bull. 5-A, 1896. (Georgia.) 16. Memminger, U. S. Geol. Surv., Min. Res., 1893: 709, 1894. (Tennessee.) 17. Penrose, U. S. Geol. Surv., Bull. 46, 1888. 18. Reese, Amer. Jour. Sci. iii, XLIII : 402, 1892. (South Carolina.) 19. Phillips, Eng. and Min. Jour., LVII : 417, 1894. (Hickman County, Tennessee.) 20. Smith, Ala. Geol. Sur., Bull. 2: 9, 1892. (Alabama.) - Greensand : 21. Clark and Martin, Md. Geol. Surv., Rept. on Eocene, 1901. (Maryland.) 22. Cook, Geol. of N. J., 1868: 261, 1868. 23. Parsons, U. S. Geol. Surv., Min. Res., 1901: 823, 1902. (General.) 24. Wilber, U. S. Geol. Surv., Min. Res., 1882 : 522, 1883. (United States.) - Guano: 25. Penrose, U. S. Geol. Surv., Bull. 46: 117, 1898. 26. Phillips, Mines and Minerals, XXI : 440, 1901. (Texas Bat Guano.) 


\section{CHAPTER IX}

\section{ABRASIVES}

Introductory. - Under this heading are included natural products employed for abrasive purposes; but brief reference will also be made to some artificial compounds which come into serious competition with the natural ones.

The natural abrasives may be divided into the three following groups: (1) Those, like grindstones, whetstones, and buhrstones, which occur in the form of massive rock, and which can consequently be cut and manufactured directly into the desired shape; (2) those, like garnet, emery, quartz, and corundum, which occur usually as grains in a rock or vein, and which have to be separated mechanically from the rock; and (3) those, like infusorial earth, quartz sand, and pumice dust, which occur in more or less unconsolidated condition.

While some abrasive substances occur as constituents of veins, the great majority form a part of rocks of either sedimentary, igneous, or metamorphic origin. That they are widely distributed both geologically and geographically is shown in the following description of the individual groups, and the map (Fig. 31):-

Grindstones $(2,3)$. - These are made from sandstones of homogeneous texture and sufficient cementing material to hold the quartz grains together, but not enough to so fill 

Plate XIII

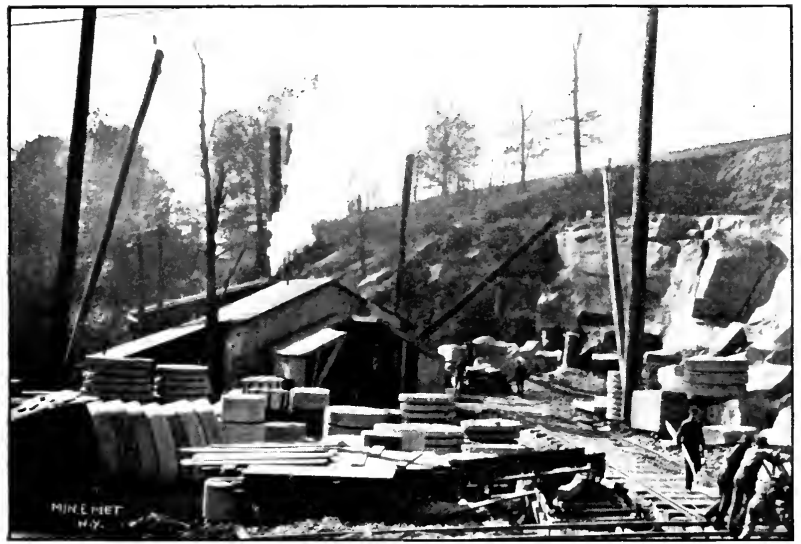

Fig. 1. - Grindstone quarry, Tippecanoe, Ohio. J. H. Pratt, photo.

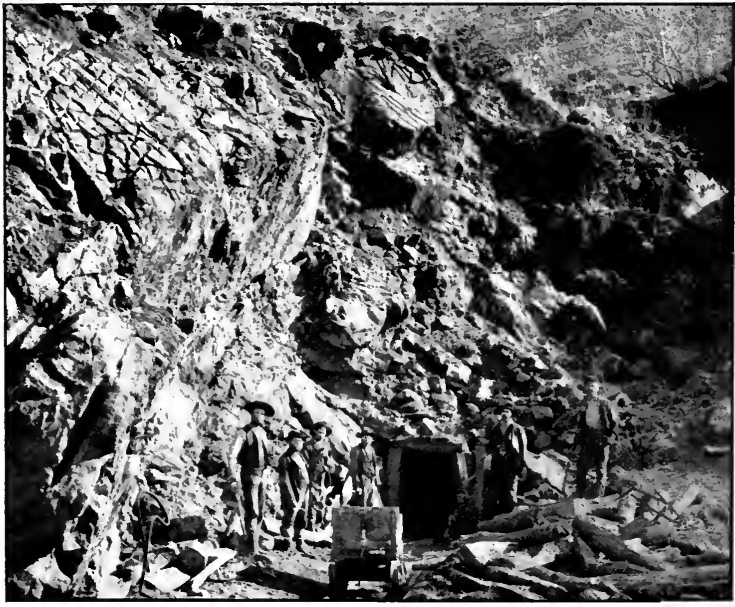

Fig. 2. - Corundum vein between peridotite and gneiss, Corundum Hill, Ga. After Pratt, U. S. Geol. Surv., Bull. 180. 
the pores as to make the rock wear smooth under use. Most of the grindstones produced in the United States are obtained from the Berea grit of Ohio (Pl. XIII, Fig. 1) and Michigan, certain layers of which are highly prized for this purpose.

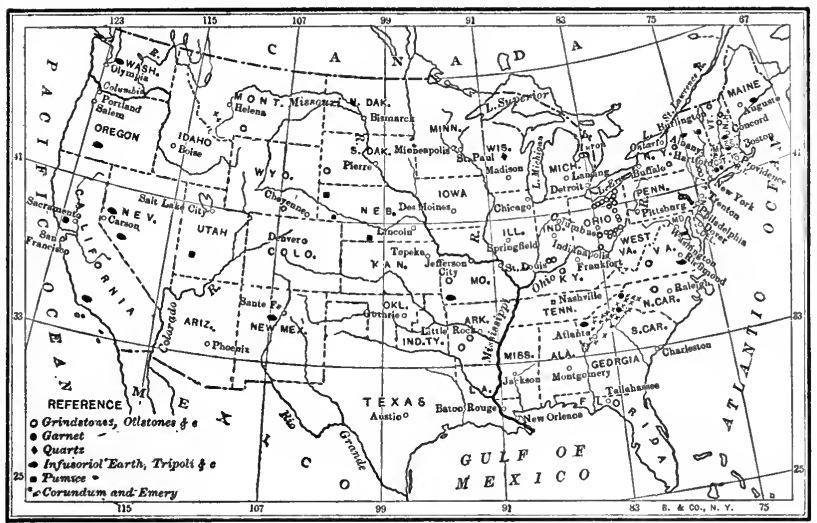

Fig. 31. - Map showing distribution of abrasives in United States.

Pulpstones, which have a diameter of 48 to 56 inches, a thickness of 16 to 26 inches, and a weight of 2300 to 4800 pounds, are a thicker variety of grindstone. They are used for grinding wood pulp in paper manufacture, and hence have to withstand continual exposure to hot water. On account of their superior quality, pulpstones from Newcastle-upon-Tyne, England, supply most of the American demand; but it is probable that certain beds of the Ohio sandstones will be found suited for this purpose (3).

Whetstones, Oilstones $(2,3,10,11)$, etc. - The term "whetstone" includes those stones used for sharpening tools, the term "oilstone" being often applied when oil is placed on the stone to prevent heating and clogging of the pores by 
grains of steel. The stones used for making whetstones are either sedimentary or metamorphic in character, and include sandstone, quartzite, mica schist, and novaculite. The stone selected will naturally vary somewhat with the exact use to which it is to be put, but even texture and comparatively fine grain are essentials. A small amount of clayey matter adds to the fineness of grinding, but an excess lowers the abrasive efficiency of the stone. In the schists used, abrasive action is due to the grains of quartz, or sometimes garnet, which are embedded among the finegrained scales of mica.

Rocks suitable for whetstone manufacture are found in many states, especially east of the Mississippi $(2,3)$, but, on account of keen competition and limited demand, only the better grades from the best-located deposits are employed. Most of the supply is therefore obtained from a few states, especially Arkansas, Indiana, Ohio, New York, Vermont, and New Hampshire.

Among the whetstones quarried in the United States, the Hindostan or Orange stone of Indiana and the Deerlick oilstone of Ohio are much used for oilstones. Scythestones are made from schistose rock in Grafton County, New Hampshire, and Orleans County, Vermont.

The novaculite, quarried in Garland and Saline counties, Arkansas (10), represents a unique type, much prized for high-grade oilstones for sharpening small tools, and in demand both at home and abroad. It is an extremely fine grained sandstone made up of finely fragmental quartz grains, visible under the microscope. The rock is chertlike in superficial appearance and has a conchoidal fracture. While the deposits, which are stratified, have a total thickness of over 500 feet, the commercial novaculite is found 
only in thin beds varying from a few inches to 15 feet in thickness. The beds have a steep dip, and are cut by several series of joints, which greatly interfere with the extraction of large blocks, and sometimes even with small ones. There are also structural irregularities and almost invisible flaws, so that much waste is caused in quarrying the rock. The rock has been variously regarded as a metamorphosed chert, a siliceous silt, or a silicified limestone.

Buhrstones and Millstones (2,3) are stones of large diameter used for grinding cereals, paint ores, cement rock, barite, fertilizers, etc. The American stones are either coarse sandstone or quartz conglomerate, and are quarried at several points along the eastern side of the Appalachian Mountains from New York to North Carolina. The most important beds are in the Oneida conglomerate, which is quarried in the Shawangunk Mountains of eastern New York and farther south in Pennsylvania. Some is also quarried in North Carolina.

Many buhrstones are imported from France, Belgium, and Germany. Those from the first two localities are hard, cellular rocks, consisting of a mixture of fine quartz particles and calcareous material; but the German buhrstone is basaltic lava.

Pumice and Volcanic Ash. - The term "pumice," as used in the geological sense, refers to the light spongy pieces of lava, whose peculiar texture is due to the rapid and violent escape of steam from the molten lava. It is put on the market either in lump form, or ground to powder, or in compressed cakes of the ground-up material. In the commercial sense the term "pumice" includes volcanic ash as well as true pumice. 
Most of the pumice used in the United States is obtained from the island of Lipari, north of Sicily. The stone, after being freed from the volcanic ash with which it is mixed, is sorted according to color, weight, and size, before it is shipped to market.

Deposits of volcanic ash are abundant in many western states, for example in Nebraska (12) and Utah (13), but owing to inaccessibility these materials cannot compete with Lipari pumice, which is imported as ballast, and sells in its prepared form for 2 to $2 \frac{1}{2}$ cents per pound.

Infusorial Earth and Tripoli. - These include all porous siliceous earths, composed of organic fragments, such as infusoria or diatom tests, which have accumulated either on the ocean bottom or in ponds. Such deposits are quite common in the coastal plain area of Maryland, Virginia (8), Georgia and Alabama, where they form beds several feet in thickness, generally interstratified with the Tertiary sands and clays. In New England and New York (7) infusorial earth is frequently found in swamps formed by the filling of ponds. A deposit of tripoli worked near Carthage, Missouri (9), differs from those mentioned above in being the residual silica left by the leaching of an impure limestone. It makes an excellent substitute for infusorial earth as an abrasive. Infusorial earth is known in other parts of the country, for example, Nevada and California, but is worked only to a small extent.

The largest and best-known deposits of infusorial earth are in northern Germany, where it is found from 15 to 18 feet below the surface, in a bed varying from 18 to 45 feet in thickness. This is exported to all parts of the world.

Infusorial earth and tripoli are used chiefly for polishing powders and scouring soaps. The porous character of 
infusorial earth also renders it valuable as an absorbent for nitroglycerine. As a nonconductor of heat it is of value for steam boiler packing, for wrapping steam pipes, and for fireproof cement. The tripoli of Missouri is used for water filters.

Crystalline Quartz (3). - Much of the vein quartz quarried in the United States is pulverized and put on the market under the name of tripoli. Considerable quartz sand is used by stone cutters as an abrasive in sawing stone, and a small quantity is employed in making sandpaper.

Garnet (3). - Although this is a common mineral in many metamorphic rocks, and of some value as an abrasive, it is produced at but few localities. Most of the supply comes from North Carolina, but some is obtained in New York, Connecticut, and Tennessee. It is used in the manufacture of garnet paper, and sometimes as a substitute for corundum in the manufacture of emery wheels, for, although softer, it possesses the advantage of having a splintery fracture, which prevents it from wearing smooth. The price varies from $\$ 20$ to $\$ 60$ per ton when cleaned for the market.

\section{Corundum and Emery $(4,5,6)$. - Corundum $\left(\mathrm{Al}_{2} \mathrm{O}_{3}\right)$ is,} next to diamond, the hardest of the natural abrasives known, having a hardness of 9 . It varies slightly in hardness, and also in chemical composition, being rarely pure alumina; it also shows variable behavior when heated, some forms crumbling when exposed to a high temperature. Such kinds are worthless for the manufacture of emery wheels, since it is necessary to fire these in order to fuse the clay cement used in their manufacture. Emery is a mechanical mixture of corundum and magnetite or hematite, and is much more abundant than cornndum. Its efficiency as an 
abrasive depends on the percentage of corundum which it contains.

Most of the commercially valuable deposits of corundum have been found in the eastern United States, in a belt of basic magnesian rocks, extending from Massachusetts to Alabama. These rocks reach their greatest development in North Carolina (Fig. 31) and Georgia, and most of the corundum is found there, in veins on the border of a peridotite mass which has been intruded into the gneiss. It

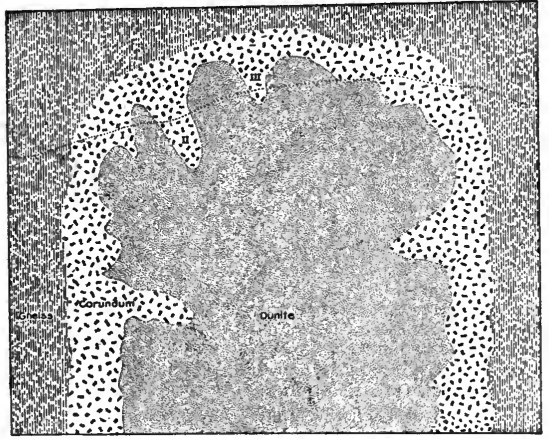

Fia. 32.- Section showing occurrence of corundum around border of dunite mass. After Pratt, $U . S$. Geol. Surv., Bull. 180: 16, 1901. is believed that the corundum, which was one of the earliest minerals to crystallize out from the cooling peridotite, was concentratedaround the borders of the mass by convection currents. This zone of corundum sent off tongues toward the interior of the mass, and now that erosion has removed the main zone of corundum, these tongues remain as apparently separate veins within the peridotite (Fig. 32). The most important emery deposit is that at Chester, Massachusetts; but some is also worked near Peekskill, New York. The emery of Chester occurs in a local widening of a belt of amphibolite schists, and forms a vein traceable for nearly five miles. The emery-bearing vein 
varies in width from a few feet up to 10 or 12 feet, while the emery streak in it averages about 6 feet, it being bordered on both sides by chlorite seams. The emery is in pockets, but these are traceable by a small vein of chlorite. After mining, both corundum and emery need to be cleaned and concentrated by special mechanical processes. The chief use of this material is as an abrasive, and for this purpose it is used in the form of wheels and blocks, emery paper, and powder.

Artificial Abrasives. - Several artificial abrasives are now much manufactured. Prominent among these is Carborundum, which is produced by fusion in the electric furnace of a mixture of silica, coke, and sawdust; the reaction being $\mathrm{SiO}_{2}+3 \mathrm{C}=\mathrm{CSi}+2 \mathrm{CO}$. The sawdust is added to give porosity to the mixture.

Artificial corundum or alundum, whose introduction is of more recent date, is made by fusing bauxite in the electric furnace. It is put on the market in the form of wheels, while carborundum is either made into wheels or sold in powdered form.

Production of Abrasives. - The value of the abrasives produced in the United States during the last three years, together with the imports and artificial abrasives, was as follows:-

\begin{tabular}{|c|c|c|c|c|c|c|c|c|}
\hline \multicolumn{6}{|c|}{ Kind of Abrasives } & 1901 & 1902 & 1903 \\
\hline \multicolumn{4}{|c|}{ Oilstones and scythestones } & & & $\$ 158,300$ & $\$ 221,762$ & $\$ 366,857$ \\
\hline \multicolumn{4}{|c|}{ Grindstones } & & & 580,703 & 667,431 & 721,446 \\
\hline \multicolumn{4}{|c|}{ Buhrstones and millstones } & & & 57,179 & 59,808 & 52,552 \\
\hline \multicolumn{2}{|c|}{ Pumice. . . . . . . } & & & & & & - 2,750 & 2,665 \\
\hline \multicolumn{4}{|c|}{ Infusorial earth and tripoli } & & & 52,950 & 53,224 & 76,273 \\
\hline Crystalline quartz & . & . & & & & 41,500 & 84,335 & 76,908 \\
\hline \multicolumn{4}{|c|}{ Garnet . • . . : } & & & 158,100 & 132,820 & 132,500 \\
\hline \multicolumn{3}{|c|}{ Corundum and emery } & & & & 146,040 & 104,605 & 64,102 \\
\hline \multirow{2}{*}{$\begin{array}{c}\text { Total. } \\
\text { Artificial abrasives }\end{array}$} & & & & & & $\$ 1,194,772$ & $\$ 1,326,755$ & $\$ 1,493,303$ \\
\hline & . & & & & & 383,386 & 390,245 & 493,815 \\
\hline \multirow{2}{*}{$\begin{array}{l}\text { Imports } \cdot \text { Grand total } \\
\text {. }\end{array}$} & & & & & & 490,712 & 426,736 & 621,585 \\
\hline & - & . & . & & & $\$ 2,068,870$ & $\$ 2,143,736$ & $\$ 2,608,603$ \\
\hline
\end{tabular}




\section{REFERENCES ON ABRASIVES}

General. 1. King, Ga. Geol. Surv., Bull. 2:119, 1894. 2. Pratt, U. S. Geol. Surv., Min. Res., 1900: 787, 1901. 3. Pratt, Mineral Census, 1902, Mines and Quarries: 876, 1905. - Corundum AND Emery: 4. Eckel, Mineral Industry, IX:15, 1901. (N. Y. emery.) 5. King, Ga. Geol. Surv., Bull. 2 : 73, 1894. (Georgia corundum.) 6. Pratt, U. S. Geol. Surv., Bull. 180, 1901. (U. S. occurrence, mining and concentration.) - Tripoli and Diatomaceous Earth: 7. Cox, N. Y. Acad. Sci., Trans. XII : 219, 1893, and XIII : 98, 1894. (Diat. earth, N. Y.) 8. Michels, Science, I : 222, 1880. (Va.) 9. Quimby, Mineral Industry, VI: 17, 1898. (Mo.) - Whetstones, Grindstones, and Millstones: 10. Griswold, Ark. Geol. Surv., Ann. Rept. 1890, III, 1892. (Ark. novaculite.) 11. Kindle, Ind. Dept. Geol. and Nat. Res., 20th Ann. Rep.: 329, 1896. (Ind.) - Pumice and Volcanic Asm: 12. Barbour, Neb. Geol. Survey, I: 214, 1903. 13. Merrill, Non-Metallic Minerals : 398, N. Y., 1904. 


\section{CHAPTER $\mathrm{X}$}

\section{MINOR MINERALS - ASBESTOS}

Asbestos Minerals. - Two different minerals are mined and sold under this name, one a variety of amphibole, the other a fibrous variety of serpentine known as chrysotile. The first, which forms pockets or veins in gneissic or schistose rocks, is white, gray, or greenish white in color. Chrysotile usually occurs in seams of varying width in serpentine rocks (Fig. 33), its color being greenish white, green, or yellow, and its luster silky.

In both forms of asbestos the fibers are easily separated, but the amphibole variety often contains gritty impurities which are difficult to remove. The fibers of chrysotile are shorter than those of the amphibole asbestos, rarely exceed. ing $2 \frac{1}{2}$ inches in length, but they have greater strength. Since the amphibole asbestos can be mined more easily, it is cheaper than the chrysotile variety, which, nevertheless, is in greater demand because more constant in character and suited to more uses. The two varieties are equal in value as nonconductors of heat.

Distribution. - Amphibole asbestos is found at a number of localities in the crystalline belt of the Appalachians, but at present Sall Mountain in White County, Georgia, is the only producer, although promising deposits are known in Polk County, North Carolina, and Bedford County, Virginia, and are worked occasionally. 
The limited supply of chrysotile asbestos has naturally stimulated prospecting, and deposits of promise have been found in Vermont (4), Wyoming, California, Montana (8),

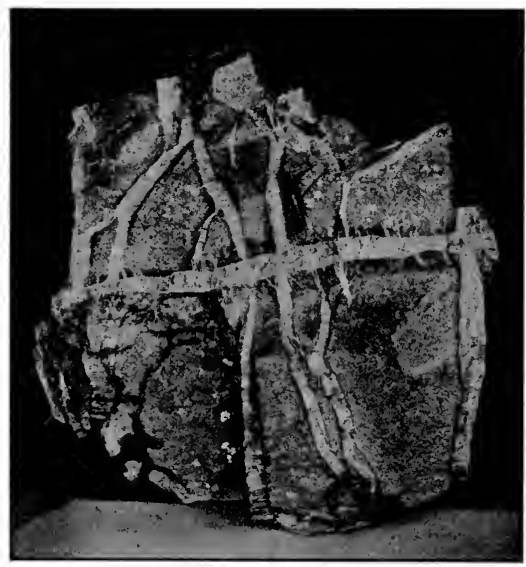

Fig. 33. - Asbestos vein in serpentine. Photo. by G.P. Merrill.

and Arizona (9). The Vermont deposits, discovered in 1900 , occur in Lamoille and Orleans County, occupying a rather limited area in a large serpentine belt (4). Two types of chrysotile are found, one forming branching veins similar in character and quality to the Canadian fiber, the other, of inferior quality, occurring as short fibers on slickensided surfaces.

The main supply of chrysotile used in the United States is obtained from Black Lake and Thetford, Quebec. The serpentine is blasted out and the lumps bearing chrysotile separated from the barren rock by hand picking. These are crushed and screened and the fibres then separated from the rock by air currents. It is stated that 100 tons of rock yields two tons of commercial asbestos $(5,8)$.

There has been some difficulty in explaining satisfactorily the origin of the chrysotile veins in serpentine, for we have 
here two quite different forms of the same mineral. Pratt, in attempting to explain the origin of the vein filling, believes that the fissures represent contraction cracks formed around the edge of the serpentine mass while cooling, and which were then filled by aqueous solutions from which the chrysotile crystallized. Merrill, on the other hand, believes the fissures to have been caused by shrinkage incident to a partial dehydration of the rocks and subsequent filling by crystallization extending from the walls inward (6).

Uses. - Asbestos is used in fireproof paints, boiler covering, for packing in fire safes, and for other purposes where non-conductivity of heat is required. Chrysotile is also used in making fireproof rope, felt, tubes, cloth, boards, blocks, and other objects. Asbestic is a name given to short-fibered chrysotile mixed with serpentine.

Production of Asbestos. - The production of asbestos for the last three years was as follows :-

\begin{tabular}{c|c|c}
\hline YeAR & ShorT ToNs & VALUR \\
\cline { 2 - 3 } 1901 & 747 & $\$ 13,498$ \\
1902 & 1005 & 16,200 \\
1903 & 887 & 16,760 \\
\hline \hline
\end{tabular}

The imports in 1903 were valued at $\$ 689,327$.

\section{REFERENCES ON ASBESTOS}

1. Ells, Amer. Inst. Min. Engrs., XVIII : 320, 1890. (Ontario.) 2. Jones, Asbestos and Asbestic: Their Properties, Occurrence, and Use (London), 1897. 3. Pratt, U. S. Geol. Surv., Min. Res., 1904. 4. Kemp, U. S. Geol. Surv., Min. Res., 1900: 862, 1901. (Vt.) 5. Merrill, National Museum Guide to Study of Non-metallic Minerals, 296: 1901. (General.) 6. Merrill, Geol. Soc. Amer., Bull. XVI, 1905. (Origin.) 7. Pratt, U.S. Geol. Surv., Min. Res.,1901 : 887, 1902. 8. Pratt, Mineral Census, 1902, Report on Mines and Quarries : 973, 1904. 


\section{BARITE}

Barite, the sulphate of barium, is abundant at many localities, and in a few places in sufficient quantity to be of commercial value. Its usual mode of occurrence is as a series of pockets or lenses, which conform to the dip of the inclosing rock, often limestones. Galena is a common associate. Deposits of commercial value are found in Connecticut, North Carolina, Tennessee, Virginia, and Missouri (2). At Evington, Virginia (3), where the mines have been worked since 1874 , the barite forms lenticular pockets in limestone. The barite-bearing stratum has a total length of about 4 miles and a width of 100 to 200 feet or more. The pockets dip from $20^{\circ}$ to $30^{\circ}$ to the east, and are sometimes separate or may be connected by thin stringers of barite. Limestone is associated with the Tennessee and Missouri deposits, but in North Carolina barite lenses 3 to 6 feet thick occur in a decomposed schist.

The following analysis of barite from Fulton County, Pennsylvania, shows the impurities which it may contain: $\mathrm{BaSO}_{4}, 95.22 ; \mathrm{Fe}_{2} \mathrm{O}_{3}, \mathrm{Al}_{2} \mathrm{O}_{3}$, $.38 ; \mathrm{MnO}_{2}, .05 ; \mathrm{CaO}, .59 ; \mathrm{MgO}, .18 ; \mathrm{CO}_{2}, .65 ; \mathrm{H}_{2} \mathrm{O}, .23 ; \mathrm{SiO}_{2}, 2.45$.

Uses. - Barite, which is pulverized, and sometimes purified by washing, is used in the manufacture of paper, rubber, paints, and for coating canvas ham sacks. It is also used in pottery glazes and in the manufacture of barium hydroxide. Its white color and great weight (sp. gr. 4.3) make it of value as an adulterant of white lead. Lithophone paint is a mixture of barium sulphate ( 68 per cent), zinc oxide ( 7.28 per cent), and zinc sulphide ( 24.85 per cent).

Production. - The production of barite for several years has been as follows : - 
Production of Crude Barite in the United States from 1901 то 1903

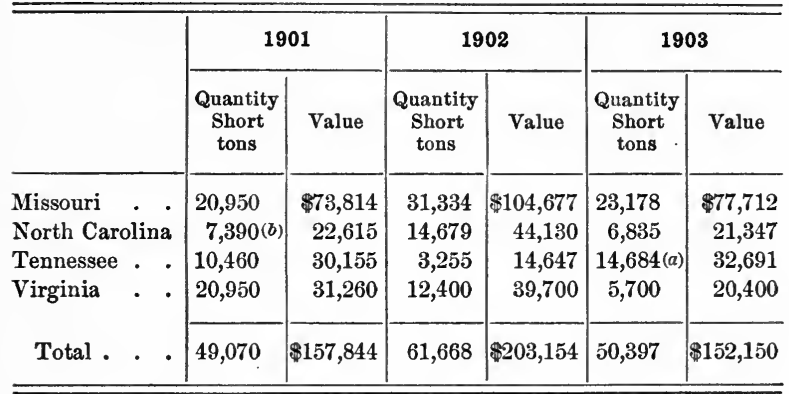

(a) Includes the small production of Kentucky.

(b) Includes the small production of Georgia.

The imports of crude barites in 1903 amounted to 7105 pounds, valued at $\$ 22,777$, while those of manufactured barites were 5716 pounds, valued at $\$ 48,726$.

\section{REFERENCES ON BARITR}

1. McCallie, Ala. Indus. and Sci. Soc., Proc. V : 25, 1895. (Ala.) 2. Eng. and Min. Jour., LXXIII : 762, 1902. (Mo.) 3. Pratt, U. S. Geol. Surv., Min. Res., 1901 : 915, 1902. (General.)

\section{FLUORSPAR}

Fluorspar or fluorite $\left(\mathrm{CaF}_{2}\right)$, a widely distributed mineral of variable colors, including white, green, and purple, is commonly found in veins, including limestones, sandstones, slates, and gneisses, but seems to favor metamorphic rocks. It is not an uncommon constituent of many igneous rocks, and enters into the composition of some minerals, such as apatite, cer- 
tain micas and topaz. Fluorite has also been observed in connection with some volcanic outbursts. (See Cripple Creek, under Gold.) Calcite and galena are sometimes found in the same vein. Fluorite is also noted, though rarely in economic quantities, in the gangue of many metallic minerals, especially lead.

Distribution in United States.-In the United States fluorite is found at a number of points in the Piedmont and Appalachian areas from Maine to Virginia, and is likewise noted in small amounts in many metalliferous veins of the West, but it is rarely found in the Mississippi Valley. In unaltered limestone it is exceedingly rare, and the only commercially important deposits found in this kind of rock are in areas of igneous intrusions.

Until 1898 the mines of Hardin and Pope counties, Illinois, were the only domestic source (1), and this area continues to be the most important producer. There the deposits fill fault fissures in Lower Carboniferous limestone or sandstone. Dikes of mica peridotite and lamprophyre also occur in the district, but not in contact with the veins. These latter in some places attain a width of 45 feet and a proven depth of 200 feet. This great width is due partly to enlargement of the fissure by solution, and partly to a replacement of the limestone walls. In the limestone footwall, the fluorspar sometimes forms a solid mass from 2 to 12 feet thick, but that on the hanging wall is less pure. The vein filling is chiefly fluorite and calcite, while associated with these are smaller amounts of galena, sphalerite, and occasionally pyrite or chalcopyrite. It is significant that the galena is slightly argentiferous. 
The origin of the fluorite is somewhat doubtful, but Bain (1) believes that it has probably been derived from heated waters of either meteoric or magmatic origin which leached the mineral from some large mass of low-lying igneous rocks of which the dikes are offshoots. These heated ascending solutions are thought to have carried fluosilicates of zinc, lead, copper, iron, barium, and calcium. The dissolved compounds were probably broken up by cold descending waters, which possibly also furnished the sulphur to combine with the metals.

Fluorspar deposits are also known in Kentucky (5), Tennessee (6), and Arizona (6), in the latter state occurring as a common gangue mineral of the metalliferous veins in Yuma County.

Uses. - Fluorspar was formerly used chiefly for making hydrofluoric acid, but not more than 5 to 10 per cent of the domestic product is now employed for this purpose, while increasing quantities are sold for the manufacture of opalescent glass. The greatest demand for it, however, is as a flux in iron manufacture, since it saves from 3 to 5 per cent more iron than limestone flux, reduces the sulphur and phosphorus contents, and increases the tensile strength of the metal. On account of its valuable reducing properties, it is also used in making spiegeleisen, in foundry work, and in cupola furnaces. One objection to the more widespread use of fluorspar as a flux has been its high cost as compared with limestone.

Fluorspar is divided into 6 grades for the market, the firstgrade lump bringing $\$ 14.40$ per ton in 1903 .

The production of fluorspar for 1903 was as follows : - 
Production of Fluorspar in United States in 1903

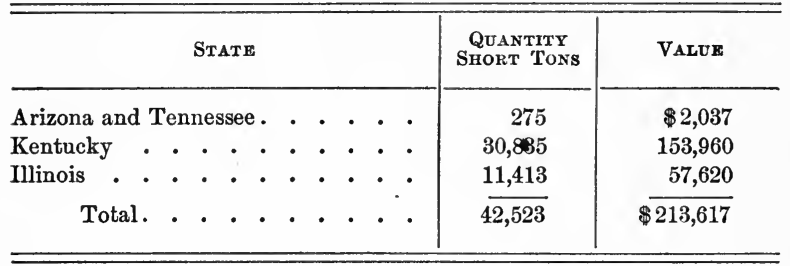

REFERENCES ON FLUORSPAR

1. Bain, U. S. Geol. Surv., Bull. 255, 1905 . (Ill.) 2. Burk, Min. Ind., IX: 293, 1901. (Ky.) 3. Emmons, Amer. Inst. Min. Engrs., Trans. XXI : 51, 1893 . (Ill.) 4. Min. Indus., IX: 203, 1901. 5. Fohs, Min. Ind., XII : 131, 1904. (Ky.-Ill.) 6. Pratt, U. S. Geol. Surv., Min. Res. 1901 : 879, 1902. (Gen.)

\section{FULLER'S EARTH}

Fuller's earth is a term applied to a claylike material which has the property of absorbing greasy substances. It was first used for fulling cloth or fur and hence the name, but in more recent years it has been found of great value for the clarification of mineral and vegetable oils, being used with the former as a substitute for charcoal.

While fuller's earth resembles clay superficially, it usually differs from it in having lower plasticity, and a higher percentage of combined water as compared with the alumina contents. It is often, though not invariably, high in magnesia. In color, fracture, and texture, it varies considerably, and the only satisfactory way of determining its value is by a practical test. 
Fuller's earth is not confined to any particular formation, but the known deposits occur in sedimentary rocks ranging from the beginning of the Mesozoic up to the Pleistocene. In Gadsden County, Florida, and in Decatur County, Georgia $(1,3)$, it is obtained from the Upper Oligocene of the Tertiary, the former locality being the most important in the country. The earth from this region is used for bleaching mineral oils.

Earth of at least fair quality has been found at other localities in the southern coastal plain district. Small quantities of fuller's earth are also produced in Arkansas, eastern Colorado, and central New York (2). The last-mentioned occurrence has been used for cleansing cloth and also in the manufacture of soap. It is known to occur in Nebraska, South Dakota (2), and Alabama.

Before the development of the Florida deposits, in 1893, much fuller's earth was imported from England, and even now a considerable amount is imported for use by the refiners of cotton-seed oil, since it bleaches better than most of the American earth.

The following analyses indicate the composition of American fuller's earth, and to these are added some analyses of the English material, for purposes of comparison, although chemical composition is of little value as a guide to the quality of the material.

\begin{tabular}{l|c|c|c|c|c|c|c|c|c}
\hline \hline & $\mathrm{SiO}_{2}$ & $\mathrm{Al}_{2} \mathrm{O}_{3}$ & $\mathrm{Fe}_{2} \mathrm{O}_{3}$ & $\mathrm{CaO}$ & $\mathrm{MgO}$ & $\mathrm{H}_{2} \mathrm{O}$ & $\mathrm{Na}_{2} \mathrm{O}$ & $\mathrm{K}_{2} \mathrm{O}$ & $\mathrm{Moist.}$ \\
\hline Quincy, Fla. . . . & 62.83 & 10.35 & 2.45 & 2.43 & 3.12 & 7.72 & .20 & .74 & 6.41 \\
Decatur Co., Ga. . & 67.46 & 10.08 & 2.49 & 3.14 & 4.09 & 5.61 & & & 6.41 \\
Fairburn, S. D. . . & 58.72 & 16.90 & 4.00 & 4.06 & 2.56 & 8.10 & 2.11 & 2.20 \\
Sumter, S. C. . . & 74.20 & 10.10 & 1.80 & 1.90 & 2.10 & 5.70 & 1.60 & 2.50 \\
Yellow earth. &. & & & & & & & & \\
Woburn Sands, Eng. & 47.10 & 16.27 & 10.66 & 2.63 & 3.15 & 5.73 & & & 15.12 \\
\hline
\end{tabular}


Production of Fuller's Earth. - The domestic output has never been large, and much is still imported from England.

Production of Fuller's Earth in United States FROM 1901 TO 1903

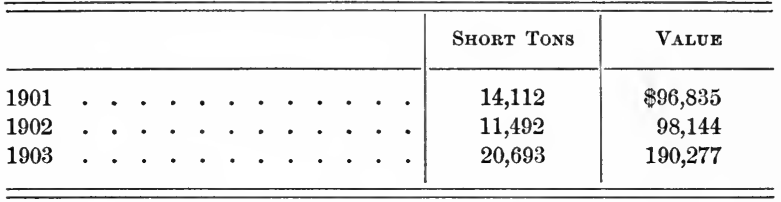

\section{REFERENCES ON FULLER'S EARTH}

1. Ries, U. S. Geol. Surv., 17th Ann. Rept., Pt. III (cont.): 876, 1896. 2. Ries, Amer. Inst. Min. Engrs., Trans. XXVII: 333, 1898. (S. Dak.) 3. Vaughan, U. S. Geol. Surv., Bull. 213 : 392, $1903 . \quad$ (Fla. and Ga.)

\section{GLASS SAND}

Glass sand is obtained from quartzose sands, sandstones, or quartzites, usually having at least 98 per cent of silica and a very low percentage of iron oxide, as seen from the analyses given below. When sand is employed, it is sometimes necessary to put it through a washing process in order to separate the impurities, while in the case of quartzite or sandstone a preliminary crushing and screening are necessary. Clay is undesirable since it tends to cloud the glass, while iron oxide imparts an undesirable color; but this may be counteracted to some extent by the addition of arsenic.

Sands for glass making are sometimes obtained from Pleistocene deposits, but those from the Tertiary and Cretaceous formations are of better quality. Quartz rock (sandstone and quartzite) is found at various localities in the Paleozoic strata. 
Much sand is obtained from Silurian sandstones in La Salle and Randall counties, Illinois (5), for use in the plate glass works at Chicago. In New Jersey there are extensive pits in the Tertiary, around Bridgeton (4), the material being used by the glass works of southern New Jersey and southeastern Pennsylvania. Large pits are also opened in the Raritan formation of the Cretaceous along the Severn River in Maryland (5). Of the quartz rocks, the Cambrian quartzites in Berkshire County, Massachusetts (5), the Oriskany sandstone of West Virginia, and those of Pennsylvania (7) are all of importance. In Iowa the St. Peters sandstone is used (2).

The following analyses taken from several American localities will serve to show the composition of the materials employed : -

\begin{tabular}{|c|c|c|c|c|c|c|c|}
\hline Locality & $\mathrm{SiO}_{2}$ & $\mathrm{Al}_{2} \mathrm{O}_{3}$ & $\mathrm{Fe}_{2} \mathrm{O}_{3}$ & $\mathrm{CaO}$ & $\mathrm{MgO}$ & $\begin{array}{l}\text { Miscel- } \\
\text { LANEOUS }\end{array}$ & $\begin{array}{c}\text { GEOLOGICAL } \\
\text { AGE }\end{array}$ \\
\hline Ottawa, Ill. . & 99.45 & & .30 & .13 & $\operatorname{Tr}$ & & Silurian \\
\hline Hanover, N. J. . & 97.705 & .755 & .150 & .955 & .442 & & Tertiary \\
\hline Berkeley Springs, & & & & & & Moist. & \\
\hline W. Va. • • & 99.37 & .33 & .04 & & & .17 & Oriskany \\
\hline Columbia, Pa. & 99.5044 & .1337 & .2998 & & & $\begin{array}{l}\text { Loss, etc. } \\
.062\end{array}$ & Oriskany \\
\hline Cheshire, Mass. . & 99.46 & .48 & & .06 & & .00 & Cambrian \\
\hline Lewiston, Pa. . & 98.84 & .17 & .34 & $\mathrm{Tr}$ & $\operatorname{Tr}$ & .23 & Oriskany \\
\hline Clayton, Ia. & 98.85 & .46 & .095 & .21 & & $\begin{array}{c}\text { Loss, etc. } \\
.384\end{array}$ & Ordovician \\
\hline
\end{tabular}

The total production of glass sand in 1903 is given by the United States Geological Survey as 823,044 short tons valued at $\$ 855,828$, and came from twelve states. It is doubtful, however, whether all this was used in glass manufacture. Ohio is credited with being the largest producer and Illinois second. 


\section{REFERENCES ON GLASS SAND}

1. Broadhead, Mo. Geol. Surv., 1872: 289, 1873 . (Mo.) 2. Calvin, Ia. Geol. Surv., I : 24, 1893 . (Ia.) 3. Collett, Geol. and Nat. Hist. Surv. of Ind., 12th Ann. Rept. : 22, 1883. (Ind.) 4. Cook, Geology of New Jersey, 1868: 690, 1868. (N.J.) 5. Coons, U. S. Geol. Surv., Min. Res., 1902 : 1007; 1903. (General.) 6. DeGroot, Calif. State Min. Bur., 9th Ann. Rept. : 324, 1890. (Calif.) 7. D'Invilliers, Second Pa. Geol. Surv., F, 1878. (Pa.) 8. Fuller, Stone, XVIII : 1, 1898. (General.)

\section{GRAPHITE}

Graphite, or black lead as it is often termed popularly, is a form of carbon, and occurs in two forms, the crystalline and amorphous. 'The first type is commonly found in granular or foliated masses, while the latter lacks crystalline structure and is often shaly in its character. On this account some carbonaceous schists which resemble the latter in appearance, but contain no graphite whatever, are put on the market under its name. Even the best grades of crystalline graphite are, however, never pure carbon, as the following analysis shows:-

\begin{tabular}{|c|c|c|c|}
\hline & C & AsH & Volatile Matter \\
\hline Ceylon graphite . . . & 98.87 & .28 & .90 \\
\hline
\end{tabular}

Distribution of Graphite in United States. - Crystalline graphite is widely distributed in the United States, occurring in contact zones between igneous and sedimentary rocks, in metamorphosed rocks, etc., but the known deposits of commercial value are few in number. Most of the domestic supply has been obtained from the mines 
near Ticonderoga (3), Essex County, New York, where the mineral occurs in a gray quartzite, which is interbedded with garnetiferous and micaceous gneiss and a quartzite. The rock contains about 10 per cent graphite, but not more than 50 per cent of this is saved in the process of extraction or concentration. Crystalline graphite is also mined in Chester County, Pennsylvania, where it forms two layers from 4 to 6 feet thick in decomposed mica schist $(2,4)$. Deposits are also known in Alabama, Georgia, North Carolina, New Hampshire, and Montana (4), but none of the localities have been important producers. Amorphous graphite occurs in Rhode Island (4) in metamorphosed carboniferous rocks, and the locality has attracted attention for many years, but its production has been very irregular, due partly to the fact that most attempts to utilize it have been unsuccessful. The material is somewhat scaly, but does not as a rule carry more than $55^{\circ}$ per cent carbon, the balance being siliceous impurities. That produced in Michigan (4) and Wisconsin is simply carbonaceous schist, containing no graphite whatever.

Most of the graphite used in the United States is obtained from Ceylon, where it occurs as veins in granulite and associated with feldspar, rutile, pyrite, biotite, and calcite. Weinschenk believes these deposits to have been formed by the decomposition of vapors carrying carbonic oxide and cyanogen compounds. Styria, Bohemia, and Bavaria are also important foreign sources of supply. All of these localities supply the American market, but Ceylon is the most important source by far.

Uses. - On account of its refractoriness and high heat conductivity, graphite is employed in the manufacture of crucibles, for which purpose it is mixed with clay and 
some sand. In addition it is employed for making stove polish, foundry facings, paint, lead pencils, lubricating powder, glazing, electrotyping, steam piping, etc.

Graphite is also made artificially from anthracite coal, but its introduction has not seriously affected the market for the natural product.

Crystalline graphite is put through a concentrating process before shipment to market. This is necessary in order to free it from the associated minerals. Both wet and dry methods of separation are employed, while more recently air separation has been tried with some success.

Production of Graphite. - The domestic production of crystalline graphite does not form more than a small proportion of the entire consumption, and has shown but a slight increase, whereas the output of amorphous graphite has shown great expansion, as can be seen by the figures given below.

Production of Graphite in United States from 1901 to 1903

\begin{tabular}{|c|c|c|c|c|c|c|c|c|}
\hline \multicolumn{3}{|c|}{1901} & \multicolumn{3}{|c|}{1902} & \multicolumn{3}{|c|}{1903} \\
\hline $\begin{array}{l}\text { Amor- } \\
\text { phous }\end{array}$ & Crystalline & $\begin{array}{l}\text { Value of } \\
\text { both }\end{array}$ & $\begin{array}{l}\text { Amor- } \\
\text { phous }\end{array}$ & Crystalline & $\begin{array}{l}\text { Value of } \\
\text { both }\end{array}$ & $\begin{array}{l}\text { Amor- } \\
\text { phous }\end{array}$ & Crystalline & $\begin{array}{l}\text { Value of } \\
\text { both }\end{array}$ \\
\hline $\begin{array}{c}\text { Short } \\
\text { tons }\end{array}$ & Lbs. & & $\begin{array}{l}\text { Short } \\
\text { tons }\end{array}$ & Lbs. & & $\begin{array}{l}\text { Short } \\
\text { tons }\end{array}$ & Lbs. & \\
\hline 809 & $3,967,612$ & $\$ 167,714$ & 4,739 & $3,936,824$ & $\$ 182,108$ & 16,591 & $4,538,155$ & $\$ 225,554$ \\
\hline
\end{tabular}

The exports in 1903 were valued at $\$ 133,651$, while the imports were valued at $\$ 1,207,730$. The total domestic consumption for that year was 37,758 short tons, valued at $\$ 1,598,589$.

The world's production in 1902 is given below :- 
World's Production of Graphite in 1902

\begin{tabular}{|c|c|c|c|c|c|c|c|c|c|c|c|c|c|}
\hline & & & & & & & & & & & & Metric Tons & VALUE \\
\hline \multirow{3}{*}{\multicolumn{2}{|c|}{$\begin{array}{l}\text { Ceylon } \cdot \\
\text { Austria • } \\
\text { United States }\end{array}$}} & . & - & . & . & . & . & - & . & . & . & 25,593 & $\$ 3,505,455$ \\
\hline & & . & . & . & . & . & . & . & . & . & . & 29,527 & 368,186 \\
\hline & & . & . & . & . & . & . & . & . & . & . & 6,085 & 182,108 \\
\hline Germany & . & . & . & . & . & . & . & . & . & . & . & 5,023 & 41,755 \\
\hline Italy . . & . & . & . & . & . & . & . & . & . & . & . & 9,210 & 35,934 \\
\hline Canada. & . & . & . & . & . & . & . & . & . & . & . & 994 & 28,300 \\
\hline Mexico . & . & . & . & . & . & . & . & . & . & . & . & 580 & 3,176 \\
\hline Sweden . & . & . & . & . & . & . & . & . & . & . & . & 63 & 1,900 \\
\hline France . & . & . & . & . & . & . & . & . & . & . & . & 150 & 1,140 \\
\hline India . . & . & . & - & . & . & . & . & . & . & . & . & 4,648 & $(b)$ \\
\hline Total & . & . & . & . & . & . & . & . & . & . & . & 81,873 & $\$ 4,167,954$ \\
\hline
\end{tabular}

(b) Statistics not available.

\section{REFERENCES ON GRAPHITE}

1. Downs, Iron Age, Apr. 19 to June 14, 1900. 2. Frazer, Amer. Inst. Min. Engrs., Trans. IX: 730, 1881. (Pa.) 3. Nason, N. Y. State Museum, Bull. $4: 12,1888$. (N. Y.) 4. See also various volumes of the Mineral Industry, especially XI : 343, 1903, and XII : $183,1904$.

\section{LITHOGRAPHIC STONE}

Lithographic stone $(1,3)$ is a very fine-grained, homogeneous limestone, used for lithographic purposes. It may be either pure lime carbonate or magnesian limestone, but so far as known this difference in composition exerts no important influence on its physical character. The two following analyses will serve to indicate this difference in composition, No. 1 being the standard Bavarian stone and No. 2 the Brandenburg, Kentucky, rock:-

INSOLUBLE IN $\mathrm{HCl}$

$\overbrace{\mathrm{SiO}_{2}(\mathrm{AlFe})_{2} \mathrm{O}_{3} \quad \mathrm{CaO}}$

1. 1.15

2. 3,15

.22 Trace

.45

$\begin{array}{lllll}.09 & .13 & .31 & 6.75 & 44.76\end{array}$

SOLUBLe IN HCl

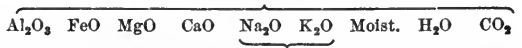

$\begin{array}{llll}.23 & .26 & .56 & 53.80\end{array}$

.07
.13

$\begin{array}{lll}.23 & .69 & 42.69\end{array}$ $.41 \quad .47 \quad 43.06$ 
The physical character of the stone is of prime importance, for in order to yield the best results it should be fine-grained, homogeneous, free from veins or cracks, of just sufficient porosity to absorb the grease holding the ink, and soft enough to permit its being carved with the engraver's tool. Owing to these strict requirements but few localities have produced good stone. Lithographic stone is not confined to any one geologic formation, and deposits have been reported from many states both east and west. Some of these appear to be of inferior quality, while others are too far from railroads. The most promising developed deposit is that found at Brandenburg, Kentucky $(2,6)$, at which locality a bed of blue-gray stone three feet thick is quarried and used by some establishments in the south and southwest. Another bed of good quality has also been described from Iowa (1).

The main source of the world's supply is obtained from the Jurassic limestone of the Solenhofen district in Bavaria (4), in which the quarries have been worked for a number of years, but the supply is said to be becoming unsatisfactory and unreliable. The stones are trimmed at the quarries, and sizes of 22 or 28 by 40 inches are in the greatest demand. From these they range up to sizes 40 by 60 inches. The best quality stones sell for 22 cents per pound.

The domestic demand is not large, and it is probable that one or two well-developed and well-managed native quarries could no doubt satisfy it.

The successful substitution of zinc or aluminum plates for certain classes of lithographic work is said to have had a noticeable influence on the demand for lithographic stone. Onyx has also, in some cases, been found to make a good substitute. 
REFERENCES ON LITHOGRAPHIC STONES

1. Hoen, Ia. Geol. Surv., XIII : 339, 1902. (Ia. also general.) 2. Kübel, Eng. and Min. Jour., LXXII : 668, 1901. (Ky.) 3. Kübel, Min. Resources, U. S. Geol. Surv., 1900: 869, 1901. (Excellent general article.) 4. Merrill, Non-Metallic Minerals : 146, 1904. 5. Mo. Geol. Surv., Bull. 3: 38, 1890. (Mo.) 6. Ulrich, Eng. and Min. Jour., LXXIII : 895, 1902. (Ky.)

\section{LITHIUM}

The two minerals most commonly used as a source of lithium are lepidolite $\left(\mathrm{KLi}\left[\mathrm{Al}\left(\mathrm{OH}_{1} \mathrm{~F}_{2}\right)\right] \mathrm{Al}\left(\mathrm{SiO}_{3}\right)_{3}\right)$ and spodumene $\left(\mathrm{LiO}_{2}, \mathrm{Al}_{2} \mathrm{O}_{3}, 4 \mathrm{SiO}_{2}\right)$. The largest deposits of lepidolite at present known in the United States are found near Pala, California. Spodumene occurs in some quantities in the Black Hills of South Dakota and in Connecticut and Massachusetts, but none of these occurrences have yet been worked to supply lithium.

In the last few years there has been a great demand for lithium minerals for use in the manufacture of lithium carbonate. Since most of this substance now in use is made in Germany, nearly all the American mineral has been shipped to that country. The American supply of carbonate is imported from Germany, selling in New York for $\$ 4.20$ a pound. The chief use of lithium salts is in the preparation of mineral waters.

The production of lithium minerals in the United States in 1903 amounted to 1155 short tons, valued at $\$ 23,425$.

\section{MAGNESITE}

This mineral (1), which is a carbonate of magnesium with 47.6 per cent of magnesia, usually occurs as a decomposition product in the form of irregular veins in serpentine, talcose schists, or other magnesian rocks. Its color is 
white or yellowish, and when massive it resembles unglazed porcelain, but is quite brittle. Most of the magnesite used in the United States is imported from Styria and Greece; but some is obtained in California (3), where a commercially valuable deposit is known.

Magnesite is employed in the preparation of magnesium salts and in the manufacture of paint and of paper. Since it is a nonconductor of heat, it finds extensive use for this purpose; in fact, its most important use is as a refractory lining for open-hearth furnaces and converters in the steel industry, and for the brick lining of rotary Portland cement kilns.

The domestic production is obtained entirely from California, and has been as follows:-

Production of Magnesite in United States from 1901 to 1903

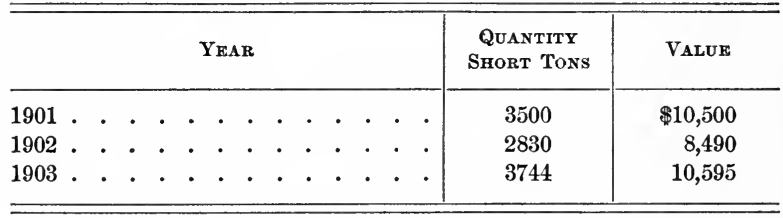

The total value of crude and calcined magnesite imported in 1903 was $\$ 461,398$.

\section{REFERENCES ON MAGNESITE}

1. Struthers, U. S. Geol. Surv., Min. Res., 1902 : 983, 1903. 2. Yale, Eng. and Min. Jour., LXXVIII : 292, 1904. (Calif.) 3. Yale, U.S. Geol. Surv., Min. Res., 1903 : 1131, 1904. (Calif. and general.)

\section{MICA}

There are few minerals more widely distributed in crystalline rocks than mica, and yet deposits of economic value are rare because the mica flakes are either too small, or too 
intimately mixed with other minerals for profitable extraction. Only two of the several known varieties of mica, muscovite $\left(\mathrm{H}_{2} \mathrm{KAl}_{3} \mathrm{Si}_{3} \mathrm{O}_{12}\right)$ and phlogopite $\left(\mathrm{H}_{6} \mathrm{~K}_{6} \mathrm{Mg}_{7} \mathrm{Al}_{2}\left(\mathrm{SiO}_{4}\right)_{7}\right.$, are of economic value, the former being more valuable than the latter. The commercial deposits are usually found in pegmatite veins, cutting granites, gneisses, and schists. In these veins, which are of variable width, the mica is associated with quartz and feldspar, being found in rough crystals, called blocks or books, and which are either distributed evenly through the vein or collected near its sides. The best mica is obtained from the more coarsely crystalline rocks; but the widest veins do not necessarily contain the largest blocks. As a rule the mica does not form more than 10 per cent of the vein, and usually not more than 10 or 15 per cent of that mined can be cut into plates, the rest being classed as scrap mica.

Mica has been mined in a number of states both east and west, and in 1902 seven states were producers, of which North Carolina was the most important.

The use of mica for stove doors and chimneys is decreasing, but there is a growing demand for small sheets which can be stamped out into circular or rectanglar forms and used for insulating purposes in electrical apparatus. Scrap mica, obtained by trimming larger sheets, is ground for use in wall papers, lubricants, boiler coverings, etc. Micanite is sheet mica obtained by cementing small clear pieces of scrap together under pressure. The value of the sheet mica ranges from 2 cents to $\$ 3$ per pound, depending on the size of the sheet. Scrap mica sells for $\$ 8$ to $\$ 10$ per ton, and after grinding for $\$ 40$ to $\$ 60$ per ton.

The production of mica in 1903 amounted to 1968 short 
tons, valued at $\$ 143,128$. Most of the supply is imported from Canada and India, and this in 1903 amounted to 2,251,856 pounds, valued at $\$ 466,332$.

\section{REFERENCES ON MICA}

1. Fuller, Stone, XIX: 530, 1899 . (Occurrences and uses.) 2. Henderson, Eng. and Min. Jour., LV: 4, 1893. (General.) 3. Holmes, U. S. Geol. Surv., 20th Ann. Rept., VI (ctd.): 691, 1899 . (U. S. deposits.) 4. Hoskins, Min. Industry, X: 458, 1902 . (N. H.) 5. Pratt, Mineral Census 1902, Mines and Quarries: 1031, 1904. (General.)

\section{MINERAL PIGMENTS}

Under this head are included a number of mineral substances which are used in the manufacture of paints (5). In most cases they are put through some form of preparation after mining, such as grinding or washing. Roasting is sometimes resorted to for improving the color.

The substances commonly used are iron oxides, barite, gypsum, slate, graphite, asbestos, and soapstone.

Hematite. - Certain kinds of hematite, such as the Clinton ore (see Iron Ores), are ground and sold under the name of metallic paints, and much used for coating wooden surfaces and coloring mortar. The ores are sometimes roasted before grinding to improve their color and durability. Although iron-ore deposits are widespread, and often of large size, the quantity of material suitable for metallic paint is small. The chief supply comes from Pennsylvania, Tennessee, and New York, and smaller amounts from a number of other states.

Ochers $(2,6)$. - This name is applied to powdery limonite deposits or clays, which, in their natural state, contain sufficient ferric oxide or hydroxide to impart a bright red or 
yellowish-red tint to the mass. Ocher may occur as a residual product resulting from the decay of limestone, shale, or other rocks, as a replacement deposit, or as a sedimentary deposit. The last-mentioned form probably contains more clay. Ocher sometimes contains as much as $50-75$ per cent iron oxide (6), and often gritty impurities, which have to be removed by washing. Uniformity of color in the product is necessary.

Ochers are classified according to shade of color, thus: yellow ocher is colored by hydrous iron oxide; red ocher owes its color to ferric oxide, and hence can be produced by roasting yellow ocher; brown ocher or umber is colored by manganese, and sienna is a yellowish-brown variety.

The most extensive series of ocher deposits found in the United States is associated with the Cambro-Silurian strata of the Appalachians from Vermont to Alabama, the chief production coming from Pennsylvania and Georgia. Both umber and sienna are produced in small quantities in Illinois and Pennsylvania, and sienna in addition is obtained from New York.

Few paints are more free from adulteration than ochers, for the reason that any adulterant that could be used is more costly than the ocher itself.

Slate. - The refuse from slate quarries is sometimes ground and sold as a pigment.

Gypsum, ${ }^{1}$ known also as terra alba or mineral white, is used to some extent as a pigment for printing wall paper.

Barite, ${ }^{1}$ or barium sulphate, which is used as an adulterant of white lead, is purified after mining by grinding and washing.

1 For mode of occurrence and distribution see these minerals, pp. 139 and 170. 
Asbestos ${ }^{1}$ is used to some extent in paint manufacture for the so-called non-inflammable or fireproof paints, but the total quantity thus utilized is small.

Graphite, ${ }^{1}$ either natural or artificial, supplies a black pigment of permanent color, which, on account of its resistance to the atmosphere and ordinary chemicals, is of much value for coating oxidizable metals, such as iron and steel.

Calcium carbonate, in the form of chalk, known commercially as whiting or paris white, is used as a pigment to alter the shade of other pigments and as a basis for whitewash.

Other paints. - Paints sometimes classed as mineral paints are made from other crude minerals, as follows: zinc white from zinc ore; white lead, red lead, and orange mineral from lead; venetian red from iron sulphate; vermilion or artificial cinnabar from quicksilver; chrome yellow from chromite; cobalt blue from cobaltite.

\section{Production of Mineral Paints in the United States from} 1901 то 1903

\begin{tabular}{|c|c|c|c|c|c|c|}
\hline & \multicolumn{2}{|c|}{1901} & \multicolumn{2}{|c|}{1902} & \multicolumn{2}{|c|}{1903} \\
\hline & $\begin{array}{l}\text { QUANTITY } \\
\text { SHORT } \\
\text { ToNs }\end{array}$ & VALUE & $\begin{array}{l}\text { QUANTITX } \\
\text { SHORT } \\
\text { ToNB }\end{array}$ & VALUE & $\begin{array}{c}\text { QUANTITY } \\
\text { SHORT } \\
\text { TONS }\end{array}$ & $\nabla_{\triangle L U E}$ \\
\hline Ocher . . & 16,711 & $\$ 177,779$ & 16,565 & $\$ 145,708$ & 12,524 & $\$ 111,625$ \\
\hline Umber . . & 759 & 11,326 & 480 & 11,236 & $\rho \in$ & \\
\hline Sienna . . & - 305 & 9,304 & 189 & $4,316\}$ & 666 & 15,367 \\
\hline Metallic paint & 15,915 & 204,397 & 19,020 & 313,390 & 25,103 & 213,109 \\
\hline Mortar color . & 9,346 & 112,943 & 8,355 & 98,729 & 10,863 & 101,792 \\
\hline Soapstone . . & 50 & 350 & 1,100 & 2,200 & + & - \\
\hline Slate. . . & 4,865 & 41,211 & 4,071 & 39,401 & 7,106 & 59,029 \\
\hline
\end{tabular}

${ }^{1}$ For mode of occurrence and distribution see these minerals, pp. 167 and 178. 
The imports of ochers in 1903 amounted to $9,960,334$ pounds, valued at $\$ 100,447$; of umber, $2,168,570$ pounds, valued at $\$ 18,172$; and of sienna, $1,875,369$ pounds, valued at $\$ 28,570$ : France is the largest producer of ocher.

\section{REFERENCES ON MINERAL PAINTS}

1. Benjamin, U. S. Geol. Surv., Min. Res. 1886: 702, 1887. 2. Hayes and Eckel, U. S. Geol. Surv., Bull. 213 : 427, 1903. (Georgia ocher.) 3. Hill, 2 d Pa. Geol. Surv., Rept. for 1886, IV : 1386, 1887. 4. Mineral Industry, IV : 491, 1896, and VII : 532, 1899 . 5. Struthers, Mineral Census, Rept. on Mines and Quarries, 1902: 955, 1905. (General.) 6. Watson, Amer. Inst. Min. Engrs., Trans. XXXIV : 643, 1904. (Georgia ocher and analyses.)

\section{MOLDING SAND}

Certain fine-grained sands and loams are employed in making molds for castings. Molding sand must be sufficiently fine grained and aluminous to permit molding into the required form; strong enough to hold its shape; resistant to heat; and porous enough to permit the escape of gases, but not to admit the melted metal. An excess of clay is undesirable, as it causes the sand to shrink and bake when the metal is poured in it. Molding sands are obtained from surface deposits at many localities, especially in the states east of the Mississippi River. The analysis of one from Manchester, England, may serve as a type, it containing $\mathrm{SiO}_{2}, 92.913 ; \mathrm{Al}_{2} \mathrm{O}_{3}, 5.85 ; \mathrm{Fe}_{2} \mathrm{O}_{3}, 1.249 ; \mathrm{CaO}$, trace. This high silica percentage accounts for its refractoriness, and its porosity is due to a low clay content. The mechanical composition of molding sands is probably as important, if not more so, as their chemical constitution, but it has been little investigated. Many thousands of tons of molding sand are used annually by foundrymen, but no statistics 
have been collected. The region around Albany, New York, supplies enormous quantities of a fine-grained molding sand. Ohio, Kentucky, and New Jersey are also important producers.

\section{REFERENCES ON MOLDING SAND}

1. Eckel, N.Y. State Geologist, 21st Ann. Rept., 1901. 2. Merrill, U. S. National Museum, Guide to Study of Non-metallic Minerals: 474, 1901. 3. Merrill, Eng. and Min. Jour., LXXVIII : 341, 1904. 4. See also forthcoming reports, Wis. Geol. Surv. and Va. Geol. Surv.

\section{MONAZITE}

This mineral is an anhydrous phosphate of the rare earth metals, cerium, lanthanum, and didymium, but its economic value is due chiefly to the small amount of thoria which it contains. Although grains of it are found scattered through many granites and gneisses, still no occurrences of this type are of any commercial value. The economically valuable deposits are all found in stream gravels, derived from the disintegration of monazite-bearing rocks. Monazite is usually light yellow to honey yellow, red, or brown in color, has a resinous luster, and a specific gravity of 4.64 to 5.3. Its gravity and color aid in its ready determination.

In the United States deposits of monazite sand have been found in the granite and gneiss areas of North Carolina (2) and South Carolina (3), and these, together with deposits found in Brazil (1), supply nearly the entire world's demand. A small quantity is also obtained from southern Norway, as a by-product in feldspar mining. The following analyses indicate the composition of monazite:- 
Analyses of North Carolina Monazite

\begin{tabular}{l|c|c|c|c|c|c}
\hline \hline & $\mathrm{P}_{2} \mathrm{O}_{5}$ & $\mathrm{Ce}_{2} \mathrm{O}_{3}$ & $\mathrm{La}_{2} \mathrm{O}_{3}$ & $\mathrm{ThO}_{2}$ & $\mathrm{SiO}_{2}$ & $\mathrm{H}_{2} \mathrm{O}$ \\
\hline Burke Co., N. C. . . & 29.28 & 31.28 & 30.88 & 6.49 & 1.40 & .20 \\
Alexander Co., N. C. . & 29.32 & 37.26 & 31.60 & 1.48 & .32 & .17 \\
\hline
\end{tabular}

Uses. - Monazite is usually separated from the gravels by a washing process, and in addition magnetic separation has in some cases been employed to separate it from the associated garnet, magnetite, and quartz.

The value of monazite lies in the incandescent properties of the oxides of the rare earths, cerium, lanthanum, didymium, and thorium, which it contains, and which are utilized in the manufacture of mantles for incandescent lights.

Production of Monazite. - The production of monazite for several years was as follows : -

\section{Production of Monazite in the United States from 1901 то 1903}

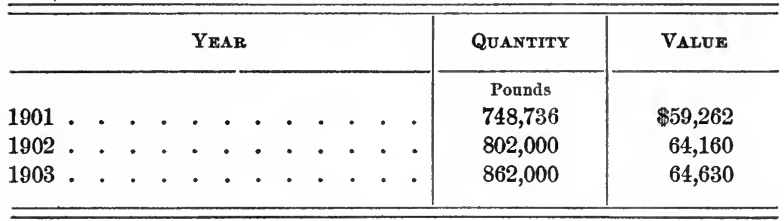

This quantity represents washed sand containing 85 to 99 per cent monazite. The crude sand brings from $2 \frac{1}{2}$ to 6 cents per pound, depending on the percentage of thoria it contains.

\section{REFERENCES ON MONAZITE}

1. Dennis, Min. Indus., VI: 487, 1898 (General). 2. Nitze, N. C. Geol. Surv., Bull. 9, 1895. 3. Pratt, U. S. Geol. Surv., Min. Res., $1902: 1003,1903$; and 1903: 1163, 1904. (N. C. and S. C.) 


\section{PRECIOUS STONES}

The names gems and precious stones $(1,2)$ are applied to certain minerals, which on account of their rarity, as well as hardness, color, and luster are much prized for ornamental use. The hardness is of importance as influencing their durability, while their color, luster, and even transparency affect their beauty. A distinction is sometimes made between the more valuable stones, or gems (such as diamond, ruby, sapphire, and emerald), and the less valuable, or precious, stones (such as amethyst, rock crystal, garnet, topaz, moonstone, opal, etc.).

Most gems are found in unconsolidated surface deposits representing either residual material, or alluvium derived from it, and in the latter their concentration and preservation is due to their weight and hardness. When found in solid rock, the metamorphic and igneous types are more often the source than the sedimentary ones.

Many different minerals are used as gems $(1,2)$, but only a few of the important ones can be mentioned here, and the number of the more valuable kinds found in the United States is very limited $(7,8,9)$.

Diamond. - This mineral, which is the hardest of all known substances, is pure carbon, crystallizes in the isometric system, and has a specific gravity of 3.525. It occurs in many different colors, of which white is the commonest, and is found either in basic igneous rocks, or in alluvial gravels.

The massive forms, known as bort or carbonado, have little or no cleavage, and are of value only as an abrasive.

The greatest number of diamonds come from South Africa, 
but other deposits of commercial value occur in India, Borneo, and Brazil.

In the United States a few scattered diamonds have been found in the southern Alleghanies, California, Wisconsin, and Indiana, but they are all small $(3,4,5,7,8,9)$.

$R u b y$. - A red, transparent variety of corundum $\left(\mathrm{Al}_{2} \mathrm{O}_{3}\right)$, having a hardness of 9 and a specific gravity of 4 . The most valuable color in ruby is a deep, clear, carmine red. Rubies of large size are scarce, so that a three-carat stone of good color and flawless is worth several times as much as a diamond of the same size. The best ones come from Burma. In the United States they have been found in the stream gravels of Macon County, North Carolina. Those found in Arizona and other Western states are not true rubies, but a variety of garnet $(7,8,9)$.

Sapphire is a blue, transparent variety of corundum $\left(\mathrm{Al}_{2} \mathrm{O}_{3}\right)$. It is of slightly greater hardness and specific gravity than the ruby, though of similar composition. Sapphires of good color and size are more common than rubies and cheaper. The best sapphires come from Siam. In the United States they have been found in the gravels of Cowee County, North Carolina, but Yogo Gulch, Montana, where they are found in an igneous dike, is now the main source of domestic supply. They range in weight from under one up to four or five carats $(7,9,10)$.

Emerald. - This gem is a variety of beryl, essentially a glucinum aluminum silicate. Its hardness is 7.5 to 8 , and its specific gravity 2.5 to 2.7. Its brilliant green color is attributed by some to chromium, by others to organic matter. Brazil, Hindostan, Ceylon, and Siberia are all important sources. In the United States a few have been found in 
western North Carolina $(7,9)$. Flawless emeralds are very rare, and equal in value to diamonds.

Aquamarine and oriental cat's-eye are also varieties of beryl. Brazilian emerald is a green variety of tourmaline, and lithia emerald an emerald-green spodumene.

Topaz. - This is a fluosilicate of alumina, crystallizing in the orthorhombic system, with a hardness of 8 , specific gravity of 3.5, vitreous luster, and yellow, green, blue, red, or colorless. It occurs in gneiss or granite, as well as in other metamorphic or igneous rocks, and is associated with beryl, mica, tourmaline, etc. It is also found in alluvial deposits. The best gem stones come from Ceylon, the Urals, and Brazil. In the United States they have been found in small quantities in Maine, Colorado, and California (7).

Turquoise is a massive hydrated aluminum copper phosphate, of waxy luster, blue to green color, and opaque. Its hardness is 6, and specific gravity 2.75. It usually occurs in streaks and patches in volcanic rocks. The best varieties are obtained from Persia, but it is also obtained from Asia Minor, Turkestan, and Siberia. In the United States turquoises are found in the Los Cerrillos Mountains near Santa Fé, New Mexico, and Turquoise Mountain, Arizona.

It is interesting to note that turquoise was hardly known in the United States in 1890, but now the bulk of the world's supply comes from the Southwestern states and territories $(6,7)$.

Garnet. - Of the several varieties of garnet, three are well known as gem stones, viz., the precious garnet or almandite, Bohemian garnet or pyrope, and manganese garnet or spessartite. The first two are of deep crimson, the last of orange-red or light red-brown color. India is the main source of supply. All three varieties mentioned are found 
in the United States, but there is a regular production only of the pyrope from Arizona and New Mexico, and a purplered garnet known as rhodonite from North Carolina $(7,9)$.

Opal, which is hydrous silica chemically, is amorphous, with conchoidal fracture, yellow, red, green, or blue color, and often showing considerable iridescence. The varieties recognized are the precious opal, fire opal, girasol, and common opal. The finest examples of precious opal are obtained from Hungary. Others are also found at Queretaro, Mexico, and in Oregon and Washington. The United States production is small, although it is thought that there are many scattered occurrences in the igneous rocks of Washington, Idaho, Oregon, California, Nevada, and Utah $(7,9)$.

Other Precious Stones. - Among the other precious stones obtained in this country and their sources of supply may be mentioned:-

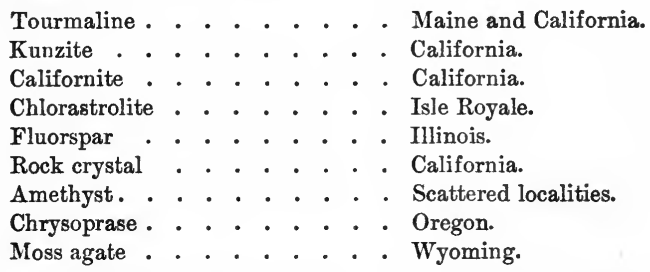

Production of Precious Stones. - The production of gems in the United States is not large, and for the last three years was as follows : -

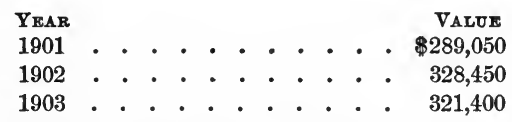

The imports of diamonds and other precious stones in 1903 were valued at $\$ 26,522,523$. 


\section{REFERENCES ON PRECIOUS STONES}

1. Bauer, Edelsteinkunde. (Leipzig, 1896.) 2. Farrington, Gems and Gem Minerals. (Chicago, 1903.) 3. Hobbs, Amer. Geol., XIV : 31, 1894. (Wis. diamonds.) 4. Hobbs, Min. Indus., IX : 301, 1901. 5. Hobbs, Jour. Geol., VII : 375, 1899. (Wis.) 6. Johnson, Sch. of Mines Quart., XXIV: 493, 1903. (N. Mex. Turquoise.) 7. Kunz, Mineral Census, 1902, Mines and Quarries. (General on United States Gems.) 8. Kunz. See Chapters on Precious Stones in Mineral Resources, issued annually by U. S. Geol. Surv. 9. Kunz, Gems and Precious Stones of N. Amer. (New York, 1892.) 10. Pratt, U. S. Geol. Surv., Bull. 180, 1901. (Sapphire.) 11. Reid, Eng. and Min. Jour., LXXV: 786, 1903. (Burro Mtn. Turquoise dist.) 12. Streeter, Precious Stones and Gems (London), 1892.

\section{SULPHUR AND PYRITE}

These two minerals are discussed in the same chapter because they both serve as sources of sulphur.

Sulphur. - The occurrences of native sulphur are of two types (4): (1) the Solfataric type and (2) the Gypsum type.

Solfataric Type. - Sulphur is often found in fissures of lava and tuff around many active and also extinct volcanic vents, being deposited by the oxidation of hydrogen sulphide, or by the sulphuretted hydrogen and sulphur dioxide, in the presence of moisture, yielding water and sulphur. Ferric chloride is sometimes deposited under the same conditions, and might, owing to its similar color, be at first mistaken for sulphur.

Deposits of the solfataric type are rarely of commercial importance, but in foreign countries they are worked in Japan, and also in the crater of Popocatepetl, in Mexico.

In the United States a deposit is known to exist in Beaver County, southwestern Utah $(4,5)$. The sulphur is found impregnating volcanic tuffs, sand (the product of decom- 
position), or in the fissures in trachyte and carboniferous limestone. The deposit is said to be 30 feet thick and the deposition still continues. Small amounts are mined in Oregon and Nevada (1), but the output is irregular.

Gypsum Type. - This is formed by the action of bituminous matter on gypsum, the former having a reducing effect. It is, therefore, always found in sedimentary rocks, in which marls, limestones, and shales are prominent.

The change involved is a reduction of the calcium sulphate of the gypsum, to calcium sulphide, with the production also of carbon dioxide and water. The sulphide then, by reaction with the carbon dioxide of the air, and water, yields calcium carbonate, native sulphur, and hydrogen sulphide.

This type of sulphur is often of great economic value, and deposits are found in a number of countries. The beds are mostly of Tertiary age, but Jurassic ones are also known.

In the United States the richest and best known is found in southwestern Louisiana $(6,8)$. Here a bed of sulphur over 100 feet thick was discovered in boring for oil. It is underlain by gypsum and salt, and covered by 300 to 400 feet of wet clay, quicksand, and gravel, which has presented great difficulties in all attempts to mine the material. Its extraction is now accomplished by means of superheated steam.

Sicily is the most important source of supply for the United States. There the sulphur is found in veinlets and cavities in a cellular Miocene limestone, which underlies and overlies gypsum. The sulphur-bearing beds are generally from 3 to 10 feet thick, and vary in their thickness as well as dip, the latter being from $25^{\circ}$ up to $70^{\circ}$. The percentage of sulphur varies from 8 to 25 per cent, the first figure representing the 
lowest economic limit. The mines contain more or less petroleum and bitumen, and sometimes even explosive gases, while barite and celestite are associated minerals. Owing to improper methods of mining there is much waste.

Uses. - The most important use of sulphur is for the manufacture of sulphuric acid, and in paper manufacture. Some is also used in making matches, for medicinal purposes, and in making gunpowder, fireworks, insecticides, for vulcanizing india rubber, etc.

In recent years pyrite has largely replaced sulphur for the manufacture of sulphuric acid, and the increase in price of Sicilian sulphur has helped this.

The greater portion of the world's supply of sulphur is obtained from Sicily, the United States consuming the largest amount.

Production of Sulphur. - The value of the domestic production and imports of sulphur for several years, as well as total domestic consumption, which includes sulphur obtained from pyrite, are given in the following table :-

Imports and Production of Sulphur in the United States

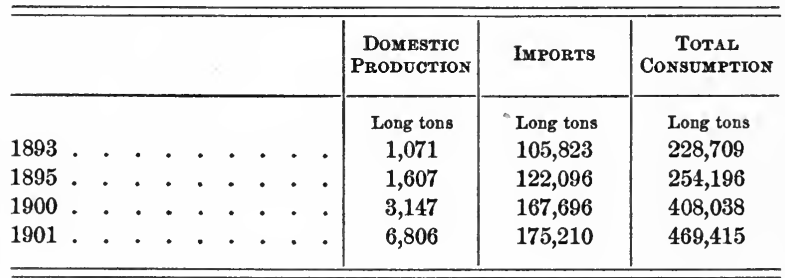

The sulphur imported into the United States comes chiefly from Sicily and Japan, with very small quantities from Mexico and Chile. 


\section{REFERENCES ON SULPHUR}

1. Adams, U. S. Geol. Surv., Bull. 225 : 497, 1904. (Nevada.) 2. Eng. and Min. Jour., XLVI: 174, 1888. (Sicily.) 3. Eng. and Min. Jour., LXXVII : 523, 1904. (Sicily.) 4. Kemp, Min. Indus., II : 585, 1894. (General.) 5. Russell, Trans., N. Y. Acad. Sci., I : 168, 1882. (Uttah and Nevada.) 6. Preussner, Zeitschr. d. d. Geol. Gesell., XL: 194, 1888. (La.) 7. Richardson, U. S. Geol. Surv., Bull. 260 : 589, 1905. (El Paso Co., Tex.) 8. Anon., Eng. and Min. Jour., LXXVIII : 592, 1904. (La.)

Pyrite. - Pyrite, the sulphide of iron, is widely distributed in nature, being found in many kinds of rocks and in all formations. It occurs in a variety of forms, such as disseminations, contact deposits, concretionary masses, fissure veins, and lenticular deposits, the last form being characteristic of most of those occurrences which are of commercial value. As mined, pyrite usually contains small quantities of other metallic minerals as well as silica and alumina; but if its sulphur content falls below 50 per cent, it is not salable. The following analysis of pyrite from Louisa County, Virginia, will serve as illustration. It is: $\mathrm{S}, 47.76 ; \mathrm{Fe}, 43.99 ; \mathrm{Cu}, 3.69 ; \mathrm{Zn}, .24 ; \mathrm{SiO}_{2}, 1.99 ; \mathrm{As}$, $.63 ; \mathrm{Pb}, .10$. If chalcopyrite is present and exceeds 3 or 4 per cent, the rock may be used as copper ore. Pyrrhotite is abundant in some of the Virginia deposits.

Distribution. - The most important domestic occurrences are found in a belt of metamorphic rock extending from New Hampshire to Alabama (4), in which the pyrite is found forming lenses in metamorphic rocks. Massachusetts and Virginia are the most important producers. New York also contributes. In Louisa County, Virginia (2), the pyrite lenses occur in Cambro-Silurian slates and schists. The 
deposits are known to be over 2 miles in length, and have been exploited to a depth of 600 feet, while their average thickness is 18 feet. Their origin is somewhat obscure and depends on the character of the original rock.

Some pyrite is obtained from Indiana and Ohio, from "coal brasses" obtained as a by-product in coal mining (3).

Uses. - Pyrite is used chiefly and in increasing quantities for the manufacture of sulphuric acid and sulphate of iron, while small amounts are consumed in the manufacture of mineral paint. It is not used as an ore of iron. Recent experiments have demonstrated the possibility of saving the sulphuric acid gas from the roasting of zinc ores, and the utilization of pyrrhotite for making sulphur and sulphuric acid.

REFERENCES ON PYRITE

1. Adams, Trans. Amer. Inst. Min. Engrs., XII: 527, 1883. (Va.) 2. Nason, Eng. and Min. Jour., LVII : 414, 1894. (Va.) 3. Struthers, Min. Indus., XI : 577, 1903. 4. Wendt, S. of M. Quart., VII : 218, 1885. (Alleghanies.)

\section{STRONTIUM}

The two minerals serving as sources of strontium salts are celestite $\left(\mathrm{SrSO}_{4}\right)$ and strontianite $\left(\mathrm{SrCO}_{3}\right)$. Of these two the former is the more important, but the latter is the more valuable, as the strontium salts can be more easily extracted from it.

Both celestite and strontianite have been found at a number of localities in the United States, but seldom in large quantities. One important deposit of celestite has been found in limestone caves near Put in Bay, Strontian Island, 
in Lake Erie, and in opening up the cave 150 tons of the mineral were taken out. Similar occurrences have been found in limestones in other states, but none of them have any commercial value.

Nearly all the strontium salts now used in the United States are imported from Germany, the crude material being obtained in part from Westphalia, Germany, and also from Thuringia, Germany, and Sicily.

Uses. - Strontium salts are used in sugar refining, in fireworks manufacture, and to a small extent in medicine.

REFERENCES ON STRONTIUM

1. Pratt, U. S. Geol. Surv., Min. Res., 1901 : 955, 1902.

\section{TALC AND SOAPSTONE}

Talc, a silicate of magnesia, is a widely distributed mineral, but rarely occurs in large quantities. It commonly represents the alteration product of other magnesian minerals, such as tremolite, actinolite, pyroxene, or enstatite, and is therefore often associated with talcose or chlorite schists, serpentine, and such basic igneous rocks as peridotite. It is also found associated with dolomite. In the southern Appalachians the alteration of enstatite rocks into talcose rocks has given rise to extensive soapstone deposits, soapstone being an impure massive form of talc.

Large deposits of pure talc, usually massive, though in places with a fibrous structure, are found in North Carolina (1). These beds, which are associated with marble and quartzite, have apparently been formed by the alteration of bands of tremolite bedded with the other rocks. Those portions discolored by iron oxide, or containing tremolite 
crystals, are of no value. A fibrous talc formed by the alteration of tremolite or enstatite occurs in St. Lawrence County, New York (3), where it is bedded with limestone and tremolite or enstatite schist. From these two regions most of the talc of the country is derived; but soapstone is obtained from a number of states, of which Virginia is the most important producer.

The following analyses from several localities show the kind and quantity of impurities which good talc may contain :-

Analyses of Commercial Talc

\begin{tabular}{c|r|r|r|r|r|r|r|r}
\hline \hline LocaLitr & $\mathrm{SiO}_{2}$ & $\mathrm{Al}_{2} \mathrm{O}_{3}$ & $\mathrm{FeO}$ & $\mathrm{CaO}$ & $\mathrm{MgO}$ & $\mathrm{Na}_{2} \mathrm{O}$ & $\mathrm{K}_{2} \mathrm{O}$ & $\begin{array}{c}\mathrm{H}_{2} \mathrm{O} \\
\text { Loss on } \\
\text { Igni- } \\
\text { tion }\end{array}$ \\
\hline $\begin{array}{c}\text { Kinsey Mine, } \\
\text { N. C. . . }\end{array}$ & 63.07 & 1.56 & .67 & .30 & 28.76 & .78 & $\mathrm{Tr}$ & 4.36 \\
$\begin{array}{c}\text { St. Lawrence } \\
\text { Co., N.Y.. }\end{array}$ & 62.10 & & 1.30 & & 32.40 & & $\begin{array}{c}\mathrm{MnO} \\
2.15\end{array}$ & 2.05 \\
\hline \hline
\end{tabular}

Uses. - Talc is marketed as rough talc, sawed slabs, or ground talc. Its peculiar physical character, extreme fineness, softness, and freedom from grit, adapt it to a number of uses, of which the following are most important: fireproof paints, electric insulators, foundry facings, boiler and steampipe coverings, soap adulterants, toilet powders, dynamite, in wall plasters, for dressing skins and leather, as a base for zubricants, and as a filling for paper. Most of the New York fibrous talc is used for the last purpose, being better suited for it than the North Carolina product. The compact varieties of pure talc are employed for pencils, and for coal- and acetylene-gas tips. 
Pyrophyllite differs from talc chemically, being a hydrous aluminum silicate, instead of a magnesium silicate, but when sufficiently free from grit it is put to the same use as talc. It is sometimes incorrectly called agalmatolite, because of its resemblance to the true mineral of that name. Deposits, more extensive than those of talc, are found near Glendon, North Carolina (1). It varies from green and yellowish white to white, but in all cases becomes nearly white when dried.

Production of Talc and Soapstone. - The production for the last three years has been as follows:-

Production of Talc and Soapstone from 1901 to 1903

\begin{tabular}{|c|c|c|c|c|c|c|}
\hline & \multicolumn{2}{|c|}{1901} & \multicolumn{2}{|c|}{1902} & \multicolumn{2}{|c|}{1903} \\
\hline & $\begin{array}{l}\text { Short } \\
\text { tons }\end{array}$ & Value & $\begin{array}{c}\text { Short } \\
\text { tons }\end{array}$ & Valne & $\begin{array}{c}\text { Short } \\
\text { tons }\end{array}$ & Value \\
\hline New York (b) & 69,200 & $\$ 483,600$ & 71,100 & $\$ 615,350$ & 60,230 & $\$ 421,600$ \\
\hline Georgia.. & 693 & 4,717 & (c) & (c) & 1,012 & 9,042 \\
\hline North Carolina . & 5,819 & 77,824 & 5,239 & 88,962 & 5,330 & 76,984 \\
\hline N. Jersey and Pa. & $2,552(a)$ & $19,132(a)$ & 7,082 & 52,812 & 5,412 & 44,058 \\
\hline Indiana and Virginia & 12,511 & 232,900 & 13,221 & 372,163 & 13,118 & 243,552 \\
\hline Other states $(d)$ & 7,068 & 90,315 & 1,312 & 11,220 & 1,799 & 44,824 \\
\hline
\end{tabular}

(a) Pennsylvania alone. (b) Fibrous talc. (c) California, Maryland, Massachusetts, New Hampshire, New Jersey, and Vermont in 1901 ; California, Massachusetts, and Georgia in 1902 ; California, Massachusetts, and Vermont in 1903.

The imports in 1903 amounted to 1791 short tons, valued at $\$ 19,677$.

\section{REFERENCES ON TALC AND SANDSTONE}

1. Pratt, N. C. Geol. Surv., Econ. Papers, No. 3, 1900. (N. Ca.) 2. Rand, Philadelphia Acad. Nat. Sci., Proc. 1894: 455. 3. Smyth, School of Mines Quart., XVII : 333, 1896. (N. Y. and bibliography.) 4. Waldo, Mineral Industry, II : 603, 1894. 


\section{CHAPTER XI}

\section{MINERAL WATERS}

ThIs term is commonly applied to those spring waters containing a variable amount of dissolved solid matter of such character as to make them of medicinal value. Their origin, although often regarded as curious, is simple, the dissolved substances having been derived from the rocks through which the spring waters have circulated. Many mineral waters contain carbonic and even other acids, and alkalies, which further increase their powers of solution. There is apparently some connection between hot mineral springs and geological structure, as they are more abundant in regions of faulting or recent volcanic activity. Mineral waters derived from sedimentary rocks usually show a greater quantity of dissolved material than those occurring in igneous rocks.

Springs whose temperature is above $70^{\circ} \mathrm{F}$. are termed thermal, those between $70^{\circ} \mathrm{F}$. and $98^{\circ} \mathrm{F}$. being classed as tepid, and those hotter than this as hot springs. The following will serve as examples to show the temperature of different thermal springs: Sweet Springs, West Virginia, $74^{\circ} \mathrm{F}$.; Warm Springs, French Broad River, Tennessee, $95^{\circ}$; Washita, Arkansas, $140^{\circ}$ to $156^{\circ}$; San Bernardino Hot Springs, California, $108^{\circ}$ to $172^{\circ}$; Las Vegas, New Mexico, $110^{\circ}$ to $140^{\circ}$.

The volume of discharge shown by mineral springs is 
quite variable. The famous Orange Spring of Florida discharges 5,055,000 gallons per hour, while others are as follows: Champion Springs, Saratoga, New York, 2500 gallons; Roanoke Red Sulphur Springs, Virginia, 1278 gallons; Warm Sulphur Springs, Bath, Virginia, 360,000 gallons; Glen Springs, Waukesha, Wisconsin, 45,000 gallons.

While a classification of mineral waters may be geographic, geologic, therapeutic, or chemical, that prepared by A. C. Peale is perhaps as satisfactory as any. He subdivides mineral waters into the following classes :-

Alkaline

Alkaline-saline $\left\{\begin{array}{l}\text { Sulphated } \\ \text { Muriated }\end{array}\right.$

Saline $\cdot \cdot \cdot\left\{\begin{array}{l}\text { Sulphated } \\ \text { Muriated }\end{array}\right.$

Acid $\cdot \cdot\left\{\begin{array}{l}\text { Sulphated } \\ \text { Muriated } \\ \text { Siliceous }\end{array}\left\{\begin{array}{l}\text { Sulphated } \\ \text { Muriated }\end{array}\right.\right.$

The springs falling in the above groups may be either thermal or non-thermal, and may be either free from gas or contain $\mathrm{CO}_{2}, \mathrm{H}_{2} \mathrm{~S}, \mathrm{~N}$, or $\mathrm{CH}_{4}$.

Distribution of Mineral Waters in the United States. There are, according to Peale, between eight and ten thousand mineral springs in the United States, and of this number 725 were producing in 1903 . The majority of the commercially valuable mineral springs are located in the eastern United States and Mississippi Valley. West of the 101st meridian they are confined chiefly to the Pacific coast. No thermal springs are known in the New England 
states. Among the American springs, those at Saratoga, New York, have an international reputation, and compare well with many of the foreign ones. Others of importance are the Hot Springs of Virginia and the Hot Springs of Arkansas.

The following table contains the analyses of several types of mineral waters from the United States:-

Analyses of American Mineral Waters

\begin{tabular}{|c|c|c|c|c|c|c|c|c|c|c|}
\hline \multicolumn{4}{|c|}{ Chemioal Conbtituents } & 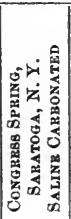 & 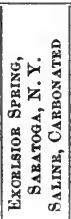 & 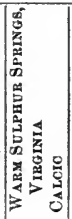 & 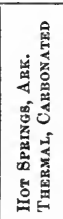 & 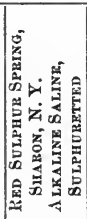 & 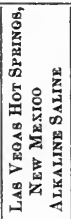 & 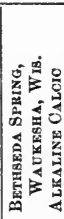 \\
\hline & & & & $\begin{array}{l}\text { gr. per } \\
\text { gal. }\end{array}$ & $\begin{array}{l}\text { gr. per } \\
\text { gal. }\end{array}$ & $\begin{array}{l}\text { gr. per } \\
\text { gal. }\end{array}$ & $\begin{array}{l}\text { gr. per } \\
\text { gal. }\end{array}$ & $\begin{array}{l}\text { gr. per } \\
\text { gal. }\end{array}$ & $\begin{array}{l}\text { gr. per } \\
\text { gal. }\end{array}$ & $\begin{array}{l}\text { gr. per } \\
\text { gal. }\end{array}$ \\
\hline Sodium carbonate & - & - & . & - & - & - & - & - & 5.00 & - \\
\hline Sodium bicarbonate & . & . & . & 10.77 & 8.75 & - & - & .49 & - & 1.26 \\
\hline Sodium sulphate & - & . & . & - & - & - & - & - & 16.27 & .54 \\
\hline Calcium carbonate. & $\cdot$ & - & - & - & - & 5.22 & & & & - \\
\hline Magnesium carbonat & & . & . & - & - & - & 3.17 & - & 11.41 & - \\
\hline Calcium bicarbonate & . & . & . & 143.40 & 41.32 & - & 12.66 & 12.93 & - & 17.02 \\
\hline Magnesium bicarbona & ate & & . & 121.76 & 29.34 & - & - & .69 & - & 12.39 \\
\hline Lithium bicarbonate & . & . & . & 4.76 & - & - & - & - & Trace & - \\
\hline Iron bicarbonate. & . & . & . & .34 & 3.00 & - & 2.17 & - & - & .04 \\
\hline Magnesium sulphate & . & . & . & - & 2.15 & - & - & 18.96 & - & - \\
\hline Potassium sulphate & . & . & . & .89 & - & 1.38 & - & - & - & - \\
\hline Sodium chloride & 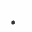 & . & . & 400.44 & 166.81 & - & - & .33 & 27.34 & .46 \\
\hline Potassium chloride & . & . & . & 8.05 & - & - & - & - & - & 1.16 \\
\hline Potassium bromide & . & . & . & - & 1.57 & - & - & - & - & - \\
\hline Sodium bromide . & . & . & . & 8.56 & - & - & - & - & - & - \\
\hline Sodium iodide . . & - & . & . & .14 & 4.67 & - & - . & - & - & - \\
\hline Silica . . . & - & . & . & .84 & .53 & 1.72 & .38 & .45 & 2.51 & .74 \\
\hline Calcium sulphate. & . & . & . & - & - & 14.53 & 2.54 & 96.64 & - & - \\
\hline
\end{tabular}

Production of Mineral Waters. - The production of mineral waters in the United States for the last three years was as follows :- 
Production of Mineral Waters in United States from 1901 то 1903

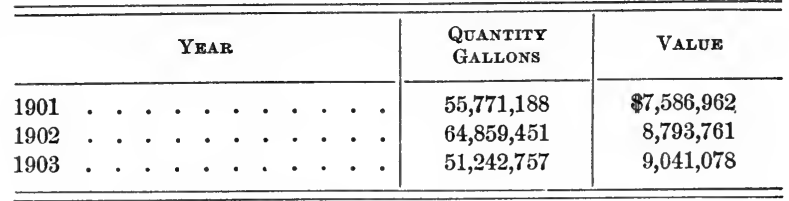

The production of the more important states in 1903 was as follows : -

Production of Mineral Waters in Several States in 1903

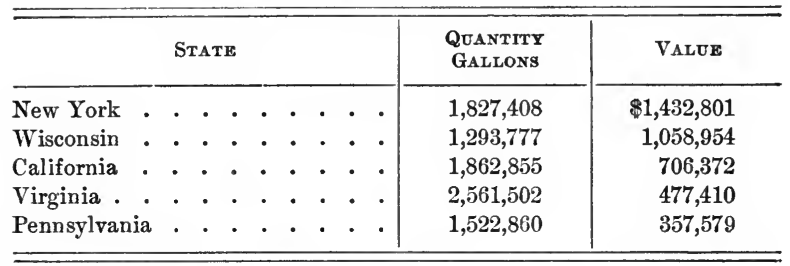

REFERENCES ON MINERAL WATERS

1. Bailey, Kas. Geol. Surv., VII, 1902. (Kas.) 2. Branner, Ark. Geol. Surv., Rept., I, 1891. (Ark.) 3. Crook, Mineral Waters of United States and their Therapeutic Value. (N.Y. 1899.) 4. Lane, U. S. Geol. Surv., Water Supply Bull. XXXI, 1899. 5. Peale, U. S. Geol. Surv., 14th Ann. Rept., II: 51. (U. S.) 6. Schweitzer, Mo. Geol. Surv., III, 1892. (Mo., also general.)

\section{UNDERGROUND WATERS}

While much of the water used for supplying towns and cities, for irrigation purposes, etc., is obtained from below the surface, all of it originates in rainfall. The rain water falling on the surface is disposed of in part by evaporation and surface run-off, but a variable and sometimes large percentage seeps into the ground. 
Ground Water (22). - Of this portion soaking into the ground, a small part is retained by capillarity in the surface soil, to be returned again to the atmosphere either by direct evaporation or through plants, but most of it finds its way into the deeper layers of the soil, which it completely saturates.

The water in this saturated zone, which is termed the ground water, forms a great reservoir of supply for lakes, springs, and wells, and its upper surface, known as the water table, agrees somewhat closely with that of the land surface, but is nearer

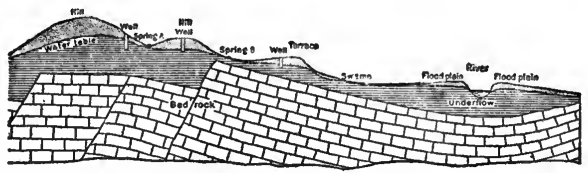

FIg. 34. - Ideal section across a river valley, showing the position of ground water and the undulations of the water table with reference to the surface of the ground and bed rock. After Schlichter, U. S. Geol. Surv., Water Supply Bull. $67: 1$.

to it under valleys, and farther from it under hills (Fig. 34). The depth of the water table is quite variable, being but a few feet below the surface in moist climates, while in arid regions it may be 100 feet or more. In any area, however, the water table may show periodical fluctuations. In all ground water there is a slow but constant movement from higher to lower levels, just as in the case of surface waters, so that the ground water flows towards the valleys. There it may discharge into the streams, but in some instances it follows the valley bottom below the river bed, separated from the river water by a more or less impervious layer (22). The composition of the ground water also shows a somewhat close relation to the rocks or soils in which it accumulates. 
Artesian Water. - In some areas much of the water which percolates through the soil is caught up by porous beds of sandstone, gravel, or in rarer instances limestone, and where these are between impervious beds such as shale, the absorbed water may follow them for some distance, especially if the porous stratum is inclined. Water thus confined is under pressure, and tends to rise towards the surface along any path of escape open to it, such as joint or fault planes, or where the water-bearing bed is cut into by a stream. A drill hole bored to tap the water-bearing bed serves the same purpose; and when the pressure is sufficient to force the water upward so that it flows from the tube, it is called an artesian well. The term is however rather loosely used now and applied to many deep wells which are not flowing.

The requisite conditions (1) for a supply of artesian water are: (1) a porous stratum; (2) an impervious bed below and above the water-bearing bed; (3) inclined beds, so that the point of intake or fountain head can be higher than the well; (4) a sufficient area of outcrop or collecting area to obtain a large enough supply - this may be many miles from the well; (5) adequate rainfall; (6) absence of escape for the water at a lower level than the surface at the well. Artesian water was formerly looked for only in synclinal basins, but it is now known that sedimentary beds may be water bearing in areas of monoclinal dip.

Artesian wells vary greatly in their capacity and depth. Some are not more than 100 feet deep, while others are 2000 or more feet deep.

Though the most productive artesian wells are found in pre-Pleistocene sedimentary rocks of regular structure (Fig. 35 ), still, flowing artesian wells even of large capacity are 
at times found in the glacial drift where water-bearing lenses of sand or gravel are overlain or surrounded by clay.

Even in areas of igneous and metamorphic rocks the water seeps in along joint planes, and collects at times in sufficient quantities to serve as a source of supply which may even be under pressure (6, paper by G. O. Smith).

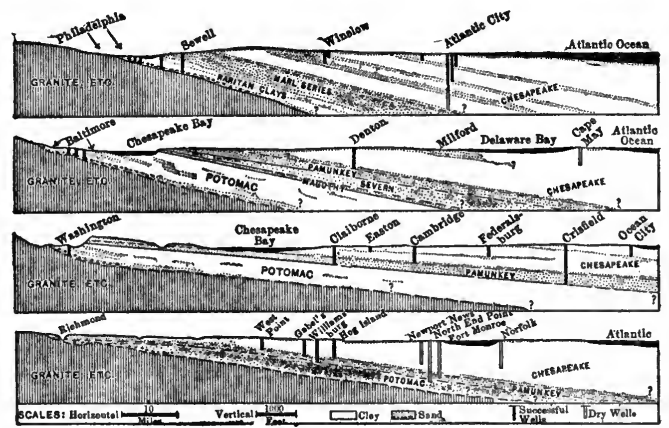

Fig. 35. - Geologic section of Atlantic Coastal Plain, showing water-bearing horizons. After Darton, Amer. Inst. Min. Engrs., Trans. XXIV: 375.

Artesian wells are to be distinguished from ground water wells by their greater constancy, absence of relation to surrounding climatic conditions, and, in moist climates at least, of a high constituent of mineral matter.

There are many areas in the United States in which the conditions are favorable to an artesian water supply, as the various state and government reports will show. A few of the more important may be briefly referred to.

Along the Atlantic and Gulf Coastal Plain an abundant supply of artesian water is obtained from the Cretaceous and Tertiary beds, at depths varying from 50 feet along 
the inland border, to 1000 feet and over along the coast (4) (Fig. 35).

A second area is that of the upper Mississippi Valley (19), in which an abundant supply of potable water is obtained from the St. Croix and St. Peters sandstone, whose outcrop in Minnesota and Wisconsin covers some 14,000 square miles.

In the Great Plains (2) region water is obtained from the Dakota sandstone, whose collecting area is around the border of the Black Hills (Fig. 36). This source is available in

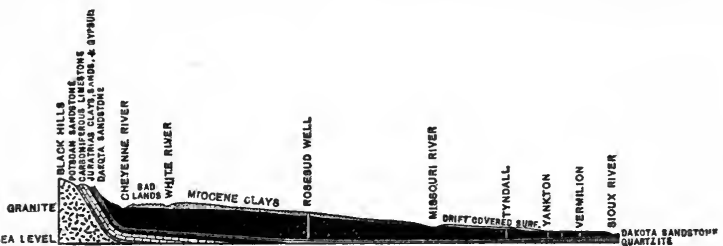

FiG. 36. - Section from Black Hills across South Dakota, showing artesian well conditions. After Darton.

South Dakota and eastern Nebraska and Kansas. The chief use of the water in this region is for irrigation.

For the arid regions of the West this source of supply has been of inestimable value, and has been the means of reclaiming many an area of hitherto useless land.

\section{REFERENCES ON UNDERGROUND WATER}

1. Chamberlin, U. S. Geol. Surv., 5th Ann. Rept.: 125, 1885 . (Artesian water supply.) 2. Darton, U. S. Geol. Surv., Prof. Paper 32, 1905. (Central Great Plains.) 3. Darton, U. S. Geol. Surv., Water Supply Bulls. 57 and 161. (List of deep borings in United States.) 4. Darton, U. S. Geol. Surv., Bull. 138, 1896. (Atlantic Coastal Plain.) 5. Eldridge, U. S. Geol. Surv., Mon. 27. (Denver basin.) 6. Fuller and others, U. S. Geol. Surv., Water Supply Bull. 114, 1905. (Underground waters, E. United States.) 7. Fuller, U. S. Geol. Surv., Water Supply Bull. 100, 1905. (Hydrography E. United States.) 8. Gilbert, U.S. Geol. Surv., 17th Ann. Rept., II: 557, 1896. (Arkansas 
Valley, Col.) 9. Hall, Ala. Geol. Surv., Bull. 7. (Ala.) 10. Hill, U.S. Geol. Surv., 21st Ann. Rept., VII : 387, 1901. (Tex.) 11. Holmes, A mer. Inst. Min. Engrs., Trans. XXV : 936, 1896. (Piedmont plateau.) 12. King, U. S. Geol. Surv., 19th Ann. Rept., II : 59, $1899 . \quad$ (Underground water circulation.) 13. Knight, Wyo. Univ. Exp. Sta., Bull. 45, 1900. (Wyo.) 13 a. Lane, U. S. Geol. Surv., Water Supply Bulls. 30 and 31, 1899. (Mich.) 14. Leverett, U. S. Geol. Surv., 17th Ann. Rept., II: 701, 1896. (IIl.) 15. Leverett, U. S. Geol. Surv., Water Supply Bulls. 26 and 21. (Ind.) 16. Singley, 'Texas Geol. Surv., 4th Ann. Rept.: 87. (Galveston well.) 17. McCallie, Ga. Geol. Surv., Bull. 7, 1899. (Ga.) 18. McGee, U. S. Geol. Surv., 14th Ann. Rept., II : 1. (E. United States.) 19. Norton, Ia. Geol. Surv., VI : 115, 1897. (Iowa.) 20. Orton, U. S. Geol. Surv., 19th Ann. Rept., IV : 640, 1899. (Ohio rock waters.) 21. Ruddy, Wash. Geol. Surv., I : 296, 1901. (Wash.) 22. Slichter, U. S. Geol. Surv., Water Supply Paper No. 67,1902 . (General on underground waters.) 23. Woolman, see various annual reports N. J. Geol. Surv. Many other papers in Water Supply and Irrigation bulletins issued by U. S. Geol. Surv. 


\section{CHAPTER XII}

\section{soILs}

THE term soil is applied to the upper few inches of the mantle of unconsolidated material (regolith) which covers the earth's surface, and which is composed of a mixture of rock, sand, and clay fragments in all stages of decay; with it there is usually mixed a variable amount of decayed and decaying organic matter (humus).

Origin. - Soils are classed, according to their mode of origin, as residual and transported.

Residual Soils are those formed by rock weathering (see Residual Clay, under Clay, Chapter IV), and are found resting on the parent rock from whose decay they have originated; they consequently, in most instances, show a gradual transition from the surface soil to the solid rock beneath. Such soils are often of great extent in the unglaciated areas of the South, and their clayey character and brilliant coloring is a marked feature.

With this class there is sometimes grouped the humus, or peaty soil, formed by the accumulation of vegetable matter in bogs or swamps (see Peat, under Coal, Chapter I).

Transported Soils. - The materials of residual areas are frequently carried away by the agency of water, ice, or wind and deposited elsewhere, commonly at lower levels, giving rise to transported soils. These are classified either according to their mode of origin or texture. 
The former grouping recognizes: Alluvial soils, deposited by water on the lowlands bordering rivers or on their deltas; these form one of the most important soil types, and the fertile soils of the Nile Valley and the Mississippi bottoms are of this character. Their continued high fertility is due to the fact that the soil layer is added to annually or oftener during periods of flood. Glacial drift soils, representing the débris of decayed rocks of various kinds brought down from the north during the glacial period. They are made up of a mixture of many different rock types in all stages of decay; the continual decomposition of their component mineral grains gives them a more or less permanent fertility. Aolian soils, or those formed by wind action, include : (1) Sand dunes heaped up by the action of wind along the shores of many oceans or inland seas. When anchored by systematic planting, they develop an abundant plant growth. (2) Ash soils, representing the accumulations of ash thrown out over a region during outbursts of volcanic activity; these are sometimes of high productivity, for although at first barren and sandy they rapidly decompose to a good soil.

Properties of Soils. - The productivity of a soil depends largely on its chemical and physical properties, and to a lesser extent on climatic conditions.

Chemical Properties. - The chemical analysis of a soil shows a variable percentage of nitrogen, silica, phosphoric acid, chlorine, alumina, lime, magnesia, iron oxide, potash, and soda, all of which, with the exception of the first, are derivable from mineral grains present in the soil. When there is a deficiency of any one of these, it is commonly remedied by adding fertilizers to the soil; but the value of the latter for plant maintenance depends not so much on the total quantity of each of these present, but upon the amount existing in soluble form. While soils vary in their composition from place to place, there is a most marked difference between the soils of humid and arid regions, those of the latter showing a much larger proportion of fertilizing con- 
stituents because they have been subjected to less leaching action by rain water. Soils in arid regions are often covered by a whitish crust termed "alkali," which is composed chiefly of sulphates and carbonates of soda, and is formed by the soil water bringing these to the surface, where it escapes by evaporation. An excess of alkali is injurious to plants.

Physical Properties, which are of equal importance to the chemical ones, include texture, structure, color, weight, and temperature; a proper physical condition may often make up for a deficiency in plant food. The physical characters of a soil are produced to a large extent by natural processes, and can be modified but slightly by man.

The texture of a soil refers to the size of its grains, those recognized being clay, silt, sand, and gravel; depending on the amount of each of these present, we have clay soils, silt soils, loams, sandy soils, and gravelly soils. Texture is of importance because it affects the retentive power of the soil for moisture and gases. Clay soils hold much water and hence are wet and cold, whereas sandy soils, on account of the coarseness of their particles, have large pores and hold little water, and warm up easily. Loamy soils stand intermediate between these.

The structure of the soil refers to the arrangement of the particles. If compacted, the pores are small and the soil holds more water, while if loose the soil behaves like sand, retaining little moisture. A puddled soil is one in which the grains are single, while in a flocculated soil the particles are bunched together, forming compound grains, and all good soils show this structure; it increases the pore space and hence facilitates the circulation of air and water through the mass. Lime encourages flocculation. 
The temperature of soils depends on their color and position with relation to the sun's rays.

In moist climates the clay particles are washed out of the upper layers of the soil and settle in the lower ones, producing a differentiation known as soil and subsoil. This is not found in arid regions.

Distribution of Soils in the United States. - So varied are the soils of the United States that it would require many pages to describe them even partially; nevertheless, there are a few well-marked types underlying extensive areas which may be briefly referred to. The residual soils occupy a large area throughout the southern states, and in the Appalachian belt are especially prominent, being easily recognized by their clayey character and bright colors. Glacial soils are prominent in the northern United States, and their high fertility has been noted by various writers. The alluvial soils are prominent in all parts of the country. In the central states the prairie soil is a peculiar silty type, heavily impregnated with humus. The loess is a silty soil, low in organic matter, covering many square miles of the Great Plains, and needs but irrigation to make it blossom with harvests. Marsh soils and dune soils both cover many thousands of acres along the Atlantic coast; and the latter are also extensive around the Great Lakes as well as along the Pacific coast. Although reclaimable they are rarely cultivated.

\section{REFERENCES ON SOILS}

Hilgard, U. S. Dept. Agric., Weather Bur., Bull. 3, 1892 (Relations of Soil to Climate); King, The Soil, Wiley \& Sons (New York, 1898); Merrill, Rocks, Rock Weathering, and Soils, Macmillan Co. (New York, 1897); Ramann, Forstliche Boden-kunde und Standortslehre 
(Berlin, 1897) ; Shaler, U. S. Geol. Surv., 12th Ann. Rept., I : 213, 1891 (Origin and Nature); Warrington, Physical Properties of Soils (Oxford, Eng., 1900). See also bulletins U. S. Dept. Agric., Bur. of Soils, especially Nos. 4, 10, 15, 17, 18, 19, 22, and the Reports on Field Operations published annually.

\section{ROAD MATERIALS}

Under this term are included clay, sand, gravel, and different kinds of consolidated rock, used for covering the surface of a highway. In former years but little consideration was given to the proper selection of these materials, but now the subject is receiving an increasing amount of attention from engineers, with the results that certain required standards have been set up, and in many localities carefully adhered to. Such standards can however be applied only to consolidated materials.

In many parts of the United States the roads have natural beds, whose character depends on that of the local formations. The road, therefore, may consist of elay, sand, loam, gravel, or bare rock, and such a road surface is unfortunately used even when better materials are at hand, but are overlooked through indifference or ignorance.

Clay makes a hard road in dry weather, but becomes very sticky in wet, or even dusty after prolonged drought. Sand packs well if wet, but makes hard pulling when dry. Gravel, if ferruginous, will often cement to a good road surface, which wears well under light traffic. Shale will also make a good road. Natural road beds are, however, unsatisfactory at best, and artificial ones of crushed stone (macadam roads) are rapidly superseding them.

For this purpose a number of different kinds of rock are 
employed, including trap, granite, limestone, dolomite, and sandstone.

The essential qualities of a stone for macadamizing are : (1) Hardness to resist crushing under traffic. (2) Sufficient abrasion to permit the formation of some dust which when moistened will form a cement to bind the particles together. (3) Freshness of the mineral grains. (4) Cheapness. Great variation is found to exist among the different stones with respect to these requirements, and even stones of the same kind lack uniformity.

While the most practical test for road material is actual use, this is not always a cheap or rapid method, and consequently a series of physical tests has been adopted, which is in use in most highway laboratories. The two important tests are the abrasive test and impact test. In the former the abrasive resistance of the stone is determined, in the latter the cementing power of the powdered stone is measured, by forming it into briquettes, which are broken by a series of blows. The same powder is remolded and again broken to determine its recementing power. Stones with a small amount of argillaceous and calcareous impurities often appear to have good cementing power; but in every case the qualities of each stone have to be determined separately.

Since, however, stone for road building will not bear the cost of long transportation, it becomes necessary to make a careful selection of the best that the vicinity affords. Trap rock and hard argillaceous limestone are perhaps more used than any other materials.

Good stones for road building are more or less widely distributed in most parts of the United States, so that any detailed mention of localities is not needed. 
REFERENCES ON ROAD MATERIALS

Merrill, N. Y. State Museum, Bull. 17, 1897 (N.Y.); Reid and Johnson, Md. Geol. Surv., I and IV; Shaler, U. S. Geol. Surv., 16th Ann. Rept., II : 227, 1895 (Mass.). See also bulletins issued by Highway Division of Dept. of Agric., Wash., and Reports of Massachusetts Highway Commission. 



\section{PART II}

\section{METALLIC MINERALS}





\section{CHAPTER XIII}

\section{ORE DEPOSITS}

Definition. - The term ore deposits is applied to concentrations of economically valuable metalliferous minerals found in the earth's crust, while under the term ore are included those portions of the ore body of which the metallic minerals form a sufficiently large proportion to make their extraction profitable. A metalliferous mineral or rock might therefore not be an ore at the present day, but become so at a later date, because improved methods of treatment or other conditions rendered the extraction of its metallic contents profitable.

A few metallic minerals serving as ores, such as gold, copper, platinum, or mercury, sometimes occur in a native condition; but in most cases the metal is combined with other elements, forming sulphides, hydrous oxides, carbonates, sulphates, silicates, chlorides, phosphates, or rarer compounds, the first five of these being the most numerous. A deposit may contain the ores of one or several metals, and there may also be several compounds of the same metal present.

Gangue Minerals. - Associated with the metallic minerals there are usually certain common non-metallic ones which carry no values worth extracting. These are termed the gangue minerals. They often form masses in the ore deposit 
which can be avoided or thrown out in mining, but at other times they are so intermixed with the valuable metalliferous minerals that the ore is crushed and the two separated by special methods.

Quartz is the most abundant gangue mineral, but calcite, barite, fluorite, and siderite are also common, while dolomite, hornblende, pyroxene, feldspar, rhodochrosite, etc., are found in some ore bodies.

Origin of Ore Bodies. - The fact that ores form masses of greater or less concentration is explainable in two ways: either they have been formed contemporaneously with the inclosing rock; or else they have been formed by a process of concentration at a later date. The first theory is found to be applicable to some ores in igneous rocks, and probably some sedimentary ones, while the second applies to most ore deposits regardless of the character of the inclosing rock.

Ores of Contemporaneous Origin. - If the ore in an igneous rock were formed at the same time as the rock, it would indicate a crystallization of metallic minerals from the igneous magma during cooling; and this, in some cases, is true, it being found that the metallic elements in many basic rocks tend to segregate during cooling, sometimes forming masses of considerable size and of high purity. This mode of origin, termed magmatic segregation $(18,34,35$, 36), was shown by Vogt to apply to the titaniferous ores of Scandinavia; and although the importance of the theory was not at first generally appreciated in America, where deposits of this type are rare, still it is now generally accepted. The best-known American examples of this class are the titaniferous magnetites and the chromite ores. 
Spurr has suggested (34) that certain ores found in acid rocks, such as quartz veins, have also been formed by magmatic segregation. He believes that siliceous rocks, such as granites, may originate by differentiation from a more basic magma. A further development of this process yields quartz-feldspar rocks, and after the minerals of these have crystallized out, only pure silica is left, which forms quartz veins. Examples of this type have been noted by Spurr from Alaska, and by Turner from Silver Peak, Nevada.

If ores in sedimentary rocks are of contemporaneous origin, then the deposit must be a bedded one conforming to the stratification of the rock, and this explanation moreover requires the presence of metalliferous minerals in and their deposition from sea water. While certain metallic elements are found in the waters of the ocean, their quantity is extremely small and not to be compared with what may be found in disseminated or concentrated form in sedimentary and igneous rocks. It has been shown, however, that some metallic minerals, such as limonite, pyrite, or manganese, are occasionally precipitated on the ocean floor. While economic geologists have assigned a contemporaneous origin to certain ores found in sedimentary strata, and in certain instances their theories have been quite generally regarded as correct (iron ores, ref. 36), still the majority at the present day believe that most ore deposits are of later date than the inclosing rock, and must have been formed by a process of concentration, aided in the majority of cases by circulating water.

Concentration of Ores in Rocks. - In order to demonstrate this, it is necessary to show: (1) the presence of disseminated 
minerals in the earth's crust; (2) the existence of a solvent or carrier; and (3) the presence in most cases of cavities in which the precipitation of the ore can occur.

It is well known that metallic minerals in small quantities are widely distributed, in both igneous and sedimentary rocks. Sandberger (31), for example, has shown by analyses the presence of nickel, copper, lead, tin, and cobalt in such minerals as hornblende, olivine, and mica; and Curtis has found traces of silver, gold, and lead in the quartz-porphyries at Eureka, Nevada (U. S. Geol. Surv., Mon. VII : 80), and silver, arsenic, lead, copper, gold, and silver in the granite at Steamboat Springs, Nevada (U. S. Geol. Surv., Mon. XIII : 350). Winslow has pointed out the presence of small quantities of lead and zinc in the limestones of Missouri and Wisconsin (lead and zinc, ref. 17), and Wagoner has made similar tests on California sediments (42). Since, however, the sediments were originally derived from the igneous rocks, it follows that the latter must be the original source of the minerals. It is interesting to note that even in the igneous rocks the metals are not impartially distributed, but that certain metals seem to favor certain rocks (De Launay, Ann. d. Min., August, 1897, and ref. 34). Tin seems to favor granite, and chromite, peridotite.

As regards the second point, it is now generally admitted that water is an important agent in the concentration of many ores. While cold water, free from impurities, has comparatively little solvent power, the presence of acids or alkalies materially increases its capacity for solution, and heat and pressure have also a great influence. Analyses of mine, spring, and surface waters have shown the presence 
of many dissolved alkalies and other salts (24), and occasionally small quantities of metals.

The following two analyses, which will serve as examples, give the calculated composition of (1) vadose, or shallow water, from the 500 -foot level of the Geyser silver mine, Silver Cliff, Colorado, and (2) deep water from the 2000foot level of the same mine. The ore occurs in rhyolite. The figures are grams per 1000 liters:-

\begin{tabular}{|c|c|c|c|c|c|c|c|c|c|c|c|c|c|}
\hline & & & & & & & & & & & & 1 & 2 \\
\hline $\mathrm{SiO}_{2}$ & - & - & . & - & • & • & . & & & & & 25.90 & 24.42 \\
\hline $\mathrm{Al}_{2} \mathrm{O}_{3}$ & . & . & • & . & . & . & . & . & . & . & . & - & 1.06 \\
\hline $\mathrm{Al}_{2} \mathrm{O}_{3}, \mathrm{P}_{2}$ & ${ }_{2} \mathrm{O}_{5}$ & & - & - & - & - & - & • & • & & • & .80 & - \\
\hline $\mathrm{FeCO}_{3}$ & . & & - & . & . & . & . & - & . & . & . & 1.50 & 7.25 \\
\hline $\mathrm{MnCO}_{3}$ & . & - & - & - & - & - & • & . & - & • & . & 1.70 & 1.19 \\
\hline $\mathrm{CaCO}_{3}$ & . & . & . & - & . & . & . & . & • & . & . & 93.50 & 366.03 \\
\hline $\mathrm{Ca}_{3} \mathrm{P}_{2} \mathrm{O}_{8}$ & - & • & - & - & - & - & • & & & & - & - & $\operatorname{Tr}$ \\
\hline $\mathrm{CaF}_{2}$ & . & - & - & - & - & . & - & - & - & & . & - & $\operatorname{Tr}$ \\
\hline $\mathrm{SrCO}_{3}$ & . & . & . & - & . & - & . & . & . & & . & - & 3.29 \\
\hline $\mathrm{MgCO}_{3}$ & - & - & . & - & - & - & - & - & & & - & 42.85 & 621.84 \\
\hline $\mathrm{K}_{2} \mathrm{SO}_{4}$ & • & - & - & - & - & - & - & - & & & • & 4.20 & 19.18 \\
\hline $\mathrm{KCL}$. & . & . & . & . & . & - & - & - & & & . & 16.60 & 361.34 \\
\hline $\mathrm{KBr}, \mathrm{KI}$ &. & . & . & . & . & . & . & - & . & & - & - & $\operatorname{Tr}$ \\
\hline $\mathrm{Na}_{2} \mathrm{CO}_{3}$ & - & - & - & - & - & - & - & • & & & - & 38.70 & 1489.67 \\
\hline $\mathrm{Na}_{2} \mathrm{SO}_{4}$ & - & - & - & - & - & • & • & - & - & & • & 60.50 & 223.53 \\
\hline $\mathrm{NaNO}_{3}$ & . & . & - & - & - & - & . & • & . & & • & - & 2.19 \\
\hline $\mathrm{Na}_{2} \mathrm{~B}_{4} \mathrm{O}_{7}$ & . & . & - & • & - & - & - & • & & & - & - & $\operatorname{Tr}$ \\
\hline $\mathrm{LiCl}$ & . & - & • & - & - & - & • & • & & & - & - & 17.30 \\
\hline $\mathrm{CO}_{2}$. & . & . & - & - & . & - & . & • & & & - & 37.20 & 1418.61 \\
\hline $\mathrm{PbCO}_{3}$ & . & . & - & - & - & - & - & - & & & . & $\mathrm{Tr}$ & 1.74 \\
\hline $\mathrm{CuCO}_{3}$ & • & • & - & - & - & • & - & • & • & & • & $\mathrm{Tr}$ & .04 \\
\hline $\mathrm{ZnCO}_{3}$ & . & - & . & - & - & • & • & • & . & & - & .40 & .66 \\
\hline
\end{tabular}

The higher percentage of dissolved substances in the deep water is quite marked.

While the importance of hot waters as an agent in the 
formation of ore deposits is clearly recognized by many, and traces of metals in solution are sometimes found, still examples of such deposits now forming are rare. Weed has described a hot spring near Boulder, Montana (49), which is depositing auriferous quartz, and the deposit is pointed out by him to be identical with silver and gold bearing quartz veins of the region between Butte and Helena, Montana. At Steamboat Springs, Nevada, it has been found that the alluvial gravels underlying the hot spring sinters are cemented by stibnite and pyrite (Lindgren, Amer. Inst. Min. Eng., Trans. 1905: 275). Of still more interest is the collection by evaporation of copper from certain Javan hot springs, in which the metal occurs as iodide of copper (Stevens, Copper Handbook, IV : 156, 1904).

Water is known to be widely $(11,39)$ but not uniformly distributed in the rocks of the earth's crust, and much of it is in slow but constant circulation. While it is admitted by most geologists that this water has been an important ore carrier, collecting the disseminated metals in the rocks and concentrating them in localities favorable to deposition, still, there exists a difference of opinion regarding its source, one class maintaining that it is largely of meteoric origin, the other that it is derived chiefly from igneous intrusions.

The chief exponent of the former theory is Van Hise, who points out that the earth's crust may be divided into three zones: (1) an upper zone of fracture, beginning at the surface; (2) a zone of combined fracture and flowage; and (3) a zone of rock flowage, or of no fracture. In the zone of no fracture the pressure is so great that any dynamic disturbances will cause flowage instead of fracturing, and no 
cavities of appreciable size can exist. The depth of this zone will depend on the kind of rock, Van Hise having figured that cavities probably cannot exist in soft shales at depths below 1625 feet ( 500 meters), and in firm granites below $32,500 \mathrm{ft}$. (10,000 meters).

Into this zone of no fracture, water from the surface cannot penetrate, but above it there may be active percolation by water. It is well known that rain water, falling on the earth's surface, seeps through the soil into the underlying rocks, permeating them to a variable depth, and forming a more or less saturated zone, whose upper limit, lying at a variable depth, is known as the ground-water level. In this zone of more or less complete saturation there is a slow but continual circulation, from areas of high to areas of low pressure, along irregular winding routes, often leading back to the surface and giving rise to springs. According to Van Hise this percolating meteoric water obtains its load of metallic elements from the rocks, which it traverses in its passage through the zone of fracture, depositing some of it in the trunk channels, but being incapable of entering the zone of no fracture.

The opponents $(6,18,20,21)$ of Van Hise's theory point to the following facts as evidence that waters of igneous origin are more important as ore carriers, and are the ones involved in deep circulation. Meteoric waters do not reach great depths, in fact probably not more than 2000 feet or sometimes less from the surface, and when they do penetrate to a greater distance from it, it is because they have followed some fissure. The lower levels of many deep mines are so dry as to be dusty. Ores have been concentrated at a much greater depth than that reached 
by surface waters. It is perfectly reasonable to regard igneous rocks as an important source of water, and the experiments of Daubrée have shown that a molten granite contains a large amount of water vapor which it retains while at great depths, but gives off on approaching the surface and cooling. While the temperature and pressure are still high this water escapes as vapor, and later, with decrease in temperature and pressure, as a liquid. Under favorable conditions this water may force itself upwards and finally mingle with meteoric waters, carrying metals obtained both from the liberated waters and, to a less extent, from the leaching of cooled igneous rock.

It is an undeniable fact that most metalliferous veins are found in areas of igneous rocks, and Lindgren (see refer-ences on gold, 79) has shown that in the case of the gold deposits of North America the periods of vein formation agreed closely with those of igneous activity. It is also a noteworthy fact that, with the exception of the deposits of commoner metals, such as iron, and some copper, lead, and zinc, ores are found in close association with igneous intrusions, which seems to postulate a close connection between igneous rocks and ore deposits, as advocated by such authorities as Weed, Kemp, Lindgren, and Emmons; and although opposed by Van Hise, it is now held by many economic geologists that most metalliferous deposits, aside from ores of iron, have resulted by deposition from ascending waters in regions of igneous intrusions, the waters being probably in large part at least of igneous origin. This much should be said. The metalliferous minerals as originally deposited have not always been sufficiently concentrated to serve as ores, but they have become concentrated at a later date by meteoric 
waters, as at Bisbee, Arizona. (See Ransome, under copper references.) Posepny (24), in his work on the Genesis of Ore Deposits, distinguishes between descending surface waters, or vadose circulations, and ascending waters from great depths. It is the former that have been active in the secondary concentration of ores.

Formation of Cavities. - The deposition of ores in the rocks is greatly facilitated by the presence of cavities along which the ore-bearing solutions freely pass, and consequently a great many ore deposits occur in such spaces. There are a number of different ways in which cavities may be formed in rocks. The percolation of surface water through certain ones, such as limestones, often results in the formation of solution cavities, these in many instances attaining the size of veritable caverns; a soluble rock may contain more or less insoluble material, such as clay or chert, which collapses when the surrounding rock is dissolved, and partly fills the cave thus formed. At times the more resistant parts are so bound together that they remain in their original position, forming a porous mass, in the cavities of which mineral matter is later deposited.

Dynamic disturbances produce cavities of variable extent in many different rocks. These range from microscopic cracks, like the rift planes of granite, to enormous faults of great depth and linear extent, and include the joint planes so common in the rocks of almost all regions. Fault fissures form one of the most important types of passageways for ore-bearing solutions. They are often irregular, branching, and partly filled by fault breccia, caused by the breaking of the rock during the movement along the fault plane. A third important group of cavities in the rocks are 
those resulting from shrinkage of the mass, which may be due to (1) shrinkage during cooling, as in igneous rocks; (2) shrinkage during certain forms of replacement. For example, the change of carbonate of lime to dolomite is accompanied by a shrinkage of the mass, which renders the dolomite more porous than the original rock; and in the alteration of siderite to limonite there is a shrinkage of fully 20 per cent (25). A fourth type of channelway for the passage of underground water is the contact plane between two quite different kinds of rock, one of them fairly dense and impervious; for example, the contact plane between a granite mass and a series of sedimentary strata.

Precipitation of Metals from Solution. - The conditions which increase the solvent power of water have already been referred to. To this should be added the statement that solution generally takes place out of contact with the air.

When the ore-bearing solutions approach the surface or enter a cavity, the load of dissolved minerals is deposited wholly or in part, due to cooling of the solution, release of pressure, or by oxidation, which converts certain soluble salts into an insoluble form. Chemical reactions between two different solutions meeting in a cavity or at the intersection of fissures may also cause precipitation. Iron compounds, for example, may go into solution in the form of carbonate, but on exposure to the air the latter is rapidly changed to limonite, which is insoluble.

While the deposition of the ore often takes place in cavities below the surface, there are cases in which it is not precipitated until it reaches the surface, as in a pond or in the soil. Certain special conditions of deposition should also be noted. 
Replacement or Metasomatism (22). - It is a well-known fact that under favorable conditions mineral-bearing solutions may attack the minerals of the rocks which they penetrate, dissolving them wholly or in part, and depositing some of the original burden in place of the material removed. This replacement, termed "metasomatism," is an important factor in the formation of many ore deposits, and may involve a total or partial loss of certain constituents of the rock attacked and a gain of others, even to the extent of introduction of entirely new compounds and elements. The change takes place molecule by molecule, a grain of vein material being deposited for each grain of replaced rock dissolved. The ore-bearing solutions penetrate the rock first along the smallest cracks, and then work their way into the individual mineral grains along their cleavage planes, until they finally permeate the entire mass.

Metasomatic processes show great variety, and are not confined to one kind of rock or mineral. In its simplest form the result of metasomatism may often be seen in fossiliferous rocks, where organic remains have been replaced by common mineral compounds, as in the replacement of the lime carbonate of corals by quartz, or the replacement of molluscan shells by pyrite. From such simple conditions there is every gradation to the complete replacement of extensive areas of rock by ore, or to the extensive operation of metasomatism along the walls of fissure veins. In most cases the changes are believed to be due to the action of underground water; but in some instances it seems probable that the processes of pneumatolysis (see below) were involved. Moreover, high temperature, pressure, and concentration seem to have been present in replacement, especially 
in the case of ore deposits in fissure veins. It is rarely possible, without examination of a thin section with the

- microscope, to decide whether minerals present are due to replacement or to simple interstitial filling. Fig. 37 shows a replacement vein in syenite.

Some minerals are more easily replaceable than others, consequently the rocks in which such predominate might

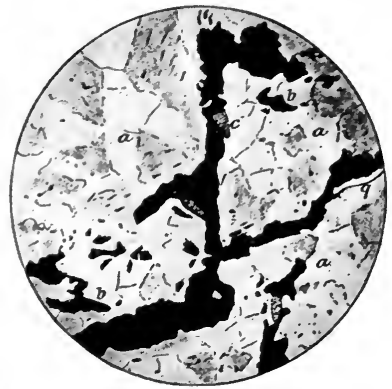

Fig. 37. - Replacement vein in Syenite

Rock, War Eagle Mine, Rossland,

B. C. (a) granular orthoclase with a little sericite; $(b)$ secondary biotite; $(q)$ secondary quartz; (c) chlorite; black, secondary pyrrhotite. After Lindgren, Amer. Inst. Min. Eng., Trans. $X X X: 62$. be more widely affected than others. (See Butte, Montana, and Clifton, Arizona, under Copper.)

The theory of metasomatism was first applied in America by Pumpelly in 1871, in explanation of the copper deposits of Michigan; but the ore bodies of Leadville, Colorado, and Eureka, Nevada, were the first large deposits whose origin was explained by it. Since then the great importance of metasomatism has been widely recognized, and it has become evident that preëxisting cavities are not necessary to the formation of ore bodies.

Concentration by Eruptive After-action (45) (Pneumatolysis). - The term pneumatolysis was first used by Bunsen to describe the combined action of gases and water. This assumes that during cooling many magmas give off watery vapor, heated above its critical temperature $\left(365^{\circ} \mathrm{C}\right.$.) and under high pressure. With this there are also mineralizing 
vapors and metals, combined to form volatile compounds. These materials, together with any other elements given off, may then be deposited either at the contact between the intrusive and the surrounding rocks, forming a true contact deposit, or, as in the case of the tin veins of Cornwall, England, in fissures formed in the surrounding rocks by the intrusions. Though the great importance of this class of ore deposits has been but recently recognized, it is now being found that a number of known deposits are of this origin. They are usually found in calcareous rocks at or near the contact with granitic intrusions. The ore minerals are specularite, magnetite, bornite, chalcopyrite, pyrite, pyrrhotite, and more rarely galena and blende; while associated with them are characteristic contact minerals, such as epidote, wollastonite, garnet, vesuvianite, and hematite. The sulphides sometimes carry gold and silver, and tellurides are not rare (51). A characteristic feature, however, is the association of iron oxides and sulphides, an almost unknown thing in fissure veins. Since these minerals are sometimes found in limestones of great purity, it is considered as quite evident that in such cases, at least, most of the foreign matter has been derived from the igneous mass. Examples of contact deposits are South Mountain, Idaho, Seven Devils District, Idaho, and Clifton, Arizona (in part).

Other Causes of Precipitation. - Some fifty years ago not a few geologists, prominent among them De la Beche, advo. cated the theory of ore precipitation by galvanic action $(1,9)$, and number of experiments were made attempting to prove the existence of such action; now little weight is attached to this theory.

More recently Gillette (13) has expressed the view that 
osmotic pressure is an important factor in ore deposition, aiding to spread the dissolved metals through the water in the rocks, toward centers of crystallization.

Forms of Ore Bodies. - Ore bodies vary greatly in their form, and this character has at times been used as a basis of classification by some writers ; but the more modern tendency is to use genetic characters instead, making form of secondary importance in the grouping. Certain forms of ore bodies are so numerous as to deserve special mention.

Fissure Veins $(8,12,16,29,47)$. - A fissure vein may be defined (22) as a tabular mineral mass occupying or closely associated with a fracture or set of fractures in the inclosing rock, and formed either by filling of the fissures as well as pores in the wall rock, or by replacement of the latter (metasomatism). When the vein is simply the result of fissure filling, the ore and gangue minerals are often deposited in successive layers on the walls of the fissure (Rico, Colorado), the width of the vein depending on the width of the fissure and the boundaries of the ore mass being sharp. In most cases, however, the ore-bearing solutions have entered the wall rock and either filled its pores or replaced it to some extent, thus giving the vein an indefinite boundary. Therefore the width of the fissures does not necessarily stand in any direct relation to the width of the vein (47) (Butte, Montana).

Veins formed by the simple filling of a fissure often show a banded structure of varying regularity termed crustification $^{1}$ by Posepny (Fig. 38), which may sometimes be brecciated by later movements along the fissure. Secondary bands may be formed after reopening of the fissures (Fig. 38), and such a movement may cause brecciation of the vein

1 The replacement of certain layers only in a bed of stratified rock may also produce a banded structure. 
material, or allow the ingress of the weathering agents which decompose the wall rock, giving rise to a layer of clay known as selvage. Where the fissure has not been completely filled, thus leaving a central space into which the crystals of gangue project, a comb structure is formed. The bands in a filled fissure may consist of gangue and ore alternating, or of different ores. Among the commonest ores seen in these fissure veins are pyrite, chalcopyrite, galena, blende, and sulphides of silver. Some regions afford especially fine examples of banded veins, notably those

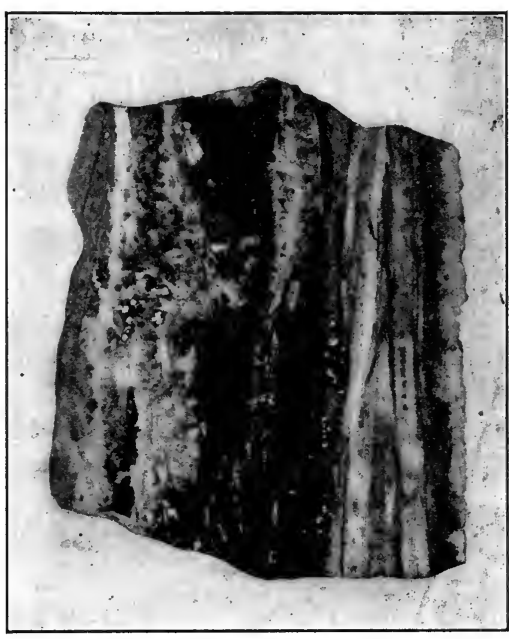

FIG. 38. - Section of vein in Enterprise mine, Rico, Colo. The right side shows later banding due to reopening of the fissure. After Ransome, $U . S$. Geol. Surv., $22 d$ Ann. Rept., II : 262.

of Grass Valley, California, and Rico, Colorado. Abroad the mines of Freiberg, Saxony, and Clausthal, Prussia, also often yield magnificent specimens. Even in a single vein the ore may follow certain streaks which are termed shutes, or again it may be restricted to pockets of great richness, which are known as bonanzas.

Fissure veins in which metasomatic action has predominated show great irregularity of width and an absence of 
well-defined boundaries; they also lack as a rule the symmetrical banding and the breccias cemented by vein material. There are all gradations between these two types of fissure veins; and even in a single vein, simple filling may occur in one part and replacement in another.

Veins often split (Pl. XX, Fig. 2), or intersect, and at the point of intersection or splitting the ore is apt to be richer. There are other reasons for variations in richness, among the most important being the character of the wall rocks, some kinds being more easily replaceable or more porous than others. Their physical character will moreover exercise considerable influence on the shape and size of the fissure. Tough.rocks like gneiss, for example, give a clean-

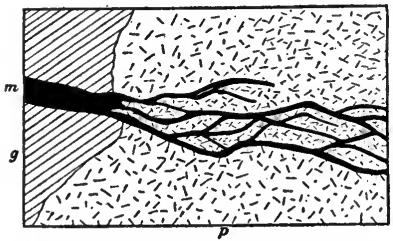

Fra. 39. - Section showing change in character of vein passing from gneiss $(g)$ to quartz porphyry $(p)$. After Beck, Lehre von der Erzlagerstätten: 135, 1901. cut fissure, but in brittle rock the fissure is apt to split frequently, and therefore a vein may be workable in one kind of rock, but becomes worthless when passing to another, since the profuse branching interferes with economical mining (Fig. 39). A dike may also cause local irregularities, and in a given region the fissures not uncommonly show great variation in their direction. Thus at Butte, Montana, east-west veins predominate (Fig. 53), while in the Silverton district of Colorado they cut the rocks in all directions, but the majority show a north of east trend. In the Monte Cristo, Washington, district the veins with northeast trend are predominant (Fig. 40).

Fissure veins vary considerably in their width, swelling 


\section{ROBERT W. WEBB \\ GEOLOGY DEPT., U.C.L.A.}

ORE DEPOSITS

at some points and pinching or narrowing at others. They also at times show lateral enrichment; for instance, where the ore cuts through stratified beds, into which the orebearing solutions have spread out laterally along the planes of stratification or other planes. It has been noticed in some veins, especially those formed by replacement, that the filling varies with the wall rock, at times changing suddenly; but where the vein is formed wholly by the filling of an open fissure, the rock exerts

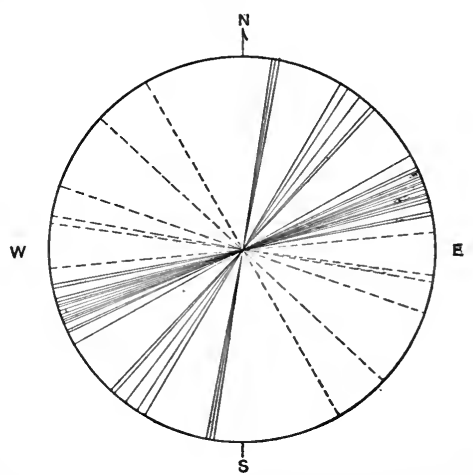
no influence on the FIa. 40.-Tabulation of strikes of principal character of the ore (47). If the vein is veins in Monte Cristo, Wash., district. After Spurr, U. S. Geol. Surv., 22d Ann. Rept., $I I: 810,1902$.

inclined, the lower wall is spoken of as the foot wall and the upper one as the hanging wall.

Parallel fissures are not uncommon, but the several veins do not necessarily show an equal degree of richness. Where the vein is of composite character, - that is, consisting of closely spaced parallel fissures accompanied sometimes by a mineralization of the intervening rock, - it is termed a lode. The top of the vein is called the apex, and is occasionally traceable for a long distance.

Linked veins represent a type in which the parallel fissures are connected by diagonal ones (Fig. 41), giving a series resembling the links of a chain. 
Gash veins are a special type of fissure vein, formed by the enlargement of joint planes and sometimes bedding

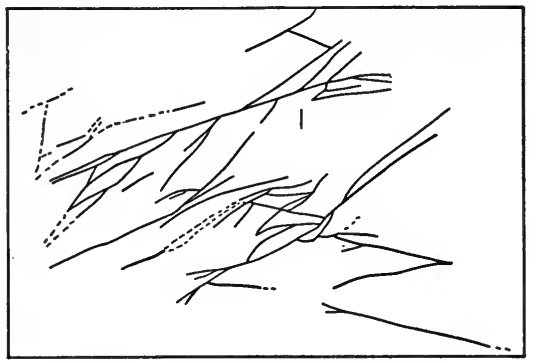

Fig. 41.-Linked veins. After Ordonez.

planes. They are characteristic of the upper Mississippi Valley lead and zinc region, but are usually of limited extent and local importance. In the simplest form

they are a vertical fissure, but develop into types shown in Fig. 42.

Filling of Fissure Veins (16). - The manner in which fissure veins have been filled, and the source of the metals which they contain, formed a most fruitful subject of discussion among the earlier geologists. Four general theories were advanced at an early date (2). They are: (1) Contemporaneous formation, a theory no longer advocated by any one. (2) Descension, which likewise no longer has many adherents. (3) Lateral secretion, in which the vein contents are supposed to have been leached from the wall

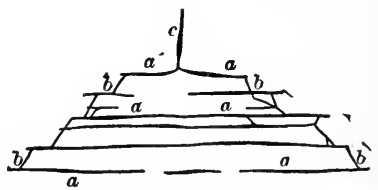

Frg. 42.-Gash vein with associated "flats" (a) and "pitches" (b). Wisconsin zinc region. After Grant, Wis. Geol. and Nat. Hist. Surv., Bull. $I X: 62$. rock, usually in the immediate vicinity of the fissure, but at variable depths below the surface; some geologists holding this view believe that the area leached was very exten- 
sive and not confined to the immediate vicinity of the walls. (4) Ascension, the material being deposited by infiltration, sublimation with steam, sublimation as gas, or igneous injection. The several arguments for or against these theories are well set forth in Kemp's paper (ref. 16), and it will suffice here to state that of the various ones those of lateral secretion and ascension by infiltration are the most rational. It is probable that the majority of geologists now believe in a modified theory of lateral secretion, in which the area of supply extends beyond the immediate walls of the fissure, and that the ore-bearing solutions have either ascended the fissure or entered through the walls.

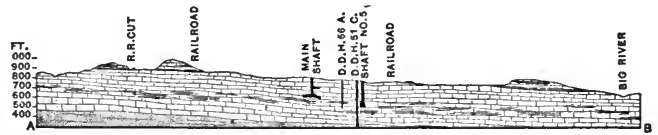

Fig. 43. - Section at Bonne Terre, Mo., slowing ore dissemiuated through limestone.

Other Forms of Ore Deposits. - Impregnations represent deposits in which the ore has been deposited in the pores of the rock, or the crevices of a breccia (Keweenaw Point, Michigan). Fahlband is a belt of schist impregnated with sulphides. Ore channels include those ore bodies formed along some path which the mineral solutions could easily follow, as the boundary between two different kinds of rock (Leadville, Colorado, Mercur, Utah). Bedded deposits, found parallel with the stratification of sedimentary rocks, and sometimes of contemporaneous origin (Clinton iron ore). Contact deposits, as now understood, represent ore bodies formed along the contact of a mass of igneous and sedimentary rock (usually calcareous), the ore having been derived 
wholly or in part from the intrusive mass (Clifton, Arizona, in part). Chamber deposits, whose ore has been deposited in caves of solution (Missouri lead and zinc ores). Disseminations, deposits in which the ore is disseminated through the rock (Southeastern Missouri lead ores).

Secondary Changes in Ore Deposits. - Ore deposits may be changed in their upper parts by weathering agents, while the lower-lying portions, below the ground water level, are often enriched by secondary processes.

Weathering or Superficial Alteration (25). - This involves both chemical and physical changes similar to the decay and disintegration of common rocks, but the great number of mineral compounds involved, including many with metallic base, give rise to a large number of intricate chemical reactions. Since many of the minerals in ore deposits are more easily decomposed than the common rock-forming minerals, the alteration is quite rapid and extends to a greater depth than in the country rock. There is, however, marked variation in the rate at which the different ore-forming minerals decay, and this variation exists even in a single group, like the sulphides in which the order or rate of decomposition is arsenopyrite, pyrite, chalcopyrite, blende, galena, chalcocite, and tetrahedrite (41).

The altered portion of the ore deposit is known as the gossan, or iron hat (French, chapeau-de-fer; German, eisener $H u t$ ), because the deposit is usually stained by iron minerals, such as limonite, which may sometimes completely mask the true nature of the ore.

The first chemical changes are oxidation or hydration, or both, and these, together with other changes, produce many 
soluble compounds, which can be, and often are, leached out of the gossan by percolating waters. An example of oxidation is the alteration of pyrite to ferrous and ferric sulphate, and by hydration and further oxidation to limonite. Chalcopyrite oxidizes to copper sulphate, and by hydration and further oxidation to copper carbonate, silicate, or oxide. We see therefore that the first change in each of the above cases is the same, sulphates being formed from sulphides, but the later changes are different, the iron sulphate changing to hydrous oxide, while the copper forms a different set of com-

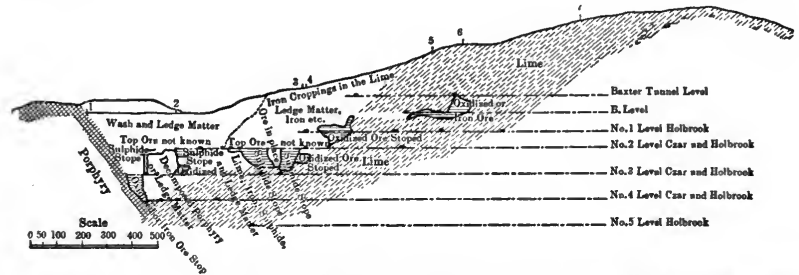

Fig. 44. - Section through Copper Queen Mine, Bisbee, Ariz., showing variable depth of weathering. After Douglas, Amer. Inst. Min. Engrs., Trans. $X X I X ., 1900$.

pounds. Reduction may, however, occur, as when, for example, two partly oxidized salts of iron and copper react with each other, giving ferric salts and metallic copper, owing to the stronger affinity of iron for oxygen.

The porosity of the gossan is sometimes due to leaching, sometimes to shrinkage, as when siderite or pyrite change to limonite. Hydration, on the contrary, causes expansion.

The depth of weathering depends on topographic conditions, chemical nature and porosity of the deposits, and climate; but in any event it is liable to vary in the same deposit, owing to variation in the permeability of different parts of the mass (Fig. 44). In Arizona many copper de- 
posits have been changed from sulphides to carbonates, to a depth ranging from 100 to 700 feet; the oxidized ores of the Appalachian region average about 100 feet in depth; while those of the Rocky Mountain area range from 50 to 700 in depth.

The ferric sulphate produced by the weathering of pyrite is a most important factor in the alteration of ore deposits. When formed it attacks pyrite and other sulphides, converting them into sulphates, at the same time being itself reduced to ferrous sulphate, which is in part changed to limonite and sulphuric acid. That portion remaining unreduced begins anew the scale of change. Ferric sulphate is thus the main agent by which the sulphides are dissolved. Moreover it also acts as a solvent of free gold.

All the metallic contents are not, however, leached from the gossan, for some minerals are either difficult to dissolve or remain unattacked. Thus in some cases the leaching produces an enrichment by the removal of worthless constituents and a consequent increase per ton of valuable minerals. The soluble compounds produced by weathering are often carried downward by percolating water and deposited in an irregular zone between the gossan and the unweathered ore below. In many copper deposits there is found a rich zone of black copper between the gossan and unaltered sulphides.

Secondary Deposition below Ground Water Level $(4,41)$. If the body of unaltered sulphides below is broken by fissures, the solutions containing the various metallic sulphates and sulphuric acid will enter them, penetrating at times to considerable depths.

If pyrite or pyrrhotite are present at these depths, a reac- 
tion occurs between the ferric sulphate, the dissolved metallic sulphides, and the pyrite. This may result in the precipitation of new sulphides on the walls of the fracture, forming rich patches of ore or bonanzas (28). The association of these fractures formed after the primary sulphides is an important character of value to the mining engineer, and from what has been said above, it can be seen what an important rôle pyrite plays in the secondary enrichment process. It has been noticed, however, that pyrite is not the only reducing and precipitating agent in ore deposits. Carbon is a strong reducer, and other minerals also exert a variable influence (14). (See deposition of lead and zinc in Wisconsin and Ozark region, Chap. XVII.)

Value of Ores. - The terms rich and poor, as applied to ores, are used with great frequency, although most indefinite and often meaningless. Under very favorable conditions it is possible to profitably work an ore of given value at one locality, while if found under other less favorable conditions at another point it might be almost worthless.

Those who have not given special study to ore deposits often fail to realize that in the majority of ores the percentage of metal contained in the ore falls considerably below the theoretic percentage of the metallic contents in the ore-bearing minerals, due of course to the presence of a greater or less quantity of gangue minerals which tend to dilute the metallic values of the vein. Lake Superior copper ores contain as little as .65 per cent native copper; and many sulphide ores running as low as 5 or 6 per cent metallic copper or even less are successfully worked. Many lowgrade lead ores are profitably mined because their gold and 
silver contents more than pay the cost of metallurgical treatment. Gold ores alone, running as low as $\$ 2$ or $\$ 3$ per ton, can likewise be successfully worked at times. In many cases the metallic contents of the ore is increased by mechanical concentration or by roasting (in the case of sulphides), or both, before the ore is smelted.

Classification of Ore Deposits. - Many attempts have been made to develop a suitable classification of ore deposits, and many schemes have been suggested (17). These are usually based either on form, mineral contents, or mode of origin. The first is perhaps the most practical from the miner's standpoint, the second is undesirable because several kinds of ore may often be found in the same ore body, while the third is the most scientific, and is of value to the mining geologist and engineer.

Those desiring to look into this phase of the subject in more detail are referred to the bibliography at the end of this chapter, especially the papers by Kemp (17), Posepny (24), and Van Hise (40).

Only one classification is given here, viz. that of $\mathrm{W}$. H. Weed, not because it is considered entirely satisfactory or especially simple, but because it embodies the results of the more modern studies of ore deposits and their genetic character.

\section{Classification of Ore Deposits (after Weed)}

A. Igneous, magmatic segregation.

(a) Siliceous.

1. Masses, Aplitic masses. Ehrenberg, Shartash.

2. Dikes, Beresite or Aplite. Berezovsk.

3. Quartz veins. Alaska, Randsburg, Black Hills. 
(b) Basic.

1. Peripheral masses. Copper, iron, nickel.

2. Dikes, titaniferous iron. Adirondacks, Wyoming.

B. Igneous emanations. Deposits formed by gases above or near the critical point, e.g. $365^{\circ} \mathrm{C}$. and 200 atmospheres for $\mathrm{H}_{2} \mathrm{O}$.

(a) Contact metamorphic deposits.

1. Deposits confined to contact. Magnetite deposits, chalcopyrite deposits, Kristiania type, gold ores, Bannock type.

2. Deposits impregnating and replacing beds of contact zone. Chalcopyrite deposits, pyrrhotite ores, magnetite ores, Cananea type, Gold tellurium ores, Elkhorn type, Arsenopyrite ores, Similkameen type.

(b) Veins closely allied to magmatic veins and to Division D.

1. Cassiterite. Cornwall.

2. Tourmaline copper. Sonora.

3. Tourmaline gold. Helena, Mont., Minas Geraes, etc.

4. Augite copper, etc. Tuscany.

C. Fumarolic deposits.

(a) Metallic oxides, etc., in clefts in lava. No commercial importance. Copper, iron, etc.

D. Gas-aqueous or pneumato-hydato-genetic deposits, igneous emanations, or primitive water mingled with ground water.

(a) Filling deposits.

1. Fissure veins.

2. Impregnation of porous rock.

3. Cementation deposits of breccia.

(b) Replacement deposits.

1. Propylitic. Comstock.

2. Sericitic kaolinic, calcitic, Copper silver, Silver lead. Clausthal.

3. Silicic dolomitic, silver lead, aspen.

4. Silicic calcitic, cinnabar.

5. Sideritic silver lead. Cœur d'Alene, Slocan, Wood River.

6. Biotitic gold copper. Rossland.

7. Fluoric gold tellurium. Cripple Creek.

8. Zeolitic. 


\section{Structure Types of Above}

Fissure veins.

Volcanic stocks, Nagyag. Cripple Creek.

Contact chimneys. Judith.

Dike replacements and impregnations.

Bedding or contact planes. Leadville, Mercur.

Axes of folds, synclinal basins, anticlinal saddles. Bendigo, Elkhorn.

E. Meteoric waters. Surface derived.

(a) Underground.

1. Veins.

2. Replacements. Iron ores, Michigan; copper ores, Michigan; lead, zinc.

3. Residual. Gossan iron ores, manganese deposits.

(b) Surficial.

1. Chemical. Bog iron ores, copper ores, sinters.

2. Mechanical. Gold and tin placers.

Sedimentary beds, iron ores, etc.

F. Metamorphic deposits. Ores concentrated from older rocks by metamorphism, dynamo or regional.

Igneous ore deposits, forming the first division, are those in which the metallic minerals have crystallized directly from the igneous magma during cooling.

The pneumatolytic deposits include those formed along igneous contacts, the material being supplied by the intrusive, as explained on an earlier page.

The gas-aqueous deposits include those which have been deposited from a mixture of water and steam, probably under pressure and at high temperature. They may either fill true fissures or porous deposits, or replace the wall rock lining a narrow fissure. It will be seen that the types mentioned under $\mathrm{B}$ and $\mathrm{C}$ might pass into each other. The same igneous mass could at great depths give off metallic min- 
erals under conditions mentioned under B, while higher up the emission from it would yield a deposit, classifiable under $\mathbf{C}$.

Fumarolic deposits include those in which metallic compounds are deposited from volcanic vapors or gases in clefts in lavas. They are of no commercial importance.

The last class is the result of meteoric circulation, the waters having collected the ore particles from the rocks through which they moved, and deposited them under favorable conditions, either on the surface or below it.

\section{REFERENCES ON ORE DEPOSITS}

General. 1. Barus, Amer. Inst. Min. Engrs., Trans. XIII : 417, 1885. (Electrical activity in ore bodies.) 2. von Cotta-Prime, Ore Deposits (English translation by Prime, N. Y., 1870). 3. Don, Amer. Inst. Min. Engrs., Trans. XXVII : 564, 1898. (Genesis of gold.) 4. Emmons, Amer. Inst. Min. Engrs., Trans. XXX : 177, 1901. (Secondary enrichment ore deposits.) 5. Emmons, Amer. Inst. Min. Engrs., Trans. XXII : 53, 1894. (Geol. distribution useful metals.) 6. Emmons, Geol. Soc. Amer., Bull. XV: 1, 1904. (Theories of ore deposition.) T. Emmons, A mer. Inst. Min. Engrs., Trans. XVI : 804, 1888. (Structural relations of ore deposits.) 8. Emmons, Colo. Sci. Soc., Proc. II : 189, 1885-7. (Origin of fissure veins.) 9. Fox, Amer. Jour. Sci. i, XXXVII : 199, 1839. (Vein formation by galvanic agency.) 10. Fuchs et De Launay, Traité des Gîtes Minéraux et Metallifères, Paris, 1893. 11. Finch, Colo. Sci. Soc., Proc. VII: 193, 1904. (Underground waters and ore deposition.) 12. Glenn, Amer. Inst. Min. Engrs., Trans. XXV : 499, 1896. (Fissure walls.) 13. Gillette, Amer. Inst. Min. Engrs., Trans. XXXIV: 710. (Osmosis theory.) 14. Jenney, Amer. Inst. Min. Engrs., Trans. XXXIII: 445, 1904. (Chemistry of ore deposition.) 15. Kemp, S. of M. Quart., $\mathrm{X}: 54,116,326,1889 ; \mathrm{XI}: 359,1890 ; \mathrm{XII}: 218,1891$. (Literature on ore deposits.) 16. Kemp, S. of M. Quart., XIII : 20, 1892. (Filling of veins.) 17. Kemp, S. of M. Quart., XIV : 8, 1893. (Classification of ore deposits.) 18. Kemp, Min. Indus., IV : 755, 1896. (Theories of origin of ores.) 19. Kemp, Ore Deposits of United States and Canada, N. Y., 1903. 20. Kemp, Amer. Inst. Min. Engrs., Trans. XXXIII : 699, 1903. (Relation of igneous rocks to ore deposition.) 21. Kemp, Amer. Inst. Min. Engrs., Trans. XXXI : 169, 
1901. (Igneous rock and vein formation.) 22. Lindgren, Amer. Inst. Min. Engrs., Trans. XXX : 578, 1901 . (Metasomatic processes in fissure veins.) 23. Lindgren, Amer. Jour. Sci. iv, V : 418, 1898. (Orthoclase gangue.) 24. Posepny, Amer. Inst. Min. Engrs., Trans. XXIII : 197, 1894. (Genesis of ore deposits.) 25. Penrose, Jour. Geol., II : 288, 1894. (Weathering of ore deposits.) 26. Phillips, Treatise on Ore Deposits, London, 1884. 27. Rickard, Eng. and Min. Jour., LXXIII : 106, 1902. (Recent advances in study of ore deposits.) 28. Rickard, Amer. Inst. Min. Engrs., Trans. XXXI: 198, 1902. (Bonanzas in gold veins.) 29. Rickard, Amer. Inst. Min. Engrs., Trans. XXVI : 193, 1897. (Vein walls.) 30. Rickard, Eng. and Min. Jour., LXV : 494, 1898. (Minerals accompanying gold.) 31. Sandberger, Untersuchungen über Erzgänge, Wiesbaden, 1882. 32. Suess, Eug. and Min. Jour., LXXVI : 52, 1903. (Hot springs.) 33. Spurr, Eng. and Min. Jour., LXXVI : 54, 1903. (Relation of rock segregation to ore deposition.) 34. Spurr, Amer. Inst. Min. Engrs., Trans. XXXIII : 288, 1903. (Magmatic segregation of rocks and ores.) 35. Vogt, Zeitsch. f. Prak. Geol., I : 4, 125, 257, 1893. (Magmatic segregation of ores.) 36. Vogt, Min. Indus., IV: 743, 1896. (Formation of eruptive ore deposits.) 37. Vogt, Zeitsch. f. Prak. Geol., VI : 225, 314, 377, 413, 1898; VII : 10, 1899 . (Distribution of elements and concentration of metals in ore bodies). 38. Vogt, Amer. Inst. Min. Engrs., Trans. XXXI : 125, 1902. (Problems in geology of ore deposits.) 39. Van Hise, Amer. Inst. Min. Engrs., Trans. XXX : 27,1901. (Deposition of ores.) 40. Van Hise, U. S. Geol. Surv., Mon. XLVII, 1905. (Metamorphism.) 41. Weed, Amer. Inst. Min. Engrs., Trans. XXX: 424, 1901. (Enrichment, gold and silver veins.) 42. Wagoner, Amer. Inst. Min. Engrs., Trans. XXXI : 798, 1902. (Gold and silver in sedimentary rocks.) 43. Weed, Eng. and Min. Jour., LXXVI : 193, 1903. (Cross vein ore shoots.) 44. Weed, Eng. and Min. Jour., LXXIV: 545, 1903. (Vein enrichment by ascending alkaline waters.) 45 . Weed, Eng. and Min. Jour., LXXIV : 513, 1902. (Contact deposits.) Also Lindgren. 46. Weed, Amer. Inst. Min. Engrs., Trans. XXXIII: 747, 1903. (Vein enrichment by ascending hot waters.) 47. Weed, Amer. Inst. Min. Engrs., Trans. XXXI : 634, 1902. (Influence of wall rock on mineral veins.) 48. Weed, U. S. Geol. Surv., Bull. 260, 1905. (Hot spring deposits.) 49. Weed, U. S. Geol. Surv., 21st Ann. Rept., II : 227, 1900. (Hot springs depositing gold.) 50. Whitney, Metallic wealth of U. S., Phil., 1854. 51. Weed, Amer. Inst. Min. Engrs., Trans. XXXIII: 731, 1903. (Contact deposits.) 


\section{CHAPTER XIV}

\section{IRON ORES}

IRON is an abundant constituent of the earth's crust, and yet few minerals are capable of serving as ores of this metal, because they do not contain it in the right combination or in sufficient quantity to make its extraction possible or profitable.

The iron ores having the greatest commercial value at the present day are usually those which are favorably located, of high quality, in considerable quantity, and possessing a structure such as to render their extraction easy. These four requirements have been met to such an eminent degree by the deposits located in the Lake Superior district that they now form the main source of supply for furnaces in the Eastern and Central states, many of the iron mines in the eastern part of the United States having been forced to shut down, although it is true that a number of small deposits are worked to supply local demand, owing to their proximity to furnace, flux, and coal, or because they possess certain desirable characteristics.

Ores of Iron. - The ores of iron, together with their composition and theoretic percentage of metallic iron, are :-

Magnetite. Magnetic iron ore. $\mathrm{Fe}_{3} \mathrm{O}_{4}$. . . 72.4 per cent. HEMatite. Specular iron ore, red hematite, fossil ore, clinton ore. $\mathrm{Fe}_{2} \mathrm{O}_{3}$. . . . 70 per cent. 
Limonite. Brown hematite, bog iron ore, ocher. $2 \mathrm{Fe}_{2} \mathrm{O}_{3}, 3 \mathrm{H}_{2} \mathrm{O}$. . . . . . . 59.89 per cent. SidERITE. Spathic ore, blackband, clay ironstone, kidney ore. $\mathrm{FeCO}_{3}$. . . . . 48.27 per cent. Prrite. $\mathrm{FeS}_{2}$. . . . . . . . . . 46.7 per cent.

Of these hematite is the most valuable by far, chiefly on account of its easier reduction, but also because of the greater richness of the known important deposits. The deficiency in iron contents shown by many ores is due to the presence of common rock-forming minerals in the gangue, the impurities yielded by them being: alumina, lime, magnesia, silica, titanium, arsenic, copper, phosphorus, and sulphur.

The effect of the last six is to weaken the iron in general. While silica in high amounts is not desirable, still some furnaces turn out iron for foundry purposes containing 10 or more per cent. Pyrite is the source of the sulphur, and apatite of the phosphorus. Titanium, a common but injurious ingredient, is found in many magnetite deposits (see Titaniferous magnetites; also refs. 20, 21), and up to the present time has rendered them practically useless, not because it interferes with the quality of the iron, but because it makes the ore highly refractory, and drives much of the iron into the slag. Experiments have been undertaken looking towards the utilization of these titaniferous magnetites for the manufacture of ferro-titanium. Manganese, when present, is found mostly in the limonite ores, and for certain purposes is desirable. It is also prominent in some of the Lake Superior hematites.

As phosphorus cannot be eliminated in either the blast furnace or the acid converter used in making Bessemer steel, and as the allowable limit 
of phosphorus in pig iron used for this purpose is $\frac{1}{16}$ per cent, a distinction is usually made between Bessemer and non-Bessemer ores, the maximum amount of phosphorus permissible in iron ore to be used for this purpose being ${ }_{10 \gamma \sigma}^{2}$ of the percentage of metallic iron contents of the ore. The phosphorus content of many high-grade ores, however, falls considerably below the allowable limit.

With the exception of iron ores formed by magmatic segregation, gas-aqueous action, and some deposits of sedi-

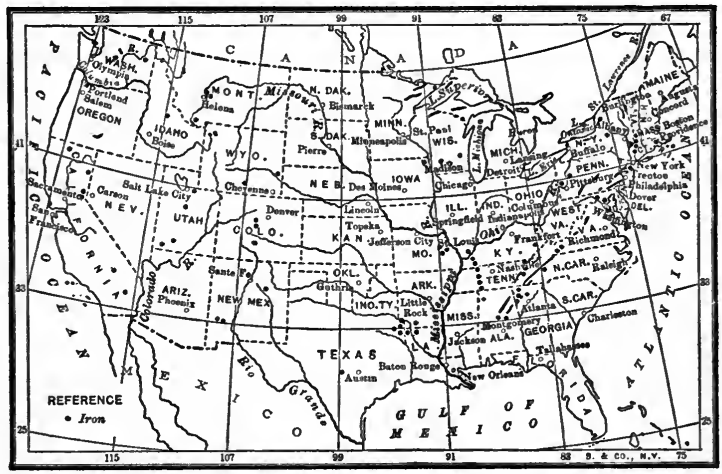

FIG. 45. - Map showing distribution of iron ores in the United States. Adapted from Ransome, Min. Mag., $X: 1$.

mentary character, most iron ores owe their concentration to the action of circulating meteoric waters, which have leached the iron out of the rocks and deposited it under favorable conditions either in cavities or by replacement.

The ore most commonly formed in this manner is limonite, and the deposits are of surficial character, but hematite bodies of similar origin are known. Deposits of siderite formed 
by replacement are frequently changed to limonite by weathering. Iron-ore bodies may show a variety of form, but most of those known in this country are lens-shaped or basin-shaped in outline.

The iron ores found in the United States are widely distributed (Fig. 45), and their age ranges from pre-Cambrian to recent. The occurrence and distribution of the different kinds of ore are best discussed separately.

\section{MAGNETITE}

Magnetite occurs in the United States, (1) as lenticular masses commonly in metamorphic rocks; (2) as more or less lens-shaped bodies in igneous rocks; (3) as sands on the shores of lakes and seas; and (4) as contact deposits.

The first class includes the most important deposits now worked in this country. The second and third groups run too high in titanium to have any commercial value at the present time, but the second may become of importance in the future, and moreover some of the deposits of this group are of large size. Undoubted representatives of the fourth class of commercial value are not worked. There are some, it is true, which occur along the contact of an intrusive and sedimentary rock, but their origin is ascribed to meteoric circulations.

Distribution of Magnetites in the United States. - NonTitaniferous Magnetites. - These are usually found in the form of lenticular deposits in metamorphic rocks. The most important series of occurrences is found in the crystalline belt of rocks extending from New York into Alabama, deposits being known in New York, New Jersey, Pennsylvania, Virginia, and North Carolina. 
Plate XIV

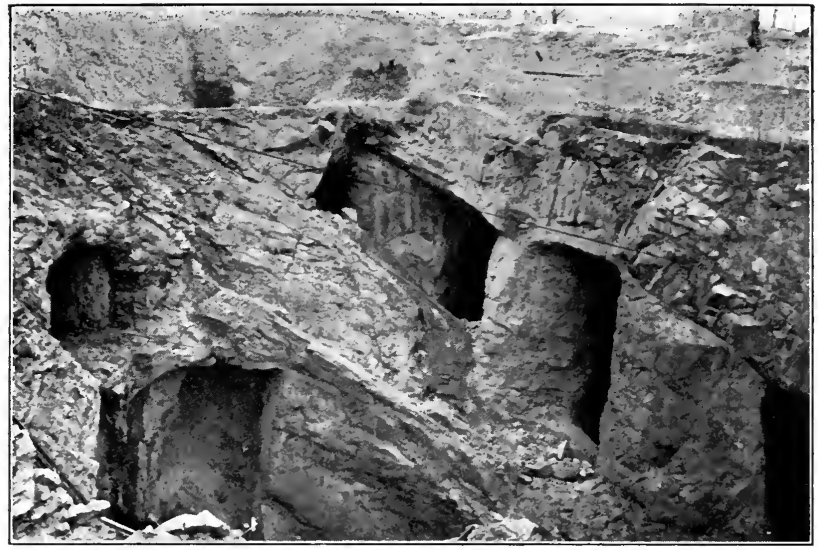

FJG. 1. - View of open eut in magnetite deposit, Mineville, N.Y. The pillars are ore left to support the gneiss hanging wall. After Witherbee, Iron Age, Dec. 17, 1903.

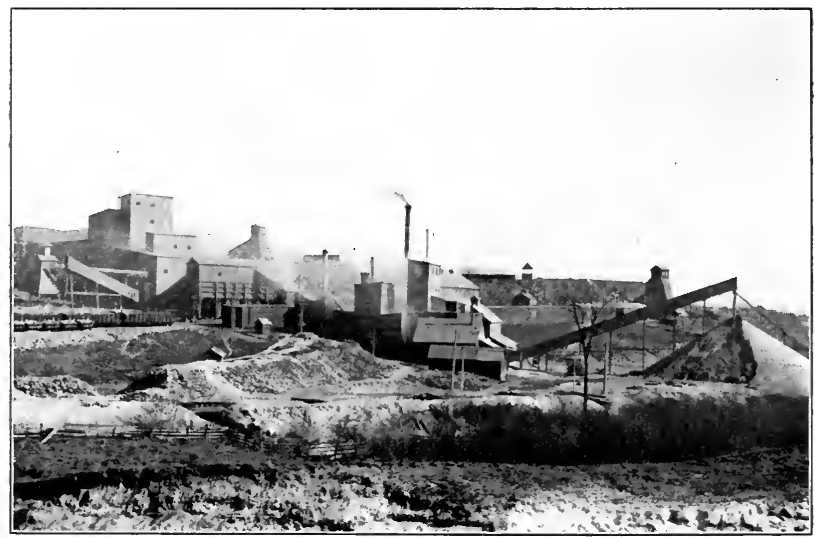

FIG. 2.-General view of magnetic separating plants and shaft houses, Mineville, N.Y. After Witherbee, Iron Age, Dec. 17, 1903. 
The lenses, which are interbedded with the gneisses of either acid or basic character and often conform with the latter in dip and strike, are of variable size, and may occur either singly or in series, the ore body commonly showing pinching and swelling, or even faulting. Welldefined boundaries are sometimes wanting. Feldspar, hornblende, and quartz are common gangue minerals, while apatite is prominent in some. Although the ore as mined is frequently of sufficient purity to be shipped direct to the blast furnace, in some instances it is so lean as to require concentration by magnetic methods. This same plan has been adopted at Mineville, New York, to treat the high phosphorus magnetite, thereby yielding a rich concentrate (68 per cent $\mathrm{Fe}$ ) for iron manufacture, a fairly pure apatite used in making fertilizers, and a hornblende tailings or waste product.

The magnetites have been extensively worked on the northern and eastern side of the Adirondacks, notably at Mineville (19), where one lens has been traced for a distance of 2000 feet. Many ore bodies have also been mined in New Jersey, where they are disposed in more or less parallel belts.

The origin of these magnetites has been a subject of much discussion, but their interfoliation with the gneisses is thought by some to indicate that the ores and rock had a common origin. Those believing the gneisses to be metamorphosed sediments thought the magnetites were originally limonite, but if the gneisses are metamorphosed igneous rocks, then the ore may represent magmatic segregations. The North Carolina magnetites have been suggested by Keith (18 a) to be replacement deposits, while Kemp be- 
lieves that the ore bodies at Mineville (19) have been formed by iron-bearing magmatic waters, which were given off from the neighboring gabbros and penetrated the gneisses, while the latter were probably still at great depths and before their metamorphism was complete. The presence of apatite and fluorite shows that mineralizing vapors also played a part. A similar origin has recently been suggested by Spencer (23) to explain some of the New Jersey magnetites. Other theories advanced are that the magnetite deposits were formed as beach sands or even river bars, but such an assumption would require the gneisses to be metamorphosed sediments.

A somewhat unique deposit and one of the largest ever worked occurs at Cornwall (17), Pennsylvania, where a bed of soft magnetite with some pyrite is found between Cambrian limestone and Triassic shales, and against igneous dikes. Their age has been placed as both Cambro-Silurian and also Triassic, and whether they represent metamorphosed pyritiferous shale or limonites is also unsettled. The ore runs from 40 to 55 per cent $\mathrm{Fe}$ and usually under $.02 \mathrm{P}$, but is rather high in $\mathrm{S}$ and $\mathrm{SiO}_{2}$.

Other Occurrences. - Magnetite occurs sparingly in the Marquette range of Michigan, where it is found in the schists. Other western occurrences include Colorado (6), Utah (32), Wyoming (1a), New Mexico (1a), and California.

In the table given below there will be found the analyses of a number of magnetite samples from eastern mines.

These it will be seen show considerable variation in their metallic iron contents, and are not all to be regarded as a strict average of the region which they represent. 
Analyses of Magnetites

\begin{tabular}{|c|c|c|c|c|c|c|c|c|c|c|c|c|}
\hline & Fe & $\mathrm{SiO}_{2}$ & $\mathbf{P}$ & $\mathrm{Mn}$ & $\mathrm{Al}_{3} \mathrm{O}_{3}$ & $\mathrm{CaO}$ & $\mathrm{MgO}$ & s & $\mathrm{THO}_{2}$ & Alk & $\mathrm{H}_{3} \mathrm{O}$ & $\mathrm{FeS}_{2}$ \\
\hline Belvidere, N.J. · & 51.42 & 8.85 & 1.048 & .17 & 3.86 & 1.68 & .18 & & & & & \\
\hline Little Mine, N.J. . & 67.54 & 1.20 & .02 & .90 & .74 & .31 & .51 & .08 & $\mathbf{T r}$ & & & \\
\hline $\begin{array}{l}\text { McKnightstown, } \\
\text { Adams Co., Pa. . }\end{array}$ & 46.90 & 17.054 & $\begin{array}{r}\mathrm{P}_{2} \mathrm{O}_{5} \\
.128\end{array}$ & $\begin{array}{l}\mathrm{MnO} \\
.896\end{array}$ & 4.424 & 1.868 & 4.198 & & & .953 & 5.00 & .05 \\
\hline Dillsburg, York Co. & & & $\mathrm{P}_{2} \mathrm{O}_{3}$ & $\mathrm{MnO}$ & & & & $\mathrm{SO}_{3}$ & & & & \\
\hline Pa. . . . & 45.00 & 20.33 & $\begin{array}{l}.107 \\
P\end{array}$ & .036 & 3.775 & 5.604 & 4.129 & 1.105 & & & 1.14 & 1.605 \\
\hline Cornwall, Pa. . & 42.70 & & .135 & & 3.411 & & & .62 & & & & \\
\hline $\begin{array}{l}\text { Mineville, N.Y. } \\
\quad \text { (Mine 21) . . . }\end{array}$ & 62.10 & & $\begin{array}{c}P \\
1.198\end{array}$ & & & & & & & & & \\
\hline
\end{tabular}

Titaniferous Magnetites. - These form a peculiar class by themselves, and with only one or two exceptions are found always associated with rocks of the gabbro family. The ore bodies occur in the midst of igneous intrusions, and according to $\operatorname{Kemp}(19,20,21)$, seem to have been formed by the segregation of fairly pure titaniferous iron oxide, either before or during the process of cooling and consolidation.

Mineralogically they may contain both ilmenite, $\mathrm{FeO}$, $\mathrm{TiO}_{2}\left(\mathrm{FeO}, 46.75 ; \mathrm{TiO}_{2}, 53.25\right)$, and titaniferous magnetite, which is of variable composition. The gangue minerals may be pyroxene, brown hornblende, hypersthene, enstatite, olivine, spinel, garnet, and plagioclase. The ores are usually low in phosphorus and sulphur, but $\mathrm{Va}, \mathrm{Cr}, \mathrm{Ni}$, and Co are almost always present. In the United States they are found in New York, New Jersey, Colorado, Minnesota, and several other states, but are not worked.

The following analyses illustrate their composition :- 
Analyses of Titaniferous Magnetites

\begin{tabular}{|c|c|c|c|c|c|c|c|c|}
\hline & & & & & 1 & 2 & 3 & 4 \\
\hline $\begin{array}{l}\mathrm{FeO} \\
\mathrm{Fe}_{2} \mathrm{O}_{3} \\
\mathrm{TiO}_{2} \\
\mathrm{SiO}_{2} \\
\mathrm{Al}_{2} \mathrm{O}_{3} \\
\mathrm{Cr}_{2} \mathrm{O}_{3} \\
\mathrm{~V}_{2} \mathrm{O}_{5} \\
\mathrm{MnO} \\
\mathrm{CaO} \\
\mathrm{MgO} \\
\mathrm{H}_{2} \mathrm{O} \\
\mathrm{P}_{2} \mathrm{O}_{5}\end{array}$ & $\begin{array}{l}\cdot \\
\cdot \\
\cdot \\
\cdot \\
\cdot \\
\cdot \\
\cdot \\
\cdot \\
\cdot \\
\cdot \\
\cdot \\
\cdot\end{array}$ & 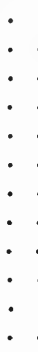 & $\begin{array}{lc}\cdot & \cdot \\
\cdot & \cdot \\
\cdot & \cdot \\
\cdot & \cdot \\
\cdot & \cdot \\
\cdot & \cdot \\
\cdot & \cdot \\
\cdot & \cdot \\
\cdot & \cdot \\
\cdot & \cdot \\
\cdot & \cdot \\
\cdot & \cdot\end{array}$ & 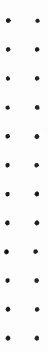 & $\begin{array}{c}70.50 \\
14.00 \\
8.60 \\
4.00 \\
- \\
- \\
- \\
1.60 \\
2.30 \\
- \\
-\end{array}$ & $\begin{array}{r}80.78 \\
12.09 \\
2.02 \\
2.58 \\
2.40 \\
- \\
- \\
- \\
- \\
- \\
.03\end{array}$ & $\begin{array}{c}\left\{\begin{array}{l}27.95 \\
15.85\end{array}\right\} \\
15.66 \\
17.90 \\
10.23 \\
.51 \\
.55 \\
\operatorname{Tr} \\
2.86 \\
6.04 \\
.04 \\
.14\end{array}$ & $\begin{array}{c}79.78 \\
12.08 \\
.75 \\
4.62 \\
.32 \\
\text { Tr } \\
.28 \\
.13 \\
2.04 \\
- \\
-\end{array}$ \\
\hline & & & & & 101.00 & 99.90 & 99.05 & 100.00 \\
\hline
\end{tabular}

1. Grape Creek, Colo.

2. Mayhew Range, Minn.
3. Split Rock, N.Y.

1. Greensboro, N.C.

Magnetite Sands. - These are found in those regions where the beach sands are composed of weathering products of metamorphic and igneous rocks. The sorting action of the waves serves to carry the heavy mineral grains high up on the beaches, where they form black streaks, composed mostly of magnetite (usually titaniferous), mixed with monazite, apatite, and other heavy minerals.

Deposits are known in this country on the shores of Lake Champlain, Long Island, etc., but they are of small extent as well as lacking in quality.

New Zealand and Brazil are said to possess magnetite sands of commercial value. 


\section{HEMATITE}

This is by far the most important ore of iron in the United States, having in 1903 formed 86.6 per cent of the total production. Its distribution, however, is rather restricted, and about five sixths of the total quantity mined came from the Lake Superior region. The varieties mined in the United States include the earthy, specular, oölitic, and fossiliferous. Most of the deposits belong to the replacement type and are basin-shaped, while bedded and contact deposits are also known, but the last are not worked.

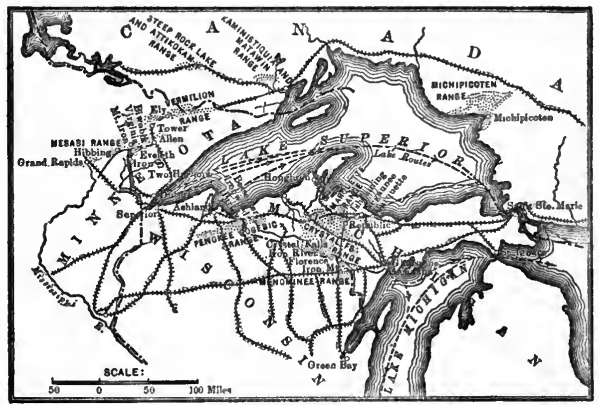

Fra. 46. - Map of Lake Superior iron regions, shipping ports, and transportation lines. After Grant, Min. Mag., X: 175.

Distribution of Hematite Ores in the United States. - At the present day there are but two very important hematite producing regions, viz. the Lake Superior region and the Birmingham, Alabama, area.

Lake Superior Region. - Under this head are included a great series of deposits lying in the region surrounding the south and west sides of Lake Superior (13). The rocks are of remote geological age, as can be seen from the following section:- 
Cambrian. Lake Superior sandstone.

Keweenawan. $\{$ Upper sedimentary, or copper series.

$\{$ Lower igneous, with interstratified sediments.

Upper Huronian. $\left\{\begin{array}{c}\text { Sedimentaries with local volcanics, and cut by Upper } \\ \text { Huronian and Keweenawan intrusions. }\end{array}\right.$

Lower Huronian. Sediments with some volcanics, cut by intrusives.

Archæan or

Basement com-

plex. Mainly ancient igneous rocks and some sediments. These igneous intrusions pierced by many others of later date.

Each of the above series is separated from its neighbor by a great unconformity, due to intervals of elevation
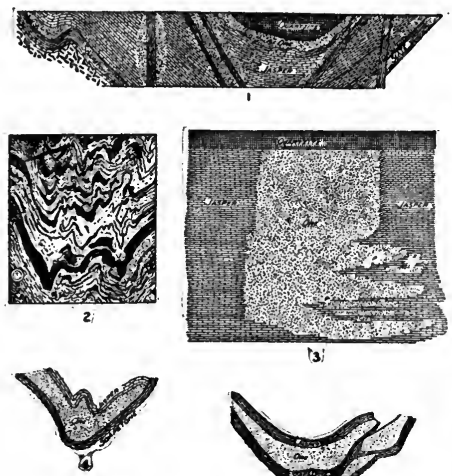

(3)
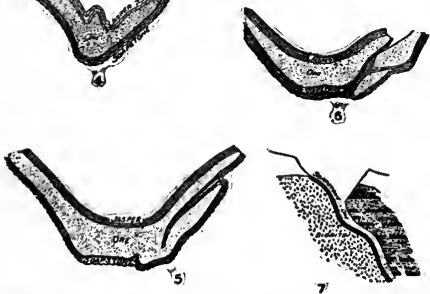

FIG. 47. - Sections of iron-ore deposits in Marquette range. After $\mathrm{V}$ an Hise. above the sea level and periods of erosion.

The rocks of the ironbearing formations are cherty iron carbonates; ferrous silicate rocks; pyritic quartz rocks (Archæan); ferruginous slates; ferruginous cherts ; jaspilites ; amphibolites and magnetite schists; iron ore deposits; detrital ferruginous rocks from foregoing. Since their formation they have been folded, faulted, and sometimes brecciated, and it is in the troughs formed by folding that the ore usually occurs (Fig. 47). 



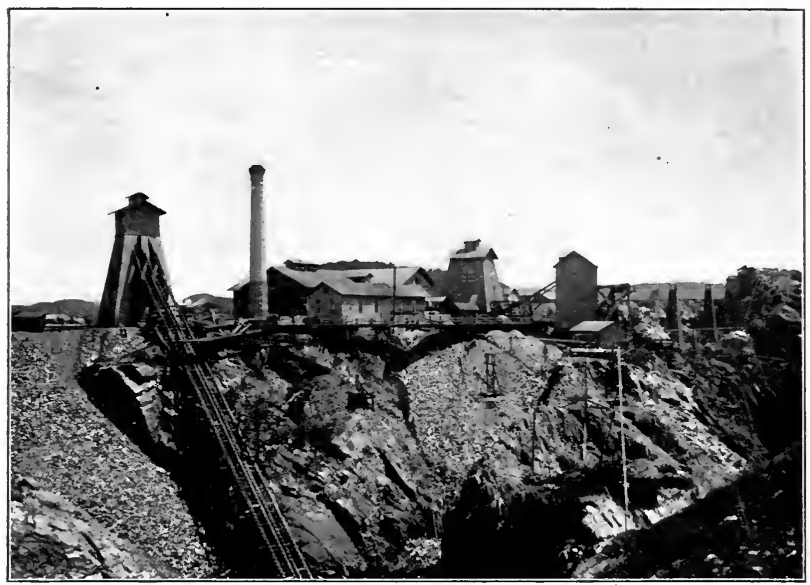

Fug. 1. - Iron mine, Soudan, Minn. Shows old open pit with jasper horse in middle.

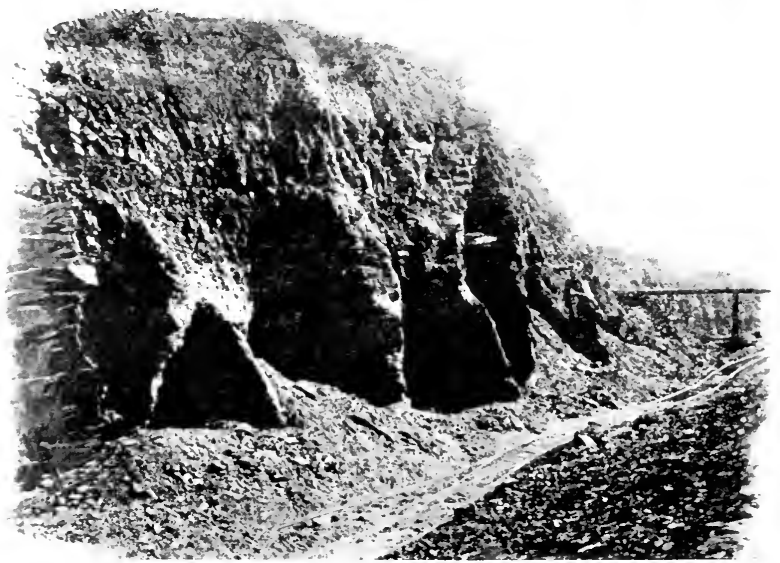

Fig. 2. - Outcrop of Clinton iron ore, Red Mountain, near Birmingham, Ala. Photo. from Tennessee Coal and Iron Company. 
The Archæan, Lower Huronian, and Upper Huronian are the most productive iron-bearing formations, the last mentioned containing the ore at two horizons, viz. near its base and in its central portion.

Six districts, or ranges, are recognizable in the Lake Superior region, viz. Marquette (13) and Crystal Falls (27) in Michigan; Menominee (25) in Wisconsin; PenokeeGogebic (37) on the Michigan-Wisconsin boundary; Mesabi

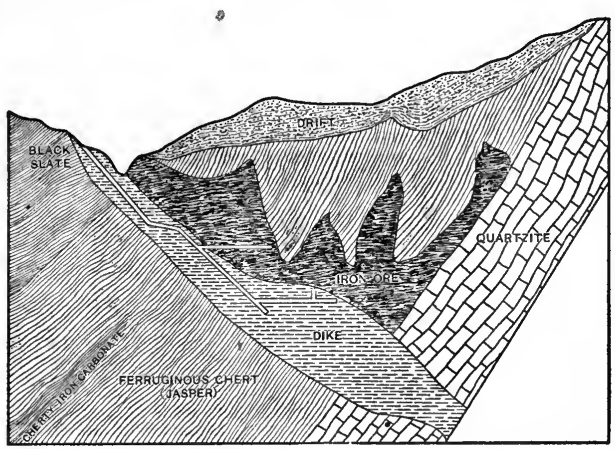

FıG. 48. - Generalized vertical section through Penokee-Gogebic ore deposit and adjacent rocks; Colby mine, Bessemer, Mich. After Leith.

(31) and Vermilion (28) in Minnesota. The general mode of occurrence of the ore in several of these is shown in Figs. 47,48 , and 49 .

The ore is not found at the same horizons in all the districts, the Marquette being the only one where all the iron-bearing formations of the series are found. Of these, the Archæan iron-bearing formations are unproductive, the chief ore bodies lying within the Lower Huronian and at the base of the Upper Huronian. In the Crystal Falls district, the iron-bearing horizon of the Lower Huronian carries the ore as well as the horizon within the Upper Huronian. In both the 
Penokee and Mesabi districts the conditions are similar to those in the western part of the Crystal Falls district, the ore being found in a single formation in the Upper Huronian, while the same one in the Marquette region is thin and of little consequence.

The smaller deposits are associated with plications, folding, brecciations, etc., but the larger masses of ore occur at the contact of the iron-bearing formations with others or between different members of the iron-bearing formations. These contacts were favorable for concentration of ore, because they are planes or horizons of slipping, and the effect of this movement would be to loosen the rock, thus making channels for the percolating water. Underfying the deposits of first

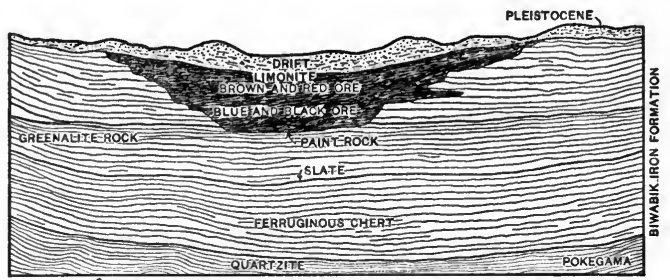

FIG. 49. - Generalized vertical section through Mesabi ore deposit and adjacent rocks. After Leith.

magnitude there occur impervious formations which are bent into troughs. Slate, quartzite, limestone, or igneous rock may all serve as floors, or two may combine, as in the Penokee-Gogebic district, where the trough is formed by the intersection of quartzite and dikes. The ore bodies are often $U$-shaped in section, being thickest at the bottom.

The origin of these ores has for years been a puzzling problem to geologists (37). Foster and Whitney considered them eruptive, while Brooks and Pumpelly looked upon them as altered limonite beds. In recent years the studies of Irving and Van Hise (37), aided by others, have demonstrated that the ores owe their origin partly to a replacement of the chert. The trough-shaped location shows that 
the deposits were formed after the rocks had been folded, and it is also noticed that these troughs are even still the lines of underground waters. That they have been produced by descending waters is shown by the fact that they are on the upper side of the impervious bed, and because the ores are oxidized ones, viz., hematite and limonite.

The chemistry of the process is thought to be as follows: Part of the ferric oxide was deposited as an original sediment containing silica and other impurities, or in some cases as sulphides or carbonates. This was later enriched by the addition of iron carbonate. These were originally contained in the rocks near the surface, and became oxidized by percolating waters, which took up the carbon dioxide liberated, and were thus able to dissolve iron carbonates or silicates, which they came in contact with in their downward course toward the troughs in which the ore is found.

The precipitation of the ore was then caused by these solutions meeting with others which had filtered in by a more open and direct path from the surface, and hence contained some free oxygen, which converted the dissolved iron compounds into oxides.

The same solutions, carrying carbon dioxide, dissolved the alkalies out of the basic igneous rocks and these waters were then able to dissolve silica. In some cases the solution of silica proceeded faster than the deposition of the iron ore, and made the rock quite porous. The general result was therefore a concentration of the iron and removal of silica.

The ores of the Lake Superior region vary from hard blue ores to soft earthy ones. They are mostly hematite, with small quantities of limonite, but some magnetite is known in the Marquette district. The following table taken from Birkenbine's report gives a number of typical analyses ( 1 a). Many additional ones can be found in the reports on Mineral Resources issued annually by the United States Geological Survey. 
Typical Analyses of Lake Superior Iron Ores

\begin{tabular}{|c|c|c|c|c|c|c|c|}
\hline Conten? & & & $\begin{array}{c}\text { MARQUETTE } \\
\text { RANGE }\end{array}$ & $\begin{array}{c}\text { MENOMINEE } \\
\text { RANGE }\end{array}$ & $\begin{array}{l}\text { Gogebic } \\
\text { RANGE }\end{array}$ & $\begin{array}{c}\text { VERMILION } \\
\text { RANGE }\end{array}$ & $\begin{array}{l}\text { MEsabi } \\
\text { RANGE }\end{array}$ \\
\hline Iron & • & - & 56.5 & 55.2423 & 56.308 & 61.36 & 56.0996 \\
\hline Phosphorus . & - & . & .0353 & .05994 & .0338 & .0373 & .0365 \\
\hline Silica . . & . & . & 4.584 & 6.7693 & 3.3961 & 4.2545 & 3.4867 \\
\hline Sulphur . & . & . & .0089 & - & - & - & - \\
\hline Moisture . & • & . . & 11.85 & 6.525 & 10.828 & 4.5649 & 12.3158 \\
\hline
\end{tabular}

Analyses of Siliceous Ores

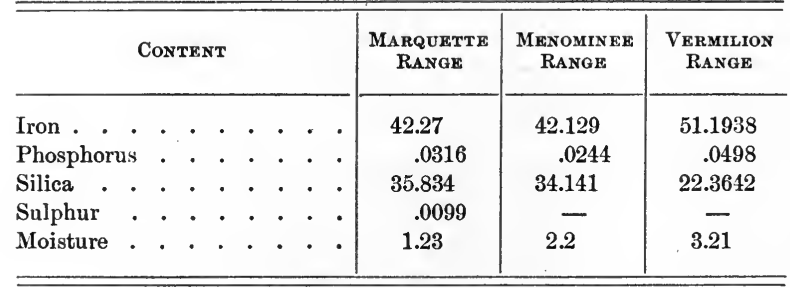

Most of the rich ores are found above the 1000-foot level, except in the Mesabi district where the deposits are shallow, as compared with their horizontal extent, some, however, being over 400 feet deep.

In the early period of mining many of the Lake Superior bodies were worked as open cuts, but with depth underground working has been resorted to. There are many deposits in the Mesabi district which are worked as open pits from which the granular ore is dug with a steam shovel and loaded directly on to the ore cars, which are run along the working face (Pl. XVI):

The development of the Lake Superior region has ad- 
Plate XVI

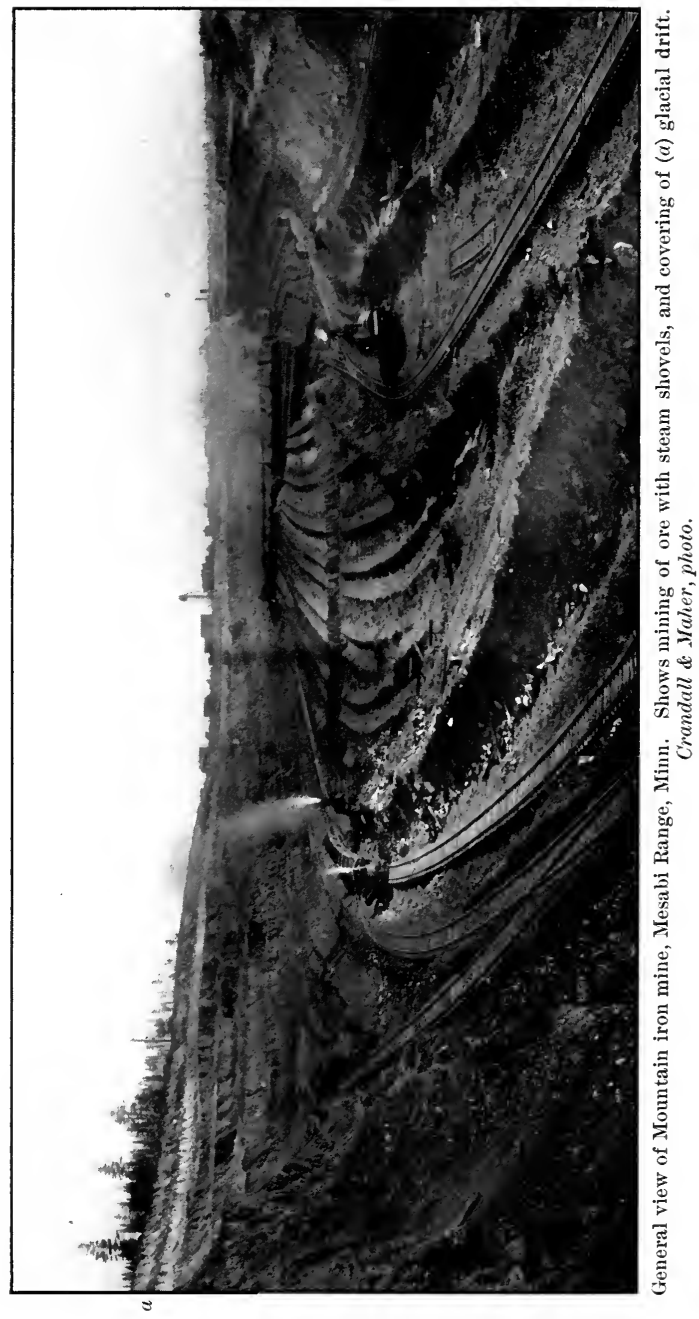



vanced with phenomenal strides. The Marquette range was developed as early as 1849 , and the Mesabi as late as 1892 .

The total yield of the Lake Superior region from 1850 to 1902 was $246,558,896$ long tons. Between 1891 and 1903 it was $191,646,959$ long tons, or 77.75 per cent of the total amount mined. Van Hise, in estimating the available quantity of high-grade ore still in the ground, believes that even if it approached 1,000,000,000 long tons, mining at the rate of $20,000,000$ tons per year would exhaust the supply in the first half of the twentieth century. Indeed, it will not be many years before lower grades of ore, hitherto thrown aside, will be shipped to market. Already ore carrying 40 per cent iron, but low in phosphorus and high in silica, has been sold for mixing in with highgrade Mesabi ores, and Van Hise believes that ores below 40 per cent in iron will be marketed before another generation.

The market value of the ores is based on the iron contents, percentage of water, and amount of phosphorus, and at times the manganese contents is taken into consideration. Some objection has been raised in the last few years to the fine character of the Mesabi ore and its tendency to clog the blast furnace, therefore requiring the admixture of lump ore from the other ranges; but this objection is rapidly disappearing, and some furnaces now use over $\mathbf{7 5}$ per cent of Mesabi ore in their charge.

The Lake Superior iron ore region is not only the most important in the world, but the production of some of the individual mines is startling. This enormous output can, perhaps, be best appreciated by some comparative figures. Thus, for example, the production of $15,371,396$ long tons of ore mined in Minnesota in 1903 is about three quarters of the total amount extracted from the famous magnetite deposits of Cornwall, Pennsylvania, since they were opened in 1740 , or of the total 
quantity of New Jersey magnetites mined since they were first worked in 1710. The production even of single mines is often great, six mines in 1903 producing over $1,000,000$ long tons of ore each $(1 a)$.

Clinton Ore $(35,36,30)$. - This ore, which is also called fossil, pea, or dyestone ore, was given the first name on account of the ore bed having been originally discovered at Clinton, New York. It is one of the most persistent ironore deposits that is known, for it occurs wherever rocks belonging to the Clinton stage of the Silurian are found,

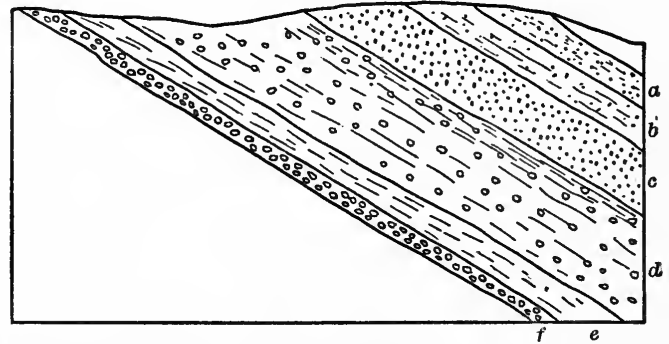

Fra. 50.- Section Clinton ore beds, Oxmoor, Ala. a, red sandstone, 5'; $b$, yellow sandstone, $6^{\prime}$; $c$, red sandstone, $15^{\prime} ; d$, ore, $22^{\prime}$, npper $2^{\prime}$ soft; $e$, shale, $6^{\prime}: f$, rich ore, $2^{\prime} 6^{\prime \prime}$. After Smyth, Amer. Jour. Sci., June, 1892.

including many localities, therefore, along the line of the Appalachians from New York to Alabama, as well as in Ohio and Wisconsin. In Pennsylvania there are several belts of the ore, owing to the presence of many eroded folds carrying the Clinton rocks.

The ore is interstratified with sandstones and shales, varies in thickness from a few inches to ten or twenty feet, is at times oölitic in its structure, and at others is made up of a mass of small fossils. At Birmingham, where the greatest development has occurred, the ore occurs in a ridge known as Red Mountain, the bed having a shale roof and sandstone 
floor, while the thickness of the main bed varies from twelve to twenty feet. The beds dip gently to the east, and the iron ore is worked by means of slopes, although the early workings at some of the mines were open cuts, on account of the thin overburden. The prominence of this locality is due to peculiar conditions, the ore being bordered on the west by Cambrian limestone which forms the valley floor, while on the western side of the valley the coals of the Warrior Field outcrop. Thus the three essential elements for iron manufacture are brought in close contact by folding and faulting. East of the iron range are two additional coal basins.

The great development of this ore in Alabama is due partly to favorable local conditions and partly to its remoteness from the Lake Superior region.

The origin of these ore bodies has been argued from different standpoints, some holding that they represent altered limestone beds $(35 a)$, because of the presence of fossils in them, while the concentric nature of the oölites, with a nucleus of worn quartz grains, has led others, especially Smyth, to ascribe a concretionary origin (36) to them. The former theory is strengthened by finding at many places an increase of the lime contents of the ore with the depth. Thus at Attalla, Alabama, the Clinton limestone at 250 feet from the surface carries only 7.75 per cent of iron, while at the outcrop it has 57 per cent of iron.

The Clinton iron ores usually run high in phosphorus and also silica. Of the two following analyses, No. 1 is soft ore and No. 2 hard ore. The latter runs higher in lime. A difference also appears to exist between the composition of the fossil or upper ore bed and the oolitic or lower ore bed, as represented by analyses 3 and $4(30)$ of the following table:- 


\begin{tabular}{|c|c|c|c|c|c|c|c|c|c|c|c|c|c|}
\hline & & & & & & & & & & 1 & 2 & 3 & 4 \\
\hline $\mathrm{Fe}$. & . & . & - & - & - & - & - & - & . & 52.87 & 37.00 & & \\
\hline $\mathrm{Fe}_{2} \mathrm{O}_{3}$ & • & • & • & . & • & • & • & . & . & - & - & 30.24 & 46.04 \\
\hline $\mathrm{P}$. & . & . & . & . & . & . & . & . & . & .43 & .37 & - & 一 \\
\hline $\mathrm{P}_{2} \mathrm{O}_{5}$ & . & . & . & . & - & . & . & . & - & & & .75 & 1.29 \\
\hline $\mathrm{S}$. & . & . & . & . & . & 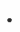 & . & . & • & .11 & .07 & - & - \\
\hline $\mathrm{SO}_{3}$. & . & . & - & - & - & . & . & - & - & - & - & .15 & .20 \\
\hline $\mathrm{SiO}_{2}$. & & . & . & . & . & • & . & • & • & 13.66 & 13.44 & 8.71 & 16.82 \\
\hline $\mathrm{Al}_{2} \mathrm{O}_{3}$ & - & . & . & . & . & - & • & • & • & 6.13 & 3.18 & 3.67 & 3.54 \\
\hline $\mathrm{CaO}$ & . & - & - & • & - & . & . & - & . & 1.26 & 16.20 & 20.64 & 9.96 \\
\hline $\mathrm{MgO}$ & . & . & . & . & . & . & . & . & • & .37 & - & 7.84 & 3.41 \\
\hline $\mathrm{MnO}$ & . & - & - & - & . & - & . & . & • & .30 & - & - & - \\
\hline $\mathrm{H}_{2} \mathrm{O}$. & . & . & • & . & . & - & . & . & - & 1.62 & .50 & - & - \\
\hline $\mathrm{CO}_{2}$. & - & • & - & - & - & . & - & - & • & .08 & 12.24 & 24.78 & 13.62 \\
\hline
\end{tabular}

Other Occurrences. - Extensive deposits of hematite in Carboniferous limestone are found in Laramie County, Wyoming (1). The ore carries 60 to 67 per cent iron, $2 \frac{1}{2}$ to 5 per cent silica, and is low in phosphorus. In New Mexico, near Hanover, a deposit carrying about one quarter hematite and three quarters magnetite, along the contact of granite and limestone, is also extensively worked. Deposits of hematite in brecciated Carboniferous limestones, and formed probably by replacement, are known in Iron and Washington counties of southwestern Utah, and are probably the largest iron-ore deposits in the West. Other deposits are found in the Wasatch Mountains, along the contact of andesite and limestone. The ore here consists of hard black crystallized hematite and magnetite, associated with chalcedony and crystalline quartz. Leith (32) considers it to be a replacement deposit. While much of the ore is of good quality, it is mostly non-Bessemer. The Utah deposits are 
at present too far from the railroad to be of much value, but are to be looked on as an important future source of supply. Specular hematites also occur at Pilot Knob, Missouri, interstratified with breccias and porphyry sheets, and were formerly much worked.

\section{LIMONITE}

Limonite (41-52) or brown hematite is, like magnetite, of comparatively little importance in the United States as compared with hematite, having yielded an average of but 12.2 per cent of the total iron production of the United States in the last fifteen years, and but 8.8 per cent of the total domestic iron ore production in 1903.

Although deposits of limonite are widely scattered over the United States, about nine tenths of the total quantity comes from the deposits located in western New England and the Appalachian belt.

Owing to their mode of origin, limonites are rarely of high purity, being commonly associated with more or less ferruginous clay, which has to be separated from the ore by washing.

Limonite may occur under a variety of conditions and associated with different kinds of rocks, but two important types are recognized, viz. bog ores, and residual limonites.

Bog Ores. - The bog ores are formed by the precipitation of limonite in swamps, ponds, or lakes. The iron is dissolved from the rocks or soil by percolating waters charged with carbon dioxide or organic acids, either in the form of ferrous carbonate or ferrous sulphate. As these iron-bearing waters 
discharge into the ponds the iron compounds are oxidized to hydrous ferric oxide or limonite, which settles on the bottom. Such ores are usually impure from an admixture of sand or clay which has been deposited at the same time, and are rarely of any thickness. They are of no commercial value in the United States, but in foreign countries are worked in Sweden, in which kingdom they have been known to accumulate in ponds to the depth of 18 inches or more every 15 to 30 years. The ore is collected periodically by dredging. Bog ore is also obtained in Quebec, Can.

Residual limonites. - The residual limonites are a much more important class, and form (1) by the weathering of

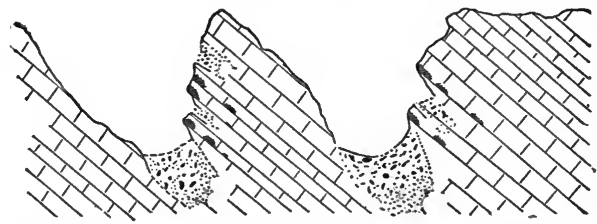

Fig. 51. - Section illustrating formation of residual limonite in limestone. After Hopkins, Geol. Soc. Amer., Bull. XI: 485.

pyritiferous veins (see gossan, Chapter XIII), or (2) more often from the weathering of ferruginous rocks. The second process results in the formation of deposits of ironstained clay scattered through which are nodules and irregularly shaped masses of limonite, these making up from 5-10 per cent of the entire mass.

The limonite may accumulate first by deposition in the cracks of the rock, or by impregnation or replacement, and prior to the breaking down of the rock to a mass of residual clay. Since these deposits often represent the concentration of iron from a great thickness of rock, it is not 
Plate XVII

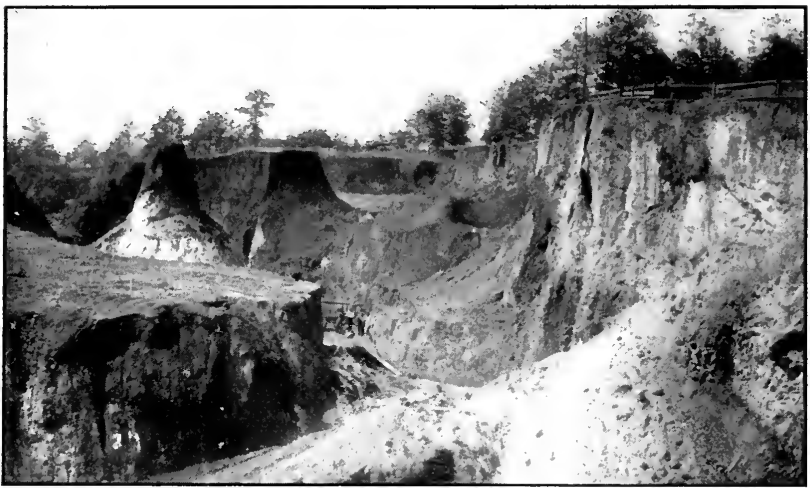

Fig. 1. - Pit of residual limonite, Shelby, Ala. After MeCulley, Alu. Geol. Surv. Report on Valley Regions, Pt. II: 77, 1897.

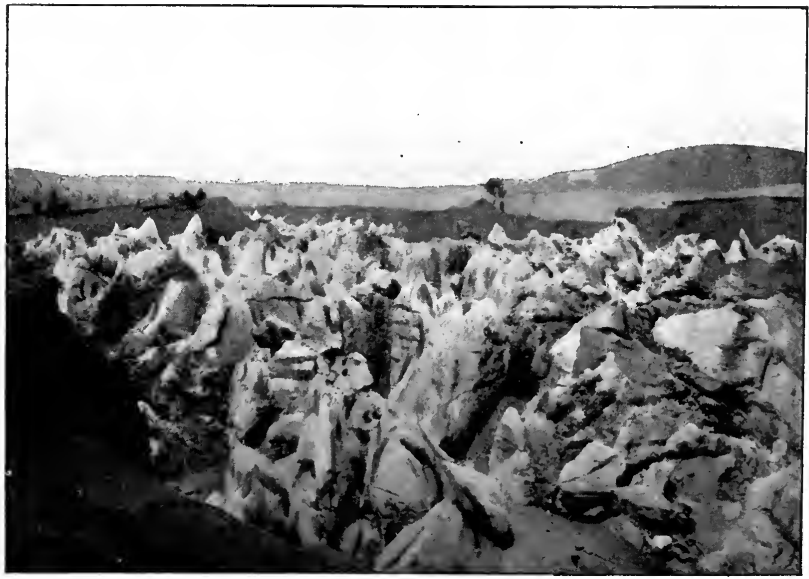

Fig. 2. - Old limonite pit, Ivanhoe, Va., showing pinnacled surface of limestone which underlies the ore-bearing clay. The level of surface before mining began is seen on either side of excavation. H. Ries, photo. 

necessary that the parent material contain a high percentage of iron.

An important belt of residual limonites of Cambro-Silurian age, and associated with slates, schists, or limestone, is found extending from Vermont to Alabama, along the Great Valley, and consisting of beds of residual clay carrying limonite nodules $(42,44-48 a)$. This type of deposits is worked from Vermont to Alabama, and some of the larger mines in the latter state have an annual production of over 100,000 tons. Those found in Georgia are associated with manganese. Plate XVII, Fig. 2, shows the irregular surface of the Cambro-Silurian limestone in one of the Virginia pits.

In addition to these, important deposits are found in Virginia, representing the weathered portion of a great belt of pyrite bodies. This extends for over 20 miles and is known as the "Great Gossan Lead," its contents averaging from 40 to 41 per cent metallic iron ( $48 b$, see also Copper, Ducktown, Tennessee).

The Oriskany formation also carries large deposits of limonite to the westward of the Cambro-Silurian belt, and these are actively worked in Virginia (49).

Other Occurrences. - Limonites of more or less distinctly bedded character are found in the Tertiary of northeastern Texas $(50,52)$, where they occur as thin beds capping the hills and are mined for local use (50). Others are found at the same horizon in Arkansas but promise to be of little commercial value. In the former case they are closely associated with greensands, and may have formed by weathering either from these or from pyrite grains. Small deposits are known in Iowa (41), Wisconsin, Minnesota, and Oregon (3a). Much limonite, at times manganiferous and containing even small 
quantities of silver, is obtained from the gossan of the Leadville ore bodies. Its chief use is as a flux.

The following analyses give the composition of limonites from several localities.

Analyses of Limonites

\begin{tabular}{|c|c|c|c|c|c|c|c|c|c|c|}
\hline & $\mathrm{Fe}$ & $\mathbf{P}$ & $\mathbf{s}$ & $\mathrm{SiO}_{2}$ & $\mathrm{Al}_{2} \mathrm{O}_{3}$ & $\mathrm{CaO}$ & $\mathrm{MgO}$ & $\mathrm{H}_{2} \mathrm{O}$ & Moist. & $\mathrm{MnO}_{2}$ \\
\hline $\begin{array}{l}\text { Average coniposition Alabama } \\
\text { limonite . . . . . . } \\
\text { A verage of } 29 \text { commercial } \\
\text { analyses, Pa., Cambro-Silurian } \\
\text { ores . . . . . . . } \\
\text { Rusk, Cheroke Co., Texas . . } \\
\text { Allamakee County, Ia. . . . }\end{array}$ & $\begin{array}{l}48.54 \\
43.47 \\
44.68 \\
54.32\end{array}$ & $\begin{array}{c}.38 \\
\mathrm{P}_{2} \mathrm{O}_{5} \\
1.10 \\
.09 \\
1.8\end{array}$ & $\begin{array}{c}.09 \\
.06 \\
\mathrm{SO}_{5} \\
.20 \\
-\end{array}$ & \begin{tabular}{|l}
11.22 \\
18.97 \\
18.90
\end{tabular} & $\begin{array}{l}8.61 \\
\\
2.89 \\
\\
5.76\end{array}$ & $\begin{array}{l}.84 \\
.48 \\
.18\end{array}$ & $\begin{array}{l}.42 \\
\mathrm{Tr}\end{array}$ & 6.00 & $\begin{array}{r}7.00 \\
11.62\end{array}$ & 2.85 \\
\hline
\end{tabular}

Those of the Appalachian belt are much used by pig-iron manufacturers because, owing to their siliceous character, they can be mixed in with high-grade Lake Superior ores which are deficient in silica. They are also cheaper, and their mixture with other ores seems to facilitate the reduction of the iron in the furnace.

\section{SIDERITE}

Siderite (53-58) is the least important of all the ores of iron mined in the United States, both on account of the small quantity and its low iron contents. When of concretionary structure, with clayey impurities, it is termed clay ironstone, and these concretions are common in many shales and clays. In some districts siderite forms beds, often several feet in thickness, but containing much bituminous and argillaceous matter, and known as blackband ore. This is found in many Carboniferous shales. 
Eastern Ohio (54) and Kentucky (53) and western Pennsylvania (55) are the most important producing states. The ore is obtained chiefly from the Lower Coal measures, although known in the other stages of the Pennsylvania series. Another important occurrence is at the Burden Mines, near Hudson, New York (56), where lens-shaped beds of clay ironstone are found in the Hudson River shales and sandstones. The beds have been folded and faulted, so that the ore bodies lie in basins. The ores are rather magnesian, and on this account it has been suggested by Kimball that they have been formed in shore waters receiving drainage from the Archæan Highlands; they are also high in phosphorus. Siderite is of far greater importance in foreign countries, and large quantities are shipped to the United States from Spain. It is roasted for use, thereby expelling the carbonic acid and raising the iron contents.

Production of Iron Ores. - The iron ore mining industry in the United States has progressed with phenomenal strides, and this country now leads the world in the production of iron ore. Indeed, so great has the production become that in 1903 it was equal to the combined output of Germany and Luxemburg and the British Empire for 1902. Moreover, the average iron content of the ore mined in the United States is higher than that mined in foreign countries, thereby resulting in the production of a greater amount of pig iron from a given quantity of ore.

The Lake Superior region is now producing at least three quarters of the iron ore used in the United States, and it 
has much the largest reserves of high-grade ores, but even these may be exhausted in fifty years or less at the present rate of consumption. The low-grade ores of this region and others will, however, be available for a much longer time.

While there is not danger of the present supply of ore soon becoming exhausted, still with the present consumption it is well to consider possible sources of the future.

In the United States the Utah and some other western deposits will no doubt be drawn upon, and many ores now looked upon as too low grade to work will also be considered. Aside from domestic sources of supply there are foreign ones which may perhaps be eventually turned to, such as those from Canada, Newfoundland, and Brazil on this side of the Atlantic, or even those of Scandinavia on the European side. In the last-mentioned country especially attention has been drawn in the last few years to magnetite deposits located well within the Polar circle and of stupendous size.

The production of iron ores in the United States from 1889 to 1903 was as follows :-

Total Production of Iron Ores in the United States

\begin{tabular}{c|c|c|c}
\hline YeAR & LoNG ToNs & YeAR & LoNG ToNs \\
\cline { 2 - 3 } 1889 & $14,518,041$ & 1895 & $15,957,614$ \\
1890 & $16,036,043$ & 1896 & $16,005,449$ \\
1891 & $14,591,178$ & 1897 & $17,518,046$ \\
1892 & $16,296,666$ & 1898 & $19,433,716$ \\
1893 & $11,587,629$ & 1899 & $24,683,173$ \\
1894 & $11,879,679$ & 1900 & $27,553,161$ \\
\hline
\end{tabular}


Production of Iron Ore in the more Important States from 1901 то 1903

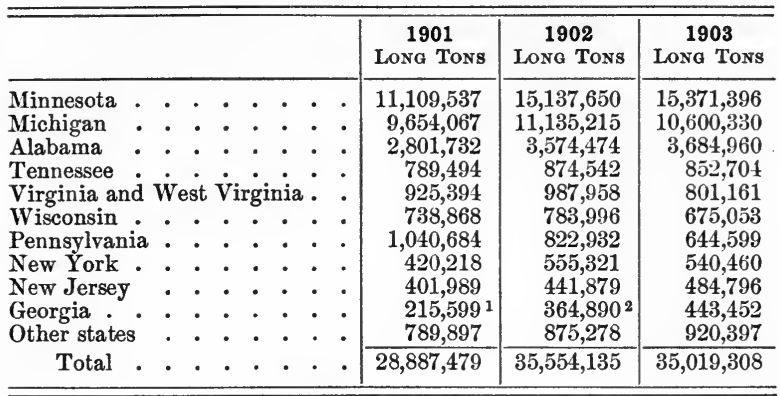

Production of Lake Superior Iron Ores by Ranges

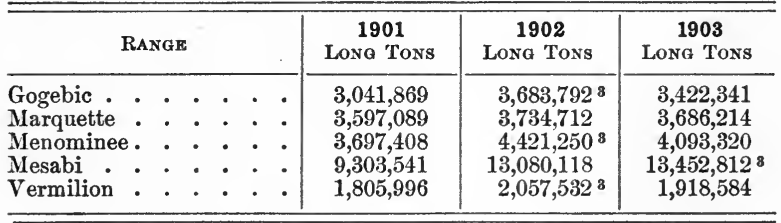

Production of Most Important Iron-Ore Producing Countries

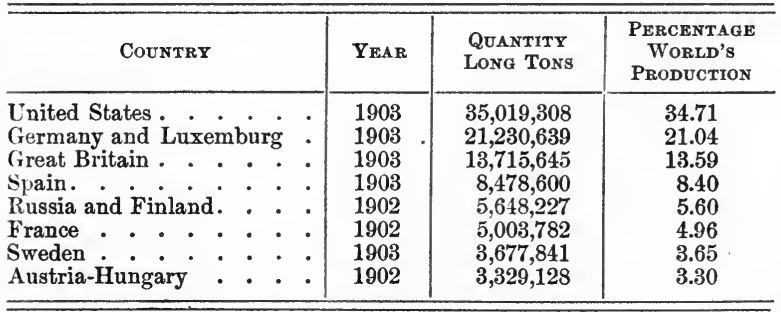

1 Includes North and South Carolina.

2 Includes North Carolina.

3 Maxima. 
The exports of iron ore from the United States in 1903 amounted to 80,611 long tons, valued at $\$ 255,728$.

\section{REFERENCES ON IRON ORES}

General. 1. Birkenbine, Chapters on Iron Ores in Mineral Resources of United States, published annually by U. S. Geol. Survey; $1 a$. Mining Census, 1902, Mines and Quarries. 2. Kimball, Amer. Geol., XXI : 155, 1898. (Concentration by weathering.) 3. Penrose, Jour. Geol., I : 356, 1893. (Chemical relations of iron and manganese.) 3 a. Pumpelly, Tenth Census, XV. 4. Swank, Eng. and Min. Jour., LXXIII : 347,1902 . (U. S. iron and steel works.) 5. Winchell, Amer. Geol., X: 277, 1892. (Theories of origin.)

State Reports. 6. Chauvenet, Amer. Inst. Min. Engrs., Trans. XVIII : 266, 1890. (Colo.) 7. Nason, Mo. Geol. Surv., II, 1892. (Mo.) 8. Nitze, N. Ca. Geol. Surv., Bull. I, 1893. (N. Ca.) 9. Orton, Ohio Geol. Surv., V: 371, 1884. (Ohio.) 10. Putnam, 10th Census, XV : 469. (U.S.) 11. Shaler, Ky. Geol. Surv., New Series, III : 163, 1877. 12. Smock, N. Y. State Museum, Bull. 7, 1889. (N.Y.) 13. Van Hise, U. S. Geol. Surv., 21st Ann. Rept., III : 305, 1901. (Lake Superior region.) 14. Winchell, Minn. Geol. Surv., Bull. 6, 1891. (Minn.).

Special Papers. Magnetite. 15. D’Invilliers, Second Pa. Geol. Surv., D3, II, pt. 1 : 237, 1883. (Berks Co.) 16. Prime, Ibid. $1: 190$, 1883. (Lehigh Co.) 17. D'Invilliers, Amer. Inst. Min. Engrs., Trans. XIV: 873, 1886. (Cornwall.) 18. Hulst, Eng. and Min. Jour., LXXVIII : 350,1904. (Titaniferous ores.) 18 a. Keith, U.S. Geol. Surv., Bull. 213: 243, 1903. (N. Ca.) 19. Kemp, Amer. Inst. Min. Engrs., Trans. XXVII : 146, 1898. (Mineville, N. Y.) 20. Kemp, U. S. Geol. Surv., 19th Ann. Rept., III : 377, 1899. (Adirondack titaniferous ores.) 21. Kemp, S. of M. Quart., XX: 323, 1899. (Titaniferous magnetites.) 22. Nason, Amer. Inst. Min. Engrs., Trans. XXIV : 505, 1895. (N.J.) 23. Spencer, Min. Mag., X: 377, 1904 . (N.J.) 24. Wolff, N. J. Geol. Surv., Ann. Rept. for 1893: 359,1894 . (N.J.)

Hematite. 25. Bayley, U. S. Geol. Surv., Mon. XLVI, 1904. (Menominee range.) 26. Boutwell, U. S. Geol. Surv., Bull. 225: 221, 1904. (Uinta Mts., Utah.) 27. Clements, Smythe, Bayley, and Van Hise, U. S. Geol. Surv., 19th Ann. Rept., III : 1, 1899. (Crystal Falls district.) 28. Clements, U. S. Geol. Surv., Mon. XLV, 1903. (Vermilion range.) 29. Dewees, Second Pa. Geol. Surv., Rept. F, 1878. (Pa.) 30. Eckel, Eng. and Min. Jour., LXXIX : 897, 1905. 31. Leith, 
U. S. Geol. Surv., Mon. XLIII, 1903. (Mesabi range.) 32. Leith, U. S. Geol. Surv., Bull. 225 : 229, 1904. (S. Utah.) 33. McCreath, Second Pa. Geol. Surv., MM:229, 1879. (Many analyses.) 34. Pechin, Amer. Inst. Min. Engrs., Trans. XIX : 1016, 1891. (Va.) 35. Porter, Amer. Inst. Min. Engrs., Trans. XV: 170, 1887. (Tenn., Ala., Ga.) $35 a$. Russell, U. S. Geol. Surv., Bull. 52: 22, 1889. (Clinton ore.) 36. Smyth, Amer. Jour. Sci., XLIII : 487, 1892 (Clinton ore); and N. Y. State Geologist, 22d Ann. Rept., $1902: 116,1904$. 37. Van Hise, U. S. Geol. Surv., 21st Ann. Rept., III : 305, 1901. (Lake Superior region.) 37 a. Van Hise, Bayley and Smyth, U. S. Geol. Surv., Mon. XXVIII, 1897. (Marquette.) 38. Van Hise and Irving, U. S. Geol. Surv., Mon. XIX, 1892. (Penokee-Gogebic range.) 39. Weidman, Wis. Geol. and Nat. Hist. Surv., Bull. 13, 1904. (Baraboo district, Wis.) 40. Woodbridge, Series of articles on Mesabi range, Eng. and Min. Jour., 1905.

Limonite. 41. Calvin, Ia. Geol. Surv., IV: 97, 1895 . (Ia.) 42. Catlett, Amer. Inst. Min. Engrs., Trans. XXIX : 308, 1900. (Va.) 43. Diller, U. S. Geol. Surv., Bull. 213 : 219, 1903. (Redding quadrangle, Calif.) 44. Eckel, Eng. and Min. Jour., IXXVIII : 432, 1904. (E. N. Y. and W. New Eng.) 45. Garrison, Eng. and Min. Jour., LXXIII : 258, 1904. (Chemical characteristics.) 46. Hayes, Amer. Inst. Min. Engrs., Trans. XXX: 403, 1901. (Ga.) 47. Hayes and Eckel, U. S. Geol. Surv., Bull. 213 : 233, 1903. (Cartersville, Ga.) 48. Hopkins, Geol. Soc. Amer., Bull. XI : 475, 1900. (Pa.) $48 a$. McCalley, Ala. Geol. Surv., Report on Valley Region, II, 1897. (Ala.) 48 b. Moxham, Amer. Inst. Min. Eng., Trans. XXI : 133. (Great Gossan Lead.) 49. Pechin, Eng. and Min. Jour., LIV: 150, 1892. (Va. Oriskany ores.) 50. Penrose, Geol. Soc. Amer., Bull. III : 44, 1892 (Ark. and Tex. Tertiary ores); also Ark. Geol. Surv., Rep. 1892, vol. 1, 1892. 51. Phillips, Eng. and Min. Jour., LXV: 489, 1898. (Ala.) 52. Walker, Tex. Geol. Surv., 2d Ann. Rept., 291, 1891. (Cherokee Co., Texas.)

Siderite. 53. Moore, Ky. Geol. Surv., 2d Ser., I, pt. 3: 63, 1876. (Ky.) 54. Orton, Ohio Geol. Surv., V : 378, 1884. (Ohio.) 55. Second Pa. Geol. Surv., K : 386, and MMI: 159, 1879. (Pa.) 56. Raymond, Amer. Inst. Min. Engrs., Trans. IV : 339, 1876. (N.Y.) 57. Smock, N. Y. State Museun, Bull. 7 : 62, 1889 . (N.Y.) 


\section{CHAPTER XV}

\section{COPPER}

Ores of Copper. - Copper-bearing minerals are not only numerous, but widely although irregularly distributed. More than this, copper is found associated with nearly every variety of ore or ore deposit. Nevertheless but few minerals serve as ores of copper, and the same may be said regarding the number of important producing districts in the United States.

The ores of copper together with their theoretic composition are as follows :-

\begin{tabular}{|c|c|c|c|c|}
\hline ORE & Composition & $\mathrm{Cu}$ & $\mathbf{s}$ & $\mathrm{Fe}$ \\
\hline Native copper . . . . . & $\mathrm{Cu}$ & 100 & & \\
\hline Chalcocite . . . . & $\mathrm{Cu}_{2} \mathrm{~S}$ & 79.8 & 20.2 & \\
\hline $\begin{array}{l}\text { Chalcopyrite } \cdot{ }_{\text {(Copper pyrite) }} \\
.\end{array}$ & $\mathrm{CuFeS}_{2}$ & 34.5 & 35.0 & 30.5 \\
\hline Bornite . . . . . & $\mathrm{Cu}_{3} \mathrm{FeS}_{3}$ & 55.5 & 28.1 & 16.4 \\
\hline Covellite . . . . . . & $\mathrm{CuS}$ & 66.48 & 33.52 & \\
\hline Tetrahedrite . . . . & $4 \mathrm{Cu}_{2} \mathrm{~S}, \mathrm{Sb}_{2} \mathrm{~S}_{3}$ & 52.1 & 23.10 & 1.39 \\
\hline Enargite. . . . . . & $\mathrm{Cu}_{3} \mathrm{AsS}_{4}$ & 48.40 & 32.50 & \\
\hline Melaconite (Black oxide) & $\mathrm{CuO}$ & 79.86 & & \\
\hline Cuprite . . . . . . . & $\mathrm{Cu}_{2} \mathrm{O}$ & 88.80 & & \\
\hline 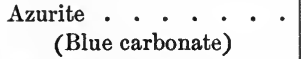 & $3 \mathrm{CuO}, 2 \mathrm{CO}_{2}+\mathrm{H}_{2} \mathrm{O}$ & 55.00 & & \\
\hline $\begin{array}{l}\text { Malachite } \\
\text { (Green carbonate) }\end{array}$ & $2 \mathrm{CuO}, \mathrm{CO}_{2}, \mathrm{H}_{2} \mathrm{O}$ & 57.40 & & \\
\hline Chrysocolla. . . . & $\mathrm{CuO}, \mathrm{SiO}_{2}, 2 \mathrm{H}_{2} \mathrm{O}$ & 36.10 & & \\
\hline
\end{tabular}


Very few ores approach the theoretic percentages given above. Thus in Michigan, where native copper is the ore mineral, this, as now mined, rarely averages above 1 per cent metallic copper. At Butte, Montana, the copper-bearing minerals are chalcocite, enargite, bornite, and chalcopyrite, but much of the ore does not usually contain more than 5 or 6 per cent metallic copper, and in rarer instances 12 per cent. The same holds true in many other regions. At the present time chalcopyrite is probably the most widely distributed of all the copper ores, and the one most often worked, but it is not the prominent ore in the largest producing districts.

Copper ores are found in many formations, ranging from the pre-Cambrian to the Tertiary, but grouped according to their mode of origin they fall mostly into one of the four following groups (2):-

1. Magmatic segregations. No workable deposits of this type are known in the United States.

2. Contact metamorphic deposits, in crystalline, usually garnetiferous limestone, along igneous rock contacts. The copper is thought to have been introduced by vapors from the igneous rock.

3. Deposits formed by ascending, circulating, probably hot waters, the ores being deposited in fissures, pores, spaces of brecciation, or sometimes by replacement of the rock.

4. Pod or lens-shaped deposits in crystalline schists, which may represent concentration of material from a disseminated condition in the surrounding rocks.

While the third and fourth groups include all the largest deposits of the world, still these do not in all cases owe their economic importance to the mode of formation, but rather to 
secondary changes which have taken place in them, resulting in a leaching of the copper in the upper part of mass, as copper sulphate, and its transference to lower levels, where it is redeposited through the influence of copper sulphide, iron compounds, or limestone.

Impurities in Copper Ores. - The impurities which copper ores may contain are iron, silver, antimony, arsenic, tellurium, silica, sulphur, and phosphorus, and in the metallurgical treatment of the ore it is desirable to rid the metal of these as fully as possible. Both iron and silver may affect the electrical conductivity of copper, and antimony and arsenic do so to a smaller extent.

Tellurium is not uncommon in some districts, and renders the metal red-short even in small amounts. Silver, even if present in as small amounts as .5 per cent, lowers the electrical conductivity, and above 3 per cent affects the toughness and malleability of the copper. Sulphur up to .25 per cent lowers the malleability and .5 per cent renders the metal cold-short, while .4 or more per cent phosphorus makes it red-short.

Many low-grade ores can be concentrated by crushing and mechanical concentration, as in the Lake Superior district of Michigan and at Butte, Montana. Sulphide ores may also be given a preliminary roasting to get rid of the volatile sulphur, arsenic, etc. The ore is then usually put through a smelting process, followed sometimes by electrolytic treatment for refining the metal.

Superficial Alteration of Copper Ores (see 25, ore deposits). - This may produce results of great economic importance, and excellent examples of it are seen in some of the Arizona 
deposits, where the upper portions of the copper deposits are brown or black ferruginous porous masses brightly colored with oxidized copper minerals such as cuprite, malachite, azurite, and chrysocolla, while below this at a variable depth they pass into sulphides.

In weathering, the copper minerals, such as chalcopyrite or other sulphides, are usually oxidized first to sulphates, and subsequently changed to oxides, carbonates, or silicates and occasionally even to chlorides and bromides. A concentration of the ore deposit may take place partly by segregation and partly by leaching, and pockets of the ore form, which are surrounded by oxidized iron minerals forming part of the gangue.

While the oxidation will not increase the total copper contents of the ore body, still it may change it into a more concentrated form, for the carbonates and other oxidized copper minerals contain more copper than the original sulphide. The ore in the gossan may therefore run from 8 to 30 per cent or more, while below it may show only 5 per cent of copper (see 25, ore deposits). These altered ores cannot however be more cheaply treated. If leaching follows oxidation, the gossan may be freed of its ore, as at Butte, Montana, where the upper part of the ore-bearing fissures is poor siliceous gangue. Secondary enrichment may also occur below the water level, giving chalcocite, chalcopyrite, and bornite of later origin. ${ }^{1}$

Distribution of Copper Ores in the United States. - About 90 per cent of the copper produced in the United States is obtained from three states, viz., Montana, Michigan, and Arizona, named in the order of their output, the rest coming

${ }_{1}$ Both chalcopyrite and bornite are more often regarded as primary sulphides. 
from the Appalachians and Cordilleran area; the ores of the latter are often worked chiefly for their gold contents, with copper as a secondary product.

Montana. - The mining camp of Butte (29-31), which is not only the greatest producer of copper in the world, but in which one mine, the Anaconda, yields one seventh of the entire world's supply, lies in the central part of the Rocky

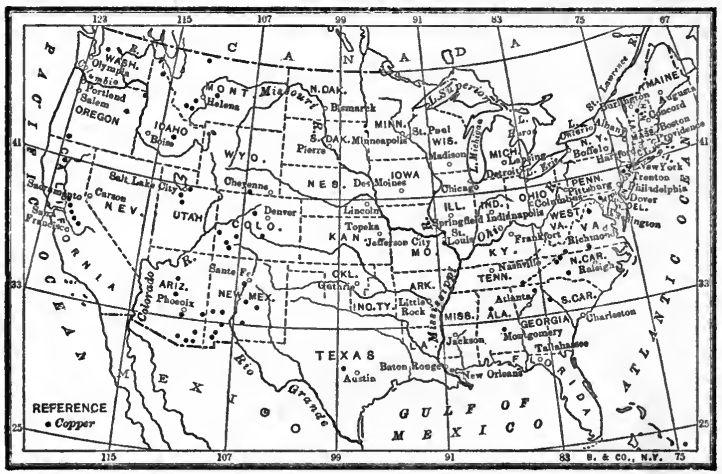

Fig. 52. - Map showing distribution of copper ores in United States. Adapted from Ransome, Min. Mag., $\boldsymbol{X}: 1$.

Mountain region. The ore-bearing veins occur in an older hornblendic granite, known as the Butte granite, found chiefly in the eastern part of the district, and which is cut by the acid Bluebird granite or aplite, that forms dikes and small masses in this region. Both of these granites are intersected by dikes of quartz porphyry of doubtful genetic relation to the ore bodies, although the latter are usually low-grade when bounded by either the porphyry or the aplite. The last stage of igneous activity consisted of the extrusion of 


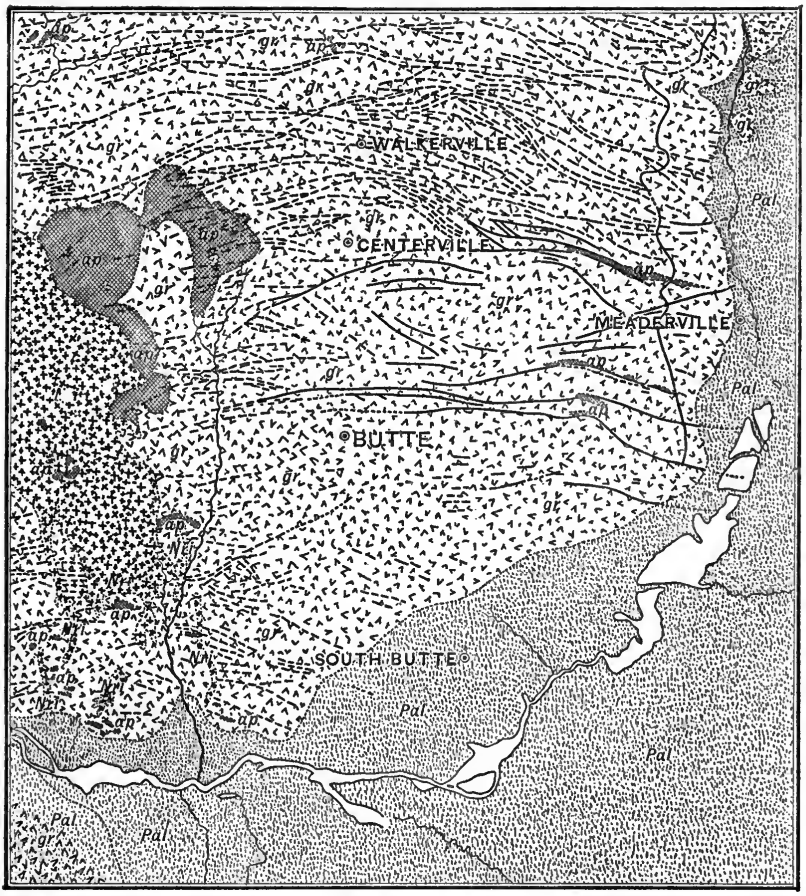

7iding Pal - ALLUVIUM AND WABH PLEISTOCENE

SILVER VEINS

Fi: Nri - INTRUSIVE RHYOLITE NEOCENE

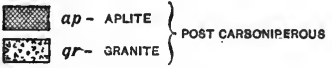

Fra. 53.- Map of Butte, Mont., district showing distribution of veins and geology. After Weed, U.S. Geol. Surv., Atlas Folio. 
rhyolite flows and ash beds, and dikes of the same rock also cut the silver veins of the region.

The Butte district contains both silver and copper veins. The latter are found in an area about a mile long and one

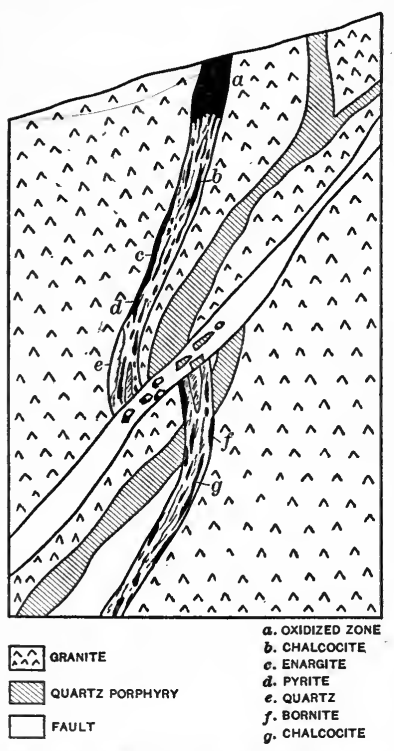

Frg. 54. - Section at Butte, Mont., showing mode of occurrence of ore. After Winchell, Eng. and Min. Jour., $L X X V I I I:-7$.

half mile wide, in the southeastern part of the district, while the silver veins surrounding it are of much less importance.

The granites are traversed by several systems of joints and shear planes, and the ore has not only been deposited in them, but has replaced the wall rock as well. The veins are of varying age, the larger and richer ones having been broken, reopened, and even displaced by faulting, and a careful study of the district has shown four separate periods of fracture, in three of which ores have been formed.

In the earliest, the vein filling, which was the result of replacement in sheeted granite, is quartz and pyrite with some copper. Later fracturing produced large masses of crushed granite, clay, etc., with boulders of ore, and this was sometimes added to by the deposition of enargite by later ascending solutions. The richest masses or bonanzas 

Plate XVIII

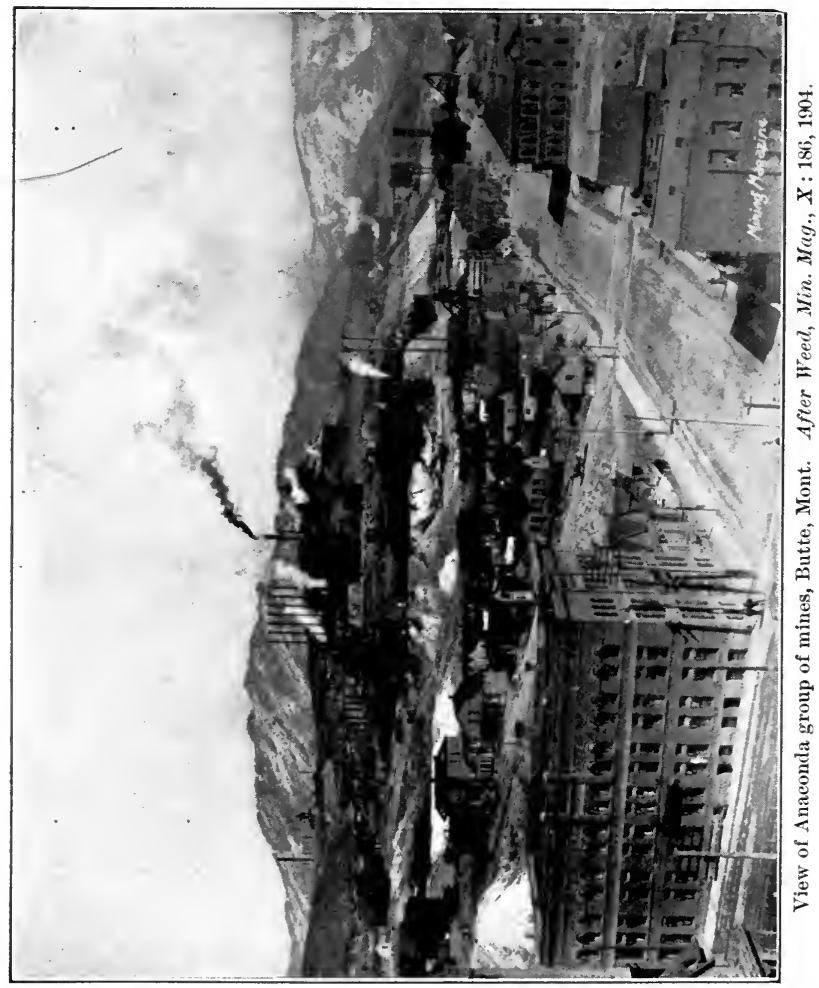


of glance found in some of the mines are of secondary origin.

While the veins exhibit a curious uniformity of direction, most of them striking nearly east and west, and few of them departing more than $15^{\circ}$ to $20^{\circ}$ from the vertical, still they show considerable variation in width, ranging from a few feet to 50 , or even 150 where the altered country rock is impregnated with glance. Unfortunately, the complexity of the veins and uncertainty of boundaries has given rise to much costly litigation in the district.

The common vein minerals are quartz, pyrite, and chalcocite. Bornite and enargite are locally important, while chalcopyrite and covellite are known. Present in subordinate quantities are tetrahedrite, tennantite, and argentite. The chalcocite is always of secondary character.

The average composition of first-class ore in Butte in 1902 was: $\mathrm{Cu}, \mathbf{1 1 . 4}$ per cent; $\mathrm{Fe}, \mathbf{1 6 . 6}$ per cent; $\mathrm{Zn}, .3$ per cent; S, 22.6 per cent; $\mathrm{As}$ and $\mathrm{Sb}, 1.4$ per cent; $\mathrm{Al}_{2} \mathrm{O}_{3}, 7.9$ per cent; insoluble, 44.7 per cent; $\mathrm{SiO}_{2}, 38.2$ per cent; $\mathrm{Ag}$, oz. $5.2 ; \mathrm{Au}$, oz. .04. Second-class ore averages: $\mathrm{Cu}, 5.2$ per cent; $\mathrm{Fe}, 16$ per cent; S, 19.8 per cent; insoluble, 56 per cent; Ag, 3 oz.

Gold is quite universally distributed through the ores, though in very small amounts, forming 3 per cent of the values in the copper bullion. Small amounts of arsenic, antimony, bismuth, tellurium, selenium, and nickel have been found, and manganese is widespread in the silver veins, though wanting in copper-bearing ones. Zine is not limited in distribution, but is more abundant in the silver veins.

The deposition of the ores is considered by Weed to be due to aqueous alkaline solutions, which have probably 
leached the metals from the granite at considerable depths. These solutions, which came up in the fissures, were hot, but not necessarily under pressure. Where the fissures were open they were filled with ore, and where narrow, replacement of the walls occurred, so that the vein matter shades off into the country rock. Since their formation faulting has occurred, usually parallel to the vein. The entrance of meteoric waters into the vein has carried much ore downward, resulting in a richer zone below even the zone of oxidation, and showing bornite, chalcocite, and covellite as a result of this; some of these have been derived from the breaking up of the pyrite. It has been found that these bonanza bodies of secondary origin pass downward into lower-grade ores. Most of the ores are put through a process of mechanical concentration before being sent to the smelter. The vertical limits of the ore have not yet been determined, but certain silver mines have reached a depth of 1450 to 1500 feet, while most of the copper mines have gone to 2000 or 2500 feet.

The history of this mining camp is full of interest. Butte in 1864 was a gold camp, but difficulties in working the gravels directed attention to the mineral-vein outcrops, and unsuccessful attempts were made to work their copper and silver contents, so that it was not until 1875 , following a period of quiescence, that the discovery of rich silver ore in the Travona lode revived the mining industry of Butte. In 1877 several silver mines were opened, followed by others; but this did not last many years, for with the drop in the price of silver many mines closed, although one, the Bluebird, had produced 2,000,000 ounces of silver from 1885 to 1892 .

The copper mines were worked to only a limited extent at first, and the industry did not assume permanence until 1879-1880, when matte smelting was introduced. In 1881 the Anaconda mine, which 
was first worked for silver, began to show rich bodies of copper ore, and since then the output of copper has steadily increased, there being a number of large smelting plants distributed between Butte, Anaconda, and Great Falls.

Up to the end of 1896 the commercial value of the copper produced was about $\$ 330,000,000$. This greatly exceeds the total output of Leadville, and nearly equals the famous Comstock lode. W. H. Weed has estimated that up to January 1, 1897, the district had yielded 500,000 ounces of gold, 100,000,000 ounces of silver, and $1,600,000,000$ pounds of copper. In 1887 Butte passed the Lake Superior District in the production of copper, and has kept ahead of it ever since, having in 1903 produced 38.9 per cent of the United States production.

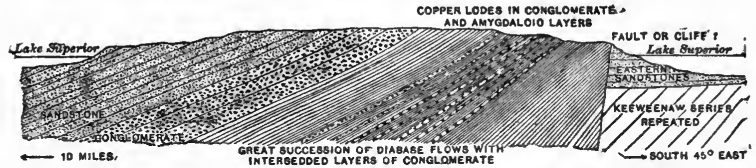

GEOLOGICAL CROSS-SECTION OF THE COPPER MINING REGION

Fig. 55. - Section across Keweenaw Point. After Rickard.

Michigan (2, 24-26). - This region, which was discovered in 1830 by Douglas Houghton, a young geologist, has become one of the most famous, and for some years one of the leading, copper-producing districts of the world.

The rocks of the region, known as the Keweenaw series, consist of steeply northwesterly dipping, interbedded lava flows, sandstones, and conglomerates. These form a belt from 2 to 6 miles wide, which extends from Houghton to the end of the Keweenaw peninsula, and rises as a ridge from 400 to 800 feet above the lake, being flanked on either side by Potsdam sandstone (Fig. 55).

The ore, which is native copper, and is occasionally associated with native silver, occurs (1) as a cement in the 
conglomerate of porphyry pebbles or replacing the latter; (2) as a filling in the amygdules of the lava beds; (3) as masses of irregular and often large size, in veins with calcitic and zeolitic gangue.

The veins, which cut both the igneous and sedimentary rocks, have yielded much copper in former years, and the large masses obtained from them have made the region famous; but at the present time about 75 per cent of the production comes from the Calumet conglomerate, while

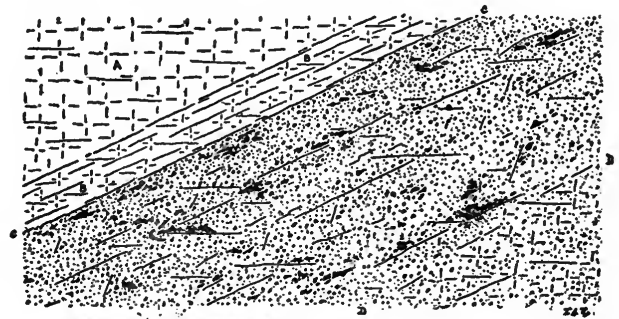

Coposi

FIG. 56. - Section showing occurrence of amygdaloidal copper, Quincy mine, Mich. After Rickard, Eng. and Min. Jour., LXXVIII: 626, 1904.

the balance comes from two other copper-bearing conglomerates known as the Albany and the Allouez, and from the ash-beds and amygdaloids, whose gas cavities are filled with a mixture of native copper, calcite, and zeolites.

A curious and hitherto unexplained feature is the irregular distribution of the copper in the different beds. Thus the Calumet conglomerate carries practically no ore outside of the Calumet and Hecla ore shoot which is three miles long, 12-15 feet thick, and has been mined to a depth of 5000 feet.

Various theories have been brought forward to account for the origin of the copper ores in this region. 
That it is not a true contact deposit is shown by the fact that the amygdules in the diabase, the fissure veins, and the crevices in the broken pebbles are filled with copper, showing a subsequent deposition. The diabase was looked upon by Pumpelly (25 $b$ ) as a possible source of the ore, and since its extensive alteration was no doubt accompanied by the oxidation of protoxides, this might account for the reduction of copper mineral to the native or metallic condition, it being known that ferrous salts may precipitate metallic copper (1). More recently Lane (25a) has suggested that originally buried water has also been an important factor in concentration, but agrees that the final precipitation was by water working downward. For the water in the upper part of the mines is fresh, below saline, and copper is also in the iron ores, and has been thought to occur mainly under the higher portions of the point.

Although these deposits have been worked in prehistoric times, as evidenced by copper implements and ornaments found in the mines, the famous Calumet and Hecla Mine was not opened up until 1846. In 1847 Michigan produced 213 long tons of the total United States production of 300 tons of copper. Since 1863 the annual output has exceeded 1000 tons and has gradually and steadily increased, reaching 85,893 long tons in 1903, having a market value of $\$ 20,269,000$.

The ores from this district, which are known as Lake ores, are all of low grade, some running as low as .55 per cent native copper. Owing, however, to the brittle character of the gangue and the malleability of the ore, as well as their difference in specific gravity, it is possible to separate the two quite thoroughly by crushing in stamps and concentrat- 
ing by jigs, tables, etc. This concentrated material is then refined by smelting.

Arizona (8-16). - This territory ranks third as a producer of copper ores in the United States, and differs from most other copper-producing localities in supplying chiefly ores of oxidized character; in fact, from 1880 to 1895 Arizona was the only copper area in the world whose ores were exclusively oxidized.

The territory contains four important districts, all lying within the mountain region, and which in the order of their importance are, (1) Bisbee or Warren, (3) Jerome or Black Range, (3) Clifton, Morenci, or Copper Mountain, and (4) Globe. In all except the second the modes of the ore occurrences possess certain similarities.

Bisbee or Warren District. - This district $(11,15)$, which contains the famous Copper Queen Mine, lies on the eastern slope of the Mule Pass Mountains, but a short distance from the Mexican boundary. The section at that locality involves strata from pre-Cambrian to Cretaceous age, with an important unconformity between the Carboniferous and Cretaceous (Fig. 57). Prior to the deposition of the latter the rocks had been broken by numerous faults, one of these, the Dividend fault, being specially prominent in forming one boundary of the ore-bearing area. This was followed by intrusions of a granitic magma forming dikes, sills, or irregular stocks, which have metamorphosed the Carboniferous limestones, with the production of characteristic contact minerals.

The ore bodies, which are generally developed in the zone of metamorphic silicates surrounding the porphyry, as well as sometimes outside of it, form large, irregularly distributed, 
but rudely tabular masses; which are generally parallel to the limestone bedding. As now found they consist of oxidized ores, such as malachite, azurite, and cuprite, above, which pass at variable depths into unaltered sulphides; but between the two, or at least never far from the effects of

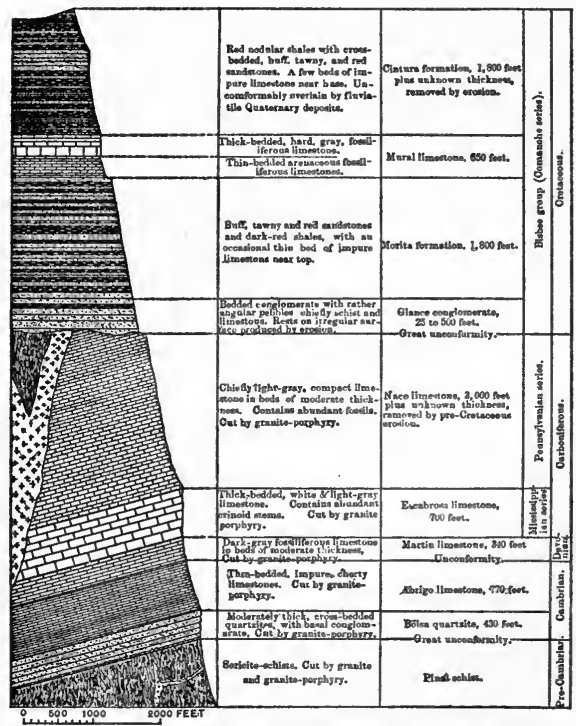

GENERALIZED COLOMNAR SECTION OF THE BQCKS OF THE SISBEE QUAORANGLE.

Frg. 57. - Geological section at Bisbee, Ariz. After Ransome. U.S. Geol. Surv., Prof. Pap. 21.

oxidation, masses of massive or sooty chalcocite are frequently found.

The ore-bearing solutions are believed to have been stimulated by the porphyry and to have risen from an unknown source, but although they may have followed some of the 
fault fissures, the ore, which originally consisted of pyrite, chalcopyrite, and occasionally sphalerite, owes its deposition to metasomatic replacement in the limestone. As originally formed, the deposits contained too little copper to make
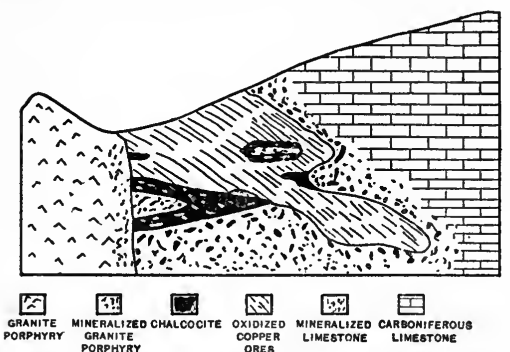

Fra. 58. - Generalized section of ore bodies at Bisbee, Ariz. After Ransome.

them of commercial value, but they have been subsequently enriched by concentration due to weathering in the upper part, and secondary deposition of chalcocite in the underlying zone. Indeed it is said that nearly all the bodies of workable sulphides owe their value to its presence.

The gossan of some of the ore bodies forms prominent ferruginous ledges, and while these rarely show surface indications of copper, still experience has shown that they are connected with underlying ore bodies; however, many of the latter have no outcrops.

Although always important, this region assumed great prominence in 1903 , due to the opening and extensive development of new ore bodies of great extent.

Jerome District.-This was the leading copper-producing district of Arizona for 1897 to 1900 inclusive, but then dropped to second place. The mode of occurrence of the ore differs markedly from that noted in other areas. It is bornite and chalcopyrite, which is associated with a sheared dike and fills fissures and impregnates the slate rock. 



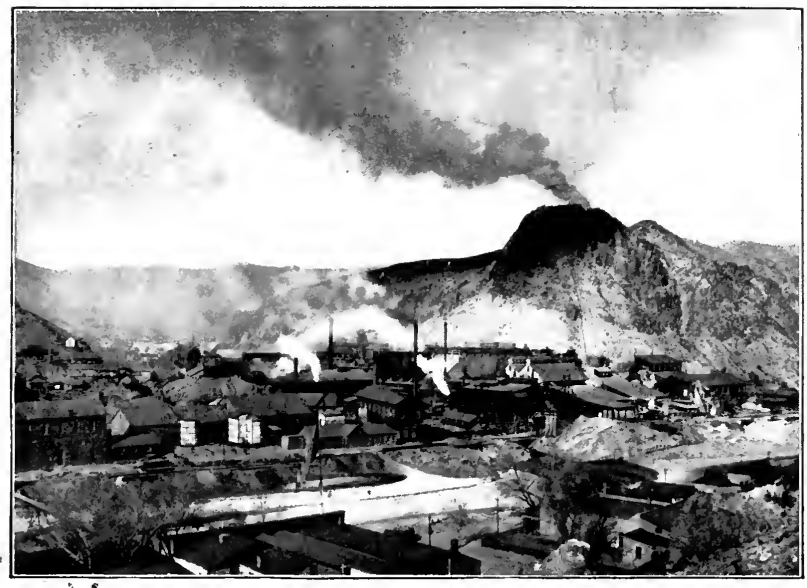

Fig. 1. - Smelter of Arizona Copper Co., Clifton, Ariz. After Church, Min. Mag., $X: 2,1904$.

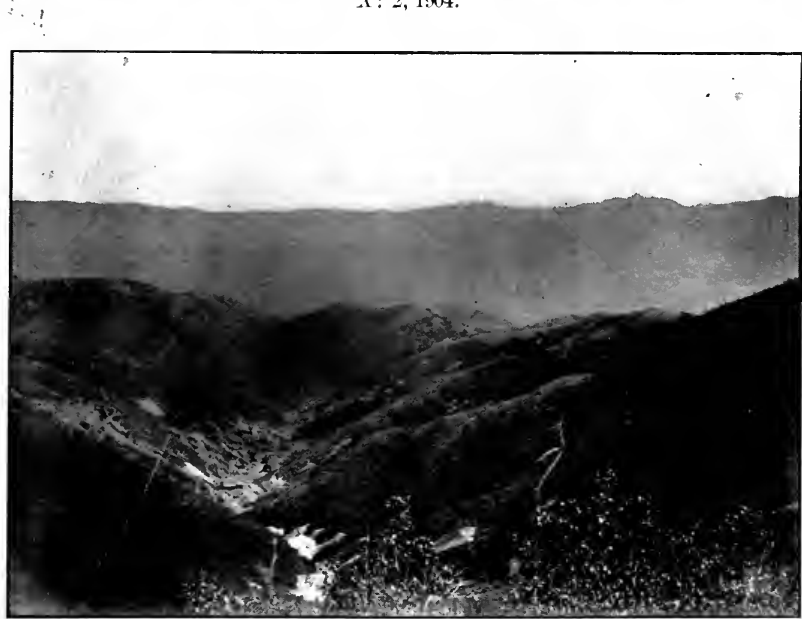

Fig. 2. - View of Bingham Cañon, Utah. After Keith, U. S. Geol. Surv., Prof. Paper 38, 1905. 
Clifton District. - In this district $(12,13)$, which ranks third among the Arizona copper districts, the conditions are in part similar to the Bisbee district in so far as the geologic section and the intrusion of porphyry and granite into the Palæozoic sediments is concerned. They have likewise been broken by extensive fracturing and faulting, the faults sometimes having a throw of 1000 to 1500 feet, and there was also an extensive flow of Tertiary eruptives. The ore bodies differ from the Bisbee ones, however, in point of origin, being true contact deposits, the porphyry by contact influence having produced great masses of garnet

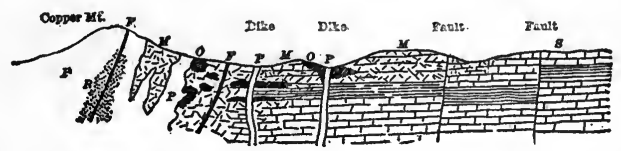

Fia. 59. - Section of Morenci district. $P$, porphyry; $S$, unaltered sediments; $F$, fissure veins; $M$, metamorphosed limestone and shale; $O$, contact metamorphic ores; $R$, disseminated chalcocite. After Lindgren, Eng. and Min. Jour., LXXVIII: 987, 1904.

and epidote in the Carboniferous limestones; and wherever alteration has not masked the phenomena, the metallic minerals, magnetite, pyrite, chalcopyrite, and sphalerite, are found accompanying the contact silicates, and often intergrown with them in such a manner as to leave no doubt concerning the contact origin of the ores and the porphyry as their source. The concentration and commercial value of the ores is due, however, to later processes intimately connected with weathering. This has produced malachite and azurite in the gossan, but some of the copper has been carried to lower levels and precipitated as chalcocite. The sphalerite has been removed in solution as zinc sulphate, and the magnetite and garnet have yielded silica and limonite. 
The ore deposits in the limestone are irregular or tabular, due to the accumulation of the minerals along bedding planes, but in addition, fissure veins, cutting through many of the rocks, and of later age than the porphyry, are found.

Globe District (14). - While the most important deposits here occur in limestone, near the contact with granite and trachyte, still others are found as fissure veins in sandstone (Old Dominion Mine), or in slate and gneiss, or even veinlets in gneiss; the ores are largely oxidized. The output of this district, which has been the least actively worked of any, though small for several years, increased greatly in 1901.

Appalachian Region (42, 43). - The existence of copper in the Appalachian belt has been known for a number of years, but the copper-mining industry has not been active. The early attempts to work the deposits were chiefly to obtain both gold and copper, and resulted in failure, due chiefly to the low market values of copper; hence for many years the deposits, with few exceptions, have been but little worked, and it is only recently that a demand for the metal and cheaper metallurgical treatment have revived copper mining.

The deposits in many cases occur in metamorphic rocks scattered over a wide belt, but five important types are recognizable (42):-

1. True fissure veins, filled with quartz and copper, the vein crossing or conforming to the banding of the schists, and replacement of the wall rock being rare. The ores are bornite, with a little chalcopyrite and iron pyrite. The deposits at Virgilina, Virginia, belong in this group.

2. True fissure veins with auriferous quartz, chalcopyrite, 
and pyrite formed chiefly by replacement. The fissures are usually found along sheeting planes, and the deposits at Gold Hill, North Carolina, are taken as a type of this group.

3. Pyrrhotite veins of the Ducktown type (36-38), filling true fissures, and consisting chiefly of pyrrhotite and pyrite with a little quartz. The ore has been formed by the replacement of a zone of sheeted rock, which was composed chiefly of metamorphic minerals, such as garnet, actinolite, epidote, pyroxene, etc., these latter being the products of alteration of a calcareous shale. The Ducktown ore body represents a type forming a belt extending all the way from Vermont to Alabama. They all show a gossan which can be mined for iron ore, while under this there is a zone of black copper, the result of local enrichment, which passes into the sulphide ore below. The copper is richest in those portions where the pyrrhotite predominates. The Ducktown ore, which has been worked for a number of years, averages 3.5 per cent copper as it comes from the mine. Some of the chambers are from 50 to 150 feet across, and from 25 to 150 feet high without timbering.

The great gossan lead of Virginia and the copper deposits of Ore Knob, North Carolina, also belong to this type.

4. The Catoctin type, representing segregations of native copper, copper oxides, and carbonates along shear zones in altered igneous rocks of Algonkian age, the ores extending below ground water level. They are found at a number of localities in the Appalachian and Piedmont plateau districts, usually in the Catoctin schist. The ore shows 
on the outcrop, but does not extend usually more than 50 to 60 feet below the surface. It is supposed to have been leached out of the vein walls. Occurrences of this type occur in Green County, Virginia.

5. Deposits of native copper along the contact of diabase and sandstone. These have been found in New Jersey $(32,33)$, but are unimportant, although the mines have been worked from time to time. Similar occurrences have been reported from Pennsylvania $(34,35)$ and Connecticut.

Utah. - This state ranks fourth among the copper-producing regions of the United States. The most important district is that of Bingham Cañon (44), in the Oquirrh range, southwest of Salt Lake City, and is unique in that it includes the oldest mining claim in the state. It moreover differs from the other important copper mining localities in the country, in having a considerable quantity of gold, silver, and lead associated with the copper.

The rocks of this district include: (1) a great thickness of sedimentaries of Carboniferous age and divisible into a lower member consisting of massive quartzite with several interbedded limestones which carry most of the ore bodies in the camp, and an upper member of quartzite with black calcareous shales, sandstones, and impure limestones; (2) igneous rocks, which have pierced the entire series of sedimentaries, forming dikes, sills, or laccoliths, and consisting either of a type between diorite porphyrite and monzonite, which is closely associated with the ore bodies, or an andesite, having no relation to the ores.

Folding, fracturing, and faulting have greatly complicated the structural relations of this region.

The ores form lenses in the limestone, which lie roughly 
parallel to its bedding, or occupy fractures or fissure zones. Copper, lead, silver, and gold may occur in either, but the copper rather favors the lenses, and the lead and silver the fissures.

The mining operations have been based in turn on the oxidized gold ores, carbonate ores of lead and copper, sulphides of lead, and finally sulphides of copper, which now constitute the mainstay of the district. These copper sulphides are cupriferous pyrite, chalcopyrite, black sulphides (probably tetrahedrite), and chalcocite with a little galena, zinc, and siliceous gangue. The pyrite, which is widespread in the district, forms immense replacement bodies in the limestone, but is of secondary importance in the fissure zones. The Bingham ores are of low value, and bonanzas are rare; indeed, the copper ores can often only be profitably worked because of their gold, lead, and silver contents.

California. - California $(17,18,2)$ in 1903 was fifth in the list of copper-producing states, and owes its position to the output from Shasta County in the northern part of the state. This region lies at the northern end of the Sacramento Valley, and contains a series of sedimentary rocks, ranging from Devonian to Miocene and pierced by igneous intrusions. Folding, faulting, and shearing are common. The ore is found either: (1) as sulphide deposits in contact zones, between diabase dikes and Carboniferous limestones; or (2) as bodies of sulphides, in shear zones, the latter having been mineralized with the development of irregular ore bodies of variable size. The ores are rare generally in the metamorphosed igneous rocks. Superficial alteration has produced a gossan which may show a thickness of as much as 100 feet at some localities (Iron Mountain). 
The important districts are the Iron Mountain and Bully Hill. In both, the ores are chalcopyrite and pyrite, but that from the latter district also contains some bornite and chalcocite. An analysis of the Iron Mountain ore gave, $\mathrm{Cu}$, 7.45 per cent; S, 45.60 per cent; Fe, 36.97 per cent; $Z n$,

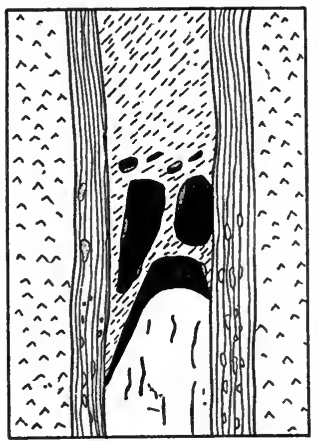

[9.

OXIDIZED ORES

四 ENRICHEO SOLPHIOES

FIG. 60. - Section of ore body at Bully Hill, Calif. After Diller.

3.41 per cent; $\mathrm{SiO}_{2}, 5.62$ per cent; $\mathrm{Al}_{2} \mathrm{O}_{3}, 1.57$ per cent; Moisture, 0.88 per cent. This is probably higher than the average in copper.

Copper deposits are also known in other parts of California (17).

Other Occurrences. - Colorado has few copper mines proper, but many of the ores mined in the state carry copper, and it is utilized by lead smelters as a carrier in the extraction of other metals. Copper is mined in New Mexico and Idaho, the Seven Devils District of the latter state being well known (23). The Grand Encampment district of southern Wyoming (50) has also supplied more or less ore, and a small amount is mined in Missouri (28). Copper has been found at several localities in Alaska (4-7), but no shipments were made prior to 1903 .

Uses of Copper. - Since prehistoric times copper alloyed with tin has been used in various parts of the world for the manufacture of bronze. Thus it was used for this purpose in Homeric times, and it is found in the lake dwellings of 
Switzerland. The bronze found in Troy contains a very little tin, and since this metal is not found in the excavations in the West, it seems probable that the bronze was made in Asia, perhaps in China or India, by some secret process and imported to the western countries.

By an alloy of copper and tin, although both metals are soft, a comparatively hard metal is produced. The properties of this alloy, bronze, vary greatly according to the proportions of the two metallic constituents, and these vary with the use for which the alloy is intended. United States ordnance is 90 per cent copper and 10 per cent tin, while ordinary bell metal is about 80 per cent copper, though the percentage varies with the tone required. Statuary bronze is generally an alloy of copper, tin, and zinc; and, in these various bronzes, the color varies from copper-red to tin-white, passing through an orange-yellow.

An alloy of copper and zinc produces brass, which is found of so much value for small articles used in building and for ornamental purposes in machinery. Copper is also used in roofing and plumbing.

A large supply of this metal is made into copper wire, and the most important present use of copper is in electricity, for which its high conductivity especially fits it for the transmission of electric currents.

Production of Copper. - The production of copper in the United States has increased steadily and rapidly in the last fifty years, placing the United States in the lead of the world's copper producers. This increase can be seen from the table given below:- 
Production of Copper in United States from 1845 to 1903

\begin{tabular}{c|c|c|c}
\hline YeAR & $\begin{array}{c}\text { Production } \\
\text { LoNG ToNs }\end{array}$ & YeAR & $\begin{array}{c}\text { Production } \\
\text { LoNG ToNs }\end{array}$ \\
\hline 1845 & 100 & 1885 & 74,052 \\
1850 & 650 & 1890 & 115,996 \\
1855 & 3,000 & 1895 & 169,917 \\
1860 & 7,200 & 1900 & 270,588 \\
1865 & 8,500 & 1901 & 268,782 \\
1870 & 12,600 & 1902 & 294,423 \\
1875 & 18,000 & 1903 & 311,627 \\
1880 & 27,000 & & \\
\hline \hline
\end{tabular}

Production of Copper in the United States by States (In pounds)

\begin{tabular}{|c|c|c|c|c|c|c|c|c|c|c|}
\hline \multicolumn{7}{|c|}{ SoUrce } & & \multirow{2}{*}{$\frac{1901}{130,778,511}$} & \multirow{2}{*}{$\begin{array}{c}1902 \\
119,944,944\end{array}$} & \multirow{2}{*}{$\begin{array}{c}1903 \\
147,648,271\end{array}$} \\
\hline Arizona . & . & & & • & & & & & & \\
\hline California & . & & & & & & & $33,667,456$ & $25,038,724$ & $17,776,756$ \\
\hline Colorado ${ }^{1}$ & . & & & . & . & & • & $9,801,783$ & $8,422,030$ & $4,158,368$ \\
\hline Lake Superi & & & & • & - & & • & $156,289,481$ & $170,609,228$ & $192,400,577$ \\
\hline Montana . & . & & & . & - & $\bullet$ & - & $229,870,415$ & $288,903,820$ & $272,555,854$ \\
\hline New Mexico & & & & . & e & & • & $9,629,884$ & $6,614,961$ & $7,300,832$ \\
\hline Utah . & . & & & & & & - & $20,116,979$ & $23,939,901$ & $38,302,602$ \\
\hline Eastern Atl & ant & & & ate & & & & $6,860,039$ & $13,599,047$ & $13,855,612$ \\
\hline All others & . & & & 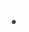 & & & • & $4,526,341$ & $1,935,989$ & $3,546,645$ \\
\hline
\end{tabular}

Of the several producing states Montana has for some years been the first, with Michigan second and Arizona third. The marked decrease of Montana in 1903 was due to litigation and labor troubles.

1 Including copper smelters purchasing copper ore and mattes in the open market, sources not known. 
World's Production of Copper in Long Tons

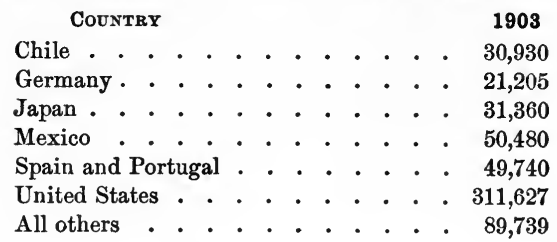

The total value of the imports of copper (including ore, matte, and manufactured copper) in 1903 was $\$ 20,441,977$, while the total value of the exports covering the same class of materials was $\$ 44,365,155$.

\section{REFERENCES ON COPPER}

General. 1. Biddle, Jour. Geol., IX:430, 1901. (Origin.) 2. Weed, Min. Mag., X:185, 1904. (United States.) 3. Winchell, Geol. Soc. Amer., Bull. XIV : 269, 1903. (Origin.)._Alaska : 4. Brooks, Eng. and Min. Jour., LXXIV: 13. (Tanana and Copper River regions.) 5. Mendenhall and Schrader, U. S. Geol. Surv., Bull. 213: 141, 1903. (Mt. Wrangell region.) 6. Rohn, U. S. Geol. Surv., 21st Ann. Rept., II : 393, 1900. (Chitina River and Skolar Mts.) 7. Schrader, U. S. Geol. Surv., 20th Ann. Rept., VII : 341, 1900. (Prince William Sound and Copper River district.)-Arizona: 8. Blandy, Eng. and Min. Jour., LXIV : 97, 1897. (Ariz.) 9. Church, Amer. Inst. Min. Engrs., Trans. XXXIII: 3, 1903. (Tombstone district.) 10. Douglas, Min. Indus., VI: 227, 1898. 11. Douglas, Amer. Inst. Min. Engrs., Trans. XXIX: 511, 1900. (Copper Queen Mine). 12. Lindgren, U.S. Geol. Surv., Bull. $213: 133,1903$. (Clifton district.) 13. Lindgren, Amer. Inst. Min. Engrs., Trans. XXXV, 1905. (Clifton district.) 14. Ransome, U. S. Geol. Surv., Prof. Paper 12, 1903. (Globe district.) 15. Ransome, U. S. Geol. Surv., Prof. Paper 21, 1904. (Bisbee district.) 16. Wendt, Amer. Inst. Min. Engrs., Trans. XV : 25, 1887. - California : 17. Aubury, Calif. State Mining Burean, Bull. 23, 1902. 18. Diller, Eng. and Min. Jour., LXXIII : 857, 1902. (N. Calif.) - Colorado: 19. Emmons, Tenth Census, XIII :68, 1885. (Gilpin Co.) 20. Spencer, U. S. Geol. Surv., Bull. 213:163, 1903. (Pearl, Colo.) 21. Emmons, U. S. Geol. Surv., Bull. 260:221, 1905. (Red Beds, Colo. plateau.)- 
Georgia : 22. Weed, U. S. Geol. Surv., Bull. 225:180, 1904.Idaho: 23. Lindgren, Min. and Sci. Pr., LXXVIII: 125, 1899. (Seven Devils district.) - Michigan : 24. Irving, U. S. Geol. Surv., Mon. V, 1883, also 3d Aun. Rept.: 89, 1883. 25. Lane, Amer. Geol., XXII : 251, 1898. (Magmatic differentiation in copper rocks.) 25a. Lane, Mich. Miner, Jan.-Feb., 1904. 25̃ . Pumpelly, Mich. Geol. Surv., I, pt. 2, 1873. 26. Rickard, Eng. and Min. Jour., LXXVIII : 585, 625, 665, 745, 785, 865, 905, 1025, 1904.-Missouri : 27. Nicholson, Amer. Inst. Min. Engrs., X: 444, 1882. (St. Genevieve district.) 28. Bain and Ulrich, U. S. Geol. Surv., Bull. 260 : 233, 1905. (General.) - Montana : 29. Weed, U. S. Geol. Surv., Bull. 213:170, 1903. (Butte.) 30. Winchell, Eng. and Min. Jour., LXXVIII: 7, 1904. 31. Winchell, Geol. Soc. Amer., Bull. XIV : 269, 1903. - New Jersey: 32. Kümmel, N. J. Geol. Surv., Ann. Rept., 1899 : 171, 1900. 33. Weed, U. S. Geol. Surv., Bull. 225: 187, 1904. (Griggstown.) Pennsylvania: 34. Bailey, Eng. and Min. Jour., XXXV : 88, 1883. (Adams County.) 35. Lyman, Jour. Franklin Inst., CXLVI: 416, 1898. (Bucks and Montgomery counties.) - Tennessee: 36. Henrich, Amer. Inst. Min. Engrs., Trans. XXV :173, 1896. (Ducktown.) 37. Kemp, Amer. Inst. Min. Engrs., Trans. XXXI : 244, 1902. (Ducktown.) 38. Weed, Amer. Inst. Min. Engrs., Trans. XXX: 449, 1901. (Southern Appalachians.) - Texas: 39. Schmitz, Amer. Inst. Min. Engrs., Trans. XXVI: 97, 1897. (Permian ores.) United States: 40. Douglas, Amer. Inst. Min. Engrs., Trans. XIX: 678, 1891. 41. Stevens, Copper Handbook, published annually at Iloughton, Michigan, by the author, \$5. 42. Weed, U. S. Geol. Surv., Bull. 213 :181, 1903 (Appalachians); and Bull. $260: 217$, 1905. (E. U. S.) 43. Weed, U. S. Geol. Surv., Bull. $260: 211,1905$. (U. S. localities and industry.) - Utah: 44. Boutwell, U. S. Geol. Surv., Bull. 213 : 105, 1903. (Bingham.) Also U. S. Geol. Surv., Prof. Paper 38, 1905. - Vermont: 45. Weed, U. S. Geol. Surv., Bull. 225 : 190, 1904. 46. Smyth and Smith, Eng. and Min. Jour., April 28, 1904. - Virginia : 47. Watson, Geol. Soc. Amer., Bull. XIII : 353, 1902. (Virgilina district.) - Wisconsin: 48. Grant, Wisconsin Geol. and Nat. Hist. Surv., Bull. No.6, 1900. (Douglas Co.) - Wyoming: 49. Kennedy, Eng. and Min. Jour., LXVI : 640, 1898. 50. Spencer, U. S. Geol. Surv., Bull. 213 : 158, 1903. (Encampment region.) 


\section{CHAPTER XVI \\ LEAD AND ZINC}

THese two ores can hardly be treated separately for the reason that they occur so often associated with each other; the combination of lead and silver, of importance in the Rocky Mountain region, is treated under a separate head.

Ores of Lead. - The ores of lead, together with their composition and the percentage of lead which they contain, are :Galena, $\mathrm{PbS}, 86.4$;

Cerussite, $\mathrm{PbCO}_{3}, 77.5$;

Anglesite, $\mathrm{PbSO}_{4}, 68.3$;

Pyromorphite, $\mathrm{Pb}_{3} \mathrm{P}_{2} \mathrm{O}_{8}+\frac{1}{3} \mathrm{PbCl}_{2}, 76.36$.

Of these, galena is the commonest, while the other two are usually found in those localities where superficial oxidation of the ore deposit has taken place. The lead obtained from argentiferous ore is commonly spoken of as desilverized or hard lead, while that from non-argentiferous ones, such as those of the Mississippi Valley areas, is known as soft lead.

Ores of Zinc. - The ores of zinc, together with the percentage of zinc they contain, are:-

Sphalerite, $\mathrm{ZnS}, 67$;

Smithsonite, $\mathrm{ZnCO}_{3}, 51.96$;

Calamine, $\mathrm{H}_{2} \mathrm{Zn}_{2} \mathrm{SiO}_{5}, 54.2$;

Zincite, $\mathrm{ZnO}, 80.3$;

Willemite, $\mathrm{Zn}_{2} \mathrm{SiO}_{4}, 58.5$;

Franklinite ( $\mathrm{FeZnMn}) \mathrm{O}(\mathrm{FeMn})_{2} \mathrm{O}_{3}$, composition vari-

able but containing about $51.8 \mathrm{Fe}$ and $7.5 \mathrm{Mn}$. 
Of these ores, sphalerite (also known as blende, jack, or black-jack) is by far the most important, except in northern New Jersey, where it is practically lacking and franklinite and willemite abound. With few exceptions, zinc is constantly associated with lead, and at times, as in portions of the Cordilleran region, carries silver or even gold.

Calcite, dolomite, and pyrite are common gangue minerals of non-argentiferous lead, and zinc ores, and others may occur at certain localities. In the argentiferous ores, quartz is probably the commonest gangue mineral, but there may be other less important ones.

Iron, lead, and manganese are not uncommon impurities in zinc ores, and those of Missouri contain small amounts of cadmium, but this is not injurious, as it is more volatile than the zinc and easily driven off by heat.

Argentiferous lead ores sometimes contain antimony, arsenic, and iron as impurities. Those of the Appalachians, which are practically non-argentiferous, are free from most of these.

Neither lead or zinc ores are restricted to any one formation, but the majority of economically valuable deposits of these metals, without silver, gold, or copper, are found in the Paleozoic formations, although a few are known in preCambrian rocks. They exist as disseminations, chamber deposits, as filling in brecciated zones, in gash veins and replacements. While the metallic contents of the ore as mined is often low, still, owing to the great difference in gravity between ore and gangue (excepting pyrite), it is often possible to separate them by mechanical concentration; and for the zinc ores magnetic separation has been successfully tried. 
Superficial Alteration of Lead and Zinc Ores. - Galena is often altered near the surface to anglesite or cerussite. The former, however, is unstable in the presence of carbonated waters and changes readily to carbonate. Phosphates are developed in rare instances.

Sphalerite, the common ore of zinc, is often changed superficially to smithsonite, hydrozincite, or calamine. Such oxidized ores are of greater value than unoxidized ones, because

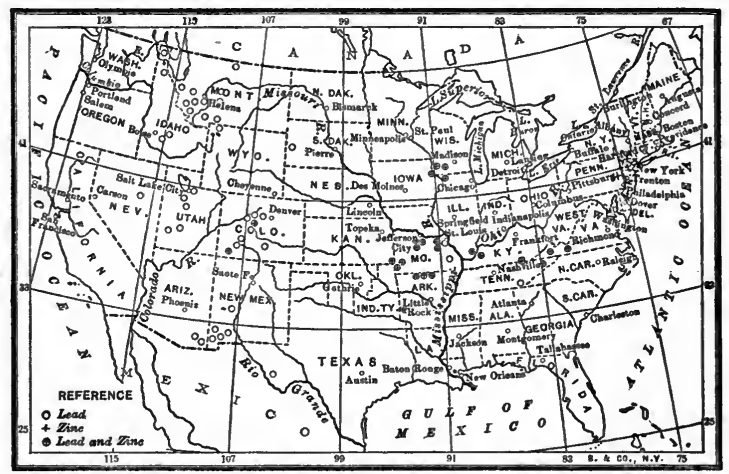

Fig. 61.- Map showing distribution of lead and zinc ores in United States. Adapted from Ransome, Min. Mag., $X: 1$.

although carrying a lower percentage of zinc, they occur in a more concentrated form and yield more easily to metallurgical treatment.

\section{Distribution of Lead and Zinc Ores in the United States. -} The occurrence of lead or zinc with gold, silver, and copper is confined chiefly to the Cordilleran region, and shows a most varied mode of occurrence; but commercially valuable deposits of lead alone, or lead and zinc, are confined to the 
Mississippi Valley, while those of zinc alone or with little lead are restricted to the Appalachian region as seen below.

Lead Alone. Appalachian Belt (11, 25, 29). - Lead (sometimes argentiferous) occurs at a number of localities from Maine to Georgia, filling small veins in metamorphic rocks, and the deposits have at various times aroused temporary interest. There is no likelihood of their ever becoming important producers, although exciting rumors regarding them are occasionally circulated.

Southeastern Missouri (12, 18, 19). - This area forms a subdistrict of the Ozark lead and zinc region, to be

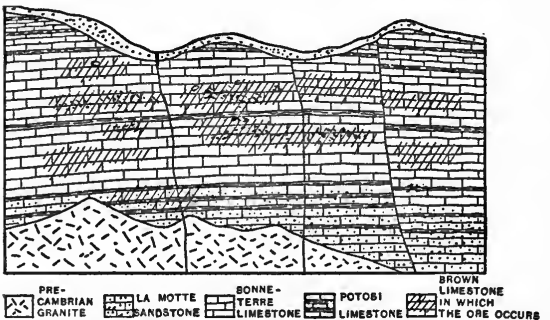

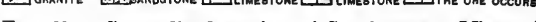

Fra. 62.-Generalized section of Southeastern Missouri lead region. After Bain. mentioned later. The galena is found in Lower Silurian limestones, the larger lead deposits occurring in massive strata near the base, called St. Joseph limestone, while others with a little zinc are in the cherty Potosi limestone near the summit; the sandstone layers are barren. The ore forms great impregnations, but cavern or vein deposits so common in other parts of Missouri are wanting in this region; while many small faults occur, the ore seldom favors them. The origin of these ores is treated under lead and zinc. The average ore runs from 6 to 8 per cent galena; when roughly handpicked, 10 to 12 ; and subse- 
quent jigging of the crushed ore brings the galena contents up to 60 or 70 per cent.

The Missouri lead mines were worked at a very early date for making bullets, and their product is said to have been used during the Revolution.

Desilverized Lead. - The important localities supplying this type of lead are described under lead-silver ores, but brief reference may be made to them here. Idaho is the most important producer, more than 96 per cent coming from the Cœur d'Alene district. In Utah much is obtained from the Park City district of Summit County, the Bingham Cañon and Cottonwood districts of Salt Lake County, and the Tintic district of Juab County. Colorado's main supply is yielded by the Leadville mines in Lake County and the Aspen mines of Pitkin County, while smaller amounts are obtained from Creede, Lake City, Ouray, and Rico. (See Lead-Silver references, also map, Fig. 73.) (28.)

Comparatively little lead is produced in the western states, except in the three mentioned above.

As pointed out by Bain, the important lead ores of this region are closely associated with both igneous and sedimentary rocks. At Leadville, Aspen, and Park City the sediments are dolomites and limestones, and at Cœur d'Alene they are shales and quartzites. While the ores seem to favor igneous associations, still the larger bodies are found where both classes of rocks occur.

Zinc Ores. - The zinc-producing regions of the United States are the eastern and southern states, the Mississippi Valley, and the Rocky Mountain region. 
The ore from the different districts varies in grade, associations and mode of occurrence.

In tonnage terms, the main zinc-producing districts are the Joplin, Missouri, Sussex County, New Jersey, and Colorado. The Joplin ores are the main source of supply of the Kansas, Missouri, and Illinois smelters, but Colorado and even British Columbia ore is shipped to Kansas. Most of the New Jersey ore is used for zinc oxide, but smaller amounts are exported or used for spelter.

Eastern and Southern States. - The localities where zinc alone occurs are Sussex County, New Jersey; Saucon Valley, Pennsylvania; and the Virginia-Tennessee belt. Of these the first is the most important, and the third yields a little lead.

Sussex County, New Jersey (20-22). - The output of these mines is second in importance to those of the Mississippi Valley region. The district includes two general mining areas situated close together, the one called Mine Hill, at Franklin, and the other called Sterling Hill, at Ogdensburg, two miles farther south, but not now worked.

The ore-bearing minerals, which represent a unique type of occurrence, consist of franklinite, zincite, willemite, and calamine, the typical ore being a granular mixture of franklinite and calcite, with zincite and willemite scattered through it. Manganese minerals are also present, thus giving a combination of three common elements, viz., manganese, zinc, and iron.

The average mineralogical composition of the Franklin Furnace ore (Ingalls) is franklinite, 51.92; willemite, 31.58 ; calcite, 12.67 ; zincite, .52; other silicates, 3.31 ; 
while the average chemical composition is : $\mathrm{Fe}_{2} \mathrm{O}_{3}, 32.06$; $\mathrm{MnO}, 11.06 ; \mathrm{ZnO}, 29.35 ; \mathrm{CaCO}_{3}, 12.67$; silica and insoluble matter, 14.57 .

The ore body at both localities is interbedded with a white crystalline limestone of probably pre-Cambrian age, which in turn rests on gneiss. The Ogdensburg ore deposit forms a great hook, giving two veins apparently, and the ore body seems to be an impregnated streak of limestone; while at Mine Hill the northerly pitching ore body is also

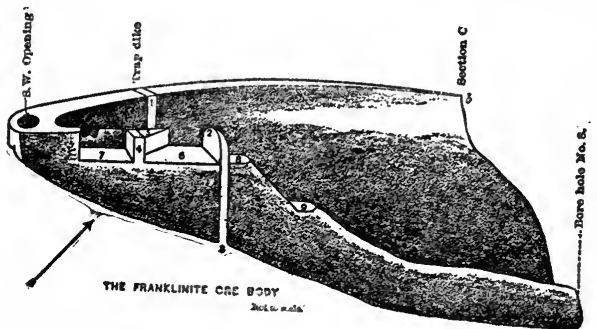

FIG. 63. - Model of Franklin zinc ore body. After Nason, Amer. Inst. Min. Engrs., Trans. XXIV: 127.

a synclinal fold, whose southern end in addition appears to be doubled over into an anticline. In both cases the wall rock is heavily impregnated at the bends of the fold with franklinite and other minerals, while the ore bodies are pierced by intrusive rocks. The origin of these deposits is of unusual interest, for they not only contain in abundance a number of zinc minerals rare or unknown elsewhere, but many other mineral species as well. No sulphides of either zine or iron have been noted, to suggest a derivation from that source, and faults which might serve as ore channels are likewise lacking, consequently their origin is difficult to explain. 
Kemp (20) considers that the ore was probably deposited from solutions stimulated by intrusions of granite, and subsequently metamorphosed, but Wolff (21) suggests that they are contemporaneous in form and structure with the inclosing limestones, and hence older than the granites. The extent to which they have been metamorphosed has served to hide their original character, and theories regarding their possible origin have been largely speculative.

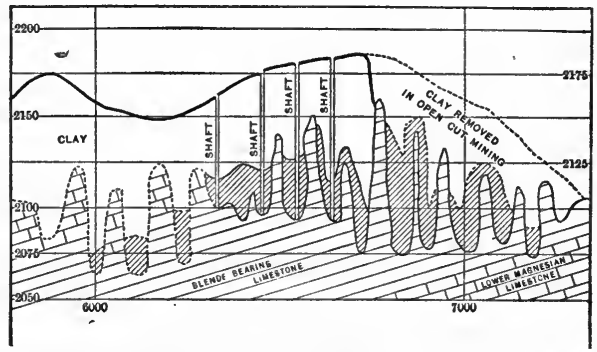

FIG. 64. - Section of Bertha zinc mines, Wythe Co., Va., showing irregular surface of limestone covered by residual clay bearing ore. After Case, Amer. Inst. Min. Engrs., Trans. XXII: 520.

These ore bodies are of some historic interest, having been prospected as early as 1640 and mined in 1774 . The Mine Hill deposits were worked for iron ore as early as the beginning of the last century, the zinc mining having begun about 1840. The ores are now treated by magnetic separators, which remove the franklinite and garnet from the willemite and zincite, while the calcite is taken out by jigging. The zinc ores are used for metallic zinc and zinc white, and the manganese for Bessemer steel.

Virginia-Tennessee Belt (32-35, 26, 27). - Zinc and some lead occur in a belt extending from southwest Virginia into Tennessee. The ores are intimately associated with Cambro-Ordovician limestone, and show two types, viz.: (1) secondary or weathered ores, including calamine, smith- 
sonite, and cerussite, which are concentrated in the residual clays next to the irregular weathered surface of the limestone (PL. XVII, Fig. 2); and (2) primary ores, including sphalerite, galena, and some pyrite, belonging to the disseminated replacement breccia type, and which have been localized by ground waters along the crushed and faulted axes of the folds. The gangue minerals are chiefly calcite, dolomite, and some barite. Fluorite is known, and quartz may occur in the form of chert. One deposit only, in Albemarle County, is found in schist, and is closely associated with igneous rocks.

Pennsylvania (25a). - The Saucon Valley deposits promised at one time to become prominent producers, but have not, owing more to geological conditions than actual scarcity of ore.

\section{Lead and Zinc Ores of the Mississippi Valley Region. -} This includes two important areas, viz., the Upper Mississippi Valley and the Ozark Region.

Upper Mississippi Valley Area $(36,8,9)$.—This area embraces soutthwestern Wisconsin, eastern Iowa, and northwestern Illinois, but the first-named state contains the most productive territory. The section in the Wisconsin area, which may be taken as typical, involves the following formations, beginning at the top:-

Niagara limestone . . . . . . . Silurian.

Cincinnati (Maquoketa) shales

Galena limestone . . . . . $250 \mathrm{ft}$.

Trenton limestone . . . 40-100 ft. Ordovician.

St. Peter's sandstone . . . . $150 \mathrm{ft}$.

Lower magnesian limestone, 100-250 ft.

Potsdam sandstone . . . 700-800 ft. $\}$ Cambrian. 
A bituminous shaly layer, known as the oil rock, occurs at the base of the Galena, and below it, or at the top of the Trenton, is a fine-grained limestone called the glass rock. While the series as a whole shows a very gentle southwest dip, there are a few low folds.

The ore-bearing minerals, consisting of galena, smithsonite, and sphalerite, associated with marcasite and some

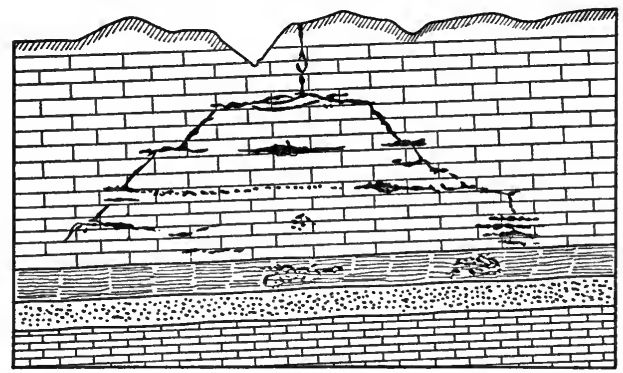

堅

FIG. 65. - Section showing occurrence of lead and zinc ore in Wisconsin, showing fissure ore in flats and pitches, and disseminated ore in oil rock. After Chamberlin.

calcite, occur as disseminations, as honeycomb masses in brecciated or porous limestone, and in crevices. The last type, which forms the most important source of the ore, consists of a vertical fissure, which at its lower end splits into two horizontal branches called flats, while these in turn pass into a steeply dipping fissure termed pitches (Figs. 42 and 65). There are at times several flats. Galena commonly predominates in the crevices, while sphalerite occurs in great abundance lower down. The main crevices extend approximately east and west, but there are other 
less important intersecting fissures. The Galena limestone is the most important ore-bearing formation, but ore is also known to occur in the lower-lying limestones and sandstones, although no deposits have been worked in them. In the crevices the order of deposition is marcasite, sphalerite, and galena. The ores, are frequently oxidized, yielding smithsonite and some calamine.

A careful study of the origin of the ore bodies indicates that the metallic minerals have been gathered by circulating meteoric waters from the Galena limestone; these waters entered the limestone probably from the northeast, where the overlying shales had been eroded, and moved to the southwest. The ore was precipitated in crevices as sulphides, either because of a reducing action exerted by bituminous matter present in the rocks or hydrogen sulphide.

Surface waters descending crevices have produced a secondary concentration, which has resulted in a separation of the zinc and galena, accompanied by a transferal of much of the former to lower levels.

Lead was discovered in the Upper Mississippi area as early as 1692, and the first mining was done in Dubuque in 1788. The early work was restricted to lead mining entirely, the zinc ores being disregarded. Owing to uncertainty regarding the size of the deposits, the mining for many years has been done in a most primitive manner, but more recently prospecting at lower levels and the discovery of new ore bodies has stimulated the erection of better plants. Mechanical concentration methods have also been introduced, and while the galena can be separated quite thoroughly from the sphalerite and marcasite, the last two are parted with difficulty. On account of the presence of marcasite in most of the mines, the zinc ores of this district command a lower price than those from other areas. For this same reason much of the ore cannot be used for spelter, but is employed for zinc oxide and sulphuric acid manufacture. 
Ozark Region $(12,13,15,17)$. - The position of the region is shown on the map, Fig. 66. The southern part of the area is underlain by Carboniferous sandstone and shales,

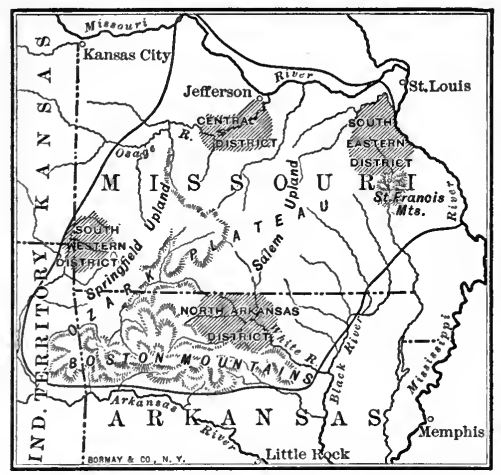

Fig. 66. - Map of Ozark region. After Branner, Eng. and Min. Jour., LXXIII: 475.

while the northern part, forming the Ozark plateau, and containing the lead and zinc deposits, is underlain by slightly disturbed sedimentaries. In the eastern part of the plateau, or Salem Upland, they are Cambro-Silurian dolomites and magnesian limestone, while those of the western portion, or Springfield Upland, are Lower Carboniferous limestones.

Within this region the following four districts are recognized :-

1. Southeastern Missouri, yielding lead from disseminated ores. This area has been mentioned under Lead Alone.

2. Southwestern Missouri, or the Missouri-Kansas district, with Joplin as the most important mining town. It yields chiefly zine, with some lead. The ore occurs in limestones of Subcarboniferous age, filling fissures, as a cement of brecciated patches, or more rarely parallel to the bedding. The ore bodies are sometimes hundreds of feet in diameter. In some cases the ore extends to the 
surface, and is then usually surrounded by more or less residual clay.

3. Central Missouri district, containing small deposits of both lead and zinc. In this area the ore as far as exploited occurs rather in vertical crevices or chimneys than in breccias.

4. The northern Arkansas district, but partly developed, and with many rich ores, occurring as bedded deposits (dissem-
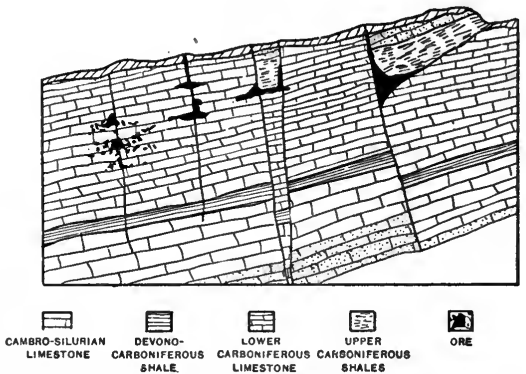

Fig. 67.-Generalized section showing occurrence of lead and zinc ore in southwest Missouri. After Bain.

inations), veins (in faults or filling breccias), or as alterations.

The common ores are sphalerite and galena, with a gangue of secondary chert, dolomite, calcite, and barite. Residual clays occur in some mines, and bitumen is not uncommonly found with the ores.

These deposits afford an interesting example of the paragenesis of minerals, the succession seeming to be (Winslow, Trans. Am. Inst. Min. Engrs., p. 651, 1893) dolomite, blende, galena, barite, calcite, and pyrite.

The ores of this region are mechanically concentrated after mining, and the composition of an average sample of 3800 carloads of blende shipped from the Joplin district in the first part of 1904 is given by Ingalls as: $\mathrm{Zn}, 58.26$; $\mathrm{Cd}, .304 ; \mathrm{Pb}, .70 ; \mathrm{Fe}, 2.23 ; \mathrm{Mn}, .01 ; \mathrm{Cu}, .049 ; \mathrm{CaCO}_{3}$, 
$1.88 ; \mathrm{MgCO}_{3}, .85 ; \mathrm{SiO}_{2}, 3.95 ; \mathrm{BaSO}_{4}, .82 ; \mathrm{S}, 30.72$; total, 99.773.

Origin of the Ores. - Most of the theories of the origin of these ores agree in considering that their concentration has been caused by circulating meteoric waters which have collected the ore particles from the limestones, although in one instance at least they seem. to be associated with

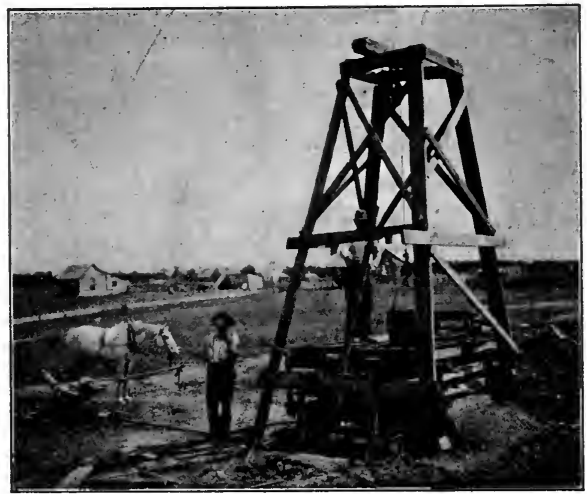

Fra. 68. - A typical hoisting outfit in the southwestern Missouri zinc region. Photo. by H. F. Bain.

igneous intrusions (19). Analyses of the limestones show amounts of from .001 to .015 per cent of lead and zinc in the Cambro-Silurian magnesian limestones and Archæan rocks to the southeast of the region, and from .002 to .003 per cent in the Lower Carboniferous limestones. These averages calculated give 87 pounds of galena per acre in a one-foot layer, and 261 pounds of blende in the same volume of rock. W. P. Jenney, who studied the deposits in some detail, has emphasized the importance of ascend- 
ing waters, while Winslow has argued for their concentration by descending currents.

The more recent studies of $\mathrm{H}$. F. Bain indicate that both ascending and descending waters were active, and that the chemical reactions involved were characteristic of dilute solutions; rich ores, therefore, indicate great aqueous activity.

The more important circulations have occurred in the Cambro-Silurian limestones and those of the Mississippi or Lower Carboniferous series, but the concentration process has been often repeated in many different horizons and at different depths. .

The chemical changes which took place in the primary concentration of the ores were the oxidation of sulphides to sulphates, the transportation of these in solution, and their reprecipitation as sulphides in favorable localities. The localization of the ore bodies has been due to the presence of fissures which permitted the mixing of the ore-bearing solutions, but the circulation of the latter has been limited in many instances by impervious beds of shale, and organic matter has served as a' reducing agent. All of the ores are found to be closely associated with lines of subterranean seepage, and since the open character of the breccias favored circulation, much ore is found in them. Where folding has occurred, the water has also sought the troughs of synclines as in the Lake Superior district.

In the section presented in the Ozark region, the DevonoCarboniferous shales and the undifferentiated Carboniferous shales afforded impermeable barriers to circulation. The former, where not faulted, held down the ascending solutions; but where absent or fissured, the solutions from the 
underlying Cambro-Silurian formation were able to pass upward into the Mississippian and impregnate them.

The Cambro-Silurian ores were first concentrated by deep circulation, and formed the disseminated ores. Later, when erosion cut away the Devono-Carboniferous capping, further concentration took place by descending solutions, giving rise to the ore bodies in crevices, breccias, and synclines.

Two concentrations have occurred in the Mississippian limestones.

The ore bodies are of two types, viz. : (1) those containing sulphides and clean untarnished minerals, the result of primary concentration; and (2) those due to surface concentration, and containing oxidized ones with red clay. The ores pass into sulphides below the water level.

Where ascending solutions alone acted, the ore bodies are less rich but more reliable, however secondary enrichment of the deposits has been marked.

Rocky Mountain States (28). - Although much ore is mined in this region, its resources of this metal are still largely undeveloped, and up to 1903 most of the ore mined was either shipped to Kansas smelters or exported. The recent construction of a zinc-smelting plant at Pueblo, Colorado, and the enlargement of the oxide plant at Canyon, Colorado, has largely stimulated the production of both that state and Utah.

The zinc-producing localities of Colorado are chiefly the same as those yielding lead, Leadville being the largest producer. According to Ingalls the zinc shipments average about 25 per cent $\mathrm{Zn}, 10 \mathrm{~Pb}, 2.2 \mathrm{Fe}, 4 \mathrm{SiO}_{2}, 39 \mathrm{~S}$, and 10 oz. Ag. Much zinc ore is also supplied by the mines at 
Creede (Ingalls), where it is concentrated to a product assaying 55-59 per cent $\mathrm{Zn}, 3.75-6 \mathrm{~Pb}$, and 1.1-2.1 Fe, which is shipped to Kansas. The blende carries 2-3 oz. Ag per T. Blende concentrates are also produced at Montezuma and Rico, Colorado. The Colorado ores are usually of lower grade than the Joplin ones, and their complex nature makes treatment difficult; indeed until recently zinc has been a source of loss to the miners and smelters, those ores high in zine being either neglected or thrown out.

In addition to Colorado, New Mexico produces considerable ore, the deposits near Hanover yielding blende and smithsonite (28) from Carboniferous limestone near igneous contacts. It was shipped to Wisconsin for treatment. Utah, Idaho, and Montana will no doubt also become important sources of supply in the future.

Uses of Lead and Zinc. - Both of these are important base metals, although in value of production they rank below gold, silver, copper, and iron, neither do they come into competition with these, for they lack the high tenacity of iron and steel, the conductivity of copper, and the value resulting from scarcity possessed by gold and silver. They are of value, however, on account of their high malleability and the application of their compounds for pigments.

Uses of Lead. - Lead finds numerous uses in the arts, the most important being for white lead. Litharge, the oxide of lead, is used not only for paint, but also somewhat in the manufacture of glass, although red lead is more frequently employed instead.

A further use of lead is for making pipe for water supply, sheet lead for acid chambers, and shot. 
Among the alloys formed by lead are type metal (lead, antimony, and bismuth, with copper or iron), white metal, organ pipe composition, and fusible alloys used in electric lighting.

In addition to these, the acetate, carbonate, and other compounds are used in medicine. In smelting, lead is used to collect the gold and silver, and the bulk of the lead of commerce is obtained as a by-product in the smelting of the precious metals.

Uses of Zinc. - Metallic zinc is used for a variety of purposes, partly owing to its slight alteration in air, and secondly, because it can be rolled into thin sheets. In this condition it is used extensively for roofing and also for plumbing, and as a coating to iron this metal is extensively called for in galvanizing. It is also used for cyaniding gold.

One of the most important applications is for making brass, which is ordinarily composed of from 66 to 83 parts of copper and 27 to 34 parts of zinc. The composition varies, entirely depending on the use to which it is to be put, and, with the variation in proportion, the color becomes more golden, or whiter, according as the percentage of copper is increased or decreased. With an increase in the amount of zinc, the alloy becomes more fusible, harder, and more brittle. Brass was made long before zinc, as a metal, was discovered, and Aristotle says that the people by the Euxine Sea made their copper a beautiful whitish color by mixing it with a white earth found there. Strabo also tells us that the Phrygians made brass in this way.

White metal is an alloy of zinc and copper in which zinc predominates, and which is often employed for making buttons. Imitation gold is also made by alloying zinc with a predominance of copper, varying from 77 to 85 per 
cent of the mass, and this is in common use as "gold foil" for gilding. Zinc is also made use of in the construction of electric batteries.

German silver has 60 parts copper, 20 zinc, and 20 nickel. Its use is for mathematical and scientific instruments.

Production of Lead and Zinc. - The production of lead in the United States from $\mathbf{1 8 2 5}$ to 1900 was as follows :-

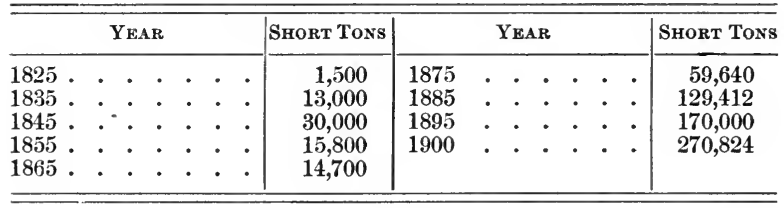

About 70 per cent of the lead produced in the United States is derived from five districts, viz.: Southeastern Missouri ; Joplin, Missouri ; Leadville, Colorado; Park City, Utah; and Cœur d'Alene, Idaho.

\section{Lead Content of Ores smelted in the United States FROM 1901 To 1903}

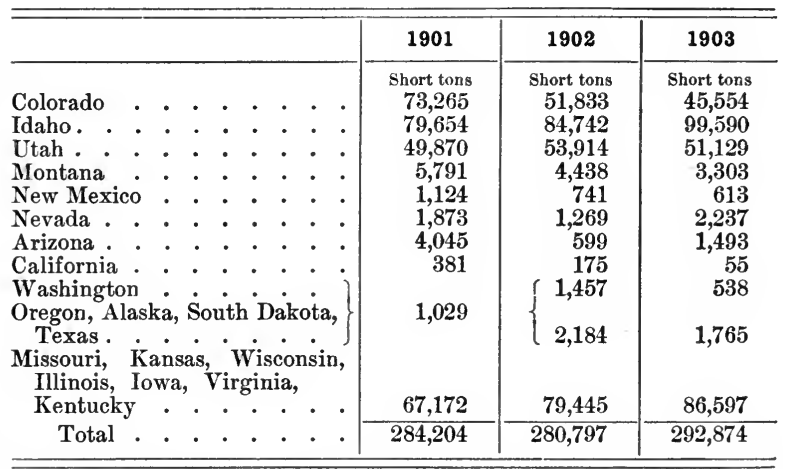


The production of spelter in the United States from 1873 to 1900 was : -

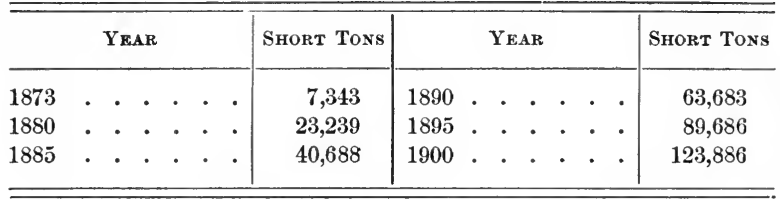

Production of Spelter from 1901 to 1903 by States

\begin{tabular}{|c|c|c|c|c|c|c|}
\hline & $\begin{array}{c}\text { EASTERN } \\
\text { AND } \\
\text { SOUTHERN } \\
\text { STATES }\end{array}$ & $\begin{array}{l}\text { ILLINOIS } \\
\text { AND } \\
\text { INDIANA }\end{array}$ & KANSAS & Missouri & Colorado & TotaL \\
\hline & Short tons & Short tons & Short tons & Short tons & Short tons & Short tons \\
\hline 1901 & 8,603 & 44,896 & 74,240 & 13,083 & & $140,822^{1}$ \\
\hline 1902 & 12,180 & 47,096 & 86,564 & 11,087 & & $156,927^{2}$ \\
\hline 1903 & 12,301 & 47,659 & 88,388 & 9,994 & 877 & $159,219^{3}$ \\
\hline
\end{tabular}

World's Production of Lead. - This in 1902 amounted to 926,895 metric tons. Of this quantity the United States produced approximately 26 per cent; Spain, 19 per cent; Germany, 15 per cent; and Mexico, 11 per cent. Of these countries Spain and Mexico afforded the greatest surplus production, and both Germany and the United Kingdom required more lead than they mined.

The figures of world's production together with imports and exports in metric tons for 1902 are given below :-

1 Including 2716 tons dross spelter.

2 Including 2675 tons dross spelter.

${ }^{8}$ Including 3302 tons dross spelter. 


\begin{tabular}{|c|c|c|c|c|c|c|c|}
\hline & & & $\begin{array}{l}\text { ProduC- } \\
\text { TION }\end{array}$ & IMPORTS & Total & ExPORTS & $\begin{array}{c}\text { CoNSUMP- } \\
\text { TION }\end{array}$ \\
\hline Austria-Hungary & & & 13,543 & 8,706 & 22,249 & 53 & 22,196 \\
\hline Belgium . . & - & • & 19,500 & 53,000 & 72,500 & 50,000 & 22,500 \\
\hline France. . . & • & & 18,817 & 72,730 & 91,547 & 6,454 & 85,093 \\
\hline Germany . & & & 140,331 & 39,006 & 179,337 & 23,100 & 156,237 \\
\hline Italy . . & & & 26,494 & 7,563 & 34,057 & 5,650 & 28,407 \\
\hline Prussia & $\bullet$ & & 250 & 23,000 & 23,250 & & 23,250 \\
\hline Spain . & • & $\bullet$ & 177,560 & & 177,560 & 172,480 & 5,080 \\
\hline United Kingdom & & $\bullet$ & 27,100 & 235,522 & 262,622 & 24,408 & 238,214 \\
\hline United States . & ${ }^{\circ}$ & ${ }^{*}$ & 342,160 & 65,235 & 407,395 & 129,637 & 277,758 \\
\hline
\end{tabular}

World's Production of Zinc. - The production of zinc ore and spelter in metric tons for 1902 is given below :-

\begin{tabular}{|c|c|c|c|c|c|c|c|c|}
\hline Country & SPELTER & ORE & Count & TRY & & & SPELTER & ORE \\
\hline Germany . & 174,927 & 702,504 & Austria & & - & & 7,960 & 31,927 \\
\hline United States & 143,552 & 500,000 & Spain & . & . & & 5,569 & 127,618 \\
\hline Belgium . . & 124,780 & 3,852 & Italy. & . & . & & 485 & 149,965 \\
\hline United Kingdom & 40,244 & 25,462 & Sweden & . & . & & & 48,783 \\
\hline France. . . & 36,282 & 57,982 & Algeria & . & • & & & 33,139 \\
\hline Holland & 20,760 & & Greece & - & - & & & 18,020 \\
\hline Russia . . & 8,280 & & Tunis & . & . & & & 18,400 \\
\hline
\end{tabular}

The above table indicates that the mining districts and smelting centers are not identical. Belgium and Holland have a smelting industry greatly in excess of the local mining interests, but in the United States they are in approximate equilibrium.

\section{REFERENCES ON LEAD AND ZINC}

Arkansas : 1. Adams, U. S. Geol. Surv., Bull. 213 : 187, 1903. (N. Ark.) 2. Adams, U. S. Geol. Surv., Prof. Paper No. 24, 1904. 3. Branner, Ark. Geol. Surv., Rept. for 1892, V. (N. Ark.) - Colorado : 4. Emmons, U. S. Geol. Surv., Mon. XII, 1886. (Leadville.) 5. Ransome, U. S. Geol. Surv., 22d Ann. Rept., II : 229, 1901. (Rico Mts.) 
6. Spurr, U. S. Geol. Surv., Mon. XXXI, 1898. (Aspen.)-Idaho: 7. Lindgren, U. S. Geol. Surv., 20th Ann. Rept., III : 190, 1900. (Wood River district.) - Illinois: 8. Bain, U. S. Geol. Surv., Bull. 225 : 202, 1904, and Bull. 246, 1904. - Iowa : 9. Leonard, Ia. Geol. Surv., VI : 10, 1897. - Kentucky : 10. Ulrich and Smith, U. S. Geol. Surv., Prof. Paper No. 36, 1905._Massachusetts : 11. Hubbard, Amer. Jour. Sci., IX : 166, 1825. - Missouri : 12. Bain, U. S. Geol. Surv., 22d Ann. Rept., II : 23, 1901. (Ozark region.) 13. Bain, U. S. Geol. Surv., Bull. 267, 1905. (Mo.) 14. Ball and Smith, Mo. Bureau Geol. and Mines, Bull. Vol. I, 2d Series, 1903. (Central Mo.) 15. Branner, Eng. and Min. Jour., LXXIII : 475, 1902. (Ozark region.) 16. Jenney, Amer. Inst. Min. Engrs., Trans. XXII : 171, 1894. (Mo.) 17. Winslow, Mo. Geol. Surv., Vols. VI and VII, 1894. 18. Winslow, U. S. Geol. Surv., Bull. 132, 1896. (S. E. Mo.) 19. Wheeler, Eng. and Min. Jour., LXXVII: 517, 1904. (Relation of lead ore to igneous rock.) - New Jersey: 20. Kemp, Trans. N. Y. Acad. Sci., XIII : 76, 1894. 21. Wolff, U. S. Geol. Surv., Bull. 213 : 214, 1903. 22. Nason, Amer. Inst. Min. Engrs., Trans. XXIV : 121, 1894. A U. S. Geol. Surv. report by Spencer is also in preparation.-New Mexico: 23. Blake, Amer. Inst. Min. Engrs., Trans. XXIV: 187, 1894. (S. W. New Mexico.) 24. Keyes, Min. Mag., XII : 109, 1905. (Magdalena Mts.)-New York: 25. Ihlseng, Eng. and Min. Jour., LXXV : 630, 1903. (Ellenville.) - Pennsylvania : $25 a$. Clerc, U. S. Geol. Surv., Min. Res. 1882, 361. - Tennessee : 26. Keith, U. S. Geol. Surv., Bull. 225 : 208, 1904. 27. See also Morristown, Maynardville, and Cleveland folios, U. S. Geol. Surv. - United States : 28. Bain, U. S. Geol. Surv., Bull. $260: 251,1905$. 29. Whitney, Metallic Wealth of U. S., 1854. (Appalachians.) - Utah : 30. Emmons, Amer. Inst. Min. Engrs., Trans. XXXI : 658, 1902. (Delamar and Hornsilver Mines.) 31. Tower and Smith, U. S. Geol. Surv., 19th Ann. Rept., III : 601, 1899. (Tintic.) - Virginia : 32. Boyd, Resources of Southwest Virginia, 1881. 33. Case, Amer. Inst. Min. Engrs., Trans. XXII : 511, 1894. 34. Payne, Eng. and Min. Jour., LXXVIII : 544, 1904. 35. Watson, Va. Geol. Surv., Bull. 1, 1905. (Va.-Tenn.)-Wisconsin: 36. Grant, Wis. Geol. and Nat. Hist. Surv., Bull. 9, 1903. 


\section{CHAPTER XVII}

\section{GOLD AND SILVER}

GowD and silver are obtained from a variety of ores, in some of which the gold predominates, in others silver, while in still a third class these two metals may be mixed with the baser metals, lead, copper, and zinc. Few gold ores are absolutely free from silver, and vice versa, so that a separate treatment of the two is more or less difficult; however some lead-silver ores, although they may carry some gold, are sufficiently prominent to be discussed as a separate type, and are described as such on a later page.

Ores of Gold. - Gold occurs in nature chiefly as native gold, mechanically mixed with pyrite, or as a telluride such as calaverite (Au, 39.5 per cent; Ag, 3.1 per cent; Te, 57.4 per.cent). ${ }^{1}$

Ores of Silver. - The minerals which may serve as ores of silver, together with the percentage of silver they contain, are :-

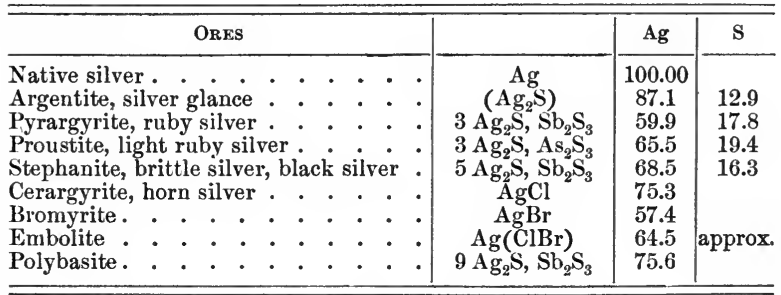

1 Other tellurides are sylvanite, kalgoorlite, and krennerite. 
Mode of Occurrence. - Most of the gold and silver mined in the United States is obtained from fissure veins, or closely related deposits of irregular shape (79), in which the gold and silver ores have been deposited from solution, either in fissures, or other cavities, or by replacement. Considerable gold and a little silver is obtained from gravel deposits. Some true contact deposits are known. Gold has been found to occur in rare instances as an original constituent of igneous rocks $(1,8,11)$ and also metamorphic ones $(12)$, but there are no known deposits of commercial value belonging to this type.

The gold and silver-bearing fissure veins include two prominent types (79), viz.: (1) the quartz veins, and (2) the propylitic type, in which the metasomatic alteration of the wall rock is often propylitic, that is, accompanied by the formation of chlorite and epidote, but near the veins of sericite and kaolin. In the quartz-vein type silver is present usually in but small quantities, while in the propylitic type the silver often is an important constituent.

While the mode of occurrence of gold and silver is quite variable, the character of the wall rock is equally so, gold and silver ores being found in either sedimentary or igneous rocks, and along the contact between the two, showing that the kind of rock exerts little influence, except perhaps where replacement has been active. On the other hand the influence of locality is much stronger, for it has been found that many gold and silver-bearing deposits are closely associated with masses of igneous rock, the most common of these being diorite, monzonite, quartz-monzonite, granodiorite, while true granites are rare as associates. A second large class of vein systems shows a close association with lavas of recent age, and the telluride ores rather favor these (6). 
Weathering and Secondary Enrichment. - The superficial alteration of gold ores differs somewhat from that of deposits containing ores of the other metals. In quartz veins with auriferous pyrite, the change of the latter to limonite leaves a rusty quartz with nuggets or threads of free gold, and leaching may remove most of the iron. Some of the gold may also be leached out by the ferric sulphate, formed by the oxidation of the pyrite, and carried to lower levels, where it is reprecipitated. Whether the reprecipitation of the gold is due to pyrite or carbonaceous matter, is, in some cases at least, an unsettled question (4, and Ref. on ore deposits).

The silver sulphides are changed to sulphates or chlorides, part of which at least are leached out of the gossan and carried to lower levels, where they are reprecipitated by iron or even copper sulphides.

Classification. - The gold and silver ores are sometimes grouped (80) according to their associations, as below; this also has the advantage of bringing out more clearly their metallurgical character.

1. Placers or gravel deposits. These serve chiefly as a source of native gold, but may and often do contain a little silver, much of which is never separated from the ore in which it occurs. These gravels are derived chiefly from quartz veins of Mesozoic age in the Pacific coast region, and to a less extent from pre-Cambrian veins of the Appalachian region and Black Hills of South Dakota. Some are also derived from veins in Tertiary lavas, but these usually contain the metals in such a finely divided condition, or in such combination, that they do not readily accumulate in stream channels. 
2. Quartzose or dry ores, in which the gold and some silver are found in a quartz gangue, and are either free or mixed with sulphides, commonly pyrite. They are of varying age. Those of California, Oregon, and Alaska are Mesozoic and associated chiefly with quartz monzonite, granodiorite, and diorite. Another great class of post-Miocene age, found chiefly in Colorado, Nevada, and Montana, is associated with Tertiary lavas and characterized by bonanzas. The most productive ones carry fluorite and normally also tellurides. In some, gold may predominate; in others, silver. A third class, of pre-Cambrian age, is found in the Atlantic States, Wyoming and South Dakota, the last mentioned including the famous Homestake Mine. These are classified as dry ores, because they are not as a rule smelting ones; they contain limited quantities of copper and lead, but may have some pyrite.

3. Gold and silver bearing copper ores. These are widely distributed throughout the United States, and exhibit great differences in form and age, neither do all the occurrences yield much gold or silver. The output is obtained chiefly from Colorado, Utah, and Montana. Those of the last two states, which supply most of the production, are found as replacement veins in granites or early Tertiary igneous rocks. The large copper deposits of Arizona produce but little gold or silver, with the exception of those at Jerome. This class of ores yields about one third of all the silver mined in the United States.

4. Gold and silver bearing lead ores. This class includes a variety of deposits, containing much lead, and also silver, with gold usually in subordinate amounts. They occur chiefly in Colorado, Utah, and Idaho, and furnish about one 
half of the silver obtained in the United States. They are discussed separately under the head of Silver-Lead ores.

A subtype of this class is represented by the veins of argentiferous galena and tetrahedrite of the Wood River district, Idaho. These are veins in slates near the contact of intrusive granite and are of late Mesozoic age. Arizona, California, Washington, and New Mexico produce small amounts of argentiferous lead ores.

Geological Distribution. - Gold and silver ores have been formed at a number of different periods in the geological history of the continent, notably in the pre-Cambrian, Cambrian, Cretaceous, and Tertiary ages, but Silurian, Devonian, and Carboniferous gold deposits are not definitely known to exist in North America, although some of the Appalachian veins may be of this age (79). Silver ores show much the same geological distribution.

Extraction. - Since gold and silver ores vary so in their mineralogical associations and richness, the metallurgical processes involved in their extraction are varied and often complex.

Those ores whose precious metal contents can be readily extracted after crushing, by amalgamation with quicksilver, are termed free-milling ores. This includes the ores which carry native gold or silver, and often represent the oxidized portions of ore bodies. Others, containing the gold as telluride or containing sulphides of the metals, are known as refractory ores and require more complex treatment. These, after mining, are sent direct to the smelter if sufficiently rich, but if not they are often crushed and mechanically concentrated. The smelting process is also used for mixed 
ores, the latter being often smelted primarily for their lead or copper contents, from which the gold or silver is then separated. While in some cases there are smelters at the mines, still there is a growing tendency towards the centralization of the industry, and large smelters are now located at Denver, Salt Lake City, etc., which draw their ore supply from many mining districts.

Low-grade ores may first be roasted, and the gold then extracted by leaching with cyanide or chlorine solutions. The introduction of the cyanide and chlorination processes, which are applied chiefly to gold ores, has permitted the working of many deposits formerly looked upon as worthless, and in some regions even the mine dumps are now being worked over for their gold contents. It is estimated that in $1902 \$ 8,000,000$ worth of gold ores were cyanided. The chief fields are in the Cripple Creek region of Colorado; the De Lamar district, Idaho; Marysville, Montana; Bodie, California; and in Arizona.

The most important gold-milling centers of the United States are the Mother Lode district of California, the Black Hills, South Dakota, and Douglas Island, Alaska.

The value of ore and bullion is determined from a sample assay, and the smelter, in paying the miner for his ore, allows for gold in excess of $\$ 1$ per ton of ore at the coining rate of $\$ 20.67$ per ounce, and for silver at New York market price, deducting 5 per cent in each case for smelter losses. Lead and copper are paid for in the same manner, as are also iron and manganese, if there is a sufficient quantity present. No allowance is, however, made for zinc, and, in fact, a deduction is made if it exceeds a certain per cent. 
Distribution of Gold and Silver Ores. - Gold ores are widely distributed in the Cordilleran region and Appalachian province, while the silver ores are found chiefly between the Great Plains and Pacific coast ranges, exclusive of the Colorado plateau region. This occurrence in two widely separated areas is brought out in an interesting manner in Fig. 69.

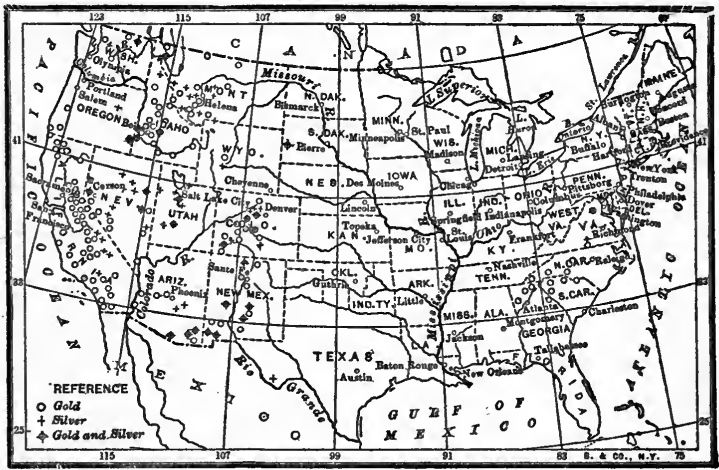

Fra. 69. - Map showing distribution of gold and silver ores in United States. Adapted from Ransome, Min. Mag., X: 1 .

More than a third of the United States production of gold comes from the southern half of the Rocky Mountains, Colorado being the main producer. In this area, however, the ores vary widely in their mineralogical associations, the gold occurring mostly in combination with silver, lead, copper, and zinc ores, but also at times free, or, in the most productive district, as a telluride.

The Pacific belt, excluding Alaska, supplies about one fourth the total amount of gold produced, the famous Mother Lode region, mentioned later, being the most im- 
portant producer. Alaska yields about 10 per cent, and the Basin Range province about 14 per cent, collected from widely separated deposits in Utah, Nevada, Arizona, and New Mexico, and in which the gold is associated with copper, silver, or lead.

Probably two thirds of the silver obtained in the United States comes from the Rocky Mountain region, Colorado alone yielding about one third, while Montana supplies about one third of the total amount produced, and about three fourths of this is obtained as a by-product in copper smelting. The Basin Range province furnishes about 28 per cent, two thirds of this coming from Utah, especially from the Park City mines near Salt Lake City (83).

The gold and silver occurrences of the United States and Alaska can be grouped under five areas, as follows:-

1. Cordilleran region.

2. Black Hills, South Dakota region.

3. Michigan region.

4. The eastern crystalline belt.

5. Alaska.

Of these, the first, second, and fifth are the most important, while the third is insignificant.

\section{CORDILLERAN REGION}

This area contains a number of important deposits of gold and silver ores, occurring chiefly in quartz veins, and to a lesser extent in gravels. There are also some representatives of the propylitic type.

Pacific Coast Cretaceous Gold-quartz Ores. - Extending along the Pacific coast from Lower California up to the 
1 


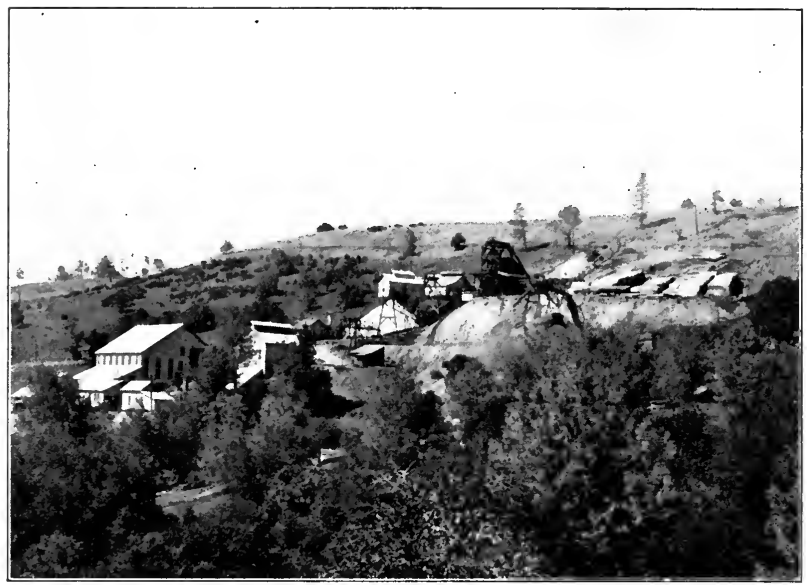

Fig. 1. - Kennedy mine on the Mother Lode near Jackson, Calif.

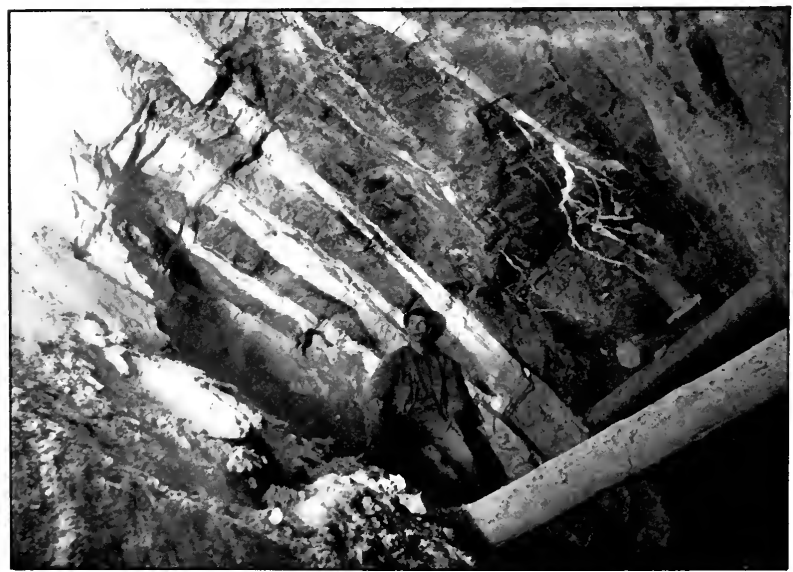

Fig. 2. - Auriferous quartz veins in Maryland mine, Nevada City, Calif. After Lindgren, U.S. Geol. Surv., 17th Ann. Rept., III. 
British Columbia boundary there is a gold belt of great importance, which throughout its extent is characterized by quartzose ores and gold-bearing sulphides. The deposits belonging to this are especially important in California, but farther north, in Oregon and Idaho, the veins in many cases have been covered up by the lava flows of the Cascade Range, and those known in that region differ somewhat from the California deposits in containing many mixed silver-gold ores and also veins carrying auriferous sulphides without free gold. The ores of this belt are all of undoubted Mesozoic age, and are accompanied by many extensive placer deposits, which have been derived by the weathering down of the upper parts of the quartz veins, the portions now remaining in the ground representing probably but the stump of originally extensive fissure veins (79).

Among the deposits of this belt two groups stand out in some prominence, namely, those of the so-called Mother Lode district and of Nevada County.

Mother Lode Belt $(25,27)$. - This includes a great series of quartz veins, beginning in Mariposa County and extending northward for a distance of 112 miles. The veins of this system break through black, steeply dipping slates and altered volcanic rocks of Carboniferous and Jurassic age, and since they are often found at a considerable distance from the granitic rocks of the Sierra Nevada, they have apparently no genetic relation with them. The veins, which occur either in the slate itself or at its contact with diabase dikes, show a remarkable extent and uniformity, due to the fact that in the tilted layers of the slates there lay planes of weakness for the mineral-bearing solution to follow. The ore is native 
gold or auriferous pyrite in a gangue of quartz, and the average value may be said to vary from $\$ 3$ or $\$ 4$ up to $\$ 50$ or $\$ 60$ per ton. The veins often split and some of the mines have reached a depth of several thousand feet.
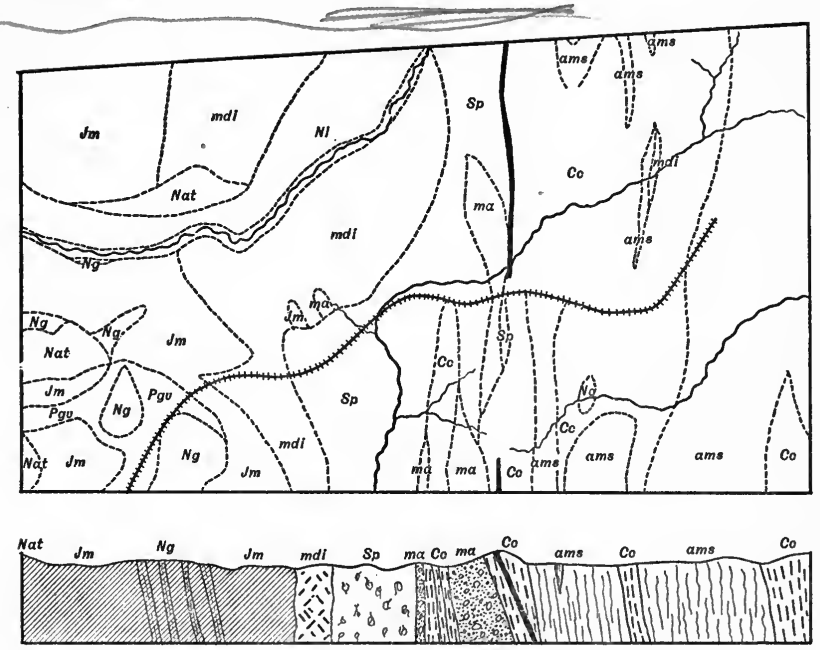

Fra. 70. - Map and section of portion of Mother Lode district, Calif. Pgv, river gravels, usually auriferous; $N g$, auriferous river gravels. Sédimentary rocks: $J m$, mariposa formation (clay, slate, sandstone, and conglomerate); $\mathrm{Cc}$, calaveras formation (slaty mica schists). Igneous rocks: $\mathrm{Nl}$, latite; Nat, andesite tuffs, breccia, and conglomerate; mdi, meta-diorite ; $S p$, serpentine; ma, meta-andesite; ams, amphibole schist. From U.S. Geol. Surv., Atlas Folio, Mother Lode sheet.

Nevada County (26). - In Nevada County the mines of Grass Valley and Nevada City are likewise quartz veins, but they occur along the contact between a granodiorite and diabase porphyry, as well as cutting across the igneous rock (Fig. 71). Two systems of fault fissures occur, and in these the ore is found either in native form or associated 
with metallic sulphides. The width of the vein averages from 2 to 3 feet, and the lode ore generally occurs in welldefined bodies or pay shutes. The vein filling was deposited by hot solution, and while the wall rocks contain the rare metals in a disseminated condition, Lindgren (26) believes that the ores have been leached out of the rocks at a considerable depth. The mines at Nevada City and Grass Valley have been large producers of gold and some silver. Placer mines have furnished a small portion of the product, but at the present day these latter are of little importance.

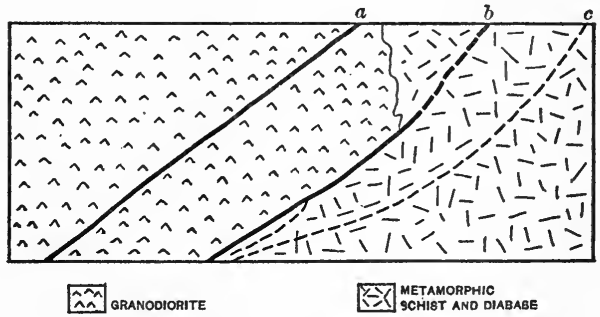

- a. Merrifielo Vein b. URAL Vein c.sLate vein

Frg. 71. - Section illustrating relations of auriferons quartz veins at Nevada City, Calif. After Lindgren, U. S. Geol. Surv., 17th Ann. Rept., II.

In Oregon, the quartz veins are worked in Baker County, which is the most important gold-producing region of the state $(72,73)$. Gold ores with sulphides in quartz gangue are worked in the Monte Cristo district of Washington (88).

Central Belt of Gold-Silver Ores. - To the east of the Cretaceous gold-quartz belt there lies a second one, in the central and eastern part of the Cordilleran region, containing many gold and silver deposits of late Cretaceous or early Tertiary age, although they occur in older rocks, such as Carboniferous. 
Mercur, Utah. - The gold-silver mines of the Mercur (85) district in Utah form perhaps the most important occurrence in this central zone. Here the Carboniferous limestones, shales, and sandstones, representing about 12,000 feet of sediments, are folded into a low anticline. Near the center of the section is the great blue limestone, carrying an upper and a lower shale bed. Quartz porphyry has intruded the limestone, and at two places especially, spread out laterally in the form of sheets, on whose under side the ore is found, the silver ores under the lower sheet, the gold ores under the

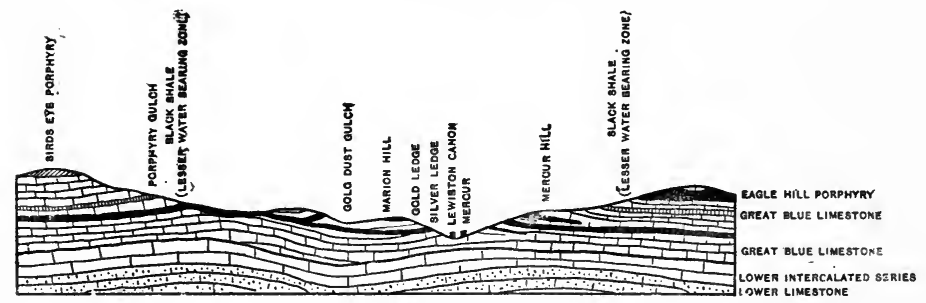

Fra. 72. - Section of Mercur, Utah. After Spurr, U. S. Geol. Surv., 16th Ann. Rept., II.

upper one, about 100 feet above the first. The silver ore is cerargyrite and argentiferous stibnite in a silicified belt of the limestone. The gold is native and occurs in a belt of residual contact clay, near northeast fissures cutting the limestone, being oxidized in places and accompanied by sulphides in others. The ore runs 1-19 ounces of silver per ton, and 2-3 ounces of gold, with a gangue of quartz, barite, limonite, and arsenical sulphides. The silver minerals are thought to have been deposited by heated solutions which came up along the igneous sheet some time after its intrusion, and the deposition of the gold ore is believed to have taken place some time 
after the silver was deposited. Some doubt exists as to the exact source of the ascending waters, but in all probability they were derived from some deep-seated cooling laccolith. The ores are especially suited to the cyanide treatment.

Other Occurrences. - The northward continuation of this belt of gold-bearing veins in Idaho and Montana presents somewhat different types of deposits, for there the veins are causally connected with great batholiths of Mesozoic granite; and while the veins resemble those of the Pacific Coast in the quartz filling and free gold contents, they differ from the latter in containing more silver, and often large quantities of sulphides with little free gold. In fact in their geologic relations they are intermediate between the quartz vein and propylitic type. Of special prominence are those of Marysville, Montana, and Idaho Basin, Florence, etc., in Idaho. This difference is more marked in the Montana occurrences, in which the gold becomes subordinate and is obtained as a by-product in silver mining.

Eastern Belt of Tertiary Gold-Silver Veins. - Of greater importance than the preceding class are the veins of Tertiary, mostly post-Miocene, age, which, according to Lindgren, are characteristic of regions of intense volcanic activity, and cut across andesite flows, or more rarely rhyolite and basalt. The veins may be entirely within the volcanic rocks, or the fissures may continue downward into the underlying rocks, which have been covered by the extrusive masses. Most of these Tertiary deposits belong to the propylitic class, showing characteristic alterations of the wall rock. The ores are commonly quartzose, and though either gold or silver may predominate, the quantities of the two metals are 
apt to be equal. Bonanzas are of common occurrence, and on this account the mines may be very rich but short-lived; still, the workable ore in many, extends to great depths, but is less rich than nearer the surface. Extensive and rich placers are rarely found in the Tertiary belt of veins, for the reason that the fine distribution of the gold is not favorable to its concentration and retention in stream

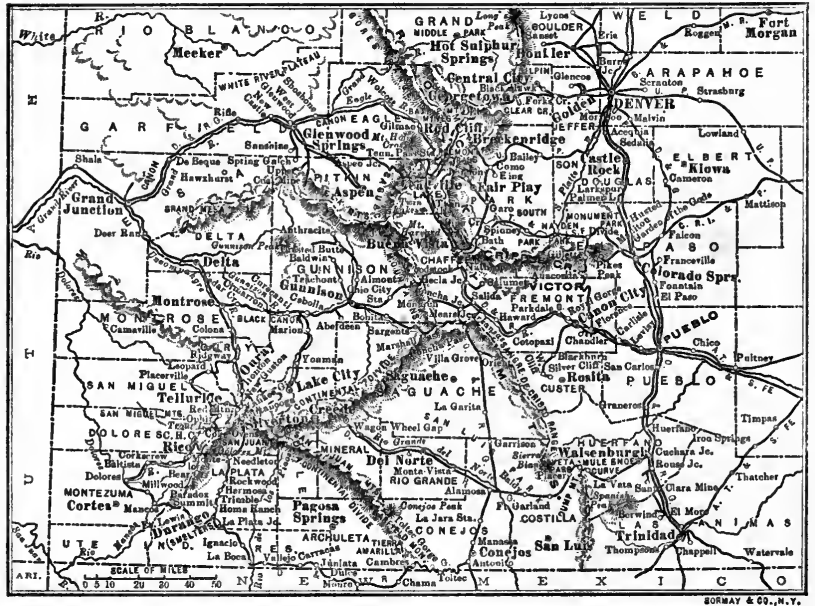

FIG. 73. - Map of Colorado showing location of mining regions. After Rickard, Amer. Inst. Min. Eng., Trans., 1904.

channels. Deposits of this type are worked in a number of states, including Colorado, Nevada, Arizona, New Mexico, and Idaho. Colorado leads in the production of gold ores, for in no state are the Tertiary deposits of the propylitic type developed on such a scale.

Cripple Creek (39, 45, 47). - This district, which is the most important in this belt, is a producer of ores containing 
gold almost exclusively, and may therefore be mentioned in some detail. The region lies about ten miles west of Pikes Peak proper, but in the foothills of this mountain mass.

The most common rock of the region is the red Archæan granite of Pikes Peak, in which, however, are inclusions of still older schists. In Tertiary times, the region was one of great volcanic activity, which began with the expulsion of the breccias of phonolitic and possibly in part andesitic types, and was followed by a series of phonolitic rocks, which grade into each other. Finally, there were intrusions of basaltic dikes of several types.

The ore is chiefly calaverite, and to a less extent sylvanite, and probably some other goldsilver-lead tellurides. The tellurides are often associated with auriferous and highly

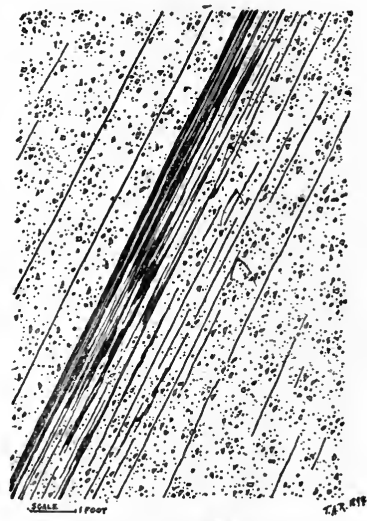

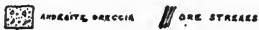

ORE ALONG SHEETED ZONE:

FIg. 74. - Section of vein at Cripple Creek, Colo. After Rickard. argentiferous tetrahedrite, molybdenite, and even stibnite. Pyrite, though widely disseminated in both country rock and fissures, rarely carries enough gold to serve as an ore. Native gold exists only as an oxidation product of the telluride. The common gangue minerals are quartz, fluorite, and dolomite; secondary orthoclase is sometimes prominent in the granites, while other minerals occur in small amounts. 
Two types of ore bodies exist: 1. Fissure veins, sometimes simple, but more often compound, and formed in the more or less closely spaced fractures of a sheeted zone. These may occur in any kind of rock, but favor the breccias. Their dip is generally steep, and the lode may vary from 1 foot to 50 or 60 feet in width. A subtype of this are composite veins in sheeted basalt dikes.

2. Irregular deposits, often of large size, formed by the replacement of granite, and usually occurring close to or within 1000 feet of its contact with the breccias. The ore is of somewhat lower grade than that found in the fissures.

The two types are not always distinct, and in both the ore has been deposited in relatively small spaces, with but small quantities of gangue minerals, so that the fissures are never completely filled. The ores which show oxidation to a depth of from 200 to 400 feet often occur in shutes, but no evidence of secondary enrichment has been found by recent investigators. The principal productive zone does not seem to extend more than 1000 feet from the surface, and while ore may be looked for below this, the quantity of it will probably be less.

The Cripple Creek ores as a rule run low in silver and from 1 to 10 ounces of gold per ton, with an average value of $\$ 30$ to $\$ 40$ per ton. Most of the ores are treated by the chlorination or cyanide process, especially the former, and about one sixth of the output is shipped directly to the smelters at Denver and Pueblo.

The rapid rise of this district is well shown by the following figures of production. A maximum was reached in 1900 , since which the output has gradually declined. 


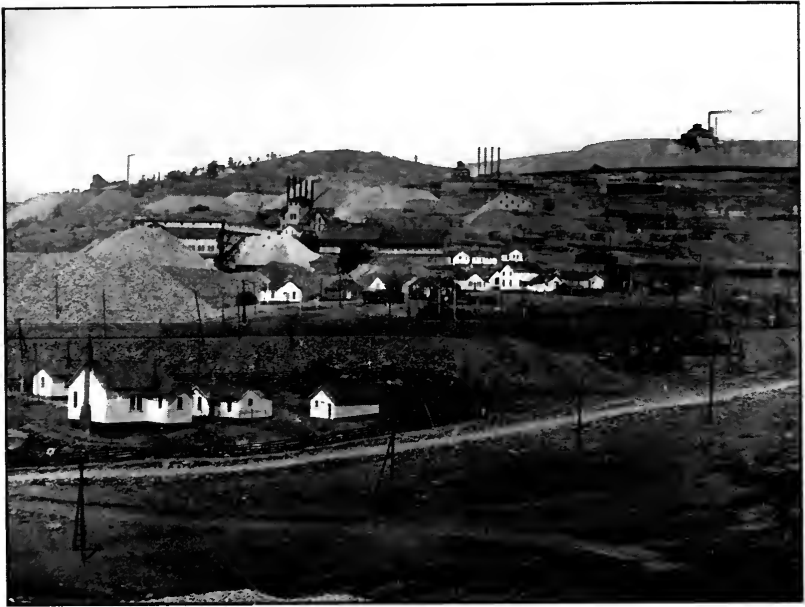

FIG. 1. - View of Independence Mine and Battle Mountain, Cripple Creek, Colo. A. J. Ifarlan, photo.

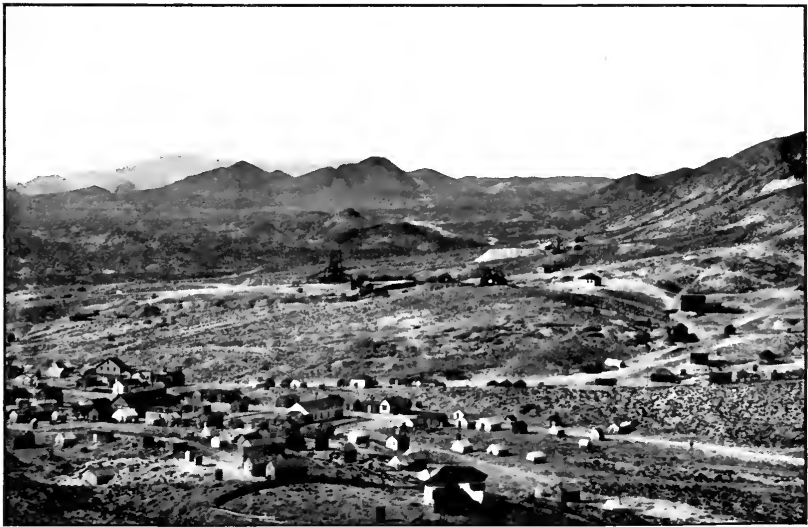

FIG. 2.-General view of region around Tonopah, Nev. J. E. Spurr, photo. 

Production in Cripple Creek District in 1893-1903

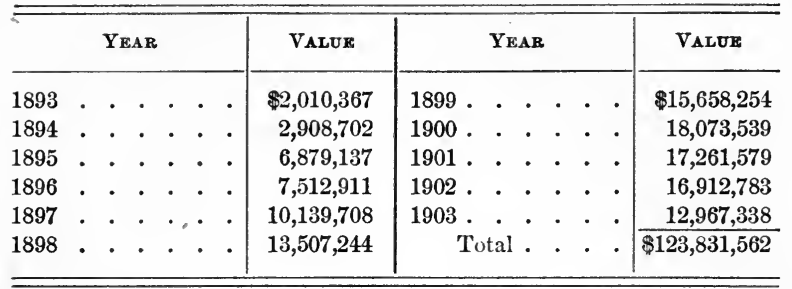

San Juan Region. - As an example of a more mixed type of ore of this class may be mentioned the San Juan region of southwestern Colorado, which includes the counties of San Juan, Dolores, La Plata, Hinsdale, and Ouray, and is one of the most important gold and silver producing regions of the state, being noted for its persistent vertical veins, carrying gold, silver, and lead ores in varying proportions. Those in the vicinity of Rico are mentioned under SilverLead. Other important mining camps are Silverton, Creede, Telluride, and Ouray.

The rocks of the San Juan district consist of a series of older sedimentaries, ranging from Algonkian to Cretaceous, buried under a complex of Tertiary volcanics, of both acid and basic types. In the Silverton quadrangle (43), for example, this volcanic series is several thousand feet thick and consists of tuffs, agglomerates, and lava flows. The more or less distinctly horizontal surface volcanics have been penetrated by later stocks of igneous rock, ranging from gabbro nearly to granite in composition, and by many small dikes of different types.

The ore deposits form lodes, stocks, or masses (locally called chimneys), and replacement deposits. The lode 
fissures, which form the most important class, have been formed at several different periods and show varying strikes, but are often of great length, two or three miles being not uncommon, while some of the fractures probably extend continuously for as much as six miles. The ore-bearing

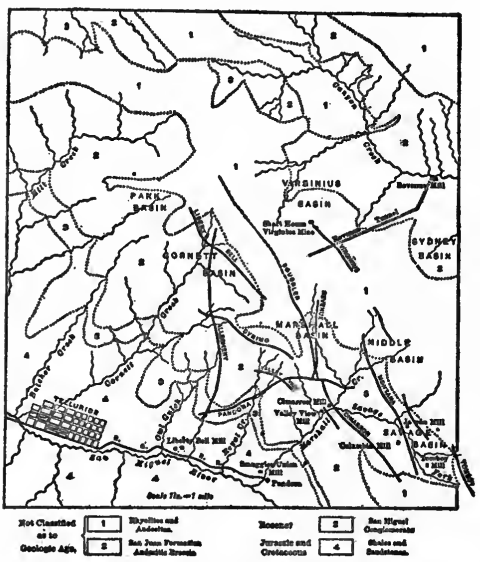

FIG. 75. - Geologic map of Telluride district, Colorado, showing outcrop of more important veins. After Winslow, Amer. Inst. Min. Eng., Trans. XXIX: 290. minerals are pyrite and sulphides of copper, silver, lead, or zinc, in a gangue of quartz, barite, calcite, dolomite, rhodochrosite, etc. They have probably been deposited from aqueous solutions either in spaces or pores of the rock, or by replacement. The ores are mostly low grade, and require careful milling to yield profitable returns, but some are sufficiently rich to be shipped directly to the smelter.

Another remarkable development of veins is found around Telluride (42) (Fig. 75), one of which, the Smuggler vein, has been traced four miles, and cuts the Tertiary volcanics. The ores are gold and silver in a gangue of quartz, with some rhodochrosite, siderite, calcite, and barite. The ore bodies around Ouray (36) differ from those around Silverton and Telluride in being found in the sedimentaries of the region, and form either fissure veins or replacements 
in quartzite or limestone connected with vertical fissures. Owing to the different degrees of replaceability shown by the wall rocks, the ore bodies present a most varied form.

Tonopah, Nevada. - Some fine examples of replacement deposits are also known in Nevada, an excellent one being that found in the recently discovered mining district of Tonopah, Nevada (63), which, although opened up only in 1900 , has during the first three years produced over $\$ 3,000,000$ worth of gold. The district, which lies in the arid desert

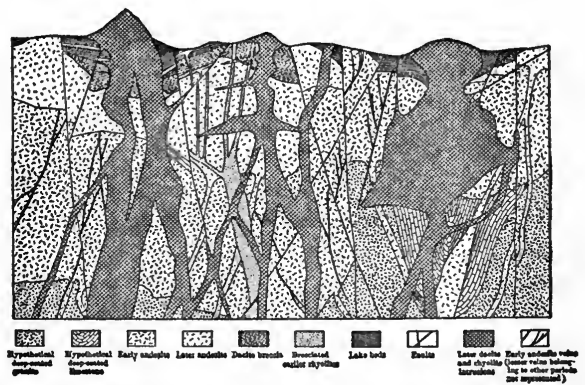

Frg. 76. - Ideal cross section of rocks at Tonopah, Nev. After Spurr, U.S. Geol. Surv., Bull., 225: 108.

region of Nevada, contains a series of Tertiary lavas and tuffs, the former including andesites, dacites, rhyolites, and basalt (Fig. 76). The earlier lavas and tuffs have been broken by a complex series of faults which have not, however, affected the older dacites and closely associated rhyolite necks. Four periods of vein formation have been discovered closely following periods of eruption, and of these only the oldest, namely, those found in the earlier andesite, are available sources of ore. The veins, which have been formed by replacement in sheeted zones and show more or less de- 
velopment of ore shoots, contain quartz with orthoclase, and inclose as metallic minerals stephanite and probably polybasite. The values are about two sevenths gold and five sevenths silver. Subsequent to their formation they have been pierced and covered by later volcanic rocks, and these, together with the complex faulting, has produced most puzzling structural conditions. The Tonopah ore deposits are analogous genetically to the Comstock lode deposits of Nevada (61).

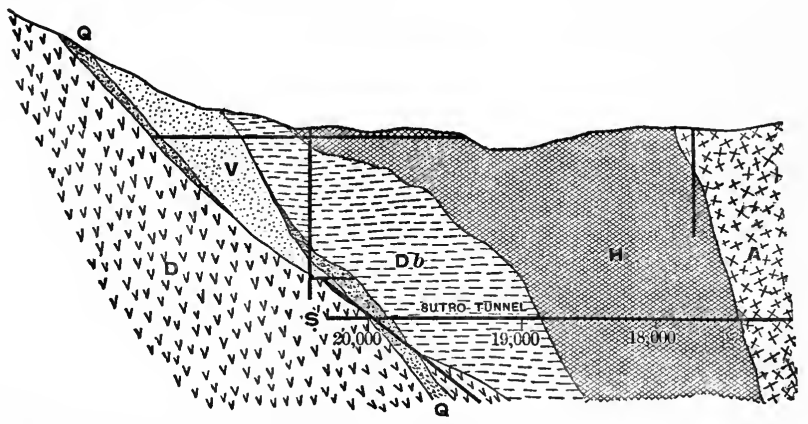

Fig. 77. - Section of Comstock lode. $D$, diorite; $Q$, quartz; $V$, vein matter in earlier diabase $(D b)$; $H$, earlier hornblende andesite; $A$, augite andesite. After Becker.

Comstock Lode, Nevada. - This lode, which is of historic interest, occurs near Virginia City, in southwestern $\mathrm{Ne}$ vada, and is a great fissure vein, about four miles long, several hundred feet broad, and branching above, following approximately the contact between eruptive rocks, and dipping at an angle of 35 to 45 degrees. There is abundant evidence of faulting, which in the middle portion of the vein has amounted to 3000 feet. The lode is of Tertiary age, and contains silver and gold minerals in a quartzose gangue. 
One of the peculiar features of the deposit is the extreme irregularity of the ore, which occurs in great "bonanzas," some of which carried several thousand dollars to the ton. The faulting is considered to have been quite recent, and the high temperatures encountered in the lower levels of the mine indicates that there is probably a partially cooled mass of igneous rock at no great depth.

In former years the enormous output of this mine caused Nevada to be one of the foremost silver producers. It was discovered as early as 1858 , and increased until 1877, after which it declined. Many serious obstacles were met with in the development of the mine, such that it has never become a source of much profit in spite of its enormous output. In 1863, at a depth of 3000 feet, the mine was flooded by water of a temperature of $170^{\circ} \mathrm{F}$, due to a break in the clay wall; and to drain it $\$ 2,900,000$ were spent in the construction of the Sutro tunnel, which was nearly four miles long, but by the time it was finished the workings were below its depth. A second difficulty was the encountering of high temperatures in lower workings, these in the drainage tunnel mentioned being $110^{\circ}$ to $114^{\circ} \mathrm{F}$. The mine is credited with a total production of $\$ 368$,000,000 . In recent years its output has been slowly increasing again.

Other occurrences of the propylitic type are found in Gilpin, Boulder, and Clear Creek (48) counties, Colorado.

In Arizona the Commonwealth Mine of Cochise County is probably referable to this group, as is also the Congress Mine $(19,20)$.

Fissure veins associated with Tertiary eruptives are found in Owyhee County, Idaho, in the Monte Cristo district of Washington (88), and the Bohemia district of Oregon (70). The auriferous copper veins of Butte, Montana, also belong in this group, but since they are more important as producers of copper, they are described under that head. 
Auriferous Gravels (23, 29, 30). - These form an important source of supply of gold, together with a little silver, and, although widely distributed, become prominent chiefly in those areas in which auriferous quartz veins are abundant. So, while they are found in many parts of the Cordilleran region, in the Black Hills, and in the Atlantic States, their greatest development is in the Pacific coast belt from California up to Alaska.

These auriferous gravels represent the more resistant products of weathering, such as quartz and native gold, which have been washed down from the hills on whose slopes the gold-bearing quartz veins outcrop, and were too coarse or heavy to be carried any distance, unless the grade was steep. They have consequently settled down in the stream channels, the gold, on account of its higher gravity, collecting usually in the lower part of the gravel deposit.

Although the gold-bearing gravels have been derived from veins of varying age, the deposition of the gravel has rarely occurred in pre-Tertiary times, and some, indeed, are of very recent origin.

The gold occurs in the gravels in the form of nuggets, flakes, or dustlike grains, the last being usually hard to catch. The nuggets represent the largest pieces, and the finding of some very large ones has been recorded from time to time in different parts of the world. Two large nuggets are recorded from Victoria: one, the "Welcome Stranger," weighing 2280 ounces; and the other, the "Welcome Nugget," weighing 2166 ounces. Since the auriferous gravels of the Pacific coast belt are the most important, they will be specially referred to.

These have been derived from the wearing down of the 
Sierras, and are found in those valleys leading off the drainage from the mountains. Many were formed during the Tertiary period, when the Sierras were subjected to a long-continued denudation, while violent volcanic outbursts at the close of the Tertiary have often covered the gravels and protected them from subsequent erosion. These lava cappings are at times 150 to 200 feet thick, as in Table Mountain,' Tuolumne County.

Many of the gravel deposits are on lines of former drainage, while others lie in channels still occupied by streams. Some show but one streak of gold, while in others there may be several, some of which are on rock benches of the valley bottom (Fig. 78).

During the early days of gold mining in California the gravels at lower levels and in the valley

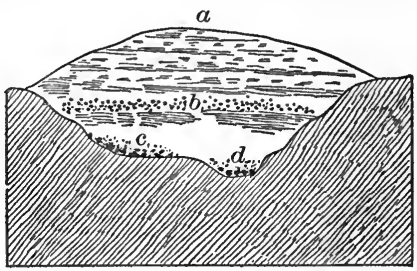

Fig. 78.-Generalized section of old placer, with technical terms. $\alpha$, volcanic cap; $b$, upper lead; $c$, bench gravel; $d$, channel gravel. After $R$. E. Browne. bottoms were worked, but as these became exhausted, those farther up the slopes or hills were sought.

In the earlier operations the gravels were washed entirely by hand, either with a pan or rocker, and this plan is even now followed by small miners and prospectors; but mining on a larger scale is carried on by one of three methods, viz. drift mining, hydraulic mining, and dredging.

Drift mining is employed in the case of gravel deposits covered by a lava cap, a tunnel being run in to the paying portion of the bed and the auriferous gravel carried out and washed. 
In hydraulic mining, a stream is directed against the bank of gravel and the whole washed down into a rock ditch lined with tree sections, or into a wooden trough with cross pieces or riffles on the bottom. The gold, being heavy, settles quickly and is caught in the troughs or ditches, while the other materials are carried off and discharged into some neighboring stream. Mercury is sometimes put behind the riffles to aid in catching the gold.

The water which is used to wash down the gravel deposits is often brought a long distance, sometimes many miles, and at great expense, bridging valleys, passing through tunnels, and even crossing divides, this being done to obtain a large enough supply as well as a sufficient head of water.

Owing to the great amount of débris which was swept down into the lowlands, a protest was raised by the farmers dwelling there, who claimed that their farms were being ruined; and it soon became a question which should survive, the farmer or the miner, for in places the gravels and sand from the washings choked up streams and accumulated to a depth of 70 or 80 feet. The question was settled in 1884 in favor of the farmer by an injunction, issued by the United States Circuit Court, which caused many of the hydraulic mines to suspend operations; and at a later date this was extended by state legislation, adverse to the hydraulic mining industry. Owing to this setback, hydraulic mining fell to a comparatively unimportant place in the gold-producing industry of California, while at the same time quartz mining increased.

The passage of the Caminetti law now permits hydraulic mining, but requires that a dam shall be constructed across 
Plate XXII

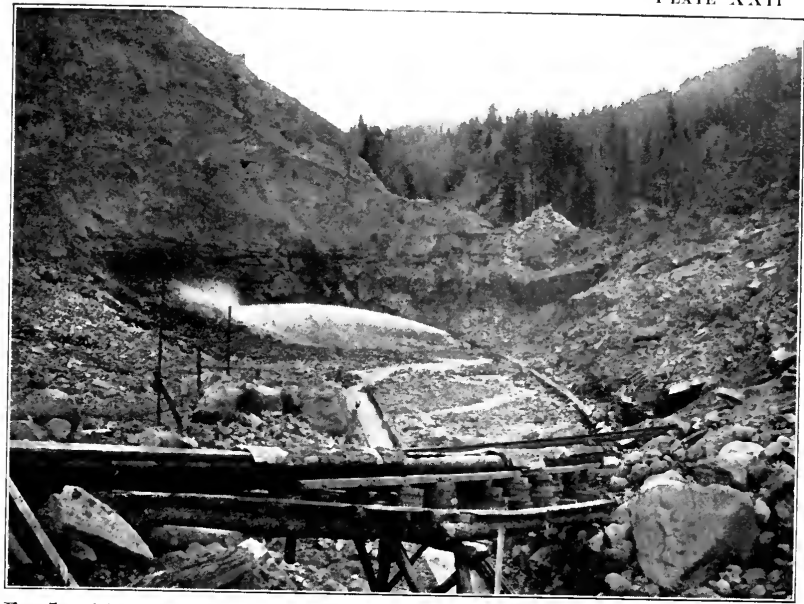

FiG. 1. - Hydraulic mining of auriferons gravel. The sluice box in the foreground is for catching the gold.

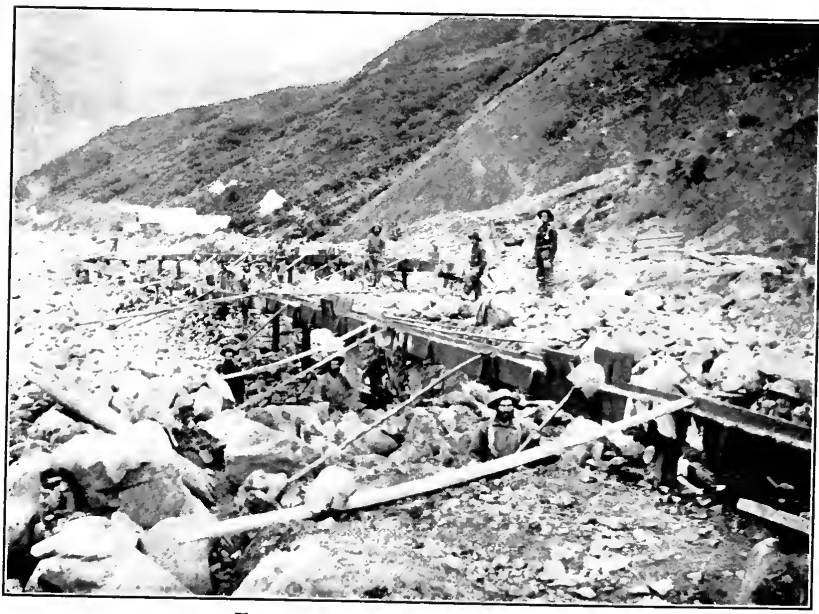

FIG. 2. - An Alaskan placer deposit. 

the stream to catch the tailings. This resulted in a revival of the industry.

Dredging consists in taking the gravel from the river with some form of dredge. The method, which was first practised in New Zealand, has been introduced with great success into California, especially on the Feather River, near Oroville, and its use has spread to other parts of the Cordilleran region. The gravel when taken from the river is discharged on to a screen, which separates the coarse stones, and the finer particles pass over amalgamated plates, tables with riffles, and then over felt.

Formerly much placer gold was obtained by hydraulic mining, but the annual supply from this source is slowly decreasing, as is that from drift mining, while the returns of dredger gold have been continually increasing since 1900, being $\$ 200,000$ in that year and $\$ 1,500,000$ in 1903 . This is due to the fact that large areas in Yuba, Sutler, Nevada, Butte, and Sacramento counties have been found adapted to dredging processes, while the improvement and enlargement of the dredging machines has greatly decreased the cost of mining.

Placer gold is also worked in Idaho, Montana, Oregon, New Mexico, and Colorado, all of the deposits except those of the last two states having been derived mostly from Mesozoic veins.

Gold also occurs in beach sand of certain portions of the Pacific coast of Washington (86), and placer mining has been carried on since 1894; but the supply of gold, which is obtained from Pleistocene sands and gravels, is small.

In arid regions where the gold-bearing sands are largely the product of disintegration, and water for washing out the metal is wanting, a system known as dry-blowing is sometimes resorted to. 


\section{BLACK HILLS REGION}

The gold-bearing ores are found chiefly in the northern Black Hills, and include (1) auriferous schists in preCambrian rocks; (2) Cambrian conglomerates; (3) refractory siliceous ores; (4) high-grade siliceous ores; and (5) placers. Of these the first and third are the most important.

The surface placers, being the most easily discovered, were developed first, followed by the conglomerates at the base of

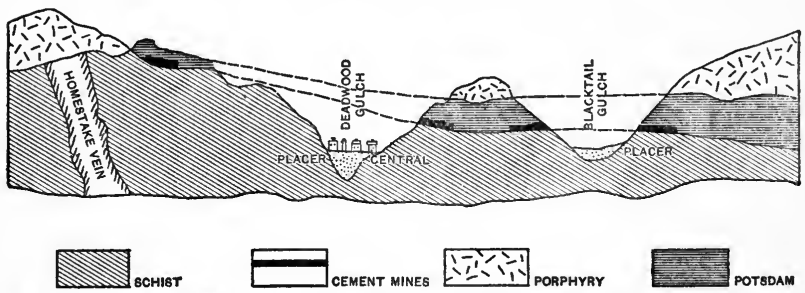

FIG. 79. - Section of Homestake belt at Lead, S. Dak., showing relation of ancient and modern placers to Homestake lode. From Min. Mag. XI: 467.

the Cambrian. These are found near Lead, occupying depressions in the old schist surface, and the material is thought to have been derived from the reef formed by the Homestake ledge in the Cambrian sea. These deposits are of interest as being probably the oldest gold placers known in the United States. The fact, however, that the matrix of the gold-bearing portion of the conglomerate is pyrite rather than quartz, and the occurrence of the gold along fractures stained by iron, has led some to believe that the gold has been precipitated chemically by the action of iron sulphide and is not a detrital product. 
ROBERT W. WEBB

GEOLOGY DEPT., U.C.L.A. 


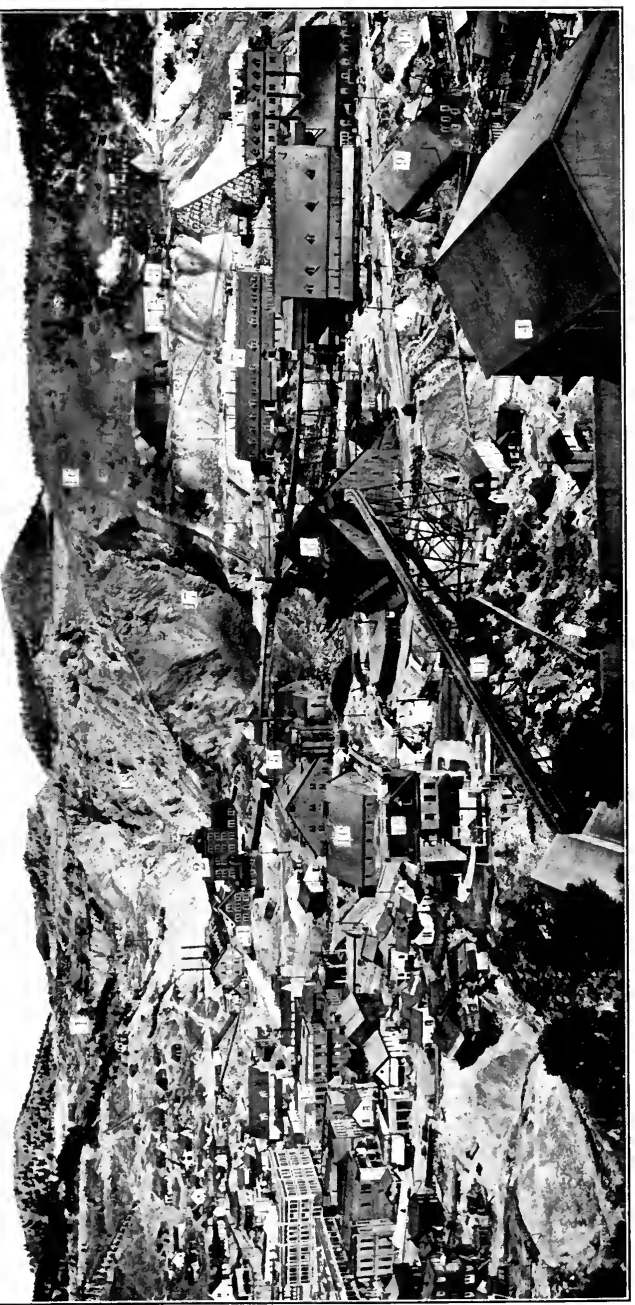

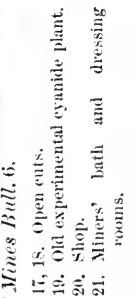

$$
\begin{aligned}
& \text { के } \\
& \text { अ } \\
& \text { 离 密 } \\
& \text { 芒落 }
\end{aligned}
$$

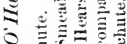

$$
\begin{aligned}
& \text { ง }
\end{aligned}
$$

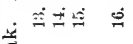

$$
\begin{aligned}
& \text { 吾 } \\
& \text { is } \\
& \text { ت्ञ }
\end{aligned}
$$

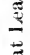

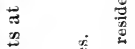

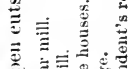

$$
\begin{aligned}
& \text { 产䒠密 } \\
& \Xi \cong ّ \\
& \widetilde{0}
\end{aligned}
$$

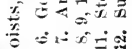

$$
\begin{aligned}
& \cong \\
& \stackrel{2}{\equiv}
\end{aligned}
$$

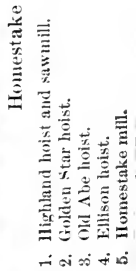


Homestake Belt. - The gold ores of the Homestake belt $(76,77)$, which are the most important in the Black Hills, occur in a broad zone of impregnated schists, containing many quartz lenses, alternating with dikes of fine-grained rhyolite, which also formed sheets in the Cambrian sediments overlying the schists, and now remain as a resistant cap on many of the surrounding ridges. The ore, which is all low grade, averaging $\$ 5$ to $\$ 6$ per ton, is usually a mixture of quartz,
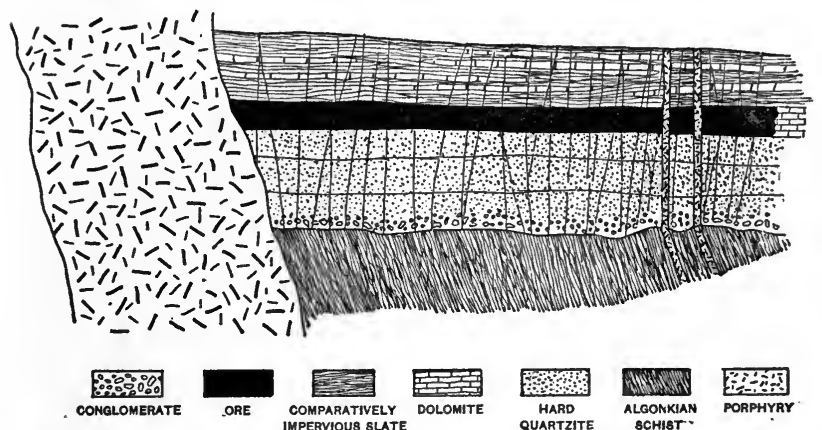

Fra. 80. - Typical section of siliceous gold ores, Black Hills, S. Dak. After Irving, U. S. Geol. Surv., Prof. Pap. 26.

pyrite, and occasionally other minerals having no definite connection with it, occupying a zone in the Algonkian rocks which shows greater hardness, irregularity of structure, and mineralization than the surrounding schists. The boundaries are poorly defined, and superficial examination may fail to distinguish between ore and barren rock. In the upper levels the ore seems to be with the dikes, but diverges from them in depth, and there is apparently no genetic relation between the two. In the earlier days the ore encountered was oxidized and free-milling, but the appearance of sulphides with depth 
has necessitated the introduction of the cyanide method of extraction. In spite of the low grade of its ores the Homestake mine, due to proper management, stands out as one of the richest mines of the world, its monthly production amounting to about $\$ 300,000$ (Curle). The ore was originally worked as an open cut (Pl. XXIII), but later by underground methods.

Siliceous Cambrian Ores. - A second important type is the refractory siliceous Cambrian ore found in the region between Yellow Creek and Squaw Creek, and yielding about two thirds as much gold as the Homestake. The deposits, which occur as replacements in a siliceous dolomite, are found at two horizons, one immediately overlying the basal Cambrian quartzite, and the other near the top of the Cambrian series. The ore forms flat banded masses known as shoots, and varying in width from a few inches to 300 feet. It is overlain by shale or eruptive rock, and associated with a series of vertical fractures, made prominent by a slight silicification of the wall rock. These fractures, which are termed verticals, are supposed to have conducted the ore-bearing solutions.

The ore is a hard, brittle rock, composed of secondary silica, with pyrite and fluorite, and at times barite, wolframite, stibnite, and jarosite. Its contents range from $\$ 3$ or $\$ 4$ per ton to in rare cases $\$ 100$ per ton, with an average of $\$ 17$. Other, but less important, siliceous ores occur in the Carboniferous rocks.

Michigan Region (55). - A small amount of gold has been found in a quartzose zone in schists, near Marquette, Michigan, but the area is of little importance.

Eastern Crystalline Belt (82). - Gold, with some silver, has 
been found in the rocks of this belt from Vermont to Alabama, but the deposits are of little importance except in North Carolina (68), South Carolina (74), Georgia (49, 50), and Alabama (3). In this belt the ore occurs as auriferous pyrite, in quartz veins, as impregnations in metamorphic rocks, or in placers derived from either of the foregoing groups. The last-named type is practically exhausted. Of the other types, there are many occurrences, in all of which the ore exists in variable quantities, but is of very low grade, so that to be profitable the deposits must be worked on a large scale by proper methods. In many localities the free gold of the oxidized portion of the ore body has been worked out and the mine abandoned.

The deposits are in many instances associated with intrusives, some of which are metamorphosed, still they bear no genetic relation to them, being frequently of later origin. They are usually classed as pre-Cambrian, but some may be of later age.

Alaska (14). - Although gold has been known to occur in Alaska since the early part of the century, and was even worked in 1860, its production is not definitely stated until 1880, when it was added to the list of gold-producing regions, with an output of $\$ 6000$, which since that time has increased many times over, but not steadily, until in 1903 it amounted to $\$ 8,614,700$.

The first gold was discovered on the islands of the Alexander Archipelago and along the adjoining coast, but subsequently prospectors found their way into the interior, the first strikes there being made in British Columbia near the head of the Stikine River. These were followed by dišcoveries in the Yukon Valley, especially along some of the 
tributaries known as Birch Creek, Mission Creek, and Forty Mile Creek. In 1896 still richer discoveries were made along the Klondike River, and within one year the yield of this region had exceeded the purchase price of Alaska. Other discoveries have since followed rapidly.

The gold deposits of Alaska are of two types, viz. quartz

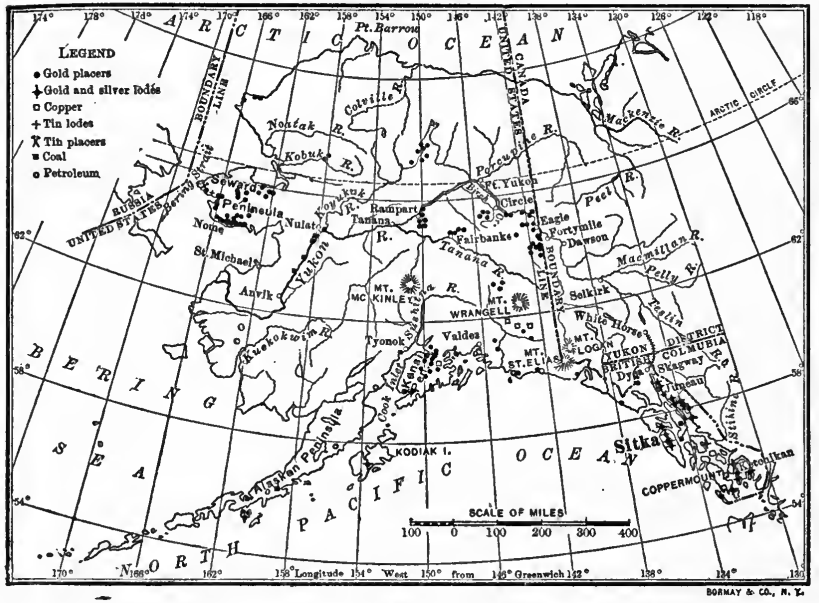

Fra. 81. - Map showing mineral deposits of Alaska as far as known. After Brooks, U. S. Geol. Surv., Bull. 259.

veins and placers. The former are prominent along the coast, and the most important producer is the Treadwell group of mines on Douglas Island, southeast of Juneau (14). The geology of this region bears in many ways a strong resemblance to the California gold belt, and is probably of similar age. The section involves a series of steeply dipping slates and greenstone and diorite dikes (Fig. 83). The ore 
bodies are dikes of albite-diorite, permeated with metallic sulphides and carrying small amounts of gold (14), with a hanging wall of greenstone and a foot wall of black slate. The veinlets, which are thought to have been formed by shearing stresses incident to epeirogenic movements, occur in two sets of fractures at right angles to each other. Spencer believes that the mineralization has been caused by hot ascending solutions of possibly magmatic origin.

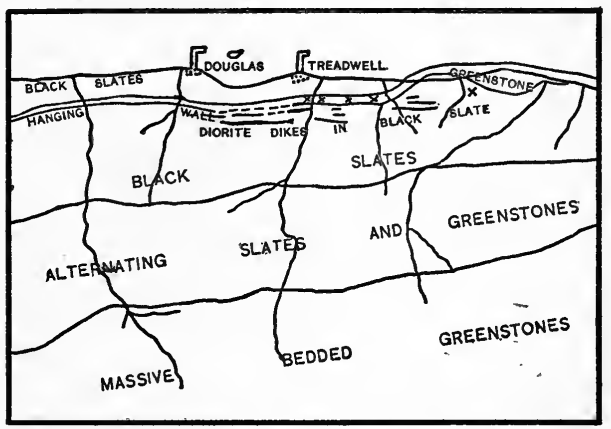

Fia. 82. - Sketch map of Douglas Island, Alaska. After Spencer, U. S. Geol. Surv., Bull. 259:71.

Secondary concentration is not in evidence, and it is thought that the depth to which the ores can be worked will depend more on the increased cost of mining at great depths rather than on exhaustion of the ore. At present an almost continuous ore body has been developed for 3500 feet.

The placer deposits have been found in many parts of Alaska, but the two regions which have yielded the largest amount are the Yukon region (16) and the Seward Peninsula $(14,15)$, the latter being now the first. 
Gold was discovered in the Forty Mile district of the Yukon in 1886, and caused a stampede for this region; but the deposits of the Klondike did not become known until 1896, and their discovery was followed by a rush of gold seekers that eclipsed all previous ones. Indeed, it is said that by 1898 over 40,000 people were camped out in the vicinity of the present site of Dawson.

The Klondike region proper is situated on the eastern side of the Yukon River, and the richer deposits found have been on the Canadian side of the boundary. The

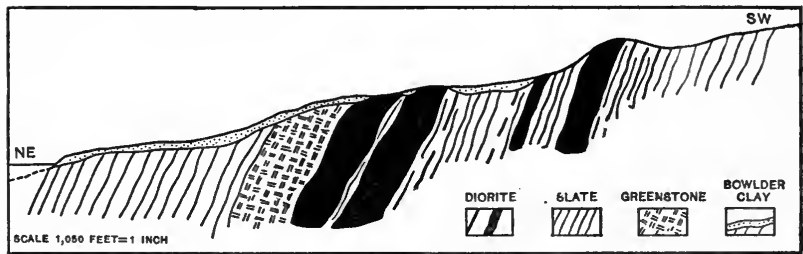

FrG. 83. - Cross section through Alaska Treadwell mine on northern side of Douglas Island. After Spencer, U. S. Geol. Surv., Bull. 259

gold has collected either at the bottom of the gravel in the smaller streams tributary to the Yukon, or else in gravels on the valley sides, this latter occurrence being known as bench gravel. The metal is supposed to have been derived from the quartz veins found in the Birch Creek, Forty Mile, and Rampart series of metamorphic rocks lying to the east. Up to the end of 1902 the total production of the Klondike is stated to have been $\$ 80,000,000$. The annual output has, however, decreased, and mining in that region has settled down to a more permanent basis. Gravels running under $\$ 9$ per cubic yard cannot be worked at a profit, because the difficulties and expenses of running in such a region are 
great, and form an interesting comparison with conditions in California, where gravel carrying 25 cents per yard is considered good, while that running as low as 5 cents per yard can be worked (18).

Since the discovery of the rich gold gravels on the Yukon, auriferous gravels have been developed in many other parts of Alaska, where they are being more or less actively worked (Fig. 81), but of these various finds those in the Seward Peninsula, which is now the largest producer, have been the most important.

The first of the localities discovered in the last-mentioned region was Cape Nome (15), which for a time proved to be a second Klondike. The gold was discovered here on Anvil Creek, and the following year in the beach sands where Nome now stands. These discoveries caused another northward stampede, which resulted in the rapid exhaustion of the beach sands; but other deposits were found farther inland near Nome, as well as the other localities on the Seward Peninsula. Some quartz veins are also worked. Ophir Creek is now the largest producer on the Seward Peninsula. Up to the end of 1902 the Seward Peninsula had produced $\$ 20,000,000$ in gold, and in 1903 the production of the Nome region is given as $\$ 4,437,449$.

Uses of Gold. - Gold is chiefly used for coinage, ornaments, and ornamental utensils. It is also employed to a considerable extent in dentistry and in an alloy for the better class of gilding.

Its value for use in the arts depends on its brightness, freedom from tarnish, and its ductility and malleability, which permit it to be easily worked. As pure 24-carat 
gold is too soft for use, it is alloyed with a small amount of some other metal, such as copper, to gain hardness.

Uses of Silver. - This metal was formerly of much importance for coinage, but is much less so now. It is, however, widely employed in the arts for making jewelry and utensils such as tableware. Its salts are of more or less value in medicine and in photography. Its brightness and white color are valuable properties when the metal is used, but, unlike gold, it tarnishes somewhat readily when exposed to sulphurous gases. There are a number of alloys of silver, those with gold and copper, respectively, being of importance.

Production of Gold and Silver :-

Production of Gold and Silver in the United States from 1845 то 1903

\begin{tabular}{|c|c|c|c|c|c|c|c|}
\hline \multicolumn{5}{|c|}{ YeAR } & \multirow{2}{*}{$\begin{array}{c}\text { Total } \\
\$ 1,058,327\end{array}$} & \multirow{2}{*}{$\frac{\text { GoLD }}{\$ 1,008,327}$} & \multirow{2}{*}{$\begin{array}{c}\begin{array}{c}\text { Silvkr } \\
\text { (Coining Value) }\end{array} \\
\$ 50,000\end{array}$} \\
\hline 1845 & . & . & . & •. & & & \\
\hline 1855 & . & . & . & . & $55,050,000$ & $55,000,000$ & 50,000 \\
\hline 1865 & . & . & - & • & $64,475,000$ & $53,225,000$ & $11,250,000$ \\
\hline 1875 & - & - & - & • & $65,100,000$ & $33,400,000$ & $31,700,000$ \\
\hline 1885 & . & . & . & . & $83,400,000$ & $31,800,000$ & $51,600,000$ \\
\hline 1895 & . & . & . & . & $118,661,000$ & $46,610,000$ & $72,051,000$ \\
\hline 1900 & . & . & . & . & $153,704,495$ & $79,171,000$ & $74,533,495$ \\
\hline 1901 & - & . & . & . & $150,054,500$ & $78,666,700$ & $71,387,800$ \\
\hline 1902 & - & . & - & . & $151,757,575$ & $80,000,000$ & $71,757,575$ \\
\hline 1903 & . & . & . & . & $143,797,760$ & $73,591,700$ & $70,206,060$ \\
\hline
\end{tabular}

The production by states for 1903 is given below, and shows well the overwhelming importance of the Cordilleran region :- 
Production and Value of Gold and Silver in the United States In 1903, BY States

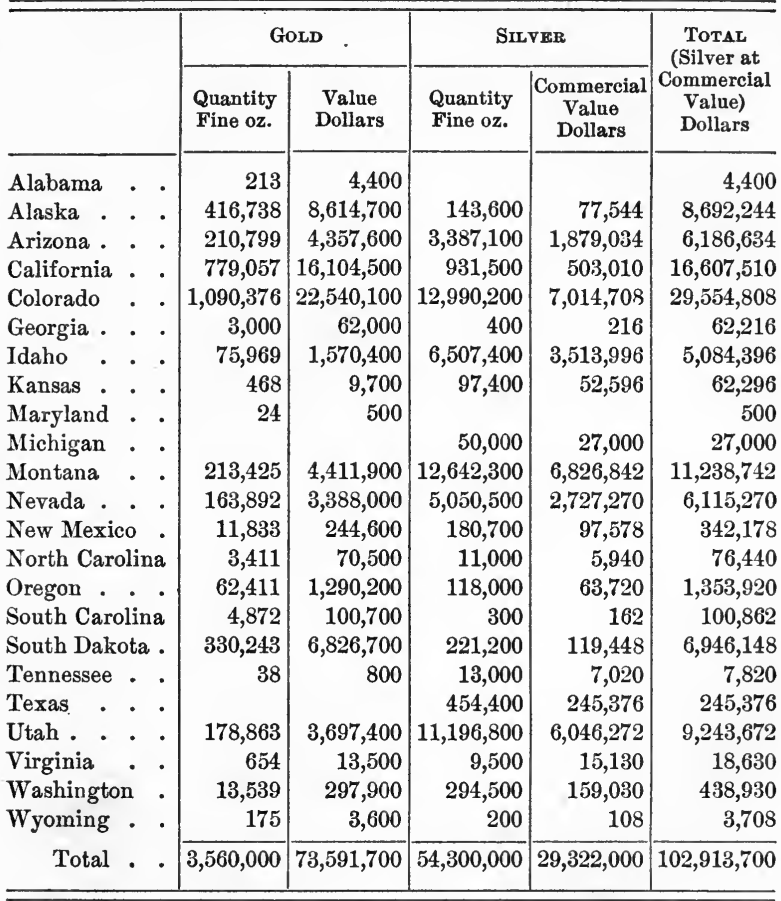

Mr. Lindgren (80) has recently given a most interesting and valuable classification of the figures of gold and silver production, grouped according to the kind of ores from which they have been derived. These are given below, and indicate that the Tertiary quartz veins yield the largest amount of gold, and the lead ores the greatest quantity of silver. 
Production of Gold and Silver in 1904 According to KINDS OF ORE

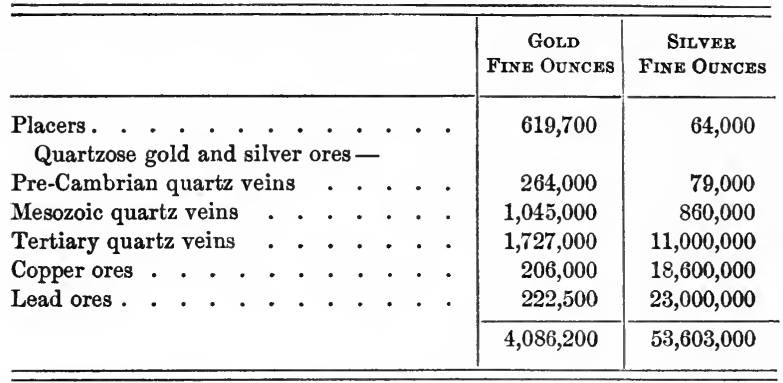

World's Production of Gold and Silver in 1903

\begin{tabular}{|c|c|c|c|c|c|c|c|c|}
\hline & & & & & & GoLD & SILVER & Total \\
\hline North and Centro & & Am & heri & ica & & $\$ 104,979,000$ & $\$ 70,235,500$ & $\$ 175,214,500$ \\
\hline Australia . . & . & . & · & . & & $89,210,100$ & $5,228,700$ & $94,438,800$ \\
\hline Africa . & . & 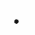 & - & . & . & $67,998,100$ & 185,300 & $68,183,400$ \\
\hline Europe & & ${ }^{\circ}$ & $\cdot$ & . & . & $27,117,800$ & $8,182,100$ & $35,299,900$ \\
\hline Asia . . . & & - & - & . & • & $25,434,000$ & 359,100 & $25,793,100$ \\
\hline South America & & . & . & & & $10,788,200$ & $7,848,900$ & $18,637,100$ \\
\hline Total & - & . & . & & - & $\$ 325,527,200$ & $\$ 92,039,600$ & $\$ 417,566,800$ \\
\hline
\end{tabular}

\section{REFERENCES ON GOLD AND SILVER}

General. 1. Blake, Amer. Inst. Min. Engrs., Trans. XXVI : 290, 1897. (Gold in igneous rocks.) 2. Cumenge and Robellaz, L'Or dans la nature (Paris, 1898). 3. Curle, The Gold Mines of the World (London, 1902). 4. Don, Amer. Inst. Min. Engrs., Trans. XXVII : 564, 1898. (Genesis of certain auriferous lodes.) 5. Emmons, Amer. Inst. Min. Engrs., Trans. XVI: 804, 1888. (Structural relations of ores.) 6. Kemp, Min. Indus., VI : 295, 1898. (Telluride ores.) 7. Liversidge, Amer. Jour. Sci., XLIII : 245, 1892. 8. Merrill, Amer. Jour. Sci., I: 309, 1896. (Gold in granite.) 9. Pearce, Ores of Gold, etc., Colo. Sci. Soc. Proc., III : 237. 10. Rickard, Min. and Sci. Pr., LXXVII: 81 and 105, 1898. (Minerals ac- 
companying gold.) 11. Spurr, Eng. and Min. Jour., LXXVI: 500, 1903. (Gold in diorite.) 12. Spurr, Eng. and Min. Jour., LXXVII : 198, 1904. (Native gold original in metamorphic gneisses.) - Alabama : 13. Brewer, Ala. Geol. Surv., Bull. 5, 1896; Phillips, Ala. Geol. Surv., Bull. 3, 1892._Alaska: 14. Brooks and others, U. S. Geol. Surv., Bull. 259, 1905. (Mineral resources.) 15. Schrader and Brooks, Amer. Inst. Min. Engrs., Trans. XXX: 236, 1901. (Cape Nome.) 16. Spurr, U. S. Geol. Surv., 18th Ann. Rept., III : 101, 1898. (Yukon district.) 17. See also various papers on Alaska in U. S. Geol. Surv., Bull. 213, 1903, and Bull. 225, 1904. 18. Penrose, Eng. and Min. Jour., LXXVI : 807, 852, 1903.Arizona : 19. Blandy, Amer. Inst. Min. Engrs., Trans. XI : 286, 1883. (Prescott district.) 20. Comstock, Amer. Inst. Min. Engrs., Trans. XXX: 1038, 1901. (Geology and vein phenomena.) 21. Pratt, Eng. and Min. Jour., LXXIII : 795, 1902. Literature on Arizona gold ores, especially of recent character, is scarce. 22. See reports of Director of Mint.-California: 23. Browne, Calif. State Min. Bur., 10th Ann. Rept.: 435 . (River gravels.) 24. Diller, U. S. Geol. Surv., Bull. 260: 45, 1905. (Indian Valley region.) 25. Fairbanks, Calif. State Min. Bur., X: 23, 1890, and XIII: 665, 1896. (Mother Lode district.) 26. Lindgren, U. S. Geol. Surv., 17th Ann. Rept., II : 1, 1896. (Nevada City and Grass Valley.) 27. Lindgren, Geol. Soc. Amer., Bull. VI : 221, 1895. (Gold quartz veins.) 28. Lindgren, U. S. Geol. Surv., 14th Ann. Rept., II : 243, 1894. (Ophir.) 29. Lindgren, U. S. Geol. Surv., Bull. 213 : 64, 1903. (Neocene river gravels.) 30. Turner, Amer. Geol., XV: 371, 1895. (Auriferous gravels.) 31. See also various annual reports of Calif. State Mineralogist. - Colorado: 32. Comstock, Amer. Inst. Min. Engrs., Trans. XV: 218, 1886, and XI: 165, 1882. (Geology and vein structure, southwestern Colo.) 33. Emmons, Eng. and Min. Jour., XXXV : 332, 1883. (Summit district.) 34. Emmons, U. S. Geol. Surv., 17th Ann. Rept., II : 405, 1896. (Custer Co.) 35. Farish, Colo. Sci. Soc., Proc. IV : 151, 1892. (Rico.) 36. Irving, U. S. Geol. Surv., Bull. 260 : 50, 1905. (Ouray.) 37. Irving, U. S. Geol. Surv., Bull. 260 : 78, 1905. (Lake City.) 38. Kedzie, Amer. Inst. Min. Engrs., Trans. XVI: 570, 1888. (Red Mt.) 39. Lindgren and Ransome, U. S. Geol. Surv., Bull. 246, 1905. (Cripple Creek.) 40. Penrose and Cross, U. S. Geol. Surv., 16th Ann. Rept., II : 111, 1895. (Cripple Creek.) 41. Porter, Amer. Inst. Min. Engrs., Trans. XXVI : 449, 1897. ('Telluride.) 42. Purington, U. S. Geol. Surv., 18th Ann. Rept., III : 751, 1898. (Telluride.) 43. Ransome, U. S. Geol. Surv., Bull. 182, 1901. (Silverton.) 44. Rickard, Min. Indus., II : 325, 1894, and IV : 315, 1896. 45. Rickard, Amer. Inst. Min. Engrs., 
Trans. XXX: 367, 1901. (Cripple Creek.) 46. Schwartz, Amer. Inst. Min. Engrs., Trans. XVIII : 139, 1890. (Cripple Creek.) 47. Skewes, Amer. Inst. Min. Engrs., Trans. XXVI: 553, 1897. (Cripple Creek.) 48. Spurr, U. S. Geol. Surv., Bull. 260: 99, 1905. (Georgetown.) Georgia : 49. Eckel, U. S. Geol. Surv., Bull. 213: 57, 1903. (Dahlonega district.) 50. Yeates, McCallie, and King, Ga. Geol. Surv., Bull. $4 a$, 1896. - Idaho: 51. Lindgren, U. S. Geol. Surv., 20th Ann. Rept., III : 75, 1900. (Silver City, De Lamar Co.) 52. Lindgren, U. S. Geol. Surv., 18th Ann. Rept., III : 625, 1898. (Idaho Basin and Boise Ridge.) - Kansas : 53. Lindgren, Eng. and Min. Jour., LXXIV : 111, 1902. (Tests for gold and silver in shales.) - Maryland : 54. Weed, U. S. Geol. Surv., Bull. $260:$ 128, 1905. (Great Falls.) - Michigan: 55. Wadsworth, Ann. Rept., 1892, Mich. State Geologist. - Minnesota : 56. Winchell and Grant, Minn. Geol. and Nat. Hist. Surv., XXIII : 36,1895. (Rainy Lake district.) - Montana : 57 . Lindgren, U. S. Geol. Surv., Bull. 213: 66, 1903 . (Bitter Root and Clearwater Mts.) 58. Weed, U. S. Geol. Surv., Bull. 213: 88, 1903. (Marysville.) 59. Weed and Barrell, U. S. Geol. Surv., 22d Ann. Rept., II : 399, 1902. (Elkhorn district.) 60. Weed and Pirsson, U. S. Geol. Surv., 18th Ann. Rept., III : 589, 1898. (Judith Mts.) - Nevada: 61. Becker, U. S. Geol. Surv., Mon. III, 1882. (Comstock Lode.) 62. Lord, U. S. Geol. Surv., Mon. IV, 1883. (Comstock mining.) 63. Spurr, U. S. Geol. Surv., Prof. Pap. 42, and Bull. $260: 140,1905$. (Tonopah.) 64. Spurr, U. S. Geol. Surv., Bull. 225 : 118, 1904, and Bull. $260: 132,1905$. (Gold fields.) 65. Spurr, U. S. Geol. Surv., Bull. 225: 111, 1904. (Silver Peak quadrangle.) 66. See also annual reports of Director of Mint. - New England: 67. Smith, U. S. Geol. Surv., Bull. 225: 81, 1904. (Me. and Vt.) - North Carolina : 68. Nitze and Hanna, N. Ca. Geol. Surv., Bulls. 3 and 10. -Oklahoma: 69. Bain, U. S. Geol. Surv., Bull. 225 : 120, 1904. (Wichita Mts.) - Oregon: 70. Diller, U. S. Geol. Surv., 20th Ann. Rept., III : 7, 1900. (Bohemia district.) 71. Kimball, Eng. and Min. Jour., LXXIII : 889, 1902. (Bohemia district.) 72. Lindgren, U. S. Geol. Surv., 22d Ann. Rept., II : 551, 1901. (Blue Mts.) 73. See also bulletin on Oregon Mineral Resources issued by University of Oregon. - South Carolina : 74. Thies and Mezger, Amer. Inst. Min. Engrs., Trans. XIX : 595, 1891. (Haile Mine.) See also No. 82. - South Dakota: 75. Carpenter, Amer. Inst. Min. Engrs., Trans. XVII : 570, 1889. 76. Irving, U. S. Geol. Surv., Bull. 225: 123, 1904, and U. S. Geol. Surv., Prof. Paper 26, 1904. (N. Black Hills.) 77. O'Harra, S. Dak. Geol. Surv., Bull. 3, 1902. (Black Hills.) 78. Smith, Amer. Inst. Min. Engrs., Trans. XXVI: 485, 1897. (Cambrian ores.) - United States : 79. Lindgren, Amer. Inst. 
Min. Engrs., Trans. XXXIII : 790, 1903. (N. Amer. production and geology.) 80. Lindgren, U. S. Geol. Surv., Bull. 260 : 32, 1905. 81. Nitze and Wilkens, Amer. Inst. Min. Engrs., Trans. XXV: 661, 1896. (Appalachians.) 82. Pratt, Eng. and Min. Jour., LXXIV: 241, 1902. (S. Appalachians.) 83. Ransome, Min. Mag., X: 7, 1904. See also annual reports on Precious Metals, issued by Director of Mint, the Mineral Resources issued by U. S. Geol. Survey, the Mineral Industry, and Census Report on Mines and Quarries, 1902. - Utah : 84. Spurr, U. S. Geol. Surv., 16th Ann. Rept., II : 343, 1895. (Mercur.) See also annual reports of Director of Mint, all of which contain much general information, partly of statistical character; also references under Silver-Lead. 85. Warren, Eng. and Min. Jour. LXVIII : 455, 1899. (Daly-West Mine.) - Vermont: See New England.-Washington: 86. Arnold,.U. S. Geol. Surv., Bull. 260 : 154, 1905. (Beach placers.) 87. Smith, Eng. and Min. Jour., LXXIII: 379, 1902. (Mt. Baker district.) 88. Spurr, U. S. Geol. Surv., 22d Ann. Rept., II : 777, 1901. (Monte Cristo.) 


\section{CHAPTER XVIII}

\section{SILVER-LEAD ORES}

The Silver-Lead Ores form a large class, which are widely distributed in the Cordilleran region, and not only supply most of the lead mined in the United States, but in addition may also and often do carry variable quantities of silver, gold, and copper.

The deposits as a whole present a variety of forms. The associated rocks are often faulted, and the ore bodies are commonly oxidized above so that the altered portions require different metallurgical treatment from the sulphide ores found below. Secondary enrichment has in some cases raised the grade of the ore. Deposits of this class are prominent in Colorado, Idaho, and Utah, but are also known in New Mexico, Montana, Wyoming, Nevada, Arizona, California, and South Dakota. Idaho is the largest producer of silver-lead ores, but they average only one third silver, while those of Colorado average three quarters silver, and those of Utah about two thirds silver. A few of the more prominent occurrences are mentioned.

Leadville District, Colorado $(1,7) .-$ This region lies in the Mosquito range at the headwaters of the Arkansas River in south central Colorado, while the town of Leadville is situated in an old lake basin on the west side of the range. The latter is composed of crystalline rocks, Paleozoic sedi- 
ments, and igneous intrusions, the last in part conforming to the bedding planes of the sedimentary rocks. The Paleozoic section alone is over 5000 feet and involves the following members:-

Upper Carboniferous limestone . . 1000 to 1500 feet.

Weber shales and sandstone . . 2000 feet.

Oldest or white porphyry . . . .

Carboniferous blue limestone (chief ore-bearing stratum) . . . . 200 feet.

Gray porphyry .

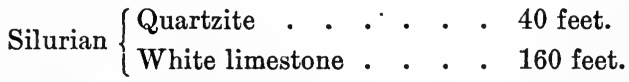

Cambrian quartzite . . . . 150 to 200 feet.

The rocks on the western side of the Mosquito range are folded and faulted, this having taken place during late Cretaceous times, when the Rocky Mountains were uplifted, and subsequent to the intrusion of the igneous rocks. It is considered that the latter stimulated the ascension of the orebearing solutions, the ore being commonly deposited on the under side of the porphyry sheets and in contact with the blue Carboniferous limestones. Later developments have shown its presence along some of the other contacts. The unaltered ore is argentiferous galena with some native gold, but within the zone of oxidation the galena is changed to carbonate and sulphate, with silver chloride and at times containing considerable limonite. The gangue is calcite, barite, and chert.

The older mines are mostly east of the city on Fryer, Carbonate, and Iron Hill, but in recent years the continuation of the deposits has been found under the city. 
The origin of the ores has been discussed by several geolo. gists, among them Emmons and Blow $(1,7)$. The former believes that the ores were originally deposited as sulphides

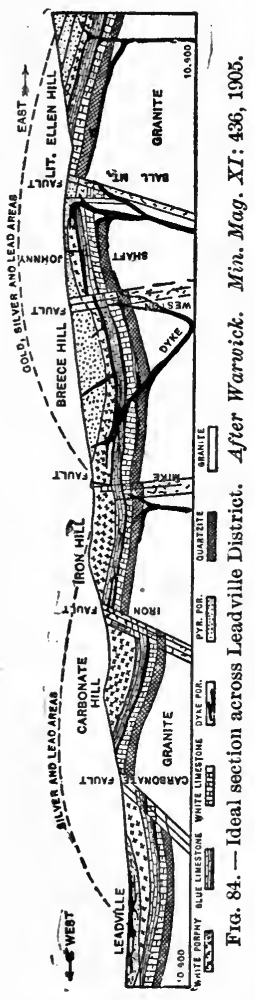

from aqueous solutions ascending from some deep source, and by a process involving metasomatic interchange, the ore-bearing solutions following the contact because it happened to form a good channel.

For many years the oxidized ores of the Leadville district have been an important source of material for the smelters; but latterly the silver ores have shown signs of exhaustion, and their place has been taken to some extent by the discovery of gold ore to the east of the town, as well as of zinc sulphides at greater depths and the shipment of larger quantities of iron and manganese ores than formerly.

Even in former years Leadville was a mining camp of great importance, having indeed given Colorado its first serious start as a mining state. From an area of about a square mile the output of silver was for a number of years greater than that of any foreign country except Mexico, and during the same period the production of lead was nearly equal to that of England and greater than that of any European country excepting Spain and Germany. Although regarded originally as a silver camp, it really ceased being such nearly ten years ago, and is now an important producer of at least eight metals, of which five or six are 
sometimes all obtained from the same group of properties. It will thus be seen that the successful marketing of one may affect all the others. Leadville began as a gold camp in 1860, when a placer deposit of gold was found in a gulch near there and several million dollars' worth of metal were extracted, resulting in the establishment of a flourishing town called Oro, which, however, soon lost its importance when the gold began to be exhausted. Not until 1875 was the carbonate of lead, which has since been so important, actually recognized.

That Leadville is no longer entirely a lead-silver camp is evident from the fact that, in 1901 , of the 850,000 long tons of ore mined, 35,000 tons were zinc ores, 70,000 tons manganese iron ores, and the remainder lead and copper smelting ores.

Aspen, Colorado (15). - Here again the ores are oxidized and occur in highly folded and faulted Carboniferous limestone, although the section involves rocks ranging in age from Archæan to Mesozoic. Two quartz porphyries, one at the base of the Devonian, the other in the Carboniferous, are present, but bear no special relation to the ore.

At the close of the Cretaceous the rocks were folded into a great anticline, with a syncline on its eastern limit, which passed into a great fault along Castle Creek west of the mines. Contemporaneous with the folding there were also produced two faults parallel to the bedding of the Carboniferous dolomite, while at the same time much cross faulting occurred. The ore is found chiefly at the intersection of these two sets of fault planes, and Spurr considers that the ore-bearing solutions followed the bed faults. ${ }^{1}$

On account of the intimate association of the dolomite, quartz, and barite with the ore their origin is considered as similar.

1 Weed has suggested that this accumulation of ore at the intersection of fault planes is the result of secondary enrichment, rather than of primary concentration. 
The ores are peculiarly free from other metals except lead, and the rich polybasite $\left(\mathrm{Ag}_{9} \mathrm{SbS}_{6}\right)$ ores of Smuggler

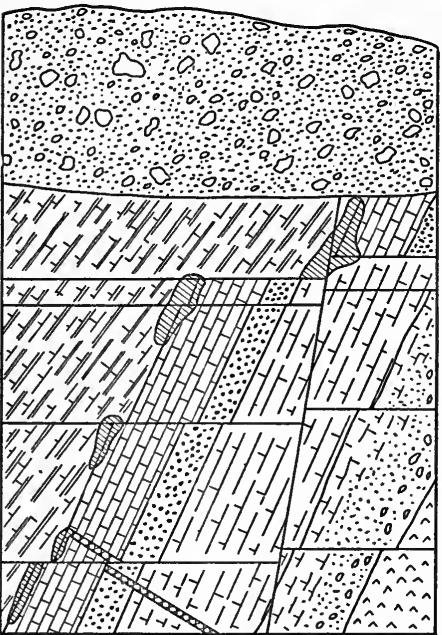

GLACIAL DRIFT

PARTING QUARTZITE

DY.X WEBER FORMATION EY YULE FORMATION

NORE

区::

WEA LEADVILLE DOLOMITE

$$
\text { [ind GRANITE }
$$

Fia. 85. - Section of ore body at Aspen, Colo. After Spurr, U.S. Geol.Surv., Mon. XXXI.

Mountain do not contain even this.

The mining camp of Aspen started in 1879, but its development for a time was much retarded by lawsuits. The richer ore bodies were not discovered until 1884 , and then by underground exploration, for owing to the heavy mantle of glacial gravels their outcrops were hidden. Since also the ore carries no iron or manganese, as do the Leadville ores, its outcrop may be inconspicuous.

The railroads did not reach the camp until 1887 , so that during the first few years of its history the ore had to be carried out on burros.

In both Aspen and Smuggler mountains long tunnels have been run for drainage and hauling purposes. The Cowenhoven tunnel, which is the largest of these, is over 8300 feet long, and taps a number of mines. Aspen was one of the first mining camps in the West to install electric machinery for hoisting, haulage, etc., and the current was cheaply supplied by the neighboring water power. One shaft 1000 feet deep is operated electrically. 

Plate Xxiv

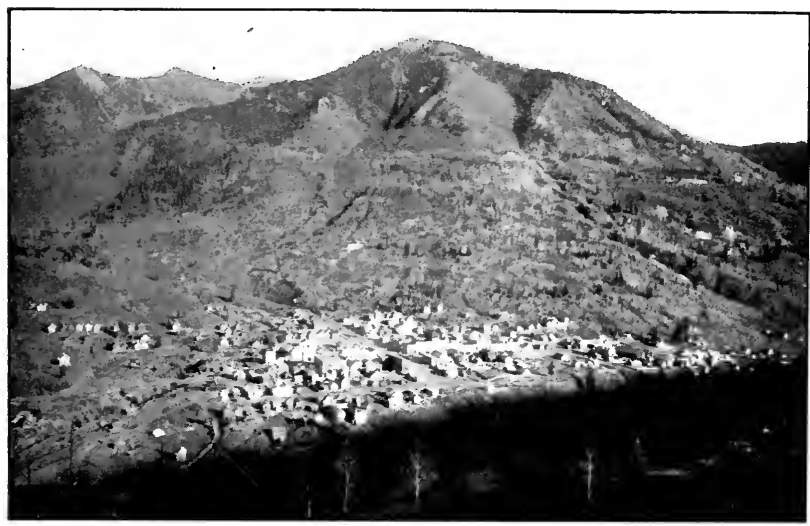

Fic. 1. - General view of Rico, Colo., and Enterprise group of mines.

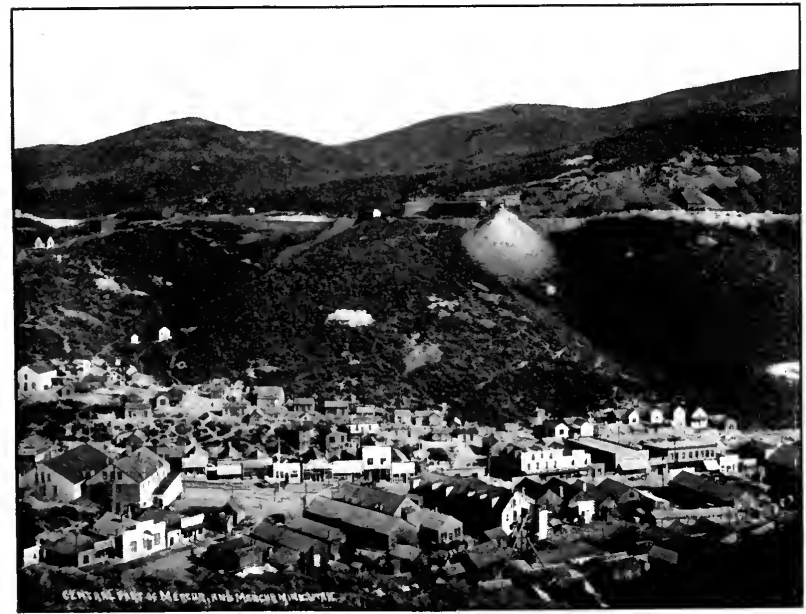

Fig. 2.-Ontario mine, Park City, Utah. 
At the present day the larger ore bodies are worked out, but the camp is still an active producer. From 1881 to 1895 it produced $\$ 63,653,989$ worth of silver.

Other Occurrences. - Argentiferous lead ores also occur in the Ten Mile district (8), in Chaffee County, and along the Eagle River (11). They are also known in Red Mountain (10a), and in Rico Mountain, Dolores County $(4,12,13)$. In the last-mentioned region the mountains, which are the remains of the structural dome arising above the Dolores plateau lying in the San Juan region, contain a series of sedimentary beds ranging from Algonkian to Jurassic in age, which have been uplifted partly by the intrusion of igneous

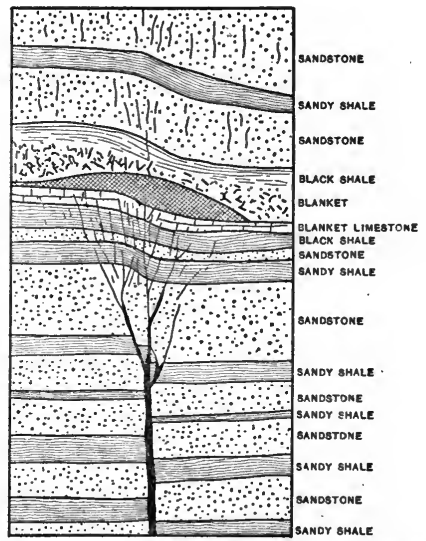

Fig. 86. - Diagrammatic section across a northeasterly lode at Rico, Colo., showing "blanket" of ore. After Ransome, U.S. Geol. Surv., $22 d$ Ann. Rept., II. rocks, as stocks, sills, and dikes, and partly by upthrows due to faulting.

The ore occurs as lodes, replacements in limestone, stocks, and blankets, the last consisting usually of deposits lying parallel to the planes of bedding or to the sheets of igneous rock, and known locally as "contacts," although not such in the true sense.

The four types of deposit mentioned may pass into each other. Most of the ore in the district has, however, 2 B 
come from the blankets, and the bulk of this has been found in the Carboniferous, especially in the Hermosa formation, a striking feature of the deposits being their limited vertical range.

The ores are primarily galena, often highly argentiferous and associated with rich silver-bearing minerals. In

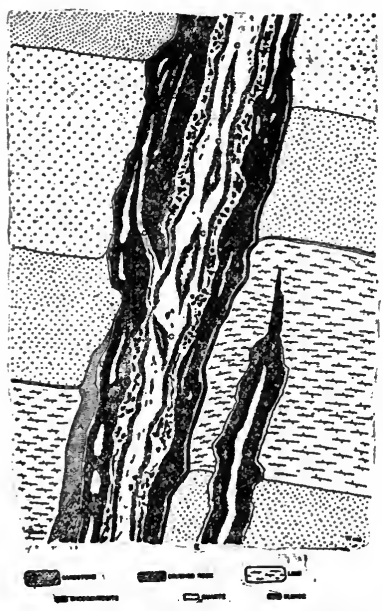

Fig. 87. - Vein filling a fault fissure, Enterprise mine, Rico, Colo. After Rickard, Amer. Inst. Min. Eng., Trans. $X X V I: 927$. many deposits the more or less complete oxidation of the silver ores has resulted in powdery masses, often very rich in silver. Below the zone of oxidation, the veins have not been successfully worked.

The bulk of the ores can be roughly divided into pyritic ores, usually low grade, and silver-bearing galena ores, sometimes containing rich silver minerals. Quartz is the commonest gangue mineral, but the beautiful pink rhodochrosite is also conspicuous.

The ore deposition is believed to be closely associated with the igneous intrusions of the district, especially with the later ones.

Most of the ore produced in the Rico district has been shipped crude or smelted in Rico without mechanical concentration.

Park City, Utah (2), which is located on the eastern 
slope of the Wasatch range, about 25 miles southeast of Salt Lake City, has made Summit County famous as one of the important mining centers of this country, as there are here large bodies of rich silver-lead ores carrying minor values of gold and copper. The success of this camp, therefore, depends more or less on the condition of the silver and copper industry.

The geological section involves a series of limestones, sandstones, and shales, chiefly of Carboniferous age, and having an aggregate thickness of over 6000 feet, with a general dip of 30 to 40 degrees northwest, and traversed by many fissures, faults, and intrusions, the last being of either dioritic or porphyritic types. The ores, which in the oxidized zone are cerussite, anglesite, azurite, malachite, etc., and in the sulphide zone are galena, tetrahedrite, and pyrite, occur either as lodes or fissures, or as bedded deposits in limestones. The latter, which supply most of the ore, form replacements in certain strata of both the upper Carboniferous and Permocarboniferous, and lie between siliceous members as walls. Both types of ore deposit are frequently associated with porphyry.

The fissures carry either silver or lead with or without zinc, and copper or gold with some silver. The replacement ores of the limestones hold silver and lead chiefly. The contact ores contain copper and gold with or without silver, and form irregular bodies in metamorphic limestone adjacent to the igneous rock. The ordinary crude ore carries 50 to 55 ounces silver, 20 per cent lead, .04 to .05 ounce gold, 1.5 per cent copper, 10 to 18 per cent zinc. Silver is obtained in the proportion of 3 ounces silver to each per cent iron, 1 ounce silver to each per cent lead, 
and .5 ounce silver to each per cent zinc. Bonanzas are known. The low-grade ores are treated at the concentrating mill, while the rich ores are shipped to the smelter.

Tintic District, Utah (16). - This district lies in the Tintic Mountains, about 65 miles southwest of Salt Lake City. The ores are argentiferous galena, with a little copper, the average per ton of 240,000 tons being silver, $52.44 \mathrm{oz}$; lead, 270 lbs.; copper, 11.2 lbs.; gold, .135 oz.

The section of nearly 14,000 feet of folded Paleozoic sediments includes chiefly limestones, which after uplift and erosion were covered by Tertiary lavas and tuffs. The ores occur in zones in the limestones, as fissures in the igneous rocks, and along the contact. The minerals in the ore bodies are quartz, barite, pyrite, galena, sphalerite, enargite, silver and gold minerals and their oxidation products.

The Tintic is one of the oldest camps in the state, the ore having been discovered in 1869, and it was at first shipped as far as Baltimore and Wales. Since then mills have been erected at the mines. The chief towns are Eureka, Mammoth, Robinson, Silver City, and Diamond.

The same type of ore occurs in Big and Little Cottonwood cañons and Bingham Cañon, the latter having been worked longer than those of the Tintic district. The camps lie southeast and southwest of Salt Lake City, and the ores are oxidized lead-silver ores, parallel to the bedding of Carboniferous limestones and the underlying quartzite. Galena and pyrite occur in the lower workings below water level.

Cour d'Alene, Idaho (14), lying in the northern part of the state, is one of the most prominent producers in the 
United States, having, in the fifteen years preceding 1902, produced about $\$ 60,000,000$ worth of lead and silver.

The formations of the region consist of slates, sandstones, and quartzites, which have been bent into east and west folds, the accompanying metamorphism having been sufficient to produce new minerals. Igneous intrusions are, however, rare. The ore bodies, which are typical veins, containing argentiferous galena, associated with much siderite, occupy fault planes, and are oxidized above. The chief minerals are quartz, siderite, galena, and sphalerite. The

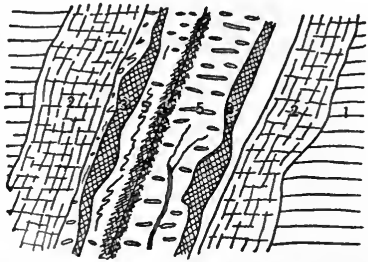

FiG. 88. - Section of lead-silver vein, Cœur d'Alene, Ido. (1) Country rock. (2) Sheared rock. (3) Galena and siderite. (4) Fissure with finegrained galena. (5) Barren, silicified country rock. After Finlay, Amer. Inst. Min. Engrs., Trans. $X X X I I I$ : 249.

workable deposits carry from 5 to 25 per cent lead, the average of the district being 10 per cent and 7 ounces per ton silver.

Montana and Nevada, etc. - Montana contains several lead-silver ore localities. Those of Neihart (17) occur as veins in gneiss and igneous rocks, the ores being galena, silver sulphides, and some blende. The veins are best defined in the gneiss, and are mostly replacement deposits, which have been subsequently fractured and secondarily enriched. Lead-silver ores also occur at Glendale and in Jefferson County. Some are also known in South Dakota and New Mexico (3).

The Eureka district (10) of eastern Nevada, discovered in 1868 , is chiefly of historic importance. The ores are oxidized lead-silver ores, carrying some gold. They occur in Cambrian 
limestone which is much faulted and crushed, and is part of a Paleozoic section 30,000 feet thick.

The ore is associated with a great fault, and is oxidized to a depth of 1000 feet. There are two mining districts, Prospect Hill and Ruby Hill. Near the mines are great porphyry masses which are supposed to have afforded the ores. Up to 1882 the output was not far from $\$ 60,000,000$ of precious metals and 225,000 tons of lead.

\section{REFERENCES ON LEAD-SILVER ORES}

1. Blow, Amer. Inst. Min. Engrs., Trans. XVIII : 145, 1889. 2. Boutwell, U. S. Geol. Surv., Bull. 213 : 31, 1903; 225 : 141, $1904 ; 260$ : 150, 1905. (Park City, Utah.) 3. Clark, Amer. Inst. Min. Engrs., Trans. XXIV : 138. (Lake Valley, New Mex.) 4. Cross and Spencer, U. S. Geol. Surv., 21st Ann. Rept., II : 15, 1900. (Rico Mts., Colo.) 5. Curtis, U. S. Geol. Surv., Mon. VII, 1884. (Eureka, Nev.) 6. Eldridge, U. S. Geol. Surv., 16th Ann. Rept., II: 217, 1895. 7. Emmons, U.S. Geol. Surv., Mon. XII, 1886. (Leadville, Colo. A new report is in preparation.) 8. Emmons, U. S. Geol. Surv., Ten Mile Atlas Folio. (Ten Mile district, Colo.) 9. Farish, Colo. Sci. Soc., Proc. IV : 151. (Rico.) 10. Hague, U. S. Geol. Surv., Mon. XX, 1892. (Eureka, Nev.) $10 a$. Kedzie, Amer. Inst. Mlin. Engrs., Trans. XVI: 570, 1888. (Red Mt.) 11. Olcott, Eng. and Min. Jour. XLIII : 418, 436, 1887, and LIII: 545, 1892. (Eagle Co., Colo.) 12. Rickard, Amer. Inst. Min. Engrs., Trans. XXVI : 906, 1896. (Enterprise mine, Rico, Colo.) 13. Ransome, U. S. Geol. Surv., 22d Ann. Rept., II : 229, 1901. 14. Ransome, U. S. Geol. Surv., Bull. 260: 274, 1905. (Cœur d'Alene.) 15. Spurr, U. S. Geol. Surv., Mon. XXXI, 1898. (Aspen, Colo.) 16. Tower and Smith, U. S. Geol. Surv., 19th Ann. Rept., III : 601, 1899. (Tintic district, Utah.) 17. Weed, U. S. Geol. Surv., 20th Ann. Rept., III : 271, 1900. 


\section{CHAPTER XIX}

\section{ALUMINUM}

Ores. - This is one of the few metals whose ores do not present a metallic appearance. Many different minerals contain aluminum, but it can be profitably extracted from only a few. Common clay, for example, presents an inexhaustible supply, but the chemical combination of the aluminum in it is such that its extraction up to the present time has not been found practicable.

The ores of aluminum, together with the percentage of the metal which they contain, are: corundum, $\mathrm{Al}_{2} \mathrm{O}_{3}$ (53.3 per cent); cryolite, $\mathrm{AlF}_{3}, 3 \mathrm{NaF}$ (12.8 per cent); bauxite, $\mathrm{Al}_{2} \mathrm{O}_{3}, 2 \mathrm{H}_{2} \mathrm{O}$ (39.13 per cent); gibbsite, $\mathrm{Al}_{2} \mathrm{O}_{3}$, $3 \mathrm{H}_{2} \mathrm{O}$ (34.6 per cent). Of these, corundum is too valuable as an abrasive, and is not found in sufficient quantity to permit its use as an ore of aluminum. Until the discovery of bauxite, cryolite was the chief source of the metal, all of it being obtained from Greenland (8).

Bauxite derives its name from Baux in southern France, where it was first discovered, but in recent years large deposits have been found in the United States. It is usually pisolitic in structure, and may sometimes resemble clay in appearance. The common impurities are silica, iron oxide, and titanic acid; and the variation in the amount of these ingredients can be seen from the following analyses of both domestic and foreign occurrences:- 


\section{ANalyses of Bauxite}

\begin{tabular}{|c|c|c|c|c|c|c|c|}
\hline & & 1 & 2 & 3 & 4 & 5 & 6 \\
\hline Alumina $\left(\mathrm{Al}_{2} \mathrm{O}_{8}\right)$. . & - & 57.60 & 61.89 & 63.16 & 59.22 & 61.00 & 62.05 \\
\hline Ferric oxide $\left(\mathrm{Fe}_{2} \mathrm{O}_{8}\right)$. & - & 25.30 & 1.96 & 23.55 & 3.16 & 2.20 & 1.66 \\
\hline Silica $\left(\mathrm{SiO}_{2}\right)$. . . & . & 2.80 & 6.01 & 4.15 & 3.30 & 2.10 & 2.00 \\
\hline Lime carbonate $\left(\mathrm{CaCO}_{3}\right)$ & ). & .40 & & & & & \\
\hline Titanic acid $\left(\mathrm{TiO}_{2}\right)$. . & . & 3.10 & & & 3.62 & & \\
\hline Water $\left(\mathrm{H}_{2} \mathrm{O}\right)$. ... & . & 10.80 & 27.82 & 8.34 & 28.80 & 31.58 & 30.31 \\
\hline Moisture . . . & - & & & & 1.90 & 3.12 & 3.50 \\
\hline Alkalies $\left(\mathrm{Na}_{2} \mathrm{O}, \mathrm{K}_{2} \mathrm{O}\right)$. & - & & & .79 & & & \\
\hline
\end{tabular}

1. Baux, France. 2. Glenravel, Ireland. 3. Wochein, Germany. 4. Georgia. 5. Rock Run, Alabama. 6. Arkansas.

Distribution of Bauxite in the United States. - Bauxite in commercial quantity is known to occur in but three districts in the United States. These are the Georgia-Alabama district, the Arkansas district, and a small area in southwestern New Mexico. The New Mexico deposits are of little commercial importance on account of their inaccessibility.

Georgia-Alabama $(4,6,7)$. - The bauxite deposits of these two states form a belt about 60 miles long extending from Jacksonville, Alabama, to Cartersville, Georgia. The ore, which is either pisolitic or claylike in its character, forms pockets or lenses of variable diameter and depth, in the residual clay derived from the Knox dolomite. A pronounced feature is their occurrence close to 900 feet above sea level, few being found above 950 feet or below 850 (4).

The bauxite is believed by Hayes (4) to be a hot spring deposit. It is underlain by the Knox dolomite and this in turn by the Connasauga shales which are several thousand feet in thickness, and contain from 15 to 20 per cent of alumina, and also pyrite. The region is one of marked faulting. 
Plate XXV

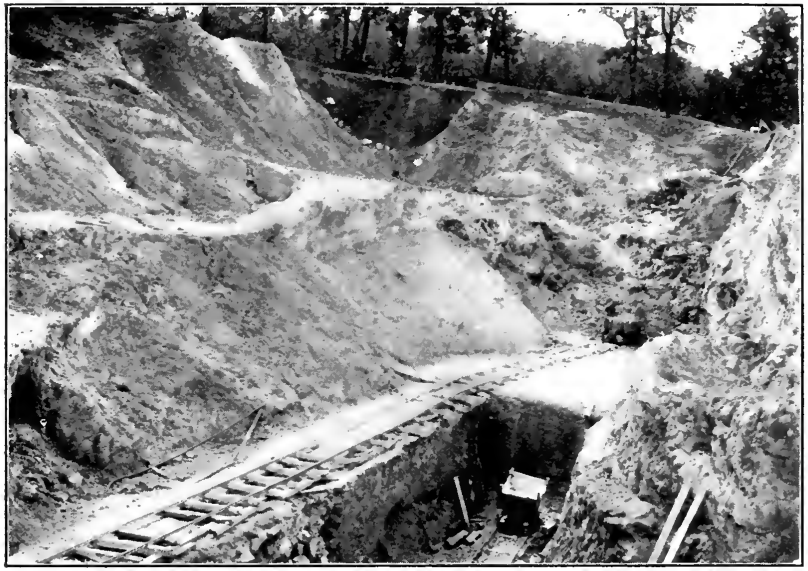

Fıg. 1. - View of Bauxite bauk, Rock Run, Ala. II. Ries, photo.

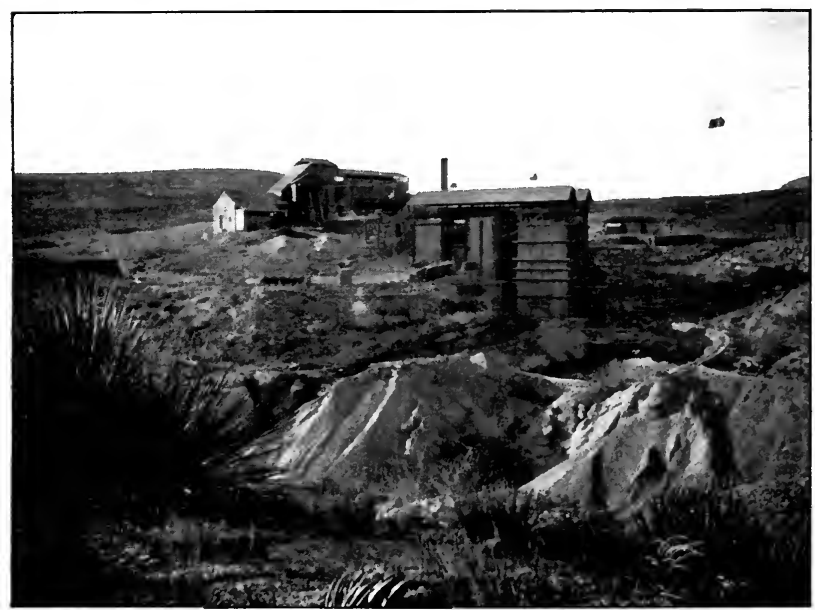

FIG. 2.-Furnace for roasting mercury ore, Terlingua, Tex. W. H. Turner, photo. 

Alteration of the pyrite by percolating meteoric waters has yielded sulphuric acid, which attacked the alumina of the shale, with the formation of alum and also ferrous sulphate. Both of these have been carried toward the surface by spring waters, but since they had to pass through the higher lying

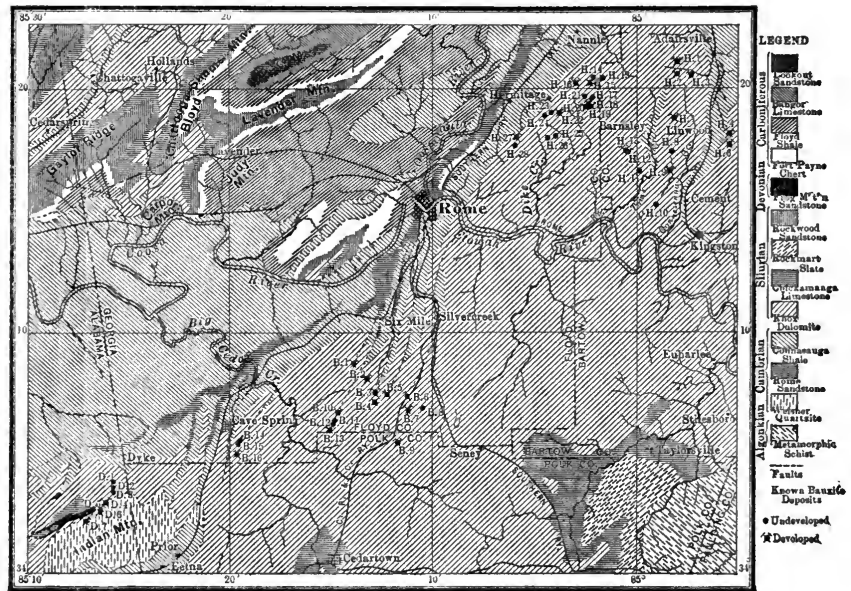

Frg. 89. - Geologic map of Alabama-Georgia bauxite region. After Hayes, U. S. Geol. Surv., 16th Ann. Rept., III: 552.

limestones, the lime carbonate acted on the dissolved alum according to the following equation: ${ }^{1}$ -

$$
\mathrm{Al}_{2}\left(\mathrm{SO}_{4}\right)_{3}+3 \mathrm{CaCO}_{3}=\mathrm{Al}_{2} \mathrm{O}_{3}+3 \mathrm{CaSO}_{4}+3 \mathrm{CO}_{2} \text {. }
$$

The alumina thus formed was a light, gelatinous precipitate, which was carried upward into spring basins on the surface, where it finally settled. The pisolitic structure is thought to have been caused by the balling together of the gelatinous mass by currents.

1 For clearness, the water combined with the alumina is left out. 
The Georgia-Alabama deposits, which represent a unique type of occurrence, were discovered in 1887 , and have been worked steadily since that time. There have been some misgivings regarding the exhaustibility of the domestic supply, but the discovery and development of the next described district have allayed these fears.

Arkansas $(2,3) .-$ The occurrence of bauxite in Arkansas has been known since 1891, but owing to a more accessible eastern supply, there was little development in that region until 1900. The deposits, which are much more extensive than the Georgia-Alabama ones, are confined to a small area

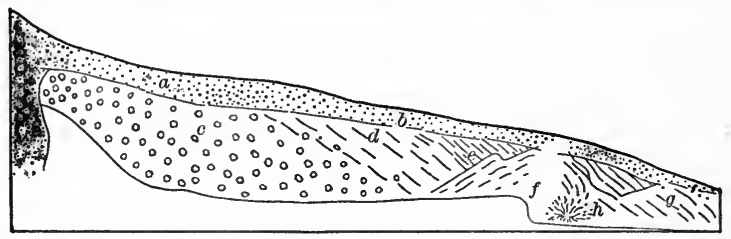

Fig. 90. - Section of Bauxite deposit. (a) Residual mantle; (b) Red sandy clay soil; (c) Pisolitic ore; (d) Bauxite with clay; (e) Clay with bauxite; $(f)$ Talus; $(g)$ Mottled clay; $(h)$ Drainage ditch. After Hayes.

in Pulaski and Saline counties, north and southwest of Little Rock. They have an average thickness of 10 to 15 feet and show two distinct types. In the southwesterly or Bryant district the lower beds show a granitic structure and rest directly on a mass of kaolin derived from the elæolitesyenite, and it is probable that the bauxite has also been derived directly from this rock. The upper beds are pisolitic and similar in character to the Georgia-Alabama ones. In the Fourche Mountain area only the pisolitic form is found. The granitic type is the purest and corresponds in composition to the formula of gibbsite rather than bauxite, while the white bauxitic kaolins run high in silica. 
The origin of the Arkansas bauxites is somewhat obscure, but Hayes (3) considers that subsequent to the intrusion of the syenite into the palæozoics of that region, the former was exposed by erosion of the latter. This was followed by a submergence of the surface below a body of salt or highly alkaline waters, which in some way penetrated the still partially hot syenite, and dissolved its minerals. On returning to the surface they attacked the syenite there, removing silica and alkalies and depositing alumina in its place. Much of the alumina was also deposited from these waters as a gelatinous precipitate on the ocean bottom, over the syenite surface. Some was also deposited with the Tertiary sediments then forming.

New Mexico (1). - The bauxite deposits which occur near Silver City appear to have been derived from a basic volcanic rock, by decomposition and alteration in place.

Uses of Aluminum. - The chief use of this metal is for making wire for the transmission of electric currents, but a large quantity of it is also used in the manufacture of articles for domestic or culinary use, instruments, boats, and other articles where lightness is wanted. It is also employed in the manufacture of special alloys, among which may be mentioned magnalium, an alloy of aluminum and magnesium; and wolframinium, a tungsten-aluminum alloy. One alloy of this type known as partinium is said to have a tensile strength of over $\overline{49,000 \text { pounds }}$ per square inch; McAdamite, an alloy of aluminum, zinc, and copper, is said to possess a tensile strength exceeding 44,000 pounds per square inch; aluminum silver is an alloy of copper, nickel, zinc, and aluminum; aluminum zinc includes a series of 
alloys containing various proportions of these two metals. Of growing importance is the use of aluminum for lithographic work as a substitute for stone or zinc. Another extending application is that of powdered aluminum for the production of intense heat by combustion, and in this connection it is used for welding tramway rails, or for the reduction of rare metals from their oxides. Aluminum has also been tried for the manufacture of grindstones and whetstones, for which purpose it is said to be peculiarly suited owing to the property it has for forming under whetting action a very fine mass which adheres strongly to steel. A small amount of aluminum added to steel prevents air holes and cracks in casting.

Uses of Bauxite. - Aside from being used for the manufacture of aluminum and alum, bauxite is of some value for the manufacture of refractory products, its heat-resisting qualities being very great.

Production of Bauxite. - The production of bauxite in the United States has been as follows :-

Production of Bauxite in the United States from 1889 to 1903

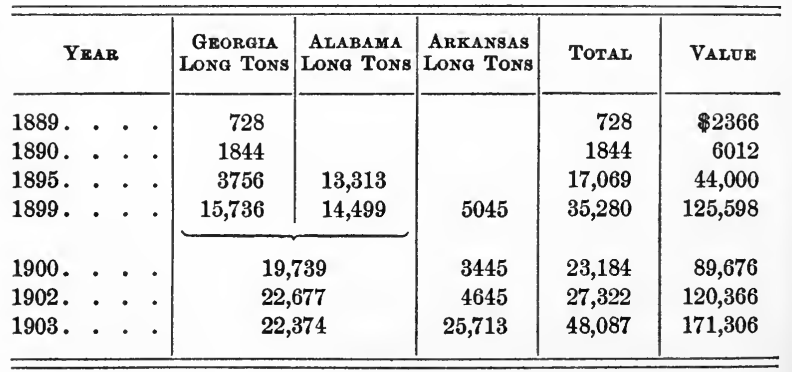


The following table shows the annual consumption of bauxite and its value in the United States:-

Production, Imports, Exports, and Consumption of Bauxite in the United States

\begin{tabular}{|c|c|c|c|c|c|c|c|c|}
\hline \multirow[b]{2}{*}{ YEAR } & \multicolumn{2}{|c|}{$\begin{array}{c}\text { Total } \\
\text { Production }\end{array}$} & \multicolumn{2}{|c|}{ IMPORTS } & \multicolumn{2}{|c|}{ ExPORTs } & \multicolumn{2}{|c|}{ CoNSUMPTION } \\
\hline & $\begin{array}{l}\text { Quan- } \\
\text { tity } \\
\text { Long } \\
\text { Tons }\end{array}$ & Value & $\begin{array}{l}\text { Quan- } \\
\text { tity } \\
\text { Long } \\
\text { Tons }\end{array}$ & Value & $\begin{array}{c}\text { Quan- } \\
\text { tity } \\
\text { Long } \\
\text { Tons }\end{array}$ & Value & $\begin{array}{l}\text { Quan- } \\
\text { tity } \\
\text { Long } \\
\text { Tons }\end{array}$ & Value \\
\hline 1901 & 18,905 & $\$ 79,914$ & 18,313 & $\$ 67,107$ & 1,000 & $\$ 3,000$ & 36,218 & $\$ 144,021$ \\
\hline 1902 & 27,322 & 120,366 & 15,790 & 54,410 & nil & - & 43,112 & 175,875 \\
\hline 1903 & 48,087 & 171,306 & 14,684 & 49,684 & nil & - & 62,976 & 220,990 \\
\hline
\end{tabular}

World's Production of Bauxite

\begin{tabular}{|c|c|c|c|c|c|c|}
\hline \multirow[b]{2}{*}{ Country } & \multicolumn{2}{|c|}{1900} & \multicolumn{2}{|c|}{1901} & \multicolumn{2}{|c|}{1902} \\
\hline & $\begin{array}{l}\text { QUANTITY } \\
\text { METRIC } \\
\text { TONS }\end{array}$ & Value & $\begin{array}{l}\text { QUantit } \\
\text { Metric } \\
\text { Tons }\end{array}$ & Value & $\begin{array}{l}\text { QUANTITY } \\
\text { METRIC } \\
\text { ToNs }\end{array}$ & Value \\
\hline United & & & & & & \\
\hline States & 23,556 & $\$ 89,676$ & 19,207 & $\$ 79,914$ & 29,785 & $\$ 128,206$ \\
\hline France . & 58,530 & 92,596 & 76,620 & 124,168 & 96,900 & 174,685 \\
\hline United & & & & & & \\
\hline Kingdom & 5,873 & 6,750 & 10,357 & 14,515 & 9,192 & 13,395 \\
\hline Total & 87,959 & $\$ 189,022$ & 106,184 & $\$ 218,597$ & 135,877 & $\$ 316,286$ \\
\hline
\end{tabular}

Prior to 1890 nearly all the bauxite consumed in the United States was imported from France. The French ore has a high iron oxide content, and very little is now imported, except during periods of low ocean freights. Most of it is purchased by Germany. 
Most of the bauxite used in the United States is for the manufacture of aluminum, but from one fourth to one half of the total is employed in the manufacture of chemical salts of aluminum, and artificial corundum, known as alundum. The Georgia-Alabama bauxites, on account of their freedom from iron, are of special value for the manufacture of alum. In Europe much is used as a refractory material for lining furnaces.

The production of aluminum in the United States since 1883 has been as follows :-

Production of Aluminum in the United States

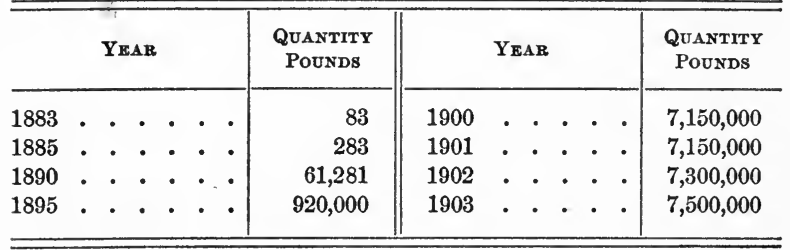

The domestic output comes from four large plants.

World's Production of Aluminum

\begin{tabular}{|c|c|c|c|c|c|c|}
\hline \multirow[b]{2}{*}{ Codrtay } & & & \multicolumn{2}{|c|}{1901} & \multicolumn{2}{|c|}{1902} \\
\hline & & & $\begin{array}{c}\text { QUANTITY } \\
\text { METRIO } \\
\text { Tons }\end{array}$ & VALUE & $\begin{array}{c}\text { QUANTITY } \\
\text { METRIO } \\
\text { Tons }\end{array}$ & VALUE \\
\hline United States & . & & 3,244 & $\$ 2,238,000$ & 3,311 & $\$ 2,284,900$ \\
\hline France . . . & - & & 1,200 & 560,000 & 1,355 & 638,830 \\
\hline United Kingdom & . & & 560 & - & 600 & - \\
\hline Switzerland . & - & • & 2,500 & $1,225,000$ & 2,500 & $1,201,425$ \\
\hline Total . & - & - & 7,504 & - & 7,766 & - \\
\hline
\end{tabular}




\section{REFERENCES ON ALUMINUM AND BAUXITE}

1. Blake, Amer. Inst. Min. Engrs., Trans. XXIV : 571, 1895. (N. Mex.) 2. Branner, Jour. Geol., V: 263, 1897. (Ark.) 3. Hayes, U. S. Geol. Surv., 21st Ann. Rept., III : 435, 1901. (Ark.) 4. Hayes, U. S. Geol. Surv., 16th Ann. Rept., III: 547, 1895. (Ga.-Ala.) 5. Laur, Amer. Inst. Min. Engrs., Trans. XXIV : 234, 1895. (The bauxites.) 6. Watson, Amer. Geol., XXVIII : 25, $1901 . \quad$ (Ga.) 7. Watson, Ga. Geol. Surv., Bull. 11, 1904. (Ga.) 8. For cryolite, see Min. Indus., VI : 251, 1897.

\section{MANGANESE}

Ores. - While many different minerals contain this metal, practically the only ones of commercial value are the oxides and carbonates, and in this country only the former. The silicates are not used as a source of manganese, owing to their high silica percentage.

The important ores of manganese are the following : pyro lusite, the black oxide $\left(\mathrm{MnO}_{2} ; 63.2\right.$ per cent $\left.\mathrm{Mn}\right)$; psilomelane (chiefly $\mathrm{MnO}_{2}, \mathrm{H}_{2} \mathrm{O} ; \mathrm{K}$ and $\mathrm{Ba}$ variable), one of the most abundant manganese ores; braunite $\left(\mathrm{Mn}_{2} \mathrm{O}_{3} ; 69.68\right.$ per cent $\mathrm{Mn}$ ); and wad, a low-grade, earthy brown or black ore, with the percentage of manganese varying from 15 to 40 per cent. Wad is often of too low grade, due to impurities, to be used as an ore of manganese; but it is sometimes employed for paint. Rhodochrosite $\left(\mathrm{MnCO}_{3}\right)$, though found as a common gangue mineral in some western mines, does not serve as a source of manganese.

The several ores of manganese are often intimately associated, the pyrolusite generally assuming a crystalline and the psilomelane a massive character. Manganese oxides are also often intermixed with more or less oxide of iron, and considerable amounts of the metal are obtained from man- 
ganiferous zinc, silver, or iron ores. Since much manganese is used in iron reduction, the last association is of importance.

To be of commercial value a manganese ore should have at least 40 per cent metallic manganese, and should be low in phosphorus and silica. High-grade ores run from 50 to 60 per cent manganese.

The price of manganese ores in 1903 was $\$ 8.97$ per long ton; of manganiferous iron ore, $\$ 2.69$ (18-32 per cent $\mathrm{Mn}$ ) and $\$ 2.40$ (1-10 per cent $\mathrm{Mn}$ ); of manganiferous silver ores, $\$ 3.63$.

Origin. - Manganese oxide deposits are usually of secondary origin, having been formed by weathering processes, which caused the decay of the parent rock containing manganiferous silicates, and the change of these latter to oxides. By circulating ground water they have often been concentrated in residual clays. Although iron also may have been present in the parent rock, and the two are sometimes deposited together, still they have in many instances been separated from each other, due to the fact that conditions favorable for precipitation are not the same for both (4), or because the soluble compounds of manganese formed by weathering are sometimes more stable than corresponding iron compounds, and hence may be carried farther by circulating waters before they are deposited.

Distribution of Manganese Ores in the United States. Although manganese ores are widely distributed in the United States, only a few localities are of commercial importance. This is partly owing to the uncertainty of the extent of the ore deposits and partly to the high percentage 
of phosphorus which many of the ores contain, together with their remoteness from lines of transportation.

Eastern Area. - Manganese deposits are found in the Atlantic States from Vermont to Alabama, and two states in this belt, Georgia and Virginia, lead in the domestic production. The common mode of occurrence in this district is as nodules or lumps in residual clay, similar to the limonites of the same area. In Virginia, at Crimora, Augusta County (2), the ore

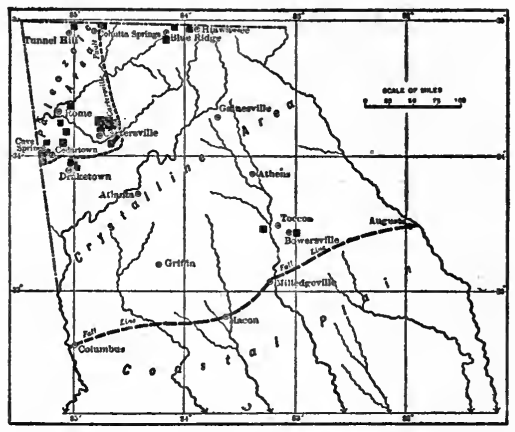

FIg. 91. - Map showing Georgia manganese areas. After Watson, Amer. Inst. Min. Engrs., Trans. XXXIV: 209.

forms pockets 5 to 6 feet thick and 20 to 30 feet long in a bed of clay 276 feet thick.

In northern Georgia $(1,3,7)$ the ore results from the decay of limestone and shales, Cave Spring and Cartersville being important localities. The deposits are found in the areas underlain by both the crystalline and Paleozoic rocks, but only those associated with the latter have proven to be of commercial importance. In this region the rocks consist of Cambro-Silurian limestones and quartzites, which have been much folded and faulted, and have then weathered down to a residual clay, which is often not less than 100 feet thick. The ore occurs as pockets, lenticular masses, stringers, grains, or lumps, irregularly scattered through the 
clay and rarely forming distinct beds. None of the deposits are large, though some 30 feet in length have been worked. More or less limonite, barite, ocher, and bauxite may be associated with the ore, and, indeed, complete gradations from manganese to iron ore are found, as shown by the following analyses:-

\begin{tabular}{|c|c|c|c|c|c|c|c|c|c|c|}
\hline Mn . & . & • & . & . & . & 60.61 & 54.94 & 41.98 & 15.26 & 2.30 \\
\hline $\mathrm{Fe}$. & . & . & . & . & . & 1.45 & 3.62 & 16.22 & 39.25 & 52.02 \\
\hline $\mathrm{P}$ & - & . & - & . & . & .052 & .034 & .227 & .193 & .24 \\
\hline
\end{tabular}

The better-grade ores are usually low in silica, iron, and phosphorus. In the Cartersville district, which is the more

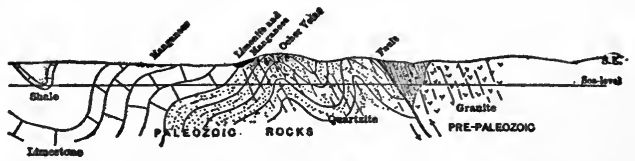

Fra. 92. - Section in Georgia manganese area, showing geologic relations of manganese, limonite, and ocher. After Watson, Amer. Inst. Min. Engrs., Trans. $X X X I V: 219$.

important, the ore is found in residual clays derived from the Beaver limestone and Weisner quartzite, while in the Cave Spring area it occurs only in the clays overlying the Knox dolomite.

Penrose (5) thought that the manganese was derived from the underlying Cambro-Silurian sediments, while Watson on the contrary believes that the crystalline rocks to the east and south have furnished the ore, as none is found in the parent rock from which the clays were derived. The manganese was probably taken into solution as a sulphate and concentrated by circulating waters of meteoric origin in the residual clays where now found. 
The Georgia (7) deposits have been worked for a number of years, and the manganese was formerly marketed chiefly in England; but the output is now sold entirely in the United States. The ore, which has to be purified by washing and crushing, is used in part for paint and in part for steel manufacture.

Arkansas. - Manganese ore is found in the region around Batesville $(5,6)$, associated with horizontally stratified limestones and shales, ranging from Ordovician to Carboniferous age (Fig. 93). The Cason shale, of Silurian age, occurring near the middle of the section (Fig. $93 \mathrm{~b}$ ), carries

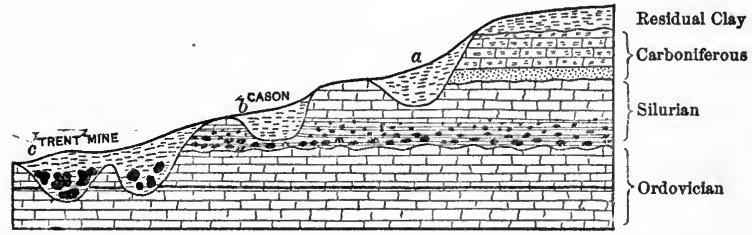

Frg. 93. - Section in Batesville, Ark., manganese region, illustrating geological structure and relation of different formations to marketable and non-marketable ore. After Van Ingen, Sch. of M. Quart., XXII: 324.

manganese nodules high in phosphorus, which are not marketable, and others are found in the pits of residual clay derived from it. Farther down the slopes marketable ore (Fig. $93 \mathrm{c}$ ), which has been derived by leaching of the first-mentioned ore, is found occurring in residual pockets in the lower lying limestones, while the residual clays (Fig. $93 \mathrm{a}$ ), formed at a higher level than the Cason shale, are barren of manganese.

Other United States Occurrences. - California has a number of manganese deposits, of which some are reported to be of high quality (8); they have been used largely in 
chlorination works for the reduction of gold ores. Manganese occurs in Triassic sandstones near Thompson, Utah, and the locality became a producer in 1901 (8). Much manganiferous iron ore and manganiferous silver ore is annually obtained from the Leadville district of Colorado, the former being used by steel works in making spiegeleisen and the latter as a flux in smelters. Lake Superior iron ores at times carry manganese, but it usually does not exceed 1 per cent.

Uses of Manganese. - One of the principal uses of manganese is in the manufacture of alloys. Of these, spiegeleisen, an alloy of iron and manganese with under 20 per cent manganese, and ferromanganese, a similar alloy with over 20 per cent manganese, are important. Other alloys are manganese bronze, manganese and copper with or without iron; silver bronze, an alloy of manganese, aluminum, zinc, copper, and silver; and manganese-titanium alloys.

Manganese is also used as an oxidizing agent in the manufacture of chlorine, bromine, and disinfectants; as a coloring agent in calico printing and dyeing, in the making of glass, pottery, brick, as well as in paints. It is also employed as a decolorizer in green glass.

Production of Manganese. - Although much used in making glass and steel, of which latter material the United States is the largest manufacturer in the world, nevertheless the domestic production is small. This consequently necessitates the importation of large quantities, which are obtained chiefly from Brazil. 

Production and Value of Manganese Ores in the United States (in Long Tons)

\begin{tabular}{|c|c|c|c|c|c|c|c|c|c|c|c|c|c|}
\hline & & & & & YEAR & & & & & & & Production & Value \\
\hline 1880 & . & . & . & . & . & . & . & - & . & . & . & 5,761 & $\$ 86,415$ \\
\hline 1885 & . & . & . & . & . . & - & . & - & . & . & - & 23,258 & 190,281 \\
\hline 1890 & . & . & . & . & . & . & . & . & . & . & • & 25,684 & 219,050 \\
\hline 1895 & . & - & - & - & - & - & - & - & - & • & • & 9,547 & 71,769 \\
\hline 1900 & . & . & . & . & - & - & . & . & . & . & • & 11,771 & 100,289 \\
\hline 1901 & . & . & . & - & . & - & . & - & . & . & - & 11,995 & 116,722 \\
\hline 1902 & . & . & . & - & . & . & . & - & . & . & • & 7,477 & 60,911 \\
\hline 1903 & . & . & . & • & . . & - & . & . & . & . & . & 2,825 & 25,335 \\
\hline
\end{tabular}

Production and Value of Manganese Ores in the United States by States (IN Long Tons)

\begin{tabular}{|c|c|c|c|c|c|c|c|c|}
\hline \multirow{2}{*}{\multicolumn{3}{|c|}{ State }} & \multicolumn{2}{|c|}{1901} & \multicolumn{2}{|c|}{1902} & \multicolumn{2}{|c|}{1903} \\
\hline & & & $\begin{array}{l}\text { Prodec- } \\
\text { TION }\end{array}$ & VALUE & $\begin{array}{l}\text { Produc- } \\
\text { tion }\end{array}$ & VALUE & $\begin{array}{l}\text { Produc- } \\
\text { TION }\end{array}$ & VALUR \\
\hline Arkansas & & & 91 & $\$ 657$ & 82 & $\$ 422$ & - & - \\
\hline Georgia . & & • & 4,074 & 24,674 & 3,500 & 20,830 & 500 & $\$ 2,930$ \\
\hline Utah. . & & • & 2,500 & 31,250 & - & - & 483 & 2,415 \\
\hline Virginia . & & • & 4,275 & 52,853 & 3,041 & 29,444 & 1,801 & 19,611 \\
\hline All others & & . . & 1,055 & 7,288 & 824 & 10,215 & 41 & 379 \\
\hline Total & & . . & 11,995 & $\$ 116,722$ & 7,477 & $\$ 60,911$ & 2,825 & $\$ 25,335$ \\
\hline
\end{tabular}

Production and Value of Different Kinds of Manganese Ores in the United States (in Long Tons)

\begin{tabular}{|c|c|c|c|c|c|c|}
\hline \multirow[b]{2}{*}{ KIND OF ORI } & \multicolumn{2}{|c|}{1901} & \multicolumn{2}{|c|}{1902} & \multicolumn{2}{|c|}{1903} \\
\hline & $\begin{array}{l}\text { Produc- } \\
\text { TION }\end{array}$ & VALUE & $\begin{array}{l}\text { PeondC- } \\
\text { TION }\end{array}$ & VALUE & $\begin{array}{c}\text { Produc- } \\
\text { TION }\end{array}$ & VALUE \\
\hline $\begin{array}{l}\text { Manganese ores. } \\
\text { Manganiferous }\end{array}$ & 11,995 & $\$ 116,722$ & 7,477 & $\$ 60,911$ & 2,825 & $\$ 25,335$ \\
\hline $\begin{array}{l}\text { iron ores. } \\
\text { Manganiferous }\end{array}$ & 574,489 & $1,475,084$ & 901,214 & $2,001,626$ & 584,493 & $1,571,750$ \\
\hline $\begin{array}{c}\text { silver ores } \\
\text { Manganiferous }\end{array}$ & 228,187 & 865,959 & 194,132 & 908,098 & 179,205 & 649,727 \\
\hline zinc residuum 1 & 52,311 & 52,311 & 65,246 & 65,246 & 73,264 & 73,264 \\
\hline Total . . & 866,982 & $\$ 2,510,076$ & $\overline{1,168,069}$ & $\$ 3,035,881$ & $\overline{839,787}$ & $\$ 2,320,076$ \\
\hline
\end{tabular}

1 As this is a by-product in the treatment of zinc ores, the value given to it is nominal. 
The imports of manganese ore in 1903 amounted to 146,056 long tons, valued at $\$ 1,278,108$, and came chiefly from Brazil, but the British East Indies, Cuba, Germany, and Russia also supplied some.

\section{REFERENCES ON MANGANESE}

1. Brewer, Ala. Ind. and Sci. Soc. Proc., VI : 72. (Ga.) 2. Hall, Amer. Inst. Min. Engrs., Trans. XX : 46, 1892. (Crimora, Va.) 3. Hayes, Amer. Inst. Min. Engrs., Trans. XXX : 403, 1901. (Ga.) 4. Penrose, Jour. Geol., I : 27う, 1893. (Chemical relations of iron and manganese in sedimentary rocks.) 5. Penrose, Ark. Geol. Surv., Rept. for 1890, Vol. I, 1891. (Uses, ores, and deposits.) 6. Van Ingen, Sch. of M. Quart., XXII : 318, 1901. (Batesville, Ark.) 7. Watson, Amer. Inst. Min. Engrs., Trans. XXXIV : 207, 1904. (Ga.) 8. Birkenbine, Mineral Census, 1902, Mines and Quarries.

\section{MERCURY}

Ores. - While mercury is sometimes found native in the form of quicksilver, the most common ore is cinnabar ( $\mathrm{HgS})$, which contains 86.2 per cent mercury. Native amalgam of mercury and silver is known, and calomel, the chloride, as well as other compounds, are sometimes found.

Mode of Occurrence. - Mercury ores are not confined to any particular formation, but are found in rocks ranging from the Ordovician to Recent Age in different parts of the world. Nor are they peculiar to any special type of rock, although igneous rocks are often found in the vicinity of them. They occur as veins, disseminations, or as masses of irregular form. Silica, either crystalline or opaline, and calcite are common gangue minerals, while pyrite or marcasite are rarely wanting, and bitumen is widespread.

Distribution in the United States. - California has always been the most important, and, in fact, at times, the only 
producing state. Deposits are, however, also known in Texas, Oregon, Utah, Nevada, and New Mexico.

California $(1,2,7)$. - The California ores occur chiefly in metamorphosed Cretaceous or Jurassic rocks, with some in the Miocene and even Quaternary. The deposits, which are termed "chambered veins" by Becker, are fissured zones. Eruptive rocks seem in many cases to be involved in the ore formation, and at New Almaden a rhyolite dike runs parallel with the ore body. The ore here occurs along the contact between serpentine and shale, filling in part the interstices of a brec-

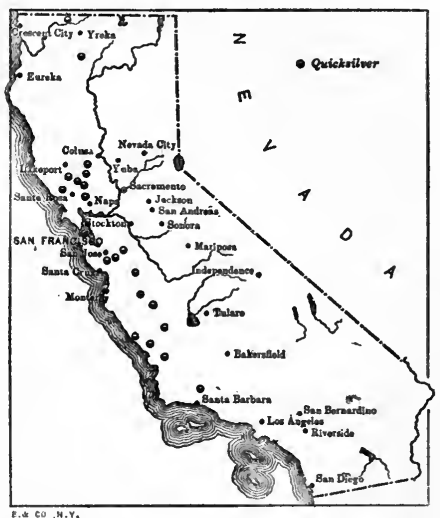

Fra. 94. - Map of California mercury localities.

cia. These mines, which are the largest in the state, have been worked to a depth of over 2500 feet.

Other occurrences are in Colusa County, where the cinnabar is found in altered serpentine, and in Napa County, where it occurs along the contact of sandstone and slate. The minerals associated with these are bitumen, free sulphur, stibnite, mispickel, gold and silver, chalcopyrite, pyrite, millerite, quartz, calcite, barite, and borax. At New Idria the ore is the same, but the wall rock is metamorphic sandstones and shales. A third important mine is the Sulphur Bank, which is of very recent date. The vein is a fissure filled with brecciated fragments, and cuts 
through sandstone, shale, and augite andesite, the cinnabar cementing the breccia together, but at times also impregnating the walls. Hot waters which circulate through the vein still deposit gelatinous silica.

At Steamboat Springs the waters carry gold, sulphide of arsenic, antimony, and mercury, sulphides or sulphates of silver, lead, copper, zinc, iron oxide, and possibly other metals. They also contain sodium carbonate, sodium chloride, sulphur, and borax.

Cinnabar is known in Lane and Douglas counties, Oregon.

Texas $(3,4,5)$. - The Terlingua district of Brewster County, Texas, has caused much interest in recent years. The ore bodies thus far known lie in a belt 15 miles east

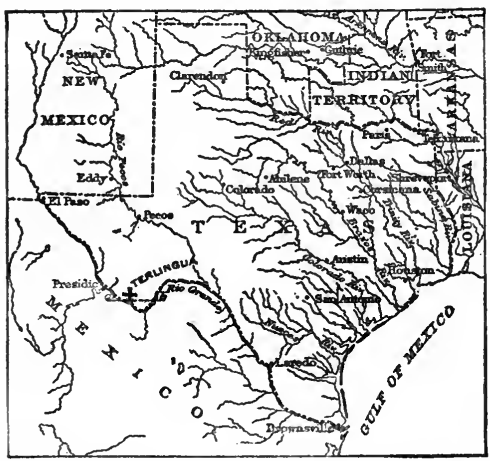

Fig. 95. - Map showing Texas mercury region. After Hill, Eng. and Min.Jour., LXXIV: 305. and west by 4 miles wide, with Fresno Cañon on the western boundary, but the remoteness from the railroad miles) and the lack of water form serious obstacles to the rapid development of this district. The rocks are Cretaceous limestone, which have been broken by several large northwest-southeast faults, with minor parallel ones between. Overlying these are younger sediments and volcanics. Only one of the ore bodies is close to an intrusive contact. 
Cinnabar is the commonest ore, but other mereury minerals are present, including quicksilver, which is usually intimately associated with calcite. Hematite and limonite are very common accessories, but pyrite is rare. The ore is most frequently found in fissure veins with calcite gangue, these fissures forming two series at right angles to each other, of which the northeastsouthwest ones are productive. The ore also occurs in brec-

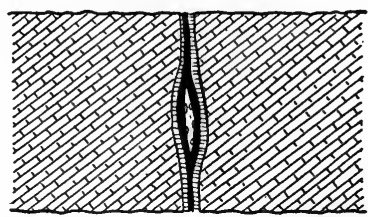

Fra. 96. - Section of cinnabar vein in limestone, Terlingua, Tex. After Phillips, Univ. Tex. Min. Surv., Bull. 4: 32 . ciated strips, or as lateral extension veins. The workings are all shallow. Recently an extension of this area has been found in the Chisos Mountains near Terlingua.

Origin. - The origin of mercury ores has been studied chiefly by Becker (1) and later by Schrauf (6). The former points out that silica (either crystalline or amorphous) and calcite are common gangue minerals, but pyrite or marcasite are almost equally abundant, as is also bitumen. In addition to these, the ores show an irregular association with other metallic minerals, such as antimony, silver, lead, copper, arsenic, zinc, or even gold. Becker believes that the cinnabar has been precipitated from ascending waters by bituminous matter, having come up in solution as a double sulphide with alkaline sulphides. He further suggests that the deposits represent impregnations and are not replacements.

Uses of Mercury. - The most important use of quicksilver is in the extraction of gold and silver by the process 
of amalgamation (see Gold and Silver). Its power of forming amalgams with other metals makes it of value in the arts for the preparation of a substance used for silvering mirrors and for other purposes. Because it is liquid at ordinary temperatures it can be employed in the manufacture of thermometers; and this fact, added to its weight, renders it of special value in the construction of mercurial barometers. In medicine mercury is used in various forms, chiefly as calomel, while cinnabar and other compounds of mercury are valuable in the manufacture of pigments. For this purpose it was used by the American Indians and by the other early races of people.

Extraction. - The mercury is usually obtained from the ore by the simple process of sublimation, the cinnabar being heated in furnaces, and the fumes of sulphur and metallic mercury allowed to pass off. The latter are caught in condensing chambers, while the former escape into the air.

Production of Mercury. - California was for many years practically the only domestic source of mercury, but in 1898 Texas became a producer, and will no doubt continue so. The output of mercury is quoted in flasks of $76 \frac{1}{2}$ pounds net. That of California since 1850 has been as follows :-

Production of Mercury in California from 1850 to 1900 (Flasks of $76 \frac{1}{2}$ pounds)

\begin{tabular}{|c|c|c|c|c|c|c|c|c|c|c|c|c|c|c|}
\hline 1850 & - & - & - & . & . & . & . $\quad 7,723$ & 1880 & . & . & . & - & . & . 59,926 \\
\hline 1860 & . & . & . & . & . & . & . 10,000 & 1890 & . & . & . & . & . & - 22,926 \\
\hline 1870 & - & . & - & . & . & . & . 30,077 & 1900 & . . & . & . & . & • & - 26,317 \\
\hline
\end{tabular}


Production of Mercury in California and Texas from 1901 то 1903

\begin{tabular}{|c|c|c|c|c|c|c|}
\hline & \multicolumn{2}{|c|}{1901} & \multicolumn{2}{|c|}{1902} & \multicolumn{2}{|c|}{1903} \\
\hline & $\begin{array}{l}\text { QUANTITY } \\
\text { FLASKS }\end{array}$ & VALUE & $\begin{array}{c}\text { QUANTITY } \\
\text { FLasKS }\end{array}$ & VAluE & $\begin{array}{l}\text { QUaNTITY } \\
\text { FLA8KS }\end{array}$ & VALUE \\
\hline Texas. . & 2,932 & $\$ 132,438$ & 5,319 & $\$ 239,350$ & 5,029 & $\$ 211,218$ \\
\hline California & 26,720 & $1,285,014$ & 28,974 & $1,228,498$ & 30,526 & $1,330,916$ \\
\hline
\end{tabular}

The imports of mercury in 1903 were valued at $\$ 1065$, and the exports at $\$ 446,845$.

The world's production for 1902 was as follows:-

\begin{tabular}{|c|c|c|c|c|c|c|c|c|c|c|c|}
\hline \multicolumn{10}{|c|}{ Country } & $\begin{array}{c}\begin{array}{c}\text { QUANTTYX } \\
\text { METRIC ToNs }\end{array} \\
1,190\end{array}$ & $\begin{array}{c}\text { VALUE } \\
\$ 1,467,848\end{array}$ \\
\hline $\begin{array}{l}\text { United } \\
\text { Austria } \\
\text { Italy . } \\
\text { Spain }\end{array}$ & $\begin{array}{l}\text { States } \\
\text { - } \\
\text { - } \\
\text { - }\end{array}$ & $\begin{array}{l}\mathbf{s} \\
\dot{\bullet} \\
\dot{\bullet}\end{array}$ & $\begin{array}{l}\cdot \\
\cdot \\
\cdot \\
\cdot\end{array}$ & $\begin{array}{l}\dot{\bullet} \\
\dot{\bullet} \\
\dot{ }\end{array}$ & $\begin{array}{l}\cdot \\
\cdot \\
\cdot \\
\cdot\end{array}$ & $\begin{array}{l}\cdot \\
\cdot \\
\cdot \\
\cdot\end{array}$ & $\begin{array}{l}\cdot \\
\dot{\bullet} \\
\dot{\bullet}\end{array}$ & $\begin{array}{l}\cdot \\
\cdot \\
\cdot \\
\cdot\end{array}$ & $\begin{array}{l}\cdot \\
\cdot \\
\cdot \\
\cdot\end{array}$ & $\begin{array}{r}1,190 \\
511 \\
260 \\
1,425\end{array}$ & $\begin{array}{r}\$ 1,467,848 \\
568,929 \\
310,080 \\
1,941,387\end{array}$ \\
\hline
\end{tabular}

\section{REFERENCES ON MERCURY}

1. Becker, Geology of Quicksilver Deposits of Pacific Slope, U. S. Geol. Surv., Mon. XIII, 1888. 2. Becker, U. S. Geol. Surv., Min. Res., 1892: 139, 1893. (Origin.) 3. Blake, W. P., Amer. Inst. Min. Engrs., Trans. XXV : 68, 1896. (Cinnabar in Texas.) 4. Hill, Eng. and Min. Jour., LXXIV : 305, 1902. (Tex.) 5. Phillips, Univ. Tex. Min. Surv., Bull. 4, 1902. (Terlingua district, Texas.) 6. Schrauf, Zeitsch. prak. Geologie, II : 10, 1894. (Origin.) 7. Watts, W. L., Cal. State Min. Bur., XI : 239, 1893. (Lake County, California.) 


\section{CHAPTER XX}

\section{ANTIMONY}

Ores. - Stibnite $\left(\mathrm{Sb}_{2} \mathrm{~S}_{3}\right)$ is the most important ore of antimony, and the metal is rarely obtained from any other mineral, although native antimony has been sparingly found. The oxide senarmontite $\left(\mathrm{Sb}_{2} \mathrm{O}_{3}\right)$ seldom occurs in any quantity. A small amount of antimony is present in some silver-lead ores. The stibnite, together with a gangue of quartz, and sometimes calcite, usually forms veins cutting igneous, sedimentary, or metamorphic rocks.

Distribution of Antimony in United States. - Antimony has been found at a number of localities in the Cordilleran region, but the great distance of the deposits from the railroad, together with the fact that the smelting plants are located in the East, make them of little commercial value, and no domestic production has been reported since 1901 . Moreover, the large output of antimony ores and metal abroad, combined with low ocean freights and the absence of any import tax on crude antimony, are of themselves discouraging to domestic competition.

The large amount of antimony now manufactured in the United States is obtained: (1) as a by-product from the smelting of foreign and domestic lead-silver ores containing small quantities of antimony; (2) antimony regulus, or metal from foreign countries; (3) foreign ore. 
Uses. - Antimony metal is used chiefly in the manufacture of alloys of lead, tin, zinc, etc. Type metal, which is an alloy of lead, antimony, and bismuth, has the property of expanding at the moment of solidification. Britannia metal is tin with 10 to 16 per cent antimony and 3 per cent copper. Babbitt, or antifriction, metal consists of antimony and tin, with small amounts of lead, copper, bismuth, zinc, and nickel. Tartar emetic, a potassium-antimony tartrate, is used in medicine and as a mordant for dyeing, while antimony persulphide is employed for vulcanizing and coloring rubber.

Production of Antimony. - The production of metallic antimony from domestio and foreign ores since 1890 was as follows : -

Production of Antimony from Domestic and Foreign Ores

\begin{tabular}{|c|c|c|c|c|c|}
\hline Year & $\begin{array}{l}\text { QUaNTITY } \\
\text { SHORT TONS }\end{array}$ & VaLue & YeAR & $\begin{array}{c}\text { QUANTITY } \\
\text { SHORT TONS }\end{array}$ & Value \\
\hline 1890 & 938 & $\$ 175,508$ & 1901 & 2639 & $\$ 539,902$ \\
\hline 1895 & 2013 & 304,169 & 1902 & 3561 & 634,506 \\
\hline 1900 & 4226 & 837,896 & 1903 & 3128 & 548,433 \\
\hline
\end{tabular}

The production in 1903 was about three fifths of the entire consumption. The hard lead (antimonial lead) produced in the United States in 1903, as a by-product from impure lead-silver ores, was $21,237,440$ pounds, containing 24 per cent antimony.

\section{REFERENCES ON ANTIMONY}

1. Blake, U. S. Geol. Surv., Min. Res., 1883-4 : 641, 1885. 2. Comstock, Ark. Geol. Surv., Ann. Rept. for 1888, I: 136. (Ark.) 3. Min. Indus., 2 : 13, 1894. (General.) 


\section{ARSENIC}

Although arsenic-bearing minerals are widely distributed in many countries, the commercially valuable occurrences are few.

Arsenopyrite (FeAsS), called also mispickel and arsenical pyrites, is the main source of the metal. Realgar $\left(\mathrm{As}_{2} \mathrm{~S}_{2}\right)$ and orpiment $\left(\mathrm{As}_{2} \mathrm{~S}_{3}\right)$ may also serve as ores.

Arsenopyrite is mined in Washington, where the mineral is used for making arsenious oxide, and more recently deposits have been opened up in Floyd and Montgomery counties, Virginia. At the former locality the ore, which is chiefly arsenopyrite, averages about 14 per cent arsenic, .7 ounce gold, and 3 ounces silver per ton (2).

Arsenopyrite is used chiefly for the manufacture of arsenious oxide. It is employed in medicine, as a pigment, and as an alloy with lead for making shot. Arsenious oxide is used for making paris green, in glassware for destroying the iron coloration, in certain enamels, and as a fixing and conveying substance for aniline dyes.

The domestic production of arsenious oxide in 1903 amounted to 611 short tons valued at $\$ 36,691$, and was all made at Everett, Wash. This, however, supplied only one quarter of the domestic demand, and large quantities were imported from Canada, Germany, and Spain. The imports of arsenic and its compounds in 1903 amounted to 8,357,661 pounds, valued at $\$ 294,602$.

\section{REFERENCES ON ARSEMIO}

1. Min. Indus., II : 25, 1894. 2. Struthers, U. S. Geol. Surv., Min. Res., 1903 : 321, 1904. (General.) 3. Merrill, Non-Metallic Minerals, 30,1904 . 


\section{BISMUTH}

Ores. - The principal ores of this metal, together with the percentage of metallic bismuth which they contain, are : Bismuthinite $\left(\mathrm{Bi}_{2} \mathrm{~S}_{3}, 81.2\right)$; bismite $\left(\mathrm{Bi}_{2} \mathrm{O}_{3}, 96.6\right)$; and bismutite $\left(\mathrm{Bi}_{2} \mathrm{O}_{3}, \mathrm{CO}_{2}, \mathrm{H}_{2} \mathrm{O}, 80.6\right)$. Although all of these contain a high percentage of metallic bismuth, the content of the ore as mined does not usually exceed ten or fifteen per cent. Bismuth ores are commonly associated with those of gold and silver, and the metal is obtained as a by-product in the smelting of these.

Distribution. - There are many scattered occurrences of bismuth ores throughout the Rocky Mountain states, but Colorado is the most important, and in 1904 Leadville was the only producing region.

Uses and Production. - Bismuth is chiefly valuable on account of the easily fusible alloys which it forms with lead, tin, and cadmium; the melting point of some of these lies between $64^{\circ} \mathrm{C}$. and $94.5^{\circ} \mathrm{C}$. They are therefore employed in safety fuses for electrical apparatus, safety plugs for boilers, dental amalgams, etc. The production of bismuth in 1904 was 5184 pounds, valued at $\$ 314$. The imports of metallic bismuth in 1904 amounted to 185,905 pounds, valued at $\$ 339,058$.

\section{CHROMIC IRON ORE}

Ores. - Chromite $\left(\mathrm{FeO}, \mathrm{Cr}_{2} \mathrm{O}_{3}\right)$ is the chief source of the compounds of the metal chromium which are used in the arts. This ore occurs sometimes in alluvial deposits, but more commonly in basic magnesian rocks, notably serpentine. 
Origin of Chromite. - It has been pointed out by Pratt (4) that chromite occurs most commonly around the border of basic magnesian rocks of igneous origin. This is believed to indicate that the chromium existed in the original molten rock, and that, as this basic magma cooled, the chromite, being one of the earliest minerals to crystallize, separated out along the border of the mass because this portion was the first to cool. As the cooling proceeded, convection currents within the molten mass would bring additional supplies to the border.

Analyses (5). - The following table gives the composition of several of the types of chromic iron ores :-

\begin{tabular}{l|r|r|r|r|r|r}
\hline \hline France & $\begin{array}{c}\text { Colkraine, } \\
\text { Can. } \\
\text { Concentrated } \\
\text { Product }\end{array}$ & $\begin{array}{c}\text { Asia } \\
\text { Minor }\end{array}$ & Styria & CaliF. & Russia \\
\hline $\mathrm{Cr}_{2} \mathrm{O}_{3}$ & 37.00 & 53.64 & 53.00 & 53.00 & 42.20 & 59.00 \\
$\mathrm{SiO}_{2}$ & 2.53 & 2.31 & 2.15 & 2.50 & 5.48 & 2.20 \\
$\mathrm{Al}_{2} \mathrm{O}_{3}$ & 13.15 & 14.02 & 7.62 & 8.00 & 13.60 & 10.00 \\
$\mathrm{MgO}$ & 12.53 & 15.75 & 12.31 & 11.58 & 14.88 & 11.62 \\
$\mathrm{FeO}$ & 34.79 & 11.47 & 24.92 & 24.92 & 23.84 & 18.18 \\
$\mathrm{CaO}$ & & 2.81 & & & & \\
\hline
\end{tabular}

The price of chromic iron ore is based on its percentage of chromic oxide, the standard ore containing 50 per cent. Every unit above this is valued at from 75 cents to $\$ 1$ per ton; but when the percentage is below 50 per cent, the value decreases at an even greater rate. However, ores carrying only 45 per cent of chromic oxide are easily marketable. Low silica is desirable.

Distribution in the United States. - In the United States chromite was for a time obtained from Chester and Delaware counties, Pennsylvania, and Baltimore County, Maryland, 
and the exhaustion of these deposits was followed by the opening of others in San Luis Obispo County, California. Subsequently the importation of Turkish and Russian chromite commenced, followed by additional supplies from Canada and Newfoundland. This foreign chrome iron ore, especially the Turkish, can be placed on the American market so cheaply that there has been little development of our own deposits. The importation of chromic iron ore from New Caledonia is also increasing.

Chromite occurs in a number of places in California besides the one referred to above; and also in North Carolina, in a belt of peridotite rock extending from Ashe County to Clay County. In this area, however, the chromite has been found in quantity at only a few localities (3).

Uses. - Metallic chromium has no direct use; but raw chromite and chromium salts have a variety of applications. Owing to its great heat-resisting qualities, chromite is employed in the manufacture of refractory bricks. Such bricks are sometimes used for lining basic open-hearth furnaces, and as a hearth lining for water-jacket furnaces in copper smelting. They stand rapid changes of temperature well, and are not attacked by molten metals.

In the presence of carbon, chromium makes steel extremely hard and resistant to shocks; therefore chrome steel is suited to a variety of uses, as in the manufacture of plates, hard-edged tools, etc. An alloy of iron and chromium is used in armor plates, alloys of ferro-chromium and ferronickel being added to the molten steel before casting. Most of the chromite mined is used for pigments because of the red, yellow, and green color of its compounds, chromate and bichromate of potash. In these forms the substance is em- 
ployed in dyeing, calico printing, and the making of pigments useful in painting, printing wall papers, and coloring pottery. Alkaline bichromates are employed for tanning skins, and some chromium salts have a medicinal value.

Production of Chromite. - The amount of chromite produced in the United States is small, and in 1903 California was the only source of supply. The production for several years was as follows :-

Production of Chromite in the United States from 1900 to 1903

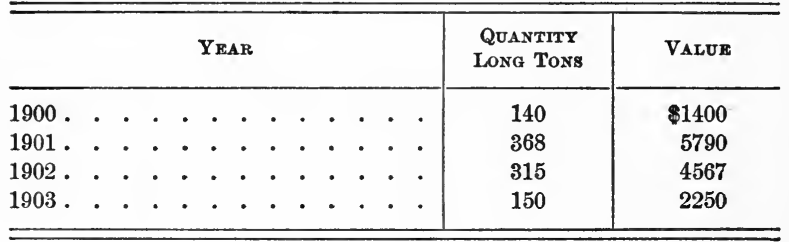

The value of the imports for the last three years was:-

\begin{tabular}{|c|c|c|c|c|c|c|c|c|c|c|c|}
\hline & \multicolumn{7}{|c|}{ Y } & $\begin{array}{c}\text { Cheomate AND } \\
\text { Bichromate } \\
\text { of Potash }\end{array}$ & $\begin{array}{c}\text { Chromic } \\
\text { ACID }\end{array}$ & $\begin{array}{c}\text { Chrome } \\
\text { Ore }\end{array}$ & TotaI \\
\hline 1901 & - & . & • & . & . & . & . & $\$ 29,224$ & $\$ 10,861$ & $\$ 363,108$ & $\$ 403,193$ \\
\hline 1902 & . & . & . & . & . & . & . & & 11,115 & 582,597 & 593,712 \\
\hline 1903 & - & . & - & . & . & . & . & 32,174 & & 292,025 & 324,199 \\
\hline
\end{tabular}

\section{REFERENCES ON CHROMIC IRON ORE}

1. Glenn, Amer. Inst. of Min. Engrs., Trans. XXXI : 374,1902. 2. Maynard, ibid., XXVII : 283, 1898. (Newfoundland.) 3. Pratt, U.S. Geol. Surv., Mineral Resources, 1901: 941, 1902. (General.) 4. Pratt, N. Ca. Geol. Surv., I : 269, 1905. (Origin.) 5. Anon., Min. Indus., VI: 147, 1898. (Analyses.) 


\section{MOLYBDENUM}

Ores and Occurrences. - Molybdenite $\left(\mathrm{MoS}_{2}\right)$ and, less commonly, wulfenite $\left(\mathrm{PbMoO}_{4}\right)$, are the chief sources of this metal.

Molybdenite forms irregular masses or disseminations in crystalline rocks, and many occurrences are known in the West, for example, in California, Washington, Montana, Utah, Arizona, New Mexico, and in the East, in Maine. An ore to be marketable must contain over 45 per cent of molybdenum and be free from copper, the average price of a 50 to 55 per cent ore being about $\$ 400$ per ton.

Uses. - Its chief use is in the manufacture of chemicals, especially ammonium molybdate, and for coloring porcelain green. A nickel-molybdenum alloy is also made. The use of molybdenum for hardening steel is increasing, it being used chiefly for tool steel.

Production of Molybdenum. - The production of molybdenite in 1903 was 6200 tons crude ore, but very little of this was concentrated and marketed.

\section{REFERENCES ON MOLYBDENUM}

1. Crooks, Bull. Geol. Soc. Amer., XV: 283, 1904. (N.Y.) 2. Pratt, U. S. Geol. Surv., Min. Res., 1903: 307, 1904. (General.) 3. Smith, U.S. Geol. Surv., Bull. 260 : 197, 1905. (E. Me.)

\section{NICKEL AND COBALT}

Ores. - These two metals can best be treated together, for nearly all the ores containing one are apt to carry some of the other, and furthermore, in smelting, the two metals go into the same matte, and are separated later in the refining process. 
The ores of nickel and cobalt, together with their composition and the percentage of nickel or cobalt they contain, are:

\begin{tabular}{|c|c|c|c|}
\hline ORE & Composition & 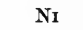 & Co \\
\hline Pyrrhotite (nickeliferous) & $\mathrm{Fe}_{11} \mathrm{~S}_{12}$ & $0-6$ & - \\
\hline Millerite . . . . . & $\mathrm{NiS}$ & 64.6 & - \\
\hline Pentlandite . . . . . & $(\mathrm{FeNi}) \mathrm{S}$ & 22 & - \\
\hline Genthite . . . . & $2 \mathrm{NiO}_{2}, 2 \mathrm{MgO}, 3 \mathrm{SiO}_{2}, 6 \mathrm{H}_{2} \mathrm{O}$ & 22.46 & - \\
\hline Niccolite. . . . . & NiAs & 43.9 & - \\
\hline Linnæite . . . . . & $(\mathrm{CoNi})_{3} \mathrm{~S}_{4}$ & 30.53 & 21.34 \\
\hline
\end{tabular}

The nickeliferous pyrrhotite is the most widely distributed of the nickel ores, and may carry small amounts of cobalt. It is also called magnetic pyrites. The percentage of nickel ranges from a trace to 6 per cent, but an increase above this brings it into pentlandite. The millerite is sometimes found associated with pyrrhotite ores. Of the genthite, the variety known as garnierite forms the ores, and carries from 21 to 45 per cent nickel oxide.

Distribution. - Very little direct mining for nickel and cobalt is done in the United States, but at Mine la Motte, Missouri, considerable quantities have been obtained annually as a by-product in lead mining. (See under Lead.)

Eastern Occurrences of Nickel. - The Gap Nickel Mine, Lancaster County, Pennsylvania, is the most important eastern occurrence. It was actively worked from 1863 to 1880 , being during that period the only nickel ore mined on this continent. In 1902 the mine was again operated. The ore is pyrrhotite associated with amphibolite, an altered intrusive, the whole inclosed by mica-schist. The pyrrhotite is believed to have originated by magmatic segregation (4). 
Nickel minerals have also been found in the basic magnesian rocks of North Carolina.

Western Occurrences. - Deposits of nickel and cobalt ores are known in Idaho and Oregon, but they have not yet assumed importance. Nickel ore is found in Ferry County, Washington, and other deposits are reported from Sheridan and Piney Creek, Wyoming, as well as at several localities in Nevada, Idaho, Arizona, and South Dakota; but none of the occurrences are worked, and the main source of supply on this continent comes from Sudbury, Ontario $(1,2)$.

There, the ore, which occurs in enormous masses, is a nickeliferous pyrrhotite, and the output forms probably one half of the world's production. The ore occurs on the contact of quartzite and diorite, or forms, more often, scattered irregular masses in the latter. Its origin has been a matter of some dispute, some having regarded it as a product of magmatic segregation, while others believe the ore to have been deposited in the crushed diorite. A partial analysis shows: $\mathrm{Cu}, 8.05 ; \mathrm{Ni}, 2.97 ; \mathrm{Fe}$, $26.21 ; \mathrm{SiO}_{2}, 26.05 ; \mathrm{S}, 19.08$.

The second important source of the world's nickel ore is the mines of New Caledonia, in the Pacific Ocean, off the east coast of Australia. The ore is garnierite.

Uses of Nickel. - The most important and increasing use of nickel is for the manufacture of nickel and nickel-chromium steel. This, on account of its great hardness, strength, and elasticity, is used for making armor plate, gun shields, turrets, ammunition hoists, etc. Krupp steel, which may be taken as a type, has approximately 3.5 per cent nickel, 1.5 per cent chromium, and .25 per cent carbon. Owing to its abrasive resistance, nickel-steel is now much used for rails. Other important uses are for large forgings, marine engines, wire cables, and electrical apparatus. A steel with 25 to 30 per cent nickel shows high resistance to corrosion by salt, fresh 
or acid waters, or by superheated steam. German silver is an alloy of zinc, copper, and nickel.

Uses of Cobalt. - Cobalt steel, while having a high elastic limit and breaking strength, cannot compete with nickel steel on account of its high cost, and the main use for cobalt is as a pigment.

Production.- The production of nickel from domestic ores and cobalt oxide in the United States from 1892 to 1901 was :

Production of Nickel and Cobalt from Domestic Ores

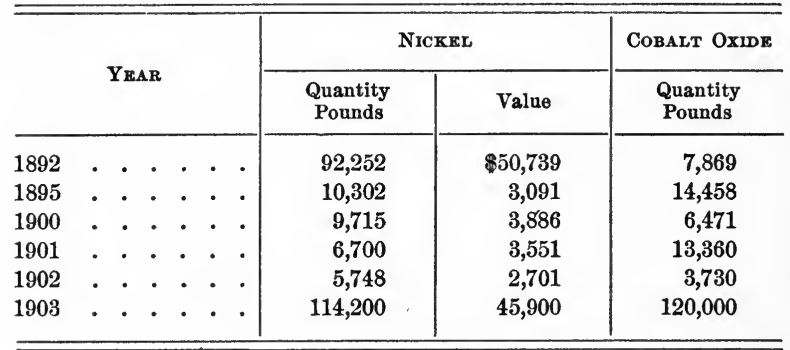

The amount of nickel produced in Canada in 1903 was $12,505,510$ pounds. The imports of cobalt oxide in 1903 were 73,350 pounds, valued at $\$ 145,264$, while the total value of the nickel imported in the same year was $\$ 1,849,620$. The exports of nickel oxide and matte in 1901 were $\$ 1,483,889$.

The World's Production of Nickel

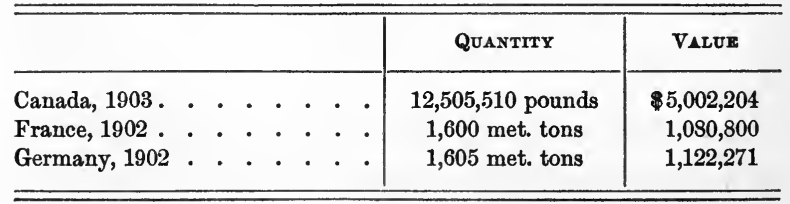




\section{REFERENCES ON NICKEL AND COBALT}

1. Barlow, Can. Geol. Surv., Ann. Rept., XIV, pt. H, 1904. (Ontario.) 2. Dickson, Amer. Inst. Min. Engrs., Trans. XXXIV: 3, 1904. (Ontario.) 3. Hodges, Amer. Inst. Min. Engrs., Trans. XIII : 657, 1885. (Nev.) 4. Kemp, Amer. Inst. Min. Engrs., Trans. XXIV: 620, 1895. (Pa.) 5. Neill, Amer. Inst. Min. Engrs., Trans. XIII : 634, 1885. (Mo.)

\section{PLATINUM GROUP OF METALS}

Platinum. - The ores of platinum are native platinum (100 per cent $\mathrm{Pt}$ ), and sperrylite, $\mathrm{PtAS}_{2}$ (56.5 per cent Pt). The former is commonly found in placer deposits, but it has also been noted in basic igneous rocks rich in olivine, such as peridotite, or in serpentine derived from it. The sperrylite never occurs in large quantities, but has been found in association with nickel and copper ores. Iridosmine and osmiridium are also known to carry platinum.

The nuggets found in placers are commonly regarded as being pure native platinum, but this, according to Kemp (4), is only true in part, most of those assayed yielding between 70 and 85 per cent, and the richest recorded being 86.5 per cent. The balance is made up largely of iron, the highest percentage of this noted being $\mathbf{1 9 . 5}$ per cent in a Ural specimen. Iridium, rhodium, and palladium are always present. Until the platinum falls below 60 per cent the iridium rarely reaches 5 per cent, rhodium 4 per cent, while palladium is less than 2 per cent. Other elements that have been detected in the nuggets are osmium, ruthenium, copper, and even gold, while chromite is a common associated mineral (4).

Distribution in the United States. - The domestic supply of platinum, never large, has been obtained in recent years 
as a secondary product from gold-placer deposits in Trinity and Shasta counties, California, and while its occurrence has been reported in many other gold placers of the Northwest and Alaska, still none of them have proven sufficiently rich to work. Iridosmine and a natural alloy of iron and nickel called josephinite are found associated with the gold.

In addition to the above sources, platinum is also found in the copper ores of the Rambler mine, Wyoming, and has been saved from the slimes obtained in treating the copper ore and matte at this locality. The covellite in the ore assays .06 to 1.4 ounces per ton of platinum.

Uses. - Platinum was first used as an adulterant of gold, and in Russia it was used for coinage from 1828 to 1845. At the present time it is employed for crucibles and other chemical apparatus which are to be subjected to high temperatures or strong acids. It is also of value in dentistry, for electric lamps and electric apparatus, for jewelry, and in photography. The price of it has risen steadily in recent years, so that it is as valuable as gold.

Production. - The production in the United States from 1880 to 1903 was as follows : -

Production of Platinum in the United States

\begin{tabular}{|c|c|c|c|c|c|}
\hline Yrar & $\begin{array}{l}\text { Quantity } \\
\text { OUnces }\end{array}$ & Value & Year & $\begin{array}{l}\text { QUANTITY } \\
\text { OUNCES }\end{array}$ & Value \\
\hline 1880 & 100 & $\$ 400$ & 1900 & 400 & $\$ 2,500$ \\
\hline 1885 & 250 & 187 & 1901 & 1,408 & 27,526 \\
\hline 1890 & 600 & 2,500 & 1902 & 94 & 1,874 \\
\hline 1895 & 150 & 900 & 1903 & - & 6,080 \\
\hline
\end{tabular}


Since the close of 1899 platinum has risen steadily in price, reaching a maximum of $\$ 20$ per ounce in 1902 .

The imports of platinum, both crude and manufactured, amounted to $\$ 1,987,980$ in 1902 , and $\$ 2,055,933$ in 1903 . The domestic production is entirely inadequate to supply the demand, and the greater portion of the supply of the United States, and in fact the world, is obtained from the platinum placers of the Urals (5).

\section{REFERENCES ON PLATINUM}

1. Day, U. S. Geol. Surv., 19th Ann. Rept., VI : 265, 1898. 2. Day, Amer. Inst. Min. Engrs., Trans. XXX : 702, 1901. (N. Amer.) 3. Donald, Eng. and Min. Jour., LV: 81, 1893. (Can.) 4. Kemp, Min. Indus., X: 540, 1902; and U. S. Geol. Surv., Bull. 193, 1902. (General.) 5. Purington, Eng. and Min. Jour., LXXVII : 720, 1904. (Russia.)

Palladium. - This metal is found associated with platinum and also native and alloyed with gold (Brazil). It is of silver-white color, ductile and malleable, and is unaffected by the air. Its great rarity and consequent high value has restricted its use, but a small amount is used for some mathematical and surgical instruments, for compensating balance wheels and hair springs for watches, and for finely graduated scales.

In the United States it has been reported from the platinum deposits of the Pacific Coast and from the Rambler mine in Wyoming.

Osmium. - This, the heaviest and most infusible metal known, occurs alloyed with platinum and also with iridium in iridosmine. In the United States small quantities have been found in the platinum placers of California.

Iridosmine is employed for pointing pens and fine tools, 
while osmic acid is used for staining anatomical preparations in microscopic work.

Iridium. - Iridium is found chiefly in Russia and California, alloyed with platinum or osmium. It is a lustrous, steel-white metal of great hardness, and is, next to osmium, the most refractory metal known.

An alloy of iridium and platinum has been used for standard weights and measures, and iridium is also used in photography.

\section{TIN}

Ores. - Cassiterite $\left(\mathrm{SnO}_{2}\right)$, with 78.6 per cent metallic tin, is the principal ore of this metal, but owing to the presence of impurities the ore rarely shows this composition. Its hardness (6-7), imperfect cleavage, nonmagnetic character, high specific gravity (6.8-7.1), and brittleness help to distinguish it from other minerals that are liable to occur with it. The mineral stannite, or tin pyrites, a complex sulphide of copper, iron, and tin, rarely serves as an ore. Stream tin is the name applied to cassiterite found in placers.

Mode of Occurrence. - Cassiterite of primary character is usually found in veins of pegmatite, or, more commonly, greisen (quartz and muscovite or lepidolite), around the edges of granite areas. This, together with the association of fluorite, tourmaline, and topaz with the ore, indicate quite clearly that it may be the result of fumarolic action. This type of occurrence is, however, of little commercial value, and over 80 per cent of the world's supply comes from placers whose materials have been derived from tinbearing veins. 
Distribution in the United States. - Although tin has been found at a number of localities in the United States, only a very few of these can be looked upon as commercial sources.

The Black Hills $(1,2,6)$ of South Dakota and Wyoming is perhaps the best known tin-producing region of the United States, and although much money has been sunk in its development and many exciting rumors have been published regarding it, the output has been exceedingly small. Here the tin occurs either in pegmatite dikes

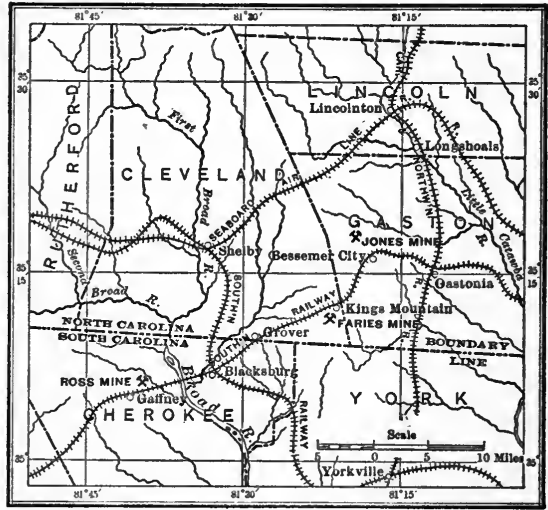

FIG. 97. - Sketch map showing location of Carolina tin belt. After Graton, U.S. Geol. Surv., Bull. 260. or quartz veins and in placers. The Harney Peak deposits of the northern Black Hills have produced but little, but the Nigger Hill region of Wyoming, in the northwestern part of the hills, seems to be more promising.

More recently the tin deposits of North and South Carolina $(4,6)$ have been attracting considerable attention. These lie in a belt extending from Cherokee County, South Carolina, to Lincoln County, North Carolina. The cassiterite occurs as an original constituent of pegmatite dikes, but is somewhat irregularly distributed in them. Some of the 
mines now being worked at Gaffney, South Carolina, and Kings Mountain, North Carolina, are promising. An interesting feature is that the dikes are of undoubted igneous origin.

Tin has been reported from a number of localities in Alaska (3), but the production is still very small, that during 1903 and 1904 having amounted to not more than 100 tons.

The most important occurrences are on the Seward peninsula, where it occurs in placers, quartz-porphyry dikes, granites, or in sedimentaries near their contact with the igneous rock. In the dikes the accompanying minerals are tourmaline, topaz, fluorite, zinnwaldite, wolframite, quartz, epidote, pyrite, galena, etc.

The amount of tin ore produced in the United States is entirely too small to supply the demand, and the main source of supply for this country, and indeed for the world, is the Malay peninsula, while other regions of commercial importance are Australia, Bolivia, and Great Britain.

Uses of Tin. - Tin is used chiefly for the manufacture of bronze and tin plate, and to a smaller extent in plumbing as well as less important purposes. Britannia metal is composed of from 82 to 90 parts of tin alloyed with antimony, copper, and sometimes zinc.

Production of Tin. - The world's production for a number of years has been behind the demand, a fact which has not only kept up the price of this metal, but also stimulated prospecting and mining.

The world's production for 1904 as given by the Engineering and Mining Journal was :- 
Country

Tons

Straits Settlements . . . . . . . . 65,696

Banka and Billiton . . . . . . . . 16,394

Bolivia . . . . . . . . . . . 10,304

Australia and Tasmania . . . . . . . . . 5,692

England . . . . . . . . . . . . . 4,796

Germany and Austria . . . . . . . 112

Miscellaneous . . . . . . . . . . 140

Total . . . . . . . . . . $\overline{103,134}$

The price of tin on the New York market in 1904 averaged about 28 cents per pound. The United States in 1904 consumed about 43,120 tons of tin.

REFERENCES ON TIN

1. Blake, Amer. Inst. Min. Engrs., Trans. XIII : 691. (Black Hills.)

2. Blake, U. S. Geol. Surv., Min. Res., 1883-84 : 592, 1885. (Ores and deposits). 3. Collier, U. S. Geol. Surv., Bull. 225, 1904. (Alaska and general.) 4. Graton, U. S. Geol. Surv., Bull. $260: 188$, 1905. (N. Ca. and S. Ca.) 5. Hess and Graton, U. S. Geol. Surv., Bull. $260:$ 161, 1905. (Occurrence and distribution). 6. Struthers and Pratt, U. S. Geol. Surv., Min. Res., 1903: 335, 1904. (U. S.) 7. Weed, U. S. Geol. Surv., Bull. 178, 1901. (Texas.) Also Bull. 213: 99, 1903. 8. Winslow, Eng. and Min. Jour., XL : 320, 1885. (Va.)

\section{TITANIUM}

Ores. - Among the minerals carrying titanium the most abundant is ilmenite $\left(\mathrm{FeO}, \mathrm{TiO}_{2}\right)$, which occurs in many deposits of magnetite. Rutile $\left(\mathrm{TiO}_{2}, 60\right.$ per cent $\mathrm{Ti}$ when pure), though less abundant, is not uncommon. Titanium is also found in a number of other minerals, many of which are rare.

Occurrence. - For many years Norway has been the chief producer of this metal; but in 1900 large deposits of rutile were discovered in Virginia, from which, up to the end of 1901, about 40,000 pounds had been extracted. 
The Virginia ore (2), which is found in Nelson County, occurs in the form of small granules, disseminated through a ground mass of feldspar or as a segregation in quartz, in a rock of probable igneous origin. Until the discovery of the Virginia deposits, the domestic demand, which has been small, was supplied from deposits in Chester County, Pennsylvania.

Uses. - Titanium is used for producing yellow underglaze colors on pottery, and also in the manufacture of artificial teeth, to give them an ivory tint. Another use is in the alloy ferro-titanium. Its commercial values as a steel-hardening metal are not yet thoroughly proven, but from .5 to 3 per cent titanium appear to materially increase the transverse and tensile strength of steel. By the use of the electric furnace, ferro-titanium can be produced directly from the ores, which would open a use for our American titaniferous magnetites.

\section{REFERENCES ON TITANIUM}

1. Merrill, Non-metallic Minerals : 109, 1904. (General.) 2. Merrill, Eng. and Min. Jour., LXXIII : 351, 1902. (Va.) 3. Pratt, U. S. Geol. Surv., Min. Res., 1903 : 309, 1904.

\section{TUNGSTEN}

Ores. - The ores of tungsten are wolframite $\left([\mathrm{FeMn}] \mathrm{WO}_{4}\right)$, hübnerite $\left(\mathrm{MnWO}_{4}\right)$, and scheelite $\left(\mathrm{CaWO}_{4}\right)$. Of these wolframite is the most abundant, and scheelite, the most easily reducible ore of tungsten, the least abundant. Scheelite is found in but few localities in the world, and in the United States occurs in commercial quantity at only one locality. Although the ores of tungsten are rare, the quantity available exceeds the demand. 
Occurrence. - Most of the known American deposits of tungsten ores are found in the western states, especially Arizona $(1,2,6)$, Nevada, and Colorado. That found near Dragoon, Arizona (6), consists of hübnerite with subordinate scheelite, and concentrates easily to a product yielding $\mathrm{WO}_{3}$, $70.22 ; \mathrm{SiO}_{2}, .30 ; \mathrm{Fe}, 1.90 ; \mathrm{Mn}, 19.82 ; \mathrm{CaO}, 4.87 ; \mathrm{MgO}$, 3.40. Rich ores are found in White Pine County, Nevada, at some distance from the railroad. In Colorado wolframite and hübnerite occur in several counties, and have been mined to some extent. Eastern occurrences are rare, but scheelite is found at Longhill, Connecticut (8), where it occurs along the contact of limestone with diorite and hornblende gneiss. Tungsten is also found associated with the Cambrian siliceous gold ores of the Black Hills region, South Dakota (4), but this source has not become of great importance.

Uses. - Tungsten has been used for some years to fix the color in wash goods and make them fireproof. It has also been employed for manufacturing stained paper. But the most important present use is for the alloy ferro-tungsten, or in the manufacture of tungsten-steel. Alloys of tungsten, aluminum, and copper are also made. The fluorescent properties of tungstate of lime make it useful in the Röntgen ray apparatus. Tungsten is also employed for coloring glass.

Production. - In 1903 the production was 2451 short tons, yielding 292 short tons concentrates valued at $\$ 43,639$, or $\$ 149$ per ton. This production came from Colorado, Arizona, and Connecticut.

In 1903 ferro-tungsten-chrome alloys were imported to the value of $\$ 18,136$. 


\section{REFERENCES ON TUNGSTEN}

1. Blake, Eng. and Min. Jour., LXV: 608, 1898. (Ariz.) 2. Blake, Min. Indus., VII : 720, 1899 . (Ariz.) 3. Blake, Amer. Inst. Min. Engrs., Trans., XXVIII : 543, 1899. 4. Irving, Amer. Inst. Min. Engrs., Trans., XXXI : 683, 1902. (S. Dak.) 5. Pratt, U. S. Geol. Surv., Min. Res., 1903 : 304, 1904. (General.) 6. Rickard, Eng. and Min. Jour., LXXVIII : 263, 1904. (Ariz.) 7. Thomas, Min. and Met., XXIV : 301. (Ores and uses.) 8. Hobbs, U. S. Geol. Surv., 22d Ann. Rept., II : 13, 1902. (Conn.)

\section{URANIUM AND VANADIUM}

Ores. - The minerals serving as the ores of uranium metals are uraninite $\left(\mathrm{UO}_{3}, \mathrm{UO}_{2}, \mathrm{PbO}, \mathrm{N}\right.$, etc.), gummite (doubtful composition), and gamotite. The last-mentioned also carries vanadium, as does also vanadinite $\left[(\mathrm{PbCl}) \mathrm{Pb}_{4}\left(\mathrm{VO}_{4}\right)_{3}\right]$. The chief sources of uraninite are the mines near Central City and in Montrose County, Colorado. Gamotite occurs in Montrose County, Colorado, and also in Utah, while vanadinite has been found in some quantity in the gold and silver mining districts of Arizona and New Mexico.

Uses. - Uranium and vanadium increase the strength and toughness of steel, and are used to a small extent in the manufacture of ferro-alloys. Uranium oxides are used for coloring porcelain and glass, and vanadium oxide as a dyeing material. Vanadium compounds are employed in making vanadium bronze.

Production. - The output of the ores of these minerals in 1901 came chiefly from Colorado, and amounted to 375 short tons. In 1903, as a result of much prospecting and developmental work, there was a production of 432 short tons of crude ore. Thirty tons of concentrates were sold 
at a value of $\$ 5625$. Most of the uranium and vanadium ores mined in the United States are exported, but a large quantity of uranium and vanadium salts are imported, the value of these in 1903 amounting to $\$ 13,498$.

\section{REFERENCES ON URANIUM AND VANADIOM}

1. Boutwell, U. S. Geol. Surv., Bull. $260: 200,1905$. (Utah.) 2. Pratt, U. S. Geol. Surv., Min. Res., 1901. 3. Merrill, Non-Metallic Min. erals : 299 and 320, 1904. (General.) 



\section{APPENDIX I}

\section{STATISTICS OF MINERAL PRODUCTION}

UnLess otherwise stated, the statistics are in all cases those for 1905 , the figures being taken from the annual roport on Mineral Resourcesissued by the United States Geological Survey. 'These figures, when first published by the Geological Survey, are not always to be regarded as final, because, when repeated in the report of the following year, they are not infrequently changed, probably because of corrected returns. A similar set of statistics is issued annually by the Engineering and Mining Journal.

\section{COAL}

\begin{tabular}{|c|c|c|c|c|c|}
\hline State & & $\begin{array}{c}\text { QUantity } \\
\text { SHOBT TONS }\end{array}$ & $V_{\text {ALUE }}$ & Freld & SHORT TONS \\
\hline $\begin{array}{l}\text { Pennsylvania } \\
\text { Anthracite } \\
\text { Bituminous } \\
\text { Illinois } \\
\text { West Virginia } \\
\text { Ohio. : : } \\
\text { Indiana : } \\
\text { Alabama : } \\
\text { Colorado: } \\
\text { Kentucky: } \\
\text { Iowa. : : } \\
\text { Kansas : : } \\
\text { Tennessee: } \\
\text { Wyoming : }\end{array}$ & : & $\begin{array}{r}77,659,850 \\
118,413,637 \\
38,434,363 \\
37,791,580 \\
25,552,950 \\
11,895,252 \\
11,866,099 \\
8,826,429 \\
8,432,523 \\
6,798,609 \\
6,423,979 \\
5,963,396 \\
\mathbf{5 , 6 0 2 , 0 2 1}\end{array}$ & $\begin{array}{r}\$ 141,879,000 \\
113,390,507 \\
40,577,592 \\
32,341,790 \\
26,486,740 \\
12,492,255 \\
14,387,721 \\
10,810,978 \\
8,385,232 \\
10,586,381 \\
9,350,542 \\
6,797,550 \\
7,336,951\end{array}$ & $\begin{array}{l}\text { Anthracite (Pa., Colo., } \\
\text { N. Mex.) } \\
\text { Triassic } \\
\text { Appalachian } \\
\text { Northern } \\
\text { Eastern Interior } \\
\text { Western } \\
\text { Rocky Mountain, etc. } \\
\text { Pacific coast } \\
\text { Alaska }\end{array}$ & $\begin{array}{r}77,734,673 \\
1,557 \\
212,830,030 \\
1,473,211 \\
55,255,541 \\
23,265,750 \\
19,303,188 \\
3,051,617 \\
3,774\end{array}$ \\
\hline
\end{tabular}

Total United States production in 1905, 392,919,341 short tons; value, $\$ 476,756,963$. Exports in 1905: $2,229,983$ long tons anthracite; value, $\$ 11,104,654$; $6,959,265$ long tons bituminous; value, $\$ 17,867,964$.

\section{Production of Leading Coal-Producing Countries}

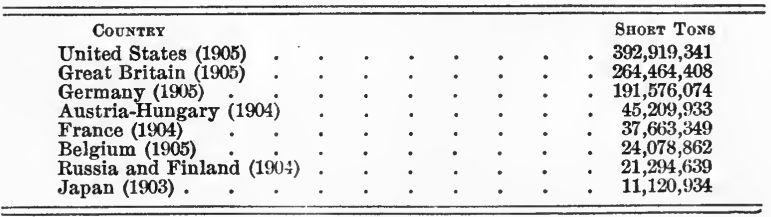




\section{PETROLEUM SERIES}

\begin{tabular}{|c|c|c|c|c|c|}
\hline \multicolumn{4}{|c|}{ Petroleum } & \multicolumn{2}{|c|}{ Natural Gas } \\
\hline State & & BARRELS & VALUE & StATE & VALUR \\
\hline California. . & & $33,427,473$ & $\$ 8,201,846$ & Pennsylvania & $\$ 19,197,336$ \\
\hline Texas... & & $28,136,189$ & $7,552,262$ & West Virginia . & $10,075,804$ \\
\hline Ohio . . . & & $16,346,660$ & $17,054,877$ & Ohio . . . & $5,721,462$ \\
\hline Kansas, Oklahoma, & & & & Indiana & $3,094,134$ \\
\hline Indian Territory. & & $12,013,495$ & $6,546,398$ & Kansas. & $2,261,836$ \\
\hline West Virginia & & $11,578,110$ & $16,132,631$ & New York & 623,251 \\
\hline Indiana . & & $10,964,247$ & $9,404,909$ & Kentucky and & \\
\hline Pennsylvania & & $10,437,195$ & $14,653,278$ & Tennessee. & 237,590 \\
\hline Louisiana. . & . & $8,910,416$ & $1,601,325$ & Indian 'Territory & \\
\hline Kentucky . . . & . . & $1,217,337$ & 943,211 & and Oklahoma . & 130,137 \\
\hline Total, United States & & $134,717,580$ & $\$ 84,157,399$ & Total, United States & $\$ 41,562,855$ \\
\hline
\end{tabular}

Production of Asphaltum and Bitu- $\mid$ Production of Asphaltum minous Rock in the United States

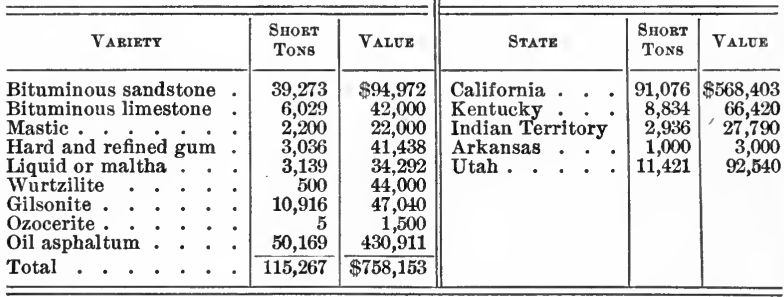

World's Production of Petroleum

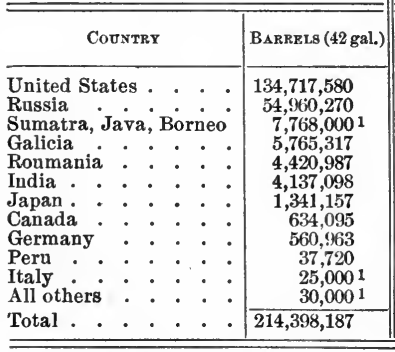

Exports in $1905,1,220,513,587$ gallons; value, $\$ 79,640,929$.

Refined oil imports, 13,725,720 gallons; value, \$672,127.

1 Estimated.
World's Production of AsphalTUM IN 1904

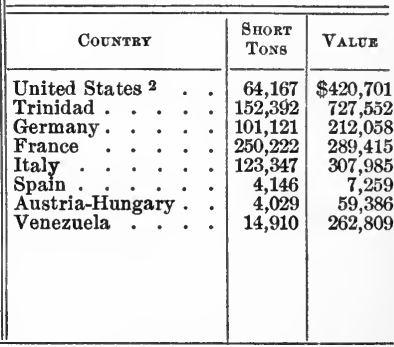

Imports of crude asphaltum, 100,596 shert tons, valued at $\$ 479,296$.

2 Exclusive of oil asphaltum. 
BUILDING STONES

Production of Building Stones in ThE UNITED States

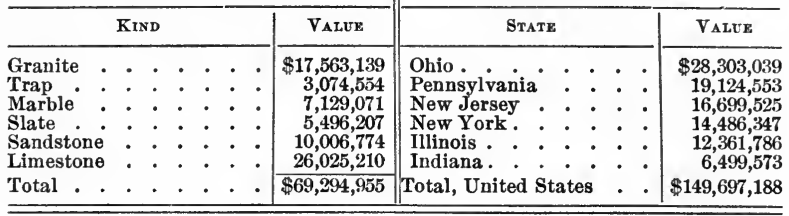

CLAY PRODUCTS

Production of Clay Products in THE UNITED STATES

CEMENTS

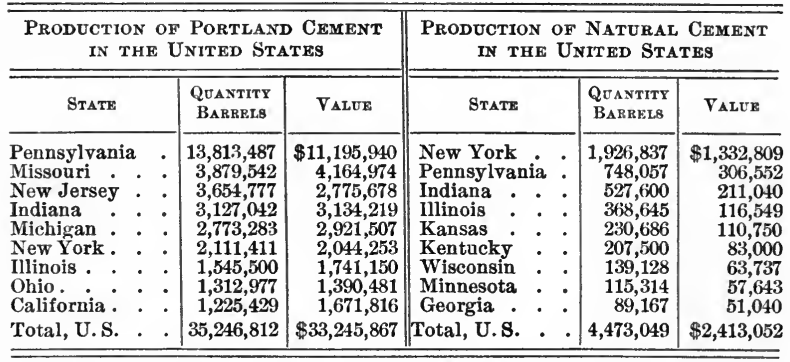

Imports of hydraulic cement in $1905,846,577$ barrels. Exports of hydranlic cement in $1905,897,686$ barrels; value, $\$ 1,387,906$. Production of slag cement in United States, 382,447 barrels; value, $\$ 272,614$.

\section{SALT}

\begin{tabular}{|c|c|c|c|c|c|c|}
\hline \multicolumn{4}{|c|}{$\begin{array}{c}\text { Production of Salt in the United } \\
\text { States }\end{array}$} & \multicolumn{3}{|c|}{$\begin{array}{l}\text { WORLD's PRODUCTION OF SALT IN } \\
1904\end{array}$} \\
\hline STATE & & BARRELS & VALUE & CoUnter & $\begin{array}{l}\text { SHORT } \\
\text { ToNs }\end{array}$ & VALUE \\
\hline $\begin{array}{l}\text { Michigan } \\
\text { New York: } \\
\text { Ohio . } \\
\text { Kansas : } \\
\text { Louisiana : } \\
\text { California : } \\
\text { Texas } \\
\text { West Virginia } \\
\text { Utah : } \\
\text { Total, U.S. }\end{array}$ & 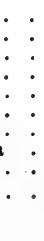 & $\begin{array}{r}9,492,173 \\
8,359,121 \\
2,526,558 \\
2,098,585 \\
1,055,186 \\
664,099 \\
444,832 \\
202,151 \\
177,342 \\
25,966,122\end{array}$ & $\begin{array}{r}\$ 1,851,332 \\
2,167,931 \\
565,946 \\
576,139 \\
303,507 \\
188,330 \\
142,993 \\
74,063 \\
135,465 \\
\$ 6,095,922\end{array}$ & $\begin{array}{l}\text { United States } \\
\text { United Kingdom } \\
\text { France and Al- } \\
\text { geria } \\
\text { German Empire } \\
\text { Japan (1903): } \\
\text { Italy } \\
\text { Anstro-Hungary } \\
\text { Russia : : : } \\
\text { Spain : }: \\
\text { India : : : } \\
\text { Canada: : : }\end{array}$ & $\begin{array}{r}3,084,200 \\
2,118,629 \\
1,292,557 \\
1,875,733 \\
724,750 \\
511,827 \\
595,335 \\
\text { not avail } \\
599,292 \\
1,236,702 \\
68,777\end{array}$ & $\begin{array}{r}\$ 6,021,222 \\
2,900,375 \\
\\
3,660,052 \\
4,693,122 \\
4,692,539 \\
713,595 \\
16,024,783 \\
\text { able } \\
738,348 \\
318,628\end{array}$ \\
\hline
\end{tabular}

Exports in 1905, 50,886,454 pounds; value, $\$ 190,376$.

Imports in $1905,308,572,025$ pounds; value, $\$ 496,734$. 


\section{BORAX}

Production in California, 46,334 short tons crude borax, valued at $\$ 1,019,154$.

Imports of borax, borates, and boric acid, 863,460 pounds, valued at $\$ 32,800$.

World's Production of Borax in 1904

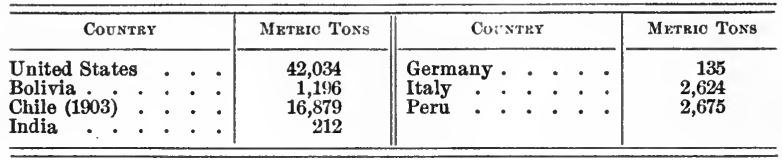

GYPSUM

\begin{tabular}{|c|c|c|c|c|c|}
\hline \multicolumn{3}{|c|}{$\begin{array}{c}\text { Production of Gypsum in the } \\
\text { United States }\end{array}$} & \multicolumn{3}{|c|}{$\begin{array}{l}\text { WORLd's PRODUCTION OF GYPSUM } \\
\text { IN } 1904\end{array}$} \\
\hline States & $\begin{array}{l}\text { SHoRT } \\
\text { ToNs }\end{array}$ & VALUE & Country & $\begin{array}{l}\text { SHORT } \\
\text { ToNs }\end{array}$ & VALUE \\
\hline 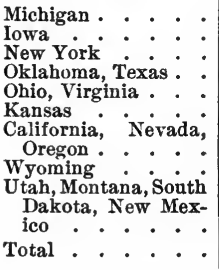 & $\begin{array}{r}299,585 \\
179,016 \\
153,367 \\
148,947 \\
134,276 \\
47,276 \\
29,155 \\
26,880\end{array}$ & \begin{tabular}{|r|}
$\$ 143,597$ \\
114,354 \\
151,272 \\
148,947 \\
134,474 \\
32,946 \\
\\
39,947 \\
26,930
\end{tabular} & $\begin{array}{l}\text { France } \\
\text { United States : } \\
\text { Canada } \\
\text { Great Britain } \\
\text { German Empire: } \\
\text { Algeria : } \\
\text { Cyprus : : }\end{array}$ & $\begin{array}{r}1,749,875 \\
940,917 \\
298,211 \\
262,086 \\
25,095 \\
386 \\
12,449\end{array}$ & $\begin{array}{r}\$ 2,916,483 \\
2,784,325 \\
316,436 \\
354,138 \\
17,307 \\
169 \\
31,721\end{array}$ \\
\hline
\end{tabular}

Imports of ground and unground gypsum, and plaster of Paris, $\$ 446,152$.

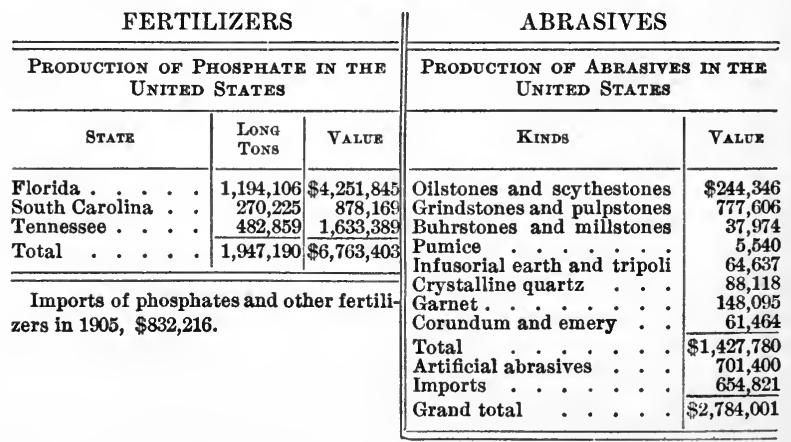


Production of Minor Non-metallic Minerals in United States

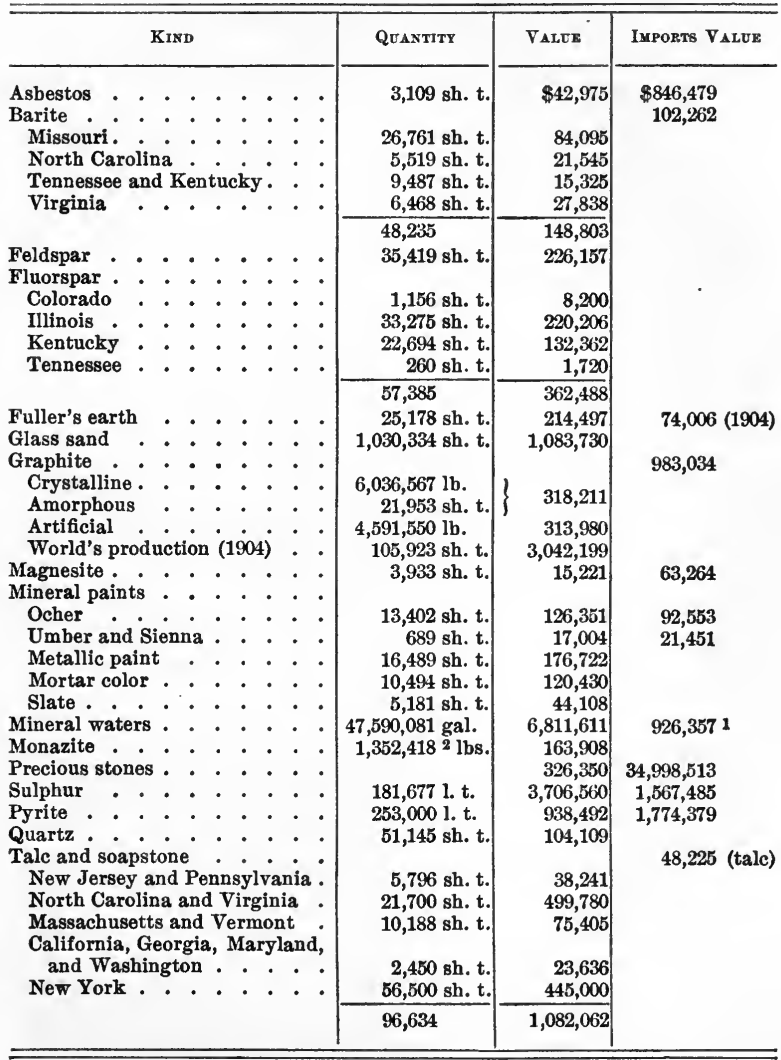

1 Includes artificial. ${ }^{2}$ Includes a small quantity of zircon and columbite. 


\section{METALLIC MINERALS}

IrON ORES

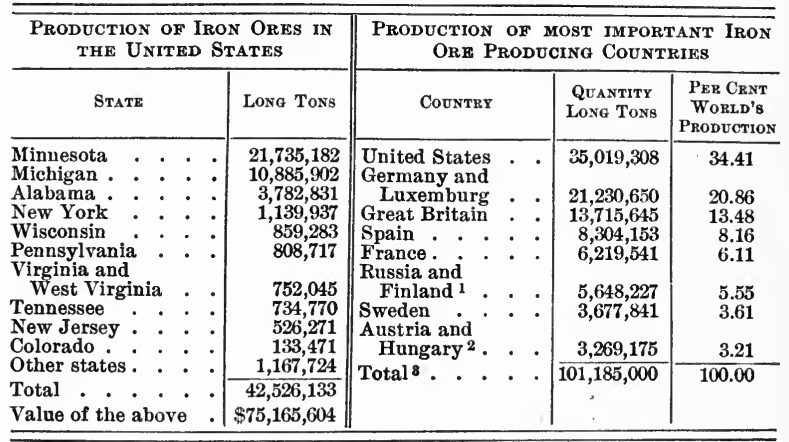

Imports in 1905, 845,651 long tons; value, $\$ 2,062,161$.

Exports in 1905, 208,017 long tons; value, $\$ 530,457$.

\section{Copper Ores}

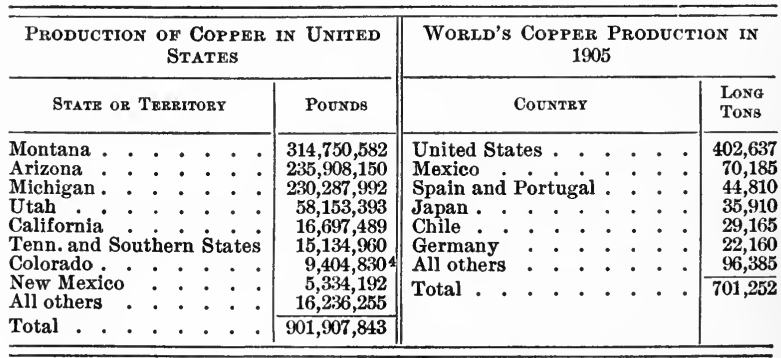

Imports of copper ore and matte, $\$ 5,765,238$.

Exports of copper ore and metal, $\$ 86,408,731$.

1 1902. 2 Includes Bosnia-Herzegovina. $\quad{ }^{8}$ Approximate.

4 Including copper smelters. 


\section{LEAD AND ZINC}

Production of Lead and Spelter in the United States

SHoRt Toxs

Lead .

307,000

Spelter

Lead Content of American

Ores Smelted in 1905

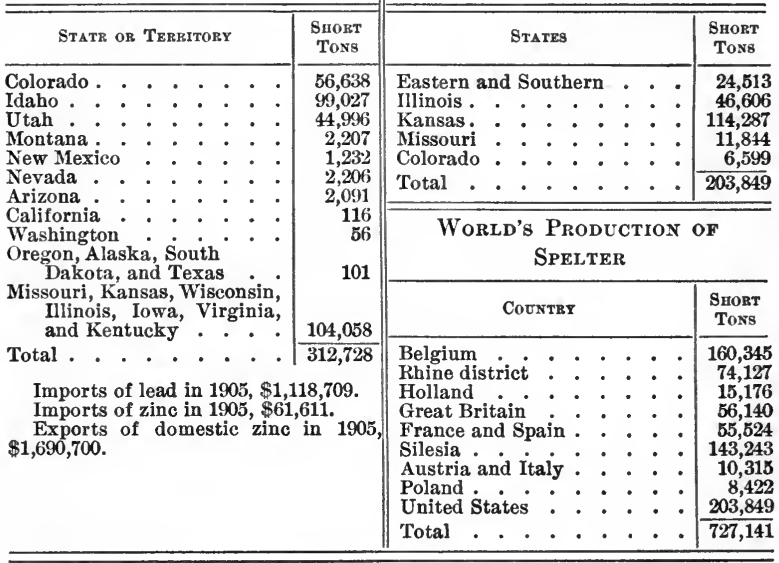

\section{ALUMINUM}

United States production in $1905,11,347,000$ pounds. ${ }^{1}$

Imports in 1903 of crude and manufactured aluminum, $\$ 143,471$.

\section{World's Production of Aluminum in 1904}

\begin{tabular}{|c|c|c|c|c|c|c|c|c|}
\hline & OUNTRY & & & & & & $\begin{array}{c}\text { QUaNTITY } \\
\text { MrtBio TONB }\end{array}$ & VALUE \\
\hline \multirow[t]{2}{*}{$\begin{array}{l}\text { United States } \\
\text { Switzerland : } \\
\text { France : } \\
\text { United Kingdiom }\end{array}$} & \multirow{2}{*}{\multicolumn{2}{|c|}{$\begin{array}{l}\cdot: \dot{:}: \\
\dot{0}: \dot{:}\end{array}$}} & \multirow{2}{*}{\multicolumn{2}{|c|}{$: \dot{:}$}} & \multirow{2}{*}{\multicolumn{2}{|c|}{$: \dot{:}$}} & $\begin{array}{r}3,402 \\
2,500 \\
1,700 \\
650\end{array}$ & $\begin{array}{r}\$ 2,325,000 \\
1,413,125 \\
849,025 \\
328,250\end{array}$ \\
\hline & & & & & & & 8,252 & $\$ 4,915,400$ \\
\hline
\end{tabular}

1 Consumption. 


\section{GOLD AND SILVER}

Production of Gold and Silver in 1904, by States and TERRITORIES

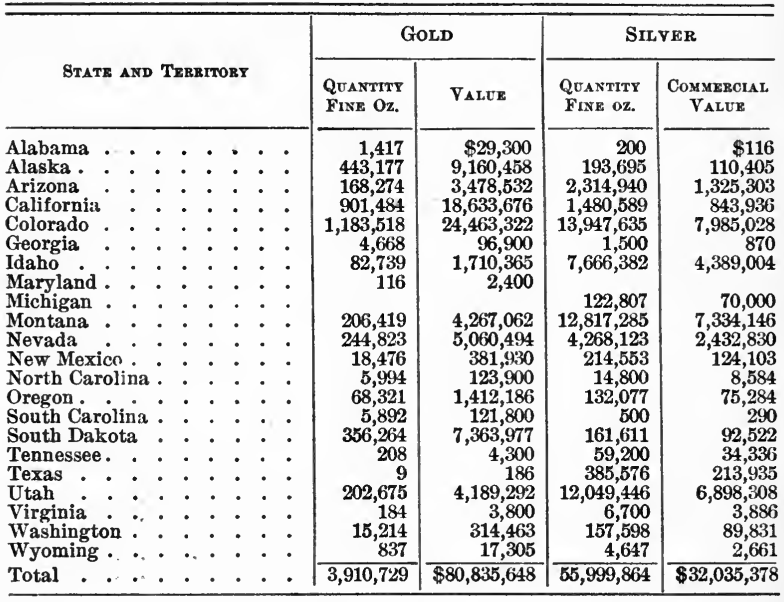

\section{BAUXI'TE}

\begin{tabular}{|c|c|c|c|c|c|c|}
\hline \multicolumn{4}{|c|}{$\begin{array}{c}\text { Production of Bauxite in } \\
\text { United States }\end{array}$} & \multicolumn{3}{|c|}{$\begin{array}{l}\text { World's Production of Bauxite } \\
\text { in } 1904\end{array}$} \\
\hline State & & & Lone Tons & COUNTEY & LoNe Tons & VALCE \\
\hline 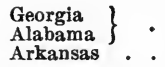 & . & $\begin{array}{l}\cdot \cdot \cdot \\
\cdot \cdot\end{array}$ & $\begin{array}{l}15,173 \\
32,956\end{array}$ & $\begin{array}{l}\text { United States . } \\
\text { France : } \\
\text { United Kingdom : }\end{array}$ & $\begin{array}{r}47,661 \\
74,449 \\
8,700\end{array}$ & $\begin{array}{r}\$ 235,704 \\
131,229 \\
8,340 \\
\end{array}$ \\
\hline $\begin{array}{l}\text { Total } \\
\text { Value of above }\end{array}$ & . & $\dot{.} \cdot$ & $\begin{array}{r}48,129 \\
\$ 240,292\end{array}$ & Total . . . . & 130,810 & 375,273 \\
\hline
\end{tabular}

Imports of bauxite, 11,726 long tons; value, $\$ 46,517$.

Exports of bauxite, none since 1901. 


\section{MANGANESE}

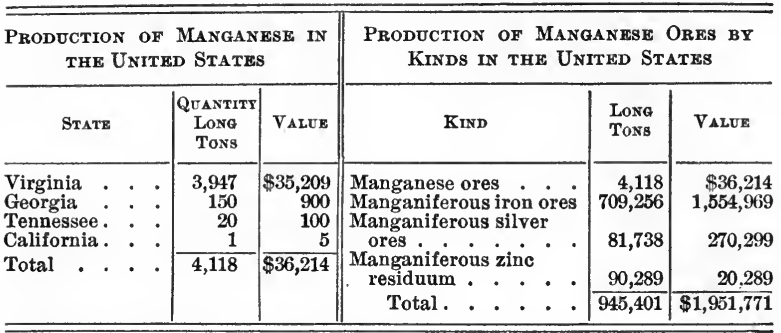

Imports of manganese ores in $1905,257,033$ long tons; valued at $\$ 1,952,407$.

\section{MERCURY}

\section{Production of Mercury in the United States}

\begin{tabular}{|c|c|c|c|c|c|c|c|c|c|c|c|c|c|c|c|}
\hline & & & & & Srat & & & & & & & & & 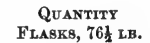 & VALUK \\
\hline $\begin{array}{l}\text { California } \\
\text { Texas : } \\
\text { Oregon : } \\
\text { Utah : } \\
\text { Total : }\end{array}$ & $:$ & $\dot{:}$ & $\dot{:}$ & $\dot{.}$ & 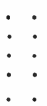 & $\dot{:}$ & $\dot{:}$ & $\dot{5}$ & $\dot{.}$ & $\dot{:}$ & $\dot{:}$ & : & $\dot{:}$ & $\begin{array}{r}24,635 \\
4,723 \\
43 \\
1,050 \\
30,451\end{array}$ & $\begin{array}{r}\$ 886,081 \\
173,362 \\
1,677 \\
42,000 \\
\$ 1,103,120\end{array}$ \\
\hline
\end{tabular}

Imports of mercury in $1905,2690 \mathrm{lb}$; value, \$1710. Exports of mercury in $1905,13,534$ flasks; value, $\$ 489,756$.

World's Production of Mercury in 1904

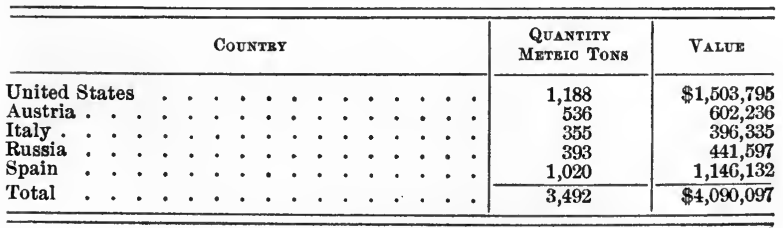


Production of Minor Metals in the United States

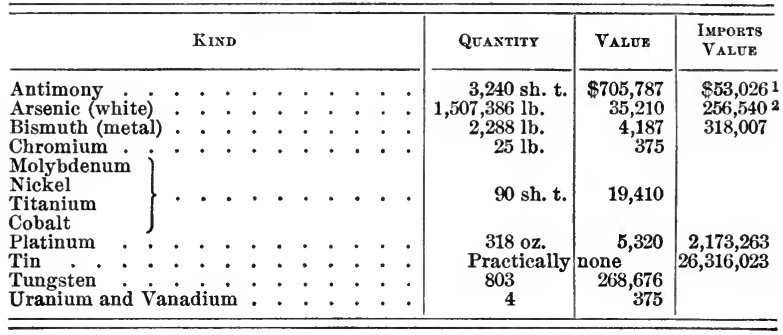

1 Crude antimony and ore.

2 Arsenic and compounds. 


\section{APPENDIX II}

THrs contains a list of the more important papers which have been issued since the appearance of the first edition. Except in the case of a few important mineral products, such as Coal and Gold, the references under each kind of material are arranged alphabetically by authors.

\section{COAL}

General. Reports on Fuel-testing Operations at St. Louis; U. S. Geol. Surv., Prof. Paper 48, and Bulls. 261 and 290. Campbell, Amer. Inst. Min. Engrs., Bimonthly Bull., March, 1906. (Classification.) Campbell, Econ. Geol., I, No. 1, 1905. (Origin.) Smith, Econ. Geol., June, 1906. (Criticism of Campbell's theory.) Ford, Nat. Ass'n. Coll. Mgrs., June 30, 1906. (Origin.) Parr, Jour. Amer. Chem. Soc., Oct., 1906. (Classification.)

Area L. Alaska : Collier, U. S. Geol. Surv., Bull. 278. (Cape Lisburne.) Martin, Ibid., Bull. 284. (Bering River.) Stone, Ibid., Bull. 277. (Kachemak Bay.) - California : Arnold, U. S. Geol. Surv., Bull. 285. (Mount Diablo Range.) - Colorado : Schrader, U. S. Geol. Surv., Bull. 285. (Durango-Gallup field.) Fenneman and Gale, U. S. Geol. Surv., Bull. 285. (Yampa field.)-Illinois : Parr, Illinois Geol. Surv., Bull 3, 1906. - Kentucky : Ashley and Glenn, U. S. Geol. Surv., Prof. Paper 49. (Cumberland Gap field.) Crandall, Ky. Geol. Surv., Bull. 4, 1905. (Big Sandy Valley.) - Montana : Rowe, Univ. of Mont., Bull. 4.-New Mexico : Schrader, U. S. Geol. Surv., Bull. 285. (Durango-Gallup field.) Lee, U. S. Geol. Surv., Bull. 285. (Engle field.) - North Dakota : Wilder, Econ. Geol., July-Aug., 1906. (Lignites.) - Pennsylvania : Ashley, U. S. Geol. Surv., Bull. 285. (Clearfield field.) - Utah: Taff, Ibid. (Weber River field.) Taff, Ibid. (Book Cliffs field.) Richardson, Ibid. (Sanpete Co.)-Virginia : Randolph, Cassier's Mag., Feb., 1905. (Anthracite.)-Wyoming: Trumbull, Bull. 7, Wyo. Sch. of $\mathrm{M}$.

\section{PEAT}

Hindshaw, U. S. Geol. Surv., Min. Res., 1904. (General U. S.) McCourt and Parmelee, N. J. Geol. Surv., 1905: 223. (N. J. and general.) Wilder and Savage, Ia. Geol. Surv., 1905. (Iowa.) 


\section{PETROLEUM}

Arnold, U. S. Geol. Surv., Bull. 285. (California.) Ashburner, Amer. Inst. Min. Engrs., XVI : 906. (New York.) Bishop, N. Y. State Museum, 22d Ann. Rept. N. Y. State Geologist : r. 63. (New York.) Blatchley, Ill. Geol. Surv., Bull. 2. (S. E. Illinois.) Clapp, U. S. Geol. Surv., Bull. 285. (Greene Co., Pa.) Coste, Amer. Inst. Min. Engrs., XXXV: 288. (Volcanic origin.) Fenneman, U. S. Geol. Surv., Bull. 282. (Texas-Louisiana field.) Gould, Eng. and Min. Jour., Aug. 11, 1906. (Kansas-Oklahoma.). Richardson, Jour. Frank. Inst., July, 1906. (North America.) Veatch, U. S. Geol. Surv., Bull. 285. (Uinta Eo., Wyo.)

\section{NATURAL GAS}

Adams, Haworth, Crane, U. S. Geol. Surv., Bull. 238. (Kansas.) Newland, N. Y. State Mus., Bull. 93 : 943. (New York.)

\section{ASPHALT}

Taff and Smith, U. S. Geol. Surv., Bull. 285. (Utah ozokerite.) Eldridge, Econ. Geol., I : 437. (Asphalt vein formation.)

\section{BUILDING STONES}

Dale, U. S. Geol. Surv., Bull. 285. (Maine slate.) Dale and others, U. S. Geol. Surv., Bull. 275. (United States slate.) McCourt, N. Y. State Mus., Bull. 100. (Fire tests, N. Y. stones.) Watson, Laney, and Merrill, N. Ca. Geol. Surv., Bull. 2. (North Carolina general.)

\section{CLAYS}

Ries, Clays, their Occurrence, Properties, and Uses, New York, 1906. (Wiley and Sons.) Ashley, U. S. Geol. Surv., Bull. 285. (Clearfield Co., Pa.) Crider, Ibid. (W. Kentucky.) Fuller, Ibid. (Cape Cod.) Phalen, Ibid. (N. W. Kentucky.) Siebenthal, Ibid. (Bentonite in Wyo.) Grimsley and Grout, W. Va. Geol. Surv., III. (West Virginia.) Logan and Hand, Bull. Miss. Agric. and Mech. Coll., II, No. 3. (Mississippi.) Ries, Amer. Inst. Min. Engrs., Bimonthly Bull., Sept., 1906. (Texas.) Ries, Va. Geol. Surv., Bull. II. (Virginia.)

\section{LIME AND CALCAREOUS CEMENTS}

Eckel, Cements, Limes, and Plasters, New York, 1906. (Wiley and Sons.) Meade, Portland Cement, Easton, 1906. (Chemical Publishing Co.) Bastin, U. S. Geol. Surv., Bull. 285. (Knox Co., Me.) Bain and Eckel, Ia. Geol. Surv., XV : 33. (Iowa.) Eckel, U. S. Geol. Surv., Bull. 285. (Tenn.-Va. district.) Grimsley, W. Va. Geol. Surv., III. (West Virginia.) Kümmel, N. J. Geol. Surv., 1905: 173. (Sussex and Warren counties limestones.) Landes, U. S. Geol. Surv., Bull. 285. (Washington.) Orton and Peppel, Ohio Geol. Surv., 4th ser., Bull. 4. (Ohio.) 


\section{SALT}

Bownocker, Ohio Geol. Surv., 4th ser., Bull. 8. (Ohio.) Lane, Jour. Geol., XIV : 221. (Chemical evolution of ocean.)

\section{GYPSUM}

Siebenthal, U. S. Geol. Surv., Bull. 285. (Laramie dist., Wyo., and Uncompahgre region, Colo.)

\section{FERTILIZERS}

Jumeau, Annales de Chimie, June 15, 1906. (United States.) Prather, Jour. Geol., Sept.-Oct., 1905. (N. J. glauconite.)

\section{ABRASIVES}

For general on diatomaceous earth see: Bull. Imp. Inst., III, No. 1: 88 and Can. Geol. Surv., Ann. Rept., XV, Pt. S. Magnus, N. Y. State Mus., 57th Rept., I : 158. (New York.) Newland, Eng. and Min. Jour., Jan. 6, 1906. (New York garnet.) Pratt, N. Ca. Geol. Surv., I. (Corundum, North Carolina.) Pratt, U. S. Geol. Surv., Bull. 269. (Corundum, United States.) Desau, Min. World, Dec. 31, 1904. (Borts and carbons.)

\section{MINOR MINERALS}

Asbestos: Cirkel, Can. Dept. Int., Mines Branch, 1905. (Occurrence and uses.) Pratt, Min. World, July 8, 1905. (Arizona.)-Barite : Dickson, Sch. of M. Quart., XXIII : 366. (Conc'n in limestone.) Lakes, Min. Rep., Aug. 16, 1906. (Idaho.) - Feldspar: Hopkins, Min. Indus., VII : 262. (General.) Also A. A. A. S., XLVII : 293. (S. E. Pennsylvania.) Ries, U.S. Geol. Surv., Min. Res., 1901 : 937. (General.) Fluorspar: Fohs, Eng. and Min. Jour., Jan. 6, 1906. (U.S. industry.) - Grass Sand : Burchard, U. S. Geol. Surv., Bull. 285. (General and Missouri.) Stose, ibid. (E. West Virginia.)-Graphite : Newland, Eng. and Min. Jour., Jan. 13, 1906. (New York.) - Magnesite : Hess. U. S. Geol. Surv., Bull. 285. (California.) - MicA : Cirkel, Can. Dept. Int., Mines Branch, 1905. (Occurrence, etc.) Colles, Mica, and the Mica Industry. New York, 1906. (General.) - Molding SANd : Field, Iron Tr. Rev., Mar. 15, 1906. Kümmel and Hamilton, N. J. Geol. Surv., 1904: 187. (New Jersey.) Palmer, Amer. Mach., Oct. 5, 1905. (Core sands.) Ries, Foundry, July, 1906. (Laboratory examination methods.) Visonneau, Bull. de la Soc. d'Enc. pour l'Ind. Nat., Rev. de Met., July 1, 1906. (General.) - Precious Stones : Crookes, Min. Jour., Sept. 9, 16, 23, and 30, 1905. (Diamonds.) Kunz, Calif. St. Min. Bur., Bull. 37. (Calif.) See also same author in U. S. Geol. Surv., Min. Res., 1904 and 1905. - Sulphur axd Pyrite : Nasnn, Eng. 
and Min. Jour., July 28, 1906. (Origin Appalachian pyrites.) Thomas, Min. World, Aug. 25, 1906. (Texas sulphur.) - TALC: Peck, N. J. Geol. Surv., 1904 : 163. (N. J.-Pa.) - W Ater : Gautier, Econ. Geol., July-Aug., 1906. (Genesis of thermal waters.) Numerous watersupply bulletins issued by U. S. Geol. Surv. - Sorls: Hilgard, Soils, New York, 1906. (Macmillan Co.) Merrill, Rocks, Rock-weathering, and Soils, New York, 1906. (Macmillan Co.)

\section{ORE DEPOSITS}

Bain, Econ. Geol., I. No. 4. (Classification.) Beck, Trans. Geol. Soc. S. Afr., VIII : 147. (Ore veins and pegmatites.) Demaret, Annal. des M. de Belg., XI : 542. (Genesis.) Kemp, Econ. Geol., I, No. 3. (Formation of ore deposits.) Kemp, Min. and Sci. Pr., March 31, 1906. (Garnet zones.) Kemp, Econ. Geol., I, No. 1. (Sec'y enrichment copper ores.) Lane, Jour. Can. Mg. Inst., IX. (Magmatic segregation.) Lindgren, Econ. Geol., Oct. to Nov., 1905. (Ore deposition and deep mining.) Miller, Elements of Mining Geology and Metallurgy, Denver, 1906. Parks, Inst. Mg. and Met., Apr. 13, 1905. (Border segregation.) Park, A Text-book of Mining Geology, Philadelphia, 1906. Read, Amer. Inst. Min. Engrs., Bimonthly Bull., Mar. 1906. (Sec'y enrich.) Smyth, Amer. Jour. Sci., XIX : 277, 1905. (Pyrite replacing quartz.) Spurr, Geology Applied to Mining, New York, 1904. Stokes, Econ. Geol., July-Aug., 1906. (Sec'y enrich.) Sullivan, Ibid., Oct.-Nov., 1905. (Ore deposition.) Weed, Eng. and Min. Jour., Feb. 23, 1905. (Absorption.) Day and Richards, U. S. Geol. Surv., Bull. 285. (Investigation of black sands.)

\section{IRON ORES}

Bowron, Amer. Inst. Min. Eng., Trans. XXXVI : 587. (Clinton ore, Ala.) Eckel, U. S. Geol. Surv., Bull. 285. (Clinton ore, Ala.) Eckel, Ibid. (Oriskany and Clinton ore, Va.) Holden, Ibid. (Virginia limonites.) Kindle, Ibid. (Bath Co., Kentucky.) Leith, Econ. Geol., I, No. 4 (Iron ore reserves.) Leith, U. S. Geol. Surv., Bull. 285. (W. United States.)

\section{COPPER ORES}

Kemp, Econ. Geol., I. (Sec'y enrich.) Beeler,Wyo. Geol. Surv., Sept. 1, 1905. (Grand Encampment dist.) Fishburn, Eng. and Min. Jour., Sept. 22, 1906. (Inyo Co., Calif.) Grant, U. S. Geol. Surv., Bull. 284. (Alaska.) Lane, Lake Sup. Min. Inst., 1906. (L. Sup. dist.) Lawson, Bull. Dept. Geol. Univ. Calif., IV : 287. (Robinson dist., Nev.) Lindgren, U. S. Geol. Surv., Prof. Paper 43. (Clifton-Morenci.) Phalen, U. S. Geol. Surv., Bull. 285. (Luray, Va.) Root, Min. World, Sept. 29, 1906. (Ely, Nev.) Weed, U. S. Geol. Surv., Bull. 285. (U. S. copper deposits.) Weed and Watson, Econ. Geol., I: $309 . \quad$ (Virginia.) 


\section{LEAD AND ZINC ORES}

Bain, U. S. Geol. Surv., Bull. 246. (N. W. Illinois.) Bain, Min. Mag., July, 1905. (Soft lead resources, U.S.) Buckley and Buehler, Mo. Geol. Surv., 2d ser., IV. (Granby area, Mo.) Bain, U. S. Geol. Surv., Bull. 285. (Nevada zinc.) Brinsmade, Mines and Min., Sept., 1906. (Kelly, N. Mex.) Grant, Wis. Geol. and Nat. Hist. Surv., Bull. 14. (Wisconsin.) Miller, Ky. Geol. Surv., Bull. 2. (C. Kentucky.) Siebenthal, Econ. Geol., I : 119. (Joplin district, Mo.) Ulrich and Smith, U. S. Geol. Surv., Prof. Paper 36. (W. Kentucky.) Watson, Amer. Inst. Min. Engrs., XXXV : 681. (Va.-Tenn. area.)

\section{GOLD AND SILVER}

General. Lovewell, Trans. Kan. Acad. Sci., XX, Pt. 1:205. (Genesis placer and vein gold.) Smyth, Eng. and Min. Jour., June 29, 1905. (Placers, origin, and class'n.) De Launay, Rev. gen. d. Sci., June 15 and 30,1906 . (Gold occurrence and production in world.)

Aresc. - Alaska : Papers by various authors in U. S. Geol. Surv., Bulls. 277, 284, 247, 280, 251, and 287.-Arizona : Kellogg, Econ. Geol., JulyAug., 1906. (Cochise Co.) Crosby, Amer. Inst. Min. Engrs., Trans. XXXVI: 626. (Washington Camp.)-California: Bateson, Amer. Inst. Min. Engrs., Bimonthly Bull., Jan., 1906. (Mojave dist.) Diller, U. S. Geol. Surv., Bull. 260: 45. (Indian Valley region.) Ball, U. S. Geol. Surv., Bull. 285. (S. W. Nev. and E. Calif.) - Colorado : Spurr and Garrey, Ibid. (Idaho Springs.) Wolff, Min. World, Dec. 16, 1905. (Boulder Co.) Gale, U. S. Geol. Surv., Bull. 285. (Hahn's Peak.) Idaho: Collier, Ibid. (St. Joe River basin.)-Montana : Douglass, Mines and Min., Feb. 1905. (Alder Gulch.) - Nevada : Ball, U. S. Geol. Surv., Bull. 285. (S. W. Nev. and E. Calif.) Hastings, Amer. Inst. Min. Engrs., Trans. XXXVI. (Silver Peak.) Hastings and Berkey, Amer. Inst. Min. Engrs., Bimonthly'Bull., March, 1906. (Goldfield.) Pack, Sch. of M. Quart., April and July, 1906. (Pioche.) Reid, Bull. Dept. Geol. Univers. Calif., IV : 177. (Comstock Lode.) Rice, Eng. and Min. Jour., Sept. 22, 1906. (Bullfrog district.) Spurr, U. S. Geol. Surv., Prof. Paper 55. (Silver Peak.) Spurr, Amer. Inst. Min. Engrs., Trans. XXXVI : 372 . (W. Nevada ores.) - New Mexico : Lindgren and Graton, U. S. Geol. Surv., Bull. 285.

\section{MERCURY}

Phillips, Econ. Geol., I, No. 2. (Texas.) Stovall, Min. World, Aug. 25, 1906. (Oregon.) Turner, Econ. Geol., I, No. 3. (Texas.)

\section{NICKEL, COBALT}

Coleman, Ont. Bur. Mines, XIV, Ann. Rept., Pt. III. (Sudbury nickel field.) Miller, Ibid., Pt. II. (Cobalt-nickel deposits, Temiskaming.) 


\section{TIN}

Hess, U. S. Geol. Surv., Bull. 284. (Alaska.) Richardson, Ibid., Bull. 285. (Texas.)

\section{TUNGSTEN}

Joseph, Eng. and Min. Jour., March 3, 1906. (Washington.) Van Wag. enen, Colo. Sch. of M. Bull., Jan., 1906. (Colorado and general.) 


\section{INDEX}

Abrasives, 158.

artificial, 165 .

production of, 165 .

references on, 166.

Sec Buhrstones, Whetstones, Pumice, Corundum, Garnet, Quartz, Infusorisl Earth.

Actinolite, as gangue mineral, 295.

Adobe clay, defined, 99.

Eolian soils, 214.

Alsbama, bsuxite, 376 ; clinton ore, 266 ; fuller's earth, 175; graphite, 179; kaolin, 101 ; limonite, 271 ; phosphate, 153 ; Portlsnd cement materials, 119 ; stoneware clay, 103 ; Warrior coal, analysis, 7 .

Alabaster, 143.

Alsska, coal, 82 ; coal mining, 83 ; copper, 298 ; gold, 353 ; lignite, snalysis from, 6 ; magmatically segregated ores, 225 ; petroleum, 54 ; tin, 412 ; yield of gold ores, 832.

Albertite, properties, 59.

distribution, 59.

Algeria, onyx marbles, 83.

Algonkian, copper in, 295 ; iron in, 260.

Alkali soils, 215.

Alkalies, effect on clsy, 96.

Alluvial soils, 214.

Almandite, uses ss gem, 194.

Alumina, effect on clay, 95.

in iron ores, 252.

in soils, 214 .

Aluminum, 375.

for lithographic work, 182.

ores of, 375 .

production of, 882 .

references on, 388 .

uses of, 379.

Alnndum, 165.

Amethyst, as gem, 195.

Amorphous phosphates, 686 Phosphates.

Amygdaloids, copper-bearing, 288.

Anslyses of, anthracite coal, 8; asphaltites, 60 ; bsuxite, 876 ; bituminous coal, 8 ; bituminous rocks, 61 ; cement rock, natural, 112 ; chromite, 400 ; clays, 98 ; coal, elementary, 14; copper ores, Butte, 285; fuller's earth, 175 ; glass sand, 177 ; greensand, 156 ; gypsum, 143; hematites, 264, 268; kaolin, crude, 101 ; kaolln, washed, 101 ; lignite, elementary, 14; limestones, 109 ; limonites, 272; lithographic stone, 181 ; magnetites, non-titaniferons, 257 ; magnetites, titaniferous, 258 ; maltha, 60 ; mine waters, 227 ; mineral waters, 206; monazite, 191 ; nstural gas, 43; peat, elementary, 14 ; petroleum, 41 ; phosphstes, 154 ; Portland cement msterials, 115 ; Portland cements, 116; proximste, of United States coals, 6 ; rock salt, 181; solld matter in brine, 181; waters, sea snd ocesn, 124.

Analysis of, barite, 170 ; bst gusno, 155 ; bituminous coal ash, 9 ; brick clay, 98 ; calcsreous clay, 98 ; copper ore, 298; fire clay, 98; grsphite, 178; gypsum, calcined, 144 ; kaolin, 98 ; kaolinite, 98; lignite ash, 9 ; molding sand, 189 ; nickel ore, Canada, 405; oll shaje, 57 ; peat ash, 9 ; pyrite, 199 ; shale, 98 ; stoneware clay, 98 ; tungsten concentrates, 415 ; zine ore, 815 ; zinc ore, Creede, Colo., 819; zino ore, Leadville, 818; zine ore, New Jersey, 809.

Anglesite, 808, 805, 871.

Anhydrite, defined, 189.

Anthracite, 5, 22.

effect of igneons intrusions on, 15.

price per ton, 34 .

properties of, 5 .

Anthraxolite, occnrrence and properties, 59.

Antimony, 896.

distribution in United States, 396.

gangue minerals, 896.

mode of occurrence, 896.

production, 897.

references on, 897 .

sources, 896.

nses, 897 .

with mercury, 893.

Apatite, as a fertilizer, 14t. sources, 147.

A pex, 239.

A ppalachian coal field, 20.

anthracite area, 22.

bituminous ares, 21.

chsracter of bituminons coals, 22.

Appalachian petroleum, distillates from, 42. 
Appalachian region, copper ores of, 294. depth of oxidation in ore bodies, 244. petroleum in, 48.

Apsdin, Joseph, discoverer of Portland cement, 118.

Aquamarine, 194.

Archæan, iron ores in, 261.

Argentite, 285, 825.

Argillaceons limestone, for Portiand cement,114.

Arizons, asbestos, 168 ; fluorspar, 173 ; garnet, 195; molybdenum, 403 ; rubies (so called), 193 ; tungsten, 415 ; turquoise, 194 ; vanadium, 416 ; weathering of ores, 281.

Arkansas, bauxite in, 378; bituminous coal, snalysis of, 7 ; cosi fields, 29 ; fuller's earth, 175; lignite, 80 ; limonite, 271 ; manganese, 887 ; novaculite, 160 ; phosphate, 158 ; Portland cement materials, 119; semi-bituminous cosl, ansiysis of, 7 ; whetstone, 160 ; zinc ores, 315 .

Arkose, defined, 85 .

Arsenio, 898.

distribution, Virginis, 898; Washington, 398.

in iron ores, 252.

references on, 398.

sources of, 898.

uses, 898.

with mercury, 898.

Arsenopyrite, 898.

Artesian water, 209.

depth below surface, 209.

distinction from ground water, 210.

distribution, Atlantic coast, 210; Grest Plains, 211; Mississippi Valley, 211. geologic horizon of, 209.

in metamorphic rocks, 210.

A sbestos, asbestos minerals, 167.

amphibole, mode of occurrence, 167.

as mineral pigment, 188.

chrysotile veins, origin, 168 .

distribution, 167; Canada, 168; Georgis, 167 ; North Carolina, 167 ; Virginia, 167.

production, 169.

references on, 169.

serpentine, mode of occurrence, 167. uses, 169.

Ashburner, on origin of petroleum, 44.

Ash, cosl, analyses of, 9 .

Ash in cosl, 9.

Ash soils, 214.

Ash, volcanic, sec Volcanic Ash.

Asia Minor, turquolse in, 194.

Aspen, Colo., lead-silver, 807, 367.

A sphsitites, defined, 57.

properties, 58.

uses of, 61.

A sphaltum, references on, 67.

Astral oil, 56 .

A tiantic Ocean, analysis of water, 124 .

Azurite, 278, 281, 291, 293, 871.

\section{B}

Babbitt metal, 897.

Bain, on Missouri lead-zinc ores, 817 .

Ball clay, defined, 99. distribution of, 103.

Barite, as mineral pigment, 187.

distribution, 170; Connecticut, 170; Mis. souri, 170; North Carolina, 170; Pennsyivania, 170 ; Tennessee, 170 ; Virginla, 170.

mode of occurrence, 170.

prodnction, 170.

references on, 171.

uses, 170.

Barre, Vermont granite, 77.

Bauxite, analyses of, 876 .

distribution, Alabama, 876 ; Arkansas, 873 ; Georgia, 876; New Mexico, 379.

production of, 880 .

properties, 375.

references on, 883 .

uses, 880 .

Bavaria, Hthographic stone, 182.

Beaufort, S. C., phosphate deposits, 150.

Beanmont, Texas, petroleum, 51 .

Becker, on mercury origin, 893.

Bedding planes, effect on quarrying, 74.

Belgium, buhrstones from, 161 .

Benzine, in petroleum, 42.

Berea sandstone, 86.

Bessemer ores, defined, 252.

Bingham Canyon, Utah, copper, 296, 807.

Bisbee, Ariz., copper, 290.

Bismite, 399.

Bismuth, distribution, Colorado, 899. ores, 399. production, 899. uses, 899.

Bismuthinite, 399.

Bismutite, 899.

Bitumen, with mercury, 890, 893. with zinc, 315 .

Bituminous coal, price per ton, 34. propertles of, 4. See Coal.

Bituminous rocks, analyses, 61 . California, described, 60 . defined, 57.

distribution, geographic, 57 . geologic, 57.

Indisn Territory, mentioned, 60.

Kentucky, mentioned, 60. origin, $\mathbf{5 7}$.

Black copper, at base of gossan, 244.

Black Hilis, S. Dak., tin, 411. tungsten, 415.

Biack Sea, analysis of water, 124.

Black silver, 825 .

Blende, as contact ore, 235. See Sphalerite.

Blnestone, defined, 65. See Bullding stones. 
Bonsnzas, 237, 286, 338, 345.

Bone cosl, 24.

Boracite, 134.

Borax, 184.

marshes, California, 135.

minerals containing, 134.

near Daggett, 135.

production, 186.

references on, 185 .

uses, 185 .

Bornite, 278, 279, 286, 292.

as contact ore, 235. secondary, 286.

Bort, 192.

Boulder, Colo., petroleum at, 58.

Boulder, Mont., auriferous hot apring, 228.

Bradford district, $\mathrm{Pa}$., nstural gas in, 54.

Brass, 299, 820.

Brsunite, 383.

Brazil, emersld, 198; magnetite sand, 258; monazite, 190; topaz, 194.

Bresker, cosl, 24.

Brick clay, analysis of, 98. defined, 99.

distribution of, 104.

Brines, natursl, 127.

Britannia metal, 897.

Brittle silver, 325 .

Bromyrite, 325 .

Bronze, 299.

Brooks, on Lske Superior ores, 262.

Brownstone, defined, 85.

Buhrstones, characters, 161.

distribution, 161.

Germsn, 161.

Building stones, 69.

absorption of, 73.

color, 70.

crushing strength, 72.

cut off, 74.

density, 70.

distribution, sec under Granite, Sandstone, Limestone, Marble, Slate.

fading, cause of, 70 .

hsrdness, 71.

lift, 74.

permsnent swelling, 78.

porosity of, 78 .

production of, 89.

properties of, 69.

quarry water in, 73.

references on, 90.

resistance to frost, 78.

to hest, 78 .

rift, 74.

sap of, 78.

specific gravity, 71 .

strength, 71 .

texture, 70.

Bully Hill, Calif., copper, 298.

Butte, Mont., copper ores, 282. metssomstism st, 284.

\section{C}

Calamine, 803, 305, 810, 818.

Calsverite, 839.

Calcareous clay, snslysis of, 98.

Calcite, see Gangue minerais.

Californis, asbestos mentioned, 168 ; coal, 81, 82 ; copper, 297 ; fire clay, 108 ; infusorial earth, mentioned, 162 ; Kern River oll field, 58; lignite, snalysis, 7 ; llthium, 183 ; magnesite, 184 ; magvetite, 256; mangsnese, 887 ; msrble, 82 ; mercury, 891 ; molybdenum, 403 ; nstural gas, 56 ; petroleum, 52 ; petrolenm, characters, 58 ; platinum, 408 ; Portlsnd cement msterials, 119 ; sait, 130 ; stoneware clay, 108 ; topaz, 194.

\section{Californite, ss gem, 195 .}

Calomel, 390, 891.

Calumet conglomerate, 288.

Csmbrisn, glass ssnd, 177.

gold ores, 329 .

ocher, 187.

silver ores, 829.

tungsten, 415.

Cambro-Sllurisn limonite, 271. pyrite, 199.

Cannel cosl, properties of, 5 .

Cape Nome, Alaska, 357.

Carbonado, 192.

Carboniferous, Appalachian section, 21; sec Coal, Anthracite, distribution ; copper, 290, 298, 296; gold ores, 836 ; gypsum, 140; hemstite, 268; limestones for Portland cement, 119 ; petroleum, 58; salt, 129 ; shales for Portland cement, 119; siderite, 278 ; silver ores, 836 ; sllver-lead, 865,867 , 870 ; zinc ores, $814,819$.

Carbonite, 25.

Carborundum, 165.

Cartersville, Ga., manganese, 886.

Csssiterite, 410.

Cat's eye (oriental), 194.

Csvities, depth of occurrence, 229.

fault, 28.

formation of, 281.

in earth's cruat, 229.

shrinkage, 281.

solntion, 231.

Cement, calcareons, 109.

hydranlic, defined, 111.

nstural, analyses, 118.

difference from Portland, 118.

properties of, 112.

Portland, analyses of, 116.

properties, 118.

raw materisls, 114.

pozznolsno, defined, 111.

composition, 111.

production, 120.

references, 121.

Boman, 112. 
Cement-continued.

Rosendale, defined, 112.

uses of, 119.

Cement materials, natural rock, Appalachian region, 117; Illinois, 118 ; Kentucky, 118; Maryland, 117; New York, 117; Ohio, 117; Pennsylvania, 117 ; Wisconsin, 118.

Portland, Alabama, 119 ; Arkansas, 119 ; Californis, 119 ; Colorado, 119 ; Indians, 119 ; Kansas, 119; Michigan, 119 ; New Jersey, 118; New York, 118; North Dakota, 119; Ohio, 119 ; Pennsylvania, 118; South Dakota, 119 ; Texas, 119 ; Utsh, 119.

geologic age, 118.

Cement plaster, 144.

Cement rock, natural, analyses, 112.

Cerargyrite, $325,836$.

Cerium, in monazite, 191.

Cerussite, 308, 305, 811, 871.

Ceylon, graphite from, 179. topaz in, 194.

Chalcocite, 278, 281, 285, 286, 291, 292, 297, 298.

Chalcocite, secondary, 286.

Chalcopyrite, 278, 279, 281, 292, 293, 294.

as a contact ore, 235 .

in pyrite deposits, 199.

Chalk, 80.

Champion Springs, N.Y., 205.

Chara, as ald in marl formation, 119.

Chester, Mass., emery deposits, 164.

China clay, defined, 99.

Chlorastrolite, as gem, 195.

Chlorine, in solls, 214.

Chlorite, 826.

Chrome yellow, ss minersl pigment, 188.

Chromic iron, 899.

Chromite, 899.

analyses, 400 .

as mineral pigment, 188.

associated rocks, 899 .

association with peridotite, 226.

distribution in United States, 400; California, 401; North Carolina, 401; Pennsylvania, 401.

origin of, 400.

production of, 402 .

references on, 402 .

uses of, 401.

with platinnm, 408.

Chrysocolla, 278, 281.

Chrysoprase, as gem, 195.

Chry sotile, 167.

Chrysotile veins, origin, 168.

Cinnabar, 890, 893.

Cinnabar, as mineral pigment, 188.

Classification of, clays, 98. ore deposits, 246.

Clay, sdobe, defined, 99. Aolian, 95. air shrinkage, 96.

alkalies in, 96.

alumins in, 95.

analyses of, 98 .

ball, distribution of, 108 .

classification of, 98 .

defined, 92.

distribution, by kinds, 100 .

fire, distribution of, 104.

fire shrinkage, 97.

flood-plsin, 94.

fusibility of, 97 .

geologic distribution, 100.

glacial, 94.

glass pots, sources, 104.

Iron oxide in, 95 .

kaolin, defined, 99, 100.

lake, 94, 104.

lime in, 96.

magnesia in, 96.

marine, 94.

miscelianeous, referred to, 104.

origin, 92, 98.

paper, sources, 104.

physical properties, 96 .

plasticity of, 96.

pottery, 99, 103.

products, production of, 105.

properties of, 95 .

references on, 106.

residual, 104.

sedimentary, 98.

silica in, 95 .

specific gravity, 97.

stoneware, distribution of, 103.

sulphur trioxide in, 96.

tensile strength, 96 .

titanic acid in, 96.

nses of, 105.

varieties, 99.

water in, 96.

Clay solis, properties, 215.

Clansthai, Prussia, banded reins at, 287.

Clifton, Ariz., copper, 293.

Clinton limestone, gas in, 55 .

Clinton ore, 266.

snalyses, 268.

Birmingham, Ala., 266.

character, 266.

distribution, 266.

origin, 267.

Coal, 8.

age of, 19.

anthracite, deflned, 5.

bituminons, defined, 4 .

bone, 24.

cannel, deflned, 5 .

Carboniferons, distribution, 19.

cretaceon8, distribution, 19.

distribution, Alabams, 20; Alaska, 82 ;

Appalachian field, 20; Arkansas, 28,

80; California, 82 ; Colorado, 81 ; 
Cos!, distribution - continued.

Dakota, 81 ; Eastern Interior field, 26 ; Illinois, 27 ; Indiana, 27 ; Indian Territory, 29; Iowa, 29; Kansas, 29 ; Kentucky, 27; Maryland, 22 ; Michigan, 27 ; Montana, 81 ; New Mexico, 81 ; Northern Interior fleld, 27 ; Oregon, 82 ; Pacific coast field, 81 ; Pennsylvanis, 22; Rhode Island field, 25; Rocky Mountain field, 80 ; South Dakota, 81; Southwestern field, 29 ; Texss, 80 ; Triassic ares, 25 ; United States, 18; Washington, 82 ; Western Interior fieid, 29.

elementary analysis, 14.

faulting, 18.

formation of, chemical changes during, 12 . geologic distribution in United Ststes, 19. heat and pressure, effect on, 14.

kinds of, 3.

origin of, 9 .

outcrops, 15.

price per ton, 84.

production of, 33 .

proximate analysis of, explained, 6.

proximate analyses of United States coals, 6 . references on, 85 .

rocks associated with, 16 .

seams, se6 Coal beds.

seml-bituminous, defined, 5 .

Triassic, distribution, 19.

Coal beds, pinching of, 16 .

splitting of, 17.

structural festures, 15.

swelling of, 16.

thickness of, 16.

Coal-blossom, 16.

Coal-brasses, 200.

Coal-breaker, 24.

Cobait, Missouri, 404.

ores, 404.

production of, 406 .

references on, 407 .

uses, 406.

Cobaltite, as mineral pigment, 188.

Coke, natura], see Carbonite. production of, 85 .

Colemanite, 184.

Colorado, anthracite coal, analysis of, 8 ; coal, 31 ; coking cosl, analysis of, 7 ; copper, 298 ; desilverized lead, 807 ; fire clay, 103 ; lignite, analysis, 6 ; limonite, 271 ; magnetite, 256 ; manganese, 888; petroleum, 53 ; Portland cement materials, 119 ; stoneware clay, 108 ; topez,194; tungsten,415; uranium,416.

Comb structure, 287.

Comstock lode, Nevada, 844.

Conglomerate, copper-bearing, 288.

Connecticut, barite, 170 ; garnet, 168 ; kaolin, 101 ; lithlum minerals, 188 ; tungsten in, 415 .
Contact deposits, copper ores, 298, 279. examples of, 235.

Contemporaneous ores, in igneous rocks, 224.

in sedimentary rocks, 225 .

Copper, 278.

in hot spring deposit, 228.

in iron ores, 252.

mode of occurrence in United States, 279.

native, $278,279,287,289,296$.

ores of, 278 .

production, 299.

references on, 801 .

uses, 298.

with mercury, 898.

Copper ore, analysis, California, 298.

analyses of, Montana, 285.

distribution, 281; Alaska, 298; Appalachian region, 294; Ariz., 290; Bisbee, Ariz., 290 ; California, 297 ; Clifton, Ariz., 293; Colorado, 298; Connecticut, 296 ; Globe, Ariz., 294 ; Idsho, 298; Jerome district, 292 ; Michigan, 287 ; Montana, 282; New Jersey, 296; New Mexico, 298; Pennsylvanis, 296; Utah, 296 ; Wyoming, 298.

Copper ores, gold and silver bearing, 828.

impurities, 280.

superficial alteration, 280.

Coquina, 80.

Corniferous limestone, gas in, $\mathbf{5 5}$.

Cornwall, England, tin veins, 286.

Cornwall, Pa., magnetite, 256.

Corsicana, Texas, petroleum, 52.

Corundum, ore of aluminum, 375 .

as abrasive, 163.

distribution, 168.

Georgia, 164.

North Carolina, 164.

mechanical concentration, 165 .

origin, 164.

Cottonwood district, Utah, 807.

Covellite, 285, 286.

carrying platinum, 408.

Creede, Colo., 307.

Crested Butte, Colo., 15.

Cretaceons, glass sand ln, 176 ; greensand in, 155 ; lignite, 19 ; limestone for lime, 116; mercnry, 892 ; petroleum, 53 ; phosphate, 153; shale for Portlend cement, 119.

Crimora, Va., manganese, 385.

Cripple Creek, Colo., gold, 388.

Crustification, defined, 286.

Cryolite, 875 .

Crystal Falls district, hematite, 261.

Culm, defined, 24. uses, 24.

Cuprite, 278, 291

Cut-off, in quarries, 74. 
D

Dakota, lignite in, 81.

Dead Ses, analysis of water, 124.

Descension theory, 240.

Devonian, phosphate in, 153.

Diamond, properties of, 192.

South Africa, 192.

United States, 192.

Didymium in monazite, 191.

Dismal Swamp, analysis of peat from, 6 .

Disseminated ores, 242.

Dolomite, see Gangue.

defined, 78.

petroleum in, 51.

Douglas Island, Alaska, 854.

Dredging gold, 348.

Drift mining, gold, 847 .

Duck River, Tenn., phosphate deposits, 151.

Ducktown, Tenn., copper at, 295.

Dune solls, 214.

\section{E}

Eagle Pass, Texas, coal, 80.

Earthenware clay, defined, 99.

Earth's crust, zones in, 228.

Eldridge, on Florida phosphate, 149.

Embolite, 825.

Emerald, distribution, Brazil, 194 ; Ceylon, 198 ; Hindostsn, 198; North Carolins, 198; Siberis, 198.

lithis, 194.

properties, 193.

Emery, defined, 168.

Massachusetts, described, 164.

New York, mentioned, 164.

Emmons, cited, 230.

Enargite, 278, 279, 284, 872.

England, fuller's earth in, 175.

Epidote, 295, 826.

in contact deposits, 235.

\section{F}

Faults, effect on oll reservoir, 58. relation to oll springs, 53 .

Feather River, Calif., gold in, 849.

Ferric sulphate, as a solvent of ores, 244. effect on pyrite, 244.

Ferro-chromium, 401.

Ferro-nickel, 401.

Ferro-titanium, 414.

Fertilizers, apatite, 147. listed, 147 . production of, 156.

references on, 157 .

See Phosphate, Gusno, Gypsnm, and Greensand.

Findlay, Ohio, oil pressure at, 45.

Fire clay, analysis of, 98.

defined, 99.

distribution in United Ststes, 102.

under coal, 16.
Fissure velns, apex, 239.

bonanzas, 237.

boundaries of, 236.

comb structure, 237.

filling of, 240.

foot wall, 239.

banging wall, 239.

linked, 239.

lode, 239.

ores common in, 237.

secondary banding, 286 .

selvage in, 237.

strike of, 239.

Fixed carbon, effect of, in coal, 8.

Flagstone, defined, 85 .

Flsts, 812.

Flint clay, defined, 99.

Florence ofl field, Colorado, 53.

Florida, ball clay, 103; phosphate, 148; phos. phate, uses, 154 .

Flnorspar, characters, 171.

distribution, Arizona, 173; Illinois, deposits described, 172; Kentucky, 178; Tennessee, 173.

gangue mineral, 172.

gems, 195.

occurrence, 171.

origin, 173.

production, 178.

references on, 178.

uses, 173 .

Foot wall, 289.

Fort Dodge, Iowa, gypsum at, 140.

Foster, on Lake Superior ores, 262.

Fountain bead, 209.

France, buhrstones, 161.

Franklinite, 803, 804, 808, 810.

Fredonis, N.Y., gas, 40.

Freestone, defined, 85 .

Freiberg, Saxony, banded veins at, 287.

Fuel ratio, 8.

Fuller's eartb, analyses of, 175.

difference from clay, 174.

distribution, Alabama, 175; Arkansas, 175 ; England, 175; Florida, 175; Nebraska, 175; New York, 175; South Dakota, 175 .

geological distribution, 175.

production of, 176.

properties, 174.

references on, 176 .

\section{G}

Gaffiney, S.C., tin, 411.

Galena, as a contact ore, 285.

mentioned, $308,305,806,811,812,818,815$, $829,865,870,871,872,878,412$.

Gslicis, ozokerite in, 59.

Galvanic action, ore precipitation by, 285.

Gangue minerals, barite, $811,815,386,842,865$, $867,872$.

caloite, $811,812,815,842,865,890,898,896$. 
Gangue minerals - continucd. chert, 315,365 .

dolomite, $811,815,339,842,867$. epidote, 295, 412.

fluorite, 311, 339, 410, 412.

garnet, 295.

lepidolite, 410.

marcasite, $812,813$.

muscovite, 410.

orthoclase, 839,844 .

quartz, $311,835,336,339,342,844,367,370$, $372,373,890,396,412$.

rhodochrosite, $842,370,383$.

topaz, 410, 412 .

zinnwaidite, 412 .

Garnet, as an abrasive, 163.

as a gem, 194.

distribution, Arizona, 195; Connecticut, mentioned, 163; India, 194; New Mexico, 195; New York, mentioned, 163 ; North Carolina, 195; Tennessee, 163.

in contact deposits, 235.

uses as abrasive, 168 .

Gash veins, in Wisconsin, 240.

defined, 240.

Gasoline, in petrolenm, 42.

Genthite, 404.

Georgia, asbestos, 167 ; banxite, 376 ; corundum, 164; graphite, 179 ; manganese, 885; ocher, 187; phosphate, 154; stoneware clay, 103.

German silver, 321.

Germany, bnhrstones from, 161.

Gibbsite, 875 .

Gilsonite, 59 .

analysis of, 60 .

occurrence, 59.

properties, 59.

Glacial soils, 214.

Glass sand, analyses of, 177.

distribution, Illinois, 177 ; Iows, 177; Maryland, 177; Massachusetts, 177; New Jersey, 177 ; Pennsylvania, 177 ; West Virginia, 177.

effect of clay in, 176.

effect of iron oxide on, 176.

geologic distribution, 176.

production, 177.

properties, 176.

references on, 178.

Glauber sait, 136.

Globe, Ariz., copper, 294.

Gold, gravels, 846 . gravels, Pacific Coast, 847.

Gold Hill, N.C., copper at, 295.

Gold, in beach sands, 849 . native, $325,336,339,865$.

Gold ores, chlorination process, 330 . classification, 327. cyanide process, 830 .

distribution, Alaska, 853; Alaska, placer deposits, 356 ; Black IIlls, 350 ; Cripple Creek, Colo., 838; Cordilleran region, 832 ; Homestake belt, S. Dak., 851; Idaho, 887; Mercur, Utah, 836; Michigan, 352 ; Montana, 837 ; Mother Lode belt, Calif., 833; Nevada Co., Calif., 334; Oregon, 335; Pacific coast belt, 832 ; Washington, 835 .

eastern crystalline belt, 852 .

extraction, 329.

free milling, deflned, 329. geologio distribution, 329 . gold-milling centres, 330 .

igneons rocks associated with, 326.

in igneous rocks, 326.

in metamorphic rocks, 326 .

in propylitic veins, 326 .

listed, 325.

mode of occurrence, 326.

production of, 858 .

quartzose, 328.

quartz veins, 826.

references on, 360 .

refractory, defined, 329 .

sands in arid region's, 349.

secondary enrichment of, 327.

siliceous, Cambrian, Sonth Dakots, 852.

uses of, 857 .

valuation of, 830 .

wall rocks, 826 .

weathering of, 827 .

with mercury, 893.

with platinnm, 408 .

Gold-silver ores, distribution, Bohemis district, Ore., 345; Boulder Co., Colo., 345; Central Belt, 385 ; Clear Creek Co., Colo., 345; Comstock lode, Nev., 844; Eastern Beit, Tertlary ores, 837 ; Gilpin Co., Colo., 845 ; Monte Cristo, Wash., 345; Ouray, Colo., 842 ; Owyhee Co., Ido., 345 ; San Juan region, Colo., 841 ; Silverton, Colo., 841 ; Telluride, Colo., 842; Tonopah, 848.

Gold veins, associations with igneons rock, 230 .

Gossan, deflned, 242.

leaching of, 244.

Grahamite, analysis of, 60 . occurrence, 59.

Grand Rapids, Mich., gypsum st, 142.

Granites, 75 .

characteristics of, 75 .

color of, 75.

distribution, California, 77 ; Central States, 77 ; eastern erystalline belt, 77 ; Minnesota, 77; Missouri, 77; Montans, 77 ; Oregon, 77 ; Sonth Dakota, 77; Texas, 77; United States, 77; Washington, 77; western states, 77.

durability of, 75 .

geologic range, 76.

uses of, 77.

weight of, 75 . 
Graphite, amorphous, 179. amorphous, Rhode Island, 179.

analysis, 178.

artificial, 180.

as mineral pigment, 188.

distribution, Alsbama, 179 ; Ceylon, 179 ; Ceylon, origin, 179; Georgis, 179; Michigan, not such, 179; Montana, 179; New Hampshire, 179; New York, 179; North Carollna, 179; Pennsylvanis, 179; Wisconsin, not such, 179.

occurrence, 178 .

production, 180.

properties of, 178.

references on, 181 .

uses, 179.

Grass Valley, Calif., 834.

banded veins at, 237.

Gravels, auriferons, 846.

Gravity of petroleum, 41.

Great gossan lead, 295.

Great Salt Lake, analysis of water, 124.

Greenland, cryolite in, 875.

Greensand, analyses, 156.

defined, 155.

distribution, $\mathbf{1 5 5}$.

source of Texss limonite, 271.

Virginia, uses of, 155.

Greisen, tin bearing, 410 .

. Grindstones, distribution, 159. properties of, 158 .

Gronnd water, 208. movements of, 208.

Gnano, 155 .

bat, 155 .

bat, analysis, 155 .

bat, Texas, 155.

kinds, 155 .

Peru, 155.

West Indies, 155.

Gumbo clay, defined, 99.

Gypsite, defined, 139.

distribution, Kansas, 141 ; Oklahoma, 142 ; Texas, 142 ; Wyoming, 142. origin of, 140.

Gypsum, absence from Kansas salt beds, 130. snalyses before and after calcination, 144 . analyses of, 143 .

as mineral pigment, 187 .

calcination process, 144.

composition, 139.

distribution, Arizona, 142; California, 142 ; Colorado, 142 ; Idaho, 142 ; Iowa, 140 ; Kansas, 141; Michigan, 142 ; Montana, 142; Nevada, 142; New York, 142 ; Ohio, 142 ; South Dakota, 142 ; Vermont, 142; Virginia, 142.

formed from pyrite, 140.

formed from sea-water, 140 . geologic distribution, 189.

occurrence, 189. origin, 189.

production of, 145 .

references on, 146 .

nses, 143.

voleanic origin of, 140 .

\section{$\mathbf{H}$}

Hamliton shales, for Portland cement, 118.

Hanging wall, 239.

Hayes, on Arkansas bauxite, 879. on Georgia bauxite, 876.

on Tennessee phosphates, 158.

Hematite, 259.

analysis, Lake Superior, 264.

as mineral pigment, 186 .

distribution, Alabama, 268; Lake Superior region, 259; Missouri, 269; Utah, 268; Wyoming, 268; United States, 259.

in contact deposits, 235.

with mercury, 393.

See Clinton ore.

Hermann, on weight of stones, 71.

Hindostan, emerald in, 198.

Hindostan stone, 160.

Holston Valley, Va., gypsum, 142.

Horn silver, 325 .

Hot spring, gold-bearing, $22 \%$.

Hot spring deposits, see Stibnite, Pyrite, Copper.

Hot Springs, 204.

Hūbnerite, 414.

Humus, 218.

Hungary, opal in, 195.

Huronian, iron ores in, 261.

Hydraulic limes, see Lime.

Hydraulic mining, 348.

I

Idaho, auriferous lead ores in, 829 ; copper, 298 ; nickel, 405 ; silver-lead ores, 372.

Idaho basin, Idaho, 337 .

Igneous rocks, miscellaneous, for building, 78 .

Illinois, brick clays, 104; bituminous coal, analysis of, 7 ; coal field, 26 ; glass sand, 177 ; natural rock cement, 118 ; ocher, 187; slenns, 187; stoneware clay, 108.

Ilmenite, 257, 418.

Indis, garnet in, 194.

sonrce of mics, 186.

Indiana, Brazil coal, analysis of, 7 ; brick clays, 104 ; cannel coal, analysis of, 7 ; coal fleld, 27 ; petroleum, distillates from, 42 ; natural gas, 55 ; natural gas analy. sis, 48; petroleum, 50; Portland cement materials, 119 ; stoneware clay, 103 ; whetstones mentioned, 160.

Indian Territory, coal fleld, 29 ; natural gas, 55 .

Infusorial earth, defined, 162.

distribution, Callfornia, 162 ; Maryland, 162 ; 
Infusorial earth, distribution - continued. Missouri, 162; Nevada, 162; New England, 162; New York, 162; Virginis, 162.

German deposits, 162.

nses, 162.

Iowa, bituminons coal, 7 ; coal in, 29; glass sand in, 177 ; gypsum, 140 ; lime rock in, 116; limonite in, 271; lithographic stone in, 182; stoneware clay in, 108 ; zinc ores in, 811.

Iridium, properties and occurrence, 410.

uses, 410 .

with platinum, 407 .

Iron, in copper ores, 280.

Iron Mountain, Calif., copper, 298.

Iron ores, distribution, Alabama, 266, 271; Arkansas, 271; California, 256; Colorado, 256, 257; Iowa, 271; Kentucky, 278 ; Michigan, 256, 261, 265 ; Minnesota, 257, 261, 264, 271; Missonil, 269 ; New Jersey, 256, 257; New Mexico, 256, 268; New York, 255, 257, 258, 266, 273; North Carolina, 255 ; Ohio, 266, 278; Oregon, 271; Pennsylvania, 256, 278 ; Sweden, 270 ; Texas, 271; Utah, 256, 268; Vermont, 271; Virginia, 271; Wisconsin, 261, 266, 271; Wyolning, 256, 268.

distribution in United States, 254.

geologie distribution, 254.

impurities in, 252.

magnetite, modes of occurrence, 254.

magnetites, origin of, 255.

modes of origin, 253.

non-titaniferous, 254.

production of, 278.

references on, 276.

Ses Hematite and Limonite.

Iron oxide, effect on clay, 95.

in soils, 214.

Irving, on Lake Superior ores, 262.

$$
J
$$

Japan, solfataric sulphur in, 196.

Jenney, on Missouri lead zinc ores, 317.

Jennings, La., petroleum, 52.

Jerome, Ariz., copper, 292.

Jet, 4.

Joplin, Mo., zinc ores, $\mathbf{3 0 8 , 8 1 4 .}$

Josephinite, 408.

Jurassic, gold, 833 ; lithographic stone, 182 ; sulphur in, 197.

\section{K}

Kansas, cosl, 29; gypsite, 141 ; gypsum, 141 ; lime rock, 116 ; natural gas, 55 ; petrolenm, 52 ; petroleum, distillates from, 42; Portland cement materials, 119 ; salt, 130.

Kaolin, defined, 99.

snalysis of, $98,101$. distribution, Alabama, 101; Connecticut, 101 ; Maryland, 101 ; North Carolina, 101; Pennsylvania, 101; Virginis, 101.

origin, 98.

Kaolinite, 92.

analysis of, 98 .

product of metasomatism, 826 .

Kemp, cited, 230, 246, 257, 810, 407.

Kentucky, ball clay in, 103 ; bat guano, 155 ; bituminous coal, analysis of, $T$; coal field, 27 ; fluorspar, 173 ; lithographic stone, 182 ; molding sand, 190 ; natural gas, 56 ; natural rock cement, 118 ; stoneware clay, 103.

Kerosene, in Wyoming petrolenm, 58.

Kerosene shale, 57.

Keweenaw series, Michigan, 287.

Klondike River, Alaska, 354, 856.

Knox dolomite, 876.

Kunzite, as gem, 195.

\section{I.}

Lake asphalt, 59.

Lake Superior ores, 259.

analyses, 264.

character, 260.

development, 265.

origin, 263.

Lanthanum, in monazite, 191.

Lateral secretion theory, 240.

Lead, desilverized, occurrences, 807. gangue minerals of, 804 .

ores of, 808.

production of, 821.

references on, 823 .

nses of, 819.

with mercnry, 393.

Lead ores, Colorado, 307.

disseminated, 306.

distribution, Appalachian belt, 806; Missonri, 806, 814; Rocky Mountain states, 818 .

gold and silver bearing, 828 .

impurities in, 804.

modes of occurrence, 804.

superficial alteration, $\mathbf{3 0 5}$.

Leadville, Colo., 364.

Lepidolite, 183.

Lesley, on origin of petroleum, 44.

Lift, in quarries, 74.

Lignite, 4.

age of, 4.

areas in United States, 19.

Gulf States ares, 30.

properties of, 4.

Lime, effect on clay, 96.

effect on soils, 215.

in iron ores, 252.

properties, 110.

references on, 121.

uses of, 119. 
Ihmes, hydranlic, distribution, 117. properties of, 112.

Limesione, analyses, 109. burning, changes in, 110.

Cretaceous, for bullding, 80 .

distribution in United States, 80.

for lime, distribution, 116.

for Portland cement, 114, 118.

general characteristics, 78 .

lithographic, 181.

varieties, 78.

Sec Building stones.

Limonite, 269.

advantage of using, 272.

snalyses of, 272.

bog ores, 269.

Cambro-Silurian, 271.

distribution, Appslachian, 271; Arkansas, 271 ; Colorado, 271 ; Iowa, 271 ; Minnesota, 271; Oregon, 271; Texss, 271 ; Wisconsin, 271.

Great Gossan Lead, 271.

mangsniferous, 271.

residual, 270.

with mercury, 893.

Lindgren, cited, 230.

on Colorado gold ores, 837.

Linked veins, 239.

Linnreite, 404.

Lipari, pumice from, 162.

Litharge, 819.

Lthium, distribution, California, 188 ; Connecticut, 183; South Dskota, 183.

indnstry, 188.

minerals as sources of, 183.

production, 183.

uses, 188.

Lithographic stone, analyses, 181.

definition, 181.

distribution, Bavaria, 182; Iowa, 182 ; Kentucky, 182.

physical properties, 182.

references on, 183.

Lithophone paint, 170.

Lode, 239.

Loess, defined, 99.

Louisians, petroleum, 52 ; sslt, 129 ; sulphur, 197.

Lower Carboniferous, fluorspsr in, 172.

Lower Helderberg, limestone for lime, 116.

\section{M}

Magmstic segregation, 224.

in acid rocks, 225.

in bssic rocks, 224.

of copper, 279.

Magmatic water, effects of, 230.

Magnesia, effect on clay, 96.

in iron ores, 252.

in natural cements, 118.

in solis, 214.
Magnesite, California, 184.

occurrence snd properties, 188.

production, 184.

references on, 184.

nses, 184.

Magnetite, as a contract ore, 285 .

non-titaniferons, 254.

sand, 258 ; see Iron ores.

titaniferous, 257.

ansiyses, 258.

distribution, 257.

origin, 257.

Maine, molybdenum, 408; topaz, 194.

Malachite, 278, 281, 291, 298, 871 .

Malay peninsula, tin from, 412.

Maltha, analysis of, 60.

Manganese, distribution, Arkansas, 887 ; Call fornia, 887; Colorado, 888 ; eastern ares, 885; Georgia, 885 ; Utah, 888 ; Virginis, 886.

in iron ores, 252.

ores of, 383 .

origin, 384 .

production, 888 .

references on, 389 .

nses, 888 .

Marbles, distribution in United States, 81. genersl characteristics, 78.

See Building stones.

Marl, for Portland cement, 114, 119.

Marquette range, 261, 263.

Marsh gas, in naturai gas, 42. properties, 42.

Marshes, sait, cause of, 127.

Maryland, coal, referred to, 87 ; glass ssnd, 177 ; infusorial earth, 162; kaolin, 101; marble, 82 ; nstural rock cement, 118.

Marysolle, Mont., 337.

Massachusetts, emery in, described, 164 ; glass sand, 177 ; marble, 82 ; pyrite, 199.

Mechanical concentration, 289, 810, 818, 815.

Mediterranesn Sea, snalysis of water, 124.

Melaconite, 278, 295.

Mendeljeff, on petroleum origin, 46.

Menominie range, 261.

Merenr, Utah, 836.

Mercury, 890.

associated minerals, 898.

distribution, Californis, 890 ; Oregon, 392 ; Texas, 892.

extraction, 394.

mode of occurrence, 890 .

ores of, 890 .

origin, 893.

production of, 894 .

references on, 895 .

nses, 898.

Merrili, G. P., on chrysotlle veins, 169.

Mesabi range, Minnesota, 261, 262.

Mesozoic, auriferons gravels, 827 ; clays of, 100 ; petroleum, 53 ; quartzose ores, 328 . 
Metals, disseminated in granite, 226.

disseminated in limestone, 226.

disseminated in quartz-porphyry, 226.

distribution in rocks, 226.

precipitation, conditions governing, 232.

Metasomatism, defined, 233.

pressure accompanying, 233.

temperature during, 233.

variation in process of, 233.

Meteoric waters, importance in secondary concentration, 230.

Mexico, opal in, 195; solfataric sulphur in, 196.

Mics, distribution, North Carolina, 185.

in kaolin, 100.

mode of occurrence, 185.

production of, 185 .

references on, 186.

species of economic valne, 185.

value of, 185 .

Micanite, 185.

Michigan, bituminous coal, analysis of, 7 ; brick clays, 104 ; coal field, 28 ; copper ores, 287 ; gold, 852 ; graphite, socalled, 180; gypsum, 142; iron ore, 261 ; magnetite, 256 ; Portland cement materials, 119 ; salt in, 129.

Millerite, 404.

Millstones, characters, 161.

distribution, 161.

Mine Hill, N.J., zinc ore, 309.

Mine waters, analyses of, 227. vadose, 227 .

Mineral pigments, 186.

asbestos, 188.

barite, 187.

graphite, 188.

gypsum, 187.

hematite, 186 .

ochers, 186.

production, 188.

references on, 189 .

slate, 187.

Mineral springs, volume of discharge, 205.

Mineral waters, analyses, 206.

classification, 205.

defined, 204.

distrlbution, 205.

origin and occurrence, 204.

production of, 206.

references on, 207.

thermal springs, 204.

Mineralizing vapors, 284.

in contact deposits, 235.

Minerals, in contact deposits, 235.

Minnesota, hematlte, 261, 264 ; limonite, 271.

Miocene, petroleum, 53 ; phosphate, 150.

Misstssippi, lignite in, 80.

Mississippi deita, solls of, 214.

Missouri, bituminons coal, analysis of, 7 ; ball clay, 103 ; barite, 170 ; hematite, 269 : infusorial earth, 162 ; lime rock, 116 ; stoneware clay, 108.
Moisture in coal, 8.

Molding sand, analy sis, 189.

distribution, 190.

mechanical composition, 189.

properties, 189.

references on, 190.

Molybdenite, 339, 403.

Molybdenum, 403.

in Maine, 408.

in western states, 408.

ores and occurrences, 408.

production of, 403 .

references on, 403 .

uses, 403.

Monazite, analyses, 191.

composition, 190.

distribution, Brazil, 190; North Carolina, 190 ; South Carolina, 190.

magnetic separation of, 191.

occurrence, 190.

prodnction of, 191.

references on, 191.

nses, 191.

Montans, asbestos, 168 ; sllver, 284 ; coal, 81 ; copper ores, 282 ; graphite, 179 ; lignite analysis from, 6; molybdenum, 403 ; sapphire, 193 ; silver-lead ores, 378.

Monte Cristo, Wash., 835.

direction of veins at, 288 .

Montezums, Colo., zinc concentrates, 819.

Moss agate, as gem, 195.

Mother lode, California, gold, 838.

Mnscovite, as source of mica, 185.

N

Naphthas, in petrolenm, 42.

Natural gas, analyses of, 43.

anticlinal theory, 43.

distribntion, California, 56; Indiana, 55; Indian Territory, 55; Kansas, 55; Kentucky, 56 ; New York, 54 ; Ohio, 55 ; Pennsylvania, 54; Texas, 56; West Virginia, 55.

exhaustion of, 54 .

geologic distribution, 48.

history of development, 40.

occurrence of, 43.

pressure in well, 44.

properties of, 42.

references on, 67 .

uses of, 56.

Natural rock cements, see Cements.

Nebraska, fullers earth in, 175.

Nevada, infusorial earth, mentioned, 162 ; mag. matically segregated ores in, 225 ; solfataric sulphur, 197 ; sliver-lead ores, 873 ; tungsten in, 415.

Nevada City, Calif., 834.

Newberry, on temperatnre petroleum formation, 47.

New Brunswick, albertite in, 59.

New Caledonia, nickel supply from, 405. 
New England, infusorial earth, mentioned, 162. lime rock in, 116.

New Hampshire, graphite in ; 179 ; whetstones mentioned, 160.

New Jersey,ballclay,103; copper,296; glass sand, 177; greensand, 155 ; magnetite, 256 ; molding sand, 190 ; Portland cement materisls, 118; stoneware clay, 103.

New Mexico, anthracito coal, analysis of, 8; bsuxite, 879 ; coal, 80,31 ; copper, 298 ; garnet, 195; magnetite, 256 ; molybdenum, 403; silver-lead ores, 878; turquoise, 194 ; vanadium, 416.

New York, Clinton ore, 266 ; emery, mentioned, 164 ; fuller's earth, 175; garnet, 163 ; graphite, 179 ; gypsum, 142 ; infusorial earth, mentioned, 162 ; limestone ; 116 ; magnetite, 255 ; marble, 82 ; millstones, 161 ; molding sand, 190 ; nstural gas, 54 ; natural rock cement, 118 ; petrolenm occurrence, 48; Portland cement materials, 118 ; production of gypsnm, 145; pyrite, 199 ; salt, 127 ; siderite, origin of, 278 ; slenna, 187 ; talc, 202 ; whetstones, mentioned, 160.

New Zesland, magnetite sand, 258.

Niccolite, 404.

Nickel ores, 404.

Nickel, analysis of, 405 .

distribution, Missouri, 404 ; North Carolina, 404 ; Ontario, Canada, 404 ; Pennsylvania, 404; western states, 404.

production of, 406 .

references on, 407 .

uses of, 405.

Nile Valley, alluvial soils, 214.

Nitrogen, in natural gas, 214.

in solls, 214.

Norite, New York, 78.

North Carolina, asbestos, 167 ; barite, 170 ; corundnm, 164 ; emerald, 198 ; garnet, 195 ; graphite, 179 ; kaolin, 101 ; magnetite, 255 ; mica in, 185 ; millstones in, 161 ; monazito in, 190 ; phosphate in, 154 ; pyrophyllte, 208 ; rubles, 193 ; talc, 201 ; tin, 411 ; Triassic cosl, 25.

North Dakota, Portland cement materials, 119.

Norway, titanium in, 418.

Novaculite, 160.

origin, 160.

Nuggets, gold, 846.

Ocher, as mineral pigment, 186. classiffcation, 187. composition, 187. distribution, 187. origin, 187.

Ochsenins, on origin of salt, 125.

Ogdensburg, New Jersey, zinc ore, 809.

Ohio, brick clsys, 104 ; brines, 129 ; Clinton ore, 266; gypsum, 142; Hocking Valley coal, anslysís of, 7 ; molding sand, 190 ; natural gas analysis, 43 ; nstural gas, 55 ; nstural rock cement, 118 ; petroleum, 50 ; Portland cement materials, 119 ; siderite, 273 ; stoneware clay, 103 ; whetstones, mentioned, 160.

Oil rock, capscity of, 44.

Oil shales, analysis, 57 .

distillation of, 57 .

geographic distribution, 57.

properties, 56.

references on, 67 .

Oil springs, 52.

Oilstones, defined, 159.

distribution, 160 .

Okiahoms, gypsite in, 142.

Oliphant, on petroleum distillates, 42.

Ontario, anthraxolite in, 39.

Ontario, nickel, 404.

Onyx marbles, 83.

characters, 83.

distribution, 83.

for lithographlc work, 182.

references on, 91.

Oölitic, limestone, defined, 80.

Opal, composition and occurrence, 195.

distribution, Hungary, 195; Mexico, 195 ; Oregon, 195 ; Washington, 195.

Orange Spring, Fla., 205.

Ordovician, lead in, 306 ; limestones, 116.

Ore deposits, bedded, 241 ; bonanzas, formation of, 245 ; chsmber deposits, 242 ; classification of, 246 ; contact deposits, 241 ; contemporaneons origin of, 224 ; disseminations, 242 ; Fahlband, 241 ; fissure veins, 236 ; forms of, 236 ; impregnations, 241 ; linked veins, 239 ; ore channel, 241 ; origin of, 224 ; oxidation, 243 ; oxidation, depth of, 244, references on, 249 ; secondary alteration in, 242; secondary enrichment, 245; westhering, 242 ; weathering, chemical changes, 243 ; weathering, conditions affecting depth, 243; weathering, minerals affected, 242.

Oregon, coal, 82 ; gold ores, 335 ; limonite, 27 ; mercury, 392 ; nickel, 404 ; opal in, 195 ; solfataric sulphur, 197.

Ores, concentration in rocks, 225.

value of, 245.

Organic matter, as redncing agent, 817 .

Oriskany, glass sand in, 177; limonite in, 271; phosphate in, 158.

Orpiment, 898.

Orton, on petroleum origin, 47.

Osminm, properties and occurrence, 409.

uses, 409.

with platinnm, 407.

Osmotic pressure, ore precipitation by, 236.

Ouray, Colo., 807, 842.

Ozark region, 814.

Ozokerite, properties, 59.

occurrence, 59 . 


\section{INDEX}

$\mathbf{P}$

Palladium, properties and occurrence, 409. uses, 409.

with platinum, 407.

Paper clay, defined, 99.

Paraffin, 56.

Paragenesis, 313, 815.

Park City, Utah, 80 \%.

Peace River, Fla., phosphate, 148.

Peale, on mineral waters, 205.

Peat, analyses of, 4,6 .

defined, 3.

references on, 38.

sections in bog, 8 .

Peckham, on temperature petroleum formation, 47.

Pegmatite, tin-bearing, 410.

Pennsylvania, anthracite coai, 8, 22; barite, 170 ; bituminous coal, 7 ; cement materiais, 117, 118 ; chromite, 401 ; Clinton ore, 266 ; copper, 296 ; fire clays, 102 ; glass sand, 177; graphite, 179 ; iron ore, 256, 273 ; kaolin, 101 ; magnetite, 256; natural gas, 54; ocher, 187 ; petroleum, 50 ; phosphate, 154 ; Portland cement materiais, 118 ; serpentine, 84 ; siderite, 273 ; sienna, 187 ; stoneware clay, 103 ; titanium, 414 ; zine, 311.

Penokee-Gogebic range, 261, 262.

Penrose, on Georgia manganese, 386.

Pentlandite, 404.

Permian, gypsum, 141; rock salt, 127; salt, 130.

Persia, turquoise, 194.

Petroleum, analyses, 41.

anticlinal, 43.

asphaltic, 40, 42.

uses, 42.

bolling point, 42 .

distlliates, percentages of, 42 .

distribution, Alaska, 54 ; Appalachian field, 48; California, 52; Colorado, 53; Kansas, 52 ; Ohio-Indiana, 50 ; Pennsylvania, 50; Texas-Louisiana, 51.

flashing point, 41.

geologio distribution, 48.

gravity of, 41.

gushers, in Beaumont field, 45.

history of development, 89 .

movement in rocks, 47 .

nitrogen in, 40.

origin, inorganic theory, 46.

organic theory, 46.

paraffin in, 42.

pool, defined, 44.

pressure in well, 44.

production, 62.

properties of, 40.

references on, 66 .

rock pressure, 45 .

sands, defined, 44. solldification temperature, 41.

uses of, 56 .

wells, depth of, 45 .

Phlogopite, as source of mica, 185.

Phosphate, analyses, 154.

distribution, Alabama, 153 ; Arkansas, 153 ;

Florida, 148; Georgia, 153; North

Carollna, 153; Pennsylvanis, 153;

South Carolina, 150; Tennessce, 150.

geological distribution, 148.

impurities, 158.

land pebble, 149.

mode of occurrence, 147.

river pebble, 149.

rock, 148 .

soft, 149.

uses, 154.

Phosphoric acid, in soils, 214.

Phosphorus, in copper ores, 280.

in iron ores, 252.

Pipe clay, defined, 99.

Pipe lines, West Virginia, 55.

Pitches, 812.

Placers, 327.

Plaster of Paris, 144.

Plasticity, clay, 96.

Platinum, associsted metals, 407.

composition, 407.

distribution, California, 408; Wyoming, 408.

native, 407.

ores, 407.

production, 408.

references on, 408 . uses, 408.

Pleistocene, clays, 100 ; glass sand, 176 ; stoneware clays, 103.

Pnenmatolysis, defined, 284.

Polybasite, 325, 344, 368.

Portland cement, sec Cement.

Posepny, on ore deposits, 246. on vadose water, 231.

Potash, in solls, 214.

Potsdam, glass sand, 177 ; sandstone, 87.

Pottery clay, defined, 99. distribution, 103.

Pozzuolane, Italy, cement from, 111.

Pratt, on chromite, 400. on chrysotile veins, 169.

on corundum, 163.

Pre-Cambrian, auriferous gravels, 827 ; clays, 100 ; gold, 329 ; iron ores, 260.

Preclous stones, defined, 192.

occurrence, 192.

production, 195.

references on, 195.

Proctor, Vt., marble, 82.

Proustite, 825.

Psilomelane, 383.

Pulpstones, properties and nses, 159.

Pumice, 161.

sources, 162 
Pnmpelly, cited, 262.

Pyrargyrite, 325.

Pyrite, 286, 839, 871, 412.

ansly sis, 199.

as contact mineral, 235.

distribution, Massachusetts, 199; New York, 199 ; Virginia, 199.

in hot spring deposit, 228.

occurrence, 199.

references on, 200.

uses, 200.

Pyrolusite, 888.

Pyromorphite, 808.

Pyrope, as gem, 194.

Pyrophylite, composition, 203.

North Carolina, 203.

nses, 203.

Pyroxene, as gangue mineral, 295.

Pyrrhotite, 404.

as contact ore, 285.

Ducktown, Tenn., 295.

in Virginia pyrite deposits, 199.

Sudbury, Ont., 405.

\section{$\mathbf{Q}$}

Quarries, bedding plsnes in, 74 .

Quarrying, structural features affecting, 74.

Quarry water, 73.

Quartz, crystalline, uses, 168.

in krolin, 100.

Quicksilver, 390, 891, 898.

Quincy, Mass., granite, 77.

Realgar, 898.

$\mathbf{R}$

Red Sulphur Springs, Va., 205.

Regolith, 218.

Replacement, defined, 233.

Residual soils, 218.

Residuum, petroleum, 42.

Retort clay, deflned, 99.

Rhigolene, 56.

Rhode Island, coal field, 25 ; graphite, 179.

Rhodium, with platinnm, 407.

Rico, Colo., 807.

banded veins at, 287 .

zine concentrates, 819 .

Rift, 74.

Road materials, 217.

clay, behavior nnder traffic, 217.

gravel, characteristics, 217.

methods of testing, 218.

references on, 218.

requisite qualities, 218.

sand, characteristics, $21 \%$.

shale, 217.

Rock crystal, as gem, 195.

Rock pressure, Orton on, 45.

Rock salt, occurrence, 125.

Rocky Monntain region, yield of silver, 332.

coal flelds of, 80 .
Ruby, properties, 198.

Arizona, 193; North Carolina, 193; United States, 193.

Ruby silver, 825 .

Ruthenium, with platinum, 407.

Rutile, 413.

\section{S}

Salina, gypsum, 142; salt, 129 .

Sallnes, 124.

Sall Mountain, Ga., amphibole asbestos, 167.

Salt, analyses of salt and brines, 131 .

analyses of sea waters, 124 .

association with gypsum, 126.

distribution, California, 180 ; Kansas, 130 ; Louisiana, 129 ; Michigan, 129 ; New

York, 127; Texss, 180 ; Utah, 130.

extraction, 131.

impurities, 126.

occurrence in waters, 124.

production, 132.

references on, 134 .

rock, origin, 125.

sources of, 124 .

nses, 132.

San Bernardino Hot Springs, Calif., 204.

Sandberger, on dissemination of metals, 226.

Sandstone, 84 .

arkose, 85.

Berea, 87.

bluestone, 85 .

distribution, 86 .

flagstone, 85.

general properties, 84 .

Potsdam, 87.

varieties of, 85 .

Sandusky, Ohio, gypsum, 142.

San Juan region, Colorado, gold-silver, 341.

Sap, 78.

Sapphire, 198.

distribution, Montana, 193 ; North Carolina 198 ; Siam, 198.

properties, 193.

Sagger clay, defined, 99.

Saucon Valley, Pa., zinc ores, 811.

Scheelite, 414.

Schrauf, on mercury origin, 398.

Ses water, pyrite precipitation from, 225.

limonite precipitation from, 225.

manganese precipitation from, 225.

Selvage, 237.

Semi-bltuminous coal, defined, 5.

Senarmontite, 896.

Sericite, 826.

Serpentine, for bullding, 88.

characteristics, 83.

distribntion, 84 .

Seward peninsula, Alasks, 857 ; tin in, 412.

Shaie, analysis of, 98 .

Shutes, 237.

Siam, sapphire, 198.

Siberia, emerald, 198 ; turquoise, 194.

Sicily, sulphur, 197. 
Siderite, $272,873$.

distribution, Kentucky, 273; New York, 278 ; Pennsylvania, 278.

geologic distribution, 272.

mode of occurrence, 272.

Stenna, defined, 187.

Silics, as an abrasive, 168.

deposition from water, 898.

effect on clay, 95 .

In iron ores, 252.

in soils, 214.

Silurian, manganese in, 887.

Silver, Butte, Mont., 284.

ores of, 825 .

production, 358 .

uses of, 857.

with mercury, 398.

Silver Cliff, Colo., analyses of mine waters, 227.

Silver glance, 825 .

Silver ores, classification, 827.

distribution of, see Gold-silver.

extraction, 829 .

geologic distribution, 829 .

mode of occurrence, 826.

production of, 858 .

references on, 860 .

secondary enrlchment, 827.

wall rocks, 826 .

weathering of, 327 .

Silver-lead ores, 364.

assays of, $\mathbf{8 7 2}, \mathbf{3 7 8}$.

distribution, Aspen, Colo., 867 ; Cour d'Alene, Ido., 872; Eagle River, Colo., 869 ; Eureka, Nev., 873 ; Glendale, Mont., 373 ; Leadville, Colo., 864 ; Neihart, Mont., 378 ; New Mexico, 378 ; Park Clty, Utah, 870 ; Red Mountain, Colo., 869 ; Rico,Colo., 369 ; South Dakota, 373 ; Ten Mile district, Colo., 869 ; Tintic district, Utah, 872.

references on, 374 .

Silverton, Colo., 841.

Slate, ss mineral pigment, 187. quarrying, waste in, 80 . uses, 89.

Slates, for building, 87.

bleaching of, 88 .

cleavage, 87 .

distribution, 88 .

Smith sonite, $808,305,810,812,819$.

Smut, of coal, 16.

Soapstone, 201.

in southern Appalachisns, 201.

See Talo.

Soda, in solls, 214.

Sod a niter, properties, 186.

references on, 186.

Sodium sulphate, 186.

Soils, 218.

æolian, 214.

alkall in, 215. alluvial, 214.

chemical properties, 214.

defined, 213.

distribution, 216.

dune, 214.

flocculated, 215.

glacial, 214.

loamy, properties, 215.

loess, 216.

marsh, 216.

origin, 213.

physical properties, 215.

prairie, 216.

puddled, 215.

references on, 216.

residual, 213.

sandy, 215 .

structure, 215.

subsoil, 216.

temperature, 216.

texture of, 215 .

transported, 218.

volcanic, 214.

Solenhofen, Bavaria, lithograpbic stone, 182.

Solfd bitumens, 57.

South Carolina, monazite, 190 ; phosphate, 150 ; tin, 411.

South Dakota, fire clay, 108 ; gold, 850 ; fuller's earth, 175; lithium, 183; Portland cement materials, 119 ; silver-lead ores, 878 ; tungsten, 415 .

Specularite, as contact ore, 285.

Sperrylite, 407.

Spessartite, as gem, 194.

Sphagnum, 8.

Sphalerite, $808,805,811,812,813,315,819$, $872,878$.

Spodumene, 188.

Spurr, on magmatic segregation, 225.

Stannite, 410.

Stassfurth, Prussia, salt at, 126.

Steamboat Spring 5, Nev., 392.

Stephanite, $825,844$.

Stevenson, on anthracite formation, 15.

Stibnite, 886, 889, 896.

in hot spring deposit, 228.

Stoneware clay, analysis of, 98.

defined, 99.

distribution of, 108.

Stream tin, 410.

Strontlan Island, celestite on, 201.

Strontium, minerals contsining, 200. references on, 201.

nses, 201.

Subcarboniferous, salt, 129; limestone for lime, 116 ; zinc, 814 .

Subsoil, 216.

Sudbury, Ont., nickel, 405.

Sulphides, in contact deposits, 235.

Sulphur, dlstribution, Lonisiana, 197 ; Japan, 196; Mexico, 196; Oregon, 197; Utah, 196. 
Sulphur - continued.

geologic age, 197.

gypsum type, 197.

in coal, 9.

in copper ores, 280.

origin, 197.

production, 198.

references on, 198.

solfatsric type, 196.

uses, 198.

Sussex County, N.J., zinc ores, 808.

Sweet Springs, W. V8., 204.

Sylvanite, 325, 839.

\section{$\mathbf{T}$}

Tabie Mountain, Calif., 847.

Talc, 201.

analyses of, 202.

as aiteration product, 201.

distribution, New York, 202; North Carolina, 201.

origin and occurrence, 201.

production, 203.

references on, 203.

uses, 202.

Teliurides, 825 .

unknown in contact deposits, 235 .

Telinrium in copper, 280.

Tennantite, 285.

Tennessee, ball clay, 103 ; barite, 170 ; fluorspar, 173; Jeliico cosi, analysis of, 7 ; garnet, 163; phosphite, 150 ; stoneware clay, 103.

Terlingus, Texas, mercury, 892.

Terra aiba, 143.

Terra-cotta clay, defined, 99.

Tertiary, fulier's earth, 175 ; gold-silver ores, 837; glass sand, 177 ; greensand, 155 ; lignite, 19 ; limonite, 271 ; phosphates, 148, 158 ; sulphur, 197.

Tetrahedrite, 278, 285, 297, 821, 381, 839.

Texss, bat guano, 155; bituminous coal, anaiysis, 7 ; coal, 29; fertilizer, 155 ; gypsite, 142 ; lignite, 6,80 ; lime rock, 116 ; limonite, 271 ; mercury, 892 ; natural gas, 56 ; petroleum, 51 ; Portland cement materials, 119 ; salt, 130 ; stoneware clay, 103.

Thermal springs, origin, 204.

Thorinm, in monazite, 190, 191.

Tin, association with granite, 226.

distribution, Alaska, 412; Black Hills, 411; Malay Peninsula, 412; North Carolina, 411 ; South Carolina, 411.

mode of occurrence, 410.

ores, 410 .

production of, 412.

references on, 418.

uses of, 412.

Titsnic acid, in clsy, 96.

Titaninm, distribution, Norwsy, 418; Pennsylvanis, 414; Virginis, 414. in iron ores, 252.

occurrence, 418.

ores, 418.

references on, 414 .

nses, 414.

Tonopah, Nev., 843.

Topaz, distribution, Brazil, 194; California, 194 ; Ceylon, 194; Colorado, 194; Maine, 194 ; Urals, 194.

properties, 194.

Torbanite, 57.

Tourmaline, as gem, 195.

with tin, 412.

Transported soiis, classiflcstion, 214. origin, 213.

Trap, 78.

Travertine, defined, 80.

Trenton, limestone for lime, 116 ; petroleum in, 51 .

Triassic, coal, 25 ; magnetite, 256.

Trinidad, asphalt in, 59 . analy sis of, 60 .

Tripoli, see Infusoriai earth.

Tully limestone, for Portland cement, 118.

Tungsten, anaiysis, Arizons, 415.

distribution, Arizona, 415; Black Hills, 415 ; Colorado, 415; Connecticnt, 415; Nevada, 415 .

ores, 414.

production, 415.

references on, 416 .

uses, 415.

Turquoise, distribution, Arizons, 194; Asia Minor, 194 ; New Mexico, 194; Persia, 194 ; Siberia, 194.

properties and occurrence, 194.

Type metal, 897.

Uintaite, 59 .

\section{U}

Ulexite, 134.

Umber, defined, 187.

Underground waters, 207.

references on, 211.

sources of, 207.

Urals, topaz in, 194.

Ursnium, distribution, Colorado, 416 ; Utsh, 416.

ores, 416.

production, 416 .

references on, 417.

nses, 416.

Utah, coal, 81 ; copper, 296 ; desilverized lead, 307 ; hematite, 268; magnetite, 256 ; manganese, 888; molybdenum, 403 ; Portland cement materials, 119 ; sait, 130 ; stiver-lesd ores, 372 ; sulphur, 196 ; uranium, 416.

\section{$\mathbf{V}$}

Vadose water, defined, 227.

Vanadium, distribution, Arizona, 416; New Mexico. 416. 
Vanadium - continued.

ores, 416.

production, 416.

references on, 417.

nses, 416.

Van Hise, on Lake Superior ores, 262.

on meteoric waters, 228.

on ore deposit classification, 246.

Veins, see Fissure veins.

Vermilion, as mineral pigment, 188.

Vermilion Range, Minn., 261, 264.

Vermont, asbestos, 168; marble, 82 ; whetstones, 160.

Vesuvianite, in contact deposits, 235.

Virgilina, Va., copper, 291.

Virginia, arsenic, 398 ; asbestos, 167 ; barite, 170 ; brines, 129 ; coal, 25 ; greensand, 155; gypsum, 142; infusorial earth, 162; kaolin, 101; limonite, 271 ; pyrite, 199 ; titanium, 414.

Virginia City, Nev., 344.

Vogt, on magmatic segregation, 224.

Volcanic ash, 161.

United States deposits, 162.

soils, 214.

Wad, 388.

W

Warm Springs, Tenn., 204.

Warm Sulphur Springs, Va., 205.

Washington, arsenic, 398; bituminous coal, analysis of, 8 ; cosls, 32 ; gold, 335 ; lignite, analysis, 6; molybdenum, 403 ; nickel, 404.

Water, artesian, 209.

as carrier of ores, 226.

circulation of meteoric, 229.

distribution in earth's crust, 228.

hot, agent in ore formation, 228.

in clay, 96.

mine, analyses, 227.

mineral, 205.

of igneous origin, 229.

of meteoric origin, 228.

underground, source of, 228.

Water lime beds, cement rock in, 117.

Water table, 208.

Watson, on Georgia manganese, 386.

Weathering, building stones, $70,75,79,85$. ore deposits, 242.

Weed, cited, 228, 280, 246.
West Virginia, brines, 129 ; gas, 55 ; glass sand, 177 ; grahamite, 59 ; natural gas, 55 ; petroleum, 48.

Westerly, R.I., granite, 77.

Whetstones, defined, 159.

distribution, 160.

White, I. C., on anticlinal theory, 43.

White lead, as mineral pigment, 188.

White metal, 320.

Whiting, as mineral pigment, 188.

Whitney, on Lake Superior ores, 262.

Willemite, 303, 304, 308, 310.

Winslow, on Missourt lead and zinc, 226.

Wisconsin, Clinton ore, 266 ; graphite, 180 ; hematite, 261, 264; limomite, 271; natural rock cement, 118; zinc ores, 812.

Wolframite, 414.

Wollastonite, 235.

Wulfenite, 408.

Wyoming, asbestos, 168 ; copper, 298 ; gypsite, 142 ; hematite, 268 ; magnetite, 256 ; nickel, 404 ; petroleum, 53 ; platinum, 408.

$\mathbf{Y}$

Yellow ocher, see Ocher.

Yukon valley, Alaska, 358.

\section{Z}

Zinc, Butte, Mont., 285. ores of, 303.

production of, 821 .

with mercury, 398.

uses of, 820 .

Zincite, 803, 808, 310.

Zine ores, analysis of, Leadville, 818 .

Missouri, 815.

New Jersey, 308.

distribution, Creede, Colo., 819 ; Iowa, 311 ;

Missouri, 314; New Jersey, 808; New

Mexicn, 819 ; Pennsylvania, 811; Vir-

ginia-Tennessee, 309 ; Wisconsin, 811.

impurities in, 304.

mechanical concentration, 813 .

references on, 323.

residual, 310 .

superficial aiteration, 305 .

Zinc oxide, manufacture in Colorado, 818.

Zone of fiowage, 228.

Zone of fracture, 228. 



\title{
ELEMENTARY GEOLOGY.
}

\author{
BY \\ RALPH STOCKMAN TARR, B.S., F.G.S.A., \\ Frofesser of Dynamic Geology and Physical Geography at Cornell Universzty; \\ Author of "Economic Geology of the United States," etc
}

2amo. Cloth. 486 pp. Price \$1.fo net.

COMMENTS OF THE PRESS.

"We do not remember to have noted a text-book of geology which seems to so go to the heart of the matter."-Phila. Evening Bulletin.

"The author's style is clear, direct, and attractive. In short, he has done his work so well that we do not see how it could have been done better." - Fournal of Pedagogy.

"It is far in advance of all geological text-books, whether American or European, and it marks an epoch in scientific instruction."

- The American Geologist.

"The student is to be envied who can begin the study of this deeply interesting, fascinating subject with such an attractive help as this text-book."-Wooster Post-Graduate.

"The Geology is admirably adapted for its purpose - that of a textbook." - Brooklyn Standard Union.

"So admirable an exposition of the science as is found in this book must be welcomed both by instructors and students. The arrangement of facts is excellent, the presentation of theory intelligent and progressive, and the style exceedingly attractive." $-N . Y$. Tribune.

\section{THE MACMILLAN COMPANY}

64-66 FIFTH AVENUE, NEW YORK

Boston

CHICAgO SAN RRATCISCO

ATLANTA 


\section{NEW PHYSICAL GEOGRAPHY}

BY

RALPH STOCKMAN TARR, B.S., F.G.S.A.

Professor in Cornell University, and co-author of the Tarr and McMurry Geographies

\section{Price \$1.00}

Modern. This being the latest book on the subject, the author has been able to describe the results of the most recent investigations into important physical phenomena, such as the eruption of Mont Pelée.

Arrangement. For the first time a text-book in the science has been prepared that proceeds from the simple to the complex. The study of springs, rivers, valleys, mountains, and hills introduces the pupil to the study, while the study of the atmosphere, the weather, and more difficult subjects is presented near the end of the book.

Application. As each new principle is presented, it is applied to definite localities with which the pupil is already acquainted. This method increases the child's interest in the study.

Illustrations. There are 568 photographs of the places mentioned in the text. Next to being on the ground, these views are the best aid to teacher and pupil. No other text-book can compare with Professor Tarr's work in this feature.

Human Element. In the chapters on the Physiography of the United States, Rivers of the United States, Distribution of Plants, Distribution of Animals, and Man and Nature, the effects and operations of physiographic laws are clearly and interestingly shown.

Teachable. By means of a summary at the close of each paragraph, of Review Questions and Topics at the end of each chapter, and of simple home experiment directions, the book becomes by far the sim. plest high-school text-book on the market.

\section{THE MACMILLAN COMPANY}

\section{4-66 FIFTH AVENUE, NEW YORK}

BOSTON CHICAGO

SAN FRANCISCO ATLANTA 


\title{
ELEMENTARY PHYSICAL GEOGRAPHY
}

\author{
BY \\ RALPH STOCKMAN TARR, B.S., F.G.S.A. \\ Professor of Dynamic Geology and Physical Geography at Cornell University; \\ Author of "Economic Geology of the United States," etc. \\ Fifth Edition, Revised $12 \mathrm{mo}$ Cloth $\$ 1.40$ net
}

"There is an advanced and modernized phase of physical geography, however, which the majority of the committee prefer to designate physiography, not because the name is important, but because it emphasizes a special and important phase of the subject and of its treatment. The scientific investigations of the last decade have made very important additions to the physiographic knowledge and methods of study. These are indeed so radical as to be properly regarded, perhaps, as revolutionary."

"The majority of the Conference wish to impress upon the attention of the teachers the fact that there has been developed within the past decade a new and most important phase of the subject, and to urge that they hasten to acquaint themselves with it and bring it into the work of the school-room and of the field." - Report of Geography Conference to the Committee of Ten.

The phenomenal rapidity with which Tarr's Elementary Physical Geography has been introduced into the best high schools of this country is a fact familiar to the school public. The reason should, by this time, be equally familiar - the existence of a field of school work in which, until the appearance of Tarr's book, there was not a single adequate or modern American text-book. That such a field did exist, is simply shown by the paragraphs reprinted above. The adoption of the book in such important high schools as those of Chicago, and the expressions of approval from representative New England schools, will indicate how well the field has been covered.

\section{THE MACMILLAN COMPANY}

64-66 FIFTH AVENUE, NEW YORK 




\section{UNIVERSITY OF CALIFORNIA LIBRARY}

\section{Los Angeles}

This book is DUE on the last date stamped below.

Form L9-10m·3,'48(A7920) 444 


\section{TN23 \\ R44e2 \\ Geoloty \\ Litrary}


$\therefore 3$

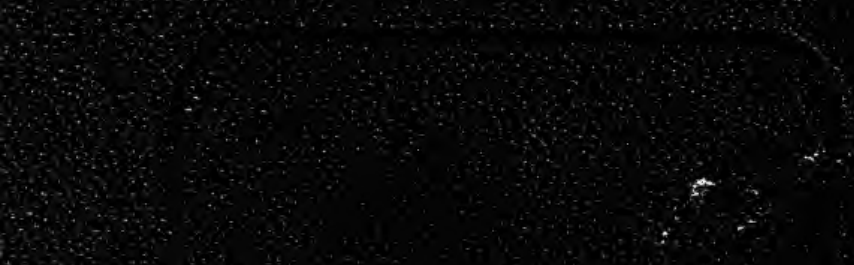

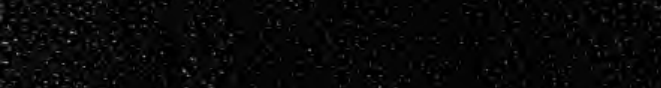

$x^{2}=$

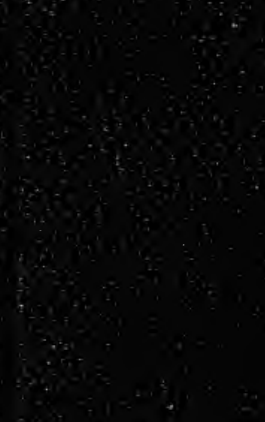

- 1040

.

$6 x^{2}+2 y$

$\sum_{5}=$

6

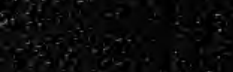

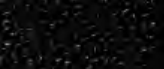

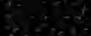

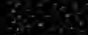

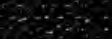

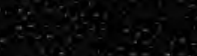

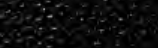

ats

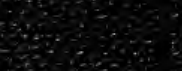

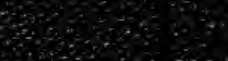

(1) 